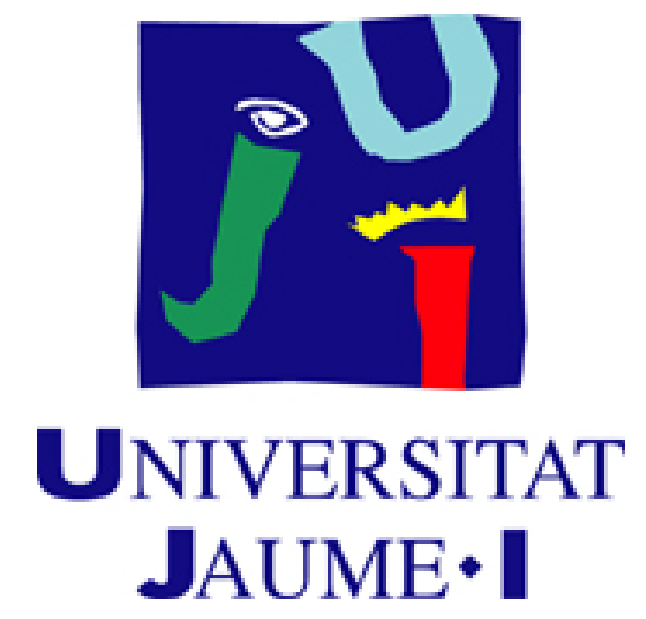

\author{
UNIVERSIDAD J AUME I DE CASTELLÓN \\ Facultad de Ciencias J urídicas y Económicas \\ Departamento de Derecho Privado
}

\title{
La Hipoteca Inversa
}

TESIS DOCTORAL PRESENTADA POR:

Da. Sara García Mares

DIRIGIDA POR:

Dr. D. Luis Martínez Vázquez de Castro 







\section{INTRODUCCIÓN}

Una tesis doctoral es, en esencia, una disección meticulosa de algún aspecto de la especialidad de cada profesional que no suele estar de moda ni en los informativos ni, menos aún, en las conversaciones cotidianas.

Una tesis doctoral suele ser a menudo un ejercicio de aridez expositiva, donde lo metódico prima sobre lo literario, lo exhaustivo sobre lo comunicativo, lo minucioso sobre lo esencial.

La elección temática no se aparta de las premisas descritas porque la hipoteca inversa en España, cuestión central de esta tesis doctoral, ni aparece en los medios, ni en los comentarios de la calle ni tampoco se presenta como inspiración de poetas o novelistas.

Esta tesis es, o pretende ser, un recorrido sobre la trayectoria y las vicisitudes de un producto financiero-inmobiliario que surgió en Reino Unido en 1965 y llegó a España hace ya más de siete años (diciembre de 2007), cuando los escenarios económicos eran otros, cuando las entidades financieras no disponían de un parque casi ilimitado de viviendas.

La investigación ha sido laboriosa, en ocasiones frustrante ante la escasez de fuentes y de antecedentes, pero el resultado final se asoma, cuanto menos, dotado de esa minuciosidad a la que se aludía. Adentrémonos en la desconocida existencia de la hipoteca inversa. A algún lugar más luminoso nos conducirá. 

INTRODUCCIÓN .............................................................. 3

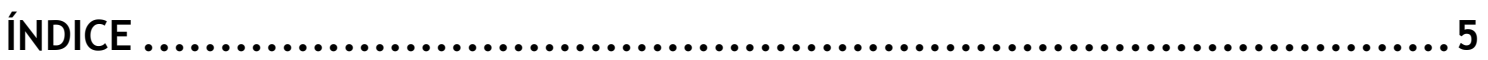

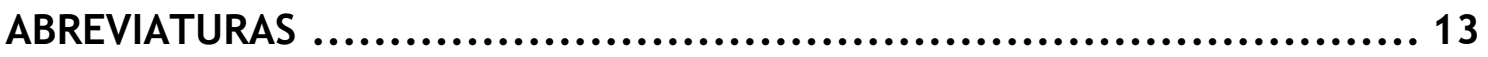

PARTE I. LA HIPOTECA INVERSA EN ESPAÑA

CAPÍTULO I: IMPLANTACIÓN DE LA HIPOTECA INVERSA EN ESPAÑA ........ 21

I. CONSIDERACIONES GENERALES.................................. 21

II. REGULACIONES QUE HAN INFLUIDO EN LA DISPOSICIÓN ADICIONAL

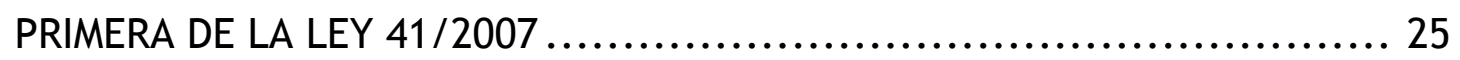

1. Real Decreto-ley 6/2012, de 9 de marzo, de medidas urgentes de protección de deudores hipotecarios sin recursos. ..................... 26

2. Ley $1 / 2013$, de 14 de mayo, de medidas para reforzar la protección a los deudores hipotecarios, reestructuración de deuda y alquiler social.. 29

III. ESCENARIO ACTUAL .............................................. 38

CAPÍTULO II: ORÍGENES DE LA HIPOTECA INVERSA ........................ 51

I. PRECISIONES EN TORNO A SU APARICIÓN............................. 51

1. La hipoteca inversa en otros países .............................. 53

1.1. Francia ...................................................... 53

1.2. Canadá .......................................................... 58

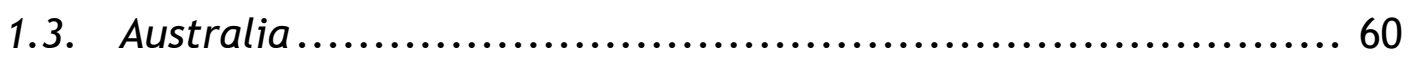

1.4. Nueva Zelanda ............................................... 61

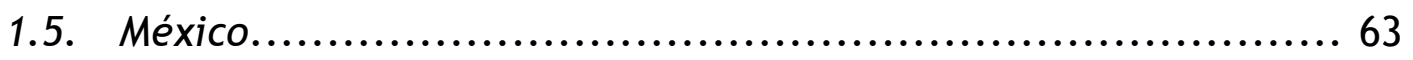

1.6. Puerto Rico ................................................... 64

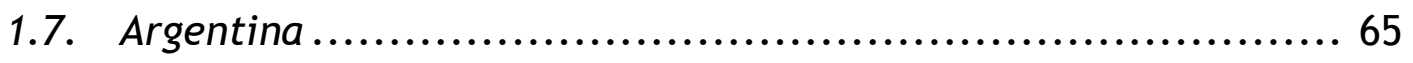

1.8. China ........................................................ 66 
I. CONCEPTO Y NATURALEZA JURÍDICA DE LA HIPOTECA INVERSA ...... 71

II. LA REGULACIÓN JURÍDICA DE LA HIPOTECA INVERSA: LA LEY 41/2007,

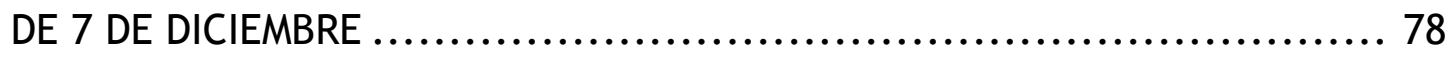

1. Cláusula de cierre de la Disposición Adicional 1. a de la Ley 41/2007. 84 III. CARACTERÍ́STICAS DE LA HIPOTECA INVERSA...................... 85

1. Breve matización sobre el carácter aleatorio del contrato formalizado con hipoteca inversa .............................................. 92

IV. MODALIDADES DE LA HIPOTECA INVERSA ......................... 97

1. Temporal ..................................................... 97

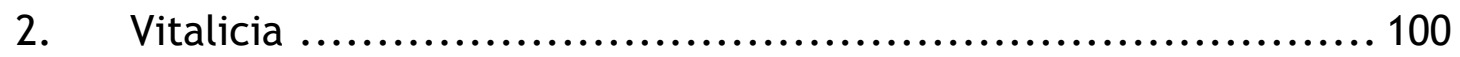

CAPÍTULO IV: ELEMENTOS DEL CONTRATO DE HIPOTECA INVERSA.........105

I. REQUISITOS SUBJETIVOS ...................................... 105

1. El acreedor hipotecario ........................................ 106

1.1. Hipoteca inversa sobre la vivienda habitual ..................... 108

1.2. Hipoteca inversa sobre otros bienes inmuebles distintos a la vivienda habitual ..................................................... 108

2. El deudor ................................................. 111

2.1. Personas de edad igual o superior a los 65 años................... 111

2.2. Personas afectadas de dependencia o personas a las que se les haya reconocido un grado de discapacidad igual o superior al 33 por ciento. 118

3. El beneficiario ............................................. 129

4. El hipotecante no deudor: el fiador ............................. 136

5. Otras Figuras............................................... 138

5.1. Tercer poseedor ........................................... 138

5.2. Constitución unilateral de hipoteca............................. 140

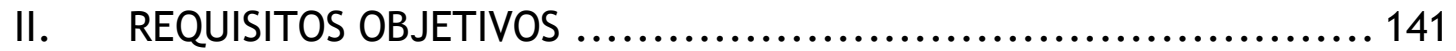

1. El crédito o préstamo garantizado con hipoteca inversa ............ 141 
1.1. Intereses................................................... 146

2. El bien inmueble hipotecado.................................... 154

2.1. El solicitante debe ser titular del bien inmueble ................. 154

2.2. Vivienda habitual.............................................. 155

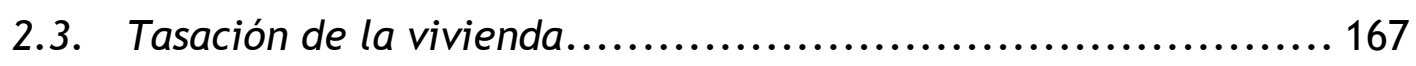

2.4. La vivienda debe ser un bien inmueble enajenable............... 171

2.5. Vivienda totalmente pagada.................................. 171

2.6. Ubicación del inmueble ....................................... 172

III. REQUISITOS FORMALES ....................................... 172

1. Régimen de transparencia y asesoramiento ..................... 173

IV. OTROS REQUISITOS ......................................... 186

1. Conservación del inmueble .................................... 186

2. Seguros vinculados a la constitución de una hipoteca inversa ....... 190

2.1. Seguro de renta vitalicia ....................................... 191

2.2. Seguro de renta temporal.................................... 192

2.3. Seguro del hogar contra daños ................................ 192

CAPÍTULO V: LEGALIZACIÓN DE LA HIPOTECA INVERSA ....................197

I. CONSTITUCIÓN DE LA HIPOTECA INVERSA ......................... 197

1. La hipoteca en garantía de cuenta corriente ..................... 202

II. INSCRIPCIÓN DE LA HIPOTECA INVERSA............................. 209

1. Comentario al pacto de anatocismo ........................... 217

III. RESPONSABILIDAD PERSONAL Y REAL.............................. 221

IV. LA EXTENSIÓN DE LA HIPOTECA INVERSA .......................... 229

CAPÍTULO VI: VENCIMIENTO Y LIQUIDACIÓN DE LA HIPOTECA INVERSA ...235

I. FALLECIMIENTO DEL DEUDOR HIPOTECARIO O DEL ÚLTIMO DE LOS BENEFICIARIOS .................................................... 235 
1. La prueba y la notificación del fallecimiento del deudor hipotecario o del último de los beneficiarios ......................................... 238

2. La identificación de los herederos .............................. 241

3. Los herederos en la hipoteca inversa ........................... 243

II. VENCIMIENTO DEL PRÉSTAMO HIPOTECARIO: EXTINCIÓN DE LA OBLIGACIÓN ASEGURADA Y CANCELACIÓN DE LA HIPOTECA ................ 247

1. Limitación de la responsabilidad de la deuda hipotecaria a los bienes de la herencia.................................................... 253

2. El recobro de la deuda por la entidad acreedora ................... 259

3. La subrogación de la parte acreedora ........................... 262

4. Declaración de vencimiento anticipado por la parte acreedora ..... 264

5. Venta de la vivienda hipotecada ............................... 266

5.1. Breve referencia a la llamada Doctrina del Trienio ............... 271

6. Acción de devastación y vencimiento anticipado del préstamo: artículo $1129.3^{\circ}$ del Código Civil ...................................... 274

6.1. Desaparición o pérdida de la garantía ........................... 277

7. Embargo de vivienda sobre la que está constituida una hipoteca inversa .......................................................... 280

8. Otras posibles causas de vencimiento ........................... 280

8.1. La falta de ocupación efectiva de la vivienda hipotecada........ 282

8.2. El arrendamiento de la vivienda hipotecada..................... 283

8.3. El incumplimiento de obligaciones con preferencia legal sobre la hipoteca inversa .................................................... 285

8.4. El incumplimiento de obligaciones en relación con el seguro contratado .......................................................... 287

CAPÍTULO VII: PROCEDIMIENTO JUDICIAL DE EJECUCIÓN SOBRE BIENES GRAVADOS CON HIPOTECA INVERSA ..................................289

I. PROCEDIMIENTO ESPECIAL DE EJECUCIÓN HIPOTECARIA ............. 292

1. Citación de la herencia yacente ................................. 295 
II. VENTA EXTRAJUDICIAL DEL BIEN................................. 299

III. PROCEDIMIENTO GENERAL DE EJECUCIÓN........................... 303

IV. JUICIO DECLARATIVO ORDINARIO .............................. 310

CAPÍTULO VIII: MÉTODO FISCAL Y RETROACTIVIDAD DE LA HIPOTECA

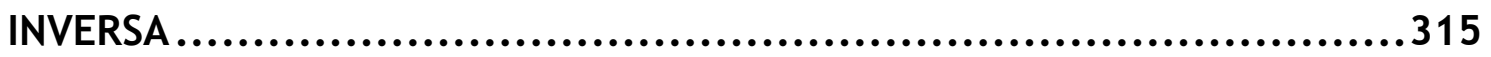

I. SISTEMA FISCAL DE LA HIPOTECA INVERSA ......................... 315

1. Impuesto sobre Transmisiones y Actos Jurídicos Documentados..... 318

2. Impuesto sobre la Renta de las Personas Físicas ................... 320

3. Derechos arancelarios notariales y registrales .................... 325

II. CARÁCTER RETROACTIVO DE LA DISPOSICIÓN ADICIONAL 1. ${ }^{a}$ DE LEY

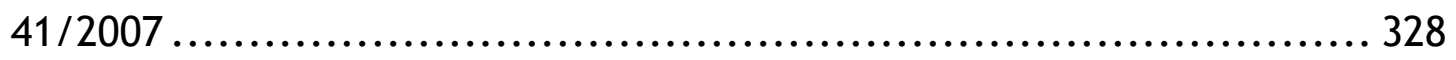

CAPÍTULO IX: FIGURAS QUE EN NUESTRO ORDENAMIENTO JURÍDICO GUARDAN CIERTAS SIMILITUDES CON LA HIPOTECA INVERSA ...............331

I. LA RENTA VITALICIA CONSTITUIDA SOBRE UN INMUEBLE ............ 331

II. LA HIPOTECA PENSIÓN ASEGURADA .............................. 336

III. LA VIVIENDA PENSIÓN ........................................... 337

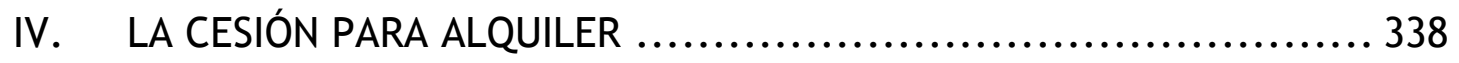

V. COMPRAVENTA DE LA VIVIENDA Y LA CONSTITUCIÓN DE UNA LÍNEA DE CRÉDITO O UN DEPÓSITO A PLAZO .................................... 340

VI. CONTRATO DE RENTA CON OPCIÓN DE COMPRA.................... 340

VII. ENAJENACIÓN DE LA VIVIENDA A CAMBIO DE PROPORCIONAR ALIMENTOS ...................................................... 341

PARTE II. ESTUDIO COMPARATIVO DE LA HIPOTECA INVERSA EN REINO UNIDO Y ESTADOS UNIDOS

CAPÍTULO X: LA HIPOTECA INVERSA EN REINO UNIDO: LOS PLANES EQUITY RELEASE 349

I. LOS HOME REVERSION PLANS....................................... 356 
II. LIFETIME MORTGAGE O HIPOTECA INVERSA

1. Formas en la que se puede pactar una Hipoteca Vitalicia.......... 360

1.1. Interest-only mortgage o hipoteca de sólo interés .............. 360

1.2. Rolled-up mortgage o hipoteca de reinversión de intereses ..... 361

1.3. Fixed-repayment mortgage o hipoteca de capital prefijado ..... 362

2. Características del contrato de Hipoteca Vitalicia................. 362

3. Requisitos subjetivos .......................................... 364

4. Requisitos objetivos ........................................ 366

5. Requisitos formales........................................... 368

6. Constitución de la Hipoteca Vitalicia en Reino Unido ............... 374

7. Vencimiento del préstamo......................................... 376

CAPÍTULO XI: LA HIPOTECA INVERSA EN ESTADOS UNIDOS: EL PLAN HOME EQUITY CONVERSION MORTGAGE ......................................381

I. PLANTEAMIENTO GENERAL SOBRE LAS HIPOTECAS EN ESTADOS UNIDOS: THE REVERSE MORTGAGE ................................. 381

II. LAS HIPOTECAS INVERSAS EN ESTADOS UNIDOS.................... 386

1. Home Equity Conversion Mortgage............................... 386

2. Deferred Payment Loan (DPL) ............................... 387

3. Property Tax Deferral (PTD) ..................................... 388

4. Proprietary Reverse Mortgages ................................. 388

III. EL PLAN HOME EQUITY CONVERSION MORTGAGE .................. 390

1. Requisitos subjetivos ....................................... 390

2. Requisitos objetivos .......................................... 393

3. Requisitos formales ......................................... 398

4. Vencimiento y exigibilidad del préstamo........................ 403

5. Sistema de Registro adoptado en Estados Unidos .................. 405

IV. SEMEJANZAS Y DIFERENCIAS EN LA CONSTITUCIÓN DE UNA HIPOTECA INVERSA, UNA HIPOTECA VITALICIA INGLESA Y UN PLAN HECM............ 410 


\section{PARTE III. EXAMEN DE LA HIPOTECA INVERSA EN ESPAÑA}

CAPÍTULO XII: OTROS INSTRUMENTOS DE PREVISIÓN PARA MEJORAR LA JUBILACIÓN Y LAS SITUACIONES DE DEPENDENCIA Y/O DISCAPACIDAD....419

I. PLANES Y FONDOS DE PENSIONES ............................. 422

II. PLANES DE PREVISIÓN ASEGURADOS............................... 427

III. LOS PLANES INDIVIDUALES DE AHORRO SISTEMÁTICO ................ 429

IV. PLAN DE AHORRO A LARGO PLAZO ............................ 430

V. SEGURO DE JUBILACIÓN ........................................ 431

VI. SEGURO DE DEPENDENCIA ..................................... 431

VII. SEGURO DE VIDA ......................................... 433

CAPÍTULO XIII: PERSPECTIVA DE DESARROLLO DE LA HIPOTECA INVERSA EN

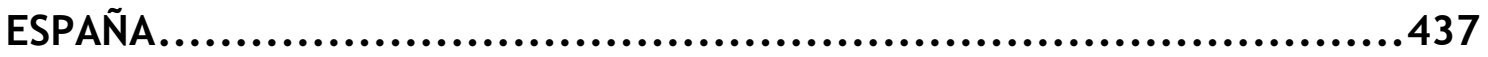

I. ANÁLISIS ESTRATÉGICO DE LA HIPOTECA INVERSA EN ESPAÑA: DAFO/CAME 437

II. LA HIPOTECA INVERSA EN ESPAÑA ¿UNA FIGURA PRESCRITA? ....... 441

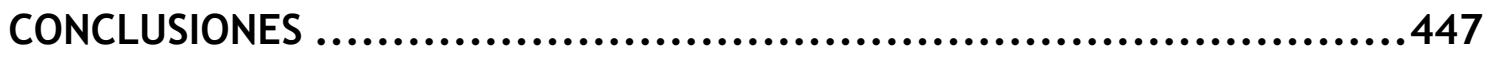
LISTADO DE SENTENCIAS Y RESOLUCIONES ..............................471 BIBLIOGRAFÍA ...........................................................481

I. BIBLIOGRAFÍA GENERAL ....................................... 483

II. MATERIALES COMPLEMENTARIOS.................................. 502

III. DIRECCIONES WEB CON INTERÉS SOBRE HIPOTECAS INVERSAS ....... 504

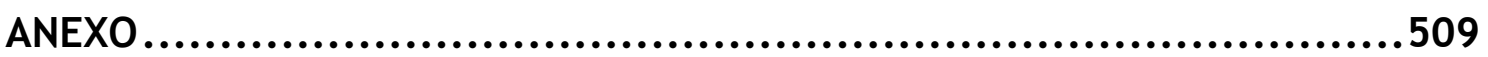

APÉNDICE 1: DA 1. ${ }^{\text {a }}$ de la Ley $41 / 2007$, de 7 de diciembre.............. 511 



\section{ABREVIATURAS}

AARP: American Association of Retired Persons

AC: Actualidad Civil

ADC: Anuario de Derecho Civil

AHE: Asociación Hipotecaria Española

ASIC: Australian Securities and Investments Commision

BOCG: Boletín Oficial de las Cortes Generales

BOE: Boletín Oficial del Estado

CC: Código Civil

CCELS: Canadian Center for Elder Law Studies

CFR: Code of Federal Regulations

Cfr.: Confróntese

CHIP: Canadian Home Income Plan

Cit.: Obra citada

CNMV: Comisión Nacional del Mercado de Valores

Coord.: Coordinador

DA: Disposición adicional

DF: Disposición final

DGRN: Dirección General de los Registros y del Notariado

DGT: Dirección General de Tributos

DOGC: Diari Oficial de la Generalitat de Catalunya

DPL: Deferred Payment Loan

ed.: Edición 
FCA: Financial Conduct Authority

FD: Fundamento de Derecho

FHA: Federal Housing Administration

FIPER: Ficha de Información Personalizada

FIPRE: Ficha de Información Precontractual

FSA: Financial Services Authority

FSSC: Financial Services Skills Council

G. P.: Grupo Parlamentario

HECM: Home Equity Conversion Mortgage

IBI: Impuesto sobre Bienes Inmuebles

Ibíd.: Obra citada inmediatamente antes

INE: Instituto Nacional de Estadística

IPC: Índice de Precios al Consumo

IPREM : Indicador Público de Renta de Efectos Múltiples

IRPF: Impuesto sobre la Renta de las Personas Físicas

LCGC: Ley de Condiciones Generales de la Contratación

LCS: Ley de Contrato de Seguro

LEC: Ley de Enjuiciamiento Civil

LGDCU: Ley General para la Defensa de los Consumidores y Usuarios

LH: Ley Hipotecaria

LHMPSDP: Ley de Hipoteca mobiliaria y prenda sin desplazamiento de la posesión

LIRPF: Ley del Impuesto sobre la Renta de las Personas Físicas,

LMH: Ley del Mercado Hipotecario

LPH: Ley de Propiedad Horizontal 
LRG: Ley del Registro Civil

MOCB: Mortgages and Home Finances: Conduct Business Sourcebook

$\mathrm{N}^{\circ}$ : Número

Núm.: Número

Núms.: Números

OECD: Organisation for Economic Cooperation and Development

op. cit.: Obra citada

OM: Orden Ministerial

p.: Página

PIAS: Planes Individuales de Ahorro Sistemático

PPA: Planes de Previsión Asegurados

pp.: Páginas

PRA: Prudential Regulation Authority

RCDI: Revista Crítica de Derecho Inmobiliario

RD: Real Decreto

RDBB: Revista de Derecho Bancario y Bursátil

RDGRN: Resolución de la Dirección General de los Registros y del Notariado

RDP: Revista de Derecho Privado

RDM: Revista de Derecho Mercantil

RGD: Revista General de Derecho

RGLJ: Revista General de Legislación y Jurisprudencia

RH: Reglamento Hipotecario

RJN: Revista Jurídica del Notariado

Sepe: Servicio Público de Empleo 
SGSS: Sistema General de la Seguridad Social.

SHIP: Safe Home Income Plans

SMI: Salario mínimo interprofesional

SOVI: Seguro Obligatorio de Vejez e Invalidez.

ss.: Siguientes

STC: Sentencia del Tribunal Constitucional

STJUE: Sentencia del Tribunal de Justicia de la Unión Europea

T: Tomo

STS: Sentencia del Tribunal Supremo

TC: Tribunal Constitucional

TS: Tribunal Supremo

UAM: Universidad Autónoma de Madrid

Vid.: Véase

Vol.: Volumen

VV. AA.: Varios autores 




\section{PARTE I}

\section{LA HIPOTECA INVERSA EN ESPAÑA}





\section{CAPÍTULO I: IMPLANTACIÓN DE LA HIPOTECA INVERSA EN ESPAÑA}

\section{CONSIDERACIONES GENERALES}

La hipoteca inversa ${ }^{1}$ se introduce en nuestro ordenamiento mediante la «Ley 41/2007, de 7 de diciembre (en lo sucesivo, Ley 41/2007) por la que se modifica la Ley 2/1981, de 25 de marzo, de Regulación del Mercado Hipotecario y otras normas del sistema hipotecario y financiero, de regulación de las hipotecas inversas y el seguro de dependencia y por la que se establece determinada norma tributaria». Su publicación en el Boletín Oficial del Estado tiene lugar el día 8 de diciembre de $2007^{2}$.

Según MULLOR, esta Ley ha sido la reforma más importante que ha tenido lugar en la regulación del mercado hipotecario español desde su origen en $1981^{3}$.

La Ley 41/2007, de 7 de diciembre se impulsa ${ }^{4}$ en un Proyecto de Ley ideado en el Ministerio de Justicia, concretamente, en la Dirección General de los Registros y del Notariado.

\footnotetext{
${ }^{1}$ Entre los artículos doctrinales previos a la actual regulación, destacar los siguientes: ANGUITA Ríos, R.M., «La hipoteca inversa y la transformación de los activos inmobiliarios en rentas», El Consultor Inmobiliario, núm. 83, octubre 2007, pp. 3-17; Asociación Hipotecaria Española (AHE), «Anteproyecto de Ley de Modernización del Mercado Hipotecario, de Regulación del Régimen de las Hipotecas Inversas y del Seguro de Dependencia», noviembre de 2006, pp. 1-11; BALAGUÉ, C., «Cómo convertir la vivienda en dinero. Reflexiones en torno a la hipoteca inversa, dos caras de una misma moneda. (Incluye modelo)", Revista del Sector Inmobiliario, núm. 64, 2006, pp. 34-51; CATENA OLIVA, A., «L'anomenada hipoteca inversa. Una perspectiva des del dret comparat a través de l'anàlisi d'una escriptura pública signada a Catalunya-Espanya», 2006, pp. 1-11, disponible en:

http://civil.udg.es/tossa/2006/textos/com/4/aco.htm; HERRANZ GonZÁLEZ, R., «Hipoteca Inversa y figuras afines», Portal Mayores, Informes Portal Mayores, núm. 49, Madrid, 2006, pp. 1-18; MuRo VILLALÓN, J.V., «La hipoteca inversa» III Congreso de Registradores de España celebrado en Granada, 2007, pp. 1-26, disponible en:

http://www.congresoderegistradores.org/ficheros/ponencias/ponencia2.pdf; RodRíGo GARCíA, G., «La hipoteca condicionada y la hipoteca inversa. Soluciones y novedades en torno a la hipoteca», Observatorio inmobiliario, núm. 14, enero 2007, pp. 54-58; TAFFIN, C., «La hipoteca inversa o vitalicia», 2004, traducido de la versión original por la $A H E$, 2005, pp.1-12, disponible en: http://www.ahe.es; TUSET DEL PINO, P., «La hipoteca inversa: un valor en alza» Inmueble: Revista del Sector Inmobiliario, núm. 71, 2007, pp. 38-42.

2 Publicada en el BOE núm. 294, de 8 de diciembre. En la Disposición final décima se indica que: «La presente Ley entrará en vigor el día siguiente al de su publicación en el Boletín Oficial del Estado».

${ }^{3}$ Así lo ha considerado MULLOR, L., «La Ley de reforma del mercado hipotecario», Circular núm. 1 de la Federación Hipotecaria Europea, enero 2008, p. 4.

${ }^{4}$ Vid. Gómez Gálligo, J., «Principios generales de la Ley 41/2007, de 7 de diciembre, de modificación de la ley de regulación del mercado hipotecario y otras normas del sistema hipotecario y financiero", Boletín del Colegio de Registradores de España, núm. 150, octubre de 2008, p. 2173.
} 
En febrero de 2005 se creó una Comisión Mixta constituida por representantes de la Asociación Hipotecaria Española, el Colegio de Registradores de la Propiedad, el Consejo General del Notariado y la Dirección General de los Registros y del Notariado para llevar a cabo la reforma del mercado hipotecario español. El Ministerio de Economía, con el propósito de gestionar las cuestiones económicas, se incorporó cuando ya se había confeccionado la base del texto legal, liderando desde ese momento el proceso.

Esta Comisión se propuso dar cumplimiento a la Proposición no de Ley de 3 de febrero de 2005, por la que el Congreso de los Diputados instaba al Gobierno flexibilizar y modernizar el régimen jurídico del mercado hipotecario con la intención de favorecer la accesibilidad de dicho mercado a los ciudadanos, asegurar la protección de los prestatarios, garantizar la estabilidad económica y mejorar la eficiencia en la asignación de recursos. En cumplimiento y desarrollo de la citada Proposición no de Ley, la Comisión propuso adoptar una serie de medidas que se consideraban convenientes para lograr estos objetivos.

En los medios de comunicación ${ }^{5}$, desde el momento en que comenzó a elaborarse el citado Proyecto de Ley se destacaron siempre los aspectos económicos. De estas informaciones, se decía, entre otras cosas, que el Gobierno perseguía, con esta Ley, dar una mayor protección a las economías familiares ante las posibles subidas de los tipos de interés. Esta protección, la quería diseñar a través de:

- La ampliación de la oferta de productos hipotecarios.

- La reducción de los costes de constitución de las hipotecas.

- La disminución de comisiones.

- Dotando de más independencia a las sociedades de tasación.

- Facilitando la transparencia en la información de las entidades financieras a los clientes.

\footnotetext{
${ }^{5}$ Se irá viendo a lo largo del Programa.
} 
- Fomentando las hipotecas a tipo mixto que protegían al ciudadano frente a las subidas de los tipos de interés.

Estas medidas derivaron en los Principios Generales ${ }^{6}$ que constituyen la Ley 41/2007. Básicamente son los siguientes:

- Adopción de medidas para potenciar y dar transparencia al mercado hipotecario secundario.

- Flexibilización del principio de accesoriedad e introducción de la hipoteca global o flotante.

- Fomento de acceso al Registro de las cláusulas financieras como fórmula de publicidad de los productos financieros.

- Introducción de la hipoteca recargable y nueva regulación de los supuestos de novación modificativa.

- Nueva regulación del régimen de subrogación para clarificar su operatividad en caso de existencia de dos o más préstamos o créditos a favor de una misma entidad financiera.

- Nueva regulación del procedimiento de enervación para garantizar su efectiva aplicación.

- Regulación de la hipoteca inversa para fomentar su utilización en determinadas condiciones.

Para GómEZ GÁLLIGo7 ${ }^{7}$ a pesar de estas medidas, se olvidó que ante todo era una Ley con importantes soluciones de tipo jurídico más que económico, y que su principal objetivo era conseguir un sistema hipotecario más flexible, superando el principio de accesoriedad que permitía admitir nuevos productos demandados por el mercado.

Entre otros autores, destacaríamos también las valoraciones de:

\footnotetext{
${ }^{6}$ Gómez Gálligo, J., «Principios generales...», op. cit., p. 2172; PARRA LuCÁN, M.A., «Los principios generales de la Ley 41/2007, de 7 de diciembre, de modificación de la Ley del mercado hipotecario y otras normas del sistema hipotecario", Revista Crítica de Derecho Inmobiliario (RCDI), № 711, 2008, pp. 261 y ss.

${ }^{7}$ Ibíd., pp. 2172 y 2192 . Este autor fue el coordinador del grupo de trabajo en la DGRN del Ministerio de Justicia del que salió el borrador de anteproyecto de ley.
} 
MIQUEL SILVESTRE ${ }^{8}$ para este autor, la Ley $41 / 2007$, por la que se modificaban ampliamente la Ley reguladora del Mercado Hipotecario, la Ley de Subrogación de Préstamos Hipotecarios y la Ley Hipotecaria, introdujo una serie de figuras bautizadas con nombres tan peculiares como hipoteca flotante, hipoteca recargable e hipoteca inversa. De estas figuras, tal vez la que más expectativas generó en nuestra sociedad fue la de la hipoteca inversa al presentarse como una especie de bondadosa creación crediticia, a medio camino entre el producto financiero y la obra social destinada a impedir la indigencia de aquellas personas mayores propietarias de un inmueble.

Desde el punto de vista de LUQUE JIMÉNEZ ${ }^{9}$, la diferencia de la hipoteca inversa con respecto a otros productos crediticios similares radicaba en que el solicitante seguía viviendo en su casa y no perdía la propiedad de la misma. Pero en la práctica, una de las dificultades que planteaba esta figura era el detrimento del futuro patrimonio hereditario. La constitución de una hipoteca inversa, en el caso de que hubiese futuros herederos, no dejaba de ser una decisión difícil, dado que no resultaría agradable dejar en herencia una deuda de esa naturaleza y, menos aún, recibirla.

En este sentido, HerRanz GonzÁlez ${ }^{10}$, ponía de relieve la importancia de los factores sociológicos y/o psicológicos en estas operaciones concretados en las reticencias y temores que provoca a una persona mayor desprenderse de uno de sus principales bienes, máxime si se trata de su vivienda, conseguida, quizá, después de años de ahorro y donde ha transcurrido parte de su vida. Además, también considera que juegan un papel importante las cuestiones relativas a la herencia, tanto desde el punto de vista de la persona mayor, que en ocasiones no está dispuesta a dejar a sus descendientes un bien hipotecado o directamente privarlos de ese bien. Como desde el punto de vista de la entidad bancaria que no desea tener problema legal alguno con los descendientes.

\footnotetext{
${ }^{8}$ Miquel Silvestre, J.A., «Hipoteca Inversa. Algunas hipótesis de conflicto 2008», Diario La Ley, núm, 6924, Sección Tribuna, 14 de abril de 2008, p. 1420.

9 LUQUE JIMÉNEZ, M.C., «Una nueva modalidad de hipoteca: la hipoteca inversa», RCDI, Año $n^{\circ} 85$, enerofebrero, № 711, Madrid, 2009, p. 218.

${ }^{10}$ Herranz González, R., «Hipoteca inversa...», op. cit., pp. 1-18.
} 
De esa misma opinión es ANGUITA Ríos ${ }^{11}$, al señalar que no siempre la constitución de una hipoteca inversa resulta un negocio beneficioso para la persona mayor.

Por su parte, Balluguera Gómez ${ }^{12}$, critica el fin social de las hipotecas inversas y destaca la inclusión de cláusulas abusivas en sus contratos.

A continuación y a lo largo de todo el temario analizaremos todos los puntos de la Hipoteca Inversa regulada en la Ley 41/2007 en relación con la Ley $1 / 2013$, de 14 de mayo, de medidas para reforzar la protección a los deudores hipotecarios, reestructuración de deuda y alquiler social ${ }^{13}$ (en adelante Ley 1/2013). Es decir, se detallarán los requisitos formales, los requisitos objetivos, la forma de constitución de dicha figura hipotecaria, su vencimiento, etc. De esta manera, se entenderá mejor el desarrollo de la citada modalidad a lo largo de estos años en nuestro país. No obstante, al final del programa aportaremos una comparativa con los países donde esta figura sí ha tenido un fuerte arraigo, como es el caso de Reino Unido y Estados Unidos.

Junto a esto, también examinaremos las posibilidades para que esta hipoteca pueda incluirse con todas las garantías en el mercado crediticio como una posible opción, bien para las personas que accedan a la jubilación, bien para las personas afectadas de dependencia o que se les haya reconocido un grado de discapacidad igual o superior al 33 por ciento.

\section{REGULACIONES QUE HAN INFLUIDO EN LA DISPOSICIÓN ADICIONAL PRIMERA DE LA LEY 41/2007}

\footnotetext{
11 Anguita Ríos, R.M., «Regulación relativa a la hipoteca inversa según la Ley 41/2007, de 7 de diciembre», El Consultor Inmobiliario, núm. 87, febrero 2008, p. 20.

12 Balluguera Gómez, C., «Hipoteca Inversa (notas prácticas)», Seminario de Derecho Registral, Boletín del Colegio de Registradores de la Propiedad, año XLII, núm. 131 (2ª́poca), Bilbao, enero 2007, pp. 7173.

${ }^{13}$ Ley publicada en el BOE, núm. 116, el día 15 de mayo.
} 
Antes de examinar la hipoteca inversa regulada en la Disposición Adicional Primera de la Ley $41 / 2007^{14}$ se ha de hacer una breve referencia al Real Decreto-ley 6/2012, de 9 de marzo, de medidas urgentes de protección de deudores hipotecarios sin recursos. Así como también, y de una manera especial, a la Ley $1 / 2013$, de 14 de mayo, de medidas para reforzar la protección a los deudores hipotecarios, reestructuración de deuda y alquiler social.

1. Real Decreto-ley 6/2012, de 9 de marzo, de medidas urgentes de protección de deudores hipotecarios sin recursos.

Junto a la Ley 41/2007, como reforma importante en materia de legislación hipotecaria, en el año 2012 se publicó el Real Decreto-ley 6/2012, de 9 de marzo, de medidas urgentes de protección de deudores hipotecarios sin recursos ${ }^{15}$. Pero, un año más tarde, tras ver que la crisis económica y financiera seguía en aumento en nuestro país, se publicó la Ley 1/2013, de 14 de mayo, de medidas para reforzar la protección a los deudores hipotecarios, reestructuración de deuda y alquiler social. Como resultado, el citado Real Decreto-ley se modificó en la Ley 1/2013 en su Capítulo IV.

La publicación de este Real Decreto-ley se debió a que nuestro país, cuatro años más tarde, es decir, desde 2008 hasta 2012, seguía atravesando una profunda crisis económica. Durante este tiempo se han adoptado medidas encaminadas a la protección del deudor hipotecario que, en más de una ocasión, han sido insuficientes para paliar los efectos más duros que sobre los deudores sin recursos continuaban recayendo. Esto se debe a que muchas familias se encuentran en situación de desempleo o de ausencia de actividad económica, que se ha ido prolongando en el tiempo y por esta razón han dejado de poder atender al cumplimiento de sus obligaciones derivadas de los préstamos o créditos hipotecarios acordados para la adquisición de su vivienda.

\footnotetext{
${ }_{14}$ Esta Disposición Adicional $1 .^{\text {a }}$ de la Ley 41/2007, de 7 de diciembre figura en el Anexo.

15 Publicado en el BOE, núm. 60, el día 10 de marzo.
} 
En su artículo 1 se establece el objeto de este Real Decreto-ley: «Este real decreto-ley tiene por objeto establecer medidas conducentes a procurar la reestructuración de la deuda hipotecaria de quienes padecen extraordinarias dificultades para atender su pago, así como mecanismos de flexibilización de los procedimientos de ejecución hipotecaria».

En estos años de crisis, los procesos de ejecución han aumentado considerablemente y, como resultado, un segmento de la población se está quedando privado de su vivienda, enfrentándose a serios problemas para su supervivencia en unas condiciones dignas. De ahí que el Gobierno considere que no se puede dejar de lado este problema social y por esta razón quiere adoptar una serie de medidas que permitan aportar soluciones a esta situación socioeconómica en consonancia con el derecho a disfrutar de una vivienda digna y adecuada, tal como queda reflejado en el artículo $47^{16}$ de la Constitución Española (CE), que ha de guiar la actuación de los poderes públicos de conformidad con el artículo 53.3 de la Carta Magna, así como también el mandato incluido en su artículo 9.2.

En este Real Decreto-ley se establecen diversos mecanismos dirigidos a permitir la reestructuración de la deuda hipotecaria de quienes padecen «extraordinarias dificultades para atender su pago», así como también la flexibilización de la ejecución de la garantía real.

Estas medidas se implementarán sin deteriorar los elementos fundamentales de la garantía hipotecaria sobre cuya seguridad y solvencia se viene asentando el sistema hipotecario español. La mayoría de las medidas serán de aplicación a quienes se encuentren en la denominada situación de umbral de exclusión. Esta situación se encuentra definida en su artículo 3. Posteriormente, con la Ley 1/2013 este artículo fue modificado. A este respecto, se determinó que los beneficiarios fueran personas que se

\footnotetext{
${ }^{16}$ Este artículo señala que: «Todos los españoles tienen derecho a disfrutar de una vivienda digna y adecuada. Los poderes públicos promoverán las condiciones necesarias y establecerán las normas pertinentes para hacer efectivo este derecho, regulando la utilización del suelo de acuerdo con el interés general para impedir la especulación».
} 
encontraran en una situación profesional y patrimonial que les impidiera hacer frente al cumplimiento de sus obligaciones hipotecarias y a las elementales necesidades de supervivencia.

Junto a esto, se elaboró un Código de Buenas Prácticas al que, voluntariamente, podrían adherirse las entidades de crédito y demás entidades que, de manera profesional, realicen la actividad de concesión de préstamos o créditos hipotecarios, y cuyo seguimiento por aquellas quedará supervisado por una comisión de control integrada por representantes del Ministerio de Economía y Competitividad, Banco de España, Comisión Nacional del Mercado de Valores y Asociación Hipotecaria Española. Con la aplicación de las medidas contenidas en el citado Código, que figura como Anexo a este Real Decreto-ley, se quería facilitar y promover la implicación del sector financiero español en el esfuerzo requerido con el fin de aliviar la difícil situación económica y social de muchas familias.

Actualmente, tras la entrada en vigor de la Ley 1/2013, en su Capítulo IV, artículo 8 relativo a la modificación del Real Decreto-ley 6/2012, de 9 de marzo, de medidas urgentes de protección de deudores hipotecarios sin recursos, en su punto 8 este Anexo se reprodujo de nuevo, aunque las modificaciones no son muy considerables con respecto al Anexo original.

El ámbito de aplicación viene dado en el artículo 2. Este artículo, desde que entró en vigor, ha sido modificado por la Ley 1/2013 y, más tarde, por la Ley 8/2013, de 26 de junio, de rehabilitación, regeneración y renovación urbanas $^{17}$ (en lo sucesivo, Ley 8/2013). El citado artículo narra lo siguiente:

«Las medidas previstas en este Real Decreto-ley se aplicarán a los contratos de préstamo o crédito garantizados con hipoteca inmobiliaria cuyo deudor se encuentre situado en el umbral de exclusión y que estén vigentes a la fecha de su entrada en vigor, con excepción de las contenidas en los artículos 12 y 13, que serán de aplicación general.

\footnotetext{
17 Publicada en el BOE, núm. 153, el día 27 de junio de 2013. Según la Disposición final vigésima de esta Ley 8/2013: «La presente Ley entrará en vigor el día siguiente al de su publicación en el Boletín Oficial del Estado».
} 
Las medidas previstas en este Real Decreto-ley se aplicarán igualmente a los fiadores y avalistas hipotecarios del deudor principal, respecto de su vivienda habitual y con las mismas condiciones que las establecidas para el deudor hipotecario».

La adopción de las medidas contempladas en este Real Decreto-ley resultaban imprescindibles para proteger a un colectivo social en situación de extraordinaria vulnerabilidad en el contexto económico generado por la crisis. Los efectos del desempleo sobre las familias españolas y su situación en la sociedad han producido un deterioro, tan marcado que la intervención pública no podía demorarse durante más tiempo. Es por ello por lo que la adopción de estas medidas exigía acudir al procedimiento del Real Decreto-ley, cumpliéndose los requisitos del artículo 86 de la CE en cuanto a su extraordinaria y urgente necesidad.

Como se ha ido comentando, tras la entrada en vigor de la Ley $1 / 2013$, este Real Decreto-ley sufrió varias modificaciones que analizaremos en el siguiente punto.

2. Ley $1 / 2013$, de 14 de mayo, de medidas para reforzar la protección a los deudores hipotecarios, reestructuración de deuda y alquiler social.

Esta Ley se dicta en atención a las circunstancias excepcionales creadas por la larga crisis económica que atravesamos y que han provocado que muchos ciudadanos suscriptores de préstamos hipotecarios para la adquisición de su vivienda habitual, se vean en importantes dificultades para atender a sus compromisos por causas que les son ajenas, corriendo con el riesgo de caer en una situación de exclusión social. Con esta Ley se dictan una serie de medidas con el fin de mejorar su posicionamiento jurídico e intentar aliviar su situación.

Estas medidas se desarrollan en cuatro Capítulos: 
En el Capítulo I se prevé la suspensión inmediata, y por un plazo de dos años, de los desahucios ${ }^{18}$ de las familias que se encuentren en una situación de especial riesgo de exclusión.

Esta medida ${ }^{19}$, con carácter excepcional y temporal, afectará a cualquier proceso judicial de ejecución hipotecaria o venta extrajudicial por el cual se adjudique al acreedor la vivienda habitual de personas pertenecientes a determinados colectivos. En estos casos, la Ley, sin alterar el procedimiento de ejecución hipotecaria, impedirá que se proceda al lanzamiento que culminaría con el desalojo de estas personas.

La suspensión de los lanzamientos afectará a las personas que se encuentren dentro de una situación de especial vulnerabilidad. En efecto, para que un deudor hipotecario se encuentre en este ámbito de aplicación será necesario el cumplimiento de dos tipos de requisitos:

1.- Los colectivos sociales que van a poder acogerse son: las familias numerosas, las familias monoparentales con dos hijos a cargo, las que tienen un menor de tres años o algún miembro con discapacidad o dependiente, o en las que el deudor hipotecario se encuentre en situación de desempleo y haya agotado las prestaciones sociales 0 , finalmente, las víctimas de violencia de género.

\footnotetext{
18 Según el artículo publicado en $A B C$ Economía en fecha de 19 de mayo de 2014, más de 49.600 familias, en concreto 49.694, perdieron su casa en 2013, un $11 \%$ más que un año antes, principalmente por decisión judicial hubo 28.173 desahucios, un 18,5\% más que en 2012 , según los datos publicados este lunes 19 de mayo por el Banco de España. Al margen de los desahucios, las familias también perdieron su casa en 2013, tras llegar a un acuerdo con el banco para entregarla, lo que se produjo en 21.521 ocasiones, un 2,6\% más que en 2012. A juicio de los expertos esto demuestra la voluntad negociadora de las entidades, que ha hecho que se reduzca más de un $9 \%$ la entrega de las primeras viviendas, hasta 17.907, y se multiplique por 2,8 la de otro tipo de inmuebles, principalmente segundas residencias, que llegó a 3.614. De esta manera, fue posible que hubiera 16.173 daciones en pago, un 1,3\% más que un año antes, con una reducción del $13,15 \%$ en el caso de viviendas habituales, hasta 13.178, y un aumento de 3,7 veces en otras viviendas, hasta un total de 2.995. En total, teniendo en cuenta desahucios y entregas voluntarias, casi el $80 \%$ de las 49.694 viviendas cedidas por las familias el pasado año, exactamente 38.961 propiedades, eran el domicilio habitual, un 0,23\% menos, y las 10.733 eran otro tipo de viviendas, como es el caso de segundas residencias, un $88,5 \%$ más. En el caso de las primeras viviendas, la mayoría, unas 21.054, fueron entregadas al banco por decisión del juez, un $8,9 \%$ más, mientras que en 17.907 casos las familias accedieron de forma voluntaria, un $6,6 \%$ menos. Junto a estos datos, señalar también que de forma general se puede considerar que cada vivienda entregada corresponde exactamente con una familia, aunque no debe obviarse que en algunos casos puntuales, que el Banco no detalla, una misma familia ha podido perder más de una vivienda.

${ }_{19}$ La Disposición Transitoria Primera de la Ley 1/2013 ordena que: «Esta Ley será de aplicación a los procesos judiciales o extrajudiciales de ejecución hipotecaria que se hubieran iniciado a la entrada en vigor de la misma, en los que no se hubiese ejecutado el lanzamiento».
} 
2.- Además, las familias que se acojan a esta suspensión, sus ingresos no podrán superar el límite de tres veces el Indicador Público de Renta de Efectos Múltiples (IPREM).

Este límite se eleva respecto de unidades familiares en las que algún miembro sea persona con discapacidad o dependiente o que conviva con personas con discapacidad o dependientes. También será necesario que, en los cuatro años anteriores al momento de la solicitud, la unidad familiar haya sufrido una alteración significativa de sus circunstancias económicas, en términos de esfuerzo de acceso a la vivienda. Así, la alteración significativa de sus circunstancias económicas se mide en función de la variación de la carga hipotecaria sobre la renta sufrida en los últimos cuatro años.

Finalmente, la inclusión en el ámbito de aplicación pasa por el cumplimiento de otros requisitos, entre los que se pueden destacar que la cuota hipotecaria resulte superior al 50 por ciento de los ingresos netos que perciba el conjunto de los miembros de la unidad familiar, o que se trate de un crédito o préstamo garantizado con hipoteca que recaiga sobre la única vivienda en propiedad del deudor y concedido para la adquisición de la misma.

La trascendencia de esta previsión normativa es indudable, pues garantiza que durante ese período de tiempo, los deudores hipotecarios especialmente vulnerables no puedan ser desalojados de sus viviendas, con la confianza de que, a la finalización de ese período, habrán superado esa grave situación. Para estos deudores especialmente vulnerables se prevé, además, que la deuda que no haya podido ser cubierta con la vivienda habitual no devengue más interés de demora que el resultante de sumar a los intereses remuneratorios un dos por cien sobre la deuda pendiente.

En el Capítulo II se introducen mejoras en el mercado hipotecario a través de la modificación de la Ley Hipotecaria, Texto Refundido según 
Decreto de 8 de febrero de 1946; la Ley 2/1981 de 25 de marzo, de Regulación del Mercado Hipotecario; y la Ley 41/2007, de 7 de diciembre por la que se modifica la Ley 2/1981, de 25 de marzo, de Regulación del Mercado Hipotecario y otras normas del sistema hipotecario y financiero, de regulación de las hipotecas inversas y el seguro de dependencia y por las que se establece determinada norma tributaria.

Cabe destacar el hecho de que, para las hipotecas constituidas sobre vivienda habitual, se limitarán los intereses de demora que puedan exigir las entidades de crédito a tres veces el interés legal del dinero. Además, se prohíbe expresamente la capitalización de estos intereses y se establece que, en caso de que el resultado de la ejecución fuera insuficiente para cubrir la deuda garantizada, dicho resultado se aplicará en último lugar a los intereses de demora, de tal forma que se permita en la mayor medida posible que el principal deje de devengar interés.

Adicionalmente se fortalece en la Ley Hipotecaria el régimen de venta extrajudicial $^{20}$ de bienes hipotecados. Por otro lado, se refuerza la independencia de las sociedades de tasación respecto de las entidades de crédito.

En este Capítulo II sobre Medidas de Mejora del Mercado Hipotecario, en lo referente al estudio sobre la hipoteca inversa, estas medidas afectan a tres leyes:

- La Ley Hipotecaria. En esta Ley se añade un apartado 3 al artículo 21 y un tercer párrafo al artículo 114 y, además, se modifica el artículo 129, ampliando en gran medida su contenido.

\footnotetext{
${ }^{20}$ En la venta extrajudicial se introduce la posibilidad de que el notario pueda suspender la misma cuando las partes acrediten que se ha solicitado al órgano judicial competente, en la forma prevista por el artículo 129 de la LH, que dicte resolución decretando la improcedencia de dicha venta por existir cláusulas abusivas en el contrato de préstamo hipotecario, o su continuación sin la aplicación de las cláusulas abusivas. Además se faculta expresamente al notario para que advierta a las partes de que alguna cláusula del contrato puede ser abusiva. Dichas modificaciones se adoptan como consecuencia de la Sentencia del Tribunal de Justicia de la Unión Europea de 14 de marzo de 2013, dictada en el asunto por el que se resuelve la cuestión prejudicial planteada por el Juzgado de lo Mercantil n. ${ }^{\circ} 3$ de Barcelona respecto a la interpretación de la Directiva 93/13/CEE del Consejo, de 5 de abril de 1993.
} 
- La Ley 2/1981, de 25 de marzo, de Regulación del Mercado Hipotecario con respecto a las Sociedades de Tasación. Se endurecen las exigencias de independencia para las Sociedades de Tasación con diversas medidas y se refuerza la obligación de las entidades financieras de aceptar la tasación entregada por el cliente. Se modifican los artículos 3, apartado 2.a) $1 .^{a}$ del artículo tercero bis, la letra a) del artículo tercero bis. 4, el artículo tercero bis I), los apartados 1 y 2 del artículo tercero ter, el segundo párrafo del artículo quinto $\mathrm{y}$, además, se suprime el tercer párrafo del artículo quinto.

- Y por último, la Ley 41/2007, de 7 diciembre, por la que se modifica la Ley 2/1981, de 25 de marzo, de regulación del Mercado Hipotecario y otras normas del sistema hipotecario y financiero, de regulación de las hipotecas inversas y el seguro de dependencia, concretamente, al requisito subjetivo. Con este requisito se amplía el número de solicitantes de esta modalidad hipotecaria.

En el artículo 5 se modifica la letra a) de la Disposición Adicional Primera, ampliándose el número de solicitantes de esta modalidad hipotecaria. Se trata de una modificación sistemática que afecta al requisito subjetivo para que el negocio jurídico se siga considerando hipoteca inversa con arreglo a lo preceptuado en la Ley 41/2007, en su Disposición Adicional $1 .^{a}$.

En el Capítulo ${ } \mathrm{II}^{21}$ se recogen diferentes modificaciones a la Ley de Enjuiciamiento Civil con el fin de garantizar que la ejecución hipotecaria se realice de manera que los derechos e intereses del deudor hipotecario sean protegidos de manera adecuada y, en su conjunto, se agilice y flexibilice el procedimiento de ejecución.

\footnotetext{
${ }^{21}$ Con la entrada en vigor de la Ley 8/2013 se modifica la rúbrica de este Capítulo III, en los siguientes términos: «Mejoras en el procedimiento de ejecución». Anteriormente, se denominaba «Mejoras en el procedimiento de ejecución hipotecaria».
} 
En particular, como medida de gran relevancia, se establece la posibilidad de que si tras la ejecución hipotecaria de una vivienda habitual aún quedara deuda por pagar, durante el procedimiento de ejecución dineraria posteriormente se podrá condonar parte del pago de la deuda remanente, siempre que se cumpla con ciertas obligaciones de pago. Además, se permite que el deudor participe de la eventual revalorización futura de la vivienda ejecutada.

Por otro lado, se facilita el acceso de postores a las subastas y se rebajan los requisitos que se imponen a los licitadores, de modo que, por ejemplo, se disminuye el aval necesario para pujar del 20 al 5 por cien del valor de tasación de los bienes. Asimismo se duplica, en idéntico sentido, el plazo de tiempo para que el rematante de una subasta consigne el precio de la adjudicación. De esta manera, se introducen determinadas mejoras en el procedimiento de subasta, estableciéndose que el valor de tasación a efectos de la misma no podrá ser inferior al 75 por cien del valor de tasación que sirvió para conceder el préstamo. Anteriormente no existía ningún límite para el tipo de subasta. Además, en caso de que la subasta concluyera sin postor alguno, se incrementan los porcentajes de adjudicación del bien. En concreto, se elevaría del 60 por cien hasta un máximo del 70 por cien, siempre para los supuestos de vivienda habitual.

Este Capítulo también recoge la modificación ${ }^{22}$ del procedimiento ejecutivo a efectos de que, de oficio o a instancia de parte, el órgano judicial competente pueda apreciar la existencia de cláusulas abusivas en el título ejecutivo y, como consecuencia, decretar la improcedencia de la ejecución o, en su caso, su continuación sin aplicación de aquéllas consideradas abusivas.

Por último, el Capítulo IV modifica el Real Decreto-ley 6/2012, de 9 de marzo, de medidas urgentes de protección de deudores hipotecarios sin

\footnotetext{
22 Esta modificación, como ya se ha señalado, se adopta con motivo de la STJUE de 14 de marzo de 2013, dictada en el asunto por el que se resuelve la cuestión prejudicial planteada por el Juzgado de lo Mercantil $n .^{\circ} 3$ de Barcelona respecto a la interpretación de la Directiva 93/13/CEE del Consejo, de 5 de abril de 1993.
} 
recursos, tanto en lo que afecta al ámbito de aplicación, como en lo relativo a las características de las medidas que pueden ser adoptadas.

Con la entrada en vigor de la Ley 1/2013, el ámbito de aplicación se extiende también a los avalistas hipotecarios respecto de su vivienda habitual y con las mismas condiciones que las establecidas para el deudor hipotecario.

Con respecto a la definición del umbral de exclusión, regulado en el artículo 3, se reducen las circunstancias que han de darse, pasando de seis a tres, aunque no por ello dejan de ser extensas y detalladas.

Se introduce un artículo 3 bis $^{23}$ referente a los fiadores, avalistas e hipotecantes no deudores, según el cual, aquellos que se encuentren en el umbral de exclusión podrán exigir que la entidad agote el patrimonio del deudor principal, y las medidas previstas en el Código de Buenas Prácticas, antes de reclamarles la deuda garantizada, aunque haya habido renuncia al beneficio de excusión ${ }^{24}$.

Se modifica el artículo 4 relativo a los intereses moratorios para los contratos de crédito o préstamo garantizados con hipoteca inmobiliaria, pero sólo para los regulados en este Real Decreto-ley. En aquéllos en los que el deudor se encuentre situado en el umbral de exclusión, el interés moratorio aplicable desde el momento en el que el deudor solicite a la entidad la aplicación de cualquiera de las medidas del Código de Buenas Prácticas y acredite ante la entidad que se encuentra en dicha circunstancia (antes en el artículo 4 original se tenía que acreditar), será como máximo, el resultante de sumar a los intereses remuneratorios pactados en el préstamo un 2 por ciento (anteriormente era de un 2,5\%) sobre el capital pendiente del préstamo.

\footnotetext{
${ }^{23}$ Este artículo ha sido modificado por la Ley 8/2013. De esta manera, las medidas previstas en el Real Decreto-ley se aplicarán igualmente a los fiadores y avalistas hipotecarios del deudor principal. En la Ley $1 / 2013$ la figura del fiador no se contemplaba.

${ }^{24}$ Con la entrada en vigor de la Ley $8 / 2013$ se ha cambiado a «beneficio de excusión». En la redacción final de la Ley $1 / 2013$ se corrigió la expresión del texto enviado al Senado «beneficio de excusión» expresión correcta, por la de «beneficio de exclusión» que en palabras de MERINO ESCARTín, Registrador de la Propiedad de Fuenlabrada (Madrid), no tenía ningún sentido. Vid. MERINo Escartín, J.F., «Resumen de la Ley 1/2013 de Protección de Deudores Hipotecarios, Reestructuración de Deuda y Alquiler Social», mayo de 2013, disponible en la página de Internet: www.notariosyregistradores.com.
} 
En el artículo 5, referente a la sujeción del Código de Buenas Prácticas, se aumenta la cuantía de los préstamos y créditos hipotecarios que se pueden acoger al Código de Buenas Prácticas, de tal manera que se aplicará a más casos. Además, se incluyen unos límites inferiores para el acceso a la dación en pago obligatoria. Se obliga también a las entidades suscriptoras, a publicitar el Código de Buenas Prácticas en su red de comercialización, aunque esto ya se recogía en el punto 4 del Anexo. Con la nueva redacción, su incumplimiento puede ser infracción grave.

En cuanto al artículo 6, se amplía la Comisión de Control del Código de Buenas Prácticas pasando de 4 a 11 miembros. Entre ellos habrá un notario nombrado por el Consejo General del Notariado. No se incluye en la Comisión a ningún registrador de la propiedad, sin considerar de esta manera el papel tan importante que cumple este colectivo en la materia y en las estadísticas que se confeccionan en el Colegio de Registradores de la Propiedad. Aumenta el número de funciones de esta Comisión, al facultarla para presentar al Gobierno propuestas relativas a la protección de los deudores hipotecarios. Y sus informes deberán remitirse también al Congreso de los Diputados.

Se añade un nuevo Capítulo, concretamente, el VI, en el que se hace mención al Régimen Sancionador, donde determinadas obligaciones de las entidades adheridas al Código de Buenas Prácticas tendrán la condición de normativa de ordenación y disciplina, conforme a lo previsto en la Ley 26/1988, de 29 de julio, sobre Disciplina e Intervención de las Entidades de Crédito, y el incumplimiento de las obligaciones que derivan de los mismos se considerará infracción grave, que se sancionará de acuerdo con lo establecido en la citada Ley.

Y, por último, con respecto al Anexo, como ya se ha dicho anteriormente, las modificaciones resultan poco considerables, aunque merece reseñarse lo siguiente: 
En cuanto a las medidas previas a la ejecución hipotecaria, se mantiene que la solicitud de reestructuración sólo cabe hasta el anuncio de la subasta. Ahora bien, se añade que el deudor podrá presentar en todo momento a la entidad una propuesta de plan de reestructuración, que deberá ser examinada por la entidad, quien, en caso de rechazo, deberá comunicar al deudor los motivos en que se fundamente.

La carencia en la amortización de capital podrá llegar a los cinco años, cuando el Real Decreto-ley establecía cuatro. El capital correspondiente a las cuotas de ese periodo podrá, o bien pasarse a una cuota final al término del préstamo, o bien prorratearse en las cuotas restantes, o hacer una combinación.

En cuanto a las medidas complementarias, se mantienen los casos en los que se procede la quita por resultar inviable el plan de reestructuración, siendo incluso posible con un procedimiento de ejecución hipotecaria en curso en el que se haya producido el anuncio de la subasta. No obstante, se amplían los casos de inviabilidad al bajar de un $60 \%$ a un $50 \%$ el porcentaje resultante de comparar la cuota con los ingresos de la unidad familiar, pues por encima de ese porcentaje se estima inviable el plan de reestructuración.

Con respecto a las medidas sustitutivas de la ejecución hipotecaria, la dación en pago contemplada sigue siendo subsidiaria de las medidas de reestructuración y quita para los deudores que cumplan los requisitos del artículo 2. Junto a esto, el interés de demora que ha de pagar el deudor que se mantenga como arrendatario en caso de impago de la renta pasa del $20 \%$ al $10 \%$.

Para finalizar, destacar la Disposición Transitoria Octava, in fine, en la que se especifica que: «Las entidades que se hubieran adherido al Código de Buenas Prácticas aprobado por el Real Decreto Ley 6/2012, de 9 de marzo, de medidas urgentes de protección de deudores hipotecarios sin recursos y no se adhieran a las modificaciones introducidas en el mismo por esta Ley seguirán obligadas en los términos de dicho Real Decreto-ley, en su versión originaria». 
Adicionalmente, esta Ley incluye un mandato al Gobierno para que emprenda inmediatamente las medidas necesarias para impulsar, con el sector financiero, la constitución de un fondo social de viviendas destinadas a ofrecer cobertura a aquellas personas que hayan sido desalojadas de su vivienda habitual por el impago de un préstamo hipotecario. Este fondo debiera movilizar un amplio parque de viviendas, propiedad de las entidades de crédito, en beneficio de aquellas familias que sólo pueden acceder a una vivienda en caso de que las rentas se ajusten a la escasez de sus ingresos.

Se ha desarrollado más este Capítulo IV de la Ley 1/2013 sobre la Modificación del Real Decreto-ley 6/2012, de 9 de marzo, de medidas urgentes de protección de deudores hipotecarios sin recursos, por la sencilla razón de que las modificaciones que aquí nos afectan, es decir, las correspondientes en los Capítulos II y III, las iremos analizando a lo largo de este estudio sobre la hipoteca inversa.

\section{ESCENARIO ACTUAL}

Un año después de la entrada en vigor de la Ley 41/2007 estalla la crisis del sector financiero y, más concretamente, del sector inmobiliario. Esta crisis ha ido evolucionando hasta nuestros días transformándose en una crisis económica generalizada que ha repercutido muy negativamente en la implantación y desarrollo de la hipoteca inversa.

Prueba de ello es la falta de liquidez de las entidades financieras y la desconfianza en el sistema, lo que se ha traducido en un endurecimiento y restricción de la concesión de préstamos hipotecarios. Por esta razón se ha hecho muy difícil la consolidación de esta figura hipotecaria, mostrándose un gran desinterés por parte de los bancos y de las entidades de crédito como consecuencia de la actual situación económica y financiera. 
De ahí que las entidades financieras no hayan anunciado ni ofertado lo suficiente esta figura hipotecaria con la finalidad de impulsar su utilización, pues a pesar de que puede constituir una buena alternativa a planes y fondos de pensiones, la hipoteca inversa ${ }^{25}$ en 2015 , sigue siendo un producto desconocido, pero ello no quiere decir que haya desaparecido ${ }^{26}$.

A todos estos obstáculos se suma la evolución que ha experimentado recientemente el precio de la vivienda, pues se ha pasado de un imparable ascenso a una congelación llegando finalmente a una depreciación de los inmuebles ${ }^{27}$, descenso que afecta muy negativamente a la estructura de la hipoteca inversa. Pues, una de las características de la hipoteca inversa es que la vivienda constituye la garantía fundamental del préstamo y este préstamo por otra parte va a ir aumentando con el paso del tiempo. Si este préstamo se incrementa y la garantía se deprecia, poca confianza puede ofrecer la hipoteca inversa a las entidades financieras.

Desde un punto de vista positivo, tal vez a medida que se estabilice la situación económica, esta figura logre desarrollarse en España, pues se

\footnotetext{
${ }^{25}$ Según el artículo publicado en $A B C$ Economía en fecha de 23 de abril de 2014 se intuye que con la reforma de las pensiones a la vuelta de la esquina, la hipoteca inversa está llamada a ser la alternativa a Planes de Pensiones y PIAS para que los jubilados afronten el retiro sin perder poder adquisitivo. En el mismo artículo se declara que existen empresas que se dedican a la gestión y tramitación de la hipoteca inversa. Además, informa de que algunas entidades siguen ofreciéndola, aunque no la promocionen tanto como las hipotecas tradicionales, así, La Caixa, BBK o Ibercaja son algunas de las entidades donde se puede encontrar este producto financiero.

${ }^{26} \mathrm{Sin}$ ir más lejos, en fecha de 8 de diciembre de 2014 se publicita la hipoteca inversa en el diario $A B C$, p. 4. En el anuncio se informa de que con la contratación de la hipoteca inversa se puede percibir una pensión vitalicia y, además, se puede vender o alquilar la vivienda. El mismo anuncio nos remite a una dirección: www.solucioneseconomicasurgentes.com. Pero, al visitar esta página ya no se dice nada al respecto.

${ }^{27}$ La crónica publicada en el periódico El Mundo en fecha de 25 de noviembre de 2013 en la Sección de Economía, indica que según la Agencia de calificación crediticia Moody's, la depreciación acumulada desde el comienzo de la crisis por las viviendas embargadas en España alcanza una media del 63\%. Es decir, un porcentaje muy por encima del descenso medio del $41 \%$ registrado, según el Instituto Nacional de Estadística (INE), en el precio de la vivienda entre el primer trimestre de 2007 y el segundo trimestre de 2013. La calificadora de riesgos señala que los mayores descensos de precios corresponden a ventas de viviendas embargadas en las Comunidades Autónomas de Murcia (-78\%), Valencia (-71\%), Cataluña y Andalucía (ambas 69\%), y junto con Canarias (-67\%). En estas regiones, el descenso medio del precio de la vivienda entre el primer trimestre de 2007 y el segundo trimestre de 2013 ha sido del $32 \%$ en el caso de Murcia, Canarias y Andalucía, del $37 \%$ en el caso de Valencia y del $48 \%$ en el de Cataluña. En el conjunto de España, las mayores bajadas del precio de la vivienda desde el comienzo de la crisis corresponden a Cataluña y Aragón (48\%), Madrid (46\%) y País Vasco (43\%). En el caso de Castilla y León, el precio de la vivienda acumula un descenso medio del 39\%. La bajada es del $37 \%$ en Castilla-La Mancha y Valencia. Además de estos datos, Moody's advierte que «las mayores pérdidas se concentran en las propiedades embargadas de la costa del Mediterráneo, Andalucía y Canarias (...) aunque no conllevará una bajada de rating, la asunción de grandes pérdidas en las viviendas hipotecadas embargadas resulta negativo para el crédito».
} 
advierte cada vez un mayor endeudamiento de los poderes públicos, lo que repercute negativamente en las pensiones. Prueba de ello es el Real Decretoley $28 / 2012$, de 30 de noviembre, de medidas de consolidación y garantía del sistema de la Seguridad Social ${ }^{28}$ que en su Disposición I dicta lo siguiente:

«La crisis está suponiendo un elevado déficit del sistema de la Seguridad Social durante el ejercicio 2012, con las consiguientes tensiones de liquidez que se verán acentuadas en el próximo mes de diciembre de 2012, en el que han de abonarse dos mensualidades, ordinaria y extraordinaria, de pensiones de la Seguridad Social.

La situación descrita determina la imperiosa necesidad de establecer, durante los ejercicios 2012, 2013 y 2014 unas condiciones excepcionales para la disposición del Fondo, dejando sin efecto durante los mencionados ejercicios la limitación del tres por ciento de la suma de los conceptos previstos en el artículo 4 de la Ley 28/2003, de 29 de septiembre.

Por todo ello, queda plenamente justificada la extraordinaria y urgente necesidad de la situación que legitima la adopción de este real decreto-ley por el que se fija un nuevo límite en la disposición de activos del Fondo de Reserva de la Seguridad Social y se autoriza durante los ejercicios 2012, 2013 y 2014 la disposición del Fondo de Reserva de la Seguridad Social, a medida que surjan las necesidades, hasta un importe máximo equivalente al déficit presupuestario de las entidades gestoras y servicios comunes de la Seguridad Social».

En su artículo 1 establece que: «Durante los ejercicios 2012, 2013 y 2014, no resultará de aplicación el límite del tres por ciento fijado con carácter general en el artículo 4 de la Ley 28/2003, de 29 de septiembre, reguladora del Fondo de Reserva de la Seguridad Social.

Durante los citados ejercicios, el límite de la disposición será el equivalente al importe del déficit por operaciones no financieras que pongan de manifiesto las previsiones de liquidación de los presupuestos de las entidades gestoras y servicios comunes de la Seguridad Social, que al efecto elabore la Intervención General de la Seguridad Social, con arreglo a los criterios establecidos en la normativa del Fondo de Reserva de la Seguridad Social».

Como resultado en la Disposición Adicional Segunda, sobre el incremento de pensiones ${ }^{29}$, se confirma lo siguiente: «Las pensiones abonadas por

\footnotetext{
${ }^{28}$ Publicado en el BOE, núm. 289, en fecha de 1 de diciembre de 2012.

29 Como novedad, en 2014, las pensiones contributivas de la Seguridad Social, así como las de las Clases Pasivas del Estado se revalorizaron en un 0,25\%. La pensión máxima quedó fijada en un valor anual de $35.762,49$ euros $(2.554,49$ euros en 14 pagas mensuales). Para este año 2015, y según el Real Decreto $1107 / 2014$, de 26 de diciembre, sobre revalorización de las pensiones del sistema de la Seguridad Social y de otras prestaciones públicas para el ejercicio 2015, estas pensiones se vuelven a incrementar en un $0,25 \%$.
} 
el sistema de la Seguridad Social, así como de Clases Pasivas, se incrementarán en 2013 un uno por ciento tomando como referencia la cuantía legalmente establecida a 31 de diciembre de 2012.

No obstante, se incrementarán un uno por ciento adicional al previsto en los Presupuestos Generales del Estado para el año 2013 todas aquellas pensiones que no superen los 1.000 euros mensuales o 14.000 euros en cómputo anual. Estas pensiones, por tanto, se incrementarán en el dos por ciento».

Con este panorama será necesario articular mecanismos que permitan a las personas mayores obtener recursos económicos. Una posibilidad podría ser la hipoteca inversa.

La figura de la hipoteca inversa no nace con esta Ley, pues con anterioridad a la misma, ya se pactaban otro tipo de hipotecas inversas ${ }^{30}$. Ahora bien, estas hipotecas no están reguladas en esta Ley. Con la Ley $41 / 2007$ lo que se pretendía era potenciar la utilización de la hipoteca inversa, entre otras razones, por los incentivos fiscales y arancelarios que se le concedían ${ }^{31}$. Tras la situación tan crítica por la que han pasado la mayoría de las entidades de crédito (promociones inmobiliarias fallidas, reestructuración de plantilla, etc.), éstas no han ofertado este tipo de producto debido a que no estaba muy claro el tipo de incentivos a los que está sometida la hipoteca inversa.

En la actualidad, los analistas creen que el sector inmobiliario comienza a dar signos de estabilización, sobre todo en las grandes ciudades. Para este año 2015 se prevé vender más casas, conceder más hipotecas y construir más edificios, pero todo en niveles aún bajos ${ }^{32}$.

Esta modalidad hipotecaria ${ }^{33}$ podría ser un instrumento muy útil para permitir que las personas mayores ${ }^{34}$ pudieran obtener ingresos

\footnotetext{
30 Con anterioridad a la Ley 41/2007, podemos encontrar varias referencias relativas a la hipoteca inversa, entre otras: las Resoluciones de la DGRN de 21 de diciembre de 2007, 8, 22, 28 y 29 de febrero de 2008; 1, 6, 14 y 15 de marzo de 2008 o 14, 16, 19 y 20 de mayo de 2008.

31 Gómez Gálligo, J., «Principios generales...», op. cit., pp. 2171 y ss.

32 Vid. artículo publicado en Expansión en fecha de 27 de diciembre de 2014. Disponible en: www.expansion.com/2014/12/26/economia/14.

33 Álvarez Álvarez, H., La hipoteca inversa. Una alternativa económica en tiempos de crisis, Lex Nova, Valladolid, 2009, p. 19.
} 
complementarios liquidando una serie de activos como, por ejemplo, la vivienda habitual u otros inmuebles.

Si analizamos los datos estadísticos, en España las personas mayores disponen de muy poco poder adquisitivo por las escasas pensiones que perciben, y a ello se le une una serie de gastos elevados debido a la necesidad de ayuda asistencial, mientras que, por otro lado, la inmensa mayoría tiene inmuebles en propiedad libres de cargas. A esto podemos sumar que como consecuencia de la situación actual de desempleo ${ }^{35}$, hemos llegado a los seis millones de parados. En nuestro país, parte de la población activa ha estado y en buena parte aún está subsistiendo gracias a las pensiones de jubilación de sus familiares (de sus padres e incluso de sus abuelos).

Antes de la implantación de esta Ley, para poder obtener dinero en efectivo utilizando la vivienda prácticamente había dos formas: una era vendiendo la casa y la otra obteniendo un préstamo garantizado por el valor acumulado de la vivienda, pero con la obligación de hacer pagos mensuales para ir pagando la deuda a la entidad acreedora. Sin embargo, con esta nueva Ley habría una tercera manera que podría ayudar a la movilización del patrimonio inmobiliario: la hipoteca inversa ${ }^{36}$.

\footnotetext{
${ }^{34}$ Martínez Escribano, C., La hipoteca inversa, Cuadernos De Derecho Registral, Fundación Registral, Colegio de Registradores de la Propiedad y Mercantiles de España, Madrid, 2009, pp. 17-23.

35 Según los datos que ha dado a conocer el Ministerio de Empleo, a través del Servicio Público de Empleo (Sepe), en febrero de 2015 el paro ha disminuido en 13.538 personas con respecto al mes anterior. Esto supone que en la actualidad hay 4,51 millones de personas en situación de desempleo. Desde el Ministerio de Empleo se insiste en que estos datos del paro reflejan una tendencia bajista del desempleo y apunta a que están en consonancia con los datos de Afiliación a la Seguridad Social. Según las mismas fuentes, también cabe resaltar que en enero de 2008 (año en que prácticamente empezó a comercializarse la hipoteca inversa) la tasa de paro era de 2,6 millones de personas en situación de desempleo. No obstante, la temporalidad sigue siendo la reina de nuestro mercado laboral y la tasa de cobertura continúa descendiendo de manera preocupante.

${ }^{36}$ A través de un estudio realizado por el Instituto BBVA de Pensiones en fecha de 23 de enero de 2014, nuestro país, como ya es sabido, es un país con un fuerte arraigo de la cultura de tener una vivienda en propiedad. Además de la función residencial, se ha considerado a la vivienda como un elemento de acumulación patrimonial, lo cual ha venido además incentivado por las fuertes revalorizaciones que ha sufrido el mercado inmobiliario durante los años de crecimiento del mismo. España es el noveno país de Europa en porcentaje de vivienda en propiedad, con un ratio de $83 \%$ en propiedad y un $17 \%$ en alquiler, frente al $71 \%$ y el $29 \%$ de la media europea. En cuanto al segmento de población de más de 65 años, el $87 \%$ de ellos, en nuestra sociedad, son propietarios de una vivienda. Este artículo ya deja ver que en los próximos años si la reciente desaceleración en el mercado inmobiliario y la actual coyuntura económica y laboral en España podrían provocar una cierta reponderación en el reparto "compra frente a alquiler", puesto que ésta última ha ganado adeptos por su flexibilidad y por no requerir de un capital inicial. En línea con la visión de la vivienda como una "hucha no financiera", existe un producto enfocado al complemento de las rentas de jubilación: la hipoteca inversa.
} 
Sin embargo, esta forma de obtener ingresos no parece la más adecuada para su desarrollo a corto plazo $^{37}$, pues juega en contra la situación tan crítica que está soportando el mercado inmobiliario. De hecho, en la práctica, tener una vivienda en propiedad y conseguir pagar una hipoteca, supone un gran esfuerzo que realizan muchas personas en todo el mundo, no sólo en España, ya que los precios de la vivienda siguen por encima de las posibilidades de la población, y más ahora en que muchas familias se encuentran en situación de desempleo y con recursos escasos para poder afrontar la carga de una hipoteca.

Además, hay que tener presente que la hipoteca convencional ${ }^{38}$, desde 2008 cuando ya se evidencia la crisis económica, está siendo cuestionada y sometida a debate casi a diario, pues se pretende que se renueve para adaptarse a la actual situación del mercado inmobiliario ${ }^{39}$. No obstante, el derecho real de hipoteca tiene una gran aceptación en nuestro país, pues es la garantía que ofrece una mayor seguridad al acreedor, ya que el sistema de publicidad inmobiliaria favorece el crédito territorial y con ello la dinamización económica de la sociedad.

Según ROCA SASTRE ${ }^{40}$, aunque refiriéndose a la hipoteca cambiaria o en garantía de letras de cambio, «es un fenómeno bastante frecuente que las necesidades del comercio entre los hombres se adelanten a las previsiones del legislador, el cual la mayor parte de las veces es tardo en sus formaciones.

Las necesidades del comercio jurídico han podido más que la previsión legislativa, de suerte que son varios los países en los que esta variante hipotecaria ha ido imponiéndose al amparo de los usos, y algunas con el auxilio eficaz del Notariado».

\footnotetext{
37 URía FernándeZ, F., «Conclusiones provisionales a propósito de la Ley 41/2007» Revista de Derecho Bancario y Bursátil (RDBB), núm. 112, octubre-diciembre 2008, p. 31.

${ }^{38}$ No obstante, según los últimos datos publicados por el INE, en fecha de 26 de febrero de 2015, el número de hipotecas constituidas sobre viviendas aumentó un 1,6\% respecto al año anterior, hasta sumar 202.954, regresando así a tasas positivas tras siete años de caídas. El tipo de interés medio para las hipotecas sobre viviendas se sitúa en el 3,50\%. Estos datos se pueden contemplar con más detenimiento en el Centro de Información Estadística del Notariado: http://www.notariado.org.

39 Denominación, en contraposición con la hipoteca inversa, señalada por RoCA SASTRE, R.M; ROCA-SASTRE MUNCUNILL, L. y BERNÀ I XIRGó, J., Derecho hipotecario, tomo VIII, 9. a ed., Bosch, Barcelona, 2009, p. 121.

${ }^{40}$ Roca Sastre, R.M y Roca-SAStre Muncunill, L., Derecho hipotecario, hipotecas, tomo VIII, 8. ${ }^{a}$ ed., Bosch, Barcelona, 1998, p. 447.
} 
Lo mismo ha sucedido con la hipoteca inversa, figura que se ha ido utilizando en la práctica, ofertándose por las entidades de crédito, ante la necesidad de las personas mayores de encontrar un complemento a sus escasas pensiones ${ }^{41}$.

El fundamento de la hipoteca inversa es su importancia práctica, pues se trata de una figura que a pesar de que no se encontraba regulada en nuestro país, las entidades financieras y aseguradoras la ofertaban a determinados clientes como una especie de seguro para la vejez. Antes de la aprobación de la Ley 41/2007, eran varias las entidades financieras que promovían esta modalidad hipotecaria como fórmula de complementar el sistema público o privado de pensiones ${ }^{42}$. Y esto se debía a que era necesario crear nuevas fórmulas hipotecarias para dar respuesta a nuevas necesidades, como es el caso de la hipoteca inversa.

Estas necesidades vienen provocadas por el aumento de la esperanza de vida $^{43}$, la disminución del poder adquisitivo de los jubilados y porque la mayoría de este colectivo son propietarios de viviendas libres de cargas, que tienen un valor económico tasable. Es decir, la hipoteca inversa nace en un momento muy concreto, en el que concurren las anteriores circunstancias descritas a las que cabe añadir la trayectoria vital ahorradora de ese colectivo de jubilados-propietarios.

\footnotetext{
41 Según el estudio realizado por Abellán García, A. y Pujol RodrígueZ, R., «Un perfil de las personas mayores en España, 2013. Indicadores estadísticos básicos», Informes Envejecimiento en red $n^{\circ} 1$, Madrid, 2013, p. 17, prácticamente la totalidad de las personas mayores recibe alguna prestación económica del sistema público de pensiones (directamente o a través del cónyuge). En febrero de 2013 la pensión media ascendía a 851,2 euros mensuales. Las pensiones más altas corresponden a las del régimen especial del carbón y las del régimen general y las más bajas son las antiguas del SOVI (Seguro Obligatorio de Vejez e Invalidez). La mayor parte de las pensiones del Sistema de Seguridad Social (SGSS) corresponde al régimen general (6,1 millones). La pensión de jubilación (5,4 millones) es el tipo de pensión más extendida frente a los 2,3 millones de pensiones de viudedad. En total hay 9 millones de pensiones en el SGSS.

42 Vid. Díaz Fralle, J.M., «La nueva regulación de las novaciones y subrogaciones de los préstamos hipotecarios. Retos y riesgos de la reforma hipotecaria», Diario La Ley, 6727, junio 2007.

${ }^{43}$ Alonso PÉreZ, M., «Diversas formas de valorar la ancianidad y sus consecuencias», Protección jurídica de los mayores, La Ley, Madrid, 2004, p. 4, en la citada ponencia apuntaba lo siguiente: «Hay un hecho evidente: durante siglos (a principios del siglo XX, aún la media de vida en España era de cuarenta años; treinta, la media del mundo) la ancianidad fue un hecho circunstancial. Hoy las esquelas mortuorias nos brindan a menudo edades de 90 años hacia arriba».
} 
Hay que señalar que en el año 2007, año en el que se aprueba la citada Ley, el 92 por ciento de las personas mayores de 65 años ya contaba con una vivienda en propiedad ${ }^{44}$. La prensa económica ${ }^{45}$, en ese mismo año, ya se hacía eco de la importancia que estaba teniendo la hipoteca inversa, incluso antes de su regulación legal.

Con la hipoteca inversa, las personas que tuvieran un inmueble que no les produjera ninguna renta, sino todo lo contrario, pues deben sufragar una serie de gastos de mantenimiento y conservación, podrían obtener unos ingresos complementarios a su pensión sin necesidad de vender la vivienda. Además, uno de cada tres hogares de personas mayores en España tiene ingresos inferiores a 9.000 euros anuales, y se estima que en el año 2020 el grupo de personas de más de 85 años habrá aumentado un 50 por ciento ${ }^{46}$. De igual manera, se ha señalado que en el 2050, España será, en términos de envejecimiento de la población, el segundo país más envejecido del mundo (sólo por detrás de Japón), situándose por tanto como el primero de Europa.

Según el Instituto Nacional de Estadística, en el año 2011 ya había más de 8 millones de personas con más de 65 años (17,3\% de población), mientras que para el 2051 se espera llegar a superar la cifra de 15 millones (36,5\% del total de la población $)^{47}$. Esto ya se está apreciando en nuestro país, pues desde 2009, el número de personas mayores de 65 años supera ya al de

\footnotetext{
44 Dato publicado en el artículo «Nueva fuente de ingresos», de El Norte de Castilla de 20 de agosto de 2007, p. 40.

${ }^{45}$ Por ejemplo, en la sección Guía Inmobiliaria de 20 de julio de 2007 de El Norte de Castilla, p. 7, aparecía un artículo basado en un estudio realizado por la Universidad de Barcelona titulado «A favor de la hipoteca inversa", en el que se decía que una de cada cuatro personas muere "rico" en patrimonio pero atraviesa dificultades en sus últimos años de vida. En el mismo artículo también se decía que el 44 por 100 de las personas que en ese momento tenían entre 50 y 64 años, por tanto, posible público potencial en los futuros años de la hipoteca inversa, estarían dispuestas a complementar sus futuros ingresos por jubilación gracias a la contratación de una hipoteca inversa unida al seguro de rentas vitalicias, en el caso de que tuvieran graves dificultades económicas para afrontar su vejez. Posteriormente en un artículo publicado en Expansión el día 11 de noviembre de 2007, titulado «Qué hipoteca inversa presenta mejores costes y condiciones», se decía que el 87,2 por 100 de las personas mayores de 65 años eran propietarios de sus viviendas. Y, en un artículo publicado en el Diario El País el 14 de marzo de 2008 titulado «Pros y contras de la hipoteca inversa», p. 24, se dice también que el 87 por 100 de la población mayor de 65 años es dueña de una vivienda. En cualquier caso, el porcentaje es elevadísimo.

${ }^{46}$ Datos publicados en el periódico Expansión, el 3 de agosto de 2007, titulado «Los notarios demandan mejoras fiscales en las hipotecas inversas», disponible en: http:www.expansion.com.

47 Para ese año se espera que el porcentaje sea del 36,5 por ciento, es decir, una de cada tres personas en España tendrá más de 65 años. Así lo señalan ABELLÁN GARCíA, A. y PuJol RodríGUEZ, R., «Un perfil de...» op. cit., p. 6.
} 
menores de 15. Esta tendencia se acentuará en el futuro y requiere ser abordada mediante un esfuerzo colectivo que garantice la cohesión social y la igualdad de trato y la solidaridad entre generaciones ${ }^{48}$.

También resulta necesario hacer una mención especial a la Exposición de motivos de la Ley 39/2006, de 14 de diciembre, de Promoción de la Autonomía Personal y Atención a las personas en situación de dependencia, que establece lo siguiente:

«En España, los cambios demográficos y sociales están produciendo un incremento progresivo de la población en situación de dependencia. Por una parte, es necesario considerar el importante crecimiento de la población de más de 65 años, que se ha duplicado en los últimos 30 años, para pasar de 3,3 millones de personas en 1970 (un 9,7 por ciento de la población total) a más de 6,6 millones en 2000 (16,6 por ciento). A ello hay que añadir el fenómeno demográfico denominado «envejecimiento del envejecimiento», es decir, el aumento del colectivo de población con edad superior a 80 años, que se ha duplicado en sólo veinte años.

Ambas cuestiones conforman una nueva realidad de la población mayor que conlleva problemas de dependencia en las últimas etapas de la vida para un colectivo de personas cada vez más amplio. Asimismo, diversos estudios ponen de manifiesto la clara correlación existente entre la edad y las situaciones de discapacidad, como muestra el hecho de que más del $32 \%$ de las personas mayores de 65 años tengan algún tipo de discapacidad, mientras que este porcentaje se reduce a un $5 \%$ para el resto de la población».

Junto a estos datos, también se señala que: «A esta realidad, derivada del envejecimiento, debe añadirse la dependencia por razones de enfermedad y otras causas de discapacidad o limitación, que se ha incrementado en los últimos años por los cambios producidos en las tasas de supervivencia de determinadas enfermedades crónicas y alteraciones congénitas $y$, también, por las consecuencias derivadas de los índices de siniestralidad vial y laboral».

Es decir, ese $5 \%$ del resto de población al que se hace mención más arriba, haría referencia a ese colectivo (personas dependientes o con alguna discapacidad).

\footnotetext{
48 Según el estudio realizado por los autores arriba indicados, «Un perfil de...» op. cit., p. 7, la generación del baby-boom, los nacidos entre 1958-1977, que cuentan con 35-54 años, en plena edad laboral, iniciará su llegada a la jubilación en torno al año 2020, de manera que la presión sobre los sistemas de protección social continuará en aumento.
} 
Volviendo a la figura de la hipoteca inversa en España, desde su implantación, esta modalidad hipotecaria ${ }^{49}$ lleva aparejada un problema cultural, ya que en nuestro país se tiene la necesidad de poseer una vivienda en propiedad ${ }^{50}$ y se mantiene la costumbre de dejarla en herencia a los hijos, por lo que al constituir una hipoteca inversa sobre ella, en cierto modo ya se pensaba que se estaba hipotecando el futuro de la familia.

Ahora bien, como señala SERRANO DE NiCOLÁs ${ }^{51}$, el concepto de familia no es en absoluto irrelevante a la hora de acudir a la hipoteca inversa. Sin duda, uno de los principales obstáculos, al menos en España, es la idea de que se priva de herencia a los hijos al «licuar» ${ }^{52}$ el propio patrimonio.

Otro gran inconveniente para el desarrollo de las hipotecas inversas es el que las entidades de crédito no quieren tener más inmuebles de los que ya tienen en la actualidad, sino que, por el contrario, optan por ofertar los inmuebles de obra nueva financiados por sus bancos o cajas, los cuales aún no se han podido vender ${ }^{53}$.

\footnotetext{
${ }^{49}$ Vid. al respecto la SAP de Madrid de 25 de julio de 2012 (TOL2.664.101).

50 Según un artículo publicado en EL MUNDO en fecha de 12 de diciembre de 2013: El porcentaje de viviendas en propiedad descendió entre 2001 y 2011 hasta el 78,9\%, a niveles cercanos a los de hace 20 años, al tiempo que el de viviendas en alquiler se ha incrementado más de dos puntos, desde el $11,4 \%$ del censo de 2001 al 13,5\% en el de 2011, según datos publicados este jueves por el INE. El organismo estadístico constata que la tendencia del alza registrada desde 1981 en el porcentaje de viviendas en propiedad se interrumpió en la década 2001-2011. En concreto, hace 30 años, el 74,9\% de las viviendas censadas eran viviendas en propiedad, porcentaje que escaló hasta el 77,8\% en 1991 y hasta el 82,2\% en 2001, para luego descender en 2011 hasta el 78,9\%, coincidiendo este periodo con algunos de los años de la crisis económica. Mientras tanto, el número de viviendas alquiladas ha ido ganando peso en los últimos diez años y en 2011 alcanzaba un porcentaje del 13,5\% sobre el total del censo. De los más de 18 millones de viviendas censadas en 2011, más de 14,2 millones eran viviendas en propiedad, mientras que algo más de 2,4 millones eran viviendas en alquiler, cifra un 51,1\% superior a la de diez años atrás. En el mismo artículo, también se destaca que las viviendas propias adquiridas por herencia o donación han subido un $7,2 \%$ hasta sumar 1,3 millones. Además, una característica muy nuestra es que en los hogares en los que todos sus miembros son de nacionalidad española, el régimen de tenencia de la vivienda más frecuente es el de propiedad por compra totalmente pagada o por herencia o donación con el $50,2 \%$, en contraste con el $8,4 \%$ que representan las viviendas en alquiler. En contrapartida, los hogares en los que alguno de sus miembros sea de nacionalidad extranjera lo más habitual es el alquiler $(49,9 \%)$, mientras que las viviendas en propiedad por compra totalmente pagada o por herencia o donación suponen el $17 \%$.

51 SERRANO DE NicolÁs, Á., «Régimen jurídico de la hipoteca inversa», Revista de Derecho Privado (RDP), enero-febrero 2008, p. 35.

52 En el Preámbulo VIII, párrafo $3^{\circ}$ de la Ley $41 / 2007$, se resalta esta función de licuación donde una de sus funciones es "hacer líquido el valor de la vivienda mediante productos financieros (...para paliar en los países desarrollados) las necesidades de renta durante los últimos años".

${ }^{53}$ No obstante, según un artículo publicado en $A B C$ en fecha de 19 de mayo de 2014, las estadísticas de compraventa de viviendas siguen dando signos de reactivación, después de ejercicios consecutivos de caídas. Según el Colegio General del Notariado, las transacciones de inmuebles se elevaron un 45,4\%
} 
Con esto podemos deducir que ya antes de la entrada en vigor de la Ley $41 / 2007$, muchas entidades de crédito $^{54}$, teóricamente, ofrecían esta figura, pero en la práctica no la concedían. Esto ha derivado en que posibles clientes de esta figura hipotecaria no la conozcan o ni tan siquiera hayan oído hablar de ella. No obstante, la hipoteca inversa puede admitirse sin ningún problema en nuestro sistema hipotecario, ya que es acorde con los principios que lo rigen, no sólo en cuanto a los requisitos de su constitución, sino también a la hora de la ejecución, pudiéndose configurar, incluso, como una hipoteca en garantía de crédito en cuenta corriente ${ }^{55}$.

De esta manera, los propietarios de las viviendas con este tipo de hipoteca pueden acceder al dinero que fueron acumulando como capital en sus viviendas. Se transforma el valor de la vivienda en una cantidad de dinero sin necesidad de abandonarla. Se trata de que en el momento de la jubilación o de la situación de dependencia, se pueda seguir disfrutando del mismo nivel de vida anterior a ella, sacando el mayor rendimiento a la vivienda y compensando la reducción de ingresos que se produce con la pensión de jubilación.

Sin embargo, debido al principio de la autonomía de la voluntad que rige en el derecho de obligaciones, han surgido multitud de figuras jurídicas similares a la hipoteca inversa que proporcionan la obtención de recursos económicos sin renunciar al uso de la vivienda y mejorando su calidad de vida. En realidad, son varios los contratos que pueden transformar en dinero la propiedad inmobiliaria. Por ello, hay que tener en cuenta que la hipoteca

durante el primer trimestre del año, en comparación con el mismo periodo del año anterior. Esto, a su vez, está impulsando el precio de los pisos, que hasta el mes de marzo registraron un alza del 1,6\%. Por tanto, en el primer trimestre del año 2014 se ha observado una recuperación en términos de tasas interanuales de las compraventas de vivienda y sus precios, aún así, los notarios aseguran que "será necesario esperar a disponer de más datos, parece que los mismos podrían estar anticipando un cambio de tendencia en el sector 0 , al menos, el fin de la espiral depresiva, siendo más visible entre los pisos de segunda mano que constituyen el principal segmento del mercado inmobiliario». Esta noticia también es difundida por el Colegio de Abogados de Castellón (ICACS) en fecha de 20 de mayo del mismo año.

${ }^{54}$ Vid. más detenidamente SánCHEZ ÁlvareZ, I.; LóPEZ ARES, S. y QuiRoga GARCía, R., «Diseño de hipotecas inversas en el mercado español», Instituto de Mayores y Servicios Sociales, marzo 2007, p. 56.

${ }^{55}$ Sobre esta cuestión volveremos con mayor amplitud en el epígrafe dedicado a la Hipoteca en Garantía de Cuenta Corriente. 
inversa es un producto más que posibilita la obtención de ingresos por la posesión de un inmueble en propiedad.

Estas figuras se estudiarán más adelante. 



\section{CAPÍTULO II: ORÍGENES DE LA HIPOTECA INVERSA}

\section{PRECISIONES EN TORNO A SU APARICIÓN}

El término hipoteca inversa proviene del derecho anglosajón, del concepto reverse mortgage, en contraposición a la hipoteca delantera o avanzada que se denomina forward mortgage, y que en realidad se asemeja a la hipoteca ordinaria de nuestro Derecho con un sistema de amortización ${ }^{56}$.

La hipoteca inversa, en su concepción moderna, empezó a comercializarse en Gran Bretaña en 1965, aunque desde los años 30 aparecieron las home equity reversion, figura similar a la de las hipotecas inversas. De hecho, en 2007, año en que se implantó en España, en Gran Bretaña ${ }^{57}$ las hipotecas inversas estaban muy extendidas, pues ascendían a 83.000 y por un valor que rondaba los 6.000 millones de euros ${ }^{58}$. Concretamente, en el año 2004 se formalizaron 26.000 hipotecas inversas en Reino Unido ${ }^{59}$, y en Estados Unidos (EEUU), en 2005, fueron $40.000^{60}$. Así pues, observamos que en los países anglosajones la hipoteca inversa ocupa un lugar importante en el mercado financiero-crediticio.

En EEUU ${ }^{61}$, su desarrollo comienza en 1989. Ahora bien, en este país el mercado de las hipotecas inversas está dominado por el programa federal

\footnotetext{
${ }^{56}$ MURO VILLALÓN, J.V., «La hipoteca...», op. cit., p. 2.

${ }^{57}$ Martínez Escribano, C., La hipoteca inversa, op. cit., p. 103, destaca que en este país hay una absoluta libertad en cuanto al destino que se quiera dar a las cantidades percibidas. No necesariamente han de cubrir necesidades básicas del prestatario, sino que también pueden dirigirse a mejorar la calidad de vida por encima de los niveles medios, o a contribuir a ayudar económicamente a hijos, nietos y otros parientes, como ocurre con cierta frecuencia en Reino Unido. Al respecto TAFFIN, C., "La hipoteca...», op. cit., p. 5, señala que uno de cada cuatro prestatarios en Reino Unido cita éste entre los destinos a los fondos percibidos.

${ }^{58}$ Según la información publicada en el periódico Expansión el día 3 de agosto de 2007 con el título «Los notarios demandan mejoras fiscales en las hipotecas inversas", disponible en: www.expansion.com.

${ }^{59}$ Sobre la hipoteca inversa en Reino Unido y EEUU, vid. SÁnCHEZ-VENTURA MORER, I., La hipoteca inversa en el Derecho Español, Aranzadi, Cizur Menor (Navarra), 2013, pp. 93-179; Álvarez Álvarez, H., La hipoteca inversa..., op. cit., pp. 37 y 38; TAFFIN, C., «La hipoteca inversa o vitalicia», op. cit., pp. 8-12; MURo VILLALón, J.V., «La hipoteca...», op. cit., p. 4. No obstante, al final del programa se realizará un estudio comparativo sobre estos dos países con respecto a España.

60 Álvarez Álvarez, H., La hipoteca inversa..., op. cit., p. 37. Vid. con más detalle López Jiménez, J.M. y MUÑOZ DE BENAVIDES, C., «Principales novedades de la Ley 41/2007, con relación al ámbito del mercado hipotecario y el sistema financiero», Diario La Ley, núm. 6864, enero 2008.

${ }^{61}$ Vid. otras opciones de hipotecas inversas que se dan en EEUU en «Dinero hecho en casa. Hipotecas revertidas: guía para el consumidor", de la American Association of Retired Persons (AARP), disponible en: www. aarp.org/espanol/dinero.
} 
Home Equity Conversion Mortgage (HECM), es decir, Hipoteca de Conversión del Valor Acumulado de la Vivienda, caracterizada por la intervención de la administración pública.

En efecto, se introduce una garantía federal y es el único tipo de hipoteca inversa asegurada por el gobierno federal, concretamente por la Federal Housing Administration (FHA), es decir, por la Administración Federal de la Vivienda. La FHA indica a los prestadores la cantidad a prestar sobre la base de su edad y el valor de su vivienda, limita los costes del préstamo y garantiza que los prestadores cumplan con sus compromisos.

Desde la crisis de la vivienda en 2009, el programa HECM ha visto cambios significativos en las características demográficas y los comportamientos de los prestatarios. Con el fin de proteger el programa, el 3 de septiembre de 2013, el Departamento de Vivienda y Desarrollo Urbano (HUD) anunció importantes cambios en el producto ${ }^{62}$ para ayudar a asegurar la viabilidad a largo plazo del programa.

Las HECM (Home Equity Conversion Mortgage), normalmente, otorgan anticipos más altos que los de cualquier otra hipoteca inversa. Suelen dar más dinero y son más flexibles en cuanto a la forma en la que se entrega el dinero. Por tanto, las Home Equity Conversion Mortgage son las únicas que están aseguradas por el gobierno federal, exactamente y desde 2013, por la Financial Conduct Authority (FCA) o Autoridad de Conducta Financiera y por la Prudential Regulation Authority (PRA) o Autoridad de Regulación Prudencial $^{63}$, que forma parte del Departamento de Vivienda y Desarrollo Urbano (Department of Housing and Urban Development-HUD).

Por lo que respecta a los países de la Unión Europea, la hipoteca inversa está bastante implantada, sobre todo en Dinamarca, Finlandia, Irlanda, Noruega, Suecia, Bélgica y Países Bajos (en los Países Bajos tiene gran

\footnotetext{
${ }^{62}$ Estos cambios se pueden consultar en la página: http://reverse.org/blog/new-reverse-mortgage/. No obstante, esta modalidad se analizará al final del Programa.

${ }^{63}$ Anteriormente le correspondía a la Financial Services Authority (FSA).
} 
éxito la hipoteca inversa a pesar de que no cuenta con ventajas fiscales). También en el resto del mundo existen países en los que está muy arraigada: como Australia, Nueva Zelanda, Canadá y Japón ${ }^{64}$.

En estos países son conscientes de que la tercera edad dispone habitualmente de un gran capital en bienes inmobiliarios, pero por el contrario, cuentan con una pensión muy baja. Sin embargo, esta figura, que proviene del derecho anglosajón, encuentra dificultades a la hora de introducirse en el sistema continental, como es el caso francés o nuestro propio derecho, al provenir de un sistema jurídico distinto.

\section{La hipoteca inversa en otros países}

\subsection{Francia}

La hipoteca inversa se introdujo en Francia en el año 2006, concretamente mediante la Ordonnance núm. 2006-346, 23 mars 2006 (JO 24 mars 2006), relative aux sûretés ${ }^{65}$. Resaltar que su regulación ${ }^{66}$ no se introdujo en el nuevo Libro IV (Des Sûretés) del Code sino en el Code de la Consommation, como «Prêt viager hypothécaire» (préstamo vitalicio hipotecario). Así, en Francia, la hipoteca inversa, conocida allí como «prêt viager hypothécaire», no era muy distinta a la regulada en nuestro país, con una marcada tendencia a la protección del contratante al igual que en España (apartados 2, 3 y 4 de la DA $1 .^{\text {a }}$ ).

\footnotetext{
${ }^{64}$ Cfr. Álvarez Álvarez, H., La hipoteca inversa..., op. cit., p. 39; Herranz GonzÁlez, R., «Hipoteca Inversa...», op. cit., pp. 5 y 6; MURO VILLALón, J.V., «La hipoteca...», op. cit., p. 4.

${ }^{65}$ Publicada en el Journal Officiel de 24 de marzo de 2006, que modifican el Code de la Consommation, se regula el régimen de la hipoteca inversa (arts. 141-1 a 141-20 del Code de la Consommation).

${ }^{66}$ Vid. con más detalle GRIMALDI, M., "L' hypothèque rechargeable et le prêt viager hypothécaire», Revue Lamy Droit des affaires, supplement au $n^{\circ} .7$, juillet 2006, pp. 28-32. Esta obra señala que en esta modalidad hipotecaria lo relevante no está en el "droit des sûretes", sino en el derecho de las operaciones de crédito, por lo que el Code, en su nuevo Libro IV, no le dedica sino una simple disposición como es la concerniente al reembolso, que, como en España, es la verdadera nota diferencial respecto de las hipotecas ordinarias. En este aspecto coincide ANGUITA Ríos, R.M., «Regulación relativa...», op. cit., p. 3.
} 
La regulación de la hipoteca inversa francesa se inspira en el modelo americano de la reverse mortgage. La ordenanza entró en vigor el 25 de marzo de 2006, a excepción de ciertos preceptos que necesitaban un decreto de aplicación. Su publicación ${ }^{67}$ se efectuó el 6 de diciembre de 2006.

En este Decreto se precisan ciertas modalidades de funcionamiento de las disposiciones de la ordenanza, en concreto, la relativa al reembolso anticipado de la hipoteca inversa por parte del deudor, estableciendo los porcentajes o las fracciones de interés que deberán entregarse a la entidad de crédito acreedora. Por lo que respecta a esta regulación francesa, y a diferencia de lo que sucede en Canadá, la hipoteca inversa sólo puede utilizarse para la residencia, es decir, el bien inmobiliario que garantiza el préstamo debe ser usado exclusivamente como residencia, no como centro de negocios.

El artículo L. 314-1 define la hipoteca inversa como: «un contrato por el cual un establecimiento de crédito o un establecimiento financiero concede a una persona física un préstamo bajo forma de un capital o disposiciones periódicas, garantizado por una hipoteca constituida sobre un bien inmobiliario del prestatario con uso exclusivo de vivienda en el que el reembolso (del principal e intereses) no puede exigirse hasta el momento del fallecimiento del prestatario o hasta la enajenación de la propiedad del inmueble hipotecado si sobreviene antes del fallecimiento».

Además, el artículo L. 314-2 determina que bajo pena de nulidad, la hipoteca inversa no puede destinarse a financiar una actividad profesional. Por ello, el inmueble que se grava debe tener como destino únicamente el de vivienda. De esta manera, el legislador francés obliga a que la hipoteca inversa se constituya sobre un bien inmueble que sea la vivienda habitual del deudor, al igual que sucede en el Derecho español, con la salvedad prevista en el apartado 10 de la DA $1 .^{a}$ de la Ley 41/2007, de 7 de diciembre, que determina que se podrán instrumentar hipotecas inversas sobre otros bienes inmuebles distintos de la vivienda habitual del solicitante, aunque a estas

${ }^{67}$ D. nº 2006-1540, 6 déc. 2006 (JO 8 déc. 2006). 
hipotecas inversas no les será de aplicación lo dispuesto en la DA $1 .^{a}$ de la Ley $^{68}$.

En el Derecho francés, el reembolso del capital y de los intereses de la hipoteca inversa sólo pueden exigirse una vez que fallece el prestatario $\mathrm{y} / \mathrm{o}$ en los casos de enajenación del inmueble hipotecado. Tan sólo las personas físicas pueden ser prestatarias, mientras que prestamistas serán exclusivamente los establecimientos de crédito o financieros.

La sección segunda de la Ordonnance (artículos L. 314-3 y L. 314-4), establece que la oferta que realiza la entidad de crédito sobre hipoteca inversa debe contener toda la información en un folleto o documento publicitario, concretamente, una serie de menciones obligatorias que recogen los preceptos sobre las modalidades de la operación, que permitan apreciar la situación financiera y patrimonial del deudor. Todo ello con la finalidad de proteger al prestatario.

En concreto, la oferta previa (art. L. 314-5) que otorga la entidad financiera debe contener las siguientes menciones:

- La identidad de las partes y la fecha de aceptación de la oferta.

- La duración de la oferta.

- La designación exacta del bien hipotecado.

- El valor del bien hipotecado de acuerdo con la tasación realizada por un perito elegido por las partes. Los gastos de dicho peritaje son de cuenta del prestatario.

- La naturaleza del préstamo y sus modalidades. Si se trata de entregas periódicas, debe fijarse la fecha de cada una de ellas, distinguiéndose entre el capital y los intereses acumulados, al efecto de que el prestatario conozca en todo momento cuándo agotará el activo neto de su inmueble. Si el capital se entrega de una sola vez, deben establecerse los intereses acumulados durante el plazo de duración previsible del préstamo para saber si ha agotado

${ }^{68}$ Serrano de Nicolás, Á., «Régimen jurídico...», op. cit., pp. 39 y ss. 
o no el activo neto de la vivienda. Si no se siguen estos requisitos, posiblemente se sancionará al prestamista con una multa, así como con la pérdida total o parcial del derecho a los intereses.

En Francia, en caso de que fallezca el deudor y no tenga herederos, el bien puede atribuirse a la entidad acreedora, bien por atribución judicial o bien en virtud de pacto comisorio (art. L. 314-3). Además, el acreedor puede proceder a la venta del inmueble.

La sección tercera contempla un periodo de reflexión de diez días que beneficiará al deudor, pues durante ese tiempo el deudor no puede aceptar la oferta. Una vez que se emite la oferta, el prestamista debe mantenerla en las mismas condiciones en las que se emitió durante un plazo mínimo de treinta días. El contrato de hipoteca inversa, al igual que en el caso español, debe realizarse ante notario, bajo pena de nulidad, al efecto de que pueda informar al deudor sobre las consecuencias patrimoniales y sucesorias que la firma de la hipoteca inversa conlleva.

En la sección cuarta se precisa que el tope máximo al que puede ascender la deuda es el valor del inmueble y si la deuda es inferior al valor del inmueble, la diferencia entre los dos valores debe entregarse al prestatario o a sus herederos. A diferencia de lo que sucede en nuestra regulación y al igual que en Estados Unidos, en el momento de la devolución, la cuantía máxima de la deuda no puede exceder del valor del inmueble fijado por un perito designado de común acuerdo por las partes o, en su defecto, judicialmente (art. L. 314-9).

En cuanto a la sección sexta, se hace referencia a que en caso de muerte del deudor, la deuda a la que deben hacer frente los herederos es la relativa al valor del inmueble estimado en el día de la apertura de la sucesión, determinado por un experto designado de común acuerdo o, en caso de desacuerdo, por la autoridad judicial. Los herederos pueden pagar la totalidad de la deuda, pero en caso contrario, el acreedor hipotecario tiene 
que elegir entre vender el bien o quedarse con la propiedad del inmueble en virtud de decisión judicial o de un pacto comisorio. El acreedor hipotecario tiene derecho a la misma opción en caso de que no haya herederos, es decir, que haya una herencia vacante.

En la sección séptima se establecen una serie de sanciones tanto civiles como penales (Arts. L.314-15 a L.314-19). La preocupación del legislador por proteger al prestatario frente a posibles prácticas abusivas se pone de manifiesto en la regulación detallada de las sanciones que se impondrán a los prestamistas que no respeten las condiciones relativas a la oferta de este producto.

Los herederos del prestatario son los que se tienen que hacer cargo de reembolsar la cantidad del préstamo más los intereses. Pero si los herederos no quieren pagar la deuda, la entidad acreedora puede elegir entre promover la ejecución judicial, requerir la atribución judicial de la propiedad de la vivienda, o bien ejercer el pacto comisorio. Si se opta por la ejecución judicial y la deuda es inferior al precio que se obtiene por el inmueble, la parte que excede debe reintegrarse al prestatario o a sus herederos.

En la regulación francesa, tal como se indica en el artículo L.314-10, el prestatario también puede poner fin al contrato mediante el reembolso anticipado de la sumas percibidas, abarcando la totalidad del principal y de los intereses.

Finalmente, la sección octava titulada «Texte d'application», precisa en su artículo L.314-20, que las condiciones de aplicación del capítulo III serán fijadas por decreto del Consejo de Estado. Este Decreto es el de 6 de diciembre de 2006. Cabe señalar pues, que la legislación francesa ${ }^{69}$ se anticipa en un año con respecto a la nuestra.

\footnotetext{
69 Según el artículo publicado en fecha de 24 de marzo de 2011 por Grupo Retiro, la Renta Vitalicia destaca de forma muy especial en Francia. En el país galo existen multitud de portales inmobiliarios donde se "venden" propiedades en régimen de Renta Vitalicia. En estos anuncios, además de explicar las características del inmueble, se especifican las edades de los inquilinos, así como la renta mensual que se tendría que pagar para comprar la nuda propiedad de estas viviendas. Entre los portales más populares destacan, entre otros, Viagers.net, Viager-europe.com, Paruvendu.fr, Seloger.com.
} 


\subsection{Canadá}

En este país ${ }^{70}$ la hipoteca inversa tiene un desarrollo muy limitado, aunque cuenta con una regulación detallada en provincias como Quebec o Manitoba. En esta última se reguló mediante la Loi modificant la loi sur les hipotèques, de fecha 6 de julio de 2001.

En Canadá71, la edad mínima para poder solicitar la hipoteca inversa es de 62 años, al igual que sucede en los EEUU, y los solicitantes tienen que ser propietarios de la vivienda. El perfil ${ }^{72}$ de los contratantes de esta hipoteca oscila entre un $40 \%$ de parejas, un $40 \%$ de mujeres y un $20 \%$ de hombres, pertenecientes, por lo general, a una clase social media-alta.

La cuantía financiada tiene una relación préstamo-valor inmobiliario mucho menor que en el caso de las hipotecas tradicionales. En esta modalidad se suele financiar entre un $10 \%$ y un $40 \%$ del valor patrimonial, lo cual se traduce en cuantías entre 20.000 y 500.000 dólares canadienses $^{73}$. Como en el caso español, en este país el que consigue una hipoteca inversa sigue conservando la propiedad del inmueble y además tiene la posibilidad de reembolsar anualmente los intereses acumulados.

De esta manera, se pueden hacer reembolsos en todo momento, y también cabe el reembolso anticipado. Se les permite trasladarse de la casa e incluso tienen la posibilidad de venderla. La devolución del préstamo tiene lugar cuando muere el último de los propietarios o cuando se venda la vivienda. Además, una característica que se da en Canadá y que no se permite en otros países, como Francia, es la posibilidad de solicitar la hipoteca inversa

\footnotetext{
(Información disponible en: http: //www.gruporetiro.com).

${ }^{70}$ Vid. Saskatchewan Law Reform Comission Report On Reverse Mortgages, 2006, pp. 1-29. Disponible en: http://sklr.sasktelweb-hosting.com/reverse-mortgage.rtf.

71 Álvarez Álvarez, H., La hipoteca inversa..., op. cit., pp. 42 y 43.

72 Sánchez Álvarez, I.; López ARes, S. y Quiroga García, R., «Diseño de hipotecas inversas en el mercado español», op. cit., p. 43.

73 Ibíd., p. 43.
} 
no sólo sobre la vivienda que constituye la residencia, sino también sobre el comercio o negocio del deudor.

En esta modalidad canadiense, en el caso de que la hipoteca sobrepase el valor de la vivienda, no es objeto de cobertura exterior. Prueba de ello es que la Sociedad Canadiense de Hipotecas y Alojamientos no ha considerado adecuado intervenir en este sector.

El tipo de interés empleado en este préstamo es variable y referenciado normalmente a la tasa de los títulos del Tesoro a un año incrementado en un margen del $4,75 \%$.

Las cuotas que los ciudadanos reciben de su hipoteca inversa tienen un tratamiento fiscal asimilado a los pagos de préstamos hipotecarios convencionales, y por tanto no sujetos a imposición.

En el mercado la entidad prestamista dominante es el denominado Canadian Home Income Plan (CHIP) ${ }^{74}$, pues a pesar de encontrar otros tres establecimientos financieros que la ofrecen, éstos se limitan a redirigir a sus clientes a dicha sociedad privada. De ahí que el número de operaciones realizadas es muy reducido, pues desde 1986, fecha en la que esta entidad dominante inició su actividad, tan solo se han contratado alrededor de 10.000 préstamos y no se manifiesta ninguna tendencia al alza ${ }^{75}$. Los precios poco elevados de la vivienda, salvo raras excepciones, las pensiones de cuantías desahogadas y la estructura demográfica sin desequilibrios actuales ni previsibles, quizás explican el escaso desarrollo de este producto ${ }^{76}$.

Paralelamente a las hipotecas inversas, el mercado crediticio canadiense, junto con la hipoteca inversa, con mayor aceptación está

\footnotetext{
74 Vid. la página web de la empresa dominante en el mercado de hipotecas inversas en Canadá: http://www.chip.ca/.

75 Vid. Canadian Center for Elder Law Studies (CCELS), Report on Reverse Mortgage, Report № 2, February 2006.

${ }^{76}$ Para un análisis más detallado vid. JACHIET, N., et alii, Rapport sur le prêt viager hypothécaire et la mobilisation de l'actif residential des personnes âgées, Agence Nationale pour l'information sur le logement, París, 2004.
} 
ofreciendo más líneas de crédito garantizadas por una hipoteca, cuya deuda total no puede superar el $80 \%$ del valor patrimonial y en la que se requiere el pago periódico de intereses.

Además de esto, en lo referente a la protección del consumidor, desde el 1 de julio de 2006 está en vigor la parte 5 del Business Practices and Consumer Protection Act. Con esta legislación se pretende dotar de una mayor protección a los clientes de este producto. De manera que, la parte prestamista, cuando se formalice la operación, tiene la obligación de entregar al prestatario un documento informativo organizado y sistematizado con los principales aspectos que caracterizan a la hipoteca que se contrata.

\subsection{Australia}

En este país, durante los años 2004 y 2005, los productos relativos a la conversión del patrimonio inmobiliario en liquidez experimentaron un importante crecimiento. Prueba de ello es que en el año 2005 más de 10.000 australianos accedieron a una hipoteca inversa, lo que representó un incremento del 150 por ciento de la actividad respecto a $2004^{77}$.

Tres tipos de productos se comercializan o están en fase de diseño en el mercado ${ }^{78}$ :

- Hipotecas inversas.

- Venta total o parcial de la vivienda (Home Reversion Schemes).

- Hipotecas de revalorización compartida.

Los productos considerados como hipotecas inversas están disponibles generalmente para propietarios de vivienda con al menos 55 años, si bien la edad mínima depende de la entidad financiera. También pueden ser

\footnotetext{
77 Trowbridge Deloitte, The Equity Release Opportunity for Financial Planners, Julio, 3-6, 2005.

${ }^{78}$ Vid. Australian SeCURITIES AND INVESTMENTS COMmISION (ASIC), Equity Release Products, 2005.
} 
beneficiarios aquellos con deudas pendientes de hipotecas cuya cuantía sea reducida y se amortice con las sumas obtenidas de la hipoteca inversa.

La cuantía prestada suele estar restringida a cifras que representan entre un $20 \%$ y un $40 \%$ del valor real del inmueble. La mayoría de los productos suele permitir obtener una financiación adicional a medida que el prestatario envejece. Todos los productos permiten realizar cancelaciones parciales a lo largo de la vida del préstamo.

Algunos productos como el EquityTap de Bluestone Mortgage tienen límites en los tipos de interés aplicados y garantizan que los valores patrimoniales no sean negativos. Otros operadores de hipotecas inversas son el Commonwealth Bank, el Homestar Finance, el St. George Bank, la Police and Nurses Credit Society y la StateWest Credit Society.

Además de los productos comercializados por la banca privada, los sindicatos y otros proveedores especializados, el gobierno australiano ofrece el Pension Loans Sheme. Este programa ${ }^{79}$ se dirige a pensionistas que no alcanzan la pensión máxima debido a sus ingresos o activos, permitiendo que obtengan un préstamo que les provea de un pago quincenal hasta alcanzar la cuantía de la pensión máxima.

\subsection{Nueva Zelanda}

En Nueva Zelanda ${ }^{80}$, los productos financieros relacionados con la conversión del patrimonio inmobiliario en liquidez se limitan a las hipotecas inversas. Al igual que en Australia, este sector ha experimentado un rápido crecimiento a partir del año 2004, pero representa todavía un porcentaje muy pequeño del total de hipotecas inmobiliarias: sólo un $0,1 \%$ del total.

\footnotetext{
79 Sánchez Álvarez, I.; López Ares, S. y Quiroga García, R., «Diseño de hipotecas inversas en el mercado español», op. cit., p. 45. Sin embargo, el número de participantes en este programa es muy reducido: 239 a finales de 2004.

${ }^{80}$ Ibíd., pp. 47-53.
} 
La legislación neozelandesa regula asimismo otro producto de liquidez inmobiliaria: el buy-back (venta con recompra posterior). El consumidor acuerda la venta de su vivienda con una entidad, pero con la intención de volver a comprarla posteriormente, usualmente en un año, a un precio mayor. Está pensado para personas con dificultades financieras que requieren acceder a transformar el patrimonio inmobiliario en efectivo.

Este tipo de producto no ha tenido un desarrollo adecuado en el mercado, recibiendo críticas por parte de los consumidores tanto en relación con la imposibilidad de obtener un préstamo transcurrido un año para volver a adquirir la vivienda, como con la pérdida del patrimonio acumulado en el inmueble.

El lanzamiento de las hipotecas inversas en el mercado se desarrolló también en 1991 a través del Invencible Life Assurance Company en Wellington. Existían diversas modalidades del producto en función de la edad y de las condiciones de contratación. La difusión del producto fue muy lenta, si bien los beneficiarios señalaron su considerable satisfacción con el producto. Este producto ha tenido continuidad en los productos actualmente desarrollados por SAI Life Ltd.

En 1991, el Taranaki Savings Bank (TSB) incorporó una línea de crédito asociada a un programa de hipoteca inversa. La oferta incluye la posibilidad de abonar los intereses periódicamente -opción estimulada por la entidad- o acumular los intereses al principal prestado. Las cuantías se limitan a un $30 \%$ del valor de la vivienda, pero las cifras medias están bastante por debajo de dicha cifra. Las tasas de interés son variables y se establecen de acuerdo con la estructura financiera del banco. Su expansión ha sido muy escasa, debido en buena medida a las exigencias al cliente de sustanciales depósitos en la entidad financiera.

SAl Life Ltd, antiguamente Invencible Life Assurance Ltd, ofrece tres tipos de hipotecas inversas: 


\section{1.-Ram Flex}

Proporciona un pago mensual mientras el cliente permanezca en la vivienda. Está disponible a partir de los 65 años, si bien las casas deben estar valoradas al menos en 250.000 dólares. La mensualidad puede dejar de pagarse, reiniciarse, reducirse o incrementarse en algunos casos. La deuda se remunera a un $11 \%$ anual.

\section{2.-Ram Sure}

Proporciona un pago vitalicio y una cuantía inicial que no puede superar el $10 \%$ del valor inmueble. La hipoteca tiene que ser amortizada cuando el propietario abandona la casa, pero el pago periódico se mantiene mientras el cliente o su cónyuge sobrevivan. Este programa se aplica a propietarios entre 65 y 75 años de edad. La tasa de interés es el $9 \%$ anual.

\section{3.-Ram Term}

Proporciona un pago vitalicio, pero la hipoteca tiene que ser amortizada transcurridos 10 años desde el inicio del contrato. Está disponible para propietarios entre 55 y 75 años. La cuantía entregada inicialmente puede alcanzar hasta el 25\% del valor de la vivienda. Está dirigida a personas que disponen de una segunda vivienda o tienen disponibilidades para hacer frente a la amortización después de 10 años. El tipo de interés devengado es el $9 \%$ anual.

Los tres tipos de hipoteca inversa no tienen garantizado que la cuantía a pagar al cancelar la hipoteca no supere el valor de mercado de la vivienda, pero exigen al cliente el mantenimiento del inmueble en buen estado y el aseguramiento.

\subsection{México}


En este país sólo ha sido aprobada en el Estado de México, para aquellas personas que tengan 60 años de edad o más ${ }^{81}$, aunque algunas entidades están evaluando replicar este modelo.

La hipoteca inversa ${ }^{82}$ fue aprobada en el mes de mayo de 2013, debido a una petición por parte de los notarios del Estado de México. Para poder lograr la aprobación legal de las hipotecas inversas se tuvieron que agregar algunas modificaciones en el Código Civil y Financiero Estatal.

Algunas de las principales características que establece el Código Civil del Estado de México son que la cantidad pactada entre el pensionario y el pensionista deberá ser suficiente para que éste último pueda cubrir las necesidades básicas y que la propiedad sólo será exigible en caso de fallecimiento.

Tal y como establece la ley, el pensionista habitará el inmueble, pero podrá arrendarlo de manera parcial o total, siempre y cuando el contrato lo permita. Al momento de fallecer el pensionista, sus herederos tendrán la posibilidad de abonar al pensionario la totalidad del adeudo. Sin embargo si transcurren seis meses y no se recibe la liquidación del mismo, la institución financiera podrá vender la propiedad.

\subsection{Puerto Rico}

Las hipotecas inversas se ofrecen a través del Departamento de la Vivienda Federal (Department of Housing and Urban Development, HUD) se conocen también en inglés con el nombre de "home equity conversion mortgages" o HECMs.

\footnotetext{
${ }^{81}$ Para una mayor información se puede consultar el Observatorio Económico. Inclusión Financiera México. Realizado por el BBVA, México, D.F., Análisis Económico, octubre 2013, pp. 1-13. Disponible en: https: / /www.bbvaresearch.com.

82 Vid. artículo publicado por Grupo Retiro en fecha de 15 de enero de 2014 disponible en: http: / /www.gruporetiro.com.
} 
En el mercado de Puerto Rico, la hipoteca inversa ${ }^{83}$ está asegurada por el Gobierno Federal. Este tipo de producto se caracteriza por ser costoso, requiere que se obtenga orientación de un consejero independiente como parte del proceso de solicitud y únicamente puede ser utilizado por personas de 62 o más años.

El uso de las hipotecas inversas en este país va en aumento. Por este motivo resulta necesario fiscalizar la calidad de la orientación o coerción de terceros $^{84}$ sobre las personas mayores de 62 años, en calidad de potenciales clientes de este instrumento financiero, y el contenido de los mensajes promocionales que se utilizan para la venta de este producto.

En este país, a tenor de las realidades sociales y económicas de la población de personas mayores de 62 años, que sigue en aumento, la Asamblea Legislativa ha creado la Ley de Protección del Consumidor de Hipotecas Inversas ${ }^{85}$ (Ley Núm. 164 de 29 de julio de 2011). A estas personas que en su mayoría cuentan con ingresos fijos limitados para satisfacer las necesidades básicas de su vida, es necesario brindarles alternativas financieras que a su vez les protejan del fraude y el abuso financiero.

\subsection{Argentina}

Hay otros países en los que resulta más difícil la existencia de la hipoteca inversa. Tal es el caso de Argentina, donde este tipo de hipoteca no se encuadra dentro del numerus clausus ${ }^{86}$ que rige en el Código Civil de aquel país, por lo que es difícil que pueda regularse y, de ser así, podría incluso acabar en nulidad de pleno derecho.

\footnotetext{
${ }^{83}$ Vid. con mayor detalle la dirección: http:www.aarp.org/espanol/dinero/creditos-y-deuda.

${ }^{84}$ Así lo señala el artículo publicado por el Grupo Retiro en fecha de 2 de junio de 2011, disponible en: http://www.gruporetiro.com.

${ }^{85}$ Ley disponible en: http://www.lexiuris.com/lexlex/Leyes2011/lexl2011164.htm.

${ }^{86}$ Según la teoría del numerus clausus, sólo existen los derechos reales que expresamente prevé y regula la ley. Los derechos reales son tipos cerrados y no se permite ninguno ajeno al tipo. Sin embargo, según la teoría del numerus apertus, los particulares pueden constituir y crear, en base al principio de autonomía de la voluntad aplicada al campo de los derechos reales, los que deseen, incluso distintos a los previstos por la ley.
} 
En Argentina, la hipoteca inversa recibe la denominación de «hipoteca revertida ${ }^{87}$, al igual que en otros países latinoamericanos, como por ejemplo Chile $^{88}$.

\subsection{China}

En China ${ }^{89}$, por parte de sus autoridades se ha anunciado la aprobación de un programa piloto para que las aseguradoras del país empiecen a comercializar las hipotecas inversas, producto que permitirá a las personas mayores conseguir un crédito con la garantía de su vivienda. En un comunicado emitido a través de su página web, la Comisión Reguladora del Sector Asegurador del país, detalla que la prueba se efectuará durante los próximos dos años en cuatro ciudades del país: Pekín, Shanghái, Cantón y Wuhan.

Tal y como establece el regulador, las personas beneficiarias de la hipoteca inversa, además de tener su vivienda en estas ciudades, deberán ser los únicos propietarios del inmueble y ser mayores de 60 años como principal requisito para poder acceder a este producto financiero.

Esta nueva iniciativa se puede interpretar como un paso más para poder diversificar las fuentes de ingresos de los jubilados chinos, en un momento en el que la población del país está envejeciendo y el sistema de pensiones del país cuenta con una mayor presión. Por un lado, el sector asegurador anima a participar en el sector de servicios a los ancianos y, por otro lado, se aporta

\footnotetext{
${ }^{87}$ CALEgARI DE Grosso, L.E., «La hipoteca revertida y las desventajas de su instrumentación», en XXI Jornadas Nacionales de Derecho Civil, tomo I, Facultad de Derecho, Universidad Nacional de Lomas de Zamora, septiembre de 2007, p. 322, considera que no es admisible la hipoteca inversa en Argentina.

${ }^{88} \mathrm{En}$ el caso de Chile, a diferencia de lo que sucede en España, quisiera destacar que no es necesario que el solicitante de esta modalidad hipotecaria conserve la propiedad. En este país se permite que el solicitante-deudor pueda vender la nuda propiedad y mantener el usufructo de la vivienda, es decir, que se realice una compraventa de la casa con usufructo simultáneo.

89 Vid. con más detalle la información publicada en Grupo Retiro en fecha de 24 de junio de 2014, disponible en: http://www.gruporetiro.com.
} 
una solución al problema del envejecimiento de la población dando así más posibilidades a este colectivo para poder mejorar sus pensiones y garantías.

El plan ofrece una nueva fórmula para garantizar los cuidados durante la vejez. Esto se debe a que a finales de 2013, China contaba con 202 millones de ciudadanos que tenían más de 60 años, casi el 15\% del total de la población. Según fuentes oficiales se espera que este segmento de la población supere los 300 millones en 2025 y llegue al 30\% del total en el año 2050. Esto supone todo un reto para la segunda economía mundial, pero a la vez también una oportunidad para desarrollar los servicios destinados al sector de la tercera edad.

Con esta iniciativa pionera se espera que otras ciudades sigan el mismo camino. Según el Banco China Citic, pasará un tiempo hasta que la gente en China reconozca y llegue a conocer en detalle y dé su visto bueno a las hipotecas inversas, tomando desde ese incremento de la notoriedad del producto un rápido impulso a medida que las personas mayores vayan conociendo poco a poco su existencia.

Por lo que respecta al ordenamiento jurídico español, hasta la Ley 41/2007 que regula la hipoteca inversa en España, carecíamos de un marco regulatorio específico, aun así, algunas entidades financieras, principalmente, las Cajas de Ahorro, la ofertaban. Desde sus inicios ya se mostraba como un producto residual, muy poco utilizado por las entidades de crédito y que en la actualidad está en desuso.

Con esta Ley «ante la imposibilidad por parte del sector público de hacer frente a ciertas cargas» se pretendía que las personas mayores de 65 años, o con gran dependencia, pudieran hacer frente con su patrimonio a los gastos que origina su asistencia y cuidado. De ahí podemos deducir que esta figura va dirigida principalmente a las personas mayores de clase media, pues si pertenecieran a clases sociales de menor poder económico, éstas, por lo 
general, no tienen una vivienda en propiedad, y si pertenecieran a las clases acomodadas, no tendrían, a priori, la necesidad de solicitar esta figura.

Sin embargo, esta Ley que se presumía que iba a tener una aceptación muy positiva, tanto por el público al que iba dirigido como por el Estado, finalmente, no se pudo llevar a cabo por distintas cuestiones:

1.- La crisis económica, particularmente acentuada en el sector financiero, que ha originado un clima de desconfianza generalizado y el especial comportamiento del sector inmobiliario español.

2. - Ciertas deficiencias ${ }^{90}$ que se detectan en la Ley debido a la falta de atención suficiente por parte del legislador sobre esta materia que «a juicio de la Asociación Hipotecaria Española» debería ser objeto de una regulación específica y más detallada91.

A causa de esto, son pocas las modificaciones ${ }^{92}$ que se han llegado a introducir respecto del proyecto inicial que presentaba bastantes carencias, desaprovechando con ello la posibilidad de mejorar sustancialmente diversos aspectos de la ley.

A pesar de todo lo comentado hasta ahora, en España es posible que la figura de la hipoteca inversa en un futuro -esperemos no muy lejano-, tenga cierta aceptación, pues la esperanza de vida va en aumento y con ella se

\footnotetext{
${ }^{90}$ No obstante, el legislador parecía felicitarse con el resultado obtenido, ya que suponía un avance respecto del anterior vacío legal. En este sentido, y como prueba de ello, el señor Martínez-Pujalte López, Diario de Sesiones del Congreso de 22 de noviembre de 2007, p.15023 afirmaba que: «Estamos ante una ley que es corta y en la que habrá que profundizar en el futuro, pero que avanza. Desde luego, lo que sí aprobamos hoy, señor Herrera, es la ley de acompañamiento y además una ley de acompañamiento que se llama Ley Hipotecaria -que es más raro aún- y además sin pasar por el Congreso porque se ha tramitado exclusivamente en el Senado».

En palabras de MARTínez EsCRIBANO, C., La hipoteca inversa, op. cit., pp. 39 y 40: «No sé, sin embargo, si hay que felicitarse por tener una regulación de la hipoteca inversa, o si la felicitación ha de venir cuando la regulación de una materia, sea ésta u otra, ha sido estudiada y meditada con profundidad y ello se refleja en el texto legal. En este sentido apuntaremos que las hipotecas inversas ya existían con anterioridad a la ley, por lo que ésta no es determinante para la utilización de esta forma de financiación, aunque fomentará su uso si la ley es el resultado de un estudio profundo de la materia y resuelve los problemas que se suscitan en torno a esta figura. Pero si la ley no se pronuncia al respecto supone un escaso avance».

91 AHE, «Resumen de las propuestas de modificación formuladas al anteproyecto de Ley de Modernización del Mercado Hipotecario, de regulación del régimen de las Hipotecas Inversas y del Seguro de Dependencia», Madrid, 5 de diciembre de 2006, pp. 8 y 9.

92 Entre otras modificaciones, se ha de destacar la Ley $1 / 2013$, de 14 de mayo, de medidas para reforzar la protección a los deudores hipotecarios, reestructuración de deuda y alquiler social.
} 
incrementa el número de personas en edad de jubilación y dependientes. Estos colectivos están sufriendo, cada vez más, una mayor disminución de su poder adquisitivo.

Además, a su favor está que en España nos caracterizamos por tener la vivienda en propiedad, circunstancia que no está tan generalizada en otros países europeos, donde la mayoría de las personas viven en régimen de alquiler. Por ello, la hipoteca inversa podría extenderse en nuestro país, una vez se hayan asentado las bases económicas para hacer frente a la situación actual.

La finalidad de la hipoteca inversa es posponer hasta el fallecimiento del solicitante o beneficiario la devolución de los ingresos extras que con dicha garantía hipotecaria se obtiene cuando ya no se tiene capacidad laboral o productiva. Se trata de una problemática y necesidad generalizada en los países desarrollados ${ }^{93}$ dada la mayor longevidad alcanzada durante el siglo XX y las mayores necesidades asistenciales derivadas de ella.

\footnotetext{
93 Así lo señala SeRRANo de Nicolás, Á., «Régimen jurídico...», op. cit., p. 35. La regulación es propia y singularizada en los diferentes sistemas jurídicos, difícilmente asimilable a la norteamericana, y con creciente expansión en el nuevo siglo XXI en los países de mayor desarrollo industrial (casos de Australia, Canadá, Dinamarca, Finlandia, Irlanda, Japón, Países Bajos, Noruega y Suecia), consecuencia de la mayor longevidad de sus ciudadanos, y, a los que tampoco es ajena la creciente pujanza de la familia nuclear y la dificultad -por razones laborales, de vivienda, etc.- para poder cuidar y atender económicamente a las personas mayores o discapacitadas.
} 



\section{CAPÍTULO III: ESTRUCTURA DE LA HIPOTECA INVERSA}

\section{CONCEPTO Y NATURALEZA JURÍDICA DE LA HIPOTECA INVERSA}

En cuanto a la hipoteca clásica u ordinaria, los artículos 1876 del CC y el 104 de la LH sólo destacan el aspecto negativo de la hipoteca relativo a la afección de los bienes y la accesoriedad a la obligación principal de que depende, olvidando algunos aspectos positivos de la hipoteca, como son la cualidad de derecho real y su función de asegurar una percepción dineraria a través de la ejecución de la cosa hipotecada ${ }^{94}$.

La hipoteca se tipifica en el Código Civil en el Libro IV De las Obligaciones y Contratos, Título XV De los Contratos de Prenda, Hipoteca y Anticresis, Capítulo III De la Hipoteca y sólo es objeto de regulación en siete preceptos (de los artículos 1874 a 1880). Esta breve regulación está justificada pues en la LH de 1861 se regulaba de forma más detallada dicha figura. Ahora bien, esto no justifica que con el paso del tiempo no se haya regulado con mayor detalle en el Código Civil.

En todo tipo de hipoteca, la vinculación de la finca hipotecada al crédito garantizado queda asegurada por los principios de causalidad (sujeción del bien derogándose el principio de la par conditio creditorum) y de accesoriedad (relación de dependencia entre la hipoteca y la obligación garantizada). Por ello, tal y como se regula en el artículo 1875 del CC, el bien hipotecado queda sujeto -independientemente de quién sea su poseedor-, al cumplimiento de la obligación asegurada. Por tanto la hipoteca prevalece sobre cualquier derecho, carga o gravamen posterior sobre la cosa hipotecada.

Nuestro ordenamiento jurídico configura la hipoteca como dependiente del crédito a cuya seguridad debe servir. Por ello, la hipoteca se constituye

\footnotetext{
${ }^{94}$ ChICO y ORTIZ, J.M., Estudios sobre Derecho hipotecario, tomo II, 4. ${ }^{\mathrm{a}}$ ed., Marcial Pons, Madrid, Barcelona, 2000, p. 1316.
} 
para asegurar el cumplimiento de una obligación principal, de acuerdo con los artículos 104 de la LH y 1857.1 y 1876 del CC.

De esto se deduce que la hipoteca inversa se presenta como una nueva modalidad de garantía real, teniendo una regulación específica en nuestro ordenamiento jurídico: la Ley $41 / 2007$, de 7 de diciembre. Cabe destacar que la denominación «hipoteca inversa» es puramente comercial o convencional, al entender que el deudor percibe prestaciones en una aparente inversión de las posiciones contractuales ordinarias, pues el deudor cobra en lugar de pagar y, además, la devolución se retrasa hasta la muerte del prestatario o del beneficiario ${ }^{95}$.

En cuanto al concepto de hipoteca inversa, el punto primero de la DA 1. ${ }^{a}$ de la Ley 41/2007 determina que: «A los efectos de esta ley, se entenderá por hipoteca inversa, el préstamo o crédito garantizado mediante hipoteca sobre un bien inmueble que constituya la vivienda habitual del solicitante y siempre que cumpla unos requisitos».

Y, a diferencia de las hipotecas convencionales o de amortización, la hipoteca inversa es la primera hipoteca en la que en lugar de pagar al acreedor se recibe dinero de éste. El acreedor va entregando cantidades de dinero que van a ir reduciendo el valor líquido del inmueble, valor que también se reduce por los intereses que se van devengando. Por tanto, la hipoteca inversa es una operación contraria a la hipoteca convencional -con esta última la vivienda se va pagando a plazos-, mientras que con la hipoteca inversa se recibe a plazos el dinero que se obtendría por la venta de la vivienda.

Además, en la hipoteca convencional el saldo inicial está llamado a ir disminuyendo gradualmente, al contrario de lo que sucede con la hipoteca inversa. Con esta modalidad hipotecaria se logra rentabilizar el patrimonio. Es decir, con esta modalidad se pide un préstamo que se garantiza mediante la

\footnotetext{
95 Ramos Chaparro, E.J., La garantía real inmobiliaria. Manual sistemático de la hipoteca, Thomson Aranzadi, Navarra, 2008, p. 573.
} 
hipoteca del inmueble, con la particularidad de que dicho préstamo vence al fallecimiento del prestatario o del último de los beneficiarios, no pudiéndose hasta ese momento ejecutar la hipoteca.

En palabras de MURO VILLALÓN ${ }^{96}$ : «se puede señalar que las dos características más relevantes de las llamadas hipotecas inversas serían: de una parte el aplazamiento de la deuda a la fecha de fallecimiento del acreditado o deudor, de otra que el reembolso de la deuda se apoya exclusivamente en el valor en cambio de la vivienda hipotecada».

Sin embargo, SERRANO DE NiCOLÁs ${ }^{97}$ considera que esta dualidad de requisitos ha quedado reducida sólo al primero, es decir, al aplazamiento de la deuda, mientras que el segundo, relativo al reembolso de la deuda, se ha hecho extensivo, pasando de ser sólo la finca hipotecada inversamente, a abarcar todo el patrimonio del deudor hipotecario.

El Preámbulo de la Ley 41/2007, de 7 de diciembre, por la que se regula la hipoteca inversa, en su apartado VIII establece que con esta figura se pretende hacer líquido el valor de la vivienda mediante productos financieros, lo cual podría contribuir a paliar la satisfacción del incremento de las necesidades de renta durante los últimos años de vida que se produce en la mayoría de los países desarrollados.

Se trata de un crédito garantizado mediante la hipoteca de la vivienda habitual que permite la obtención de una renta periódica o su disposición de una sola vez -se transforma el valor líquido acumulado $^{98}$ de la vivienda en dinero efectivo-, en un principio, a todas aquellas personas mayores de 65 años o en situación de dependencia severa o gran dependencia. Ahora tras la entrada en vigor de la Ley $1 / 2013$, la posibilidad de optar a la contratación de esta hipoteca se amplía a personas a las que se les haya reconocido un grado de discapacidad igual o superior al 33 por ciento.

\footnotetext{
${ }^{96}$ MuRo Villalón, J.V., «La hipoteca...», op. cit., p. 6.

97 SeRRANO de Nicolás, Á., «Régimen jurídico...», op. cit., p. 37.

98 «Dinero hecho en casa. Hipotecas revertidas...», cit., pp. 2 y 3.
} 
De esta manera, la hipoteca inversa podría definirse como el contrato por el cual una entidad de crédito o una entidad aseguradora autorizada para operar en España pone a disposición de una persona física, de edad igual o superior a los 65 años o afectada de dependencia, o que se le haya reconocido un grado de discapacidad igual o superior al 33 por ciento, un capital que recibirá de forma periódica (tanto si se contrata de forma temporal como vitalicia) o de una sola vez o de una única disposición.

Este capital obtenido, a su vez, generará intereses pero el reembolso de la deuda sólo será exigible a partir del fallecimiento del deudor. Esta operación quedará asegurada desde el principio, ya que la garantía objeto de esta hipoteca será el inmueble sobre el que recae, que normalmente será la vivienda habitual del solicitante-contratante.

Por lo que respecta a la naturaleza jurídica de la hipoteca inversa, al igual que la hipoteca convencional, la inversa es un derecho real susceptible de desplegar efectos frente a terceros. Si nos fijamos con la hipoteca ordinaria, ésta se tiene que inscribir en el Registro, pues se trata de una inscripción constitutiva, es decir, sin inscripción no se encuentra válidamente constituida99.

Según ROCA SASTRE ${ }^{100}$, el otorgamiento del título constitutivo de la hipoteca se configura como un negocio jurídico, generalmente bilateral, que atribuye al acreedor la titularidad de un crédito hipotecario y, por ministerio de la ley, un conjunto de derechos derivados de esta titularidad, tendentes todos ellos a proporcionarle la seguridad de su crédito, la posibilidad de ejecución de la garantía y el cobro de la obligación valorada económicamente.

\footnotetext{
99 Vid. los artículos 1875 del CC y 145.2 de la LH para las hipotecas voluntarias y 159 y 194 para las hipotecas legales.

100 Roca SASTRE, R.M. y Roca-SASTRe MUnCUnILL, L., Derecho hipotecario, hipotecas, tomo VIII, op. cit., pp. 39 y ss.
} 
Esto sucede también para la hipoteca inversa, pues es preciso que se inscriba en el Registro. El sistema inmobiliario ${ }^{101}$ de fe pública protege la hipoteca en España. En concreto, el acreedor hipotecario queda protegido por la fe pública registral gracias a la certeza resultante de la escritura pública (intervención de notario, que expresa la fecha de su otorgamiento, la presencia de los comparecientes, su capacidad, etc.) y la certeza resultante de la inscripción de la escritura (calificación de legalidad y formalidad por parte del registrador de la propiedad).

Todo crédito hipotecario implica la existencia de un crédito y una hipoteca que lo garantiza, pero en la hipoteca inversa existen peculiaridades que la separan de la hipoteca convencional u ordinaria. Mientras que, la hipoteca ordinaria es un derecho real de realización de valor que garantiza el cumplimiento de una obligación y que tiene carácter accesorio respecto al crédito asegurado $^{102}$, en la hipoteca inversa surgen dudas acerca de su naturaleza, pues el legislador no es exacto en la precisión de la naturaleza jurídica de esta figura, ya que el problema reside en tipificarla como préstamo o como crédito.

Según la Ley 41/2007, de 7 de diciembre, en el apartado 1 de la DA 1 . $^{\text {a }}$ define la hipoteca inversa como: «El préstamo o crédito garantizado mediante hipoteca sobre un bien inmueble que constituya la vivienda habitual del solicitante». $\mathrm{Y}$, además, a lo largo de los diferentes apartados de la DA se refieren indistintamente a ella como préstamo o crédito, en los apartados 1.b), 5 y 6 , en cuanto a la disposición del importe, el vencimiento anticipado y la extinción del préstamo o crédito.

Sin embargo, en el apartado 5 de la DA $1 .^{a}$ se refiere sólo a la cancelación del préstamo y no del crédito. El legislador se refiere indistintamente al préstamo o al crédito, por este motivo se intuye que la hipoteca inversa podrá formalizarse mediante cualquiera de esos dos

\footnotetext{
101 Conforme al artículo 18 de la LH relativo a la calificación de legalidad y formalidad por parte del Registrador de la Propiedad.

102 Vid. los artículos 2.2, 104 y 105 de la LH y 1858,1876 y 1528 del CC.
} 
contratos, aunque según ÁLVAREZ ${ }^{103}$, sería más lógico entenderlo como un préstamo.

Entre el contrato de préstamo y el de crédito se pueden advertir diferencias tanto conceptuales como funcionales.

El contrato de préstamo ${ }^{104}$ se regula en el Libro IV de las Obligaciones y Contratos, Título X Del Préstamo. El préstamo es un contrato real que se perfecciona con la entrega de la cosa y, además, es un contrato unilateral, pues sólo produce obligaciones para una de las partes, concretamente para el prestatario, que es quien recibe de la otra parte, el prestamista, la cosa objeto de préstamo. Por ello, la obligación principal del prestatario consiste en devolver lo prestado.

El contrato de crédito es aquél por el cual el Banco se obliga, dentro del límite pactado y mediante una comisión que percibe el cliente, a poner a disposición de éste, y a medida de sus requerimientos, una suma de dinero. En virtud de ello, la cantidad adeudada no se encuentra determinada hasta que se practique la liquidación, ya que incluso puede acontecer que el acreditado, no haya realizado ninguna disposición.

Por el contrario, el contrato de préstamo es un contrato real, en el que el banco prestamista hace entrega en el acto de una suma de dinero que el prestatario ha de devolver, junto con los intereses pactados, en plazos periódicos o en una sola vez, según se haya convenido entre las partes. De esta manera, se presenta como un contrato real, el cual se perfecciona por la entrega de la cosa prestada y además es unilateral porque de él sólo surgen obligaciones para uno de los contratantes, concretamente, para el prestatario. En cambio, el contrato de crédito es bilateral, pues surgen

\footnotetext{
103 Álvarez Álvarez, H., La hipoteca inversa..., op. cit., p. 56.

${ }^{104}$ Según el artículo 1740 del CC, el préstamo es aquel contrato por el que: «una de las partes entrega a la otra, o alguna cosa no fungible para que use de ella por cierto tiempo y se la devuelva, en cuyo caso se llama comodato, o dinero u otra cosa fungible, con condición de devolver otro tanto de la misma especie y calidad, en cuyo caso conserva simplemente el nombre de préstamo».
} 
obligaciones para ambas partes, de manera que se ha de alcanzar un consenso entre éstas.

Respecto al objeto del contrato, para el de préstamo es el dinero que se entrega mientras que para el de crédito el objeto lo constituye la disponibilidad del dinero hasta el límite pactado.

En el contrato de préstamo consta la suma entregada por el prestamista, el plazo de devolución, el tipo de interés aplicable, la cuantía y el número de los sucesivos vencimientos. En el préstamo la cantidad adeudada es líquida desde la formalización de su contrato, y con el transcurso del tiempo sólo se precisan unas simples operaciones aritméticas para determinar el saldo deudor ${ }^{105}$.

En cuanto al momento de la perfección del contrato, para el contrato de préstamo se da con la entrega del dinero prestado mientras que en el de crédito se perfecciona con el simple acuerdo de voluntades entre las partes.

En lo referente a los intereses no existen diferencias entre ambas modalidades.

De esta manera, escogiendo a TAFFIN ${ }^{106}$ entre otros autores, para él se trata de un préstamo donde el prestamista reclamará la cantidad total del préstamo (el capital) y los intereses acumulados sobre la cantidad recibida. Es decir, el prestamista, como en la hipoteca convencional, cobrará intereses al prestatario de la hipoteca inversa. Ahora bien, este autor también señala que es un tipo especial de préstamo, pues éste sería contra el valor de la vivienda.

En opinión de la profesora ÁlvAREZ ${ }^{107}$, la hipoteca inversa es un préstamo $^{108}$ con garantía hipotecaria, por medio del cual, una entidad

\footnotetext{
${ }^{105}$ Vid. SAP de Cuenca de 6 de octubre de 1998 (AC 1998/7917) y SAP de Soria de 18 de febrero de 1998(AC 199813622).

106 TAFFIN, C., «La hipoteca inversa o vitalicia», op. cit., p. 2. Cfr. RodRIGo GARCíA, G., «La hipoteca...», op. cit., p. 57.

${ }_{107}$ Álvarez ÁlvAREZ, H., La hipoteca inversa..., op. cit., p. 53.
} 
financiera pone a disposición del cliente una cantidad fija que éste tendrá que devolver con unos intereses pactados en el plazo acordado.

A pesar de estas valoraciones, algunos autores ${ }^{109}$ no han distinguido si es un crédito o préstamo, y definen la hipoteca inversa como «un préstamo o crédito hipotecario».

\section{LA REGULACIÓN JURÍDICA DE LA HIPOTECA INVERSA: LA LEY 41/2007, DE 7 DE DICIEMBRE}

Se trata de una Ley que lleva por título «Ley 41/2007, de 7 de diciembre, por la que se modifica la Ley 2/1981, de 25 de marzo, de Regulación del Mercado Hipotecario y otras normas del sistema hipotecario y financiero, de regulación de las hipotecas inversas y el seguro de dependencia y por la que se establece determinada norma tributaria ${ }^{110}{ }$.

En el texto articulado se modifica la Ley 26/1988, de 29 de julio, sobre disciplina e intervención de las entidades de crédito, la Ley $2 / 1981$, de 25 de marzo, de regulación del mercado hipotecario, la Ley 2/1994, de 30 de marzo, sobre subrogación y modificación de los préstamos hipotecarios y la Ley Hipotecaria de 8 de febrero de $1946^{111}$.

También se modifican otras leyes en las disposiciones adicionales y finales de la Ley, en concreto:

- En la DA 3. ${ }^{a}$ se modifica la LEC $1 / 2000$.

- En la DF $1 .^{a}$ se reforma la Ley $3 / 1994$, de 14 de abril, por la que se adapta la legislación española en materia de entidades de crédito a la Segunda Directiva de Coordinación Bancaria.

\footnotetext{
${ }^{108}$ En líneas generales, existen diferencias conceptuales y funcionales entre el contrato de préstamo y el de crédito. Vid. al respecto la SAP de Madrid de 6 de julio de 2002 (JUR 2003\4870).

${ }^{109}$ Cfr. en este sentido Anguita Ríos, R.M., «La hipoteca...», op. cit., pp. 3 y ss.; Gómez GÁlligo, J., «Principios generales...», op. cit., p. 2185.

${ }^{110}$ BOE núm. 294, de 8 de diciembre.

111 Vid. Gómez GÁlligo, J., «Principios generales...», op. cit., pp. 2172-2175.
} 
- En la DF 2. ${ }^{a}$ varia el Texto Refundido de la Ley de Ordenación y Supervisión de los Seguros Privados, aprobado por RD Legislativo 6/2004, de 29 de octubre.

- En la DF 3. a cambia la Ley de Hipoteca mobiliaria y prenda sin desplazamiento de posesión (LHMPSDP), de 16 de diciembre de 1954.

- En la DF $4 .^{a}$ se altera la Ley $35 / 2007$, de 15 de noviembre, por la que se establece la deducción por nacimiento o adopción en el Impuesto sobre la Renta de las Personas Físicas y la prestación económica de pago único de la Seguridad Social por nacimiento o adopción.

- En la DF 5. ${ }^{\text {a }}$ varia el Fondo de Garantía del Pago de Alimentos.

- En la DF 6. ${ }^{a}$ se modifica la LEC 1/2000 y el RD legislativo 2/1995, de 7 de abril, por el que se aprueba el texto refundido de la Ley de Procedimiento Laboral.

- Y para finalizar, en la DF $7 .^{\text {a }}$ se reforma la Ley 29/1987, de 18 de diciembre, del Impuesto sobre Sucesiones y Donaciones.

Observamos que en la Ley 41/2007 se contienen tanto disposiciones adicionales como finales muy dispares entre $\mathrm{si}^{112}$. De esta forma, junto a las ya mencionadas, podemos encontrar, entre otras:

- La DA 5. ${ }^{\text {a }}$ que trata sobre Reglas especiales para valorar las disposiciones patrimoniales a los efectos de la determinación de la capacidad económica de los solicitantes de prestaciones por dependencia.

- Y, la más estrambótica, la DA $6 .^{a}$ donde se regula el Acontecimiento

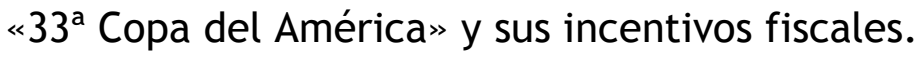

La hipoteca inversa se normaliza por vez primera a través de esta Ley, por la que se modifica la regulación ${ }^{113}$ del mercado financiero, concretamente en su DA $1 .^{\mathrm{a}}$.

\footnotetext{
112 Vid. Martínez Martínez, M., Temas sobre validez y eficacia en la «Ley de hipoteca inversa», Nulidad, 2008 (Estudios), NUL. Estudios sobre invalidez e ineficacia. Nulidad de los actos jurídicos: http://www.codigo-civil. info/nulidad/lodel/document.php?id=595.

${ }_{113}$ Con la entrada en vigor de la Ley $1 / 2013$, de 14 de mayo, en el Capítulo II se introdujo una serie de mejoras a través de la modificación de la Ley Hipotecaria (Texto Refundido según Decreto de 8 de febrero de 1946), la Ley 2/1981, de 25 de marzo, de Regulación del Mercado Hipotecario y la Ley 41/2007, de 7 de diciembre, por la que se modifica la Ley $2 / 1981$, de 25 de marzo, de Regulación del
} 
En el proyecto inicial de la Ley remitido por el Gobierno a las Cortes, la regulación relativa a la hipoteca inversa fue objeto de varias enmiendas ${ }^{114}$, tanto en el Congreso como en el Senado. A pesar de ello, muchas de las enmiendas del Senado, teniendo el mismo tenor literal que otras que se presentaron en el Congreso, no prosperaron.

De los 11 apartados, que a través de la Disposición Adicional Primera conforman la regulación de la Hipoteca Inversa, solamente los 3, 9 y 10 -no siendo objeto de ninguna enmienda en el Congreso- son originarios del Proyecto de Ley. En el Senado, los apartados 1, 4, 5, 6, 7 y 8 si fueron objeto de enmiendas en el texto definitivo, tras las modificaciones que se produjeron en el Congreso.

Hasta la aparición de esta Ley 41/2007 por la que se regula la hipoteca inversa, carecíamos de regulación específica para esta figura hipotecaria. A la vista está que en la Ley Hipotecaria de 1861, debido a las costumbres y negocios jurídicos de la época, esta modalidad fuera una auténtica desconocida. Esta circunstancia también se presenta en la Ley Hipotecaria de 1869, así como también en las reformas de 1909 y 1944-46.

En el apartado VIII del Preámbulo de la Ley 41/2007, concretamente, en los párrafos tercero y cuarto, se justifica la regulación de la hipoteca inversa, estableciendo lo siguiente:

«Hacer líquido el valor de la vivienda mediante productos financieros podría contribuir a paliar uno de los grandes problemas socioeconómicos que tienen España y la mayoría de países desarrollados: la satisfacción del incremento de las necesidades de renta durante los últimos años de la vida. La hipoteca inversa regulada en esta Ley se define como un préstamo o crédito hipotecario del que el propietario de la vivienda realiza disposiciones, normalmente periódicas, aunque la disposición pueda ser de una sola vez, hasta un importe

Mercado Hipotecario y otras normas del sistema hipotecario y financiero, de regulación de hipotecas inversas y el seguro de dependencia y por la que se establece determinada norma tributaria.

114 Este aspecto lo analiza con detenimiento QUESADA SÁNCHEZ, A.J., «Apuntes jurídico-civiles sobre la llamada «hipoteca inversa»: inquietudes iniciales sobre la cuestión», El Consultor Inmobiliario, № 88, marzo 2008, pp. 7-20. 
máximo determinado por un porcentaje del valor de tasación en el momento de la constitución. Cuando se alcanza dicho porcentaje, el mayor o dependiente deja de disponer de la renta y la deuda sigue generando intereses. La recuperación por parte de la entidad del crédito dispuesto más los intereses se produce normalmente de una vez cuando fallece el propietario, mediante la cancelación de la deuda por los herederos o la ejecución de la garantía hipotecaria por parte de la entidad de crédito.

No cabe duda, pues, que el desarrollo de un mercado de hipotecas inversas que permitan a los mayores utilizar parte de su patrimonio inmobiliario para aumentar su renta ofrece un gran potencial de generación de beneficios económicos y sociales. La posibilidad de disfrutar en vida del ahorro acumulado en la vivienda aumentaría enormemente la capacidad para suavizar el perfil de renta y consumo a lo largo del ciclo vital, con el consiguiente efecto positivo sobre el bienestar».

A continuación, se detallan los 11 Apartados de la Disposición Adicional Primera que conforman dicha Ley ${ }^{115}$.

En el apartado 1 se incluyen los requisitos necesarios para que se pueda constituir válidamente una hipoteca inversa. Estos requisitos son relativos al solicitante ${ }^{116}$ de esta hipoteca, la cuantía de la deuda y la tasación de la vivienda objeto de hipoteca inversa.

En el apartado 2 se hace referencia a que este tipo de hipoteca sólo será concedido por entidades de crédito y entidades aseguradas autorizadas para operar en España.

En el apartado 3 se hace referencia al régimen de transparencia y comercialización de dicha hipoteca implantado por el Ministro de Economía y Hacienda ${ }^{117}$.

En el apartado 4, a raíz del apartado anterior, se hace referencia al asesoramiento independiente para tramitar esta figura hipotecaria. Este

\footnotetext{
${ }^{115}$ Boletín Oficial de las Cortes Generales, Congreso de los Diputados, VIII Legislatura, Serie A (Proyectos de Ley), 5 de diciembre de 2007, núm. 127-11.

${ }^{116}$ Con la Ley $1 / 2013$, en su artículo 5 se modifica la letra a) del Apartado 1 de la D. A. $1 .{ }^{\text {a }}$ quedando de la siguiente manera: «a) que el solicitante y los beneficiarios que éste pueda designar sean personas de edad igual o superior a los 65 años o afectadas de dependencia, o personas a las que se les haya reconocido un grado de discapacidad igual o superior al 33 por ciento». Antes se aludía a «dependencia severa o gran dependencia», por tanto, se amplían los casos para poder optar a esta modalidad.

${ }^{117}$ En la actualidad se denomina Ministro de Economía y Competitividad.
} 
asesoramiento se llevará a cabo a través de los mecanismos que determine el Ministro de Economía y Hacienda ${ }^{118}$.

En el apartado 5 se aborda la cancelación del préstamo a causa del fallecimiento del deudor o del último de los beneficiarios. Se hace mención a los herederos, los cuales podrán cancelar el préstamo en el plazo estipulado, sin que para ello el acreedor les pueda exigir ningún tipo de compensación por la cancelación. También se hace referencia al vencimiento anticipado del préstamo.

En el apartado 6 se señala la cuantía máxima objeto de este contrato. Cuando se extinga el préstamo y los herederos no reembolsen los débitos vencidos con sus intereses, el acreedor sólo podrá obtener recobro hasta donde alcancen los bienes de la herencia.

En el apartado 7 se hace mención a las escrituras públicas que documenten las operaciones de constitución, subrogación, novación modificativa y cancelación, estarán exentas de la cuota gradual de documentos notariales de la modalidad de actos jurídicos documentados del Impuesto sobre Transmisiones y Actos Jurídicos Documentados.

Del mismo modo, en el apartado 8 se hace referencia al arancel de los «Documentos sin cuantía» para determinar los honorarios notariales por las escrituras relativas a las operaciones citadas en el apartado 7.

En el apartado 9 se hace hincapié en el cálculo del arancel de los Registradores de la Propiedad, en el que, tomando como base la cifra del capital pendiente de amortizar, se fija una reducción del 90 por 100.

En el apartado 10 se hace alusión a los inmuebles distintos a la vivienda habitual ${ }^{119}$ del solicitante o deudor. A las hipotecas inversas que se creen a

\footnotetext{
${ }^{118}$ Cordero Lobato, E., Tratado de los Derechos de Garantía, VV.AA., Aranzadi, Navarra, 2002, pp. 470 y 471. Este autor dispone que al posible cliente se le informe del plazo, importe de las cuotas (con una tabla orientativa), tipos de interés, comisiones y gastos a cargo del prestatario, gastos fiscales y arancelarios de la operación.
} 
favor de estos inmuebles no les será de aplicación los apartados anteriores de esta Disposición.

Finalmente, en el apartado 11 de esta Disposición Adicional Primera de la Ley 41/2007 se establece una norma de cierre algo imprecisa e innecesaria, al determinar que «en lo no previsto en esta disposición y su normativa de desarrollo, la hipoteca inversa se regirá por lo dispuesto en la legislación que en cada caso resulte aplicable».

En resumen, desde el análisis del articulado en que se estructura la hipoteca inversa, se puede decir que esta Ley ha sido objeto de crítica. Se observa que el legislador la ha dispuesto de forma muy deficiente, incluso llegando a peligrar la seguridad jurídica ${ }^{120}$ : sólo hay que fijarse en que la hipoteca inversa se regula en una disposición adicional de una Ley que regula figuras muy distintas que no guardan relación entre sí.

Las hipotecas inversas ya existían con anterioridad a la citada Ley, pues algunas entidades de crédito, normalmente Cajas de Ahorro, ya la ofertaban con denominaciones tales como Hipoteca inversa, Hipoteca pensión, Hipoteca bienestar, Pensión hipotecaria o Complemento hipotecario ${ }^{121}$. Sin embargo, dependiendo de la entidad financiera, el producto era distinto debido a la falta de una normativa específica para este tipo de producto. Esta dispersión desemboca en la necesidad de regular una normativa «coherente y uniforme» para poder ofertar este tipo de producto financiero: esta figura queda plasmada a través de la Ley $41 / 2007$, de 7 de diciembre.

\footnotetext{
119 Si nos fijamos en el apartado 1 de la DA 1. a , a pesar de la entrada en vigor de la Ley $1 / 2013$, todavía se exige que la hipoteca inversa se constituya sobre la vivienda habitual del solicitante. Y ello a pesar de que este requisito trató de suprimirse durante la tramitación parlamentaria bajo la idea de que no existían motivos para excluir a otros inmuebles de las ventajas que se podían derivar de la hipoteca inversa (Enmiendas núms. 98 y 122 en el Congreso, y 22 y 64 en el Senado). Finalmente se optó por mantener esta restricción, aunque añadiendo este párrafo 10. Esta opinión es compartida también por ANGUITA Ríos, R.M., «La hipoteca...», op. cit., p. 9.

${ }^{120}$ En este aspecto, Álvarez Álvarez, H., La hipoteca inversa..., op. cit., p. 34, opina que la hipoteca inversa se regula muy lejos de la Ley Hipotecaria, en una disposición adicional de una ley muy heterogénea lo que vulnera la seguridad jurídica. Cfr. ANGUITA Ríos, R.M., «Regulación relativa...», op. cit., p. 20; MARTínez MARTínez, M., "Temas sobre...", op. cit.; Rubio ToRRano, E., «De la Ley que define la hipoteca inversa y regula otras muchas cosas», Aranzadi Civil, núm. 17, 2007; SemPere NAVARRO, A.V., «El escondite jurídico. (Un apunte sobre topografía normativa)", Actualidad Jurídica Aranzadi, núm. 746, 2008.

${ }^{121}$ En cuanto a estas entidades podemos señalar que Ibercaja fue la pionera, en el año 2004, seguida de Caixa Terrassa, que comenzó a comercializarla a finales de 2005, y Caixa Sabadell. También alguna otra entidad la ofrecía pero con la previa petición de los clientes.
} 
También hay que detenerse en que la hipoteca inversa, como ya venía ocurriendo con anterioridad a esta Ley, queda sometida a la normativa civil e hipotecaria, jugando un importante papel la libertad de pactos. Esta libertad de pactos se puede perfilar en que nuestro país goza de un clima que la mayoría de los países de la Unión Europa no tienen. De ahí que muchos extranjeros (la gran mayoría ciudadanos de la Unión Europea), personas mayores de 65 años, hayan establecido su residencia habitual en España.

En algunos de estos países, por ejemplo en el caso de los anglosajones, la hipoteca inversa tiene un notable arraigo y no parece extraño que estas personas quieran constituir esta garantía sobre su vivienda habitual, ubicada en territorio español. Además, se puede dar el caso de que deseen concertar el préstamo con una entidad de su país y, por tanto, desconociendo la ley española, no haya un sometimiento a todos los requisitos impuestos en la Ley $41 / 2007$.

No obstante, conviene destacar que la regulación ha ido mejorando a través de la tramitación de una Ley que comenzó como un anteproyecto muy humilde que se ganó las críticas de la Asociación Hipotecaria Española ${ }^{122}$.

\section{Cláusula de cierre de la Disposición Adicional 1 . $^{a}$ de la Ley 41/2007}

Con el apartado 11 se pone fin a esta Disposición Adicional Primera de la Ley 41/2007. Este apartado se presenta como un precepto ambiguo y superfluo al disponer que: «En lo no previsto en esta disposición y su normativa de desarrollo, la hipoteca inversa se regirá por lo dispuesto en la legislación que en cada caso resulte aplicable».

\footnotetext{
122 Así lo indica MARTínez Escribano, C., La hipoteca inversa, op. cit., pp. 60 y 61, al considerar la Asociación Hipotecaria Española que «es una obligación urgente del Gobierno facilitar la movilización más eficiente y beneficiosa del patrimonio inmobiliario por parte de las personas dependientes", lo que exige «una normativa muy cuidadosa y especialmente respetuosa», por lo que la ley de 2007 «no es el marco más adecuado para regular un producto y una situación de tanta complejidad y tanta trascendencia social».
} 
Durante el proceso de tramitación legislativa del Proyecto de Ley cabe significar que en su regulación no se presentó enmienda alguna, debido a lo poco discutible que era. La única modificación que se produjo fue la de su reestructuración, es decir, en lugar de ser el apartado 10 pasó a ser el apartado 11, con motivo de la introducción de otro apartado previo.

Como consecuencia de este apartado, la hipoteca inversa deberá formalizarse $^{123}$ en escritura pública e inscribirse en el Registro de la Propiedad, tal y como se establece en el artículo 1875 del CC. Y, además, las lagunas, deficiencias o inconvenientes a que pueda dar lugar esta norma prevista por el legislador español para regular la hipoteca inversa tendrán que ser cubiertas, en la medida de lo posible, con lo estipulado en la normativa hipotecaria general.

En síntesis, la podríamos definir como una cláusula ${ }^{124}$ de carácter residual.

\section{CARACTERÍSTICAS DE LA HIPOTECA INVERSA}

La esencia de la hipoteca inversa reside en no tener que devolver ni capital ni intereses hasta que fallezca el deudor hipotecario o el último de los beneficiarios. Por tanto, el fallecimiento del deudor o, en su caso, el del último beneficiario, ordenará el vencimiento de la hipoteca y la exigibilidad de la deuda.

De esta característica principal se pueden derivar a su vez otras ${ }^{125}$, tales como:

\footnotetext{
${ }^{123}$ Este tema se verá con más detalle en el punto dedicado a los Requisitos Formales.

124 QUESADA SÁnCHEZ, A.J., «Apuntes jurídico-civiles...», op. cit., p. 30. El autor califica este apartado 11 como cláusula de cierre.

125 Vid. Álvarez Álvarez, H., La hipoteca inversa..., op. cit., p. 63; Gómez Gálligo, J., «Principios generales...», op. cit., pp. 2186 y 2187 y JIMÉNEZ CLAR, A.J., «La hipoteca inversa como instrumento de protección social», RDBB, Año n XXVIII, núm. 113, enero-marzo 2009, pp. 107-109.
} 
1. - En esta modalidad hipotecaria se garantiza una obligación futura y mortis causa, puesto que la exigibilidad del crédito depende de la muerte del deudor o del beneficiario. Por este motivo es un préstamo hipotecario especial, pues no pueden realizarse devoluciones periódicas durante la vida del beneficiario.

2.- Las personas que pueden solicitar la hipoteca inversa tendrán que tener 65 o más años o estar afectadas de dependencia o que se les haya reconocido un grado de discapacidad igual o superior al 33 por ciento. En estos casos, la Ley no especifica una edad concreta. Cuando el solicitante opte a esta modalidad por cumplir el requisito de la edad, éste lo tendrá que cumplir tanto el solicitante o solicitantes, así como también, el beneficiario o beneficiarios, en el caso de que los hubiere.

3.- La hipoteca inversa permite a sus beneficiarios percibir una cantidad complementaria a su pensión, ya sea de forma temporal o vitalicia, a modo de renta ${ }^{126}$. Se trata de una hipoteca que garantiza un capital inicialmente determinado que se entregará de una sola vez o de forma periódica, según lo hayan convenido las partes.

4.- El deudor conserva la propiedad de la vivienda. De esta manera, se garantiza que el propietario siga siendo el $\operatorname{titular}^{127}$ de la misma y pueda vivir en ella, si lo desea, hasta su fallecimiento. Se permite al deudor conservar la propiedad y a los herederos mantenerla, previo pago de las cantidades dispuestas por el causante y sus intereses. Por esta causa, el propietario deberá continuar haciéndose cargo de todas las obligaciones que recaen sobre la propiedad, como por ejemplo, el pago de impuestos, seguros, mantenimiento de la vivienda, etc.

\footnotetext{
126 Según el artículo «El éxito de las hipotecas inversas», publicado en Lex Nova La Revista, julioseptiembre de 2007, pp. 63 y 64, se sostiene que la hipoteca inversa es un crédito hipotecario. Del mismo modo, lo define Ibercaja que lo considera como un crédito hipotecario especial, por el que no se paga nada, sino que se cobra una renta.

127 Gómez GÁlligo, J., «Principios generales...», op. cit., p. 2186. En esto se diferencia de figuras jurídicas de finalidad semejante, pero mucho más leoninas -incluso cercanas a la prohibición de pacto comisorio propio del Derecho común (ex artículo 1859 del CC)- que utilizaron tiempo atrás las entidades financieras con cierta frecuencia, como es la renta vitalicia, que se caracteriza por perder la propiedad a favor de la entidad financiera a cambio de una pensión calculada actuarialmente en función de la edad del cedente del inmueble.
} 
Ahora bien, también puede ir a vivir a una residencia o con un familiar sin perder por ello la propiedad del inmueble. En estos dos últimos supuestos, se podría dar el caso de que el propietario alquilase ${ }^{128}$ la vivienda para obtener más ingresos. De esta manera, la hipoteca inversa opera igual que la hipoteca ordinaria, ya que no se produce el desplazamiento de la posesión al acreedor hipotecario.

5. - Mientras que en la hipoteca ordinaria, el deudor debe efectuar pagos mensuales al acreedor, en la hipoteca inversa es la entidad de crédito o aseguradora quien paga al deudor hipotecario. Se trata de una hipoteca que podríamos considerar de endeudamiento o desamortización, a diferencia de la hipoteca ordinaria (destinada a la adquisición de una vivienda), que es de amortización $^{129}$.

6. - Este tipo de hipoteca sólo puede ser concedida por las entidades de crédito y por las entidades aseguradoras autorizadas para operar en España. Las condiciones de vulnerabilidad de los grupos sociales (personas mayores o en situación de dependencia o discapacidad) a los que va destinado este producto hacen aconsejable la exclusión de este mercado de todos aquellos operadores financieros que no estén sujetos a la especial normativa de supervisión a la que están sometidas dichas entidades.

7.- La hipoteca inversa va a permitir obtener una renta ${ }^{130}$ -complementaria o no de las pensiones públicas- con la garantía de un patrimonio ya pagado y amortizado.

\footnotetext{
${ }^{128}$ Esta causa, como se verá más adelante, no fue contemplada por la Ley $41 / 2007$.

129 PUIG BRUTAU, J., Compendio de Derecho Civil, Volumen III, Derechos reales, Derecho hipotecario, Bosch, Barcelona, 1989, p. 421, define la hipoteca de amortización como aquélla modalidad donde: «El capital es reintegrado en cuotas de amortización crecientes, distribuidas sobre un largo plazo, según un plan fijado, cuyo pago se hace al mismo tiempo que el de los intereses. El acreedor percibe anualmente una suma igual, que comprende los intereses y la parte del capital que se amortiza, de modo que en esta cantidad unitaria la parte correspondiente a los intereses disminuye progresivamente y de manera paralela crecen las sumas destinadas al reembolso del capital».

130 En este aspecto, la STSJ de País Vasco de 28 de febrero de 2011 (TOL4.372.976) señala que: «La figura de la hipoteca inversa tiene por finalidad permitir que los mayores puedan movilizar su patrimonio inmobiliario para obtener una renta adicional, aportando su propia vivienda habitual como garantía de préstamos o créditos hipotecarios, cuya devolución no podrá exigirse, en general hasta la muerte del deudor hipotecario y en los términos fijados en la DA $1 .^{a}$ de la Ley $41 / 2007$. Si acudimos al Diccionario de la Real Academia de la Lengua por recursos se entiende "los bienes o medios de
} 
8. - Da liquidez al patrimonio inmobiliario. En la hipoteca inversa, el valor líquido en que se transforma el inmueble obtiene su máximo beneficio al inicio de su constitución, pues a medida que va pasando el tiempo se va reduciendo este valor, por lo que incluso con el transcurso del tiempo podría ocurrir que la deuda fuera superior al valor de mercado de la vivienda.

Ahora bien, siempre podría darse el caso que la vivienda se revalorizase en un periodo breve de tiempo, aunque esta posibilidad parece improbable, pues el precio de la vivienda, desde 2008 hasta 2014 ha ido en descenso. No obstante, el sector inmobiliario ${ }^{131}$ prevé para este año regresar a los niveles de inversión anteriores a la crisis.

Esta circunstancia supone un gran riesgo para las entidades de crédito. De ahí se deduce que el coste de las hipotecas inversas sea mayor que el de las hipotecas ordinarias, con respecto a los tipos de interés y a las comisiones, pues las entidades de crédito no conocen cuál va a ser el plazo de la duración del producto, al desconocerse tanto el momento en el que va a producirse el fallecimiento del prestatario como el valor de mercado que puede tener entonces la vivienda hipotecada. Para disminuir ese riesgo, la entidad prestamista obliga a que el prestatario contrate un seguro.

9.- Se impone que las entidades que concedan hipotecas inversas deberán suministrar servicios de asesoramiento independiente ${ }^{132}$ a los solicitantes de este producto, teniendo en cuenta la situación financiera del solicitante y los riesgos económicos derivados de la suscripción de este producto.

subsistencia" y por rendimientos "el producto o utilidad que da algo". De lo anterior, se evidencia con claridad que las cantidades que se obtienen por la formalización de "hipoteca inversa" tienen el carácter de recurso computable, en concepto de rendimiento del patrimonio y como tal computable para integrar la renta mensual de la unidad económica de convivencia independiente».

${ }^{131}$ Vid. Artículo publicado en $A B C$ Economía el día 20 de febrero de 2015: «La inversión inmobiliaria en España vuelve a los niveles previos a la crisis», pp. 34 y 35, disponible en: www.abc.es/economia.

132 Sobre esta cuestión volveremos con mayor amplitud en el epígrafe dedicado a los Requisitos Formales. 
Este asesoramiento independiente podrá llevarse a cabo bien a través de la figura del Defensor del Cliente, bien a través de los mecanismos que determine el Ministro de Economía y Hacienda. En la actualidad se le denomina Ministro de Economía y Competitividad.

10.- Al igual que sucede con las hipotecas convencionales, no existe una entidad que sea más competitiva en el mercado bancario español sino que dependen de las características de cada caso concreto, unas beneficiarán más a las personas que tengan una determinada edad, otras serán más competentes en función de los tipos de interés, etc. El solicitante optará por la que mejor se ajuste a sus necesidades.

11.- El inmueble sobre el que se constituye la hipoteca inversa deberá ser obligatoriamente tasado y asegurado contra daños de acuerdo con los términos y los requisitos que se establecen en los artículos 7 y 8 de la Ley 2/1981, de 25 de marzo, de Regulación del Mercado Hipotecario.

La tasación se presenta como una exigencia imperativa e imprescindible, no por la responsabilidad de la finca sino por la misma viabilidad económica al posibilitar su titulación y refinanciación. La necesidad de tasación y del seguro se debe a la condición de la hipoteca inversa con respecto a otras modalidades de hipoteca.

El diseño jurídico-económico de esta hipoteca descansa sobre el valor del inmueble y no sobre la capacidad de pago del deudor hipotecario. Por esta causa, el valor del inmueble hipotecado inversamente debe ser cierto desde el momento de la constitución de la hipoteca y ha de ser conservado durante la vida del deudor o beneficiario. En síntesis, la valoración del bien hipotecado inversamente no sólo se asienta como garantía del crédito concedido sino también como posible medio de pago.

12.- El acreedor se asegura la devolución de la deuda generada mediante la constitución de una hipoteca inversa. 
13.- La hipoteca inversa ha de constituirse necesariamente como contrato de carácter vitalicio. Las prestaciones a las que queda obligada la entidad acreedora tienen el límite temporal máximo de la vida del deudor hipotecario o, en el supuesto de que los haya, del último beneficiario.

El fallecimiento del deudor hipotecario antes de la finalización de la entrega de la totalidad del capital pactado no transmite a sus herederos derecho alguno para la reclamación de la parte pendiente de entrega.

14. - Con respecto a la configuración de la operación de activo a través de hipoteca inversa puede ser crédito o préstamo ${ }^{133}$, disponible en una sola disposición o varias de forma periódica.

15. - La cantidad que el acreedor concederá dependerá del valor del inmueble que se da en garantía. De esta manera, el importe a entregar por la entidad de crédito estará formado por el capital que se concederá teniendo en cuenta el valor de la vivienda con los intereses que se devenguen durante la duración del contrato, así como los demás costes que se produzcan, tales como impuestos, comisiones, primas de seguros, gastos de constitución de la hipoteca inversa, etc.

16. - La constitución de una hipoteca inversa genera gastos de comisión $^{134}$. Estas comisiones pueden ser fijadas libremente por la entidad de crédito pero en nuestra legislación existen limitaciones. Por una parte, las emanadas del Banco de España en forma de Circulares y Órdenes y por otra, las emitidas en materia de consumidores y usuarios por la legislación

\footnotetext{
${ }^{133}$ Desde el punto de vista de SeRRANO de Nicolás, Á., «La hipoteca...», op. cit., p. 47, podrá ser cualquier modalidad al uso de los mismos y, más concretamente, podrían caber ambas modalidades articuladas como hipoteca de máximo.

${ }^{134}$ La comisión consistirá en una prestación accesoria o, más concretamente, complementaria de la prestación principal, cuya finalidad será retribuir los servicios o gastos de administración de los créditos efectuados por el acreedor.
} 
protectora de este sector ${ }^{135}$. Además, hay que considerar que las comisiones deben responder a servicios efectivamente prestados o a gastos realizados ${ }^{136}$.

17. - El tipo de interés ofrecido en esta modalidad hipotecaria suele ser a tipo fijo $^{137}$. Para la entidad prestamista el riesgo radica en la posible variabilidad al alza de los tipos de interés durante todo el tiempo de duración del contrato hasta el momento de su exigibilidad. Y, además, en la aleatoriedad de la fecha de vencimiento del préstamo, pues estos intereses se seguirán devengando conforme al tipo pactado aunque finalice el periodo de disposición de las rentas y hasta la incierta fecha del fallecimiento del deudor o beneficiario ${ }^{138}$.

18. - No se requiere el desembolso de una cantidad inicial ya que la vivienda actúa de garantía. La única garantía ${ }^{139}$ económica del préstamo será el valor de venta del inmueble en el momento en que tengan que devolverse las cantidades adeudadas, bien de forma forzosa o voluntaria. Aunque también se pueden suscribir seguros para afrontar cualquier eventualidad.

19.- Los herederos no pierden sus derechos. La figura de la hipoteca inversa está estrechamente relacionada con la figura de la hipoteca de responsabilidad limitada y con la institución anglosajona de los non recourse loans. De esta manera, la responsabilidad por la deuda garantizada en la hipoteca inversa quedará limitada a los bienes que compongan la herencia del deudor.

\footnotetext{
135 Real Decreto Legislativo $1 / 2007$, de 16 de noviembre, por el que se aprueba el texto refundido de la Ley General para la Defensa de los Consumidores y Usuarios y otras Leyes Complementarias (BOE de 30 de noviembre).

${ }^{136}$ Cfr. Roca SAStre, R.M.; Roca-SAStre Muncunill, R. y Bernà I XIRGó, J., Derecho hipotecario, tomo VIII, op. cit., pp. 166 y ss.

${ }^{137}$ Nada se dice al respecto. Esto se deduce de la práctica adoptada por las diferentes entidades de crédito que han ofertado este producto financiero.

${ }^{138}$ Vid. RDGRN de 8 de febrero de 2008 (RJ 2008\639).

139 También se ha dicho que es un crédito con garantía inmobiliaria o un crédito hipotecario especial. Cfr. Herranz GonzÁlez, R., «Hipoteca Inversa...», op. cit., p. 4. En términos similares se ha mantenido que es un crédito con garantía hipotecaria en determinadas condiciones. En este aspecto TUSET DEL PINO, P., «La hipotecas...», op. cit., p. 38, destaca que se trataría de un crédito en cuenta corriente con garantía hipotecaria.
} 
20. - La hipoteca inversa no tiene carácter finalista. Significa esto que cuando se formaliza esta hipoteca no se exige como requisito que el capital entregado vaya a destinarse a un uso determinado. De la misma manera, la Ley 41/2007 tampoco impone la forma en que se haya de disponer el capital prestado al deudor hipotecario y, menos aún, la entrega del mismo por la entidad acreedora.

21. - Dada la vinculación de la renta o pensión con el deudor hipotecante, se admite legalmente el vencimiento anticipado por venta de la finca hipotecada.

Estas son algunas de las características de la hipoteca inversa. Cada una de ellas será analizada a lo largo del programa. Ahora bien, en este punto resulta conveniente efectuar una matización sobre el carácter aleatorio del contrato formalizado con esta modalidad hipotecaria.

\section{Breve matización sobre el carácter aleatorio del contrato formalizado con hipoteca inversa}

El Preámbulo de la Ley 41/2007, en su punto VIII señala que cuando se alcance el importe del capital concedido, en el caso de que se pague fraccionadamente, el mayor, dependiente o persona con un grado de discapacidad igual o superior al 33 por ciento, dejará de disponer de la renta y la deuda seguirá generando intereses.

Si nos vamos al CC, la definición de contrato aleatorio aparece en el artículo 1790 del CC, según el cual: «Por el contrato aleatorio, una de las partes, o ambas recíprocamente, se obligan a dar o hacer alguna cosa en equivalencia de lo que la otra parte ha de dar o hacer para el caso de un acontecimiento incierto, o que ha de ocurrir en tiempo indeterminado». 
Como se puede apreciar, esta definición resulta algo confusa ya que no permite distinguir el contrato aleatorio del contrato adicional ${ }^{140}$. Como ya hemos visto, la hipoteca inversa se caracteriza, entre otras singularidades, por tratarse de un préstamo cuyo cumplimiento de la obligación de devolución va a depender de la fecha del fallecimiento del solicitante o del último beneficiario de esta modalidad hipotecaria. Sería pues un hecho certus an incertus quando.

Junto a este hecho o acontecimiento, se puede dar, como ya se ha comentado, la posibilidad de riesgo de pérdida o ganancia para las partes contratantes (solicitante-deudor y entidad acreedora). En el caso de que no se diera esta posibilidad de pérdida o ganancia, no habría ninguna diferencia entre los contratos aleatorios y los conmutativos. Sin embargo, mientras que los contratos conmutativos se caracterizan por la equivalencia de las prestaciones, los contratos aleatorios, en este aspecto, se muestran diferentes.

De esta manera, en la hipoteca inversa se puede producir «la asunción por las partes del riesgo de que el contrato arroje un saldo económicamente dispar y dependiente de un azar, en beneficio de una parte y perjuicio de la otra ${ }^{141}$ ». Es decir, que las partes corran el riesgo de sufrir un desequilibrio entre las prestaciones. No hay que olvidar que en esta modalidad el importe total de la deuda depende de la vida del prestatario o último beneficiario. De ello se infiere que una de las características del contrato sea su aleatoriedad $^{142}$.

\footnotetext{
140 Castañ Tobeñas, J., Derecho civil español, común y foral, T. 4: Derecho de obligaciones. De las particulares relaciones obligatorias, Reus S.A., Madrid, 1993, p. 720; Díez-PICAZo, L. y Gultón, A., Sistemas de Derecho Civil II: El contrato en general. La relación obligatoria. Las particulares relaciones obligatorias. La responsabilidad civil, 9. ${ }^{\text {a }}$ ed., Tecnos, Madrid, 2001, p. 430.

141 TruJlllo Díez, I.J., "Comentario al artículo 1790" en BerCovitz Rodríguez-Cano, R. (coord.), Comentarios al Código Civil, Thomson Aranzadi, Cizur Menor (Navarra), 2006, pp. 767 y 768; GoмÁ SALCEDO, J.E., «Principales problemas de la constitución de una renta vitalicia», Revista de Derecho Notarial, Madrid, 1960, pp. 313-315.

${ }^{142}$ La doctrina no mantiene que exista un sistema numerus clausus en materia de contratos aleatorios. Vid. Díez-Picazo, L. y Gullón, A., Sistema de Derecho Civil II, op. cit., p. 430; MARTínez de AguirRe Aldaz, C. (coord.); De Pablo Contreras, P.; Pérez Álvarez, M.Á. y Parra lucán, M.Á., Curso de Derecho Civil (II) Derecho de Obligaciones, $3 .^{a}$ ed., COLEX, Madrid, 2011, pp. 781-791.
} 
En este asunto, MURO VILLALÓN ${ }^{143}$ distingue entre una aleatoriedad «absoluta»y una aleatoriedad «relativa». Será absoluta en el caso de que la hipoteca inversa se haya contratado con carácter vitalicio, es decir, cuando la cuantía de la deuda dependa totalmente de la vida del solicitante o del último beneficiario. En cambio, será relativa en el caso de la modalidad temporal.

Sin embargo, para CASTAÑ TOBEÑAS ${ }^{144}$ : «un contrato no puede ser aleatorio respecto de una de las partes; no puede haber posibilidades de ganancia o pérdida para una de ellas sin que para la otra correspondan probabilidades correlativas o inversas». De lo citado se desprende que la aleatoriedad debe afectar a ambas partes, ya que un contrato no puede ser aleatorio respecto de una sola parte.

En sentido parecido encontramos a MARTínEZ ESCRIBANO ${ }^{145}$, quien descarta la nota de aleatoriedad de esta modalidad hipotecaria al señalar que: «el prestamista tiene derecho a recibir un importe igual al principal del préstamo más los intereses, con los que se asegura el equilibrio de las prestaciones... así se eliminan los riesgos derivados de la aleatoriedad presente en las otras formas de financiación».

Si nos posicionamos en el artículo 1753 CC, relativo a la figura del préstamo se dice que: «El que recibe en préstamo dinero u otra cosa fungible, adquiere su propiedad, y está obligado a devolver al acreedor otro tanto de la misma especie y calidad».

Por tanto, en el caso de la hipoteca inversa, al tratarse de un préstamo, éste no podría definirse como aleatorio. De manera que una vez se llegase al momento del cumplimiento de la obligación, el deudor-solicitante (en el caso de la modalidad temporal) o lo más normal, los herederos de éste (en el caso de la modalidad vitalicia), procedan a la devolución de lo prestado.

\footnotetext{
${ }^{143}$ Muro Villalón, J.V., «La hipoteca...», op. cit., pp. 166 y 167. Cfr. Berrocal Lanzarot, A.I., «Hipoteca Inversa y otros instrumentos afines», Academia sevillana del notariado: Conferencias del Curso Académico 2007/08 (on line), tomo XIX, Comares, Granada, 28 de enero de 2008, p. 98.

${ }^{144}$ Castañ Tobeñas, J., Derecho civil..., op. cit., p. 721.

${ }^{145}$ Martínez Escribano, C., La hipoteca inversa, op. cit., p. 48.
} 
En conclusión, en la hipoteca inversa esta característica de aleatoriedad únicamente se dará en el caso de que el deudor hipotecario fallezca antes de la total disposición del capital inicialmente concedido, sirviendo la fecha de su muerte para determinar la suma de la deuda exigible.

De esta forma, a la hipoteca inversa no se le puede atribuir una aleatoriedad absoluta, ahora bien, si que se puede apreciar una aleatoriedad relativa, pero no en el mismo sentido en que la define MURo VILLALón ${ }^{146}$. Como bien apunta ZURITA MARTíN ${ }^{147}$, lo deseable hubiese sido que el carácter aleatorio del negocio hubiese quedado perfectamente identificado y definido por la Ley.

En resumen, la hipoteca inversa no tiene naturaleza de contrato aleatorio, aunque podemos encontrar algunos casos de aleatoriedad relativa, donde ésta afecta a una de las partes y no a las dos. Entre estos casos de aleatoriedad relativa ${ }^{148}$, podemos encontrar los siguientes:

1.- Contrato de préstamo garantizado con una hipoteca inversa de responsabilidad limitada o concretada a la cosa hipotecada ${ }^{149}$.

Esta postura se establecerá en la escritura de constitución de la hipoteca ${ }^{150}$, de manera que la responsabilidad del deudor y la acción del acreedor quedarán limitadas al importe de los bienes hipotecados y no alcanzarán a los demás bienes del deudor ${ }^{151}$. Por tanto, la responsabilidad personal queda concretada al bien hipotecado inversamente, de manera que, «la extinción de la hipoteca por consumación o agotamiento debe provocar también la

\footnotetext{
${ }^{146}$ MURO Villalón, J.V., «La hipoteca...», op. cit., pp. 166 y 167.

147 ZuRita MARTín, I., «La nueva normativa reguladora de la hipoteca inversa», RCDI, № 707, 2008, p. 1316.

${ }^{148}$ Vid. más ampliamente SÁnCHEZ-VEnTURA MORER, I., La hipoteca inversa en el Derecho español, op. cit., pp. 253-257.

${ }^{149}$ ROCA SASTRE no habla de pacto de limitación, sino de concreción a los bienes hipotecados. Vid. RoCA SAStre, R.M. y Roca-SAStre Muncunill, L., Derecho hipotecario: Ley del Suelo e Hipotecas, tomo VII, Bosch, Barcelona, 1998, p. 619.

150 lbíd., p. 629.

151 Cfr. Carrasco Perera, Á.; Cordero lobato, E. y Marín López, M.J., Tratado de los derechos de garantía, tomo I, 2. ${ }^{a}$ ed., Thomson Aranzadi, Navarra, 2008, p. 562.
} 
extinción del débito personal correspondiente, aunque no se hubiere cubierto el importe de la obligación garantizada ${ }^{152}$ ».

En este caso, si llegara a suceder, sería la figura del acreedor la que podría verse perjudicada, ya que al haberse concretado la responsabilidad o el bien hipotecado en la escritura de constitución, el acreedor no podría dirigirse contra los demás bienes del deudor. En este supuesto, el transcurso del tiempo puede generar una situación de riesgo para el acreedor.

2. - Contrato de hipoteca inversa a través de la modalidad temporal.

Esta modalidad puede resultar perjudicial para el deudor en el caso de que supere sus expectativas, pues cuanto mayor sea la duración que no se haya previsto en el contrato, la cantidad adeudada junto con los intereses se irá incrementando cada vez más.

3. - Contrato de hipoteca inversa mediante la modalidad vitalicia.

En esta modalidad, hasta que no fallezca el deudor o el último beneficiario no se conoce con exactitud el importe de la obligación principal ni tampoco los intereses generados. En este supuesto, la figura del deudor o mejor dicho su patrimonio, es quien puede verse perjudicado, situación que no ocurre con la entidad acreedora que puede llegar a incrementar sus ganancias conforme avance el tiempo.

Con el fin de que no se puedan dar estas situaciones, en las que se vean perjudicadas una u otra parte, se estableció la formalización de la contratación de un seguro y así cubrir este riesgo de aleatoriedad. Como nota negativa, reseñar que este seguro supondrá un coste más a la hora de contratar esta modalidad hipotecaria. En este sentido, algunos autores ${ }^{153}$ han defendido el contrato de renta vitalicia frente a la hipoteca inversa.

\footnotetext{
152 Roca SASTRE, R.M. y Roca-SASTRE MUnCUnILL, L., Derecho hipotecario..., op. cit., p. 627.

153 TORAL LARA, E., «Hipoteca Inversa o Contrato de renta vitalicia», Actualidad Civil (AC), N 16, 2009, p. 1867, considera que en la renta vitalicia onerosa se da «un alea equilibrada que otorga tantas
} 


\section{MODALIDADES DE LA HIPOTECA INVERSA}

La Ley 41/2007, de 7 de diciembre, que regula la hipoteca inversa establece dos modalidades: temporal o vitalicia ${ }^{154}$.

\section{Temporal}

Si se pacta una renta temporal ${ }^{155}$, la renta que se percibe coincide con el valor de la vivienda que se haya negociado, es decir, se determina la cuantía máxima a la que puede ascender el límite del préstamo concedido a favor del acreedor hipotecario.

Este límite queda precisado por un tanto por ciento en relación al valor de tasación actual del inmueble ${ }^{156}$. A partir de ahí y teniendo en cuenta la edad del solicitante de la hipoteca inversa y, derivada de ella su esperanza de vida, se calcularán las disposiciones periódicas que recibirá el deudor durante un plazo determinado. La finalidad de estos cálculos se hace para que las cantidades entregadas, los intereses devengados y la suma de otras cantidades que se puedan incluir en el crédito no excedan del límite máximo concedido.

En esta modalidad, al firmarse una hipoteca inversa por tiempo limitado, la renta que se recibe será mayor con respecto a si se hubiera contratado una renta vitalicia. Esta renta temporal dejará de ser abonada una vez haya vencido el periodo de tiempo pactado. Al terminar este periodo de

posibilidades de salir beneficiado como perjudicado» lo que se contrapone a los elevados intereses y demás costes generados en el contrato de préstamo garantizado con hipoteca inversa.

${ }^{154}$ Para una mayor información financiera vid. DEVESA CARPIO, J.E.; DeVESA CARPIO, M.; Domínguez-FABIÁN, I.; Encinas-Goenechea, B.; Meneu-Gaya, R. y Nagore-García, A., «Análisis financiero-fiscal de la hipoteca inversa en España». Innovar. Revista de Ciencias Administrativas y Sociales, Universidad Nacional de Colombia, vol. 22, núm. 45, julio-septiembre 2012, pp. 111-126.

155 Desde un punto de vista financiero actuarial vid. también SÁnCHEZ ÁlvareZ, I.; LóPEZ ARES, S. y QUIROGA GARCíA, R., «Diseño de hipotecas inversas en el mercado español», op. cit., pp. 63-66, 69 y 71.

${ }^{156}$ En el momento en que entró en vigor la Ley 41/2007, el porcentaje oscilaba entre el 90 y el 100 por 100 de ese valor de tasación. 
disposición se conocerá exactamente la cantidad adeudada, que según los cálculos de revalorización ${ }^{157}$ del inmueble será sensiblemente inferior al valor de venta de la finca en esa fecha.

En esta variante, con el fin de evitar que, una vez concluido el periodo de disposición, el deudor sobreviva y se quede sin rentas, se establece un seguro de supervivencia. Este seguro permite abonar al asegurado rentas vitalicias hasta la fecha de su fallecimiento. Es ofrecido por algunas entidades, bien de forma voluntaria bien de forma obligatoria.

Cuando se contrate el aludido seguro, éste se abonará con una prima inicial y se cargará como un gasto más del préstamo concedido. En ocasiones también se exigirá un seguro respecto de los posibles intereses indeterminados o no cubiertos por el valor del inmueble y que se puedan devengar después del periodo de disposición.

La posibilidad de contratar una hipoteca inversa está estrechamente ligada con el valor de la vivienda y, es más que evidente que no sólo tiene importancia el valor inicial de la misma, sino también su posible revalorización. Por esta razón, tal como se ha comentado anteriormente dentro de las características de esta hipoteca, la tasación resulta fundamental.

Si en la hipoteca inversa -a diferencia de lo que sucede en la ordinaria-, la exigibilidad de la deuda se produce en el momento del fallecimiento del deudor o del último beneficiario, la entidad acreedora no cuenta con la garantía adicional que supone la responsabilidad patrimonial universal tipificada en el artículo 1911 del Código Civil. En este caso la única garantía hipotecaria de que se dispone es el inmueble y su valor.

157 Estos cálculos oscilarán dependiendo de la edad del prestatario o deudor y aplicando una revalorización del 3 por 100 entre un 50 y un 70 por 100 del crédito concedido. 
El legislador, consciente del dilema que se podía presentar en el Apartado 1.d) de la DA 1. ${ }^{a}$, estableció como requisito esencial para la correcta formalización de la hipoteca inversa que:

d) «la vivienda hipotecada haya sido tasada y asegurada contra daños de acuerdo con los términos y los requisitos que se establecen en los artículos 7 y 8 de la Ley $2 / 1981$, de 25 de marzo, de Regulación del Mercado Hipotecario».

Junto a este elemento, el importe de la prestación a recibir será mayor o menor en función de la edad del solicitante de la hipoteca inversa.

En el caso de que en la hipoteca aparezca algún beneficiario ${ }^{158}$ se tendrá en cuenta, cuando haya más de uno, la edad del titular más joven y el deseo de éste de obtener estos ingresos durante el resto de su vida o, únicamente, durante un periodo de tiempo predeterminado.

Con esta modalidad se cobrará una renta cuyo importe dependerá de la tasación de la vivienda, de la edad del solicitante y de sus preferencias en la forma de percibir el dinero. Por esta causa, el riesgo de contratar una hipoteca inversa temporal es muy alto. En el supuesto de que el propietario se encuentre con vida en el momento de finalización del préstamo, tendrá, con total probabilidad, que abandonar su vivienda debido a que no será capaz de afrontar económicamente los gastos de mantenimiento.

Con esta opción, el deudor puede llegar a quedarse desprotegido si sobrevive al periodo temporal pactado en la constitución de la hipoteca. Además, tendría que pagar todo el dinero recibido junto con los intereses y los costes de finalización del préstamo llegando incluso a no tener suficiente dinero para hacer frente a esos gastos, ni tan siquiera con la cantidad obtenida por la venta de la vivienda. Lo mismo podría sucederle a su cónyuge

$\overline{158}$ ZURITA MARTín, I., «La nueva normativa...», op. cit., pp. 1284 y 1285. 
supérstite o conviviente de hecho, salvo que en el contrato específicamente se hubiera hecho constar que se hacía de por vida para ambos ${ }^{159}$.

En resumen, si el tiempo de vida del deudor se alargase por encima del cálculo actuarial realizado por las entidades aseguradoras, el valor del inmueble podría ser insuficiente para hacer frente a la deuda. Por este motivo resulta difícil que las entidades de crédito utilicen esta forma de disposición, aunque no deja de ser cierto que el riesgo asumido podría disminuirse mediante la contratación de un seguro que cubriese el infravalor del inmueble hipotecado. De esta manera, aunque la mensualidad sea menor y con el objetivo de que el deudor cobre sus rentas hasta que muera, resulta más conveniente solicitar una hipoteca inversa vitalicia.

En conclusión: que la entidad de crédito, teniendo en cuenta la edad del deudor y su esperanza de vida, así como el valor de la vivienda, calculará las disposiciones periódicas que recibirá el deudor así como su cuantía, de tal manera que las cantidades entregadas más los intereses y los gastos de la operación no excedan del límite máximo concedido. Por tanto, la cantidad adeudada será sensiblemente inferior al valor en venta de la finca según los cálculos de revalorización del inmueble. No obstante, lo ideal sería que se permitiese la posibilidad de actualizar la cantidad máxima disponible mediante el contrato de novación.

\section{Vitalicia}

En esta modalidad ${ }^{160}$, la renta se recibe durante toda la vida de los titulares de la hipoteca, aunque la mensualidad sea menor, ya que el acreedor pretende asegurarse que en ningún caso el beneficiario obtenga rentas que superen el valor del inmueble. Si la renta que suministra el

\footnotetext{
${ }^{159}$ Apartado 1.c) de la DA $1 .^{\text {a }}$ de la Ley: «que la deuda sólo sea exigible por el acreedor y la garantía ejecutable cuando fallezca el prestatario o, si así se estipula en el contrato, cuando fallezca el último de los beneficiarios».

160 Vid. Sánchez Álvarez, I.; López Áres, S. y Quiroga García, R., «Diseño de hipotecas inversas en el mercado español», op. cit., pp. 66 y 71 .
} 
acreedor se agota, el propietario puede seguir viviendo en la casa hipotecada pero los intereses se irán acumulando.

La edad y la esperanza de vida son factores determinantes a la hora de contratar una renta temporal o vitalicia. Será más recomendable optar por la temporal cuanto más avanzada sea la edad del receptor de las rentas. Ahora bien, cuando se opte por una de las posibilidades, renta temporal o vitalicia, una vez contratada, ya no se podrá variar.

La entidad financiera realiza un cálculo de la esperanza de vida de la persona mayor de 65 años $^{161}$ que quiere contratar una hipoteca inversa. Estas entidades tienen calculado que a partir de los 70 años, en función de la salud del cliente, su esperanza de vida puede oscilar entre los 15 y los 18 años. Tras una operación financiera, el banco o caja calcula la renta mensual que puede ofrecer, teniendo en cuenta el valor de la vivienda.

La esperanza de vida de una persona se determina de acuerdo con su edad y su sexo, conforme a lo que establece el Instituto Nacional de Estadística $^{162}$. De hecho, la esperanza de vida de las mujeres ${ }^{163}$ es algo mayor que la de los hombres, por lo que a igual edad e inmueble del mismo valor, la renta que recibirá periódicamente la mujer será menor que la del varón. Si la persona vive más tiempo de lo estimado, la Ley no ha establecido nada al respecto.

En la práctica, las entidades que antes de la entrada en vigor de la Ley ofertaban la hipoteca inversa establecían que una entidad aseguradora es la

\footnotetext{
161 Según datos publicados en el INE en fecha de 1 de enero de 2013, en España había 8.333.283 personas de 65 y más años, lo que suponía un 18\% de toda la población. Dentro de esta población, más del $56 \%$ de las personas mayores son mujeres, es decir, el número de mujeres de 65 años y más es de 4.721.441, frente a los 3.629.456 varones.

162 Según predicciones del INE (abril de 2014), en el año 2052 el 37\% de la población superará los 64 años. Si se mantienen constantes los ritmos actuales de reducción de la incidencia de la mortalidad por cada grupo de edad, en 2051 la esperanza de vida al nacer será de 86,9 años para los varones y de 90,7 para las mujeres. En el año 2011, según el INE, la esperanza de vida al nacimiento superaba los 82 años, en varones alcanzaba los 79,2 años y en mujeres los 85,0 años, es decir, de 2006 a 2011 aumentó en 1,2 años.

${ }^{163}$ Según datos publicados por el Ministerio de Sanidad, Servicios Sociales e Igualdad (abril de 2014), las mujeres viven más años que los hombres y la esperanza de vida para las nacidas en 2012 es de 85 años, frente a los 79,3 años de los varones.
} 
que se hace cargo de seguir pagando las rentas, pues el deudor puede contratar un seguro de rentas vitalicias hasta el fallecimiento de los titulares del préstamo.

Ahora bien, para ello es necesario que el propietario haya contratado ese seguro al mismo tiempo que la hipoteca inversa. Aunque en principio este seguro no es obligatorio, sí es muy habitual en la práctica, llegando a ser un requisito sine qua non, pues si no se contrata las entidades de crédito no celebrarán la hipoteca inversa como consecuencia del riesgo que asumen. Esto se hace para evitar que suceda lo mismo que en los primeros momentos del desarrollo de estos créditos en los países anglosajones, pues en algunos casos las personas vivían más tiempo del estimado por los bancos y acabó por desahuciarse a los propietarios.

Con el seguro de rentas vitalicias se asegura que el propietario cobre mensualmente la renta de por vida. Si el titular fallece antes de que venza el plazo fijado en el contrato de la hipoteca inversa, los herederos recibirán la parte proporcional de la prima que en su día la persona deudora pagó, atendiendo a la renta recibida por el titular y al plazo fijado.

Así, si el deudor o solicitante de la hipoteca inversa muere después del plazo contratado y ha suscrito un seguro de renta vitalicia, gracias al seguro podrá seguir cobrando la misma renta mensual, aunque la hipoteca haya vencido, pudiendo, de esta manera, seguir residiendo en su vivienda. El problema es que el coste de este seguro es bastante elevado, pues suele estar en torno al 6 por 100 del valor del inmueble.

La gran ventaja de la contratación de este seguro es que se garantiza que el titular de la hipoteca inversa cobrará las rentas de forma vitalicia, aunque haya superado el plazo establecido al contratar la hipoteca. Ahora bien, tiene un gran inconveniente $y$ es que los gastos por contratar este seguro de sobrevivencia son muy elevados, pues se trata de un gasto más al del crédito concedido. 
En el supuesto de que no se hubiera contratado el seguro de rentas vitalicias y el titular falleciera antes del vencimiento del plazo de la hipoteca inversa, los herederos sólo se harían cargo de la deuda contraída con la entidad de crédito. En cambio, si no se ha contratado este seguro y se sobreviviera al plazo estipulado con la hipoteca inversa, ya no se cobrarían más rentas $\mathrm{y}$, además, se tendría que abonar la deuda contraída con el acreedor hipotecario. El deudor, para hacer frente a estos gastos, seguramente tendría que vender su vivienda o encontrar algún otro modo de financiación, pues en última instancia la vivienda pasaría a ser propiedad del acreedor.

En principio, éstas serían las dos modalidades de hipoteca inversa ${ }^{164}$.

En la escritura de constitución de la hipoteca inversa deberá hacerse constar la forma, plazo y cuantías de las prestaciones periódicas. Por tanto, se tendrá que establecer en el momento de su constitución, la modalidad que se va a adoptar, es decir, bien a través de una renta vitalicia ${ }^{165}$ (a disposición del deudor mientras permanezca con vida) o bien a través de una renta temporal (sólo durante un período de tiempo). Como ya se ha comentado, una vez se haya optado por una u otra modalidad, ésta ya no se podrá modificar.

\footnotetext{
164 Devesa Carpio, J.e.; Devesa Carpio, M.; Domínguez-Fabián, I.; Encinas-Goenechea, B.; Meneu-Gaya, R. y NAGORE-GARCíA, A., "Análisis financiero-fiscal...», op. cit., p. 125. Los autores de este trabajo destacan que la conclusión más importante del mismo ha sido: "que la utilización de la hipoteca inversa, como parte de una operación más amplia, es altamente recomendable por la elevada rentabilidad financierofiscal obtenida.

La operación más amplía en la que estaría integrada la hipoteca inversa incluye la inversión en vivienda, junto con la consideración del alquiler como un ingreso, y junto con la utilización del valor residual como capital asegurado de un seguro para caso de fallecimiento».

${ }^{165}$ Vid. LUQUE JIMÉNEZ, M.C., «Una nueva modalidad...», op. cit., pp. 230-232.
} 



\section{CAPÍTULO IV: ELEMENTOS DEL CONTRATO DE HIPOTECA INVERSA}

\section{REQUISITOS SUBJETIVOS}

Para poder solicitar una hipoteca inversa es preciso que se cumplan una serie de requisitos que se recogen en los apartados a), c) y d) del punto 1 de la DA $1 .^{a}$ de la Ley $41 / 2007$, de 7 de diciembre, por la que se regula la hipoteca inversa.

Los requisitos que se recogen en estos apartados son los siguientes:

1. - «a) Que el solicitante y los beneficiarios que éste pueda designar sean personas de edad igual o superior a los 65 años o personas afectadas por cualquier situación de dependencia severa o gran dependencia».

Ahora bien, este apartado se ha visto modificado por la Ley $1 / 2013$, de 14 de mayo, quedando de la siguiente manera:

«a) Que el solicitante y los beneficiarios que éste pueda designar sean personas de edad igual o superior a los 65 años o personas afectadas de dependencia o personas a las que se les haya reconocido un grado de discapacidad igual o superior al 33 por ciento».

Como podemos observar, se amplían los casos de «dependencia severa o gran dependencia», pasando a «dependencia o personas a las que se les haya reconocido un grado de discapacidad igual o superior al 33 por ciento».

2.- «c) Que la deuda sólo sea exigible por el acreedor y la garantía ejecutable cuando fallezca el prestatario o, si así se estipula en el contrato, cuando fallezca el último de los beneficiarios».

3. - «d) Que la vivienda hipotecada haya sido tasada y asegurada contra daños de acuerdo con los términos y los requisitos que se establecen en los artículos 7 y 8 de la Ley 2/1981, de 25 de marzo, de Regulación del Mercado Hipotecario». 
En lo referente a los requisitos subjetivos ${ }^{166}$ se pueden contemplar, al menos, cuatro figuras distintas que necesariamente no tienen que ser cuatro personas físicas diferentes, sino que pueden coincidir en una misma. Esta coincidencia se puede dar en las figuras del solicitante (DA 1. ${ }^{\mathrm{a}}$, apartados 1, 4 y 10), del acreedor hipotecario (DA 1. ${ }^{a}$, apartado 1.c)) y del deudor (DA 1. ${ }^{a}$, apartados 1.b), 5 y 6). Esto será distinto para la figura del beneficiario (DA $1 .^{\mathrm{a}}$, apartados. 1.a) y c) y 5 y DA $\left.4 .^{\mathrm{a}}\right)$.

Señalar que los solicitantes, deudores hipotecarios y beneficiarios pueden ser más de una persona física. Significa esto que, la parte solicitante y deudora hipotecaria podría ser que sea una sola persona y varios los beneficiarios o al revés ${ }^{167}$.

\section{El acreedor hipotecario}

Inicialmente ${ }^{168}$, el Proyecto de la Ley 41/2007 contemplaba únicamente la posibilidad de que la parte prestamista fuera una entidad financiera, aunque más tarde se amplió a las entidades aseguradoras ${ }^{169}$.

En la actualidad, y de acuerdo con el apartado $2^{170}$ de la DA $1 .^{\mathrm{a}}$ de la Ley 41/2007, las hipotecas inversas sólo pueden concederlas las entidades de

\footnotetext{
166 SerRano de Nicolás, Á., «Régimen jurídico...», op. cit., p. 43.

167 Un ejemplo que justifica la diferenciación de dicho solicitante, prestatario, deudor hipotecario y beneficiario, puede ser el del cónyuge (deudor hipotecario), casado en régimen de gananciales, pero propietario privativo único -por haberla adquirido por herencia paterna-, de la vivienda habitual del matrimonio, que, además, es solicitante junto con su cónyuge -por tanto, ambos prestatarios- de un préstamo o crédito del que serán beneficiarios los dos hijos del matrimonio, a la vez, uno afectado de dependencia severa y otro de gran dependencia y, además, todos ellos, junto con la madre del solicitante (ésta sólo de forma sucesiva y para el caso de que le premuera el hijo) beneficiarios de las rentas aseguradas que se contemplan en la DA $4 .^{\text {a }}$ de la propia Ley $41 / 2007$.

168 JIMÉNEZ CLAR, J., «La hipoteca...», op. cit., p. 110.

${ }^{169}$ Aunque el objeto principal de las compañías aseguradoras sea la práctica de operaciones de seguro, reaseguro y capitalización, algunas de ellas han concedido préstamos con garantía hipotecaria. Prueba de ello es la STS de 12 de noviembre de 2009 (RJ 2010\1737) donde en su fundamento de derecho primero señala que: «Es cierto que la concesión de préstamos con garantía hipotecaria encaja propiamente en el ámbito de afectación de una provisión técnica de una entidad aseguradora, sin embargo, no es menos cierto, que el hecho de que la entidad aseguradora conceda préstamos para invertir dicha provisión no implica que tal concesión constituya su actividad habitual, que no es otra que la que se deriva del contrato de seguro». Al respecto, vid. también la Resolución del Tribunal Económico-Administrativo Central de 19 de enero de 2001 (JT 2001\190).

${ }^{170}$ Apartado 2 de la DA 1. a de Ley 41/2007: «Las hipotecas a que se refiere esta disposición sólo podrán ser concedidas por las entidades de crédito y por las entidades aseguradoras autorizadas para operar en
} 
crédito y las entidades aseguradoras ${ }^{171}$ respetando los límites, requisitos 0 condiciones que imponga la normativa sobre seguros.

ROMERO CANDAU ${ }^{172}$ opina que esta limitación que se hace a las entidades de crédito no admite excepción. De esta manera, no sería posible constituir una hipoteca inversa entre particulares. En cambio, otros autores entienden ${ }^{173}$ que sí se podría admitir la posibilidad de constituir una hipoteca entre particulares, aunque en este caso, no se aplicaría la Ley 41/2007 por la que se regula la hipoteca inversa.

En este aspecto, creemos que si se podría celebrar la contratación de una hipoteca inversa entre particulares, en virtud del principio de autonomía de la voluntad, pero, al igual que sucede con las hipotecas celebradas conforme al apartado 10 de la DA $1 .^{\text {a }}$ de la Ley $41 / 2007$, no le sería aplicable lo relativo a los beneficios fiscales y reducciones arancelarias.

Junto a esto, también habría que tener en cuenta que, en el caso de que surgiera algún conflicto entre los particulares y estos se dirigieran a los tribunales, con carácter supletorio se aplicaría la Disposición Adicional 1. ${ }^{\mathrm{a}}$ de la Ley $41 / 2007$ por la que se regula esta figura.

En síntesis, la figura del acreedor hipotecario se determina en función de si la hipoteca inversa es para gravar la vivienda habitual o es para gravar cualquier otro inmueble.

A continuación, se expone un breve análisis sobre esta cuestión.

\footnotetext{
España, sin perjuicio de los límites, requisitos o condiciones que, a las entidades aseguradoras, imponga su normativa sectorial».

${ }^{171}$ El artículo 2.3 de la Orden EHA 2899/2011 de 28 de octubre recoge, entre otros asuntos, el régimen de transparencia que debe regir en la concesión de hipotecas inversas.

172 Romero CANDAU, P.A., «La hipoteca inversa», en Hacia un nuevo derecho hipotecario. Estudios sobre la Ley 41/2007, de reforma del mercado hipotecario, VV.AA., coord. por Valerio PÉREZ DE MADRID CARRERAS, Academia Sevillana del Notariado, Consejo General del Notariado, Madrid, 2008, pp. 319 y 222.

173 Martínez Escribano, C., La hipoteca inversa, op. cit., pp. 68 y 69, señala que podría darse la posibilidad de constituir una hipoteca inversa con un acreedor distinto de las entidades de crédito y las entidades aseguradoras, pero que quedará sustraída de la aplicación del régimen jurídico previsto para la hipoteca inversa en la DA $1 .^{a}$ de la Ley $41 / 2007$. De tal manera que podrían ser otros los acreedores hipotecarios, aunque no se aplicaría entonces la citada disposición. En el mismo sentido se manifiesta SERRANO dE NicolÁs, Á., «Régimen jurídico...», op. cit., p. 45.
} 


\subsection{Hipoteca inversa sobre la vivienda habitual}

La hipoteca inversa sobre la vivienda habitual puede ser concedida por las entidades de crédito o aseguradoras y también por cualquier persona física o jurídica. No obstante, única y exclusivamente gozarán de los beneficios fiscales, notariales y registrales contemplados en los apartados 7 a 9 de la misma Ley, los préstamos y créditos garantizados con la vivienda habitual del solicitante que sean concedidos por las entidades de crédito y por las entidades aseguradoras autorizadas para operar en España.

Por este motivo, si se quiere optar a estos beneficios, el préstamo o crédito avalado no podrá concederse por ninguna otra persona o entidad, física o jurídica. A su vez y con la trascendencia práctica que esto conlleva, sólo podrán ser objeto de subrogación o novación, los concedidos por las entidades de crédito contempladas en el artículo 2 de la Ley del Mercado Hipotecario $(\mathrm{LMH})^{174}$.

Junto a este requisito, para disfrutar de estos beneficios, se tendrán que dar también determinadas circunstancias personales de los solicitantes y beneficiarios (las veremos en los puntos siguientes).

1.2. Hipoteca inversa sobre otros bienes inmuebles distintos a la vivienda habitual

En este caso, también podrían ser otros los acreedores hipotecarios, aunque no se aplicaría entonces la Disposición Adicional Primera de la Ley 41/2007, pues al tratarse de hipotecas inversas atípicas, es decir, aquellas que se rigen por el principio de autonomía de la voluntad, y de acuerdo con el

\footnotetext{
${ }^{174}$ Sobre este asunto Romero CANDAU, P.A., «La hipoteca...», op. cit., p. 319, manifiesta que no cabe la cesión de un crédito a una entidad distinta de las enumeradas en el art. $2 \mathrm{LMH}$, especialmente por el carácter creciente de la deuda que exige asegurar unos estándares adecuados de solvencia.
} 
Apartado 10 de la DA $1 .{ }^{a}$ de la Ley $41 / 2007$, al recaer en inmuebles diferentes de la vivienda habitual del solicitante, los sujetos concedentes podrían ser cualesquiera persona física o jurídica ${ }^{175}$.

Por ser estos sujetos, los concedentes, de estos préstamos o créditos, además de no gozar de ningún beneficio fiscal, notarial o registral, se añade otro riesgo evidente, salvo que se trate de un préstamo (en éste desaparece, el riesgo del cobro, al recibirse en un solo acto la totalidad del capital), ya que se requerirá la solvencia durante, posiblemente dos o más décadas, de la persona física o jurídica para el pago de las cuotas periódicas.

A ello se le une el problema de que podría resolverse en caso de incumplimiento, pues podría darse el caso de que se incluyera dentro del supuesto de insolvencia concursal (sin serles de aplicación la nueva regulación del art. 10 de la $L M H)^{176}$.

Ante esta posibilidad, de admitir que la parte acreedora o prestamista pueda ser cualquier entidad de crédito, con las graves repercusiones que podría tener para el deudor la falta de control de este tipo de hipotecas, parece más razonable entender limitado el ámbito de actuación, al igual que en el caso del artículo 153 bis (relativo a la hipoteca flotante) de la Ley Hipotecaria (introducido también por la Ley 41/2007), a las entidades financieras a las que se refiere el artículo 2 de la Ley 2/1981 del Mercado Hipotecario.

De esta manera, la hipoteca inversa podrá ser realizada por todas las entidades aseguradoras, con los límites que recoge el apartado 2 de la DA $1 .^{a}$ de la Ley $41 / 2007$. Esto no deja de ser un gran riesgo, pues no se ha tenido en

\footnotetext{
175 SeRRANO de Nicolás, Á., «Régimen jurídico...», op. cit., pp. 39-45.

${ }^{176}$ Con la entrada en vigor de la Ley 41/2007, a través del artículo 12 punto 2 , se dotó al artículo 10 de la Ley $2 / 1981$, de 25 de marzo, de Regulación del Mercado Hipotecario de una nueva regulación estableciendo que: «Las hipotecas inscritas a favor de las entidades a que se refiere el artículo 2 sólo podrán ser rescindidas o impugnadas al amparo de lo previsto en el artículo 71 de la Ley 22/2003, de 9 de julio, Concursal, por la administración concursal, que tendrá que demostrar la existencia de fraude en la constitución de gravamen. En todo caso quedarán a salvo los derecho del tercero de buena fe».
} 
cuenta que en otros países la gestión realizada por las entidades aseguradoras ha resultado fraudulenta.

A diferencia de otras normas modificadas por la Ley 41/2007, en la Disposición Adicional $1 .^{\mathrm{a}}$ no se hace referencia a la lista de entidades de crédito que contiene el artículo 2 de la Ley del Mercado Hipotecario (también redactado de nuevo por la citada Ley). Esto se justifica, como dice el Preámbulo de la Ley 41/2007, por la especial normativa de supervisión a la que están sometidas dichas entidades, reforzando así el carácter de norma excepcional y protectora de la Disposición Adicional $1 .^{a}$.

El artículo 2 de la Ley del Mercado Hipotecario, en su redacción dada por la Ley 41/2007, determina las entidades de crédito que podrán otorgar préstamos y créditos y que son las siguientes:

- Los bancos y, cuando así lo permitan sus respectivos estatutos, las entidades oficiales de crédito.

- Las Cajas de Ahorro y la Confederación Española de Cajas de Ahorro.

- Las cooperativas de crédito.

- Y, por último, los establecimientos financieros de crédito.

Estas entidades están sujetas a la Ley 2/1994, de 30 de marzo, sobre subrogación y modificación de préstamos hipotecarios ${ }^{177}$. Con esta lista quedarían excluidos cualesquiera otros operadores del mercado crediticio tales como las llamadas empresas de reagrupación de créditos y otros intermediarios financieros del capital privado.

En resumen, la justificación de las entidades aseguradoras viene dada por la incertidumbre que suele caracterizar a la hipoteca inversa, ya que en esta figura se desconoce el tiempo de su duración, así como también la cantidad final del préstamo. Por tanto, las condiciones que aquí se dan son

177 Publicada en el BOE núm. 80, el día 4 de abril y desarrollada por Real Decreto núm. 716/2009, de 24 de abril. 
muy similares a las que rigen en el contrato de seguro, basado en la idea de riesgo.

Además de estos acreedores, podríamos encontrar a cualquier persona física o jurídica. Ahora bien, no parece que sea la opción más idónea, pues la extensión de la hipoteca inversa en el tiempo, aconseja que el acreedor ofrezca amplias garantías de solvencia ${ }^{178}$.

No obstante, la Ley $2 / 2009$, de 31 de $\operatorname{marzo}^{179}$, por la que se regula la contratación con los consumidores de préstamos o créditos hipotecarios y de servicio de intermediación para la celebración de contratos de préstamo o crédito, garantiza la transparencia y la protección a los consumidores en los casos en que, entidades distintas a las de crédito, ofrezcan préstamos o actúen como intermediarios de los mismos.

\section{El deudor}

\subsection{Personas de edad igual o superior a los 65 años}

Cuando entró en vigor la Ley 41/2007, en fecha de 9 de diciembre, en el apartado 1.a) de la DA 1. ${ }^{\text {a }}$ se establecía: «que el solicitante y los beneficiarios que éste pueda designar sean personas de edad igual o superior a los 65 años o afectadas de dependencia severa o gran dependencia».

Por tanto, para poder solicitar la hipoteca inversa se tenía que tener una edad determinada ${ }^{180}$ o encontrarse en una situación de dependencia severa o gran dependencia ${ }^{181}$.

\footnotetext{
178 SerRano de Nicolás, Á., «Régimen jurídico...», op. cit., p. 46.

${ }^{179}$ BOE núm. 79, de 1 de abril de 2009.

180 En la Sentencia de la AP de Barcelona de 3 de diciembre (JUR\2015\55056), la demanda rectora de autos pretende que se declare la nulidad por simulación absoluta de la escritura de disolución de condominio de fecha 29 de abril de 2010, así como la cancelación en el Registro de la Propiedad de las inscripciones y anotaciones producidas como consecuencia de la referida escritura. Precisa la actora en su escrito inicial que los ahora litigantes están unidos por matrimonio, y para poder ayudar económicamente al hijo común, decidieron seguir el consejo de sus asesores acudiendo a la figura de la llamada «hipoteca inversa» sobre la vivienda; si bien, como quiera que la ahora demandante aún no tenía 65 años, el solicitante y beneficiario de la «hipoteca inversa» tenía que ser el Sr. Hernan, ahora
} 
Como hemos ido viendo a lo largo del temario, este apartado se ha visto modificado por la Ley $1 / 2013$, de 14 de mayo, quedando de la siguiente manera:

« a) Que el solicitante y los beneficiarios que éste pueda designar sean personas de edad igual o superior a los 65 años o personas afectadas de dependencia o personas a las que se les haya reconocido un grado de discapacidad igual o superior al 33 por ciento».

Esta reforma es aplicable desde el día 15 de mayo de 2013. Como podemos observar, con respecto al requisito de la edad, ésta se mantiene conforme al precepto original, debiendo ser igual o superior a los 65 años.

En el año 2007, la edad oficial de jubilación en nuestro país era de 65 años, de ahí, que se incluyera dicha edad en esta Ley. Ahora bien, desde el 1 de enero de $2013^{182}$, la edad de acceso a la pensión de jubilación ${ }^{183}$ depende de la edad del interesado y de las cotizaciones acumuladas a lo largo de su vida laboral, requiriendo haber cumplido la edad de:

demandado, por lo que tuvieron que proceder a disolver el condominio, adjudicándose éste en pleno dominio la vivienda con aplazamiento de pago a la Sra. Daniela de la contraprestación pactada (49.400 euros) hasta el 29 de julio de 2010, si bien nunca llegó a percibir tal importe.

${ }^{181}$ Vid. SAP de Murcia de 4 de junio de 2013 (TOL3.793.508).

182 Datos publicados en el Ministerio de Empleo y Seguridad Social para el año 2014. Apartado Seguridad Social: Prestaciones/Pensiones de Trabajadores (www.seg-social.es).

${ }^{183}$ Trabajar y cotizar en la Seguridad Social es un deber si se quiere generar el derecho a una pensión pública de jubilación. La ley exige trabajar y cotizar una serie de años para jubilarse de forma ordinaria a los 65 años (habiendo logrado una carrera de cotización completa) o, para jubilarse desde los 65 años a los 67 , de forma progresiva hasta 2027 , si no se han acumulado los años necesarios de cotización. No obstante, también existe la posibilidad de jubilarse de forma anticipada, con penalización, y siempre que se cumplan una serie de requisitos. Pero, más allá y una vez cumplidos estos deberes de años trabajados y cotizados, la jubilación también es un derecho totalmente voluntario, según reconoce la Seguridad Social. Es decir, el trabajador es el que decide cuando se retira, teniendo libertad e incluso incentivos para seguir trabajando después de cumplir la edad ordinaria en la que la ley le permitiría retirarse. Ahora bien, en ocasiones, los convenios colectivos pueden incluir cláusulas que posibiliten la extinción del contrato de trabajo por el cumplimiento por parte del trabajador de la edad ordinaria de jubilación fijada en la normativa de la Seguridad Social. En estos casos, desde la publicación de la Ley de Reforma Laboral 3/2012, la Seguridad Social entiende «nulas y sin efecto las cláusulas de los convenios colectivos que posibiliten la extinción del contrato de trabajo por el cumplimiento por parte del trabajador de la edad ordinaria de jubilación fijada en la normativa de Seguridad Social, cualquiera que sea la extensión y el alcance de dichas cláusulas». Esto significa que el trabajador será el que decidirá cuando se retira. La normativa se aplicará a los convenios colectivos que se suscriban o se hayan suscrito a partir del 8 de julio de 2012. En cuanto a los convenios colectivos suscritos con anterioridad al 8 de julio de 2012, la norma se aplicará en los siguientes términos:

- Cuando la finalización de la vigencia inicial pactada de dichos convenios se produzca después de fecha de 08/07/2012, la aplicación se producirá a partir de la fecha de la citada finalización.

- Cuando la finalización de la vigencia inicial pactada de dichos convenios se hubiera producido antes del 08/07/2012, la aplicación se producirá a partir de esta última fecha.

Nota: Esta información viene dada en el artículo «Una vez cumplida la edad ordinaria de jubilación... ¿tengo que retirarme obligatoriamente?». Publicado por el Instituto BBVA de Pensiones en fecha de 16 de abril de 2014. 
- 67 años o

- 65 años cuando se acrediten 38 años y 6 meses de cotización.

Este requisito será exigible, en todo caso, cuando se acceda a la pensión sin estar en alta o en situación asimilada a la de alta. Estas edades de jubilación y el periodo de cotización se aplicarán, de forma gradual, en los términos que publique la Seguridad Social. No obstante, se mantiene la edad de 65 años para quienes resulte de aplicación la legislación anterior a fecha de 1 de enero de 2013, de conformidad con lo establecido en la Disposición Final 12.2 de la Ley $27 / 2011$, de 1 de agosto. Además, siempre se han dado casos de jubilaciones anticipadas ${ }^{184}$, en las que el sujeto en cuestión tenía una edad inferior ${ }^{185}$ a 65 años, pasando desde ese momento a tener la condición de jubilado.

Si este requisito lo comparamos con otros países, encontramos que en EEUU se exige la edad de 62 años, en Reino Unido 60 y en la ordenanza francesa, siendo la que más se asimila a nuestra legislación, no se establece límite de edad. Antes de la aprobación de la Ley 41/2007, en España, las entidades que ofrecían la hipoteca inversa, tenían un criterio diferente respecto a la edad ${ }^{186}$.

\footnotetext{
${ }^{184}$ Atendiendo a lo estipulado por el Ministerio de Empleo y Seguridad Social. Apartado Seguridad Social: Prestaciones/Pensiones de Trabajadores, la edad mínima de jubilación puede ser rebajada o anticipada, sólo para trabajadores en alta o en situación asimilada a la de alta, en determinados supuestos especiales:

- Jubilación anticipada a partir de los 60 años por tener la condición de mutualista.

- Jubilación anticipada a partir de los 61 años sin tener la condición de mutualista.

- Jubilación parcial.

- Jubilación especial a los 64 años, para quienes resulte de aplicación la legislación anterior a 1-01-2013, de conformidad con lo establecido en la Disposición Final 12.2 de la Ley 27/2011, de 1 de agosto.

- Jubilación del personal del Estatuto Minero, personal de vuelo de trabajos aéreos, ferroviarios, artistas, profesionales taurinos, bomberos y miembros del Cuerpo de la Ertzaintza.

- Jubilación flexible.

- Jubilación de trabajadores afectados por una discapacidad igual o superior al $45 \%$ o al $65 \%$.

${ }^{185}$ Según MARTínez MARTínez, M., «Temas sobre...», op. cit., p. 71, este apartado de la DA $1 .^{\text {a }}$ de la Ley es de carácter imperativo, aunque también se ha considerado por algún sector doctrinal que la hipoteca inversa puede contratarse por todo tipo de cliente, aunque no reúna los requisitos indicados en la DA.

${ }^{186}$ Así, algunas Cajas de Ahorro ofertaban esta modalidad hipotecaria a personas mayores de 65 años, caso de la Caja Vital Cutxa. En cambio, Ibercaja exigía que el beneficiario fuera mayor de 75 años. En otras entidades, como por ejemplo Caixa Terrassa y Caixa Sabadell, la hipoteca inversa se podía contratar a partir de los 70 años. Con respecto a los Bancos, el único que la ofertaba era el BBVA y la contrataba a partir de los 65 años.
} 
Llegado aquí, también hay que hacer mención a si existe una edad tope para poder solicitar la hipoteca inversa, pues como venimos observando se exige una edad mínima para poderla solicitar (65 años). En cambio, en ningún momento se precisa si hay algún límite de edad para poder realizar esta operación: para ello, se tendría que analizar cada supuesto. Por ejemplo, a una persona de edad muy avanzada (88 años), por lógica, no se le va a permitir que contrate una hipoteca inversa ${ }^{187}$.

En la mayoría de los casos se tratará de un matrimonio o de una pareja de hecho. De esta manera, sería recomendable que la hipoteca inversa se contratara a nombre de los dos o que, por lo menos, se asegurara que en caso de fallecimiento del titular beneficiario, el cónyuge o conviviente de hecho pudiera seguir haciendo uso de la vivienda hasta su fallecimiento.

Otra cuestión a tener en cuenta es que si la hipoteca inversa se constituye sobre la vivienda habitual (causa más frecuente), el consentimiento del cónyuge no propietario será necesario ${ }^{188}$, atendiendo al artículo 1320 del $C^{189}$. De esta manera, en el caso de copropiedad, aunque sólo uno de los cónyuges sea el solicitante, también se tendrá que dar el consentimiento del otro. La razón: la hipoteca inversa recae sobre la totalidad de la vivienda.

\footnotetext{
${ }^{187}$ En este aspecto, cabría destacar la SAP de Salamanca de 11 de octubre de 2012 (TOL2.686.612) donde la parte actora-apelante fundamentó su recurso en el error de hecho y de derecho, puesto que había pruebas suficientes que acreditaban que debía declararse la nulidad e ineficacia del contrato de seguros de renta denominado contrato de hipoteca inversa objeto de juicio. Se trata de una persona de 87 años a la que las autoridades administrativas le habían reconocido un grado de minusvalía del $94 \%$, no cabe sino concluir que el presente contrato es nulo por error en el consentimiento al haber ofertado el banco un contrato de hipoteca invertida combinado con un contrato de seguro de muchas mejores condiciones que el que luego finalmente fue contratado por la causante, contrato totalmente perjudicial para sus intereses dada sus especiales circunstancias personales.

${ }^{188}$ Vid. la RDGRN de 22 de julio de 2009 (RJ 2010\1659) donde se puede leer lo siguiente: «El mismo día y con números de protocolo correlativos se otorgaron, primero, una escritura de préstamo concedido a dos cónyuges, garantizado con hipoteca constituida sobre la mitad indivisa de una finca privativa de la esposa, y, después, otra escritura por la que ésta aportó dicha finca a su sociedad de gananciales. En la primera de las mencionadas escrituras el esposo consintió la constitución de la hipoteca por tratarse de la vivienda familiar habitual».

${ }^{189}$ El citado artículo reza que: «Para disponer de los derechos sobre la vivienda habitual y los muebles de uso ordinario de la familia, aunque tales derechos pertenezcan a uno solo de los cónyuges, se requerirá el consentimiento de ambos o, en su caso, autorización judicial.

La manifestación errónea o falsa del disponente sobre el carácter de la vivienda no perjudicará al adquirente de buena fe».
} 
En este punto también conviene hacer referencia a la capacidad de obrar ${ }^{190}$, pues no se ha de olvidar que la hipoteca inversa está enfocada a un colectivo de la población muy vulnerable. En nuestro país, de forma muy generalizada y generación tras generación (excepto en esta última en la que se están cambiando los hábitos), predomina la práctica de atención y cuidados de manera informal.

\author{
Alude lo citado a que en la mayoría de los casos son los hijos o \\ familiares más cercanos los que se encargan de atender a los progenitores \\ cuando llegada una edad, éstos ven mermadas sus facultades tanto físicas \\ como intelectivas ${ }^{191}$. Por tanto, en estos casos, la capacidad de obrar $^{192}$ \\ adquiere gran importancia.
}

Nos podemos fijar en nuestra familia, amigos, vecinos, conocidos que hayan vivido esta situación o que se encuentren cuidando de sus padres ya en edad avanzada o mayores, en la que los hijos o familiares más cercanos asuman sus cuidados y actúen, de esta manera, como guardadores de hecho.

\footnotetext{
${ }^{190}$ En este tema, quisiera hacer referencia, entre otras, a la SAP de Girona de 17 octubre de 2012 (AC 2013 1789 ) en la que la parte actora ejercita la acción de nulidad del contrato de préstamo con hipoteca inversa firmado el 26 de marzo de 2009 por doña Nicolasa, de la que es tutora al haber sido declarada incapaz por sentencia de fecha 15 de febrero de 2010. La demanda se funda en los siguientes hechos: a) en el momento de firmar el contrato la Sra. Nicolasa, de 82 años de edad, se encontraba afectada de una incapacidad, pues había sido diagnosticada de epilepsia, hipoacúsia y demencia leve, según informe del médico forense de fecha 12 de marzo de 2009 y b) la negociación para la firma de la hipoteca la realizó la hija de la Sra. Nicolasa, quien fue también la persona que realizó los traspasos y reintegros tras la firma del contrato, a los que la ahora incapaz no pudo consentir ni comprender.

Y, la SAP de Les Illes Balears de 13 de febrero de 2014 (TOL4.120.443), relativa a la nulidad de contrato de compraventa por falta de consentimiento válido del vendedor por falta de capacidad pues no era dueño de sus actos ni de administrar sus bienes, teniendo su capacidad volitiva afectada por un deterioro cognoscitivo derivado de una enfermedad de Alzheimer en curso. En esta sentencia, concretamente en su Fundamento de Derecho Quinto se indica que: «En cuanto a las consecuencias de tal falta de capacidad, consideramos que se trata de un supuesto de nulidad radical de un contrato por falta del elemento del consentimiento, y cabe aplicar el artículo 1.303 del CC, y declarar la nulidad de la compraventa y "los contratantes deben restituirse recíprocamente las cosas que hubieren sido materia del contrato, con sus frutos, y el precio con sus intereses"».

191 abellán García, A. y Pujol Rodríguez, R., «Un perfil...», op. cit., p. 5. Estos autores advierten lo siguiente: «La persona que fundamentalmente cuida de los hombres mayores con dependencia es su cónyuge, seguida de su hija. En el caso de las mujeres mayores que necesitan ayuda son las hijas las que fundamentalmente se hacen cargo de los cuidados, seguidas de otros familiares y amigos».

192 Puig Brutau, J., Compendio de Derecho Civil, Volumen I, Bosch, Barcelona, 1987, p. 180. Este autor señala que «Esta capacidad de obrar puede verse limitada e incluso desaparecer cuando concurren ciertas circunstancias en el individuo que son la minoría de edad y la incapacitación. Mientras la capacidad jurídica es igual para todas las personas, la capacidad de obrar es variable en atención a que la aptitud para realizar determinados actos depende de ciertas cualidades que no concurren por igual en todas las personas. Cuando sin haberse decretado oficialmente la incapacitación de una persona, concurra en ella una incapacidad natural, la prueba de esta circunstancia permitirá impugnar el acto concreto que haya realizado».
} 
La figura del guarda de hecho se regula en el artículo 303 del CC donde se establece que: "Sin perjuicio de lo dispuesto en los artículos 203 y 228 , cuando la autoridad judicial tenga conocimiento de la existencia de un guardador de hecho podrá requerirle para que informe de la situación de la persona y los bienes del menor o del presunto incapaz y de su actuación en relación con los mismos, pudiendo establecer asimismo las medidas de control y vigilancia que considere oportunas».

Como se puede observar, el guarda de hecho también desempeña ciertas operaciones, aunque sin relevancia, sobre el patrimonio del mayor, como por ejemplo controlar la economía doméstica o la decisión de compra de alimentos y medicinas. Es decir, se puede entender como si fuera un tutor pero, sin tener reconocida la facultad legal del mismo.

Si nos fijamos en el Capítulo V De la Guarda de Hecho (arts. 303 a 313), desde el punto de vista teórico, la guarda de hecho está destinada a desaparecer y a ser sustituida por la figura del tutor o del curador según el caso concreto. Además, al guardador de hecho no se le otorga la representación legal sobre la persona mayor, por tanto, y en el caso que aquí nos interesa, no puede actuar como representante del mayor para hipotecar un bien inmueble.

Por este motivo, JIMÉNEZ CLAR ${ }^{193}$ recomienda el otorgamiento de un poder de carácter preventivo ${ }^{194}$, en el que establezca la posibilidad de hipotecar los bienes con esta finalidad.

De esta manera, los apoderados ${ }^{195}$, en estos casos se entiende que los hijos o familiares más cercanos encargados del mayor, en el supuesto de no tener los suficientes medios económicos para sus cuidados, se podrían

\footnotetext{
193 JIMÉNEZ CLAR, A.J., «La hipoteca...», op. cit., pp. 111 y 112.

194 El otorgamiento de este poder podría resultar muy útil a lo largo de la vida de la persona mayor, pues ésta podría quedar incapacitada de forma sobrevenida: sufrir Alzheimer o cualquier otra enfermedad que le condicionara su facultad de obrar. Así pues, sus representantes legales podrían disponer del patrimonio o capital de esta persona y realizar las oportunas gestiones en beneficio de la misma.

${ }^{195}$ En este aspecto, la SAP de Madrid de 19 de octubre de 2012 (TOL2.694.455) refleja que: «Salvo esos supuestos excepcionales, el desempeño de tal cometido ha de recaer en las personas que, por su relación de confianza o cercanía familiar con el declarado incapaz, se encuentren en mejores condiciones para poder atender las necesidades del mismo, tanto en el aspecto del cuidado personal, como en la gestión de su patrimonio».
} 
plantear la posibilidad de la contratación de la hipoteca inversa en representación del mayor o progenitor con el fin de obtener los recursos económicos suficientes para sufragar los gastos de atención y manutención del representado.

No obstante, para que se puedan dar estos casos será necesario que se haya declarado la incapacitación judicial ${ }^{196}$ de la persona mayor, tal como se establece en el Artículo 199 del CC: «Nadie puede ser declarado incapaz, sino por sentencia judicial en virtud de las causas establecidas en la Ley».

Estas causas vienen reguladas en el Artículo 200 del CC: «Son causas de incapacitación las enfermedades o deficiencias persistentes de carácter físico o psíquico, que impidan a la persona gobernarse por sí misma».

Por tanto, aunque la falta de capacidad de obrar fuera reconocida por el notario pero no hubiera un representante legal designado judicialmente, no se podría celebrar ningún tipo de contrato y por consiguiente, tampoco cabría la posibilidad de la contratación de una hipoteca inversa.

Aun con todo, en nuestro país es muy poco frecuente el que se incapacite a una persona a no ser que sea por alguna causa de fuerza mayor, pues a pesar de que las personas mayores van viendo mermadas sus facultades tanto físicas como intelectuales con el transcurso del tiempo, siendo estas últimas las que pueden afectar a su capacidad de obrar ${ }^{197}$, los familiares encargados de su cargo, debido a la cultura de nuestro país, ni tan siquiera se plantean esta opción ${ }^{198}$.

\footnotetext{
${ }^{196}$ La sentencia citada en la nota anterior declara que: «La normativa que, desde la reforma del Código Civil operada por la Ley 13/1983, regula la institución tutelar está basada, en cuanto pauta fundamental de toda decisión judicial al respecto, en el interés o beneficio del declarado incapaz, como así lo proclaman, en lo que concierne a la delación del cargo, los artículos 234 y 235 de dicho texto legal. En los mismos, si bien se establecen una serie de prioridades al respecto, se recoge igualmente la posibilidad de que el Juez altere dicho orden o, inclusive, prescinda de todas las personas mencionadas en el primero de dichos preceptos, si el beneficio del incapacitado así lo exigiere, pudiendo inclusive designar tutor a las personas jurídicas que no tengan finalidad lucrativa, y entre cuyos fines figure la protección de menores o incapacitados. Pero, en todo caso, la resolución judicial que altere el orden fijado legalmente, o prescinda de todas las personas llamadas al cargo por el artículo 234, reviste un carácter excepcional, y habrá de ser debidamente motivada».

197 FÁbrega RuIz, C.F., La guarda de hecho y la protección de las personas con discapacidad, Editorial Universitaria Ramón Areces, Madrid, 2006, p. 1.

198 Esta opción tampoco se plantea porque en muchos casos también se desconoce esta posibilidad por falta de conocimiento y asesoramiento. Junto a esto, en algunos casos en que se han realizado estas
} 
Además, en el caso de los solicitantes de hipoteca inversa, los cuales se caracterizan por no tener los recursos suficientes para disfrutar de una calidad de vida razonable, esta opción de declarar a una persona incapaz ${ }^{199}$, desde un punto de vista económico, no será la más adecuada debido a los elevados costes que genera tal procedimiento. De forma, que los hijos o familiares más cercanos del «presunto» incapaz no se planteen esta posibilidad.

\subsection{Personas afectadas de dependencia o personas a las que se les haya} reconocido un grado de discapacidad igual o superior al 33 por ciento

Este requisito ha sido la gran y única novedad de la Ley $1 / 2013$, de 14 de mayo. En la actualidad, este requisito se ha ampliado a las personas afectadas de dependencia o personas a las que se les haya reconocido un grado de discapacidad igual o superior al 33 por ciento.

Si nos fijamos en la Disposición adicional octava de la Ley 39/2006, de 14 de diciembre, de Promoción de la Autonomía Personal y Atención a las Personas en Situación de Dependencia ${ }^{200}$ se hace referencia a la terminología y se dice lo siguiente:

«Las referencias que en los textos normativos se efectúan a «minusválidos» y a «personas con minusvalía», se entenderán realizadas a «personas con discapacidad».

A partir de la entrada en vigor de la presente Ley, las disposiciones normativas elaboradas por las Administraciones Públicas utilizarán los términos «persona con discapacidad» 0 «personas con discapacidad» para denominarlas».

incapacitaciones, sus efectos han resultado negativos, generando una mala prensa donde se ha podido observar que el interés de las personas que querían hacerla efectiva era el poder de control del patrimonio de la persona declarada incapaz. A ello, se han de sumar los elevados costes procesales, así como la excepcionalidad del procedimiento que supone la limitación de la capacidad de obrar.

${ }_{199}$ Respecto a los procesos sobre la capacidad de las personas vid. más ampliamente MONTERO AROCA, J.; Gómez Colomer, J.L.; Barona Vilar, S. y Calderón Cuadrado, M.P., Derecho jurisdiccional II. Proceso Civil, 21. ${ }^{\mathrm{a}}$ ed., Tirant lo Blanch, Valencia, 2013, pp. 765-769.

${ }^{200}$ BOE núm. 299, de 15 de diciembre de 2006. 
En este punto también se ha de hacer referencia al Real Decreto Legislativo 1/2013, de 29 de noviembre, por el que se aprueba el Texto Refundido de la Ley General de derechos de las personas con discapacidad y su inclusión social ${ }^{201}$. Concretamente, en su artículo 4 se indica que:

«Son personas con discapacidad aquellas que presentan deficiencias físicas, mentales, intelectuales o sensoriales, previsiblemente permanentes que, al interactuar con diversas barreras, pueden impedir su participación plena y efectiva en la sociedad, en igualdad de condiciones con los demás».

El citado artículo también señala que: «... a todos los efectos, tendrán la consideración de personas con discapacidad aquellas a quienes se les haya reconocido un grado de discapacidad igual o superior al 33 por ciento».

Antiguamente, durante el periodo comprendido entre el 9 de diciembre de 2007 al 14 de mayo de 2013, se exigía ${ }^{202}$ que estas personas -para poder solicitar una hipoteca inversa- estuvieran afectadas de dependencia severa o gran dependencia. Ahora bien, tanto en el apartado anterior a la Ley 1/2013 como en el actual, a éstas se les exime del requisito de la edad, es decir, no existe correlación entre el requisito de la edad y el grado de dependencia.

El apartado 1.a) en vigor, señala: «que el solicitante y los beneficiarios que éste pueda designar sean personas de edad igual o superior a los 65 años o afectadas de dependencia o personas a las que se les haya reconocido un grado de discapacidad igual o superior al 33 por ciento». En definitiva, no establece límite de edad para este colectivo.

De todas maneras, aunque el legislador no haya limitado la edad a este colectivo, es decir, personas afectadas de dependencia o con un grado de discapacidad igual o superior al 33 por ciento, con el objetivo de que éstas gozaran de una mayor protección en nuestra sociedad, las entidades de

\footnotetext{
201 BOE núm. 289, de 3 de diciembre de 2013.

${ }^{202}$ En el anteproyecto de ley presentado por el Ministerio de Economía y Hacienda, en octubre de 2006, podía ser solicitante del préstamo la persona afectada de dependencia, sin que se especificase ningún grado concreto de dependencia. De acuerdo con el texto del anteproyecto, se requería: «que el solicitante sea una persona de edad igual o superior a los 65 años o afectada de dependencia».
} 
crédito y aseguradoras ${ }^{203}$ sí que tienen muy en cuenta la edad de estos sujetos a la hora de contratar cualquier producto, tanto desde una hipoteca como hasta un seguro de vida.

Sin embargo, durante estos años en que se aplicaba al antiguo apartado 1.a) de la DA $1 .^{a}$, dentro de este grupo ${ }^{204}$ no se comprendía a todas las personas dependientes, pues sólo se contemplaban las situaciones de dependencia severa o de gran dependencia, dejando fuera las de dependencia moderada. Por esta razón, las personas que sufrían una dependencia moderada, no podían beneficiarse de la hipoteca inversa, aun teniendo que afrontar gastos muy elevados a consecuencia de su situación.

\section{A la cuestión ¿qué debemos entender por dependencia?}

La Ley $41 / 2007$, de 7 de diciembre ${ }^{205}$, a fecha de hoy, en ningún apartado la define. Tenemos que acudir a lo establecido en la Ley 39/2006, de 14 de diciembre, de Promoción de la Autonomía Personal y Atención a las Personas en Situación de Dependencia. El objeto de esta Ley viene definido en su artículo 1, que dispone lo siguiente:

«1. La presente Ley tiene por objeto regular las condiciones básicas que garanticen la igualdad en el ejercicio del derecho subjetivo de ciudadanía a la promoción de la autonomía personal y atención a las personas en situación de dependencia, en los términos establecidos en las leyes, mediante la creación de un Sistema para la Autonomía y Atención a la Dependencia, con la colaboración y participación de todas las Administraciones Públicas y la

\footnotetext{
${ }^{203}$ Sólo tenemos que fijarnos en el hecho de que cuando vamos a contratar cualquier producto bancario o un contrato de seguro lo primero que nos preguntan es la edad que tenemos. Pues, en el caso de la contratación de una hipoteca inversa, tratándose de un colectivo tan vulnerable, este interés por la edad todavía es mayor por parte de estas entidades oferentes. Junto a esto, quisiera matizar que durante mi estudio y búsqueda de información sobre las entidades oferentes de este producto he podido observar que es muy raro que se haga referencia a las personas afectadas de dependencia.

${ }^{204}$ En este sentido, entre las enmiendas formuladas al Proyecto de Ley, el Grupo Parlamentario Catalán propuso extender el ámbito subjetivo de la hipoteca inversa a todas las situaciones de dependencia, no sólo a las muy severas o de gran dependencia, y a las personas con discapacidad. De hecho, en el texto aprobado por el Senado se sustituyeron los términos «dependencia severa o gran dependencia» por «Cualquier situación de dependencia o persona con discapacidad», modificación finalmente suprimida en el texto definitivo.

${ }^{205}$ No debemos olvidar que el ámbito en el que se planteó por primera vez la hipoteca inversa, fue en los debates acerca del establecimiento del futuro sistema de dependencia y, en concreto, del papel que la hipoteca inversa iba a cumplir en el sistema de financiación.
} 
garantía por la Administración General del Estado de un contenido mínimo común de derechos para todos los ciudadanos en cualquier parte del territorio del Estado español.

2. El Sistema para la Autonomía y Atención a la Dependencia responderá a una acción coordinada y cooperativa de la Administración General del Estado y las Comunidades Autónomas, que contemplará medidas en todas las áreas que afectan a las personas en situación de dependencia, con la participación, en su caso, de las Entidades Locales».

La Ley 39/2006, en su artículo 2, define qué hay que entender por dependencia y en su artículo 26 establece los grados de ésta, para cuya valoración se requiere de un reconocimiento administrativo. Con esta Ley ${ }^{206}$, como uno de los retos de la política social de nuestro país, se perseguía dar una atención adecuada a las personas en situación de dependencia y promocionar así su autonomía personal.

A pesar de los objetivos que se pretendían, en la actualidad, tras ocho años desde su entrada en vigor, esta Ley no ha dado el resultado esperado. A modo de ejemplo, sólo hay que detenerse en el artículo 33 de la Ley 39/2006, en el que se hace referencia a la participación de los beneficiarios en el coste de las prestaciones, concretamente en su punto 1, se establece que: «Los beneficiarios de las prestaciones de dependencia participarán en la financiación de las mismas, según el tipo y el coste de servicio y su capacidad económica personal».

Aun así, en el punto 4 del mismo precepto se regula que: «Ningún ciudadano quedará fuera de la cobertura del Sistema por no disponer de recursos económicos».

\footnotetext{
${ }^{206}$ Así se detalla en la Exposición de Motivos: «1. La atención a las personas en situación de dependencia y la promoción de su autonomía personal constituye uno de los principales retos de la política social de los países desarrollados. El reto no es otro que atender las necesidades de aquellas personas que, por encontrarse en situación de especial vulnerabilidad, requieren apoyos para desarrollar las actividades esenciales de la vida diaria, alcanzar una mayor autonomía personal y poder ejercer plenamente sus derechos de ciudadanía. En octubre de 2003 se aprobó en el Pleno del Congreso de los Diputados la Renovación del Pacto de Toledo con una Recomendación Adicional 3. ${ }^{a}$ que expresa: «resulta por tanto necesario configurar un sistema integrado que aborde desde la perspectiva de globalidad del fenómeno de la dependencia y la Comisión considera necesaria una pronta regulación en la que se recoja la definición de dependencia, la situación actual de su cobertura, los retos previstos y las posibles alternativas para su protección». El reconocimiento de los derechos de las personas en situación de dependencia ha sido puesto de relieve por numerosos documentos y decisiones de organizaciones internacionales, como la Organización Mundial de la Salud, el Consejo de Europa y la Unión Europea. En 2002, bajo la presidencia española, la Unión Europea decidió tres criterios que debían regir las políticas de dependencia de los Estados miembros: universalidad, alta calidad y sostenibilidad en el tiempo de los sistemas que se implanten".
} 
Volviendo a los requisitos exigibles para la hipoteca inversa, siempre se ha criticado que se incluyera la vivienda habitual para valorar la riqueza en las personas dependientes o con un grado de discapacidad igual o superior al 33 por ciento. En muchos casos, esta vivienda habitual es el único bien con el que cuentan estas personas en situación de dependencia ${ }^{207}$, o ni tan siquiera son titulares de ningún bien, ya que una mayoría de estas personas vive con sus padres, hermanos o incluso abuelos, los cuales son los titulares de esas viviendas. Por esta serie de circunstancias resulta muy difícil que este colectivo opte a la hipoteca inversa.

Tal y como se indica en la Exposición de Motivos de la Ley 39/2006, la Constitución Española en los artículos 49 y $50^{208}$ se refiere a la atención a personas con discapacidad y a las personas mayores y aboga por un sistema de servicios sociales promovido por los poderes públicos para el bienestar de los ciudadanos.

En la Ley 39/2006, en su artículo 2.2, se define qué se entiende por dependencia: «Dependencia: el estado de carácter permanente en que se encuentran las personas que, por razones derivadas de la edad, la enfermedad o la discapacidad, y ligadas a la falta o a la pérdida de autonomía física, mental, intelectual o sensorial, precisan de la atención de otra u otras personas o ayudas importantes para realizar actividades básicas de la vida diaria o, en el caso de las personas con discapacidad intelectual o enfermedad mental, de otros apoyos para su autonomía personal».

El procedimiento para el reconocimiento de la situación de dependencia y del derecho a las prestaciones del Sistema viene regulado en el artículo 28. Tal y como se indica en el punto 1 del citado artículo: «El

\footnotetext{
207 PEREÑA VICENTE, M., «La protección de la vivienda habitual en los supuestos de sobreendeudamiento y dependencia», $A C, \mathrm{~N}^{\circ} 16$, septiembre 2008, pp. 1727 y 1728.

208 Ambos preceptos se encuentran en el Capítulo III del Título Primero de la Constitución (De los derechos y deberes fundamentales), que versa sobre los Principios rectores de la política social y económica.

Así en el Artículo 49 de la CE: «Los poderes públicos realizarán una política de previsión, tratamiento, rehabilitación e integración de los disminuidos físicos, sensoriales y psíquicos, a los que prestarán la atención especializada que requieran y los ampararán especialmente para el disfrute de los derechos que este Título otorga a todos los ciudadanos».

Y en el Artículo 50 de la CE: «Los poderes públicos garantizarán, mediante pensiones adecuadas y periódicamente actualizadas, la suficiencia económica a los ciudadanos durante la tercera edad. Asimismo, y con independencia de las obligaciones familiares, promoverán su bienestar mediante un sistema de servicios sociales que atenderán sus problemas específicos de salud, vivienda, cultura y ocio».
} 
procedimiento se iniciará a instancia de la persona que pueda estar afectada por algún grado de dependencia o de quien ostente su representación, y su tramitación se ajustará a las previsiones establecidas en la Ley 30/1992, de 26 de noviembre, de Régimen Jurídico de las Administraciones Públicas y del Procedimiento Administrativo Común, con las especificidades que resulten de la presente Ley».

De esta manera, la Comunidad Autónoma correspondiente ${ }^{209}$ será la encargada de evaluar la situación de dependencia o discapacidad de los posibles beneficiarios, mediante el órgano de valoración que cada Comunidad tenga para ello. Tras ser evaluada, cada persona recibirá una acreditación con su grado y nivel de dependencia ${ }^{210}$, que será válido para todo el territorio español. En ese informe se indicará el grado y nivel de dependencia de cada persona y los cuidados que pueda necesitar.

Existen tres grados de dependencia. Antes de la entrada en vigor de la Ley $1 / 2013$, sólo los afectados de grado II o III ${ }^{211}$ podían solicitar una hipoteca inversa:

Grado I. Dependencia moderada. Tiene lugar cuando la persona necesita ayuda para realizar varias actividades básicas de su vida diaria al menos una vez al día, o tiene necesidades de apoyo intermitente o limitado para su autonomía personal.

Grado II. Dependencia severa. Cuando la persona necesita ayuda para realizar varias actividades básicas de la vida diaria dos o tres veces al día, pero no requiere la presencia permanente de un cuidador o tiene necesidades de apoyo extenso para su autonomía personal.

\footnotetext{
${ }^{209}$ El artículo 28.2 de la Ley 39/2006 determina que: «El reconocimiento de la situación de dependencia se efectuará mediante resolución expedida por la Administración Autonómica correspondiente a la residencia del solicitante y tendrá validez en todo el territorio del Estado».

${ }^{210}$ Cuando concurran las dos circunstancias, dependencia y edad, será suficiente acreditar la segunda circunstancia para la válida constitución de la hipoteca inversa, sin necesidad de justificar la situación de dependencia.

211 Según los datos publicados en el Informe de Financiación de la Ley de Dependencia (Datos PGE 2013: Informe Tribunal de Cuentas. Último ejercicio cerrado y definitivo) facilitado por la Secretaria de Estado de Servicios Sociales e Igualdad, en julio de 2015 se incorporarán al sistema de atención a la dependencia, los beneficiarios reconocidos de Grado I.
} 
Grado III. Gran dependencia. Se produce cuando la persona necesita ayuda para realizar varias actividades básicas de la vida diaria varias veces al día, y además requiere la presencia indispensable y continua de otra persona o tiene necesidades de apoyo generalizado para su autonomía personal debido a su pérdida total de autonomía física, mental, intelectual o sensorial.

Además, dentro de cada uno de los grados de dependencia se establecen dos niveles, en función de la autonomía de las personas y de la intensidad del cuidado que requieran. En cuanto a los intervalos para la determinación de los grados y niveles, se establecerán conforme al baremo regulado en el artículo 27 de la Ley 39/2006.

No obstante, a pesar de tener que acudir a la Ley $39 / 2006^{212}$ por la que se regula la dependencia, los grupos parlamentarios, durante la tramitación del Proyecto de la Ley 41/2007, plantearon enmiendas para que la Ley fijara expresamente qué debía entenderse por situación de dependencia o de discapacidad.

Esta situación, también la podemos apreciar en la Ley $1 / 2013$, que como ya he repetido en varias ocasiones, sólo se ha modificado la letra a) del apartado 1, por tanto y una vez más, en la Disposición Adicional 1. a de la Ley $41 / 2007$, por la que se regula la hipoteca inversa, no se ha definido qué se entiende por dependencia, teniendo que acudir, una vez más, a la Ley $39 / 2006$.

También resulta esclarecedor señalar que tal vez se pueda dar el caso de que una persona afectada de dependencia o con un grado de minusvalía de un 33 por ciento o superior, pierda esta condición ya que las causas de dependencia son muy amplias. Algunas de ellas: un accidente laboral, de tráfico, una enfermedad, una discapacidad de carácter físico o mental, etc.,

\footnotetext{
${ }^{212}$ Según el periódico Mediterráneo, en fecha de 27 de abril de 2014, p. 86, la Ley de Dependencia es una norma marcada por recortes drásticos que ha puesto en situación muy difícil a un colectivo al que el Gobierno actual parece haber olvidado. José Manuel Ramírez, Presidente del Observatorio para la dependencia asegura que esta Ley «se ha hecho de la manera más cruel, excluyendo del sistema a las 70.000 personas que murieron esperando ser atendidas».
} 
con el tiempo pueden, en algunos casos, tener curación. Si nos volvemos a fijar en el artículo 2.2 de la Ley 39/2006, citado más arriba, observamos que exige un «estado de carácter permanente», es decir, un estado que se prolongue en el tiempo. No obstante, este requisito no significa que esta situación sea totalmente irreversible ${ }^{213}$.

Sólo tenemos que fijarnos en el artículo 21 de la citada Ley en el que se hace referencia a la Prevención de las situaciones de dependencia y que reza así:

«Tiene por finalidad prevenir la aparición o el agravamiento de enfermedades o discapacidades y de sus secuelas, mediante el desarrollo coordinado, entre los servicios sociales y de salud, de actuaciones de promoción de condiciones de vida saludables, programas específicos de carácter preventivo y de rehabilitación dirigidos a las personas mayores y personas con discapacidad y a quienes se ven afectados por procesos de hospitalización complejos. Con este fin, el Consejo Territorial del Sistema para la Autonomía y Atención a la Dependencia acordará criterios, recomendaciones y condiciones mínimas que deberían cumplir los Planes de Prevención de las Situaciones de Dependencia que elaboren las Comunidades Autónomas, con especial consideración de los riesgos y actuaciones para las personas mayores».

0 , de la misma manera, en el artículo 30 de la misma Ley relativo a la Revisión del grado o nivel de dependencia y de la prestación reconocida, se detalla lo siguiente:

«1. El grado o nivel de dependencia será revisable, a instancia del interesado, de sus representantes o de oficio por las Administraciones Públicas competentes, por alguna de las siguientes causas:

a) Mejoría o empeoramiento de la situación de dependencia.

b) Error de diagnóstico o en la aplicación del correspondiente baremo.

2. Las prestaciones podrán ser modificadas o extinguidas en función de la situación personal del beneficiario, cuando se produzca una variación de cualquiera de los requisitos establecidos para su reconocimiento, o por incumplimiento de las obligaciones reguladas en la presente Ley».

${ }^{213}$ Meléndez Morillo-Velarde, L., "Delimitación conceptual de la dependencia», en Sempere Navarro, A.V. (dir.), Comentario sistemático de la Ley de la dependencia, Thomson-Aranzadi, Cizur Menor (Navarra), 2008, pp. 172 y 173. 
A la vista de su contenido se desprende que la Ley de Dependencia contempla la recuperación del dependiente. Por tanto, se podría dar el caso de que una persona dependiente o con un grado de discapacidad igual o superior al 33 por ciento solicitante de un préstamo garantizado con hipoteca inversa, perdiese esta condición (condición por la que se le ha otorgado la hipoteca inversa) y no tuviera la edad de 65 años o más.

En estos supuestos, se podría plantear la posibilidad del vencimiento anticipado, pues tal como se legisla en la Ley 41/2007 en el apartado 5, segundo párrafo, sólo se contempla para el caso de la transmisión del inmueble y no para la variación de las circunstancias personales de la persona contratante.

Respecto a este asunto se pronuncia ROMERO CANDAU ${ }^{214}$ al manifestar que en el caso de que la hipoteca inversa se haya concedido con motivo de la condición de dependiente del solicitante, se habrá de estar a lo dispuesto en la escritura de constitución. De forma que si no se indica nada al respecto «seguirá vigente la hipoteca e inejecutable el crédito hasta el fallecimiento del deudor hipotecario». De la misma manera, respecto a la pérdida del carácter de dependiente, opina que en nada afecta a la entidad acreedora, ni le beneficia ni le perjudica, por lo que la desaparición de esa condición no puede llevar consigo ninguna consecuencia jurídica relevante, es decir, no frustra la finalidad del contrato ${ }^{215}$. El interés de la entidad en el mismo, es la recuperación del préstamo con el interés pactado.

En su día, con las enmiendas ${ }^{216}$ que se propusieron por los distintos grupos parlamentarios, se quería lograr que esta modalidad hipotecaria

\footnotetext{
214 Romero Candau, P.A., «La hipoteca...», op. cit., p. 315.

${ }^{215}$ El Tribunal Supremo exige la producción de algún daño o perjuicio para el interesado en caso de frustración de la finalidad para la que se contrató, en otras palabras, se requiere la frustración de la finalidad económica. Entre otras, cabría resaltar las SSTS de 9 de marzo de 2005 (RJ 2005\2219), 17 de julio de 2007 (RJ 2007\4961) o 14 de mayo de 2008 (RJ 2008\418).

216 Inicialmente, en el proyecto se limitaba a personas afectadas de dependencia severa o gran dependencia. Sin embargo, el texto se modificó en el Senado a partir de la enmienda núm. 65, que pretendía extender el ámbito de la hipoteca inversa a cualquier situación de dependencia para que estas personas, que pueden tener elevados gastos pese a que su situación de dependencia no sea extrema, puedan beneficiarse de esta "bonificación", aunque en la aprobación definitiva en el Congreso
} 
pudiera solicitarse también por las personas con discapacidad ${ }^{217}$, pues no había motivo para discriminarlas en relación con las personas afectadas de dependencia o gran dependencia, ya que pueden existir personas con discapacidad que no tengan ni puedan tener reconocida la situación de dependencia.

De acuerdo con el Real Decreto 1971/1999, de 23 de diciembre, de procedimiento para el reconocimiento, declaración y calificación del grado de minusvalía y las modificaciones introducidas por el Real Decreto 1169/2003, de 12 de septiembre, por el que se modifica el Anexo I (Normas para la valoración de la discapacidad en casos de infección por VIH), el Real Decreto 1856/2009, de 4 de diciembre (correspondiente a la adecuación terminológica: «las referencias que en los textos normativos se efectúan a minusválidos y a personas con minusvalía, se entenderán realizadas a personas con discapacidad») y el Real Decreto 1364/2012, de 27 de septiembre sobre la determinación de la necesidad del concurso de otra persona para realizar los actos esenciales de la vida diaria, para que se considere que una persona tiene una minusvalía, ésta debe tener una discapacidad en grado igual o superior al 33 por $100^{218}$.

Ahora bien, se puede dar el caso de que estas personas, con una discapacidad igual o superior al 33 por 100, no tengan reconocida la situación de dependencia pues el ámbito de la dependencia es más reducido que el de la discapacidad.

A pesar de que la figura de la hipoteca inversa se creaba con la finalidad de dar una mayor protección social a los colectivos desfavorecidos y dentro de éstos a las personas afectadas de discapacidad, aún así, las que no tengan reconocido estar afectadas de dependencia o sufran un grado de discapacidad igual o superior al 33 por ciento, no van a poder solicitar la hipoteca inversa, a no ser que tengan 65 años o más, ya que el texto

\footnotetext{
se volvió a la redacción inicial que preveía el proyecto. Finalmente, con la entrada en vigor de la Ley $1 / 2013$, se ha admitido a este colectivo.

217 Como ya se ha comentado anteriormente, en el artículo 200 del CC se tipifican las causas de incapacitación.

218 Para una mayor información véase el portal del Instituto de Mayores y Servicios Sociales (IMSERSO): Autonomía Personal y Dependencia. Página web: www.imserso.es.
} 
definitivo de la Ley 41/2007 en relación con la Ley 1/2013, no las incluye como posible colectivo que puede solicitar la hipoteca inversa.

Por tanto, estas personas, para el caso de que no cumplan con el requisito de dependencia o tener reconocido un grado de discapacidad igual o superior al 33 por ciento, sólo podrán acceder a la hipoteca inversa si cumplen con el requisito de la edad.

En conclusión, la Ley 41/2007 en relación con la Ley 1/2013, delimita la figura del deudor desde una perspectiva marcadamente personalista y restrictiva $^{219}$. De esta manera, y con respecto a la persona del deudor o solicitante de esta modalidad hipotecaria, restringe el ámbito subjetivo de aplicación a cualquier persona de edad igual o superior a sesenta y cinco años. No obstante, esta edad se podría reducir en el caso de tratarse de una persona afectada de dependencia severa o gran dependencia.

A juicio de ZURITA MARTíN ${ }^{220}$, la restricción sobre la edad resulta acorde con la finalidad que se pretende con la regulación de esta figura hipotecaria. Esto es debido a que esta modalidad se encuentra orientada a que las personas de avanzada edad o con graves dificultades para afrontar económicamente su discapacidad o dependencia, puedan contar con liquidez suficiente para costear sus necesidades vitales. Ahora bien, el amplio margen que se deja a la designación de beneficiarios ${ }^{221}$ no casa del todo bien con la ratio de la norma.

En síntesis, a pesar de que en la Ley 41/2007 se haya dado la posibilidad de que las personas afectadas de dependencia o con un grado de discapacidad igual o superior al 33 por ciento puedan contratar esta modalidad hipotecaria, la hipoteca inversa no será la forma más idónea para conseguir recursos económicos añadidos y así disfrutar de una mayor calidad

\footnotetext{
219 JimÉnez ClAR, J., «La hipoteca...», op. cit., pp. 112-113. Cfr. RAmOS ChAPARRo, E.J., La garantía..., op. cit., p. 574.

${ }^{220}$ ZURITA MARTín, I., «La nueva normativa...», op. cit., pp. 1284 y 1285.

${ }^{221}$ Se tratará en el siguiente punto.
} 
de vida, pues tal y como señala íñIGO ARROYO ${ }^{222}$, las entidades encargadas de ofrecer esta figura tratan de diseñar «un producto económicamente rentable para la entidad y que al mismo tiempo no resulte antieconómico para su cliente».

En estos casos, sólo sería aconsejable para aquellas personas con una edad más avanzada, o dicho de otra manera, con una corta esperanza de vida. Esto vendría justificado debido a que lo normal es que la constitución de la hipoteca inversa se haga con carácter vitalicio y no temporal, de manera que no resulte perjudicial para las partes contratantes. Por ello, la edad del solicitante deberá ser avanzada o su esperanza de vida limitada, con el fin de evitar que aquél pueda llegar a recibir una cantidad ridícula en concepto de hipoteca inversa.

\section{El beneficiario}

La Ley 41/2007 sólo contempla esta figura ${ }^{223}$ a los efectos de determinar el vencimiento de la hipoteca, cuando lo normal sería que el beneficiario fuera la persona o personas favorecidas por las prestaciones económicas procedentes de la entidad acreedora.

La hipoteca inversa está pensada para ser constituida, o bien para el beneficiario de una sola persona mayor, que como se ha venido diciendo deberá tener 65 años o más o estar afectado de dependencia, o personas a las que se les haya reconocido un grado de discapacidad igual o superior al 33 por ciento, o bien para una pareja de personas mayores, $\operatorname{casadas}^{224}$ o no. En estos

\footnotetext{
222 Í́NIGO ARROYo, L., «La hipoteca inversa (Disposiciones Adicionales 1.a y 4.a Ley 41/2007)» en MUÑIz ESPADA, E., (coord.), La reforma del mercado hipotecario y otras medidas financieras en el contexto de la crisis económica, Edisofer, Madrid, 2009, p. 328.

${ }^{223}$ JIMÉNEZ CLAR, J., «La hipoteca...», op. cit., pp. 113 y 114, señala que cabría la posibilidad de que el beneficiario sólo lo fuera a los efectos de la congelación de la exigibilidad de la hipoteca y mantenimiento del uso de la vivienda, a pesar del fallecimiento del deudor hipotecario, el cual es, por definición, titular del inmueble hipotecado.

224 ZURITA MARTín, I., «La nueva normativa...», op. cit., pp. 1284 y 1285, advierte que la condición de deudor-solicitante y beneficiario puedan coincidir en la misma persona. Esta situación se dará cuando la vivienda habitual pertenezca por mitades indivisas al matrimonio, en cuyo caso cada cónyuge será solicitante-deudor por una mitad del beneficiario respecto de la otra mitad. En este aspecto, la consulta
} 
casos, la hipoteca inversa podrá ser constituida por ambas personas o por una de ellas designando como beneficiaria a la otra.

Además de estos beneficiarios, también podrán ser cualesquiera otras personas que éste pueda designar, por lo que el beneficiario no sólo podrá ser el cónyuge o conviviente de hecho, sino que podría recaer en un tercero: un hermano, un amigo con el que se convive, etc. Con esto, observamos que la condición jurídica de beneficiario ha quedado desligada de cualquier categoría legal previa, como por ejemplo, el vínculo matrimonial o determinadas relaciones de parentesco.

De esta manera, la condición jurídica de beneficiario se adquirirá por medio del acuerdo inicial que firmen las partes contratantes, en el que se determinará, sin límite de número, la persona o personas beneficiarias. En este sentido, como señala ANGUITA Ríos ${ }^{225}$, con la redacción actual de la Ley (en el Proyecto de la Ley se limitaba al cónyuge) se amplía el círculo de personas que pueden recibir la prestación económica.

Ahora bien, si nos vamos al apartado 1 de la Ley 41/2007, se exige que el bien inmueble hipotecado sea la vivienda habitual del solicitante, con lo cual, si el beneficiario no fuera la persona que conviviera con éste, se llegaría al absurdo de haber exigido legalmente que dicho inmueble fuera la vivienda habitual del solicitante pero no la del beneficiario. Por tanto, la designación de cualesquiera persona como beneficiario resulta disparatada ${ }^{226}$ y contradictoria para esta modalidad hipotecaria.

En cuanto al número de beneficiarios, la Ley no fija ni un mínimo ni un máximo. No obstante, el hecho de que el solicitante pueda designar a tantos beneficiarios como desee, tampoco se entiende con la utilidad de esta hipoteca, pues la extinción o vencimiento de la misma dependerá de la fecha

vinculante de la Dirección General de Tributos de 23 de noviembre de 2006 extiende la consideración de vivienda habitual al pleno dominio compartido.

225 ANGUITA Ríos, R.M., «Regulación relativa...», op. cit., p. 10.

226 Martínez EsCRibano, C., La hipoteca inversa, op. cit., p. 79, declara que esta posibilidad es más hipotética que real. 
de fallecimiento del último de éstos, privando a las partes intervinientes de las ventajas de esta modalidad.

A esto se le suma que la cuantía de la renta a percibir por el solicitante se calcula teniendo en cuenta la edad del deudor, con lo cual, si se diera el caso de que hubiera beneficiarios a la muerte de éste, un número desproporcionado de éstos haría prácticamente inviable la constitución de esta modalidad hipotecaria.

A pesar de lo descrito, la ausencia de límites al número de beneficiarios ni la falta de exigencia de cualquier tipo de relación entre éstos y el constituyente de la hipoteca, en palabras de ZURITA MARTíN ${ }^{227}$, no parece desafortunada, pues ello permite acoger un mayor número de supuestos de necesidad de liquidez para el colectivo al que esta figura va destinada. Ahora bien, esto será viable siempre y cuando el valor de la finca y las circunstancias o cualidades personales del constituyente y beneficiario/s lo permitan.

Profundizando un poco más en la no exigencia de grado de parentesco o relación personal del beneficiario con el solicitante de la hipoteca inversa, esta circunstancia ha suscitado ciertas críticas $^{228}$ por los problemas que pueden plantearse para los herederos cuando se designe como beneficiario a un completo desconocido para la familia. Por este motivo, las entidades financieras aconsejan, con el fin de evitar problemas ${ }^{229}$ tras la muerte del deudor, que la hipoteca inversa se constituya con el conocimiento de los familiares.

El beneficiario de la hipoteca inversa no responderá con su patrimonio $^{230}$ de la devolución del préstamo. Esta deuda será de la herencia

\footnotetext{
227 ZURITA MARTín, I., «La nueva normativa...», op. cit., p. 1285.

${ }^{228}$ Vid. LUQUE JIMÉNEZ, M.C., «Una nueva modalidad...», op. cit., pp. 222 y ss.

229 Conforme señala SeRrano DE NICOLÁs, Á., «Régimen jurídico...», op. cit., p. 44, la figura del beneficiario puede plantear problemas en el momento de fallecer el solicitante con respecto a la legítima, aunque con el tercio de libre disposición puede quedar cubierto el importe de las primas que se haya podido pagar. No obstante, la causa más normal es que el beneficiario sea el cónyuge. De esta forma, y según los casos, se podrán incluir los gastos ordinarios del matrimonio (art. 1362 del CC).

${ }^{230}$ MARTínez Escribano, C., La hipoteca inversa, op. cit., p. 78.
} 
que no de los herederos. Sin embargo, si el deudor falleciera antes, el beneficiario seguiría percibiendo las mismas cantidades que recibía el deudor hasta el momento de su fallecimiento. En este caso de supervivencia del beneficiario al deudor hipotecario, señala MORILLO FERNÁNDEZ ${ }^{231}$ que habrán de tenerse en cuenta los derechos eventuales legitimarios de éste.

Con respecto al nexo de unión del beneficiario con el contrato de hipoteca inversa, éste se puede producir de dos modos:

- Cuando la hipoteca inversa contenga una estipulación a favor de tercero a cargo de la entidad prestamista que suponga una atribución patrimonial, se requerirá la aceptación de éste ${ }^{232}$. Ahora bien, el beneficiario no tendrá la consideración de parte en el contrato ni será deudor frente a la entidad prestamista.

- En el caso de que se estipule que el vencimiento de la deuda se produzca por el fallecimiento del beneficiario, en el momento de constitución de la hipoteca será preciso establecer los mecanismos que permitan conocer de forma segura esta circunstancia.

JIMÉNEZ CLAR ${ }^{233}$, analiza en detalle la figura del beneficiario utilizando dos perspectivas diferentes. Por un lado, las repercusiones que su designación puede tener respecto de la hipoteca inversa y, por otro lado, las relaciones entre el deudor y el beneficiario.

En cuanto a la posición del beneficiario en relación con la hipoteca inversa, o, más concretamente, la relación del beneficiario con la entidad acreedora, se plantean a su vez dos cuestiones:

La primera pasa por establecer si es necesario acreditar en la escritura de constitución de la hipoteca inversa la realidad de la condición de

\footnotetext{
231 Morillo FernándeZ, F.J., «El crédito hipotecario inverso», El notario del siglo XXI, núm. 17, enerofebrero 2008, p. 162.

232 Vid. artículo 1259 del Código Civil.

233 JIMÉNEZ CLAR, J., «La hipoteca...», op. cit., pp. 112-115.
} 
beneficiario respecto de una persona determinada. En otras palabras, si el beneficiario debe concurrir al otorgamiento de la escritura, a los efectos de aceptar las atribuciones patrimoniales ordenadas en su favor por el solicitante-deudor o, por el contrario, basta su identificación por este último para tal fin.

Esto se deriva del hecho de que como la Ley 41/2007 no exige en ningún momento al deudor la justificación del destino del capital prestado, éste le puede dar el destino que desee. Por tanto, en la forma pactada para la disposición del capital se estará a cada caso concreto. No obstante, cuando la disposición de los fondos por la entidad acreedora se realice directamente a favor del beneficiario, necesariamente, se requerirá de su aceptación.

Si recalamos en el Código Civil, en el Título II relativo a los Contratos en el artículo 1257, párrafo segundo, se regula la modalidad de contrato a favor de un tercero, en nuestro caso beneficiario ${ }^{234}$. Textualmente: «Si el contrato contuviere alguna estipulación en favor de un tercero, éste podrá exigir su cumplimiento, siempre que hubiese hecho saber su aceptación al obligado antes de que haya sido aquélla revocada».

No obstante a ello, cuando el capital se entregue directamente al solicitante-deudor y éste, a su vez, lo trasmita, total o parcialmente, al beneficiario en un momento posterior, no se requerirá el consentimiento de este último.

Se puede dar el caso de que el beneficiario lo sea de forma indirecta, por ejemplo, cuando el deudor asuma su cuidado y alimentación, en cuyo caso la posición jurídica de éste, será de naturaleza externa respecto de la hipoteca inversa.

Por tanto, en todos aquellos supuestos en los que se haya estipulado que el fallecimiento del beneficiario producirá el vencimiento de la obligación

\footnotetext{
234 Luque JimÉnez, M.C., «Una nueva modalidad...», op. cit., p. 223; MelÉndez MoRILLo-Velarde, L., «Delimitación conceptual...», op. cit., p. 163.
} 
principal, en la escritura de constitución de la hipoteca será preciso consignar tanto la relación entre el deudor y el beneficiario, como también la perfecta identificación de éste, el cual tendrá que reunir las condiciones exigidas por la Ley en el momento del otorgamiento de la escritura. O dicho de otro modo, que en la escritura de constitución de la hipoteca inversa se hace necesaria la perfecta determinación de la posición jurídica del beneficiario tanto respecto de la obligación principal como de la garantía constituida.

En cuanto a la concreción de la obligación garantizada, el motivo es que las atribuciones patrimoniales dirigidas al beneficiario pueden estar directamente a cargo de la entidad acreedora.

En lo relativo al inmueble hipotecado, su precisión estará justificada debido a que el vencimiento de la obligación asegurada y una posible ejecución de la garantía puedan tener efectos directos sobre el beneficiario en el supuesto de que éste, sin ser propietario de la vivienda hipotecada, conviva con el deudor o se halle en situación de dependencia respecto de éste.

Señalar también que la relación velada entre el deudor y el beneficiario puede ser de cualquier naturaleza, onerosa o gratuita, y no afecta en nada a la hipoteca, a excepción de que su muerte haya sido acordada como cláusula para la exigibilidad de la deuda ${ }^{235}$. Fuera de esta excepción, la designación del beneficiario constituirá una facultad del deudor que únicamente necesitará para su eficacia la aceptación de la entidad acreedora. En consecuencia, esta aceptación por parte de la entidad acreedora será irrevocable.

Junto a esto, se ha de tener en cuenta que un cambio en la persona del beneficiario por parte del deudor podría llegar a suponer una disminución del valor de la garantía, en la medida en que podría influir en los cálculos actuariales de la entidad acreedora. Además, tanto el cambio de un

$\overline{235}$ De la misma opinión es JIMÉNEZ CLAR, J., «La hipoteca...», op. cit., p. 114. 
beneficiario como el de su número suponen un supuesto de novación ${ }^{236}$ de la obligación garantizada que requiere el consentimiento de los contratantes.

Llegado aquí, para la perfección de la hipoteca inversa ¿es necesario el consentimiento ${ }^{237}$ del beneficiario?

La hipoteca inversa, al igual que la hipoteca clásica, se fundamenta en la existencia de una obligación principal que se garantiza con el valor de un inmueble. Para su válida constitución se requiere el consentimiento del acreedor y del deudor y el del dueño de la finca hipotecada (por ejemplo, el cónyuge del solicitante), si no fuera a la vez deudor de la obligación principal.

Por tanto, el consentimiento del beneficiario solamente será necesario cuando su posición jurídica, como destinatario de una atribución patrimonial, sea relevante para la celebración de este contrato de préstamo o de crédito garantizado con hipoteca inversa.

Por el contrario, cuando la figura del beneficiario en la hipoteca inversa sólo sea para determinar la exigibilidad de la deuda asegurada con su fallecimiento ${ }^{238}$, bastará con su designación por parte del solicitante-deudor y la correspondiente aceptación por la entidad acreedora ${ }^{239}$. Es decir, cuando la relevancia jurídica de la designación de beneficiario se limite a que la fecha

\footnotetext{
236 Capítulo IV. De la extinción de las obligaciones, Sección Sexta. De la novación (Arts. 1203 a 1213). Concretamente, en el artículo 1203 se dice que: «Las obligaciones pueden modificarse:

$1 .^{\circ}$ Variando su objeto o sus condiciones principales.

$2 .^{\circ}$ Sustituyendo la persona del deudor.

$3 .^{\circ}$ Subrogando a un tercero en los derechos del acreedor».

${ }^{237}$ Cierto sector defiende la necesidad de que el tercero acepte para adquirir el derecho, mientras que otro defiende lo contrario. La doctrina se encuentra dividida en torno a dos grandes opiniones: Existe un grupo de autores que entiende que la aceptación es conditio iuris, es decir, requisito indispensable para la adquisición del derecho. En este caso, sólo cuando el tercero haya aceptado el derecho, pasará a formar parte de su patrimonio. La aceptación tiene eficacia retroactiva y podrá ser expresa o tácita, al respecto vid. PÉrez ConesA, C., El contrato a favor de tercero, Comares, Granada, 1999, pp. 220-221. En cambio, otro grupo considera que es razonable entender que no se precisa tal aceptación y que, por tanto, el tercero puede reclamar directamente la prestación al promitente, vid. MARTínEZ DE AGUIRRE aldaz, C.; De Pablo Contreras, P.; Pérez Álvarez, M.Á. y Parra lucán, M.Á., Curso de Derecho Civil (II), op. cit., pp. 440-443 y Díez-PicAzo, L. y Gullón, A., Sistemas de Derecho Civil II: El Contrato en general..., op. cit., p. 88.

${ }^{238}$ SeRRANO DE Nicolás, Á., «Régimen jurídico...», op. cit., p. 44, califica la hipoteca inversa como un negocio jurídico trans mortem.

${ }^{239}$ En este caso, nos encontraríamos con el supuesto regulado en el artículo 1205 del CC: «La novación, que consiste en sustituirse un nuevo deudor en lugar del primitivo, puede hacerse sin el consentimiento de éste, pero no sin el consentimiento del acreedor».
} 
de su muerte actúe como condición de la exigibilidad del capital prestado, su intervención no será precisa.

En conclusión, el beneficiario no será parte del contrato de hipoteca inversa celebrado entre el solicitante del préstamo y la entidad. Además, éste no responderá, en ningún caso, del préstamo con su propio patrimonio. Ahora bien, cuando así se haya pactado, será receptor de cierta suma de dinero hasta su fallecimiento. Por tanto, el designado beneficiario recibirá el capital directamente de la entidad sin que el capital tenga que pasar necesariamente por el patrimonio del solicitante ${ }^{240}$.

\section{El hipotecante no deudor: el fiador}

El hipotecante no deudor ${ }^{241}$ asume una responsabilidad que queda limitada al bien hipotecado, pues contra él sólo puede ejercitarse la acción hipotecaria pero no la acción personal.

De acuerdo con el artículo 1857 del CC, en la hipoteca inversa, a diferencia de las hipotecas ordinarias (en las que puede ser el propio deudor o un tercero), el hipotecante tiene que ser necesariamente el propietario, con la excepción de copropiedad del inmueble, y además, como sucede en la hipoteca ordinaria, debe tener poder de disposición y capacidad general para contratar.

De esta manera, el deudor, que es el sujeto pasivo o constituyente de la hipoteca, debe tener capacidad para enajenar, ya que toda hipoteca conlleva la posibilidad de ejercitar una acción hipotecaria que puede producir

\footnotetext{
${ }^{240}$ González Pacanowska, I., «Comentario al art. 1257 CC», en Albaladejo García, M. (dir.) y Díaz Alabart, S., Comentarios al Código Civil y Compilaciones Forales, tomo XVII, vol. $1^{\circ}$ A, EDERSA, Madrid, 1993, p. 383.

${ }^{241}$ Con la entrada en vigor de la Ley $1 / 2013$, en el Capítulo IV sobre Modificación del Real Decreto-ley $6 / 2012$, de 9 de marzo, de medidas urgentes de protección de deudores hipotecarios sin recursos se introduce un nuevo artículo 3 bis donde se puntualiza que: «Los fiadores e hipotecantes no deudores que se encuentren en el umbral de exclusión podrán exigir que la entidad agote el patrimonio del deudor principal, sin perjuicio de la aplicación a éste, en su caso, de las medidas previstas en el Código de Buenas Prácticas, antes de reclamarles la deuda garantizada, aun cuando en el contrato hubieran renunciado expresamente al beneficio de exclusión».
} 
la venta en pública subasta de la finca hipotecada para extraer de ella la cantidad necesaria para solventar la deuda. Por esta razón, la vivienda tiene que pertenecer en propiedad al que constituye la hipoteca inversa, es decir, a la figura del deudor, que tendrá que tener, además, la libre disposición de sus bienes.

La estructura económica de la hipoteca inversa, como ya se ha ido viendo, se apoya en el valor del inmueble, tanto por la previsible utilización de su valor en concepto de garantía, así como también como medio de recuperación del capital prestado. De ahí, que la hipoteca inversa esté dirigida a personas mayores de 65 años o más, dependientes o con un grado de discapacidad igual o superior al 33 por ciento, y a determinados bienes, concretamente la vivienda habitual. Por tanto, en esta estructura, la admisión de garantes personales o fiadores no plantea ningún problema con respecto a la normativa general. La cuestión radica en los efectos que su intervención puede producir en la configuración económica de esta hipoteca inversa, o dicho de otro modo, en la ratio seguridad-garantía ${ }^{242}$.

Parece claro, que en la medida que aumenten las garantías y el riesgo de incumplimiento se reduzca, las normas protectoras para la seguridad del acreedor serán innecesarias. Ahora bien, para la hipoteca inversa, a diferencia de la naturaleza de privilegio que tiene la hipoteca convencional con respecto a los otros acreedores que pueda tener el hipotecado-deudor, debido a su especial estructura jurídico-económica, este riesgo es mayor ya que podría entrar en conflicto con la normativa general.

Por esta razón, se ha de tener en cuenta el modelo cerrado de hipoteca inversa que se recoge en la DA $1 .^{\mathrm{a}}$, en la que se conforma a través de unos elementos y condiciones, que a su vez y para su correcta validez, cumplen unos requisitos de máximos y mínimos. Sin embargo, tal y como hemos visto en el apartado 10 de la citada Disposición, también pueden pactarse otras modalidades de hipoteca inversa en las que no se establezca como garantía la

$\overline{242}$ JIMÉNEZ CLAR, J., «La hipoteca...», op. cit., p.115. 
vivienda habitual pero, para estos casos, no se les aplicarán los requisitos señalados en la DA 1. ${ }^{a}$, ni las bonificaciones fiscales ni arancelarias reguladas en los apartados 7, 8 y 9 de la misma.

En conclusión, la Ley 41/2007 parece descartar, de entrada, la posibilidad del hipotecante no deudor, como certeramente señala ANGUITA Ríos $^{243}$, asociando el préstamo con la titularidad de la garantía como requisito necesario. De esta manera, la figura del hipotecante no deudor estaría fuera de la regulación de la hipoteca inversa.

No obstante y con respecto a esta figura, JIMÉNEZ CLAR ${ }^{244}$ se planteaba si podría ser viable la constitución de esta hipoteca por representante que actuase en virtud de un apoderamiento preventivo otorgado al amparo de lo previsto en el artículo 1732 del Código Civil, por persona que se hallase en situación de incapacidad no declarada legalmente. Pues bien, en este supuesto tendríamos que comprobar las facultades conferidas en el Poder.

Lo más probable es que en este Poder se contemplara la posibilidad de constituir hipotecas sobre inmuebles, pero no se hiciera referencia a la posibilidad de constituir una hipoteca inversa. Por tanto, al redactar este Poder sería conveniente estipular de forma expresa, para el caso de que las actuaciones adoptadas por el apoderado llegaran a someterse a un posterior control judicial ${ }^{245}$, los motivos y el destino que éste pudiera dar a los fondos obtenidos.

\section{Otras Figuras}

\subsection{Tercer poseedor}

\footnotetext{
${ }^{243}$ ANGUITA Ríos, R.M., «Regulación relativa...», op. cit., p. 10.

244 JIMÉNEZ CLAR, J., «La hipoteca...», op. cit., pp. 111 y 112.

245 De acuerdo con el artículo 271 del CC, el tutor, en este caso apoderado, necesitará de autorización judicial para hipotecar los bienes del incapacitado.
} 
Según LUQUE JIMÉNEZ ${ }^{246}$, el tercer poseedor es el tercer adquirente ${ }^{247}$ de la finca o derecho real sujeto a hipoteca. Se trata del adquirente de todo o parte de una finca o derecho real inmobiliario hipotecado, que posee la consideración de tercero por no estar personalmente sujeto a la correspondiente obligación garantizada, directa o indirectamente, y sea ajeno a la originaria constitución de la hipoteca, se haya o no inscrito su adquisición, y en consecuencia quede afectado por el gravamen que la hipoteca implica ${ }^{248}$.

Tal y como se indica en el artículo 460 del CC, el poseedor puede perder su posesión:

1. ${ }^{\circ}$ Por abandono de la cosa.

2. ${ }^{\circ}$ Por cesión hecha a otro por título oneroso o gratuito.

3. ${ }^{\circ}$ Por destrucción o pérdida total de la cosa, o por quedar ésta fuera del comercio.

4. ${ }^{\circ}$ Por la posesión de otro, aun contra la voluntad del antiguo poseedor, si la nueva posesión hubiese durado más de un año.

En este caso, en cuanto a la figura del tercer poseedor nos ceñiríamos al punto $2 .^{\circ}$, es decir, a la cesión hecha a este tercero por título oneroso o gratuito. En lo concerniente a esta figura, la DA $1 .^{\circ}$ la contempla en el apartado 5 , párrafo $2^{\circ}$, que dispone que: «en caso de que el bien hipotecado haya sido transmitido voluntariamente por el deudor hipotecario, el acreedor podrá declarar el vencimiento anticipado del préstamo o crédito garantizado, salvo que se proceda a la sustitución de la garantía de manera suficiente».

Este párrafo viene a excepcionar la doctrina que tradicionalmente había mantenido la Dirección General de los Registros y del Notariado ${ }^{249}$ para envolver tales pactos en una innecesaria y abusiva limitación del dueño a

\footnotetext{
${ }^{246}$ LUQUE JIMÉNEZ, M.C., «Una nueva modalidad...», op. cit., pp. 224 y 225.

247 Vid. STS de 21 de enero de 2008 (TOL1.245.335) relativa a la nulidad de la adjudicación y de las transmisiones posteriores al no ser los adquirentes terceros hipotecarios de buena fe.

248 Roca SASTRE, R.M. y Roca-SASTRE MUnCUNILL, L., Derecho hipotecario: Ley del Suelo e Hipotecas, op. cit., pp. 276 y 278.

${ }^{249}$ Vid. Resolución de la DGRN de 27 de enero de 1986 (RJ 1986\1002).
} 
disponer de sus bienes contra el principio de libertad del tráfico inmobiliario. En cambio, en la hipoteca inversa se permite, con carácter potestativo, establecer esta cláusula del contrato, dando cobertura legal a la práctica tan extendida de las cláusulas de vencimiento anticipado. La razón de esto puede encontrarse en que la finalidad de este producto financiero, en atención a las especiales circunstancias que motivan su concesión, tiene un carácter personalísimo.

De lo anterior se desprende que este préstamo se concede con el fin de hacer líquido el valor de la vivienda, al igual que la transmisión voluntaria. Ahora bien, una vez obtenida esta liquidez por medio de la transmisión voluntaria, la renta que pueda proporcionar la hipoteca inversa puede resultar innecesaria para el nuevo adquirente. Es más, no tendría ningún sentido que la percibiera un tercero que no se ajustara a los requisitos para la obtención de dicha hipoteca.

\subsection{Constitución unilateral de hipoteca}

La posibilidad de constitución unilateral de la hipoteca por parte del propietario de la finca se regula en el artículo 141 de la $\mathrm{LH}^{250}$.

De esta manera, en las hipotecas voluntarias constituidas por acto unilateral del dueño de la finca hipotecada, la aceptación de la persona a cuyo favor se establezcan o inscriban, se hará constar en el Registro por nota marginal, cuyos efectos se retrotraerán a la fecha de la constitución de la misma. En el caso de que no constare la aceptación después de dos meses, a contar desde el requerimiento que a dicho efecto se haya realizado, podrá cancelarse la hipoteca a petición del dueño de la finca, sin necesidad del consentimiento de la persona a cuyo favor se hubiese constituido.

\footnotetext{
${ }^{250}$ Este artículo se completa con lo establecido en el artículo 237 del $\mathrm{RH}$ : «Para practicar la cancelación será preciso el otorgamiento por el dueño de la finca de la correspondiente escritura cancelatoria».
} 
Según RoCA SASTRE ${ }^{251}$, cuando enumera las distintas teorías sobre la naturaleza de esta figura, el artículo 141 de la Ley Hipotecaria no adopta el modo del consentimiento formal ni de la reserva de rango, como tampoco la figura de la constitución condicionada de hipoteca, sino que explícitamente ve en el establecimiento de hipoteca por disposición del dueño, un acto unilateral, constitutivo por sí mismo del derecho real de hipoteca, si bien para que éste sea adquirido por el acreedor precisa su aceptación, retrotrayéndose los efectos de esta aceptación al tiempo de la inscripción del acto unilateral del dueño.

En la breve regulación de la hipoteca inversa no se contiene alusión alguna a esta modalidad, aunque se $\mathrm{cree}^{252}$ que resulta aplicable atendiendo a la cláusula de remisión general que se contiene en el apartado 11 de la Disposición Adicional $1 .^{\text {a: }}$ «En lo no previsto en esta disposición y su normativa de desarrollo, la hipoteca inversa se regirá por lo dispuesto en la legislación que en cada caso resulte aplicable».

En este caso y atendiendo a esta última disposición, la hipoteca inversa se podría aproximar al supuesto de hipoteca en garantía de rentas o prestaciones periódicas, regulada en el artículo 248 del RH.

\section{REQUISITOS OBJETIVOS}

Como requisitos objetivos de la hipoteca inversa, la Ley 41/2007 contempla el capital concedido en concepto de préstamo y el bien inmueble que se hipoteca.

\section{El crédito o préstamo garantizado con hipoteca inversa}

\footnotetext{
251 Roca Sastre, R.M. y Roca-SAStRe Muncunill, L., Derecho hipotecario: Hipotecas, op. cit., p. 559.

252 LUQUE JIMÉNEZ, M.C., «Una nueva modalidad...», op. cit., p. 225.
} 
Como se está viendo en el transcurso del estudio de la hipoteca inversa, la devolución de la deuda más los intereses y gastos generados, sólo podrá exigirse en el momento de fallecimiento del deudor o del último de los beneficiarios. No obstante, se ha considerado que también es posible el pacto por el que el deudor pueda, a su voluntad, anticipar el crédito con el pago de las compensaciones que procedan.

Como caso de vencimiento anticipado del crédito, destacaríamos la venta del inmueble acorde con el segundo párrafo del apartado 5 de la DA 1. ${ }^{\text {a }}$ de la Ley 41/2007, por lo que si tal venta se produjera, el dinero obtenido tendría que destinarse inexorablemente al pago del saldo deudor que existiese en ese momento a favor del acreedor.

No hay que olvidar que la hipoteca inversa es una figura especial, en la que hay un mayor riesgo para la entidad acreedora, ya que ésta no percibirá ningún reembolso de las cantidades que preste hasta un momento futuro e incierto, como es el fallecimiento del deudor o de los beneficiarios. Por tanto, en esta figura jurídica, la garantía hipotecaria adquiere un papel muy importante.

Constituir la hipoteca inversa sobre la vivienda habitual beneficia al acreedor. Por varias razones:

- Una de ellas obedece a que este tipo de vivienda es el que menos probabilidades tiene de venderse.

- Otra es que la vivienda se suele conservar en buen estado, lo cual es importante con relación al valor que tenga esta vivienda a la hora de ejecutar la hipoteca.

De manera que sólo la vivienda habitual y no una segunda residencia, por ejemplo, será susceptible de ser gravada con la hipoteca inversa. Con esta 
figura se permite obtener un complemento a la pensión ${ }^{253}$. Durante todo ese tiempo se van a ir devengando intereses de manera que, la cantidad finalmente debida será muy superior a la inicialmente prestada. La devolución de estas cantidades se retrasará hasta el momento del fallecimiento del deudor o del último beneficiario, según el caso concreto. La única garantía será la vivienda habitual y en el caso de que los herederos no puedan hacer frente al pago se procederá, en última instancia, a la ejecución de la hipoteca.

\section{En esta modalidad, el préstamo o crédito garantizado ${ }^{254}$ podrá ser} cualquiera de los utilizados en la práctica bancaria ${ }^{255}$. Atendiendo al apartado 1 de la DA $1 .^{\mathrm{a}}$ : «se entenderá por hipoteca inversa el préstamo o crédito garantizado mediante hipoteca sobre un bien inmueble que constituya la vivienda habitual...», no haciendo más distinción que ésta.

\footnotetext{
253 Para este año 2015 los jubilados recibirán una pensión que será superior a la de 2014. Ello es así porque el Gobierno ha aprobado una revalorización del $0,25 \%$ para el conjunto de los pensionistas. Sin embargo, en términos netos, el aumento será superior por el efecto de la rebaja fiscal que ha entrado en vigor este año. Las pensiones tributan como rendimientos del trabajo en el IRPF y, por lo tanto, el tipo de retención que aplica la Seguridad Social se rebajará. Un jubilado que en 2014 cobrase la pensión media bruta, que ascendió a 1.008 euros al mes, sufría una retención en el IRPF del 7,19\% y su paga mensual se quedaba en 935 euros, que equivalen a 13.097,35 euros al año en 14 pagas. Este contribuyente, verá como en 2015 su pensión bruta aumenta un 0,25\% hasta los 1.010,52 euros al mes. Es decir, 2,52 euros más cada mes o 35,28 euros más al año. Sin embargo, el efecto de la rebaja del IRPF provoca que la retención para este jubilado baje hasta el 4,7\%. Ello significa que la pensión neta mensual alcanzará los 963,03 euros al mes, 27,50 euros más. Así, la retribución neta anual aumentará en 385,01 euros. Dicho de otra forma, el contribuyente que cobra la pensión media obtendrá un 3\% más que el año anterior.

(Datos publicados en: http://www.cincodias.com/cincodias/2015/01/21/economia).

${ }^{254}$ En este aspecto, la RDGRN de 1 de octubre de 2010 (RJ 2010 5273 ) volvió a insistir en la necesidad de distinguir entre préstamo y crédito. La DGRN señala que en el caso del préstamo hipotecario, éste se ha de adecuar al régimen que para el contrato de préstamo regulan los artículos 1753 a 1757 del Código Civil y 311 y siguientes del Código de Comercio, de naturaleza real en cuanto se perfeccionan con la entrega de la suma prestada, y unilaterales por cuanto de ellos tan sólo surgen obligaciones para el prestatario. Ambas notas caracterizadoras del préstamo mutuo (real y unilateral) han sido destacadas igualmente por la jurisprudencia del Tribunal Supremo.

${ }^{255}$ A modo de ejemplo, la SAP de Madrid de 6 julio de 2002 (JUR 2003\4870) en su fundamento de derecho tercero expone que: «Existen diferencias conceptuales y funcionales entre el contrato de préstamo y el de crédito, que el propio Legislador apunta ya en el artículo 175.7. ${ }^{a}$ del Código de Comercio. En el contrato de préstamo, su objeto lo constituye el dinero que se entrega, mientras que el segundo lo constituye, en sí, la disponibilidad de numerario hasta el límite pactado; además, en cuanto al momento de la perfección, tiene lugar en el primero por la entrega del dinero o capital prestado, en tanto que, en el segundo, acaece con el sólo acuerdo de voluntades entre las partes, acreditante y acreditado; de ahí que aparezca como obligación más característica del préstamo, la que asume el prestatario de devolver la cantidad prestada, mientras que en el contrato de apertura de crédito lo es la que asume el acreditante de poner a disposición del acreditado las sumas de dinero a medida que lo requiera el acreditado, y ello con independencia de que, en realidad, se produzca una sola petición y una única entrega. Consecuentemente con esto, del contrato de préstamo deriva a cargo del prestatario una obligación de devolución del dinero líquido "per se", mientras que en contrato de apertura de crédito, es necesario que el acreditado reciba alguna cantidad del acreditante, para que la obligación aparezca, además de que es necesaria, en esta especie contractual, la oportuna liquidación». Entre otras, vid. SAP de Soria de 18 de febrero de 1998 (AC 1998\3622) y SAP de Tarragona de 29 julio de 1999 (AC 199916672).
} 
En cuanto al contrato de préstamo, como ya se ha comentado, se puede concebir como un contrato real que se perfecciona con la entrega de la $\cos a^{256}$. Una vez se haya efectuado la entrega de la cosa surgirá la obligación de su restitución por parte del prestatario, de ahí que el contrato de préstamo se caracterice por ser unilateral, ya que sólo genera obligaciones para el prestatario.

Con respecto al contrato de crédito ${ }^{257}$, la doctrina y jurisprudencia lo definen como «aquel contrato por el que el Banco concede crédito al cliente (acreditado) por un cierto plazo y hasta una suma determinada, obligándose, a cambio del percibo de una comisión y de los intereses sobre el crédito, a poner a disposición de aquél dentro de ese límite las cantidades que reclame en el plazo fijado».

A diferencia del contrato de préstamo ${ }^{258}$, el contrato de crédito se caracteriza por ser un contrato consensual y, por tanto bilateral, que genera obligaciones para ambas partes ${ }^{259}$ : acreditado y entidad acreedora. Si nos fijamos en la práctica bancaria, estos contratos se formalizan de manera consensual, donde: «la entrega ficticia de dinero anotado en cuenta corriente constituye un simple acto ejecutivo posterior al pacto de prestar ${ }^{260} \gg$.

De esta forma, se puede apreciar que en el contrato de apertura de crédito la finalidad del mismo no es la entrega inmediata del dinero sino su disponibilidad. En el caso de la hipoteca inversa, su finalidad es complementar las rentas del solicitante para una mejor calidad de vida.

En sentido parecido encontramos a VICENT CHULIÁ261, al afirmar que el deudor, cuando requiere la disponibilidad permanente e irregular de dinero con la que poder adaptar su economía doméstica, no estipula un contrato de

\footnotetext{
256 Vid. Castañ Tobeñas, J., Derecho civil..., op. cit., p. 452; Díez Picazo, L. y Gullón, A., Sistemas de Derecho Civil II, op. cit., pp. 399 y 400 y VICENT CHULIÁ, F., Compendio Crítico de Derecho Mercantil, tomo II: Contratos, Títulos valores y Derecho Concursal, 3. ${ }^{a}$ ed., José Ma Bosch, Barcelona, 1990, p. 252. 257 URía, R., Derecho Mercantil, 27. ${ }^{\text {a }}$ ed., Marcial Pons, Barcelona, 2000, p. 861.

${ }^{258}$ Martínez de Aguirre Aldaz, C.; De Pablo Contreras, P.; Pérez Álvarez, M.Á. y Parra lucán, M.Á., Curso de Derecho Civil (II), op. cit., pp. 742-744.

${ }^{259}$ VICENT Chulí́, F., Compendio Crítico de..., op. cit., p. 439.

260 URÍA, R., Derecho Mercantil..., op. cit., p. 864.

261 VICENT Chulí́, F., Compendio Crítico de..., op. cit., p. 438.
} 
préstamo sino un contrato de crédito. En cambio, SERRANO DE NICOLÁs ${ }^{262}$ constata que a pesar de que el préstamo esté concebido para la disposición de una sola vez, nada impide que tenga una larga duración, proponiendo como posibilidad el préstamo de entrega condicionada ${ }^{263}$.

Independientemente de estas valoraciones u opiniones ${ }^{264}$, lo que si queda claro es que la obligación garantizada vendrá determinada en su cuantía y, conforme a la DA $1 .^{a}$, se permitirá mediante una única entrega o por medio de entregas periódicas. En este sentido, la entrega periódica, dada su naturaleza real, parece más propia de los créditos que del préstamo. Sin embargo, en la práctica bancaria también se conocen otras modalidades de préstamo que permiten, aunque entregado de una sola vez, que, previo ingreso en una cuenta especial, se disponga de forma periódica del préstamo garantizado con la hipoteca inversa.

Para finalizar, la novación o subrogación del préstamo o crédito garantizado con hipoteca inversa no podrá acogerse en todas sus modalidades a la Ley 2/1994, de 30 de marzo, sobre subrogación y modificación de préstamos hipotecarios. Esto viene justificado para el caso de la hipoteca inversa, concedida a favor de las entidades de crédito o aseguradoras previstas en el Apartado 2 de la DA $1 .^{a}$, donde sólo cabrá la subrogación cuando se trate de las entidades financieras previstas en el artículo 1 de la Ley $2 / 1994$, el cual se remite al artículo 2 de la LMH, en el que no se incluye a las entidades aseguradoras.

\footnotetext{
${ }^{262}$ SeRrano de Nicolás, Á., «Régimen jurídico...», op. cit., pp. 48 y 49.

263 Esta modalidad de préstamo condicionado ha sido utilizada como medio para instrumentalizar alguna hipoteca inversa, aunque en la mayoría de los casos se trata de hipotecas inversas suscritas con anterioridad a la entrada en vigor de la Ley 41/2007. A modo de ejemplo, cabría señalar la RDGRN de 1 de marzo de 2008 (RJ 2008\1482) donde se indica que: «Las llamadas «hipotecas inversas» carecen, a día de hoy, de regulación legal, por lo que su análisis ha de efectuarse a la luz de la legislación actualmente vigente. En la escritura no se determina un plazo cierto de duración ni de la hipoteca ni de la obligación garantizada. Tal fijación se considera imprescindible, ya que determina, tanto la posibilidad de reclamación y ejecución de la hipoteca, como la prescripción de acciones, e incluso la caducidad de la propia inscripción de hipoteca, conforme al art. $82 \mathrm{LH}$ ».

264 Para el estudio de las más frecuentes modalidades de crédito o préstamo que podrían utilizarse y sus principales problemas véase GómEZ GÁLlıGO, J., «Principios generales...», op. cit., pp. 2175-2179. Cfr. Carrasco Perera, Á.; Cordero lobato, E. y Marín López, M.J., Tratado de..., op. cit., pp. 541-564.
} 
De la misma manera, cuando se trate de la hipoteca inversa sobre otros inmuebles, sólo cabrá la aplicación de la Ley 2/1994 cuando sea a favor de las entidades de crédito contempladas en el artículo 2 de la LMH. Como dispone el artículo 1 de la Ley 2/1994, sí sería susceptible de subrogación en este caso ya que lo que la hace posible no es el inmueble hipotecado sino que el acreedor hipotecario sea uno de los previstos por el artículo 2 de la LMH. Para este supuesto de hipoteca inversa sobre otros inmuebles distintos a la vivienda habitual (donde no hay bonificaciones ni reducciones arancelarias), al margen de la regulación especial prevista en la Ley 2/1994, siempre se acudirá al régimen general de subrogación y novación previsto en el CC (Arts. 1203 a 1213).

Además, la subrogación o novación subjetiva del prestatario o deudor es diferente a la del acreedor hipotecario. Esto se debe a la naturaleza de la hipoteca inversa, en la que la figura del prestatario o deudor aparece determinada intuitu personae $e^{265}$, al igual que la del beneficiario. Por este motivo sólo se podrá dar la alteración en la figura del acreedor hipotecario y no en la del deudor hipotecario ni tampoco en la del beneficiario, salvo que expresamente lo consientan todas las partes contratantes.

\subsection{Intereses}

Para tratar este asunto, lo primero a considerar es la mención al artículo 114 de la $\mathrm{LH}^{266}$ donde se señala que:

«Salvo pacto en contrario, la hipoteca constituida a favor de un crédito que devengue interés no asegurará, con perjuicio de tercero, además del capital, sino los intereses de los dos últimos años transcurridos y la parte vencida de la anualidad corriente.

En ningún caso podrá pactarse que la hipoteca asegure intereses por plazo superior a cinco años».

\footnotetext{
${ }^{265}$ Serrano de Nicolás, Á., «Régimen jurídico...», op. cit., p. 48.

266 Este artículo se completa con el artículo 220 del RH: «Cuando se fije en la escritura una cantidad global para responder del pago de intereses, no podrá exceder del importe correspondiente a cinco anualidades».
} 
Con respecto a los intereses remuneratorios ${ }^{267}$, la Ley $41 / 2007$ introduce una novedad respecto de las reglas sobre su cobertura establecidas por la legislación hipotecaria, indicando que no les será de aplicación el límite temporal máximo de cinco años ${ }^{268}$ impuesto por el artículo 114 de la Ley Hipotecaria, en su segundo párrafo. Esta novedad hace que se planteen algunas cuestiones sobre su forma de aplicación.

En cuanto al ámbito de aplicación, se tendrá que determinar si la derogación legal del artículo 114 de la LH se refiere sólo a los casos de vencimiento de la obligación por el fallecimiento del deudor o del último beneficiario, o por el contrario, se aplica a cualquier supuesto de vencimiento anticipado, particularmente en el caso de transmisión voluntaria del inmueble hipotecado.

En la hipoteca inversa, la limitación cuantitativa de los intereses remuneratorios se fijará mediante un criterio objetivo y no temporal, basado en la cuantía de bienes que integren la herencia del deudor hipotecario. Este criterio sólo será aplicable cuando el vencimiento se produzca por el fallecimiento del deudor y como medida de compensación, es decir, la limitación de la deuda tendrá como tope el importe de los bienes de la herencia.

Así aparece reflejado en el apartado 6 de la DA 1. ${ }^{\mathrm{a}}$ : "Cuando se extinga el préstamo o crédito regulado por esta disposición y los herederos del deudor hipotecario decidan no reembolsar los débitos vencidos, con sus intereses, el acreedor sólo podrá obtener recobro hasta donde alcancen los bienes de la herencia. A estos efectos no será de aplicación lo dispuesto en el párrafo segundo del artículo 114 de la Ley Hipotecaria».

En este apartado observamos que se hace referencia a la extinción de la hipoteca y no al vencimiento anticipado y, además, sólo se nombra a los

\footnotetext{
${ }^{267}$ Atendiendo a la propia estructura de la hipoteca inversa en la que los intereses devengados no son exigibles hasta el fallecimiento del prestatario, la DGRN en la Resolución de 1 de octubre de 2010 en su fundamento jurídico séptimo señala que: «la extensión de los intereses más allá del límite de los dos años del art. 114 de la Ley Hipotecaria debe entenderse como parte de su contenido natural, salvo que de los propios términos del propio contrato resulte lo contrario». «Puesto que no son exigibles hasta el fallecimiento del deudor, quedan ilimitadamente cubiertos por el valor de un determinado patrimonio", en este caso, el patrimonio hereditario.

${ }^{268}$ Vid. RDGRN de 19 de enero de 1996 (RJ 1996/586).
} 
herederos del deudor. La redacción de este precepto ${ }^{269}$ se supone que radica en la imposibilidad, por parte de la entidad acreedora, de exigir los intereses vencidos a los herederos del deudor. No obstante, podría darse el caso de que éstos no hicieran frente a la deuda vencida.

De ahí podemos deducir que estos intereses no son exigibles hasta el fallecimiento del deudor, de tal manera que quedan ilimitadamente cubiertos por el valor de la garantía, de la vivienda habitual hasta la fecha de la defunción. De esta forma, se sustituye una cuantificación positiva de cinco años (art. 114 de la LH) por una cuantificación delimitadora o negativa ${ }^{270}$ hasta donde alcance el valor de un patrimonio hereditario.

En este asunto no debemos olvidar que los herederos no son terceros, sino que pasan a ocupar la posición de su causante, como si del deudor hipotecario se tratase ${ }^{271}$. De tal manera, que la deuda generada por esta hipoteca inversa se extenderá entre todos los posibles herederos. Así pues la inaplicación del artículo 114 de la LH regulada en este apartado $6^{272}$ se deberá entender para el supuesto en el que existan terceros, no sólo el tercer adquirente de la propiedad gravada, sino cualquier titular de un derecho real sobre la finca y que sea de rango inferior a la hipoteca.

\footnotetext{
269 La «solución intermedia» inicialmente prevista y finalmente adoptada, fue la dada por el Grupo catalán, que aunque propuso una enmienda al apartado 6 de la DA $1 .^{\text {a }}$, tan sólo se refería a la necesidad de excluir la aplicación del párrafo segundo del artículo 114 de la $\mathrm{LH}$, relativo a la extensión de la hipoteca a los intereses de la deuda, pareciéndole, por tanto, oportuna la limitación de responsabilidad a los bienes de la herencia que preconizaba la norma proyectada. En atención a esa enmienda, se añadió ese segundo inciso del apartado sexto en el texto de la definitiva Ley. En el Congreso, Convergència $i$ Unió, a través de la enmienda número 56, justificaba así su posición: «dadas las particulares características de la hipoteca inversa, en la que no existe reembolso del capital ni pago de intereses por el deudor hipotecario y la deuda sólo es exigible al fallecimiento del mismo, no está justificada en este caso la limitación legal de cinco años de cobertura hipotecaria para los intereses". Esta enmienda, también fue formulada por el Grupo Popular en el Congreso (enmienda núm. 101) con idéntica justificación y los mismos términos esgrimidos por el Grupo Catalán. Así lo indica ZuRITA MARTín, I., «La nueva normativa...», op. cit., p. 1306.

${ }^{270}$ En este asunto la Resolución de la DGRN de 6 de mayo de 2008 (RJ 2008\2796) matiza lo siguiente: «Cabe recordar que según la doctrina de este Centro Directivo, lo que no cabe es que la hipoteca asegure (en perjuicio de tercero), intereses por plazo superior a cinco años (fuera de la excepción legal prevista expresamente para las hipotecas inversas)».

${ }^{271}$ Roca SASTRe, R.M. y RoCa-SASTRE MUNCUNILL, L., Derecho hipotecario: Hipotecas, op. cit., p.80.

272 Lo dispuesto en este apartado será de aplicación tanto para las hipotecas inversas constituidas sobre la vivienda habitual como para las gravadas sobre cualquier otro inmueble, pues tal como se indica en la RDGRN de 1 de octubre de 2010, la garantía por intereses más allá de los dos años forma parte del "contenido natural" de la hipoteca inversa, cumpla o no con los requisitos de la Ley 41/2007 para obtención de los beneficios fiscales.
} 
Respecto a este asunto, PEÑA BERNALDo DE QUIRós ${ }^{273}$ señala además, que hay que distinguir dos supuestos en función de si puede existir perjuicio o no de tercero:

- En caso de que no haya perjuicio a tercero, los bienes hipotecados responderán de todos los intereses siempre que no hayan prescrito, pudiendo ejercer la acción real hipotecaria.

- Si hubiese terceros que pudieran resultar perjudicados, los bienes hipotecados únicamente responderían de las dos últimas anualidades y la parte vencida de la anualidad corriente, salvo pacto en contrario. En virtud del pacto nunca podrán garantizarse más de cinco anualidades.

No obstante el apartado 6 de la DA 1. ${ }^{a}$ sólo hace referencia al apartado segundo del artículo 114 de la LH, pero nada dice del párrafo primero. Es decir, se podrá pactar que la hipoteca asegure intereses por un plazo superior a cinco años pero, a falta de pacto, surge la duda de si sólo serán exigibles intereses por un plazo máximo de tres anualidades vencidas (dos años y la parte vencida de la anualidad corriente, Art. 114.1 de la LH).

Pues bien, cuando al inicio de este punto ha sido citado el artículo 114 de la LH, se ha mantenido la redacción original de cuando se aprobó la Ley 41/2007, pero, con la entrada en vigor de la Ley $1 / 2013$, se añadió un tercer párrafo al citado artículo, quedando redactado de la siguiente manera:

«Los intereses de demora de préstamos o créditos para la adquisición de vivienda habitual, garantizados con hipotecas constituidas sobre la misma vivienda, no podrán ser superiores a tres veces el interés legal del dinero y sólo podrán devengarse sobre el principal pendiente de pago. Dichos intereses de demora no podrán ser capitalizados en ningún caso, salvo en el supuesto previsto en el artículo 579.2.a) de la Ley de Enjuiciamiento Civil».

El artículo 114 de la $\mathrm{LH}$, antes de la introducción de este tercer párrafo, limitaba en las hipotecas el número de años de interés que afectaban a terceros, pero no aludía a un tipo de interés máximo. Con la introducción de reales (excepto los de garantía), 4. ${ }^{\text {a }}$ ed., Centro de Estudios Registrales, Madrid, 2001, pp. 155 y 156. 
este tercer párrafo se limita el tipo de demora en el caso de viviendas habituales, ahora bien, no todo préstamo o crédito sobre la vivienda habitual gozará de este beneficio, sino sólo los obtenidos para su adquisición ${ }^{274}$.

De esta manera, la Disposición Transitoria Segunda de la Ley 1/2013 extiende su aplicación retroactivamente a los intereses garantizados con las hipotecas constituidos antes de la entrada en vigor de la Ley y que se devenguen con posterioridad a la misma, así como los que, habiéndose devengado en dicha fecha, no hubieran sido satisfechos.

Por tanto, con la introducción de este nuevo apartado al artículo 114 de la LH, podríamos destacar las siguientes ventajas:

1.- No se podrá superar el interés legal del dinero ${ }^{275}$.

2. - No cabrá el anatocismo, ni siquiera inter partes. Ello significa que los intereses no generarán a su vez intereses en ningún caso. Para los demás préstamos y créditos hipotecarios, es muy común que se pacte el anatocismo, atendiendo al artículo 317 del Código de Comercio, que vincula a las partes aunque no se extienda a él la garantía hipotecaria.

En cuanto a si se trata de la vivienda habitual, habrá que estar a la presunción iuris tantum, de ser cierto lo declarado en la escritura inicial, pues aunque la manifestación la ha de hacer sólo el deudor, el acreedor firmó el título.

En este aspecto, señalar también que la excepción al artículo 579.2.a) de la LEC se refiere a ejecuciones hipotecarias en las que no se ha saldado totalmente la deuda. Es más favorable para el deudor pues se aplica el interés legal del dinero.

\footnotetext{
${ }^{274}$ Vid. la Resolución de la DGRN de 13 de marzo de 2002 (RJ 2002\6182).

275 La Ley de Presupuestos Generales del Estado para el año 2015 (Ley 36/2014, de 26 de diciembre, BOE-A-2014-13612), en su disposición adicional trigésimo segunda, ha establecido el interés legal del dinero para el ejercicio 2015 en el 3,50\%. De esta manera, el interés legal del dinero baja un 0,5\% tras cuatro años congelado.
} 
Sin embargo, no se ha tocado una de las mayores situaciones de injusticia. Producido el impago de determinadas cuotas, suele derivarse que se satisfagan intereses de demora por todo el capital y no sólo por la parte de capital efectivamente impagada, sobre todo si se ha convenido una cláusula de vencimiento anticipado. Formalmente, parece darse el sinsentido de que los intereses ordinarios puedan superar el triple del interés legal del dinero, aunque no puedan hacerlo los de demora. Una mínima interpretación teológica debe excluirlo, porque no se puede primar que una persona se ponga en mora para pagar menos intereses.

De todos modos, no deben excluirse cláusulas que fijen una responsabilidad máxima de los intereses ordinarios por encima del 10,5\% (actualmente tres veces el interés legal del dinero), porque ese interés legal puede fluctuar. Ahora bien, sí sería conveniente que se adaptaran los tipos máximos de responsabilidad hipotecaria de los intereses ordinarios a esa exigencia de los de demora: tres veces el interés legal del dinero.

Si nos vamos a la Disposición transitoria segunda de la Ley 1/2013 correspondiente a los Intereses de demora de hipotecas constituidas sobre vivienda habitual:

«La limitación de los intereses de demora de hipotecas constituidas sobre vivienda habitual prevista en el artículo 3 apartado Dos será de aplicación a las hipotecas constituidas con posterioridad a la entrada en vigor de esta Ley.

Asimismo, dicha limitación será de aplicación a los intereses de demora previstos en los préstamos con garantía de hipoteca sobre vivienda habitual, constituidos antes de la entrada en vigor de la Ley, que se devenguen con posterioridad a la misma, así como a los que habiéndose devengado en dicha fecha no hubieran sido satisfechos.

En los procedimientos de ejecución o venta extrajudicial iniciados y no concluidos a la entrada en vigor de esta Ley, y en los que se haya fijado ya la cantidad por la que se solicita que se despache ejecución o la venta extrajudicial, el Secretario judicial o el Notario dará al ejecutante un plazo de 10 días para que recalcule aquella cantidad conforme a lo dispuesto en el apartado anterior.» 
De esta forma, este límite del apartado 3 del artículo 114 de la $\mathrm{LH}$, también cabría para los solicitantes de hipoteca inversa de vivienda habitual. Ahora bien, en el caso de que el vencimiento de la deuda tuviera su origen en una causa distinta, como por ejemplo la transmisión voluntaria del inmueble hipotecado, cabrían dos posibles soluciones:

- Una sería entender aplicable el límite señalado por el artículo 114 de la Ley Hipotecaria, ya que la norma contenida en la Ley 41/2007 tiene carácter excepcional al restringir la libre circulación de los bienes inmuebles $y$, por tanto, debe ser interpretada de manera restrictiva.

- Otra, atendiendo a la naturaleza de la Ley 41/2007, sería entender el límite máximo de cobertura de valor del bien hipotecado conforme a la hipoteca de responsabilidad limitada reconocida por el artículo 140 de la Ley Hipotecaria.

Atendiendo a este precepto, sería posible incluir, previa modificación, el llamado Pacto de inexistencia de garantía patrimonial ${ }^{276}$ (admitido por la Dirección General de los Registros y del Notariado) por el que en aquellos casos en que se tenga que reembolsar un préstamo como consecuencia de la venta de una finca, si en ese momento el importe de lo adeudado excede del valor de la finca, el deudor podrá ver limitada su responsabilidad a la cantidad neta obtenida de la venta de dicha finca, siempre que:

- Se notifique a la parte acreedora la intención de vender.

- La finca se venda por su valor de mercado.

- La entidad acreedora, con anterioridad a su venta, pueda verificar ese valor por medio de un tasador independiente.

- Y, por último, no se haya producido ninguna causa de incumplimiento del contrato.

\footnotetext{
276 JIMÉNEZ CLAR, A.J., «La hipoteca...», op. cit., p. 118, resalta que será de aplicación la doctrina de la Dirección General de los Registros y del Notariado por la que se exige que los intereses sólo podrán reclamarse en cuanto tales y dentro de los límites legales y pactados, pero nunca englobados en el capital.
} 
En este caso de transmisión voluntaria de la finca hipotecada, la responsabilidad del deudor incluirá los intereses devengados más allá del límite del artículo 114 de la Ley Hipotecaria. No obstante, esta responsabilidad quedará limitada a la cantidad neta obtenida de la venta de la finca, siempre y cuando se cumplan los demás pactos y condiciones señalados por la Dirección General de los Registros y del Notariado ${ }^{277}$.

En cuanto a la posibilidad de pacto de capitalización de los intereses remuneratorios, la cláusula que lo refleje, sólo podrá referirse a los intereses vencidos y no pagados existentes en el momento en que pueden ser reclamados. Esta situación tendrá lugar a partir de la fecha del fallecimiento del deudor.

Para finalizar, la Ley 41/2007 no específica si la hipoteca inversa debe tener la condición ${ }^{278}$ de primera hipoteca o que sea la única que grave el inmueble. En el caso de que exista una primera hipoteca cuyo vencimiento se dé antes que el de la hipoteca inversa, ésta procederá a la eliminación de la inversa, aunque cabe una excepción, y es que la entidad acreedora, mediante el pago correspondiente, se subrogue en la figura del acreedor ejecutante.

En el supuesto de que se dé esta excepción, el acreedor subrogante podrá acumular el importe satisfecho de la primera hipoteca al capital de la hipoteca inversa, o bien dar por vencida la hipoteca inversa de forma anticipada. Si esto llegara a suceder, la acumulación del capital de la primera hipoteca al de la hipoteca inversa, junto a que la exigibilidad de la obligación no se iniciará hasta el fallecimiento del deudor, esta situación podría derivar en la existencia de patrimonio negativo.

En la hipoteca inversa, la suma de toda la deuda será exigible de una sola vez al fallecimiento del deudor o del último beneficiario y, una vez haya

\footnotetext{
277 Al respecto, la Resolución de la DGRN de 21 de diciembre de 2007 (RJ 200812086) sostiene que la hipoteca inversa es un contrato de carácter personalísimo, ya que tanto el préstamo como la garantía se conceden a favor de una persona concreta que reúne determinadas características de edad, dependencia y titularidad sobre un bien inmueble.

${ }^{278}$ Esto no sucede en otros ordenamientos jurídicos. A modo de ejemplo, cabría citar el caso de EEUU.
} 
transcurrido un determinado plazo para realizar las gestiones oportunas. Esta situación podrá ser conocida por el tercer adquirente de la vivienda así como cualquier otro derecho que recaiga sobre el inmueble, a través del Registro de la Propiedad.

De esta forma, el tercero podrá comprobar la cantidad máxima por principal e intereses a que asciende la hipoteca, de tal forma que el acreedor, para exigir aquellas cuantías que superen la cifra máxima de cobertura hipotecaria establecida en el Registro, ejercitará la acción personal correspondiente ${ }^{279}$.

\section{El bien inmueble hipotecado}

\subsection{El solicitante debe ser titular del bien inmueble}

El solicitante de esta modalidad hipotecaria debe ostentar la condición de titular del bien inmueble. Esta condición se recoge en la Exposición de Motivos (VIII), donde se específica que:

«La hipoteca inversa regulada en esta Ley se define como un préstamo o crédito hipotecario del que el propietario de la vivienda realiza disposiciones, normalmente periódicas, aunque la disposición pueda ser de una sola vez, hasta un importe máximo determinado por un porcentaje del valor de tasación en el momento de la constitución».

Con anterioridad a la Ley 41/2007, algunos autores ya hacían referencia a esta condición, como es el caso de HeRRANZ González ${ }^{280}$, quien se refería a la hipoteca inversa como «un crédito con garantía inmobiliaria, es decir, un negocio por el cual una persona que posee un inmueble recibe cada mes una renta, determinada por varios factores, y al fallecimiento del propietario, los

\footnotetext{
279 Artículo 147 de la LH: «La parte de intereses que el acreedor no pueda exigir por la acción real hipotecaria podrá reclamarla del obligado por la personal, siendo considerado respecto a ella, en caso de concurso, como acreedor escriturario y salvo lo dispuesto en el artículo 140».

280 HerRanz GonzÁlez, R., «Hipoteca inversa...», op. cit., p. 4, matiza que aunque el término poseer no sea correcto desde el punto de vista jurídico, en esta caso hay que entenderlo en el sentido de ser titular del bien inmueble.
} 
herederos harán frente al pago del préstamo o la entidad procederá a ejecutar la garantía».

Del mismo modo, BALAGUÉ ${ }^{281}$ señalaba que el solicitante y el propietario debían ser la misma persona. Concretamente apuntaba que: «por medio de una hipoteca inversa o vitalicia, el titular de un bien inmueble, hipoteca su propiedad a cambio de la percepción de una renta fija».

Este requisito de ostentar la titularidad del bien se ha planteado ante la Dirección General de los Tributos ${ }^{282}$, con el fin de determinar si tendrían o no acceso a los beneficios fiscales y reducciones arancelarias. Pues bien, tal y como ya se ha comentado, para optar a estos beneficios fiscales, el solicitante de hipoteca inversa tendrá que ser el titular de la vivienda habitual ${ }^{283}$ objeto de este préstamo.

\subsection{Vivienda habitual}

La Ley $41 / 2007$, en el apartado 1 de la DA $1 .^{a}$, establece que el objeto hipotecado deberá ser la vivienda habitual ${ }^{284}$ del solicitante, aunque en el

\footnotetext{
${ }^{281}$ BALAGUÉ, C., «Cómo convertir...», op. cit., p. 34.

282 En este aspecto, quisiera destacar tres resoluciones de la Dirección General de los Tributos: Resolución de 22 de abril de 2009 (JUR 2009\895), Resolución de 20 de mayo de 2009 (JUR 2009\367878) y Resolución de 16 de junio de 2009 (JUR 2009\373019).

${ }^{283}$ Vid. también la Consulta vinculante de la Dirección General de los Tributos de 26 de mayo de 2009 (JT\2009\1171).

${ }^{284}$ BOCG, Congreso de los Diputados, serie A, núm. 127-7, de 9 de mayo de 2007, Grupo Parlamentario Catalán (Convergència i Unió), enmienda núm. 53; BOCG, Senado, serie II, núm. 130-d, de 6 de noviembre de 2007, Grupo Parlamentario Catalán Convergència i Unió (GPCIU), enmienda núm. 97. Durante la tramitación parlamentaria del Proyecto de Ley se propusieron diversas enmiendas que trataban de paliar esta exigencia. Así, por una parte, el Grupo Parlamentario Catalán en el Congreso proponía añadir un párrafo 1. bis) a la DA $1 .^{a}$ del Proyecto de Ley, según el cual no se consideraba que el bien inmueble dejaba de constituir la vivienda habitual del solicitante cuando el deudor hipotecario lo alquile, se traslade al domicilio de un familiar o ingrese en una residencia para su cuidado, especialmente, cuando se encuentre en una situación de dependencia, de acuerdo con la normativa vigente. Con esta enmienda, aunque se limita a los efectos de la exigencia inicialmente prevista por el Proyecto, se sigue considerando necesario que el inmueble constituya la vivienda habitual del deudor. En cambio, para el Grupo Parlamentario Popular y el Grupo Parlamentario de Esquerra Republicana, dicha exigencia debería ser, en cualquier caso, suprimida del texto legal, en cuanto no se aprecia qué inconveniente pueda haber en que la persona mayor pueda contar con las ventajas ligadas a la constitución de la hipoteca inversa sobre otro inmueble, siempre y cuando la finalidad del crédito sea completar la pensión con esta hipoteca en condiciones ventajosas para el titular, generando así una renta adicional para afrontar las necesidades derivadas de su vejez y rentabilizar al máximo los ahorros logrados durante toda su vida. A pesar de ello, el texto de este apartado 1 no sufrió modificación alguna, de manera que, para poder concertar esta modalidad de hipoteca se tenga que cumplir la
} 
apartado 10 del mismo texto legal se hace una matización al respecto, pudiéndose constituir sobre otro inmueble distinto al de la vivienda habitual.

En nuestro ordenamiento y desde la perspectiva del Derecho Civil, no se define el concepto de vivienda habitual. De ahí que tengamos que acudir a la definición que se da en materia fiscal ${ }^{285}$. Esta definición viene regulada en la Ley 35/2006, de 28 de noviembre, del Impuesto sobre la Renta de las Personas Físicas ${ }^{286}$, la cual, y como regla general, se basa en la permanencia durante más de 183 días al año en un mismo lugar. Concretamente, en el Artículo 72 de la citada Ley se regula el concepto de Residencia habitual en el territorio de una Comunidad Autónoma, con todas las posibles variantes que pueden surgir, tanto a nivel profesional, como familiar, como en cualquier otra situación.

En este sentido, para SERRANO DE Nicolás ${ }^{287}$, la definición de vivienda habitual viene determinada tanto por la legislación civil como por la legislación fiscal ${ }^{288}$ vigente al momento de constituirse o modificarse dicha situación.

Si nos vamos al Registro de la Propiedad, éste no tiene capacidad para informar sobre el destino del bien inmueble, con lo cual, para definir la condición de vivienda habitual (condición que se adquiere por la naturaleza

exigencia de que la finca hipotecada constituya la vivienda habitual del prestatario. Vid. con más detalle ZURITA MARTín, I., «La nueva normativa...», op. cit., p. 1282.

${ }^{285} \mathrm{La}$ mayor parte de los autores son partidarios de tomar el concepto tributario de vivienda habitual, es decir, el concepto dado por la LIRPF. Entre otros, cabría citar MARTínez EsCRIBANO, C., La hipoteca inversa, op. cit., p. 92; Í̃̃IGO ARROYO, L., «La hipoteca inversa (Disposiciones Adicionales 1.a y 4.a Ley 41/2007)» en MUÑIZ ESPADA, E. (coord.), La reforma del mercado hipotecario y otras medidas financieras en el contexto de la crisis económica, Edisofer, Madrid, 2009, p. 335; LUQUE JIMÉNEZ, M.C., «Una nueva modalidad...», op. cit., p. 226; SeRRANO de Nicolás, Á., «Régimen jurídico...», op. cit., p. 48; VAÑó VAÑó, M.J., "Aproximación al régimen de la hipoteca inversa», en GonZálEZ CASTILLA, F. (coord.), Estudios de Derecho del Mercado financiero: homenaje al profesor Vicente Cuñat Edo, Universidad de Valencia, Valencia, 2010, p. 585.

${ }^{286}$ BOE núm. 285, de 29 de noviembre.

287 SeRRANO de Nicolás, Á., «Régimen jurídico...», op. cit., p. 48.

288 Dentro de la regulación fiscal, matizar que se puede ser vivienda familiar habitual sin estar unidas dos fincas registrales. Así lo señala la Consulta vinculante de la Dirección General de Tributos (DGT) de 9 de agosto de 2006, donde considera no sólo la vivienda propiamente dicha, sino también dos plazas de garaje y un trastero, siempre que reúnan los requisitos fiscales legalmente previstos. Al efecto, vid. también, las consultas vinculantes de la DGT de 7 de marzo de 2005 y 2 de junio de 2005. 
de dato de hecho ${ }^{289}$ ), tendremos que acudir al Derecho material, civil y fiscal. El Registro de la Propiedad ${ }^{290}$ se limita a publicar titularidades: relaciones de pertenencia de determinados derechos a determinadas personas. En el caso de que un dato de hecho acceda al Registro, la publicidad registral únicamente tendrá valor de tipo probatorio pero no será de aplicación la presunción de exactitud regulada en el artículo 38 de la $\mathrm{LH}^{291}$.

En cuanto al Derecho civil tendremos que acudir al artículo 40, párrafo primero, donde se regula el domicilio y se detalla que para el ejercicio de los derechos y el cumplimiento de las obligaciones civiles, el domicilio de las personas naturales será el lugar de su residencia habitual, y, en su caso, el que determine la Ley de Enjuiciamiento Civil.

De esta forma, el domicilio, a efectos civiles $^{292}$, sirve para el ejercicio de los derechos y el cumplimiento de las obligaciones, además de ser nuestra residencia habitual ${ }^{293}$. El Código Civil, a diferencia de lo dispuesto por la LIRPF $^{294}$, no señala un plazo determinado para ser considerado residencia

289 En este sentido se manifiestan JIMÉnez CLAR, A.J., «La hipoteca...», op. cit., p.119 y De PABLO Contreras, P. (coord.); Martínez de Aguirre Aldaz, C. y Pérez Álvarez, M.A., Curso de Derecho Civil (III): Derechos Reales, 3. ${ }^{a}$ ed., COLEX, Madrid, 2011, p. 97.

${ }^{290}$ El Registro de la Propiedad y Catastro se coordinan para evitar datos contradictorios sobre un mismo bien. El Consejo de Ministros, a propuesta del entonces Ministro de Justicia, Alberto Ruíz-Gallardón, y en coordinación con el Ministerio de Hacienda, aprobó el viernes 13 de junio del pasado año, el Proyecto de Reforma de la Ley Hipotecaria y de la Ley del Catastro para facilitar el intercambio seguro de datos entre el Registro de la Propiedad y el Catastro y evitar así informaciones contradictorias e incompletas sobre un mismo inmueble. Además, la modificación de ambas normas tiene también por objeto facilitar la interoperabilidad entre ambos organismos (Registro de la Propiedad y Catastro). No obstante, esta reforma de la Ley Hipotecaria todavía no se ha originado, aunque se prevé que se produzca para mediados de noviembre de 2015.

291 De Pablo Contreras, P.; Martínez de Aguirre Aldaz, C. y Pérez Álvarez, M.A., Curso de Derecho Civil (III), op. cit., pp. 97 y 101.

292 Vid. con mayor detalle Gómez LaplazA, C., «Comentario al artículo 40», en Bercovitz Rodríguez-Cano, R. (coord.), Comentarios al Código Civil, Thomson Aranzadi, Cizur Menor (Navarra), 2006.

${ }^{293}$ Al respecto, la STS de 30 de enero de 1993 (RJ 1993\350) matiza que el artículo 40 del CC: «Sólo contiene en forma aproximada lo que debe entenderse por el domicilio de las personas naturales, al hacer referencia para el ejercicio de los derechos y cumplimiento de las obligaciones civiles el del lugar de su residencia habitual y, en su caso, el que determina la Ley de Enjuiciamiento Civil. Pero el concepto del domicilio abarca una dimensión plural amplia, pues aparte del real, que corresponde a la residencia permanente e intencionada en un precisado lugar o como también ha sostenido esta Sala en forma objetivizada, al tenerse sólo en cuenta la efectiva vivencia y habitualidad, con raíces familiares y económicas».

294 La STS de 7 de febrero de 2006 (RJ 2006/2831) señala que: «La doctrina no duda en diferenciar el concepto de domicilio tributario del concepto de residencia, al ser la residencia el punto de conexión que determina la aplicación de las Leyes tributarias a las personas naturales o jurídicas, y también el que determina las modalidades de sujeción a los impuestos que tienen el carácter de personales. Mientras que el domicilio es el que fija el lugar, dentro del espacio físico en el que las Leyes despliegan sus efectos, donde se producen las relaciones entre la Administración Tributaria y los obligados tributarios en orden a la aplicación de los tributos. Sin embargo, es lo cierto que no siempre el 
habitual. En este caso, se trata de un dato de hecho ${ }^{295}$ que no da a conocer el Registro de la Propiedad y que por tanto hay que probar porque la presunción de exactitud del Registro no alcanza a la descripción física de la finca y demás datos de hecho ${ }^{296}$.

Para PUIG BRUTAU ${ }^{297}$ el concepto de domicilio que proporciona el artículo 40 del CC es el del lugar de residencia habitual. Es el domicilio real, compuesto por la suma del elemento material de la residencia y del intencional de residir de modo permanente. De esta manera, el domicilio real es el domicilio voluntario que se manifiesta con la residencia habitual de la persona. Es la manifestación del derecho que reconoce el artículo 16 de la CE a elegir libremente la residencia.

En sentido parecido, DíEZ-PICAZO y GULLóN ${ }^{298}$ declaran que junto al hecho material de la residencia es necesario que exista cierto animus manendi, es decir, que la persona tenga la intención o voluntad de permanecer en el domicilio.

En cuanto a un concepto amplio de domicilio, podríamos interpretar el caso de la adquisición de la nacionalidad, siendo indiferente el lugar donde radique el domicilio del interesado siempre y cuando se encuentre en territorio español. $Y$ desde un punto de vista más restringido trataría del domicilio como vivienda donde habita la persona ${ }^{299}$.

legislador diferencia los conceptos de domicilio y residencia, en cuanto define unos con respecto a otros, llegando a configurar el domicilio como punto de conexión, en el mismo nivel que la residencia, para la aplicación de las Leyes tributarias de las Comunidades Autónomas con regímenes económicos especiales y como criterio de atribución para la cesión de tributos respecto de las Comunidades Autónomas del régimen general».

${ }^{295}$ Así lo ha indicado el Tribunal Supremo en las sentencias de 19 de febrero de 1997 (RJ 1997/791), de 29 de abril de 1998 (RJ 1998\3650) y de 14 de noviembre de 1998 (RJ 199819903) en las que la determinación de la residencia habitual es una cuestión de puro hecho $\mathrm{y}$, por tanto, eminentemente probatoria. De esta forma, se podrían aportar documentos tales como: certificado de empadronamiento, el contrato de suministro de energía eléctrica, etc.

296 De Pablo Contreras, P.; Martínez de Aguirre Aldaz, C. y Pérez Álvarez, M.A., Curso de Derecho Civil (III), op. cit., p. 97.

${ }^{297}$ Puig Brutau, J., Compendio de Derecho Civil, Volumen I, op. cit., p. 239.

298 Díez-PiCAzo, L. y Gullón, A., Sistemas de Derecho Civil. Introducción. Derecho de la persona, vol. I, Tecnos, Madrid, 11. ${ }^{a}$ ed., 2004, p. 271.

299 De Pablo Contreras, P. (coord.); Martínez de Aguirre Aldaz, C.; Pérez Álvarez, M.Á. y Parra lucán, M.Á.,

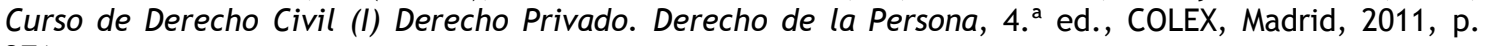
371. 
Con la entrada en vigor de la Ley $1 / 2013$, de 14 de mayo de medidas para reforzar la protección a los deudores hipotecarios, reestructuración de deuda y alquiler social, en el Capítulo II relativo a las Medidas de mejora del mercado hipotecario, se añade un apartado, el 3, al artículo 21 de la LH, que queda redactado de la siguiente manera:

«En las escrituras de préstamo hipotecario sobre vivienda deberá constar el carácter, habitual o no, que pretenda atribuirse a la vivienda que se hipoteque. Se presumirá, salvo prueba en contrario, que en el momento de la ejecución judicial del inmueble es vivienda habitual si así se hiciera constar en la escritura de constitución».

Como se puede apreciar, el legislador, en este precepto obliga a que en las escrituras de préstamo hipotecario se haga constar la condición de vivienda habitual o no. Analizándolo con detalle se observa que sólo se hace referencia a las escrituras de préstamo y no de crédito hipotecario, aunque, por analogía, se tendría que aplicar también a las escrituras de crédito hipotecario ${ }^{300}$. De esta manera, la naturaleza de vivienda habitual del bien hipotecado queda sometida al régimen de la prueba de las situaciones de hecho que se aportan a la inscripción de los derechos en el Registro de la Propiedad. Aun así, siempre cabrá la duda.

Por tanto, en los casos susceptibles de que se puedan originar problemas de calificación de la vivienda habitual, sería aconsejable incluir en la escritura de constitución de la hipoteca inversa, una declaración de notoriedad efectuada por el notario autorizante y con la práctica de la prueba que estime pertinente, a fin de fijar y dar certeza a este requisito, al resultar éste indispensable para la viabilidad de la hipoteca inversa.

\footnotetext{
300 El motivo de que en este artículo 21.3 de la LH, no se hiciera mención al crédito hipotecario y si al préstamo, no lo podemos justificar tampoco como un mero olvido del legislador, ya que en el artículo 114, el siguiente modificado por medio de la Ley $1 / 2013$, al añadir un tercer párrafo se hace referencia tanto a la figura del préstamo como a la del crédito. Por tanto, la aplicación analógica debe primar también a los créditos de este tipo, ya que, les afecta de la misma manera el límite de intereses de demora del artículo 114 de la LH y además, las ventajas que tiene la ejecución de la vivienda habitual para su propietario son tanto para las vivienda adquiridas por medio de un préstamo como las adquiridas por medio de un crédito hipotecario. Además, para utilizar el procedimiento extrajudicial, el artículo 129 (también modificado en la misma Ley) exige que conste si la vivienda es habitual, pero no distingue si ha sido adquirida a través de préstamo o crédito. En este caso, también cabrá la prueba en contrario, es decir, de que no sea la vivienda habitual, bien por error en la declaración, bien porque dejó de serlo. En estos casos, el momento para valorar definitivamente si es o no la vivienda habitual sería en el de la ejecución. Llegado aquí, cabrá probar que sí se trata de la vivienda habitual, en tal caso, deberá aportarse al Juez o Notario ejecutantes algún tipo de prueba y no una mera declaración.
} 
Junto a esto, matizar que la vivienda habitual no tiene por qué coincidir con la finca registral. De manera que, podemos distinguir varios supuestos:

Por una parte, una sola finca registral puede no ser considerara toda ella como una vivienda habitual (aunque toda tendrá que ser hipotecada, salvo que previamente se divida horizontalmente. En este caso se tendrá que distribuir la responsabilidad entre las diferentes fincas registrales hipotecadas).

Y, por otra, una vivienda habitual puede integrar más de una finca registral (con su consiguiente necesaria distribución de la responsabilidad hipotecaria entre las diferentes fincas registrales).

En todo caso, en esta vivienda habitual $^{301}$ se incluirán todos los elementos anejos y pertenencias: trasteros, garajes, etc., aunque sean fincas registrales diferentes, independientemente de que se hayan adquirido de forma simultánea con la vivienda o no, siempre y cuando tengan el mismo destino afecto a la vivienda habitual del solicitante, pues debe entenderse que todas estas fincas configuran la vivienda habitual.

Hasta ahora, sólo se ha hecho referencia al domicilio del solicitante como único titular de la vivienda, pero, situación muy normal en estos casos es que la vivienda habitual sea el domicilio conyugal regulado en el Código Civil en su artículo $70^{302}$. Y, de la misma manera, también se hace referencia a la vivienda familiar en varios preceptos, como es el caso de los artículos 90.c), 91 y 96 del mismo texto legal.

\footnotetext{
${ }^{301}$ Cfr. Romero Candau, P.A., «La hipoteca...», op. cit., p. 313.

302 Puig Brutau, J., Compendio de Derecho Civil, Volumen I, op. cit., p. 239, apunta que en el matrimonio «el domicilio real o voluntario es el que los cónyuges hayan fijado de común acuerdo, sin perjuicio de que en caso de discrepancia deba resolver el Juez, teniendo en cuenta el interés de la familia, tal y como se dispone en el artículo 70 del CC».
} 
En el caso que aquí nos atañe, y en concordancia con la Ley $41 / 2007$, el domicilio lo interpretaríamos en un sentido más restringido: como la vivienda de la que se es titular y donde habita la persona, o en el caso del domicilio conyugal, como el lugar donde habita el matrimonio titular de la vivienda sobre la que se solicita la constitución de una hipoteca inversa.

Por tanto, junto a la normativa fiscal en la que se nos amplía el concepto de vivienda habitual, en estos casos, y debido a la especial legitimación en orden a la hipotecabilidad del bien, también será importante la regulación del régimen económico matrimonial. Al tratarse de una hipoteca sobre todos los elementos que componen la vivienda habitual y aunque ésta se formalice sólo por uno de los cónyuges, aun no siendo imprescindible su consentimiento $^{303}$, se requerirá del asentamiento ${ }^{304}$ del cónyuge no propietario (no deudor ni solicitante).

Antes de la entrada en vigor de esta Ley, las entidades de crédito que ofertaban este producto, no exigían que la vivienda a hipotecar fuera la vivienda habitual, pues bastaba con tener una casa en propiedad libre de cargas. No obstante, el requisito de que la vivienda sea la habitual puede ser a consecuencia de una mayor seguridad jurídica para las entidades de crédito que ofertan este producto. Al tratarse de la vivienda habitual, las personas que solicitan este producto se muestran más cautelosas y procuran pagarla, mientras que si se tratara de otro bien inmueble, por ejemplo, un local comercial o una finca rústica, en el caso de que se ejecutara la hipoteca, no produciría los mismos efectos en una vivienda habitual (aquí el daño sería mayor) que en cualquier otro inmueble.

\footnotetext{
303 Sobre la responsabilidad patrimonial de la sociedad de gananciales MARTínez VÁzQUEZ DE CASTRO, L., Responsabilidad patrimonial de la sociedad de gananciales. Cuadernos Civitas, Madrid, 1995, p. 21, señala que aunque la obligación sea contraída por uno de los cónyuges con el consentimiento expreso del otro, conforme al artículo $1367 \mathrm{del} \mathrm{CC}$, la deuda la contrae solamente uno de los cónyuges pero la responsabilidad recae también sobre el íntegro patrimonio ganancial. Además, respecto a si es suficiente un consentimiento tácito o presunto, el citado autor opina que parece más bien que lo que el Código Civil exige es una voluntad inequívoca de contraer la deuda, lo cual puede manifestarse mediante una declaración expresa strictu sensu o una declaración tácita. De esta manera, es razonable pensar que el consentimiento expreso del otro cónyuge equivale, en sus efectos prácticos, a la actitud del cónyuge que no intervino en el contrato, cuando no ejercita la facultad que le confiere el apartado primero del artículo 1373 del CC.

${ }^{304}$ Al respecto vid. la Resolución de la DGRN de 5 de enero de 2011 (RJ\2011\3432) en la que se dispone que en el caso de hipoteca sobre bien ganancial destinado a vivienda familiar es necesario el consentimiento de ambos cónyuges.
} 
Sin embargo, esta cualidad de vivienda habitual podría cambiar con el tiempo, ¿qué sucedería entonces?

En el supuesto de que la condición de la vivienda habitual hipotecada inversamente fuera por una transmisión posterior, se produciría una causa de vencimiento anticipado ${ }^{305}$ de la obligación garantizada, prevista en el apartado 5 , párrafo 2 .

Esta causa también se mantendría para el caso de transmisión voluntaria por parte del deudor, aun reservándose éste el derecho de uso y disfrute de esa vivienda. En estos supuestos ${ }^{306}$, la transmisión del inmueble daría lugar al vencimiento anticipado de la obligación garantizada y facultaría a la entidad acreedora para exigir la devolución del capital y de los intereses devengados.

Ahora bien, si la pérdida de la condición de vivienda habitual del inmueble hipotecado no fuera por su transmisión, en principio, la entidad acreedora carecería de legitimación para dar por vencida la obligación garantizada. Para solucionar esto, se tendrán en cuenta las circunstancias por las que se origina este cambio, y más aún, si éste no es imputable a la libre voluntad del deudor, por ejemplo, que este cambio de domicilio sea debido al internamiento en una residencia o que se traslade a otra vivienda (caso de familiares o amigos) para que lo cuiden.

No obstante, no hay que olvidar que la configuración de la hipoteca inversa, especialmente en todo lo relativo al vencimiento y exigibilidad de la obligación asegurada (la vivienda habitual), obedece al intento de conciliar el

\footnotetext{
305 Las primeras hipotecas inversas en nuestro país fueron contratadas por extranjeros con entidades británicas o irlandesas, de manera que, los contratos estaban muy influenciados por el Derecho del país de origen. Así, entre las cláusulas del contrato se preveía la posibilidad de declarar vencido el préstamo por dejar de residir durante seis meses en la vivienda hipotecada, aunque se tuviese la intención de volver. En este sentido, destacar, entre otras, las RRDGRN de 21 de diciembre de 2007 (RJ 2008\2086), de 14 de enero de 2008 (RJ 2008\2091), de 1 de febrero de 2008 (RJ 2008\633) y de 8 de febrero de 2008 (RJ 2008\2094).

${ }^{306}$ Vid. las Resoluciones de la DGRN de 1 de octubre de 2010 (RJ 2010\5273), de 4 de noviembre de 2010 (RJ 2011\2461) y de 11 de enero de 2011 (RJ 2011\269).
} 
valor en uso del inmueble con su valor de cambio como instrumento de garantía.

De ahí, que la puntualización de la fecha del fallecimiento del deudor como momento para exigir esta obligación, se hace con el propósito de evitar que los posibles problemas que puedan surgir en la amortización del préstamo, impidan el uso del inmueble como vivienda habitual por parte del deudor. Si el inmueble hipotecado deja de cumplir esta función de uso, parece que no tiene demasiado sentido prolongar el vencimiento de la obligación hasta el fallecimiento del deudor, puesto que con la venta del inmueble se llegaría a la misma solución.

Este requisito de que la vivienda hipotecada sea la habitual fue matizado en el Senado ${ }^{307}$, quedando reflejado en el apartado 10 de la DA $1 .^{a}$ donde se determina que: «podrán asimismo, instrumentarse hipotecas inversas sobre cualesquiera otros inmuebles distintos de la vivienda habitual del solicitante. A estas hipotecas inversas no les serán de aplicación los apartados anteriores de esta disposición».

Por tanto, se podrán contratar hipotecas inversas sobre inmuebles distintos a la vivienda habitual ${ }^{308}$ pertenecientes al hipotecante, y también sobre inmuebles rústicos e incluso derechos, conforme a lo establecido en el artículo 106 de la Ley Hipotecaria ${ }^{309}$ y 1874 del Código Civil.

No obstante, el apartado 10 de la Disposición Adicional $1 .^{a}$ sólo hace referencia a inmuebles y no a derechos. Si examinamos el artículo 334 del CC, se observa que vienen definidos todos los bienes que pueden ser inmuebles. Concretamente, en el punto $10^{\circ}$ se dice que:

\footnotetext{
307 Vid. Enmiendas del Senado al Proyecto de Ley, BOCG, Congreso de los Diputados, serie A, núm. 12710, de 21 de noviembre de 2007.

${ }^{308}$ Álvarez Álvarez, H., La hipoteca inversa..., op. cit., p. 82, se ha manifestado al respecto señalando que habrá duplicidad de regímenes o de hipotecas inversas: las que se sometan a lo previsto en la DA $1 .^{\mathrm{a}}$ de la Ley $41 / 2007$ y las que se rijan por las reglas generales de las hipotecas. Vid. también QUESADA SÁNCHEZ, A.J., «Apuntes jurídico-civiles...», op. cit., pp. 23 y 24.

309 De esta manera, tal como se indica en este artículo: «Podrán ser hipotecados:

1. ${ }^{\circ}$ Los bienes inmuebles susceptibles de inscripción. bienes».

2. ${ }^{\circ}$ Los derechos reales enajenables, con arreglo a las leyes, impuestos sobre los mismos
} 
«Son bienes inmuebles:

$10 .^{\circ}$ Las concesiones administrativas de obras públicas y las servidumbres y demás derechos reales sobre bienes inmuebles».

En el caso de las concesiones administrativas (minas, ferrocarriles, canales, puentes y otras obras destinadas al servicio público) podrán ser objeto de hipoteca conforme al artículo 107.6 de la LH.

En cuanto a las servidumbres y demás derechos reales sobre bienes inmuebles, la hipoteca del derecho de usufructo aparece regulada en el artículo $107.1^{\circ}$ de la LH. La hipoteca de este derecho de usufructo, conforme al artículo 480 del CC, puede ser transmitida a un tercero, pero en lo que a la hipoteca inversa se refiere, es prácticamente improbable que se pueda dar este derecho de usufructo, pues aunque se ajusta tanto a lo dispuesto en el apartado 10 como en el apartado 1 de la DA 1. ${ }^{\text {a }}$ (la vivienda habitual puede disfrutarse por derecho de usufructo) no debemos olvidar el carácter vitalicio del derecho de usufructo, regulado en el artículo 513.1 ${ }^{\circ}$ : «El usufructo se extingue: $1 .^{\circ}$ Por muerte del usufructuario».

En lo relativo a la hipoteca inversa, ésta podría constituirse sobre la nuda propiedad, tal y como lo expresa el artículo $107.2^{\circ}$ de la LH. Por tanto, la nuda propiedad estaría dentro del supuesto del apartado 10 de la DA $1 .^{\mathrm{a}} \mathrm{y}$, en caso de formalizarse esta hipoteca, ésta se podría extender al usufructo.

De la misma manera, atendiendo al artículo 107 de la LH, apartados 3, 5,7 y 9, también se podrá constituir hipoteca inversa sobre derecho de hipoteca (subhipoteca), derecho de superficie, pastos, aguas, leñas y otros bienes de naturaleza real y derecho de retracto sobre los bienes retraídos.

En los casos de los bienes vendidos con pacto de retro (art. 107.7 LH) o de los bienes sujetos a condiciones resolutorias expresas (art. 107.10 LH), al igual que en el apartado 5 de la DA $1 .^{\text {a }}$, deberá tenerse en cuenta el vencimiento anticipado derivado de la transmisión voluntaria. 
En realidad, las dificultades para constituir la hipoteca sobre estos otros derechos citados en la Ley Hipotecaria son más que evidentes. La hipoteca inversa, a diferencia de la clásica, fue concebida pensando en el supuesto de hipoteca sobre la vivienda habitual, por tanto, esta Disposición Adicional $1 .^{\text {a }}$ la podemos interpretar de manera restrictiva. Si nos fijamos en el citado apartado 10, éste concluye con la siguiente matización: «no les serán de aplicación los apartados anteriores de esta disposición».

En este último punto resulta extraño que no se tengan que aplicar los apartados 1, 2, 5 y 6 que articulan la esencia de la hipoteca inversa (requisitos del solicitante y de las entidades acreedoras, exigibilidad de la deuda, etc.). Ahora bien, si lo interpretamos de forma más restrictiva, podemos llegar a entender que sólo hace referencia a los apartados 8 y 9 , relativos a los aranceles de los honorarios notariales y registrales, respectivamente.

Según ZURITA MARTíN ${ }^{310}$, el apartado 7 en el que se hace referencia a la exención del Impuesto de Transmisiones y Actos Jurídicos Documentados, atendiendo a la regla general, en la que las exenciones sólo se interpretarán de forma restrictiva (en la que el tratamiento arancelario suele ir de la mano del régimen fiscal) deberá entenderse que este apartado tampoco será aplicable para aquellos supuestos que pueda comprender el apartado 10. De ahí que podamos decir que si la hipoteca inversa se constituye sobre la vivienda habitual, estaríamos ante una hipoteca inversa típica, regulada por la DA $1 .^{a}$ de la Ley $41 / 2007$, mientras que si la hipoteca se constituye sobre cualquier otro inmueble, sería una hipoteca inversa atípica, regulada por la voluntad de las partes.

Esta posibilidad de poder hipotecar inversamente un bien inmueble que no constituya la vivienda habitual del beneficiario ha sido criticada $^{311}$, pues la figura de la hipoteca inversa nace como una medida social, y no con finalidad especulativa, para beneficiar a las personas mayores o personas con

310 ZURITA MARTíN, I., «La nueva normativa...», op. cit., p. 1309.

311 Entre otros autores, destacan QUeSADA SÁnCHEZ, A.J., «Apuntes jurídico-civiles...», op. cit., p. 23 y LUQUE JIMÉNEZ, M.C., «Una nueva modalidad...», op. cit., p. 227. 
discapacidad que tengan tan solo como riqueza su vivienda habitual. La vivienda, en la hipoteca inversa, actúa como valor para recibir a cambio una prestación, no siendo necesario acreditar unos ingresos mínimos, o un determinado patrimonio, para la devolución de lo prestado por el acreedor.

De la misma opinión es la profesora ÁLVAREZ ${ }^{312}$, al considerar que tampoco sería un inconveniente que, para obtener una renta mensual mayor, una persona constituyese una hipoteca inversa prestando como garantía no sólo una vivienda, sino dos o más si el precio de las mismas es pequeño. Lo mismo sucede con las hipotecas ordinarias, ya que en estos casos es posible que se hipotequen varias fincas para garantizar la devolución de un solo crédito, pues la hipoteca inversa, como se ha podido ver, puede recaer sobre otros inmuebles que no constituyan la vivienda habitual del solicitante, aunque no les será de aplicación la regulación prevista en la DA $1 .^{a}$ de la Ley $41 / 2007$.

Si revisamos el artículo 216 del $\mathrm{RH}$ : «No se inscribirá ninguna hipoteca sobre varias fincas, derechos reales o porciones ideales de unas y otros, afectos a una misma obligación, sin que por convenio entre las partes, o por mandato judicial, en su caso, se determine previamente la cantidad de que cada finca, porción o derecho deba responder. Los interesados podrán acordar la distribución en el mismo título inscribible o en otro documento público, o en solicitud dirigida al Registrador firmada o ratificada ante él, o cuyas firmas estén legitimadas».

De manera que, será posible hipotecar varias fincas, pero se tendrá que determinar la hipoteca en relación al bien gravado, debiendo constar la cantidad por la que cada finca deba responder, produciéndose así, una distribución de la responsabilidad hipotecaria. Ello es consecuencia del principio de especialidad, que exige la distribución o la concreción de la responsabilidad hipotecaria sobre cada una de las fincas que se hipotecan (regla general para las hipotecas ordinarias). Una vez que se produce la distribución de la responsabilidad hipotecaria entre varias fincas, existen

312 Álvarez Álvarez, H., La hipoteca inversa..., op. cit., pp. 81 y 82. 
tantas hipotecas como fincas, pero no tantos créditos como fincas. Eso implica que hay varias hipotecas pero un solo crédito ${ }^{313}$.

Sin embargo, se ha considerado que si se hipoteca inversamente la vivienda habitual junto con otros inmuebles, la distribución del crédito a efectos de tercero no será necesaria, pero al tratarse de una hipoteca inversa, no se podrá pretender una aplicación parcial de la exención del Impuesto de Actos Jurídicos Documentados o de los aranceles notariales o registrales, diferenciando la vivienda habitual de las otras fincas ${ }^{314}$. En definitiva, la hipoteca inversa podrá recaer sobre más de una finca registral, cuando todas ellas compongan la vivienda habitual ${ }^{315}$.

\subsection{Tasación de la vivienda}

Conforme al apartado 1.d) de la DA 1 . $^{\mathrm{a}}$ de la Ley $41 / 2007$, se exige que la vivienda haya sido tasada y asegurada contra daños por el valor de tasación, en las condiciones que reglamentariamente se determinen, de acuerdo con lo previsto en los artículos 7 y 8 de la Ley $2 / 1981$, de 25 de marzo ${ }^{316}$, de Regulación del Mercado Hipotecario (estos preceptos no se modificaron con la Ley $41 / 2007$, de 7 de diciembre).

\footnotetext{
313 Roca SAStre, R.M. y Roca-SASTRE MuncunilL, L., Derecho hipotecario: Hipotecas, op. cit., p. 242, indican que no tiene por qué coincidir vivienda habitual con finca registral, pues por ejemplo, una sola finca registral puede que no sea en su totalidad vivienda habitual, y una vivienda habitual puede comprender más de una finca registral, teniendo que constar en este caso la distribución de la responsabilidad hipotecaria entre las diferentes fincas registrales.

314 Romero CANDAU, P.A., «La hipoteca...», op. cit., p. 314.

315 SeRRANO de Nicolás, Á., «Régimen jurídico...», op. cit., p. 48, matiza que si se diera el caso, también se incluiría la plaza de garaje y el trastero.

316 Artículo 7: «1. Para que un crédito hipotecario pueda ser movilizado mediante la emisión de los títulos regulados en esta Ley, los bienes hipotecados deberán haber sido tasados por los servicios de tasación de las Entidades a que se refiere el artículo 2, o bien por otros servicios de tasación que cumplan los requisitos que reglamentariamente se establecerán. regulará:

2. El Ministerio de Economía y Comercio, previo informe del Instituto de Crédito Oficial,

a) Las normas generales sobre la tasación de los bienes hipotecables, a que habrán de atenerse tanto los servicios de las Entidades prestamistas como las Entidades especializadas que para este objeto puedan crearse.

b) La forma en que deba constar la tasación efectuada.

c) El régimen de inspección del cumplimiento de tales normas».

Artículo 8: «Los bienes hipotecados habrán de estar asegurados contra daños por el valor de tasación en las condiciones que reglamentariamente se determinen».
} 
La hipoteca inversa es un producto financiero en el que su amortización descansa casi exclusivamente en el valor del inmueble, ya que la entidad acreedora no va a percibir, por lo general, ninguna cantidad en concepto de amortización del capital o intereses durante la vida del deudor hipotecario. Por este motivo, la tasación de este inmueble se convierte en un requisito básico para esta modalidad hipotecaria.

El valor de tasación que se tiene en cuenta para calcular la cantidad a prestar por la entidad acreedora es el actual de la vivienda en el momento en el que se solicita la constitución de la hipoteca inversa. No obstante, lo ideal sería que se realizase obligatoriamente una revisión periódica de la tasación del inmueble ${ }^{317}$. Además, la tasación afecta directamente a la cantidad del préstamo $^{318}$ que el solicitante va a recibir.

Este tema es muy importante, debido a que las disposiciones efectuadas por el deudor tienen como límite el valor tasado de la vivienda, es decir, el principal del crédito hipotecario más los intereses devengados y otros gastos previstos al contratar la operación. La suma de estas cantidades equivaldrá al valor de la vivienda a la fecha del vencimiento de la hipoteca inversa que no es otra que la del fallecimiento del solicitante-deudor.

Cuando la Disposición Adicional $1 .^{\mathrm{a}}$ entró en vigor, el tipo de interés de los préstamos concedidos oscilaba entre el 5 y el 6 por 100, en función del plazo. El no saber cuándo se va a producir la muerte del prestatario comporta que la deuda variará en función de si el deudor vive más o menos tiempo. De esta manera, conforme al principio de especialidad, se determinará la cantidad máxima de dinero a la que se extenderá la garantía real.

\footnotetext{
317 El BBVA, en este producto financiero, permitía renegociar la tasación del inmueble en caso de revalorización.

318 Ibercaja, antes de la aprobación de la Ley 41/2007, concedía el préstamo por un valor de hasta el 100 por 100 del inmueble, otras entidades sólo constituían este crédito por el 70 por 100 del valor del inmueble. Caixa Terrassa, como importe máximo a disponer, establecía el 90 por 100 del valor de la vivienda. Y el BBVA prestaba hasta el 80 por 100 del valor de tasación de la vivienda a futuro, es decir, incluyendo la revalorización prevista en los años que debería vivir el cliente.
} 
En el momento del otorgamiento de la escritura de constitución de hipoteca inversa ${ }^{319}$, la entidad acreedora deberá aportar la correspondiente tasación, que deberá ser incorporada, en original o por testimonios, a la escritura matriz ${ }^{320}$. En todo caso, el valor de tasación formará parte del contenido contractual de la escritura de hipoteca y, por tanto, tendrá que ser aceptado, de forma expresa, por la parte deudora.

Las sociedades de tasación y los servicios de tasación de las entidades de crédito, tal como se refleja en el artículo 3 de la Ley 2/1981, de 25 de marzo, de Regulación del Mercado Hipotecario ${ }^{321}$, en su nueva redacción, estarán sometidos a los requisitos de homologación previa, independencia y secreto que se establezcan reglamentariamente ${ }^{322}$.

Anteriormente se decía que debían aceptar cualquier tasación, cuando ahora se dice que están obligadas y, además se ha añadido el último párrafo

319 JIMÉNEZ CLAR, A.J., «La hipoteca... », op. cit., p. 121.

320 La Resolución de la DGRN de 30 de septiembre de 2014 (RJ\2014\5504) señala que en el caso de novación y ampliación de préstamo hipotecario constando en la escritura original de constitución el precio de tasación de la finca no será necesario nueva certificación de tasación de la finca ni su actualización en ningún caso, atendiendo a la expresión literal y el contexto legal referidos únicamente a la «escritura de constitución de hipoteca».

${ }^{321}$ Conforme al artículo tercero bis I) de la Ley 2/1981, de la LMH, modificado por la Ley 1/2013: «Las entidades de crédito, incluso aquellas que dispongan de servicios propios de tasación, estarán obligadas a aceptar cualquier tasación de un bien aportada por el cliente, siempre que, sea certificada por un tasador homologado de conformidad con lo previsto en la presente Ley y no esté caducada según lo dispuesto legalmente, y ello, sin perjuicio de que la entidad de crédito pueda realizar las comprobaciones que estime pertinentes, de las que en ningún caso podrá repercutir su coste al cliente que aporte la certificación. El incumplimiento de esta obligación se entenderá en todo caso como infracción grave o muy grave de la entidad de crédito en los términos de los artículos 5.d) o 4.e), respectivamente, de la Ley 26/1988, de 29 de julio, de Disciplina e intervención de las Entidades de Crédito, respectivamente».

${ }^{322}$ Con la entrada en vigor de la Ley 1/2013 se endurecen las exigencias de independencia para las sociedades de tasación con diversas medidas y se refuerza la obligación de las entidades financieras de aceptar la entregada por el cliente.

La Ley reduce de un $25 \%$ a un $10 \%$ el límite de su relación de negocio con un mismo grupo de entidades de crédito que tenga en circulación títulos hipotecarios, a partir del cual se les impone determinados mecanismos de control recogidos en el artículo 3.

Se las somete a una auditoría de cuentas anual.

Se considera infracción grave el no tener el capital social mínimo exigible durante tres meses o no tener en regla el seguro de responsabilidad civil. Antes eran seis meses.

Se permite al Consejo de Consumidores y Usuarios solicitar al Banco de España la incoación de un procedimiento sancionador.

Se considerará infracción grave o muy grave de una entidad de crédito no aceptar cualquier tasación de un bien aportada por el cliente, siempre que, sea certificada por un tasador homologado.

Queda prohibida la adquisición o mantenimiento por parte de las entidades de crédito, de forma directa o indirecta, de una participación significativa en una sociedad de tasación.

También lo tienen prohibido todas aquellas personas físicas o jurídicas relacionadas con la comercialización, propiedad, explotación o financiación de bienes tasados por la misma.

La Disposición Transitoria $3 .^{a}$ da un plazo de un año para adecuar el máximo de participaciones a los nuevos límites. 
en que se califica de infracción grave o muy grave de una entidad de crédito no aceptar cualquier tasación de un bien presentada por el cliente, siempre que sea certificada por un tasador homologado.

Por tanto, la aportación del certificado de tasación es un requisito fundamental $^{323}$ para la constitución de la hipoteca inversa, exigido en la misma Disposición Adicional $1 .^{\mathrm{a}}$. La razón de que la vivienda, objeto de hipoteca inversa, sea tasada ${ }^{324}$, se debe a la necesidad de calcular el importe de esta vivienda de forma contrastada para poder llevar a cabo esta operación financiera atendiendo al valor del bien, resultante de la tasación, y prevenir así el riesgo de tener un patrimonio negativo al vencimiento.

Tal y como queda reflejado en el Preámbulo de la Ley 41/2007 (VIII) cuando define la hipoteca inversa: «como un préstamo o crédito hipotecario del que el propietario de la vivienda realiza disposiciones normalmente periódicas, aunque la disposición pueda ser de una sola vez, hasta un importe máximo determinado por un porcentaje del valor de tasación en el momento de la constitución».

De manera que, para que la hipoteca inversa obtenga plena validez, previamente se habrá tenido que realizar la tasación del bien inmueble ${ }^{325}$ objeto de la misma.

\footnotetext{
323 JIMÉNEZ CLAR, A.J., «La hipoteca...», op. cit., p. 121, señala que la tasación para la válida constitución de la hipoteca inversa es un requisito primordial. Ahora bien, en esta modalidad de hipoteca no es de aplicación directa la normativa contenida en la Ley 2/1981 sobre la proporción mínima exigida entre el valor del inmueble y el capital del préstamo. Es decir, la tasación a que se refiere la DA 1. ${ }^{a}$ no impone la ratio del $60 \%$ del valor como límite del capital concedido regulado en el artículo 5 de la Ley 2/1981.

${ }^{324}$ Sin embargo, en EEUU no se establecen unos límites similares a los que aquí apuntamos, sino que el límite máximo del préstamo se calcula sobre el previsible valor de tasación de la vivienda en el momento previsible de vencimiento del crédito, atendidas las expectativas de vida del deudor. $Y$ en la línea de crédito, el límite máximo disponible va aumentando cada año un pequeño porcentaje de acuerdo con este previsible incremento del valor de la vivienda. En este sentido vid. SAWYER, C.H.: «Reverse mortgage: an Innovative Tool for Elder Law Attorneys», p. 628; REILLY, J., «Reverse mortgages: backing into the future», Elder Law Review, 1997, p. 47.

${ }^{325}$ En este aspecto, la Resolución de la DGRN de 31 de marzo de 2014 (TOL4.234.476) señala que: «El certificado de tasación exigido por los arts. 682.2. $1^{\circ}$ LEC y 129.2.a LH ha de ser necesariamente emitido por entidad homologada conforme a la Ley $2 / 1981$, de regulación del mercado hipotecario, en relación con los RRDD 775/1997 y 716/2009. En consecuencia, no es válido el certificado emitido por un ingeniero técnico agrícola.

La citada Ley $1 / 2013$, de 14 de mayo, impone, para toda hipoteca ya se destine o no a servir de cobertura a una emisión de títulos hipotecarios, como requisito legal para poder ejercitar la acción real hipotecaria por la vía del procedimiento de ejecución directa o de la venta extrajudicial, la doble condición de que la finca haya sido previamente tasada conforme a la Ley reguladora del mercado hipotecario y que el valor de tasación a los efectos de la subasta no sea inferior al setenta y cinco por ciento de la realizada conforme a la citada legislación. A tal fin, su artículo 7 da nueva redacción al artículo 682.2, número 1, de la Ley de Enjuiciamiento Civil, y en el mismo sentido se modifica el
} 


\subsection{La vivienda debe ser un bien inmueble enajenable}

Como sucede con la hipoteca ordinaria, en esta modalidad, la vivienda también será un bien inmueble enajenable. Tal y como se indica en el artículo 1874 del $\mathrm{CC}^{326}$. Por tanto, no serán objeto de hipoteca inversa los bienes que están fuera del comercio de los hombres y aquellos a que afecte una prohibición de disponer que tenga un plazo superior al de vencimiento de la hipoteca ${ }^{327}$.

\subsection{Vivienda totalmente pagada}

Aunque no se recoja como requisito en el texto de la Ley $41 / 2007$, de 7 de diciembre, también se exige que la vivienda haya sido pagada por completo o que quede solamente un pequeño saldo.

Lógicamente, si la vivienda, con anterioridad a la constitución de una hipoteca inversa, está hipotecada, para optar a esta modalidad se tendrá que realizar un desembolso para liquidar el capital pendiente del préstamo y cancelar esa hipoteca, circunstancia que tendrá como resultado que las prestaciones que vaya a recibir el deudor en la hipoteca inversa sean menores.

De ese modo, la hipoteca inversa se utilizará en los casos en los que la vivienda esté pagada, o al menos en su mayor parte, y se tenga necesidad de dinero. La vivienda tendrá que estar libre de cargas y gravámenes.

artículo 129 de la Ley Hipotecaria en la forma anteriormente expresada. Pero es que además, conforme se ha fundamentado, esta normativa es aplicable con independencia de los sujetos y de la naturaleza del bien hipotecado y el certificado debe ser expedido por las entidades homologadas conforme la regulación de la Ley 2/1981 en relación con los términos del Real Decreto 775/1997 y del Real Decreto 716/2009».

${ }^{326}$ Artículo 1874 del CC: «Sólo podrán ser objeto del contrato de hipoteca:

$1 .^{\circ}$ Los bienes inmuebles.

2. ${ }^{\circ}$ Los derechos reales enajenables con arreglo a las leyes, impuestos sobre bienes de aquella clase».

327 Vid. los artículos 1858 del CC y 106.2 de la LH. 
En el supuesto de que se quiera optar a la hipoteca inversa y la vivienda objeto de la misma se encuentre alquilada ${ }^{328}$, no podrá constituirse esta hipoteca hasta que no finalice el contrato de arrendamiento. La justificación es que si esta vivienda ha de ser la habitual del solicitante hipotecario, no tiene ningún sentido que se encuentre alquilada a un tercero.

\subsection{Ubicación del inmueble}

Antes de la regulación de la hipoteca inversa, algunas entidades financieras exigían que la vivienda estuviera ubicada en una población con un mercado inmobiliario rentable, requisito que suponía un obstáculo para personas que no tuvieran su vivienda habitual en determinados núcleos urbanos. Afortunadamente, esta exigencia no se contempló en esta Ley por la que se regula la hipoteca inversa.

\section{REQUISITOS FORMALES}

Los requisitos formales ${ }^{329}$ en la hipoteca inversa serán los recogidos en el artículo 145 de la LH. De esta manera, para la validez de estas hipotecas voluntarias será necesario:

- Que se hayan constituido en escritura pública.

- Que la escritura se haya inscrito en el Registro de la Propiedad.

Además, tal y como se indica en el artículo 1875 del CC, para que la hipoteca quede válidamente constituida, el documento en el que se constituya deberá inscribirse en el Registro de la Propiedad. Por tanto, serán

\footnotetext{
328 LUQUE JIMÉNEZ, M.C., «Una nueva modalidad...», op. cit., p. 227.

329 Vid. Puig Brutau, J., Compendio de Derecho Civil, Volumen III, op. cit., pp. 432 y 433.
} 
los requisitos típicos ${ }^{330}$ de toda hipoteca convencional, es decir, escritura pública e inscripción en el Registro de la Propiedad.

Respecto al requisito de escritura pública se regula en el artículo 3 de la LH en el que se consagra el principio de titulación pública.

En cuanto al requisito de inscripción ${ }^{331}$, éste viene regulado en el artículo 1 de la LH. Dicha inscripción se hará en el Registro en cuya circunscripción radique el inmueble.

\section{Régimen de transparencia y asesoramiento}

El régimen de transparencia y comercialización de la hipoteca inversa se regula en los apartados 3 y 4 de la Disposición Adicional Primera de la Ley $41 / 2007$.

Con la regulación de la hipoteca inversa se pretende que la persona que quiera contratarla cuente con toda la información que necesite para tomar decisiones acertadas sobre este producto, así como tener en consideración otras alternativas que puedan resultarle más económicas y beneficiosas. Se hace necesario recordar que la modalidad de la hipoteca inversa está dirigida a un público especialmente vulnerable ${ }^{332}$ (personas mayores, afectadas de dependencia, o personas a las que se les haya reconocido un grado de discapacidad igual o superior al 33 por ciento) y por este motivo se necesita facilitar una información veraz.

\footnotetext{
${ }^{330}$ Vid. Auto de 13 de marzo de 2013 de la AP de Madrid (AC 2013\1063), correspondiente a la necesidad de que el titular del crédito inscriba o no en el Registro de la Propiedad la cesión para poder acudir a la vía del procedimiento del artículo 131 de la LH (ejecución hipotecaria).

${ }^{331}$ La constitución de una hipoteca inversa deberá cumplir con las exigencias de nuestra normativa registral para poder inscribirse en el Registro de la Propiedad, máxime cuando la inscripción de la hipoteca es constitutiva en nuestro Derecho. En este sentido, la DGRN se pronuncia en numerosas resoluciones sobre préstamos hipotecarios concedidos por la entidad mercantil irlandesa Seniors Money (Spain) Finance Limited a residentes en España, como por ejemplo, la de 22 de febrero de 2008 (RJ 2008\2790), de 15 de marzo de 2008 (RJ 20081807), de 19 de marzo de 2008 (RJ 200811483), de 25 de marzo de 2008 (RJ 200818277), de 27 de marzo de 2008 (RJ 200818278), de 14 de mayo de 2008 (RJ 200818279) o la de 16 de mayo de 2008 (RJ 200813154).

332 Vid. la SAP de Salamanca de 11 de octubre de 2012 (TOL2.686.612).
} 
En el apartado 3 de la DA $1 .^{a}$ de la Ley $41 / 2007$ se específica que: «El régimen de transparencia y comercialización de la hipoteca inversa será el establecido por el Ministerio de Economía y Hacienda».

En el apartado 4 de la misma Disposición se establece lo siguiente: «En el marco del régimen de transparencia y protección de la clientela, las entidades establecidas en el apartado 2 que concedan hipotecas inversas deberán suministrar servicios de asesoramiento independiente a los solicitantes de este producto, teniendo en cuenta la situación financiera del solicitante y los riesgos económicos derivados de la suscripción de este producto.

Dicho asesoramiento independiente deberá llevarse a cabo a través de los mecanismos que determine el Ministro de Economía y Hacienda.

El Ministro de Economía y Hacienda establecerá las condiciones, forma y requisitos para la realización de esas funciones de asesoramiento».

En la actualidad, se estará a lo que disponga el Ministerio de Economía y Competitividad.

Se observa en este apartado 4 la obligación de las entidades de crédito, entidades aseguradoras y empresas de servicios de inversión de disponer de un departamento o servicio de atención al cliente encargado de atender y resolver las quejas y reclamaciones ${ }^{333}$ que planteen los usuarios de servicios financieros. Aun así, no es obligatorio que estas entidades cuenten con un defensor individual, sino que se admite que varias se agrupen por ramas de actividad, proximidad geográfica, volumen de negocio u otro criterio ${ }^{334} \mathrm{y}$ cuenten con un único defensor del cliente para todas ellas.

Tal como se refleja en el Preámbulo de la Disposición Adicional 1. a en su punto IV, se abordan en él los tres ámbitos de actuación de las entidades de tasación bajo el principio básico de mantener y reforzar la independencia de las mismas. Se concreta el propio fomento de la independencia de las entidades de tasación.

\footnotetext{
333 En el caso de que la resolución del defensor del cliente resultara favorable a la reclamación del usuario, ésta vincularía a la entidad. Ahora bien, con esto no se impide acudir a la tutela jurisdiccional u otros mecanismos de solución de conflictos, como por ejemplo el arbitraje.

${ }^{334}$ Vid. los criterios recogidos en el artículo 29 de la Ley 44/2002, de 22 de noviembre, de Medidas de Reforma Financiera.
} 
Se trata de lograr el establecimiento de un régimen de actuación de las sociedades de tasación que garantice su independencia y la ausencia de conflictos de interés respecto de las entidades de crédito que finalmente concedan los préstamos hipotecarios. A través de dos mecanismos:

- General, a través del reglamento interno de conducta al que pueden sumarse otros medios.

- Agravado, mediante una Comisión Técnica, encargada de verificar el cumplimiento de los requisitos de independencia establecidos por el citado reglamento y, en su caso, por otros mecanismos.

En cualquier caso, el defensor del cliente ${ }^{335}$ tendrá que ser una entidad o experto independiente de reconocido prestigio y deberá cumplir la normativa de transparencia y protección de la clientela así como también, las buenas prácticas y usos financieros.

Respecto al Régimen sancionador de estas entidades de tasación, se tipificaron nuevos supuestos de infracción derivados del nuevo Régimen de obligaciones, contenido en la Ley 41/2007, fruto de la experiencia adquirida en materia de ejercicio de la potestad sancionadora.

Además, en la Ley $1 / 2013$ se modificó la letra a) del punto 4 del artículo 3 bis quedando de la siguiente manera: «a) El Banco de España incoará

\footnotetext{
335 ZURITA MARTín, I., «La nueva normativa...», op. cit., pp. 1290 y 1291, puntualiza que la intervención del Defensor del Cliente no gustó a algunos grupos parlamentarios que formularon enmiendas a este apartado de la DA $1 .^{a}$. El Grupo Popular en el Congreso entendía que la remisión a esta figura para prestar este asesoramiento no era una solución válida, ya que esta figura estaba concebida para resolver reclamaciones de los clientes en caso de discrepancia o conflicto con la entidad, pero no para prestar asesoramiento sobre productos financieros concretos, para lo que normalmente no está cualificado, al no ser su función, debía ser el Ministro de Economía y Hacienda quien estableciese las condiciones, forma y requisitos para la realización de estas funciones de asesoramiento. De la misma opinión era el Grupo catalán. El Grupo de Izquierda Unida sostenía que la referencia al Defensor del Cliente como servicio de asesoramiento independiente era excesiva, al ser nombrado por la entidad financiera y pagado por ésta, por lo que era preferible que fuera el Ministerio de Economía y Hacienda el encargado de establecer los mecanismos de asesoramiento. En verdad, estos enmendantes tenían razón cuando sostenían que el Defensor del Cliente no parecía ser la institución más adecuada para solventar los problemas derivados en estos casos, especialmente por su vinculación con la entidad por la que ostentan poder de representación y por la función de resolución de conflictos que pudieran llegar a tener asignados, por tanto, situaciones que hacían difícil que se pudiera ofrecer un asesoramiento independiente y eficaz.
} 
obligatoriamente un procedimiento sancionador cuando exista una comunicación razonada de otro organismo o autoridad administrativa en la que se ponga de manifiesto que la prestación irregular de los servicios de tasación ha tenido repercusiones en su campo de actuación administrativa. Asimismo, el Consejo de Consumidores y Usuarios podrá solicitar al Banco de España la incoación de un procedimiento sancionador cuando, a su juicio, se ponga de manifiesto la prestación irregular de los servicios de tasación».

Con la aprobación de la Ley $1 / 2013$, se refuerza la independencia de las tasadoras $^{336}$ para evitar que existan conflictos de intereses por la relación o pertenencia al grupo financiero encargado de la tasación. Por ello, la Ley $41 / 2007$, de 7 de diciembre, obliga a que se elabore un reglamento interno que recoja las incompatibilidades entre los directivos y administradores de las empresas tasadoras ${ }^{337}$.

Asimismo, las entidades financieras que cuenten con servicios de tasación ${ }^{338}$ deberán crear una comisión técnica que controle estas operaciones $^{339}$. La regulación que se da a la protección de estos clientes viene dada por el interés del legislador en dar la mayor transparencia posible a la comercialización ${ }^{340}$ de la hipoteca inversa.

Para ZURITA MARTíN ${ }^{341}$, aunque esta transparencia en la contratación debía haber quedado suficientemente garantizada por la propia Ley 41/2007 y por las normas generales de protección de los consumidores y usuarios, la

\footnotetext{
${ }^{336}$ En la Disposición Adicional Segunda de la Ley 1/2013, correspondiente al Informe del Banco de España sobre la independencia de las sociedades de tasación, se propuso que: «En el plazo de tres meses desde la aprobación de esta Ley, el Banco de España remitirá al Gobierno un informe en el que se analicen las posibles medidas a impulsar para, en aras de garantizar la estabilidad financiera y el correcto funcionamiento del mercado hipotecario, se fortalezca la independencia en el ejercicio de la actividad de las sociedades de tasación y la calidad de sus valoraciones de bienes inmuebles».

337 Nueva redacción del artículo 3.2 de la Ley $2 / 1981$, de 25 de marzo, de regulación del mercado hipotecario.

${ }^{338}$ Esto se analizará con más detalle en el apartado dedicado a la Tasación de la Vivienda.

339 Artículo 3.3 de la Ley $2 / 1981$, tras su nueva redacción.

340 Vid. SJPI de Benidorm (Provincia de Alicante) de 31 de marzo de 2015 (JUR\2015\103742).

341 TAfFIN, C., «La hipoteca inversa o vitalicia», op. cit., pp. 4 y 5 . Este autor narra que la complejidad de este producto, dirigido especialmente a las personas mayores, en algunos casos muy vulnerables, dio lugar en Estados Unidos a prácticas dudosas por parte de los prestamistas, interesados claramente en la utilización de las sumas de dinero prestadas. Por ello, actualmente, la concesión de préstamos por el Estado Federal está sujeta a evaluación por parte de un experto externo antes de que el contrato sea firmado. El propósito de esta intervención es explicar las características del producto y los riesgos asociados, además de la existencia de otras alternativas para la persona mayor. En el caso de Reino Unido, los principales prestamistas han establecido voluntariamente un Código de Buena Práctica, bajo el cual asumen cuatro obligaciones: transparencia en los temas legales del préstamo, transparencia en costes, asistencia al prestatario a través de un experto externo independiente a la entidad financiera y el establecimiento de un límite al capital prestado hasta el valor de la propiedad.
} 
especial vulnerabilidad del colectivo al que va dirigida esta figura hace que no resulte desproporcionada esta singular atención a la protección de sus derechos. La hipoteca inversa, por su finalidad y por las características de la parte deudora (público muy vulnerable), requiere de la atención de las administraciones públicas para poder comercializar correctamente este producto financiero, pues en algunas ocasiones éste podrá traer resultados irreversibles. Por tanto, la constitución de esta hipoteca acarrea tanto consecuencias jurídicas como económicas, de ahí, la importancia de la información ${ }^{342}$ sobre el mismo.

La estructura ${ }^{343}$ de este régimen de transparencia en la información se divide en dos fases:

La primera, referente a la publicitación y marketing de la comercialización de la hipoteca inversa. Se delimitará la intervención de determinados intermediarios financieros, sobre todo, cuando éstos se hallen económicamente relacionados con el destino de los fondos que se pretenda obtener.

La segunda, relativa a un asesoramiento personalizado efectuado por la correspondiente entidad financiera o aseguradora ajustándose a las circunstancias del deudor solicitante. Este asesoramiento será de naturaleza técnica y las conclusiones tendrán que estar fundamentadas en las cláusulas jurídicas y económicas que puedan afectar, en cada caso concreto a la viabilidad $^{344}$ de la operación y en los posibles riesgos que de ella se puedan derivar.

\footnotetext{
${ }^{342}$ En este aspecto, vid., entre otras, la Sentencia del TS de 9 de mayo de 2013 (RJ 2013\3088) o la Sentencia de la AP de Tarragona de 4 de diciembre de 2014 (JUR\2015\57141).

343 JIMÉNEZ CLAR, A.J., «La hipoteca...», op. cit., p. 123.

344 En la Sentencia de 8 de abril de 2013 del JPI de Madrid (AC 20131963) se aprecia el incumplimiento por la entidad financiera de su obligación de información a la clienta contratante e infracción de la normativa vigente: ausencia de práctica del imprescindible test de idoneidad: consentimiento prestado por la inversora minorista viciado de error esencial y excusable. Además, la propia comercial admite su total desconocimiento sobre la clienta, no sabía que era viuda, desconocía su profesión y, por tanto su nivel cultural, ni que tenía contratada una de las llamadas hipotecas inversas. Es decir todo lo relativo a sus conocimientos y experiencia, su situación financiera y sus objetivos de inversión, ello sin contar con su edad, 80 años en la fecha de la contratación.
} 
Junto a la transparencia de este asesoramiento se ha de hacer referencia al coste económico ${ }^{345}$ que aquél supone para el solicitante. Con respecto a esta cuestión, sería contradictorio que la Ley $41 / 2007$, después de establecer una serie de exenciones y bonificaciones notariales, registrales y fiscales para la constitución de la hipoteca inversa, incrementara su coste como consecuencia de este asesoramiento, tanto interno como externo. Se tendrán que establecer los mecanismos oportunos, tanto por la Administración Pública como por las consultoras externas que puedan llevar a cabo estos servicios, para fijar un coste mínimo a los solicitantes de esta información.

Este asesoramiento deberá constar necesariamente por escrito, expresando las diferentes modalidades (temporal o vitalicia) para la disposición del capital solicitado, tipo y forma de interés, comisiones y gastos adicionales. Además, también se reflejarán otras alternativas a la hipoteca inversa, que de la misma manera, el solicitante podría utilizar para hacer frente a sus necesidades.

Junto a este servicio de asesoramiento previo, la intervención del notario en el momento del otorgamiento de la escritura de hipoteca será fundamental para verificar la capacidad de los otorgantes, así como también, para constatar que la información entendida por la parte deudora coincide con la información suministrada (bien por un asesor independiente, bien por una entidad financiera).

En la Ley 1/2013 se introduce un nuevo artículo, concretamente, el artículo 6 sobre Fortalecimiento de la protección del deudor hipotecario en la comercialización de los préstamos hipotecarios ${ }^{346}$. Una vez más, sólo se hace

\footnotetext{
${ }^{345}$ El silencio de la Ley 41/2007 a la hora de especificar si el futuro servicio de asesoramiento sería gratuito o no fue objeto de debate por varios autores. Unos apostaban por la gratuidad pues, de otra forma, de nada serviría haber reducido los costes arancelarios de notarios y registradores. Entre éstos, Jiménez Clar, A.J., «La hipoteca...», op. cit., p. 124 y Romero CANDAU, P.A., «La hipoteca...», op. cit., p. 318.

346 Lo cito textualmente: «1. En la contratación de préstamos hipotecarios a los que se refiere el apartado siguiente se exigirá que la escritura pública incluya, junto a la firma del cliente, una expresión manuscrita, en los términos que determine el Banco de España, por la que el prestatario manifieste que ha sido adecuadamente advertido de los posibles riesgos derivados del contrato.

2. Los contratos que requerirán la citada expresión manuscrita serán aquellos que se suscriban con un prestatario, persona física, en los que la hipoteca recaiga sobre una vivienda o cuya finalidad sea
} 
referencia a los préstamos hipotecarios, aunque por analogía también se debería aplicar a los créditos hipotecarios ${ }^{347}$. Se ha de destacar que este texto manuscrito tendrá que recogerse en la matriz de estas escrituras que podrán recaer sobre una vivienda, terrenos, etc., y no sólo sobre la vivienda habitual.

Si nos fijamos en el punto 2.a), de manera indirecta, la Ley $1 / 2013$ permite las cláusulas suelo y techo, incluso cuando tengan recorrido asimétrico, tal como sucede en la práctica. En este caso, resulta polémico determinar si la constancia en la copia del cumplimiento de este requisito es o no calificable por el registrador.

En principio, este deber sería exclusivo del notario, cuya omisión le podría hacer incurrir en responsabilidad pero no tendría por qué afectar a la inscripción del título, pues la existencia de este texto manuscrito necesariamente no tiene que ir plasmada en los asientos registrales. Además, el legislador no se ha manifestado sobre las consecuencias de la no inscribibilidad de este texto manuscrito, de manera que, de esta ausencia no puede derivarse la nulidad o anulabilidad de la cláusula suelo ${ }^{348}$.

El punto de partida de esta normativa en materia de transparencia lo constituye la Ley 26/1988, de 29 de julio, de Disciplina e Intervención de las entidades de crédito. Con la entrada en vigor de la Ley 41/2007, esta Ley 26/1988 sufrió dos modificaciones que se regularon en el Capítulo I de la Ley

adquirir o conservar derechos de propiedad sobre terrenos o edificios construidos o por construir, en los que concurra alguna de las siguientes circunstancias:

a) que se estipulen limitaciones a la variabilidad del tipo de interés, del tipo de las cláusulas suelo y techo, en los cuales el límite de variabilidad a la baja sea inferior al límite de variabilidad al alza;

b) que lleven asociada la contratación de un instrumento de cobertura del riesgo de tipo de interés, o bien;

C) que se concedan en una o varias divisas».

347 Vid. SAP de Cáceres de 7 de julio de 2014 (TOL4.463.250).

348 Mientras este tema no se aclare por la DGRN o por los Tribunales, atendiendo a la doctrina de la Sentencia del Tribunal Supremo de 9 de mayo de 2013 (RJ 2013\3088), sobre cláusulas suelo, que declaró abusivas -y, en consecuencia nulas- las estudiadas en el caso concreto, por una información indebida al consumidor, atendiendo a razones de prudencia -ante la eventualidad de posibles futuras impugnaciones- podría considerarse defendible el control registral de la existencia de tal reseña, pudiendo provocar su ausencia la no constancia registral de la cláusula concreta, si los interesados aceptan la inscripción parcial. De seguirse este criterio, valdría con una manifestación notarial de la existencia de esa expresión manuscrita con el texto fijado por el Banco de España o, alternativamente, la incorporación a la copia del escrito. En este sentido, la DGRN en su Resolución de 5 de febrero de 2014 (RJ 2014\1178) se ha pronunciado entendiendo que el registrador ha de entrar en calificar si consta la expresión manuscrita cuando ésta es precisa. 
41/2007, cuyo título se refiere a la Transparencia en la Contratación de préstamos y créditos hipotecarios. Concretamente, se modificó el artículo 48, apartado 2, letra a) de la Ley 26/1988, que pasó a tener el siguiente texto:

«a) Establecer que los correspondientes contratos se formalicen por escrito y dictar las normas precisas para asegurar que los mismos reflejen de forma explícita y con la necesaria claridad los compromisos contraídos por las partes y los derechos de las mismas ante las eventualidades propias de cada clase de operación, en especial, las cuestiones referidas a la transparencia de las condiciones financieras de los créditos o préstamos hipotecarios. A tal efecto, podrá determinar las cuestiones o eventualidades que los contratos referentes a operaciones financieras típicas con su clientela habrán de tratar o prever de forma expresa, exigir el establecimiento por las entidades de modelos para ellos e imponer alguna modalidad de control administrativo sobre dichos modelos. La información relativa a la transparencia de los créditos o préstamos hipotecarios, siempre que la hipoteca recaiga sobre una vivienda, se suministrará con independencia de la cuantía de los mismos».

$\mathrm{Y}$, además, se introdujo una nueva letra h), en el apartado 2 del artículo 48.2 de la Ley 26/1988, de 29 de julio, sobre Disciplina e Intervención de las Entidades de Crédito, con el siguiente tenor literal:

«h) Determinar la información mínima que las entidades de crédito deberán facilitar a sus clientes con antelación razonable a que estos asuman cualquier obligación contractual con la entidad o acepten cualquier contrato u oferta de contrato, así como las operaciones o contratos bancarios en que tal información pre-contractual será exigible. Dicha información tendrá por objeto permitir al cliente conocer las características esenciales de los productos propuestos y evaluar si estos se ajustan a sus necesidades y, cuando pueda verse afectada, a su situación financiera».

Con estas modificaciones se quería conseguir la máxima transparencia en las relaciones comerciales entre los clientes y las entidades financieras. Desde entonces y hasta ahora se han ido sucediendo una serie de normas de carácter reglamentario, que han guiado la práctica bancaria ${ }^{349}$.

\footnotetext{
${ }^{349}$ Entre otras, cabría citar:

La Orden Ministerial de 12 de diciembre de 1989, sobre tipos de interés y comisiones, normas de actuación, información a clientes y publicidad de las entidades de crédito.

La Orden Ministerial de 5 de mayo de 1994 sobre transparencia de las condiciones financieras de los préstamos hipotecarios concedidos a personas físicas.

La Ley 7/1995 de crédito al consumo derogada por la Ley 16/2011, de 24 de junio, de contratos de crédito al consumo.
} 
En nuestro país, la regulación sobre protección de consumidores que contraten una hipoteca inversa, se recoge en la Orden EHA 2899/2011 de 28 de octubre, de transparencia y protección del cliente de servicios bancarios $^{350}$. Esta Orden tiene entre otros objetivos, tal como queda reflejado en su Preámbulo: «concentrar en un único texto la normativa básica de transparencia de modo que, de manera sistemática e ilustrativa, la propia codificación de la materia mejore por sí misma su claridad y accesibilidad para el ciudadano, superando la actual dispersión normativa».

Con la entrada en vigor de esta Orden Ministerial han quedado derogadas:

- La Orden de 12 de diciembre de 1989, sobre tipos de interés y comisiones, normas de actuación, información a clientes y publicidad de las entidades de crédito.

- La Orden de 5 de mayo de 1994 sobre transparencia de las condiciones financieras de los préstamos hipotecarios.

- La Orden PRE/1019/2003, de 24 de abril, sobre transparencia de los precios de los servicios bancarios prestados mediante cajeros automáticos.

- La Orden de 27 de octubre de 1962, por la que se regula provisionalmente la tramitación de los expedientes y asuntos en materia de banca oficial y privada y cajas de ahorro.

La Ley $41 / 2007$, de 7 de diciembre, de reforma del mercado hipotecario.

La Ley $2 / 2009$, de 31 de marzo que tiene como objeto la regulación de la contratación con consumidores de préstamos o créditos hipotecarios, cuando el concedente del préstamo no es una entidad de crédito, así como los servicios de intermediación.

La Orden EHA/1718/2010, de 11 de junio, de regulación y control de la publicidad de los servicios y productos bancarios.

La Orden EHA/1608/2010, de 14 de junio sobre transparencia de las condiciones y requisitos de información aplicables a los servicios de pago.

La Ley $2 / 2011$, de 4 de marzo, de Economía Sostenible.

350 Publicada en el BOE de 29 octubre de 2011, núm. 261. Además, en la Disposición Final quinta correspondiente a la entrada en vigor de la presente Ley, se indica que:

«1. Sin perjuicio de lo previsto en el apartado siguiente, la presente orden entrará en vigor a los seis meses de su publicación en el «Boletín Oficial del Estado».

2. Lo previsto en el capítulo II del título III, a excepción de la sección 3. ${ }^{a}$, entrará en vigor a los nueve meses de la publicación de esta orden en el «Boletín Oficial del Estado». Asimismo, la previsión a la que se refiere el apartado 4 del artículo 8 comenzará a aplicarse en 2014 sobre los servicios prestados el año anterior». 
Estas normas, hasta la entrada en vigor de la presente Orden EHA 2899/2011, es decir hasta abril de 2012, habían servido de base para la protección del cliente de las entidades de crédito. Esta Orden de 2011 resulta fundamental para la hipoteca inversa ${ }^{351}$ pues ha permitido desarrollar el régimen de transparencia, comercialización y asesoramiento independiente regulado en los apartados 3 y 4 de la DA $1 .^{a}$, donde se establecía que el Ministro de Economía y Hacienda era el competente para ello ${ }^{352}$.

De una parte, esta norma regula el contenido de las obligaciones de las entidades de crédito relativas al asesoramiento, información precontractual e información propiamente contractual, así como todo un sistema dedicado a valorar la solvencia del cliente y hacer eficaz el principio de préstamo responsable.

De otra, tal y como indica el Preámbulo de la Orden, aborda de forma específica el desarrollo de la normativa de transparencia en materia de condiciones financieras de los préstamos y créditos hipotecarios en sustitución de lo que disponía la OM de 5 de mayo de 1994.

Prueba de ello, es el artículo 21 de la Orden que dispone que las entidades de crédito deberán proporcionar a los clientes que soliciten cualquiera de estos servicios, información clara y suficiente sobre los préstamos que ofertan. Esta información, que será gratuita y tendrá carácter orientativo, se facilitará mediante la Ficha de Información Precontractual

\footnotetext{
351 Según la noticia publicada por El Mundo en fecha de 17 de enero de 2012, «La Audiencia Nacional rechaza investigar la presunta estafa de las hipotecas inversas», se daba a conocer la no admisión a trámite de la demanda presentada por la Asociación de Víctimas de Hipotecas Inversas extranjeras, contra diez entidades extranjeras por estafa, publicidad engañosa, falsedad documental y delitos contra la Hacienda Pública en la que se vieron afectados una veintena de ancianos que hipotecaron sus casas en la Costa del Sol, según el auto dictado el pasado 30 de diciembre. El Juzgado Central de Instrucción número 4 de la Audiencia Nacional ha desestimado la querella, al concluir que no se ha aportado "el mínimo argumento indiciario" y que el Juzgado "carece de competencia para investigar los hechos". En concreto, la querella iba dirigida contra las entidades Danske Bank, Nordea Bank, N M Rothschild and Sons, Lex Life 6 Pension, Landsbanki, Jyske Bank, Finansbanken, Nykredit, Sydbank y Swiss Life.

${ }^{352}$ En este sentido, la STS de 16 de diciembre de 2009 (RJ 2010 702 ) versa "in genere" sobre materia relativa a la protección de consumidores y usuarios en la perspectiva de las cláusulas-tipo previstas para diversos contratos celebrados entre Bancos y Cajas de Ahorro y los clientes usuarios de sus servicios, relativos a préstamos, de ahorro, depósitos en cuenta corriente, de crédito, de tarjeta de crédito y débito; habiéndose suscitado la declaración de nulidad por el carácter abusivo en virtud del ejercicio por una Organización de Consumidores y Usuarios de una acción de carácter colectivo, de cesación, con fundamento en la normativa legal de las Leyes 7/1.998, de 13 de abril, de Condiciones Generales de la Contratación y 26/1.984, de 19 de julio, General para la Defensa de los Consumidores y Usuarios.
} 
(FIPRE). Esta Ficha estará a disposición de los clientes de préstamos, de forma gratuita, en todos los canales de comercialización utilizados por la entidad.

Además, conforme se indica en el artículo 22 de la Orden $\mathrm{EHA} / 2899 / 2011$, una vez la entidad haya examinado la situación financiera del cliente, sus necesidades de financiación, así como sus preferencias, elaborará de forma también gratuita, un segundo documento que recibe el nombre de Ficha de Información Personalizada (FIPER). En éste se hace constar de forma personalizada el producto que mejor se acomoda a las necesidades expuestas, de manera que el cliente tenga la oportunidad de comparar las distintas posibilidades existentes de préstamo o crédito hipotecario.

Dicha ficha ${ }^{353}$ podrá, en su momento, convertirse en el documento donde se haga constar la oferta de contrato que tiene carácter vinculante para la entidad, siempre y cuando dicha circunstancia quede reflejada en el contrato junto con el periodo de vigencia de la oferta (art. 23 de la Orden EHA 2899/2011).

Respecto a la modalidad de hipoteca inversa, ésta se encuentra regulada en el artículo 32 donde se estipula lo siguiente:

«Esta orden se aplicará a las hipotecas inversas comercializadas en España conforme a lo previsto en la disposición adicional primera de la Ley 41/2007, de 7 de diciembre, por la que se modifica la Ley $2 / 1981$, de 25 de marzo, de Regulación del Mercado Hipotecario y otras normas del sistema hipotecario y financiero, de regulación de las hipotecas inversas y el seguro de dependencia y por la que se establece determinada norma tributaria, con las siguientes especificidades:

a) Será obligatoria la entrega de la oferta vinculante a la que se refiere el artículo 23.

b) Será obligatoria la prestación, a más tardar con motivo de la entrega de la oferta vinculante, de un servicio de asesoramiento independiente y previo en los términos previstos en el artículo 10.

c) Las fichas a las que se refieren los artículos 21 y 22 se ajustarán a lo previsto en el anexo III y IV y, adicionalmente, el Banco de España y la Dirección General de Seguros y

353 En el Anexo I y II de la Orden se recogen los ejemplares de dichas fichas: Ficha de información precontractual (FIPRE) y Ficha de información personalizada (FIPER), respectivamente. 
Fondos de Pensiones elaborarán conjuntamente una «Guía de Acceso a la Hipoteca Inversa» en términos adaptados y análogos a los previstos en el artículo 20 ».

De esta manera, quedarán fuera del ámbito de aplicación aquellos supuestos atípicos en los que la garantía recae sobre un inmueble que no constituye la vivienda habitual y también se encuentran excluidos aquellos contratos en los que el acreedor no sea una entidad de crédito. Por lo demás, este artículo matiza que, con carácter obligatorio, será necesario entregar la oferta vinculante y prestar asesoramiento independiente en los términos establecidos en el artículo 10 de la misma Orden.

El inconveniente que aquí nos volvemos a encontrar con esta Orden, es que el asesoramiento, conforme a lo dispuesto en este artículo, no es siempre gratuito: cuando las entidades de crédito y los clientes decidan suscribir un contrato de servicio bancario de asesoramiento deberán informar expresamente a los clientes de esta circunstancia y, salvo que el servicio sea gratuito y así se le haga saber al cliente, habrán de recibir una remuneración independiente por este concepto. El resultado será el cobro de un servicio que resulta de obligada prestación.

Tal y como se regula en el artículo 30 de la citada Orden, el notario está obligado a cerciorarse de que efectivamente se haya llevado a cabo el asesoramiento, y debe advertir al cliente de su situación en caso de que la formalización de la hipoteca inversa se realice en contra de la recomendación realizada por el asesor independiente.

Lo que sí ha previsto esta Orden que resulte gratuito es la entrega de los correspondientes ejemplares de la Ficha de Información Precontractual y la Ficha de Información Personalizada que, en lo concerniente a la hipoteca inversa, responden a modelos algo distintos del general, por lo que la Orden, en sus Anexos III y IV, recoge los modelos específicamente diseñados para esta figura, que de alguna manera puede reducir los costes de asesoramiento. 
Otro de los problemas que podemos encontrar es la regulación en materia de asesoramiento independiente ${ }^{354}$, cuando la información va a ser suministrada por la entidad de crédito. En cierto modo y para salvaguardar la protección del cliente, el artículo 10 prevé que la prestación de este servicio estará sometida al régimen de transparencia previsto en esta orden ministerial e implicará la obligación de las entidades de actuar en el mejor interés del cliente, basándose en un análisis objetivo y suficientemente amplio de los servicios bancarios disponibles en el mercado, y considerando tanto la situación personal y financiera del cliente, como sus preferencias y objetivos.

No obstante, el sistema de asesoramiento independiente adoptado finalmente resulta mejor que el que estaba previsto en el Proyecto de Ley de Reforma del Mercado Hipotecario. Pues en éste el servicio de asesoramiento se dejaba en manos del defensor del cliente de cada entidad, cuando en realidad la función inherente a esta figura no es tanto el asesoramiento como la resolución de conflictos que se planteen entre el cliente y la entidad ${ }^{355}$.

Para concluir, señalar que en nuestro país, tras la aprobación de la Ley 41/2007, siguiendo el sistema anglosajón ${ }^{356}$ de asesoramiento independiente por parte de entidad especializada, se creó en abril de 2009 la Asociación española de asesores independientes de hipoteca inversa. Siendo uno de sus miembros fundadores el grupo Óptima Mayores ${ }^{357}$ (perteneciente a Óptima Previsión) a través del cual se dirige gran parte de la actividad de intermediación entre los mayores y las entidades de crédito.

\footnotetext{
354 QUESADA SÁnCHEZ, A.J., «La Hipoteca Inversa: ¿una opción realmente atractiva?» Revista del Ministerio de Trabajo e Inmigración, (on line), № 81, Madrid, marzo 2008, p. 144. Con anterioridad a la aprobación de la Orden, ya se advertía de las posibles consecuencias que podría acarrear el hecho de que el asesoramiento independiente quedase en manos de las entidades. Cada entidad intentará ofrecer sus productos con lo que la independencia será, sin duda, algo relativa.

355 Toral LaRA, E., «Hipoteca Inversa...», op. cit., p. 1875; Quesada Sánchez, A.J., «La Hipoteca Inversa...», op. cit., p. 144.

${ }^{356}$ Sin embargo, un aspecto que diferencia nuestro ordenamiento del anglosajón es la existencia de un asesor natural como es el notario que comprueba que, efectivamente, el cliente entiende los extremos del contrato y que dicho contrato es acorde con la Ley. De hecho, en su momento, se planteó la posibilidad de que recayese sobre el notario la función de asesoramiento independiente y es que la imparcialidad e independencia que caracteriza a la función notarial hubiera satisfecho con creces el objetivo de la Ley. Con todo, hay que matizar que el notario está capacitado para prestar asesoramiento legal no financiero. Vid. Romero CANDAU, P.A., «La hipoteca...», op. cit., p. 318.

${ }^{357}$ Vid. página web: www.optimamayores.com.
} 


\section{OTROS REQUISITOS}

La especial estructura de la hipoteca inversa requiere el mantenimiento del valor de uso de la garantía o vivienda habitual, hasta el momento de su vencimiento.

\section{Conservación del inmueble}

Cuando se realiza una hipoteca inversa, la entidad acreedora pretende que en el momento en que fallezca el prestatario se produzca una revalorización del inmueble y de esta manera poder cobrar de esa vivienda, la cantidad prestada y sus intereses.

Aunque la Ley 41/2007 no lo prevea expresamente, el propietario deberá conservar el inmueble en buen estado. Si no lo hace, el acreedor podrá ejercitar ${ }^{358}$ la acción de deterioro o devastación prevista en el artículo 117 de la LH. En él se recoge que el propietario estará obligado, frente al acreedor, a conservar la finca hipotecada para que este último pueda mantener su valor económico y no vea peligrar la realización del bien hipotecado que se ha dado en garantía ${ }^{359}$.

Para poder ejercitar esta acción de devastación será preciso que se den los requisitos contenidos en el artículo 117 de la LH:

$1^{\circ}$. Que se produzca el deterioro de la finca hipotecada.

Que el deterioro de la finca suponga un menoscabo en la integridad de la misma, por tanto, se trataría de un perjuicio material. Al respecto, surgen

\footnotetext{
358 JIMÉNEZ CLAR, A.J., «La hipoteca...», op. cit., pp. 126 y 127, manifiesta que la acción de devastación permite al acreedor solicitar judicialmente la adopción de medidas necesarias cuando exista el temor fundado de daño por una disminución del valor de la cosa hipotecada que ocasione su insuficiencia como garantía.

359 Esto es consecuencia de que la hipoteca inmobiliaria no implica un desplazamiento posesorio, sino que el deudor sigue conservando la posesión del bien inmueble.
} 
dudas sobre si es posible que se ejercite la acción cuando aún no se ha producido el deterioro de la finca sino que se teme que se produzca, y también, sobre si cabe tan sólo el deterioro material y no el jurídico.

Sobre la primera de las cuestiones, la doctrina se ha pronunciado de manera diversa. Destaca la opinión de MORENO QUESADA ${ }^{360}$, que entiende que no puede ejercitarse esta acción si el deterioro aún no se ha producido. En cuanto al tipo de deterioro, se trataría de un desperfecto material, por lo que a juicio de este autor sólo cabe el deterioro económico y no el jurídico.

Sin embargo, con posterioridad se ha optado mayoritariamente por una interpretación extensiva en el sentido de que el deterioro al que se refiere el artículo 117 de la LH pueda ser tanto material como jurídico, a los efectos de poder ejercitar la acción en un mayor número de casos, pues lo que importa no es la materialidad de la cosa, sino la conservación de su valor ${ }^{361}$.

$2^{\circ}$. Que la finca disminuya de valor.

Para poder ejercitar la acción de devastación se supondrá que la finca hipotecada ha sufrido una disminución del valor. Lo normal es que si la finca padece un deterioro, a la vez tenga una disminución de valor, por lo que ambos requisitos van unidos, siendo el segundo consecuencia del primero. No es necesario que el deterioro implique la insuficiencia de la hipoteca.

En este sentido, con carácter previo deberá nombrarse, de mutuo acuerdo, un perito que será el encargado de realizar la valoración del deterioro. Si la finca hipotecada se hubiera deteriorado en más de un 20 por 100 del valor de tasación, disminuyendo la garantía y con ello la seguridad del crédito, el acreedor podría ejercitar la acción de devastación.

\footnotetext{
360 Vid. Moreno QueSADA, B., «Comentario del artículo 117 de la LH», en Comentarios al Código Civil y Compilaciones Forales, tomo VII, vol. 6º, artículos 104 a 130 de la Ley Hipotecaria, VV.AA., dir. por Manuel Albaladejo y Silvia Díaz ALABART, EDERSA, Madrid, 2000, pp. 329 y ss.

361 ANGUITA Ríos, R.M., «Algunas reflexiones sobre la acción de devastación», en Libro Homenaje al profesor Manuel Albaladejo García, I, VV.AA., coord., por J.M. GonZÁlez PoRRAS y F.P. MÉndeZ GonZÁleZ, Colegio de Registradores de la Propiedad y Mercantiles de España, Servicio de Publicaciones de la Universidad de Murcia, Murcia, 2004, p. 308.
} 
$3^{\circ}$. Que exista dolo, culpa o voluntad del dueño.

Se exige que se pueda imputar el daño al dueño de la finca hipotecada, es decir, que la finca disminuya de valor por «dolo, culpa o voluntad del dueño». Cabrá pues, tanto la acción como la omisión que lleve aparejada la disminución del valor de la finca hipotecada, ya sea de buena o de mala fe.

En el caso de que la finca se deteriore por un hecho no atribuible al propietario, por ejemplo una inundación, y posteriormente éste no realice reparaciones, también se le imputará al dueño el daño de la finca ${ }^{362}$. Por tanto, es preciso que exista voluntariedad del deudor excluyéndose el caso fortuito o la fuerza mayor, hechos de un tercero o las disminuciones de valor debidas a razones de mercado ${ }^{363}$.

Una situación especialmente compleja y delicada se puede producir en el caso de incapacidad del deudor, situación desgraciadamente muy posible a la vista del perfil subjetivo del deudor de esta hipoteca, que pueda dar lugar a un deficiente o incorrecto mantenimiento de la vivienda hipotecada, aminorando así, su garantía.

Las medidas tendentes a evitar dicha situación de insuficiencia quedan encomendadas a la prudencia judicial. Es evidente que una situación de deterioro progresivo de la parte deudora conducirá, por la propia persistencia de la situación, a la administración judicial que prevé el artículo 117 de la Ley Hipotecaria (en estos casos será preceptiva la intervención del Ministerio Fiscal).

$4^{\circ}$. Que haya temor fundado de que la garantía resulte insuficiente.

La acción de devastación podrá ejercitarse por el temor de que esa garantía hipotecaria resulte insuficiente. Este requisito se dará cuando queden acreditados los tres anteriores.

\footnotetext{
362 MoReno QuesadA, B., «Comentario del... », op. cit., p. 348.

${ }^{363}$ ANGUITA Ríos, R.M., «Algunas reflexiones... », op. cit., p. 305.
} 
La insuficiencia supone que si se procediese a la ejecución de la hipoteca, el precio de la cosa no cubriría el importe de la responsabilidad hipotecaria. En este sentido, se admite tanto el deterioro temido como el causado, pues la acción de devastación es una acción preventiva, de finalidad conservativa, no sólo reparadora, y su eficacia disminuiría o incluso desaparecería si hubiera que esperar para ejercitarla a que el deterioro estuviese consumado.

En cuanto a los efectos que produce el ejercicio de la acción de devastación, de acuerdo con el artículo 117 de la LH, en el caso de que exista un temor fundado de que resulte insuficiente la hipoteca, el juez dictará providencia ordenando que se adopten medidas para paliar la conducta devastadora del propietario.

Se trata de unas medidas muy amplias que pueden consistir tanto en conductas activas como omisivas, dependiendo del tipo de conducta que haya causado el daño. Además, puede suceder que el juez aplique todas las medidas que establece el artículo $219.2 \mathrm{del} \mathrm{RH}$, no sólo la ampliación de la hipoteca a otros bienes del deudor, sino también el vencimiento del crédito y la administración judicial, así como cualquier otra medida que estime pertinente ${ }^{364}$.

En cuanto a la posibilidad de ejercitar la acción de devastación por el acreedor de una hipoteca inversa, se ha considerado que sería plenamente posible su ejercicio en el caso de que el prestatario pretendiera disponer en vida del resto de su patrimonio, pues si éste vive más tiempo de lo previsto, para asegurar el cobro de los intereses devengados, el acreedor podrá exigir ampliación de la hipoteca sobre la misma finca hipotecada o sobre otros bienes inmuebles del prestatario, de acuerdo con lo previsto en el artículo 115 de la $\mathrm{LH}^{365}$.

\footnotetext{
364 Álvarez Álvarez, H., La hipoteca inversa..., op. cit., p. 91.

${ }^{365}$ Miquel Silvestre, J.A., «Hipoteca inversa...», op. cit., p. 1921.
} 
Sin embargo, en la práctica, en lugar de ejercitar la acción de devastación (para el caso del deterioro del bien hipotecado), se suelen introducir cláusulas de vencimiento anticipado del préstamo pues, en este caso, se produce de forma automática y de manera objetiva, con independencia de la existencia o no de culpabilidad del propietario.

\section{Seguros vinculados a la constitución de una hipoteca inversa}

La DA 4. ${ }^{a}$ de la Ley 41/2007 señala que: «las disposiciones periódicas que pueda obtener el beneficiario como consecuencia de la constitución de una hipoteca inversa podrán destinarse, total o parcialmente, a la contratación de un plan de previsión asegurado, en los términos y condiciones previstos».

A pesar de que la Ley 41/2007 guarde silencio al respecto, las entidades acreedoras obligan al solicitante de una hipoteca inversa a la contratación de estos productos ${ }^{366}$. Esto se debe a que la parte prestamista 0 entidad acreedora tiene que asumir una serie de riesgos, pues cuando concede el préstamo lo hace en función de ciertos cálculos: la esperanza de vida del deudor, las variaciones de los tipos de interés, las fluctuaciones del mercado inmobiliario, etc.

Estos riesgos implican que el coste de los préstamos que se concedan a través de las hipotecas inversas sea más elevado que el de los préstamos convencionales, teniendo además un tipo de interés más alto. Además, los costes se incrementarán cuanto mayor sea la edad del solicitante o cuantos más beneficiarios se hayan designado.

Estos seguros ${ }^{367}$ son los siguientes:

\footnotetext{
366 El importe de este seguro depende de la edad, el sexo y la esperanza de vida. A igual edad, las mujeres pagan más prima por el seguro que los hombres debido a su mayor media de esperanza de vida. Del mismo modo, su renta vitalicia mensual será algo menor que la del hombre.

${ }^{367}$ Cfr. Álvarez Álvarez, H., La hipoteca inversa..., op. cit., pp. 103 y 104.
} 


\subsection{Seguro de renta vitalicia}

A pesar de que la contratación de este seguro no era obligatoria, las entidades aseguradoras y demás entidades que ofertaban la hipoteca, aconsejaban que los solicitantes de este producto financiero se acogieran a este seguro, ofertado y comercializado por estas mismas entidades.

Al contratar este seguro, se garantiza que el titular o beneficiario de esta pensión hipotecaria perciba, mientras viva, una renta, aun habiendo superado el plazo establecido en la hipoteca. Así, en el caso de que el deudor o el beneficiario sobreviviera al momento en que se agotase la disponibilidad del crédito, una compañía de seguros le seguiría abonando los mismos ingresos mensuales hasta su fallecimiento.

En el supuesto que se contratara este seguro, y el titular del mismo falleciera antes del plazo del vencimiento fijado en el contrato de la hipoteca inversa, por ejemplo, a los cinco años de haber constituido la misma, cuando se había pensado para un plazo de veinte años (suponiendo que el deudor llegara a los ochenta y cinco años de vida), los herederos recibirían la parte proporcional de la prima que pagó en su día el titular. Esta parte la calcularía el banco en base a la renta recibida por el titular en el plazo estipulado.

En este mismo caso, si no se hubiere contratado este seguro, los herederos únicamente tendrían que hacer frente a la deuda contraída con el banco, en función del número de años que el titular se hubiera beneficiado de esta renta. En este supuesto, los herederos se ahorrarían, sin ninguna consecuencia negativa, el gasto más elevado que acarrea la hipoteca inversa.

Para estos casos y también en los que el deudor sobreviviera al plazo convenido en la hipoteca inversa celebrada con la correspondiente entidad acreedora, podríamos apreciar lo siguiente: 
En el supuesto de que una persona con sesenta y cinco años contratara una hipoteca por veinte años con un seguro de rentas y viviera hasta los noventa años, es decir, falleciera después del plazo de vencimiento, este seguro le permitiría seguir cobrando la misma renta mensual a partir de los ochenta y cinco años y seguir viviendo en la misma vivienda.

En cambio, si esa misma persona sobreviviera al plazo contratado en la hipoteca inversa y no hubiera contratado este seguro de rentas, al superar los ochenta y cinco años dejaría de percibir la renta convenida en dicha hipoteca. Este último caso vendría justificado por el gasto que supone la formalización de este seguro de rentas pues, éste, puede alcanzar el 6 por ciento del valor de tasación de la vivienda. Como caso práctico para una vivienda valorada en 100.000,00 euros el importe de este seguro ascendía a 6.000,00 euros. Esta cantidad supondría un gasto muy elevado para la parte deudora, pudiendo optar por no contratar este seguro.

\subsection{Seguro de renta temporal}

Con este seguro se garantiza el pago de los intereses sobre la totalidad del saldo dispuesto. La entidad de crédito se asegurará que, por un período de tiempo determinado, el pago de los intereses esté cubierto. Además, el beneficiario ${ }^{368}$ obtendrá un complemento más a su pensión.

\subsection{Seguro del hogar contra daños}

\footnotetext{
${ }^{368}$ Vid. con más detalle la Sentencia de la AP de Barcelona de 15 de octubre de 2014 (JUR\2015\42617). D. Laureano interpuso demanda de juicio ordinario en ejercicio de acción de resolución de contrato de seguro realizado con la compañía Catalana Occidente sociedad anónima de seguros y reaseguros en fecha 29 de septiembre de 2009 tratándose de un seguro de vida de renta diferida con una prima única de 10.857,97€. Indica que con anterioridad, el 10 de agosto de 2009, el Sr. Laureano junto con su esposa solicitaron una hipoteca inversa vitalicia con la misma demandada y al entregarse la copia de la oferta vinculante mostró su disconformidad con la contratación de la póliza de seguro de vida. Que indicaba que transcurridos 21 años el asegurado percibiría de la aseguradora una renta mensual de igual importe que la percibida hasta ese momento por la hipoteca. Indica finalmente que pretendió la resolución en los 30 días siguientes a la firma de la póliza tal y como prevé la misma sin que la aseguradora atendiera los requerimientos y sin que pudiera la demandada invocar la vinculación de los contratos.
} 
El seguro de daños aparece en el apartado 1.d) de la Disposición Adicional Primera. Su exigencia va dirigida a cubrir el riesgo derivado de la pérdida o deterioro del objeto de la garantía, la vivienda hipotecada.

De la misma manera que sucede con la tasación, el seguro contra daños es un requisito típico de la hipoteca inversa, es decir, para la configuración de la misma será condición indispensable que el inmueble esté asegurado contra incendios $u$ otras circunstancias ${ }^{369}$.

Este seguro se exigirá antes de la formalización ${ }^{370}$ de la hipoteca inversa. Se trata de un requisito previo, pues si no se contrata este seguro no se formalizará el crédito hipotecario. Con su contratación se pretende evitar las consecuencias negativas que se puedan dar a la entidad prestamista, en el caso de que, al fallecimiento del deudor, la deuda supere el valor de la vivienda hipotecada. De hecho, como se ha comentado más arriba, las entidades que venían ofertando hipotecas inversas en España, obligaban a los solicitantes a contratar un seguro con el fin de asegurar el cobro mensual de la renta vitalicia. Ahora bien, este seguro que garantizaba la amortización de la totalidad del préstamo, llevaba en contrapartida el encarecimiento del préstamo.

Su régimen legal será el establecido por la Ley 2/1981, de Regulación del Mercado Hipotecario ${ }^{371}$. El artículo 30 del Real Decreto 685/1982 $2^{372}$, que desarrolla determinados aspectos de dicha norma, establece que:

«1. Los bienes sobre los que se constituya la garantía hipotecaria deberán contar con un seguro contra daños adecuado a la naturaleza de los mismos, y en el que la suma asegurada coincida con el valor de tasación del bien asegurado.

2. El tomador del seguro notificará al asegurador la existencia del crédito que grave el bien asegurado, y éste dará traslado de aquella notificación al acreedor.

\footnotetext{
${ }^{369}$ Vid. Resolución de la DGRN de 22 de julio de 1996 (RJ 1996\5617).

${ }^{370}$ En este aspecto, destacar la STS de 2 de abril de 2014 (RJ 2014\2164) relativa a la impugnación por el registrador ante la jurisdicción civil de la decisión de la DGRN revocatoria de su calificación de autorizar la práctica del asiento denegado por él, por no haberse acreditado la constitución del seguro de daños en la construcción en relación a una obra nueva y división horizontal cuya escritura pública pretendía inscribirse.

${ }^{371}$ Publicada en el BOE, núm. 90, el día 15 de abril de 1981.

${ }^{372}$ BOE, núm. 83 de 7 de abril de 1982.
} 
3. En el caso de falta de pago de la prima por el tomador del seguro, el asegurador lo notificará al acreedor antes de que haya expirado el plazo de gracia del pago de la prima.

4. En caso de siniestro el tomador del seguro lo notificará al asegurador en los términos previstos en la póliza, y éste dará traslado de la notificación al acreedor».

De este modo la suma asegurada deberá coincidir con el valor de tasación del bien hipotecado, excluidos los elementos no asegurables por naturaleza. Además, el tomador del seguro deberá notificar a la compañía aseguradora la existencia del crédito hipotecario que grava el inmueble asegurado y aquélla dará traslado de la correspondiente notificación al acreedor.

La exigencia del seguro enlaza con la finalidad económica de la hipoteca inversa, de forma especial en los supuestos en los que se produzca un siniestro y, por ello, nazca el derecho a una indemnización. En estos casos podría surgir el conflicto a la hora de plantear el importe de la indemnización por razón del valor del inmueble y que éste, sólo alcanzase a cubrir el pago de la deuda pendiente.

Si se configura la pérdida o desaparición de la garantía como causa de vencimiento anticipado de la obligación garantizada, al amparo del artículo 1129 del Código Civil, el deudor hipotecario perderá el valor en uso que le proporcionaba la vivienda hipotecada. De esta forma, al transformarse el bien hipotecado en su equivalente económico, el deudor perderá el uso de su patrimonio al cubrir la necesidad que esta vivienda le proporcionaba. Por este motivo, se ha de excluir la posibilidad de vencimiento anticipado por la desaparición de la garantía y utilizar los procedimientos subrogatorios ${ }^{373}$ previstos por la norma.

\footnotetext{
${ }^{373}$ Entre otros procedimientos, cabría destacar la pignoración de las sumas entregadas en concepto de indemnización, de manera que sus réditos permitan pagar el uso en alquiler de una vivienda para el deudor hipotecario. Otra posibilidad, sería la reconstrucción del inmueble siniestrado bajo la supervisión de la entidad acreedora (art. 42 de la LCS). Por último, también sería factible la adquisición de una nueva vivienda con los fondos integrantes de la indemnización.
} 
Con el fin de evitar estos problemas, en la Ley 41/2007 se estableció la obligación del aseguramiento del inmueble hipotecado tanto en beneficio del acreedor como del deudor hipotecario. 



\section{CAPÍTULO V: LEGALIZACIÓN DE LA HIPOTECA INVERSA}

\section{CONSTITUCIÓN DE LA HIPOTECA INVERSA}

El artículo 105 de la LH establece que: «La hipoteca podrá constituirse en garantía de toda clase de obligaciones y no alterará la responsabilidad personal ilimitada del deudor que establece el artículo 1.911 del Código Civil».

Sin embargo, la hipoteca inversa con la entrada en vigor de la Ley $41 / 2007$, sólo podía constituirse para complementar la pensión o los ingresos de personas con 65 años o más o que estuviesen afectadas de dependencia o gran dependencia. Tras la entrada en vigor de la Ley 1/2013 se amplía a personas afectadas de dependencia o personas a las que se les haya reconocido un grado de discapacidad igual o superior al 33 por ciento.

La hipoteca ordinaria requiere de la existencia de dos elementos formales para su constitución (detallado anteriormente): escritura pública e inscripción en el Registro. La escritura pública sirve de título obligacional a la hipoteca, y la inscripción en el Registro es constitutiva. Si no hay inscripción estaríamos simplemente ante un préstamo ${ }^{374}$. Por ello, en consonancia con la constitución de la hipoteca ordinaria, en la inscripción registral de la hipoteca inversa, deberán constar necesariamente una serie de circunstancias ${ }^{375}$ :

a) La forma contractual utilizada: crédito o préstamo.

b) Las cantidades iniciales que van a ser adeudadas o entregadas con cargo a la deuda final.

c) La finalidad del contrato de obtener prestaciones periódicas o únicas.

d) Cuantía y plazos (forma) en que serán satisfechas las prestaciones periódicas.

\footnotetext{
${ }^{374}$ CHICO Y ORTIZ, J.M., Estudios sobre..., op. cit., pp. 1413 y ss.

${ }^{375}$ Así lo señalaron los Registradores en las conclusiones del Tercer Congreso de Registradores de España, celebrado en Granada en noviembre de 2006.
} 
e) El plazo de vencimiento del contrato o de exigibilidad de la obligación. Dicho plazo no podrá ser inferior a la fecha del fallecimiento del deudor o del último beneficiario, si se diera el caso.

f) La deuda sólo podrá ser exigible por el acreedor y la garantía sólo será ejecutable cuando fallezca el deudor o el último de los beneficiarios. En este último supuesto deberá expresarse la circunstancia en el contrato (apartado 1.c).

Por tanto, la hipoteca inversa se constituirá mediante escritura pública $^{376}$, que servirá de título obligacional a la hipoteca y será objeto de inscripción en el Registro de la Propiedad ${ }^{377}$. Así, la hipoteca inversa se realizará ante notario, bajo pena de nulidad, y este fedatario público deberá informar al deudor sobre las consecuencias patrimoniales y sucesorias que conllevará esta modalidad hipotecaria. En esta escritura, al igual que en las hipotecas ordinarias, se recogerán todos los derechos y todas las obligaciones del deudor, ya sean legales o pactadas.

De esta manera, el deudor, propietario de la vivienda hipotecada, asumirá, por ministerio de la ley, una serie de obligaciones y deberes derivados de su calidad de sujeto pasivo, con el fin de dotar de seguridad las expectativas del acreedor hipotecario, que en el caso de que a la muerte del deudor no pudiere recuperar el crédito, podría ejecutar la hipoteca inversa para cobrarlo.

En esta escritura pública de constitución de hipoteca inversa también deberá determinarse la cantidad máxima por la que responda la finca hipotecada, es decir, el capital que se vaya entregando al deudor y los intereses que se puedan devengar en función del valor actual de la finca, su revalorización y la edad del deudor teniéndose en cuenta la esperanza de vida, y además, los costes de la operación financiera.

\footnotetext{
${ }_{376}$ Vid. Modelo de Escritura de Constitución de Hipoteca Inversa (FOR\2012\496), Aranzadi (Westlaw.es). 377 Vid. SAP de Málaga de 13 de junio de 2013 (AC 2013\1634).
} 
En cuanto al plazo de duración de esta hipoteca, en la escritura se hará constar que la exigibilidad de la deuda no podrá producirse hasta que tenga lugar el fallecimiento del deudor o del último de ellos, si fueran varios. Es decir, en la hipoteca inversa no se producirá el vencimiento anticipado ${ }^{378}$ ni tan siquiera para el caso de la renta temporal. En este supuesto, cuando se perciba la última de las prestaciones y el deudor aún no hubiese fallecido, la deuda sería líquida y estaría vencida, pero no sería exigible hasta que se produjera el fallecimiento de éste.

Por tanto, en la escritura de constitución de la hipoteca inversa se deberá hacer referencia a las cantidades que se vayan a ir entregando por el acreedor, los plazos en que serán satisfechas y el plazo de vencimiento del contrato que, en ningún caso podrá ser anterior a la fecha del fallecimiento del deudor o beneficiario. En otras palabras, que la exigibilidad de la obligación sólo podrá producirse a la fecha de defunción del último de estos sujetos.

En cuanto a los intereses que deberán constar en la escritura de constitución apuntar que en las hipotecas inversas concedidas en el transcurso de la Ley 41/2007, el tipo de interés aplicado normalmente ha sido fijo, por lo que el riesgo para la entidad de crédito radicaba en la posible variabilidad al alza de los tipos de interés durante el tiempo de duración del contrato y en la aleatoriedad de la fecha de vencimiento del crédito. Lo ideal, y en beneficio del solicitante-deudor, sería que este interés fuera fijo y en el caso de que fuera variable, se fijase una banda de fluctuación. Con esa fórmula se evitaría, en el supuesto de que subieran mucho los tipos de interés, que éstos no afectasen a la hipoteca inversa, pues cuanto más elevados sean estos tipos, menor será la cuantía disponible a percibir con la hipoteca inversa.

A diferencia de la hipoteca ordinaria, en la que el transcurso del tiempo provoca que el importe de la deuda vaya disminuyendo como consecuencia de los pagos que va realizando el deudor, en la hipoteca inversa

\footnotetext{
${ }^{378}$ Al respecto, cabría resaltar la SAP de Málaga de 24 de enero de 2013 (JUR 2013\182553).
} 
se está garantizando un préstamo de amortización negativa, generando unos intereses bastante elevados en comparación a otros préstamos. En esta hipoteca, conforme pasa el tiempo, y como consecuencia de los sucesivos pagos, el principal de la deuda va aumentando, y desde el momento en que se entrega la primera cantidad hasta el vencimiento, se van devengando intereses.

Junto a lo anterior, se han de añadir los costes de la operación que se incluyen en el crédito garantizado por hipoteca inversa. Estos costes también devengarán intereses desde la fecha en que se originaron, que no es otra que al contratar la hipoteca y hasta el vencimiento del crédito. De ahí que uno de los principales inconvenientes a la hora de implantar este producto financiero haya sido el elevado importe de intereses que se devengan para poder llevar a cabo esta hipoteca.

Con respecto a la modalidad financiera que se va a utilizar para recoger las remesas que irán estableciendo la deuda final, la forma más utilizada es la de un contrato de apertura de crédito en cuenta corriente ${ }^{379}$. No obstante, también podría instrumentalizarse como préstamo sucesivo ${ }^{380}$. En esta cuenta corriente $^{381}$ se anotará el capital que se disponga, los intereses que se vayan acumulando por el capital dispuesto y los gastos de constitución (primas de seguros, comisiones, etc.).

Junto a estas cantidades, también se incluirán todos los gastos que se produzcan hasta el día del vencimiento. Cuando se produzca el vencimiento, la cantidad que exigirá el acreedor será la que figure en el saldo resultante de la cuenta corriente. Esto se configura como un crédito unilateral ya que la entidad de crédito es la única que se obliga a poner a disposición del deudor, de forma periódica, las cantidades establecidas.

\footnotetext{
${ }^{379}$ Sobre este asunto incidiremos con mayor detalle en el apartado dedicado a la Hipoteca en Garantía de Cuenta Corriente.

${ }^{380}$ MURo Villalón, J.V., «La hipoteca... », op. cit., pp. 10 y 11.

381 Álvarez Álvarez, H., La hipoteca inversa..., op. cit., pp. 95 y 96.
} 
Si se estructurase como apertura de crédito en cuenta corriente, además de configurarse como un crédito unilateral, se tendría que tener en cuenta la posibilidad de amortización voluntaria de la deuda. Esta posibilidad, tal como señala ÁlvAREZ ${ }^{382}$, podría darse en el caso de que al deudor le tocase la lotería. Si la cantidad del premio fuera suficiente el deudor podría, si quisiera, amortizar la totalidad o parte de la deuda. Junto a esta posibilidad, también podría darse el caso de que el deudor recibiera una herencia o una donación con capacidad suficiente para hacer frente al pago del préstamo.

Como podemos observar, esta amortización voluntaria sólo se podría dar en el caso de que aumentase el patrimonio del deudor, posibilidad un tanto remota, pues la hipoteca inversa está dirigida a personas que no tienen medios económicos suficientes o que quieren complementar su pensión para poder tener una mejor calidad de vida.

Según un estudio realizado por la Fundación MAPFRE ${ }^{383}$, los costes iniciales de la hipoteca inversa desde sus inicios, ya suponían un gran freno para sus clientes potenciales, ya que los gastos originados por impuestos, comisiones, gastos notariales y seguros solían representar entre el 6 y el 9 por 100 del valor del inmueble.

En la actualidad, tras la aprobación de la Ley 41/2007, los gastos de la hipoteca inversa no han disminuido mucho o casi nada, pues a pesar de los incentivos fiscales y notariales que se introdujeron, apenas si han tenido repercusión en el montante final. A esto, se le une la dificultad de conocer el importe final de los intereses remuneratorios que genera el crédito. Este crédito va a generar intereses hasta la muerte del deudor o de la última persona beneficiaria, por tanto, se trata de una obligación sometida a término resolutorio incierto.

\footnotetext{
382 Ibíd., p. 96.

383 Estudio realizado por la Fundación MAPFRE reflejado en el artículo «Qué hipoteca inversa presenta mejores costes y condiciones», publicado en Expansión, el día 22 de noviembre de 2007.
} 
Por último, como ya hemos visto en el punto dedicado a la vivienda habitual, la hipoteca inversa deberá ser primera hipoteca, la primera deuda que garantice la vivienda, por lo que si existiese alguna otra deuda garantizada con ese inmueble, convendría cancelar la deuda vigente antes de obtener la hipoteca inversa.

Esta situación no se da en la hipoteca ordinaria, donde la primera hipoteca no suele agotar el valor en el mercado del inmueble hipotecado, facilitando, por tanto, hipotecas sucesivas (art. 107.3 de la LH). En estos casos, sobre una misma finca podrán constituirse tantas hipotecas como se quiera, estableciéndose la prioridad ${ }^{384}$ entre ellas por el rango. Es lo que se conoce como prior tempore potior iure, la primera hipoteca tiene mejor derecho que las segundas y sucesivas. Debido a que el rango hipotecario no es susceptible de intercambio ni de reserva, cuando se cancele la primera hipoteca por cumplimiento de la obligación garantizada, la segunda hipoteca pasará a ser automáticamente la primera.

\section{La hipoteca en garantía de cuenta corriente}

La hipoteca en garantía de cuenta corriente se regula en los artículos 153 de la $L^{385}$ y 245 y 246 del RH.

En este aspecto, se ha de señalar que antes de la entrada en vigor de la Ley 41/2007, la mayoría de las resoluciones de la DGRN en las que se concertaba esta modalidad se perfeccionaban como un préstamo ${ }^{386}$. No obstante, una vez se introdujo esta Ley, la apertura de crédito en cuenta

\footnotetext{
${ }^{384} \mathrm{El} \mathrm{principio} \mathrm{de} \mathrm{prioridad} \mathrm{está} \mathrm{condensado} \mathrm{en} \mathrm{la} \mathrm{máxima} \mathrm{prior} \mathrm{tempore} \mathrm{potior} \mathrm{iure} \mathrm{(el} \mathrm{primero} \mathrm{en} \mathrm{el}$ tiempo es mejor en el derecho), que el artículo 537 del Reglamento Hipotecario erige en lema del Cuerpo de Registradores de la Propiedad. Así lo señala Puig BrUtau, J., Compendio de Derecho Civil. Volumen III, op. cit., p. 536.

${ }^{385}$ A juicio de Carrasco Perera, Á.; Cordero lobato, E. y Marín López, M.J., Tratado de los derechos..., op. cit., p. 541, el artículo $153 \mathrm{LH}$, en un principio, era de aplicación en aquellos casos en los que las partes hacían constar los créditos, que mutuamente se concedían en una cuenta especial, aplazando la exigibilidad de los mismos al momento de cierre de la cuenta, «donde, tras una compensación global entre las partidas del Debe y del Haber, todas las obligaciones incluidas en la cuenta corriente resultan ser sustituidas por la obligación del deudor de devolver el saldo resultante».

${ }^{386}$ Vid., las RRDGRN de 21 de diciembre de 2007 (RJ 200812086), de 1 de febrero de 2008 (RJ 20081633) o de 1 de marzo de 2008 (RJ 2008\1482).
} 
corriente para la contratación de esta hipoteca ${ }^{387}$ viene siendo la práctica más habitual $^{388}$. Pues, además de ser la modalidad que mejor se adapta a las necesidades del deudor, la configuración de esta apertura de crédito en cuenta corriente es la opción más idónea para la hipoteca inversa ${ }^{389}$.

En este contrato la deuda no resulta exigible hasta el fallecimiento del solicitante o del último de los beneficiarios. Este aplazamiento en la exigibilidad afecta tanto a la obligación principal como a la obligación accesoria por intereses. La parte acreedora, en este contrato de apertura de crédito en cuenta corriente, quedará obligada por tiempo determinado (fecha de fallecimiento del deudor o del último de los beneficiarios) y por una cantidad máxima, a poner a disposición del deudor (titular de la cuenta corriente) una suma máxima de dinero de la que éste podrá disponer de una vez o en fracciones ${ }^{390}$. Una vez transcurrido el plazo acordado se procederá a la liquidación de la cuenta determinando el saldo definitivo que, en el caso de que lo hubiera, deberá restituirse ${ }^{391}$.

En la escritura de constitución se fijará la cantidad máxima por la que responde la finca, el plazo de duración $y$, en su caso, la posibilidad de prórroga y los plazos de liquidación de la cuenta. De esta manera, el saldo definitivo que resulte en el momento de la liquidación de contrato de apertura de crédito en cuenta corriente quedará asegurado.

\footnotetext{
387 La RDGRN de 1 de octubre de 2010 expresa que: «Es especialmente útil en muchos casos, para el desenvolvimiento del producto en el mercado financiero, el mecanismo de la cuenta corriente, pues permitirá englobar las diversas partidas que configurarán el saldo final -o deuda- exigible al tiempo del vencimiento de la obligación garantizada por la hipoteca inversa constituida». La apertura en cuenta corriente permite englobar bajo una misma cifra de responsabilidad lo debido por principal e intereses. Por esta causa, no resulta de aplicación el principio registral de especialidad que, en el ámbito hipotecario, impone la determinación separada de las responsabilidades a que queda afecto el bien por principal y por intereses.

${ }^{388}$ MURo Villalón, J.V., «La hipoteca... », op. cit., p. 165. Esta práctica ya la había destacado con anterioridad a la entrada en vigor de la Ley $41 / 2007$.

389 Destacar las RRDGRN de 4 de noviembre de 2010 (RJ 2011\2461), 21 de diciembre de 2010 (RJ 2011 \263) u 11 de enero de 2011 (RJ 2011\269), que son copia, prácticamente exacta, de lo dispuesto en la RDGRN de 1 de octubre de 2010.

390 En términos similares, el TS en la Sentencia de 11 de junio de 1999 (RJ 1999\4607) define el contrato de apertura de crédito en cuenta corriente como aquel por el que «el banco se obliga, dentro del límite pactado y mediante una comisión que percibe del cliente, a poner a disposición de éste, y a medida de sus requerimientos, sumas de dinero o a realizar otras prestaciones que le permitan obtenerlo al cliente».

391 Montero Aroca, J., Las ejecuciones hipotecarias en la nueva Ley de Enjuiciamiento Civil, Tirant lo Blanch, Valencia, 2001, pp. 359 y 360.
} 
La hipoteca en garantía de cuenta corriente de crédito se puede definir como una hipoteca de seguridad donde su nota característica es que el título constitutivo no establece, por sí mismo, ni la existencia ni la cuantía del crédito, sino que habrá que estar a lo que determinen los datos extraregistrales.

Conforme a lo que establece el artículo 153 de la $\mathrm{LH}$, para que se pueda constituir este tipo de hipoteca se tendrán que dar dos requisitos:

- que se fije la cantidad máxima de la que responde la finca.

- que se determine el plazo de duración de la cuenta.

El artículo 153 de la LH, en su párrafo segundo, permite al acreedor utilizar la acción del proceso especial de ejecución hipotecaria de los artículos 681 y ss. de la LEC. Ahora bien, para este supuesto, junto con la demanda y el título de ejecución de la hipoteca tendrá que figurar el documento que acredite el importe líquido de la cantidad adeudada exacta objeto de reclamación. Esto viene dado porque el título ejecutivo por sí solo no determinará la liquidez de la deuda, ya que la cantidad adeudada, como es obvio, no quedará fijada en la constitución de la hipoteca.

Para ello, será necesario que el acreedor presente un documento que acredite el importe líquido de la cantidad adeudada. Este documento se podrá presentar a través de una certificación de saldo emitida por la propia entidad acreedora, pues al tratarse de Bancos, Cajas de Ahorro o Sociedades de Crédito debidamente autorizadas, se podrá convenir a los efectos de proceder ejecutivamente. En este caso, para proceder a la ejecución se notificará al deudor, judicial o notarialmente, un extracto de la cuenta pudiendo alegar éste, en la misma forma y dentro de los ocho días siguientes, error o falsedad.

En conclusión, cuando nos encontremos ante una hipoteca en garantía de cuenta corriente de crédito, tendremos que acudir a lo que establece el 
artículo 153 de la $\mathrm{LH}^{392}$. Ahora bien, tras el desarrollo de este precepto nos encontramos con un problema, pues la causa de oposición que se recoge en el artículo 695.1.2. ${ }^{a}$ de la LEC es de dudosa compatibilidad con este artículo 153 de la LH.

De acuerdo con el artículo 685 de la LEC, relativo a la demanda ejecutiva y a los documentos que han de acompañar a la misma, tendremos que acudir al artículo 573 del mismo texto legal, por el que se determinan los documentos que deberán acompañar a la demanda ejecutiva por saldo de cuenta.

Con la entrada en vigor de la LEC $1 / 2000$, en el caso de que existan cuentas corrientes abiertas en Bancos, Cajas de Ahorro y Sociedades de Crédito debidamente autorizadas, el saldo podrá acreditarse mediante certificación de la entidad acreedora, sin que se exija que se haga mediante documento fehaciente. Por esta causa se ha cuestionado que el artículo 153 de la LH pueda continuar en vigor, a pesar de no haber sido derogado expresamente por la LEC 1/2000, pues gran parte de su contenido se encuentra regulado por el artículo 695 de la LEC y, por ello, habría que estar a lo que establezca la ley procesal ${ }^{393}$. Por consiguiente, el acreedor, junto con la demanda ejecutiva, deberá presentar los documentos determinados por el artículo 573 de la LEC junto con el documento fehaciente que exprese el saldo.

De esta manera, lo regulado en el artículo 153 de la LH no podría ser de aplicación en el marco jurídico actual ya que en este precepto no se exige que el documento que acredite el saldo sea fehaciente, mientras que en el

\footnotetext{
392 SAÉNZ DE JUBERA HIGUERO, B., Relación entre el crédito y la hipoteca: alcance del principio de accesoriedad, Colegio de Registradores de la Propiedad y Mercantiles de España, Madrid, 2008, p. 273, señala que la hipoteca en garantía de cuenta corriente de crédito regulada en el artículo 153 de la LH ha resultado ser la opción utilizada en la práctica bancaria para ser apoyo a nuevas figuras. A pesar de que la intención del legislador, en su momento, fue la de que tuviese como ámbito propio el empresarial, se ha manifestado como perfectamente apta para dar cobertura a diversas fórmulas bancarias.

${ }^{393}$ Así lo ha manifestado CRESPO ALLUÉ, E., «Comentario del artículo 695 de la LEC», en Comentarios a la Nueva Ley de Enjuiciamiento Civil, tomo III, Lex Nova, Valladolid, 2000, p. 3562.
} 
artículo 573 de la LEC, en su apartado $2 .^{\circ}$, sí lo exige, no distinguiendo entre ejecución ordinaria o hipotecaria.

Respecto a este asunto, DomínGUEZ LUELMO ${ }^{394}$ ha considerado que la LEC ha variado lo contenido en la Ley Hipotecaria porque el artículo 685.2 de la LEC se remite al artículo 573 del mismo texto legal, por el cual se tipifican los documentos que se deberán acompañar a la demanda ejecutiva por saldo de cuenta. A su vez, este artículo nos remite al artículo 572, concretamente, a su apartado segundo.

Atendiendo a este precepto ${ }^{395}$ de la LEC, no se tendrán que hacer distinciones entre si el acreedor es o no una entidad crediticia, ni tampoco sobre si la garantía es o no hipotecaria. De esta forma, será suficiente el pacto de liquidez convenido entre las partes. Es decir, en este caso, no será necesario presentar la certificación emitida por la entidad acreedora, bastando ese pacto de liquidez.

En cambio, tal como señala Domínguez LUELMO, este pacto no podrá contener determinadas cláusulas ${ }^{396}$. Por ejemplo, no se podrá pactar que la certificación haga fe en juicio, ni que la liquidación se haga a juicio del acreedor, ni la certificación podrá constar en documento que no sea fehaciente, ni que no se pueda impugnar la liquidación que haga el acreedor en el juicio ejecutivo.

Junto a esto, también surgen dudas sobre si se pueden oponer sólo las causas que se recogen en el artículo 695.1.2. ${ }^{a}$ de la LEC o si se puede alegar oposición del ejecutado conforme al artículo 573 de la LEC. En este caso,

\footnotetext{
394 Cfr. Domínguez Luelmo, A., La hipoteca de propiedad intelectual, Reus, Madrid, 2005, pp. 299-300 y 427-428.

${ }^{395}$ Artículo 572.2 de la LEC: «También podrá despacharse ejecución por el importe del saldo resultante de operaciones derivadas de contratos formalizados en escritura pública o en póliza intervenida por corredor de comercio colegiado, siempre que se haya pactado en el título que la cantidad exigible en caso de ejecución será resultante de la liquidación efectuada por el acreedor en la forma convenida por las partes en el propio título ejecutivo.

En este caso, sólo se despachará la ejecución si el acreedor acredita haber notificado previamente al ejecutado y al fiador, si lo hubiere, la cantidad exigible resultante de la liquidación».

396 Vid. SAP de Málaga de 23 de abril de 2012 (AC 2012\2301).
} 
MONTERO AROCA ${ }^{397}$ opina que se podrán alegar tanto las causas de oposición del

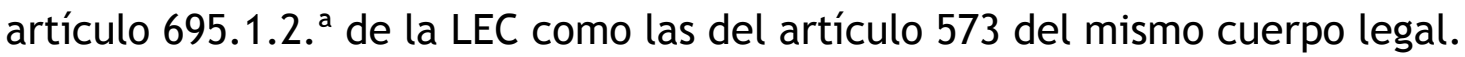

En relación con la hipoteca en garantía de cuenta corriente de crédito que acabamos de ver, resulta conveniente resaltar que con la Ley 41/2007, de 7 de diciembre por la que se modifica la Ley $2 / 1981$, de 25 de marzo, de Regulación del Mercado Hipotecario, en el Capítulo VI sobre la Mejora y Flexibilización del Mercado Hipotecario, se introduce un nuevo artículo, concretamente, el 153 bis de la Ley Hipotecaria, de 8 de febrero de 1946. En este artículo se hace referencia a la constitución de hipoteca de máximo:

«También podrán constituirse hipotecas de máximo:

a) a favor de las entidades financieras a las que se refiere el artículo 2 de la Ley $2 / 1981$, de 25 de marzo, de regulación del mercado hipotecario, en garantía de una o diversas obligaciones, de cualquier clase, presentes $y / 0$ futuras, sin necesidad de pacto novatorio de las mismas,

b) a favor de las administraciones públicas titulares de créditos tributarios o de la Seguridad Social, sin necesidad de pacto novatorio de los mismos.

Será suficiente que se especifiquen en la escritura de constitución de la hipoteca y se hagan constar en la inscripción de la misma: su denominación y, si fuera preciso, la descripción general de los actos jurídicos básicos de los que deriven o puedan derivar en el futuro las obligaciones garantizadas; la cantidad máxima de que responde la finca; el plazo de duración de la hipoteca, y la forma de cálculo del saldo final líquido garantizado.

Podrá pactarse en el título que la cantidad exigible en caso de ejecución sea la resultante de la liquidación efectuada por la entidad financiera acreedora en la forma convenida por las partes en la escritura.

Al vencimiento pactado por los otorgantes, o al de cualquiera de sus prórrogas, la acción hipotecaria podrá ser ejercitada de conformidad con lo previsto en los artículos 129 y 153 de esta Ley y concordantes de la Ley de Enjuiciamiento Civil».

Como se puede apreciar, en este nuevo precepto por el que se desarrolla la constitución de hipoteca de máximo ${ }^{398}$, el mismo artículo nos remite a los artículos 129 y 153 de la LH y concordantes de la Ley de Enjuiciamiento Civil.

\footnotetext{
397 Montero Aroca, J., Las ejecuciones..., op. cit., p. 564.

${ }^{398}$ Al respecto vid. la Resolución de la DGRN de 2 de marzo de 2013 (RJ\2013\2912).
} 
En este sentido, SERRANO DE Nicolás ${ }^{399}$ considera que la hipoteca inversa, cuando la concedan las entidades de crédito a las que se refiere el artículo 2 de la LMH, también podrá ser a la vez que inversa, de máximo o flotante, tal como se regula en este nuevo artículo 153 bis, en la redacción que le ha dado el artículo 11.4 de la Ley $41 / 2007$.

Para ROCA SASTRE ${ }^{400}$, la hipoteca con garantía en cuenta corriente constituye el ejemplo de hipoteca de máximo y a su vez se presenta como la hipoteca más idónea para garantizar obligaciones de largo tracto y relaciones de deuda de carácter continuado, es decir, igual que la hipoteca inversa. De esta forma, si el acreedor y el deudor optan por la apertura de crédito en cuenta corriente, será necesario determinar la cantidad máxima por la que responda la finca, la obligación o «al menos, los datos indispensables que permitan identificar la relación obligatoria ${ }^{401}$ » y su duración.

Asimismo, las hipotecas inversas constituidas para garantizar una apertura o línea de crédito en cuenta corriente no plantearán ningún problema. Bajo esta modalidad de hipoteca de máximo, la hipoteca garantiza el saldo resultante que arroja la cuenta de crédito en el que se entienden incluidos tanto el principal como los intereses que la entidad ha ido cargando en la cuenta ${ }^{402}$.

Sin embargo, para JIMÉNEZ CLAR ${ }^{403}$, no parece posible que esta hipoteca pueda adoptar la forma de hipoteca de máximo o de hipoteca flotante, en la medida en que pueda quedar sujeta a la garantía de la vivienda habitual del solicitante-deudor, sin que sea necesaria una deuda para cuyo nacimiento se precise un nuevo consentimiento de la entidad prestamista.

\footnotetext{
399 SerRano de Nicolás, Á., «Régimen jurídico... », op. cit., p. 47.

400 Roca Sastre, R.M. y Roca-SAStre Muncunill, L., Derecho hipotecario: Hipotecas, tomo VIII, op. cit., p. 322.

401 Ibíd., p. 321.

402 Ibíd., p. 335; Bellod Fernández DE PALENCIA, E., Hipoteca en garantía de crédito abierto en cuenta corriente bancaria, Centro de Estudios Registrales, Madrid, 2001, p. 53; CHICO Y ORTIZ, J.M., Estudios sobre..., op. cit., p. 816; NASARRE AZNAR, S., «Malas prácticas bancarias en la actividad hipotecaria», $R C D I, N^{\circ} 727$, septiembre 2011, p. 2706.

403 JimÉnEz CLAR, A.J., «La hipoteca...», op. cit., p. 116.
} 
La hipoteca no garantiza cada vencimiento de intereses de forma separada, sino el saldo final resultante al cierre de la cuenta. Ello es así, porque los intereses devengados y cargados en la cuenta no son exigibles hasta el cierre de la misma.

En el siguiente epígrafe, y con una mayor profundidad, vamos a seguir abordando este tema.

\section{INSCRIPCIÓN DE LA HIPOTECA INVERSA}

En nuestro Derecho, entre las principales características de la hipoteca cabe destacar el carácter constitutivo ${ }^{404}$ de la misma. De esta manera, atendiendo al artículo 12 de la $\mathrm{LH}$, en la inscripción de hipoteca se hará constar el importe de la obligación asegurada y, en el caso de que se hubieren estipulado, el importe de los intereses ${ }^{405}$.

En este aspecto, la hipoteca inversa presenta algunos inconvenientes con respecto al principio de especialidad ${ }^{406}$. Esto viene dado por la no concreción de algunos puntos que componen dicha hipoteca, como por ejemplo, la fecha de vencimiento y la cantidad final o valor de la vivienda en esa fecha ${ }^{407}$. No debemos olvidar que esta modalidad se caracteriza, a

\footnotetext{
404 Así lo señala la STS de 13 de septiembre de 2011 (RJ 2013\7856) en su fundamento de derecho tercero: «En un sistema registral de desenvolvimiento técnico, como es el español, en el que los asientos producen efectos sustantivos -en unos casos, constitutivos, en otros, legitimadores del titular inscrito $\mathrm{y}$, de darse ciertas circunstancias, del tercero que adquirió confiado en el contenido del registro-, además de importantes efectos propiamente registrales -la inscripción cancela las contradictorias y cierra el acceso a los títulos que lo sean con el derecho publicado, salvo consentimiento del titular o decisión judicial- y en el que, una vez practicados, los asientos quedan bajo la salvaguardia de los Tribunales y producen todas sus consecuencias mientras no se declare la inexactitud -artículo 1 de la Ley Hipotecaria-, resulta esencial el principio de legalidad, en cuanto excluyente de la posibilidad de registrar títulos que no sean perfectos y válidos, material y formalmente».

${ }^{405}$ Vid. las Resoluciones de la DGRN de 28 de enero de 1998 (RJ 1998\279) y de 12 de mayo de 2011 (RJ 2011\5826).

${ }^{406}$ Tal y como lo define Puig Brutau, J., Compendio de Derecho Civil, Volumen III, op. cit., p, 534, el principio de especialidad responde a la necesidad de concretar y determinar con toda claridad lo que se refiera a los elementos básicos de la publicidad registral, que son la finca y los derechos que recaen sobre ella.

${ }^{407}$ El principio de determinación registral exige que en la inscripción se distingan por separado lo debido en concepto de principal y lo debido en concepto de intereses ordinarios. Estos intereses, previamente, se habrán pactado como fijos o variables. Esto no sucede con los intereses moratorios que son de origen legal. Vid. RDGRN de 11 de octubre de 2004 (RJ 2005\2549).
} 
diferencia de las hipotecas convencionales, por ser un préstamo creciente, desconociéndose cuál será el montante final de la deuda, ya que dependerá de la esperanza de vida del deudor y, en el caso de que los hubiere, de la del último beneficiario.

Junto a esto, se tendrá que sumar la capitalización de intereses, pues se exige una distinción entre la deuda principal y los intereses generados ${ }^{408}$. Esto se tendrá que respetar conforme a lo dispuesto en el artículo 114 de la LH. Ahora bien, y como tantas veces se ha hecho hincapié, en el caso de la hipoteca inversa regulada en la Ley 41/2007 en la Disposición Adicional Primera, en su apartado 6 se dispone de forma expresa que no será de aplicación lo dispuesto en el párrafo segundo del artículo 114 de LH. En este aspecto, señalar que en el caso de que existan hipotecas inversas constituidas al amparo de la autonomía de la voluntad o anteriores a esta Ley, la situación sería distinta ${ }^{409}$.

Además de estas cuestiones y, a raíz del nuevo artículo 153 bis de la Ley Hipotecaria, citado anteriormente, nos podríamos plantear si la hipoteca inversa podría considerarse una hipoteca de máximo o una hipoteca convencional. Según PUIG BRUTAU ${ }^{410}$, entre las hipotecas de seguridad, la llamada de máximo ofrece las siguientes características:

«En el Registro queda fijada una cantidad máxima de responsabilidad hipotecaria, que es la parte del valor de la finca que podrá destinarse al pago del crédito. Éste, como derecho personal, no queda limitado pero sí su cobertura o garantía hipotecaria. De esta manera la finca hipotecada puede ser objeto de negociación, pues el tercer adquirente conocerá exactamente el límite de la responsabilidad.

Si la garantía real está determinada, el crédito está de momento indeterminado en cuanto a su existencia y cuantía. A pesar de ello, es indispensable que haya quedado indicado en sus líneas fundamentales para que el Registro ofrezca los datos indispensables para identificar la obligación de la que responde el inmueble. Ha de reflejar la base causal de la que podrán nacer las prestaciones exigibles.

\footnotetext{
408 Al respecto, cabría hacer mención a las Sentencias de la Audiencia Provincial de Málaga de 23 de abril de 2012 (AC 2012\2301) y de 21 de mayo de 2013 (JUR 2014\16522).

${ }^{409}$ Martínez Escribano, C., La hipoteca inversa, op. cit., p. 193.

410 Puig Brutau, J., Compendio de Derecho Civil. Volumen III, op. cit., p. 477.
} 
Al quedar registrado el crédito sólo en sus líneas fundamentales, su determinación ha de poder efectuarse por medios extraregistrales para que sea exigible oportunamente como crédito hipotecario».

Con esta definición podríamos pensar que la hipoteca inversa podría considerarse como una hipoteca de máximo ${ }^{411}$, pero aun así se plantean ciertas dudas. En este sentido, la $\mathrm{DGRN}^{412}$, con respecto a las hipotecas inversas no sujetas a la Ley $41 / 2007$, ha negado que se trate de una hipoteca de máximo ${ }^{413}$. De esta manera, no se tendrá que acudir al artículo 153 bis de la LH, por el que se regula la constitución de esta hipoteca de máximo, ya que se trataría de una hipoteca ordinaria o de tráfico.

Ahora bien, en las resoluciones en que la DGRN se pronuncia en estos términos no se aplica la Ley 41/2007 y, por ello, parte de considerar que no nos encontramos ante una hipoteca inversa, sino ante un supuesto similar. En este sentido se pronuncia MARTínEZ ESCRIBANO ${ }^{414}$, y del mismo modo que entendió el registrador de la propiedad en los casos de las resoluciones antes citadas, este tipo de hipotecas debería configurarse más bien como una hipoteca de máximo.

La hipoteca inversa, desde que aparece regulada en la Ley $41 / 2007$, ha superado algunos obstáculos que, en algunas ocasiones impedían su inscripción ${ }^{415}$. Ahora bien, este razonamiento no estaría justificado, pues esta

\footnotetext{
411 Vid. SAP de Almería de 7 de noviembre de 2012 (JUR 2014\126110) y RDGRN de 11 de octubre de 2004 (RJ 2005\2549).

412 En opinión de la DGRN: «El que el préstamo celebrado no deba reembolsarse, tanto por capital como por intereses (que se van capitalizando) hasta el término o vencimiento final de acuerdo con lo pactado en el contrato, no significa en modo alguno que nos encontremos ante una cuenta corriente de crédito y de que la hipoteca lo sea de máximo, sino que del conjunto de pactos y cláusulas contenidas en la escritura se evidencia que nos encontramos ante un préstamo de características especiales, en garantía el cual se establece una hipoteca ordinaria o de tráfico».

413 Vid. las Resoluciones de la DGRN de 3 de diciembre de 1998 (RJ 1998\10482) y 3 de septiembre de 2005 (RJ 2005\6928).

${ }^{414}$ MARTínez Escribano, C., La hipoteca inversa, op. cit., pp. 205 y 206.

${ }^{415}$ En este sentido la SAP de Málaga de 17 de abril de 2013 (AC 2013\1316) señala: "Como excepción y, resultando aconsejable para el tráfico jurídico por la publicidad con efectos de mera noticia que dimana del asiento registral, respecto de las cláusulas que carecen de dicho contenido real, la Ley 41/2007 en la modificación del art. 12 de la LH ha incluido un párrafo segundo que permite que, respecto de las hipotecas constituidas a favor de las entidades financieras a que se refiere la Ley $2 / 1981$, de 25 de marzo, además puedan hacerse constar en el Registro las cláusulas financieras, incluidas las de vencimiento anticipado, aun cuando carezcan de trascendencia real inmobiliaria y queden extramuros de la calificación. Ahora bien, respecto de estas cláusulas financieras el registrador debe limitar su actuación a hacerlas constar en el asiento, esto es a transcribir sin más las mismas, siempre que las de
} 
hipoteca, en algunos casos, dista de cumplir todos los requisitos legales que la conforman.

A modo de ejemplo, podríamos analizar el caso de los extranjeros residentes en España, normalmente ciudadanos europeos, que desean constituir una hipoteca inversa en España pero, a pesar de fijar su residencia en nuestro país, celebran el contrato de hipoteca con una entidad de su país de origen. En casos como estos, la hipoteca tendrá que inscribirse en el Registro de la Propiedad español, ya que de no ser así, el carácter constitutivo de la inscripción se vería truncado en nuestro ordenamiento jurídico. En este aspecto, la DGRN se ha pronunciado ${ }^{416}$ sobre estos casos, en los que se ha dado la negativa por parte del registrador a inscribir estas hipotecas.

Como regla general, en la hipoteca inversa el momento de devolución del préstamo, tanto el principal como los intereses, vendrá dado por la fecha del fallecimiento del deudor o del último de los beneficiarios. Sin embargo, se podría dar el vencimiento anticipado, en el caso de que se negociara, por acuerdo entre el deudor y el acreedor, la venta de la vivienda. De este modo, tanto si el vencimiento del préstamo hipotecario se produce por el fallecimiento del deudor o del último beneficiario como si se produce por la venta de la vivienda hipotecada, observamos que no se dispone de una fecha determinada en la que finalice esta hipoteca, a diferencia de la hipoteca convencional, donde al inicio de la misma ya se pacta una fecha por la que tendrá lugar el vencimiento del préstamo hipotecario.

Por tanto, esta nota de fecha indeterminada que caracteriza a la hipoteca inversa podría entrar en contradicción con el principio de

trascendencia jurídico real inmobiliaria -las enumeradas en el párrafo primero del art. 12 de la LHhubieran sido calificadas favorablemente».

416 Entre estos pronunciamientos, destacar las RRDGRN de 22 de febrero de 2008 (RJ 2008\2790), de 15 de marzo de 2008 (RJ 2008\807), de 19 de marzo de 2008 (RJ 2008\8272), de 25 de marzo de 2008 (RJ 2008\8277), de 27 de marzo de 2008 (RJ 2008\8278), de 14 de mayo de 2008 (RJ 2008\8279) y de 16 de mayo de 2008 (RJ 2008\3154), que resuelven todas casos análogos de préstamos hipotecarios concedidos por una entidad mercantil irlandesa a residentes en España siguiendo los planteamientos de la hipoteca inversa, pero sustrayéndose de la aplicación de la Ley $41 / 2007$, que por otra parte, ni siquiera había entrado en vigor por aquella época. 
especialidad registral debido a que se desconoce, desde el inicio de la misma, la duración de esta garantía hipotecaria. No obstante, la DGRN ha acomodado este tipo de supuestos con el principio de especialidad. En este sentido, concibe que:

«Aparece suficientemente determinada la duración o vencimiento del préstamo, ya que se prevé que su reembolso o amortización no se realizará gradualmente, sino en una sola vez a su vencimiento, bien coincidiendo con la venta de la casa o por el requerimiento que realice la parte acreedora, bien por incumplir los deudores el contenido de la escritura o bien a los seis meses desde la muerte del último residente nombrado o que el último residente nombrado haya dejado de residir en la finca, identificándose a los que considera residentes y especificando qué se entiende por dejar de residir. Nos encontramos pues con una obligación contraída de presente, cuya duración o vencimiento para su devolución depende de unos hechos futuros, unos ciertos en su acaecimiento, aunque inciertos en el cuándo (la muerte del último prestatario) y otros inciertos también en su existencia, como son la venta de la casa, el incumplimiento del contenido de la escritura o la falta de residencia por el último prestatario, circunstancias estas dos últimas que, para la plena efectividad de la hipoteca, requerirán en el momento de su eventual ejecución, la prueba extrarregistral de la concurrencia de la causa que hace exigible la devolución de la cantidad prestada, pero que en modo alguno impide la inscripción de la obligación garantizada tal y como está configurada».

Atendiendo a lo citado, la DGRN estima que la duración máxima de estas hipotecas inversas será hasta la fecha en que se produzca la muerte del deudor, siendo un hecho futuro y cierto en cuanto a su producción, aunque incierto respecto a cuándo se va a producir. Aún así, tal y como se ha visto, se podría producir el vencimiento anticipado, como por ejemplo, cuando se produzca la enajenación de la vivienda hipotecada inversamente.

En cuanto a la capitalización de intereses, en las hipotecas inversas que no les sea de aplicación la Ley $41 / 2007$, se plantea una posible vulneración del principio de especialidad registral ${ }^{417}$. Conforme a este principio, los intereses ${ }^{418}$ como tales y nunca englobados en el capital, sólo se podrán reclamar en perjuicio de tercero y dentro del límite de cinco años, como así

\footnotetext{
${ }^{417}$ MARTínez Escribano, C., La hipoteca inversa, op. cit., p.198.

418 PeÑa BeRnaldo de Quirós, M., Derechos reales. Derecho hipotecario, op. cit., pp. 154 y 155, apunta que en concepto de intereses, tanto fijos como variables, ante la imposibilidad de concretar la cuantía exacta, pues se desconoce el periodo por el que se devengarán, se indicará un máximo por el que responderá la finca.
} 
queda reflejado en el párrafo segundo del artículo $114 \mathrm{LH}$ : «En ningún caso podrá pactarse que la hipoteca asegure intereses por plazo superior a cinco años».

Se infiere pues que pasados estos cinco años, si se pretendiera que estos intereses pasarán a formar parte del capital, esta situación derivaría en una infracción del artículo 114 de la LH. Para que esto no suceda, nos tendremos que dirigir al apartado 6 de la DA 1. ${ }^{a}$ de la Ley 41/2007, donde de forma expresa y para las hipotecas inversas, se establece la inaplicación del párrafo segundo del artículo $114 \mathrm{LH}$.

No obstante, se podría dar el caso de la constitución de una hipoteca inversa en la que no se cumplieran todos los requisitos establecidos en Ley 41/2007. Dicha hipoteca se regiría por la autonomía de la voluntad de las partes y, además, el solicitante-deudor no se beneficiaría ni de las ventajas fiscales ni de las ventajas arancelarias reconocidas en la Ley 41/2007. En estos casos, nos encontraríamos con otro inconveniente, pues en el supuesto de que se aplicara lo regulado en el artículo 114 de la LH, la garantía del acreedor, es decir, el valor de la vivienda hipotecada inversamente, podría resultar perjudicada, ya que la parte acreedora podría llegar a obtener una rentabilidad menor a la deseada.

Estas contradicciones a la hora de aplicar unos preceptos u otros, también se pueden apreciar en el apartado 10 de la DA $1 .^{a}$ de la Ley 41/2007 donde se dispone que:

«Podrán, asimismo, instrumentarse hipotecas inversas sobre cualesquiera otros inmuebles distintos de la vivienda habitual del solicitante. A estas hipotecas inversas no les serán de aplicación los apartados anteriores de esta disposición».

En este precepto se determina la no aplicación de los apartados anteriores de dicha Disposición, por tanto, no será de aplicación el apartado 6 pero sí podría ser de aplicación el artículo 114 de LH. Es decir, cabría la posibilidad de que en los casos en los que se realizara una hipoteca inversa 
sobre otros bienes inmuebles distintos a la vivienda habitual, se aplicase este artículo 114 de la LH.

En este aspecto, la DGRN también se ha pronunciado y, con respecto a las hipotecas anteriores a la Ley $41 / 2007$ ha matizado que fuera de la excepción establecida para la hipoteca inversa, no se dará cabida a la hipoteca que asegure -en perjuicio de tercero-, intereses por plazo superior a cinco años. De esta forma, sólo sería posible exigir intereses en perjuicio de tercero dentro del límite de cinco años, tal y como se refleja en el párrafo segundo del artículo 114 de la LH. No obstante, a la vista de este estudio sobre la hipoteca inversa, no parece muy probable que se dé la presencia de un tercero, de manera que, no existiendo éste, no se aplicaría la limitación del artículo 114 de la LH.

Si analizamos la hipoteca como tal, ésta garantiza una deuda decreciente, en la que a medida que transcurra el plazo del préstamo, el deudor irá realizando pagos que se imputarán a los intereses y al capital. En contrapartida, si el deudor dejase de pagar el préstamo, el capital no aumentaría, pero sí lo harían los intereses. En este caso, el artículo 114 de la LH se limitaría a reclamar los últimos cinco años con el propósito de no perjudicar a terceros.

En cambio, en la hipoteca inversa, esta deuda es creciente, debido a que, mientras el deudor o el último de los beneficiarios permanezcan con vida, no se va a realizar ningún pago, es decir, la totalidad de la deuda será exigible una vez éstos hayan fallecido. En este caso, el capital irá aumentando con el paso del tiempo, así como también los intereses, llegando incluso a agotar el valor de la vivienda hipotecada. Por este motivo, no se admitirá la posibilidad de constituir otras cargas o gravámenes sobre este bien hipotecado, pues esta modalidad hipotecaria está destinada a consumir el valor total del inmueble, aunque podría darse el caso de que no se llegara a esta situación. 
Además, esto no es obstáculo para que, independientemente de que se trate de una deuda creciente, en la que el capital aumente con el transcurso del tiempo, se podría establecer que este aumento se delimitara de manera exacta, o al menos se fijara un límite, respetando, así, la especialidad registral.

Reflejado de otro modo, que aunque el montante de la deuda por el capital objeto del préstamo vaya aumentado con el paso del tiempo, este importe estaría delimitado, pues se conoce desde la constitución de la hipoteca inversa. En cambio, con respecto a los intereses que se pudieran generar en el transcurso de esta hipoteca, lo recomendable es que este tipo de interés fuera fijo o, en el caso de estipularse variable, éste tuviera un tope, pues de no ser así, no podríamos conocer el importe exacto de la deuda contraída.

Junto a esto, las partes, además de asegurar el principal y los intereses, podrán pactar que la hipoteca garantice también los intereses moratorios $^{419}$ derivados del posible incumplimiento de la obligación. Del mismo modo, también podrían pactar las costas y los gastos, pues éstos sólo se cubrirían si se pactaran ${ }^{420}$ de forma expresa.

De esta manera y atendiendo al principio de especialidad, todos estos conceptos deberán constar por separado ${ }^{421}$, sin perjuicio de la excepción que rige en materia de contrato de hipoteca en garantía de una apertura de crédito en cuenta corriente. Bajo este tipo de hipoteca se permite, y así lo ha admitido la DGRN, que se señale una cifra máxima que agrupe todos los conceptos: principal, intereses, costas y gastos ${ }^{422}$, sin necesidad de «fragmentar el máximo, ya que todas las obligaciones pueden ir a un único

\footnotetext{
419 Vid. la STS de 12 de marzo de 1991 (RJ 1991\2219) y la RDGRN de 22 de marzo de 2001 (RJ 2002\2188).

420 PeÑa BeRnaldo de QuiRós, M., Derechos reales. Derecho hipotecario, op. cit., p. 161.

421 Gómez-Ferrer SaPIÑA, R., «La Hipoteca», en DeLGado DE MIGUEL, J.F., Instituciones de Derecho Privado, tomo II: Reales, vol. $3^{\circ}$, Consejo General del Notariado y Thomson-Civitas, Madrid, 2003, p. 598.

422 Roca Sastre, R.M. y Roca-SAStre MuncunilL, L., Derecho hipotecario: Hipotecas, op. cit., p. 343.
} 
máximo en una única hipoteca ${ }^{423}{ }^{»}$. Así, en un contrato de hipoteca en garantía de una apertura de crédito, las distintas obligaciones pasan a incorporarse como partidas de la cuenta formando parte del saldo final que la hipoteca garantiza.

Finalmente, indicar que se considerará hipoteca inversa, tanto la regulada conforme a la Ley 41/2007, como también la estipulada con anterioridad a la misma, pues en ambas modalidades la garantía será una deuda creciente cuya exigibilidad no se producirá hasta el fallecimiento del deudor o el último de los beneficiarios, excepto en el caso de la venta de la vivienda efectuada por el propio deudor.

\section{Comentario al pacto de anatocismo}

Como ya se ha analizado en el epígrafe dedicado a los intereses, con la regulación de la Ley $1 / 2013$ de 14 de mayo, de medidas para reforzar la protección a los deudores hipotecarios, reestructuración de deuda y alquiler social, se introdujo un tercer párrafo al artículo 114 de la $\mathrm{LH}$, donde se establecía que:

«Los intereses de demora de préstamos o créditos para la adquisición de vivienda habitual, garantizados con hipotecas constituidas sobre la misma vivienda, no podrán ser superiores a tres veces el interés legal del dinero y sólo podrán devengarse sobre el principal pendiente de pago. Dichos intereses de demora no podrán ser capitalizados en ningún caso, salvo en el supuesto previsto en el artículo 579.2.a) de la Ley de Enjuiciamiento Civil».

Así pues no cabrá el anatocismo, ni siquiera inter partes, es decir que los intereses en ningún caso generarán a su vez más intereses.

${ }^{423}$ Carrasco Perera, Á. y Cordero Lobato, E., «La hipoteca inversa y el aseguramiento de intereses o de por qué tiene que ser revocada la doctrina de la DGRN sobre el anatocismo», Actualidad Jurídica Aranzadi (on line), № 741, Civitas, Madrid, 2007, p. 3. 
El pacto de anatocismo ${ }^{424}$ se solía incluir en los contratos de préstamo garantizado con hipoteca inversa, aunque en estos casos se tendría que valorar si ese pacto era o no válido y si era posible su inscripción. El aplazamiento en la exigibilidad de la obligación de interés, llevó a algunas entidades a capitalizarlos, transcurrido un determinado periodo de tiempo, a través del denominado pacto de anatocismo ${ }^{425}$, plenamente válido desde el punto de vista obligacional pero cuya inscripción ha sido denegada de forma continua por los registradores.

La DGRN, en aplicación del principio hipotecario de especialidad, señala al respecto, que los intereses sólo podrán ser reclamados en cuanto tales y nunca englobados en el capital y con los límites establecidos en los artículos 114 de la LH y 220 del RH respecto a terceros. El Tribunal Supremo ${ }^{426}$, incluso fue más allá, declarando en alguna ocasión que este límite no sólo juega frente a terceros sino también inter partes.

La única excepción en este sentido es el pacto de anatocismo incorporado a un contrato de hipoteca en garantía de una cuenta corriente de crédito $^{427}$ por su especial naturaleza y régimen jurídico ${ }^{428}$. Este contrato se caracteriza porque las distintas obligaciones pierden su propia individualidad cuando se hacen constar en la cuenta corriente, de tal forma que los intereses se acumulan al capital debido para generar nuevos intereses. Fuera de este supuesto de hipoteca en garantía de cuenta corriente, el pacto de anatocismo

\footnotetext{
${ }^{424}$ Vid. las RRDGRN de 23 de octubre de 1996 (RJ 1996\7359), de 14 de enero de 1997 (RJ 1997\280), de 12 de febrero de 1997 (RJ 1997\856), de 19 de marzo de 1997 (RJ 1997\2044) y de 24 de marzo de 1997 (RJ 1997\2047). También la SAP de Barcelona de 23 de marzo de 2007 (TOL1.123.467).

425 Dejando de un lado la plena aceptación del anatocismo legal recogido en el artículo 1109 CC, cuyo apartado primero señala que: «Los intereses vencidos devengan el interés legal desde que son judicialmente reclamados, aunque la obligación haya guardado silencio sobre este punto», se trata de discutir sobre la admisibilidad del pacto de anatocismo convencional, admisible desde el punto de vista obligacional sin más limitaciones que las derivadas de la autonomía de la voluntad y las normas aplicables en materia de represión de la usura. Al respecto vid. Díez-PICAzo, L., Fundamentos del Derecho Civil Patrimonial. Las relaciones obligatorias, vol. II, 6. ${ }^{a}$ ed., Thomson-Civitas, Cizur Menor (Navarra), 2008, p. 325.

${ }^{426}$ En este sentido se ha de destacar la STS de 12 de marzo de 1985 (RJ 1985\1153).

427 La RDGRN de 16 de junio de 1999 (RJ 1999\4379) señala en su fundamento de derecho tercero que: «La atipicidad del contrato de crédito en cuenta corriente permite un amplio juego a la autonomía de la voluntad, de suerte que respetando el efecto básico del sistema de instrumentación adoptado, la refundición en una sola obligación, la constituida por el saldo resultante de la liquidación de la cuenta al tiempo y en la forma convenidos, de los débitos y cargos que en ella se asienten que quedan reducidos a simples partidas contables, perdiendo así su autonomía y exigibilidad aislada, las particularidades pueden ser múltiples».

${ }^{428}$ Así lo señala SÁnCHEZ-VentURA MORER, I., La hipoteca inversa..., op. cit., p. 320.
} 
ha sido utilizado, en aquellos supuestos de préstamo o créditos garantizados con hipoteca en los que se conviene que la obligación de devolución se aplace a un momento posterior.

A modo de ejemplo, MARTínez Escribano ${ }^{429}$ señala que el pacto de anatocismo se podría dar en las hipotecas en las que, durante un determinado periodo de tiempo, el deudor no afronta ningún tipo de pago y, finalizado este periodo, los intereses se acumulan al capital para generar nuevos intereses. 0 también en aquél supuesto en el que el deudor paga determinadas cantidades reducidas durante los primeros meses y lo que reste por pagar en concepto de interés, transcurrido determinado periodo de tiempo, se acumula al capital para generar nuevos intereses.

Atendiendo a estos supuestos, el pacto de capitalización debería ser admitido en la hipoteca inversa, garantice un préstamo o un crédito, ya que se produce un aplazamiento en la exigibilidad de los intereses, cuestión que encuentra tanto defensores ${ }^{430}$ (Serrano de Nicolás, Carrasco Perera y Cordero LOBATO), como opositores ${ }^{431}$.

Entre los defensores destacar, entre otros, a SeRRANO de Nicolás ${ }^{432}$ que opina que el pacto de capitalización es perfectamente viable. De su exposición puede interpretarse que dicha capitalización se realizará cada cierto periodo de tiempo respecto de intereses devengados, pero no pagados, que únicamente serán exigibles en el momento del fallecimiento del deudor solicitante. $Y$ dado que únicamente son exigibles al fallecimiento, no puede decirse que la capitalización de los mismos responda al esquema propio de un pacto de anatocismo que, precisamente, implica la existencia de intereses vencidos y exigibles.

\footnotetext{
${ }^{429}$ Martínez Escribano, C., La hipoteca inversa, op. cit., pp. 128 y 129.

430 Berrocal Lanzarot, A.I., «Hipoteca Inversa...», op. cit., p. 43.

431 JIMÉNEZ CLAR, A.J., «La hipoteca...», op. cit., p. 118.

432 SerRano de Nicolás, Á., «Régimen jurídico...», op. cit., p. 53.
} 
En sentido parecido CarRasco Perera y CoRdero Lobato ${ }^{433}$ subrayan que: «en el caso de la hipoteca inversa, no se trata de un genuino pacto de anatocismo, pues en éste sólo se capitalizan intereses vencidos, mientras que en la hipoteca inversa la deuda sólo es exigible en el momento del fallecimiento del deudor o, en su caso, del último beneficiario".

A este respecto, MARTíNEZ ESCRIBANO ${ }^{434}$ señala también las especialidades que este pacto tiene en materia de hipoteca inversa cuando, a la hora de indicar que tanto principal e intereses serán exigibles en el momento de fallecimiento, destaca que puede resultar difícil «encajar un pacto de anatocismo con relación a unos intereses que, según la ley, aún no son exigibles $\mathrm{y}$, por tanto, no se ha producido su vencimiento».

En sentido contrario se muestra JIMÉNEZ CLAR ${ }^{435}$ al defender la doctrina de la DGRN en virtud de la cual: «los intereses sólo pueden ser reclamados en cuanto a tales y dentro de los límites legales y pactados pero nunca englobados en el capital».

Sin embargo, no se debe olvidar que un pacto de este estilo encarece enormemente la operación produciéndose un perjuicio para el deudor. En el caso de la hipoteca inversa, al incremento en el coste hay que oponer la rentabilidad de la operación, condición necesaria que debe darse si el legislador pretende introducir esta figura en el mercado y crear oferta de un producto con el que se pretende paliar la falta de recursos de financiación ${ }^{436}$.

La Ley 41/2007 no se ha pronunciado sobre la posible admisión de un pacto de anatocismo, pero, ante el silencio de la misma, la $\operatorname{DGRN}^{437}$ sí lo ha hecho y además, en sentido favorable. Tales argumentos son aplicables tanto a la hipoteca inversa constituida conforme a los requisitos establecidos en la Ley $41 / 2007$, como a las hipotecas inversas constituidas al margen de la

\footnotetext{
433 Carrasco Perera, Á. y Cordero lobato, E., «La hipoteca inversa... », op. cit., p. 2.

${ }^{434}$ MARTínez EsCRIBANo, C., La hipoteca inversa, op. cit., p.133.

435 JIMÉnEZ CLAR, A.J., «La hipoteca...», op. cit., p. 118.

${ }^{436}$ MARTínez Escribano, C., La hipoteca inversa, op. cit., pp. 132 y 133.

${ }^{437}$ La Resolución de la DGRN de 1 de octubre de 2010, en su fundamento de derecho quinto señala: «en este tipo de hipoteca la incertidumbre existente sobre el momento de vencimiento del préstamo o crédito garantizado impide un cálculo exacto del riesgo financiero, por lo que debe permitirse que los intereses se sumen al capital, a través de la correspondiente partida de cargo en la cuenta» $\mathrm{y}$ «dado que los intereses devengados no son pagaderos hasta el fallecimiento del acreditado, puedan acumularse al capital, pues el interés ya devengado hasta entonces no puede ser reclamado por separado».
} 
citada ley, bien a través de un préstamo, bien a través de un crédito. En todo caso, en la inscripción de una hipoteca inversa deberá constar una cifra máxima de responsabilidad hipotecaria para responder en materia de intereses.

\section{RESPONSABILIDAD PERSONAL Y REAL}

La hipoteca inversa se configura como un contrato personalísimo donde se tendrá en cuenta la edad del deudor, y la garantía será el valor de la vivienda asegurada con esta modalidad hipotecaria. La vivienda que se dé en garantía quedará afectada en todo su valor a la totalidad de la deuda que exista en el momento del vencimiento ${ }^{438}$, es decir, al fallecimiento del deudor o del último de los beneficiarios. Así pues, la vivienda será la garantía que tendrá la entidad acreedora para recuperar las cantidades que haya prestado junto con los intereses y los gastos.

De esta manera, cuando fallezca el deudor o el último beneficiario se procederá al pago de la deuda. Este pago se podrá realizar de distintas formas $^{439}$ : con el dinero que se obtenga de la venta de la vivienda hipotecada, bien de forma voluntaria o bien de forma forzosa. Otra posibilidad sería que los herederos liquidaran la deuda por su cuenta.

Con ello, observamos que en la hipoteca inversa la responsabilidad personal y la responsabilidad real no podrán separarse, pues al ser el valor de la vivienda la causa del contrato, al deudor, a diferencia de lo que sucede con las hipotecas convencionales, no se le exigirá que justifique la existencia de otros ingresos u otro patrimonio, tan sólo se le requerirá la posesión de la vivienda que hipotecó en su día de forma inversa.

De esta manera, la entidad acreedora pretenderá que la deuda quede completamente garantizada con el valor que tenga la vivienda en el momento

\footnotetext{
438 Álvarez Álvarez, H., La hipoteca inversa..., op. cit., p. 129.

${ }^{439}$ Estas formas de liquidar la deuda se verán más adelante.
} 
del fallecimiento del deudor. Por tanto, mientras el deudor viva, responsabilidad real y personal coincidirán en la misma persona del deudor y lo mismo sucederá cuando éste fallezca y la vivienda pase a sus herederos, ya que todo el valor del inmueble estará afectado por la deuda.

De lo citado se desprende que de cualquier obligación que esté reforzada con garantía real surgirá una doble responsabilidad patrimonial: la personal, que será ilimitada, en virtud de lo previsto en el artículo 1911 del CC, y la real ${ }^{440}$, que será limitada, pues se concreta sólo a bienes determinados.

Ahora bien, en el caso de la hipoteca inversa, los herederos que acepten esta herencia sólo responderán hasta donde alcance la responsabilidad hipotecaria. Por consiguiente, no será de extrañar que los herederos, como continuadores de la personalidad jurídica del deudor fallecido y a la hora de hacer frente a la misma, no quieran aceptar la herencia o, en su caso, la acepten a beneficio de inventario, pues lo más normal en estas situaciones es que el deudor sólo tenga en propiedad la vivienda hipotecada inversamente.

Al respecto, el apartado 6 de la DA 1. ${ }^{a}$ de la Ley 41/2007 señala que:

«Cuando se extinga el préstamo o crédito regulado por esta disposición y los herederos del deudor hipotecario decidan no reembolsar los débitos vencidos, con sus intereses, el acreedor sólo podrá obtener recobro hasta donde alcancen los bienes de la herencia».

A tenor del contenido, el acreedor podrá reclamar a los herederos no sólo sobre la vivienda hipotecada inversamente, sino también sobre otros bienes patrimoniales que pudiera tener el causante ${ }^{441}$. Esto nos lleva a pensar

\footnotetext{
$\overline{440}$ Cfr. Canals Brage, F., «El incierto porvenir de la hipoteca en España (a propósito de algunos proyectos más o menos normativos)», La Ley, núm. 6691, 12 de abril de 2007, p. 130.

${ }^{441}$ MARTínez EsCRIBANO, C., La hipoteca inversa, op. cit., p. 126. La citada autora, en relación con la garantía que supone la vivienda para la devolución del préstamo, indica que el apartado 6 de la DA 1. ${ }^{a}$ de la Ley 41/2007 limita la responsabilidad por el préstamo garantizado con hipoteca inversa al patrimonio hereditario. De este modo, no necesariamente queda limitada la responsabilidad a la vivienda gravada con la hipoteca, pese a los diversos intentos durante la tramitación parlamentaria de
} 
que los herederos acepten la herencia a beneficio de inventario según lo establecido en el Código Civil.

En este caso, no se va contra el principio de responsabilidad universal del deudor, que está previsto que sólo pueda limitarse en casos excepcionales en atención a situaciones de especial protección de la persona, como puede ser el caso de la hipoteca de responsabilidad limitada del artículo 140 de la LH, en esta hipoteca, la responsabilidad efectiva de la misma sólo recaerá en el bien hipotecado. Ahora bien, lo habitual es, que este tipo de $\operatorname{pactos}^{442}$ no se suelan dar.

La hipoteca inversa, no goza de especial protección jurídica en la que se excluya la responsabilidad personal tanto del deudor como de sus herederos, pues éstos tienen la posibilidad de aceptar la herencia a beneficio de inventario. Así, en lugar de aplicarse la limitación del artículo 140 de la LH en los casos de vencimiento ordinario, con la hipoteca inversa, la obligación asegurada sólo se podría hacer efectiva sobre el inmueble gravado, que no es otro que la vivienda habitual.

El crédito hipotecario, como relación jurídica compleja, requiere la existencia de dos elementos: crédito e hipoteca. De ellos, a su vez, nacen dos acciones diferentes: la personal y la real, generándose dos tipos de responsabilidad: igualmente la personal y la real. La primera de estas responsabilidades, por aplicación del artículo 1911 del CC, afectará a todos los bienes del deudor, mientras que la responsabilidad real afectará sólo a los bienes hipotecados ${ }^{443}$.

la Ley para restringir la responsabilidad al inmueble hipotecado (Enmiendas núm. 25, 100 y 124 en el Congreso y enmiendas núm. 24, 68 y 98 en el Senado). En la hipoteca inversa estadounidense, la responsabilidad sí que está limitada al valor del inmueble, en consonancia con el planteamiento general de las hipotecas, pues en Estados Unidos la responsabilidad se limita siempre al inmueble hipotecado.

442 Álvarez Álvarez, H., La hipoteca inversa..., op. cit., p.130; ZuRITA MARTíN, I., «La nueva normativa...», op. cit., p. 1292.

${ }^{443}$ Esto, en virtud del artículo 1876 del CC, por el que: «La hipoteca sujeta directa e inmediatamente los bienes sobre que se impone, cualquiera que sea su poseedor, al cumplimiento de la obligación para cuya seguridad fue constituida». Y, de la misma manera, el artículo 104 de la LH. Mientras que, en el artículo 105 de la LH podemos comprobar la coexistencia de ambas responsabilidades: «La hipoteca podrá constituirse en garantía de toda clase de obligaciones y no alterará la responsabilidad personal ilimitada del deudor que establece el artículo 1.911 del Código Civil». 
Sin embargo, hay algunos preceptos que imposibilitan la aplicación del artículo 1911 del CC, limitando así la responsabilidad. Entre estos artículos podemos destacar:

- El artículo 605 de la LEC ${ }^{444}$ donde se señalan los bienes absolutamente inembargables.

- El 140 de la LH por el que se limita la responsabilidad a los bienes hipotecados, en nuestro caso, a la vivienda habitual.

- También podemos hacer referencia al artículo 1807 del CC ${ }^{445}$, donde se indica que: «El que constituye a título gratuito una renta sobre sus bienes, puede disponer, al tiempo del otorgamiento, que no estará sujeta dicha renta a embargo por obligaciones del pensionista».

No obstante, aunque se tengan en cuenta estos artículos, el deudor hipotecario responderá con todos sus bienes del pago de la deuda y, por tanto, no sólo con la vivienda hipotecada. Es decir, la responsabilidad personal no desaparecerá del todo, ya que si la vivienda hipotecada no fuera suficiente, el acreedor podría perseguir el resto de los bienes de la herencia hasta satisfacer su crédito.

En el caso de la hipoteca inversa, el procedimiento de ejecución hipotecaria se utilizará para cobrar la deuda con el límite del valor del bien hipotecado. $Y$ en el supuesto de que no pueda cobrarse la totalidad de la deuda se deberá acudir a un procedimiento ejecutivo ordinario sobre el resto de los bienes del deudor.

También cabría la posibilidad de que la finca hipotecada inversamente fuera objeto de disposición testamentaria por el testador, en el sentido de

\footnotetext{
${ }^{444}$ El precepto dice que: «No serán en absoluto embargables:

$1 .^{\circ}$ Los bienes que hayan sido declarados inalienables.

2. ${ }^{\circ}$ Los derechos accesorios, que no sean alienables con independencia del principal.

$3 .^{\circ}$ Los bienes que carezcan, por sí solos, de contenido patrimonial.

$4{ }^{\circ}$ Los bienes expresamente declarados inembargables por alguna disposición legal».

${ }^{445}$ Este artículo lo tenemos que poner en relación con el artículo $820.3^{\circ}$ del mismo texto legal, en el que se hace referencia a lo siguiente: «Si la manda consiste en un usufructo o renta vitalicia, cuyo valor se tenga por superior a la parte disponible, los herederos forzosos podrán escoger entre cumplir la disposición testamentaria o entregar al legatario la parte de la herencia de que podía disponer libremente el testador».
} 
legarla. Incluso podría suceder que no se respetase la intangibilidad cualitativa de la legítima por existir un gravamen sobre ella. De esta forma, con el fin de evitar los problemas que puedan surgir de la separación entre responsabilidad personal y real, sería lógico establecer, por ejemplo, la prohibición de disponer de la vivienda o la prohibición del vencimiento anticipado por enajenación sin consentimiento por parte de la entidad acreedora. Aunque el problema de estas prohibiciones es que, éstas, no se podrían pactar, pues conforme a la doctrina de la $\mathrm{DGRN}^{446}$, no serían inscribibles en el Registro de la Propiedad.

Por tanto, en la hipoteca inversa no se permitirá lo que sí es posible para la hipoteca convencional a través de pacto. En este sentido, el artículo 140 de la LH establece que será válido el pacto contenido en la escritura de constitución de la hipoteca voluntaria, en virtud del cual la obligación garantizada se hará solamente efectiva sobre los bienes hipotecados, por lo que la responsabilidad del deudor y la acción del acreedor quedarán limitadas al importe de los bienes hipotecados, no alcanzando al resto de los bienes del deudor.

Es decir, se admitirá el pacto entre acreedor y deudor, por el cual se concrete la responsabilidad personal al importe de la obligación asegurada. A juicio de ÁLVAREZ ${ }^{447}$, «Esto no supone que la responsabilidad esté limitada al valor de los bienes gravados, sino que como el acreedor no puede cobrar su deuda sobre otros bienes diferentes de la vivienda hipotecada, la responsabilidad está concretada y eventualmente limitada, en el caso de que el remate sea insuficiente para cobrar el crédito, al valor del inmueble gravado».

Según el artículo 140 de la LH, la responsabilidad del deudor y la acción del acreedor, en virtud del préstamo hipotecario, quedarán limitadas al importe de los bienes hipotecados, no alcanzando los demás bienes del

\footnotetext{
${ }^{446}$ Entre otras, destacar las Resoluciones de la DGRN de 27 de enero de 1986 (RJ 1986\1002) y de 23 de octubre de 1987 (RJ 1987 7660 ).

447 Álvarez ÁlvareZ, H., La hipoteca inversa..., op. cit., p. 132.
} 
patrimonio del deudor. Así, la responsabilidad no estaría limitada pro viribus, sino cum viribus ${ }^{448}$.

En resumen, el artículo 140 de la LH permitirá el pacto por el que se limite la responsabilidad del deudor al importe de los bienes hipotecados. Ahora bien, si nos atenemos al apartado $6^{449}$ de la DA $1 .^{\mathrm{a}}$ de la Ley por la que se regula la hipoteca inversa, este pacto no se podrá realizar, pues en los casos de ejecuciones de hipotecas inversas esta posibilidad no se admite. Además, este pacto tampoco se utiliza en la práctica diaria. Esto se debe a que no es fácil que se constituyan hipotecas con el pacto de limitación de responsabilidad al importe de los bienes hipotecados, pues el acreedor prescindiría gratuitamente de la garantía patrimonial universal del deudor.

Como regla general, para que se admita el pacto del artículo 140 de la LH, y con ello, la responsabilidad no exceda del valor de la finca hipotecada, será preciso lo siguiente:

- El pacto sólo será válido en el momento de la constitución de la hipoteca. Ahora bien, el problema del pacto no surgirá en la constitución de la hipoteca, sino cuando la finca hipotecada se transmita a un tercero y éste adquiera la finca con esa posible responsabilidad personal limitada al bien hipotecado.

- Este pacto sólo será válido para las hipotecas voluntarias y no para las legales.

- Deberá tratarse de una hipoteca en garantía de un préstamo hipotecario, es decir, deberá basarse en una deuda inherente a la propiedad de la finca.

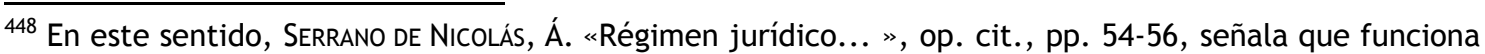
de forma similar a la aceptación de la herencia a beneficio de inventario, pues con el pacto del artículo 140 de la LH la responsabilidad personal del deudor se concreta en la cosa hipotecada, es decir, opera cum viribus, a diferencia de la responsabilidad limitada pro viribus, en la cual subsiste la responsabilidad general o universal, pero tan solo exigible hasta el límite del valor del bien hipotecado. Sin embargo, a pesar de tal pacto, el crédito subsiste aunque su ejecución forzosa tenga que realizarse sólo sobre el valor de la finca gravada, es decir, como el deudor no deja de serlo a pesar del pacto del artículo 140 de la $\mathrm{LH}$, es plenamente válido los pagos voluntarios que éste pudiera realizar. Cfr. CORDERO LOBATO, E., Tratado de..., op. cit., pp. 562 y 563; ChICO y ORTIZ, J.M., Estudios sobre..., op. cit., p. 1422. 449 No obstante, en el caso de que el deudor viva más de lo esperado y se distorsionen los cálculos actuariales realizados en relación al valor del inmueble, el montante de lo adeudado podría superar el valor de la finca hipotecada.
} 
Por tanto, la extinción de la hipoteca significará también la extinción de la deuda personal.

Además de esto, también se ha de hacer mención a la figura del tercero. Abundando en él, la profesora ÁlvAREz ${ }^{450}$ plantea la posibilidad de pactar un límite de responsabilidad para que éste no resulte perjudicado. Este límite sería el valor que alcanzase la venta de la vivienda -bien de manera voluntaria o bien de manera forzosa-, por lo que en caso de ejecución de la hipoteca, el tercer adquirente respondería de la totalidad de la deuda sólo hasta donde llegase el valor total de venta de la vivienda.

En este sentido, MURO VILLALóN ${ }^{451}$ considera que si la obligación del deudor fuera una obligación propter rem, se solucionaría este problema de diferenciación entre responsabilidad personal y real. De esta forma, se evitaría que en el caso de que la deuda final fuera superior a la responsabilidad hipotecaria, el tercer adquirente sólo respondería de la cantidad máxima garantizada, con lo que haría suya la revalorización del inmueble por la diferencia, mientras que los herederos del deudor tendrían que hacer frente a la parte de la deuda no cubierta por la hipoteca.

Llegados aquí, cabría hacer una mención especial al artículo 157 de la $\mathrm{LH}$, párrafo tercero in fine $e^{452}$. Este precepto ${ }^{453}$ configura las prestaciones censales como una carga real, de manera que el débito quedará unido a la responsabilidad de carácter real. En este aspecto, si consideramos que la hipoteca inversa tiene naturaleza ob rem, de modo similar al censo, la deuda

\footnotetext{
450 Álvarez Álvarez, H., La hipoteca inversa..., op. cit., p. 133.

${ }^{451}$ MURO VILLALÓN, J.V., «La hipoteca...», op. cit., pp. 17 y 18.

452 En el mismo se establece que: «El que remate los bienes gravados con tal hipoteca los adquirirá con subsistencia de la misma y de la obligación de pago de la pensión o prestación hasta su vencimiento. Iguales efectos producirá la hipoteca en cuanto a tercero; pero respecto a las pensiones vencidas y no satisfechas, no perjudicarán a éste sino en los términos señalados en los artículos 114 y párrafos $1^{\circ}$ y $2^{\circ}$ del 115 de esta Ley».

${ }^{453}$ Anguita Ríos, R.M., Aspectos críticos en la estructura de la hipoteca inmobiliaria, Dykinson, Madrid, 2006, pp. 221 y 224, considera que la ratio del art. 157 de la LH es establecer una excepción al sistema general de ejecución hipotecaria produciéndose un supuesto de asunción automática de la deuda, puesto que ante una obligación de naturaleza peculiar le corresponde un sistema especial.
} 
se atribuirá ob rem, debiendo pues satisfacerla el sujeto que en cada momento sea propietario de la cosa hipotecada.

No obstante, al igual que en el censo, existirán dos acciones: una real, la de hipoteca, para reclamar todas las pensiones vencidas y, otra personal, para pedir las rentas o pensiones devengadas mientras el demandado haya sido propietario de la cosa. Y, además, se asumirá la deuda tanto en el caso de enajenación extrajudicial como judicial de los bienes hipotecados.

Al igual que sucede en las pensiones censales, si se considerara que existiese una obligación ob rem, no habría distinción entre responsabilidad personal y responsabilidad real, por lo que el nuevo adquirente del inmueble gravado con la hipoteca inversa adquiriría la obligación de pagar la deuda generada al acreedor.

Por tanto, el tercer adquirente del bien sobre el que recaiga una hipoteca inversa se subrogará en la responsabilidad real derivada del gravamen de la hipoteca y también en la obligación personal garantizada. Así, la hipoteca inversa tendría la característica propia de las prestaciones censales, es decir, el débito quedaría unido con la responsabilidad real, de forma que la obligación personal sería inseparable de la responsabilidad real.

En este aspecto, de acuerdo con el artículo 157 de la $\mathrm{LH}$, el adjudicatario $^{454}$ del bien o bienes hipotecados pasaría a convertirse en el nuevo obligado a satisfacer la deuda generada. Con esta subrogación, el legislador quiere garantizar la posición acreedora de la entidad de crédito, pues en el supuesto de que no se tratase de una obligación ob rem, la parte acreedora vería mermadas las expectativas de cobro de la deuda.

No obstante, aunque se produzca la subrogación del adquirente del inmueble en la posición del deudor de las pensiones, en la hipoteca inversa, al

\footnotetext{
454 Sobre la hipoteca en garantía de rentas o prestaciones periódicas, vid., con mayor detalle ÁlVAREZ ÁlvareZ, H., «El legado de rentas o prestaciones periódicas: su protección registral», La Ley, Madrid, 2007, pp. 204 y ss.
} 
igual que las hipotecas ordinarias, tendrá carácter accesorio en el momento de su constitución (donde existe débito personal y real) y, en consecuencia, sólo cuando se transmita el inmueble hipotecado inversamente, se producirán las diferencias con respecto a las otras hipotecas. Por consiguiente, en el caso de que no se produjera ni la ejecución ni la transmisión voluntaria de la finca, la hipoteca inversa se configuraría con carácter accesorio y con dualidad de responsabilidades: de la misma forma en que lo hacen las hipotecas convencionales.

La obligación del deudor como una obligación propter rem supondrá una mayor protección para el acreedor, pues aunque el inmueble sea propiedad de un tercero, éste tendrá garantizado el cobro del valor que alcance la finca en el momento de la venta, bien de manera voluntaria, bien de manera forzosa. En este caso, también deberá ser tenido en cuenta que siempre existirá un riesgo ${ }^{455}$ para la entidad financiera, pues como ya se ha comentado, el precio de esta vivienda hipotecada podrá sufrir una revalorización pero también una devaluación.

En la actualidad, el precio de la vivienda ha bajado de forma considerable y todavía se prevé que siga bajando hasta $2020^{456}$, cosa que no ocurría, ni tan siquiera se visionaba, en el año 2007, cuando se creó la Ley 41/2007. De esta forma, en el caso de vender la vivienda sobre la que recae una hipoteca inversa, lo más probable es que el precio de la venta sea inferior al de la deuda generada, originando así, un problema para la entidad acreedora.

\section{LA EXTENSIÓN DE LA HIPOTECA INVERSA}

\footnotetext{
${ }^{455}$ Vid. RDGRN de 8 de noviembre de 1993 (RJ 1993\9114).

456 Para una mayor información vid. artículo publicado en http://www.elconfidencial.com en fecha de 17 de septiembre de 2014 donde se indica que el precio de la vivienda en España seguirá bajando durante los próximos 14 años. También se puede consultar el artículo publicado en $A B C$ titulado: ¿El precio de la vivienda sube o baja? El caos de los datos oficiales en España, disponible en: http://www.abc.es/economia/20140920/abci-precios.
} 
Respecto a la extensión ${ }^{457}$ de la hipoteca tendremos que acudir a los artículos 109 a 113 de la LH, 215 del RH y 1877 del CC. A continuación, se examinan estos artículos con mayor detalle.

El artículo 109 de la LH indica el ámbito de extensión de la hipoteca ${ }^{458}$, de esta forma, la hipoteca se extiende a las accesiones naturales, a las mejoras y al importe de las indemnizaciones concedidas o debidas al propietario por razón de los bienes hipotecados.

En el artículo 110 del mismo texto legal se detallan todos los bienes o elementos objeto de ser hipotecados juntamente con la finca, aunque no se mencionen en el contrato, siempre que corresponda al propietario. De esta manera, nos podremos encontrar con:

- Las mejoras que consistan en nuevas plantaciones, obras de riego o desagüe, obras de reparación, seguridad, transformación, comodidad, adorno o elevación de los edificios y cualesquiera otras semejantes que no consistan en agregación de terrenos, excepto por accesión natural, o en nueva construcción de edificios donde antes no los hubiere.

- Las indemnizaciones ${ }^{459}$ concedidas o debidas al propietario de los inmuebles hipotecados por razón de éstos, siempre que el siniestro o hecho que las motivare hubiere tenido lugar después de la constitución de la hipoteca y, asimismo, las procedentes de la expropiación de los inmuebles por causa de utilidad pública.

\footnotetext{
$\overline{457}$ En este aspecto, la RDGRN de 31 de marzo de 2014 (TOL4.234.476) señala que la extensión objetiva de la hipoteca comprenderá los elementos mencionados en los artículos 109, 110 y 111 de la Ley Hipotecaria.

458 Vid. la Resolución de la DGRN de 16 de marzo de 1990 (RJ 199012301).

459 Atendiendo al artículo 110 de la $\mathrm{LH}$, párrafo $2^{\circ}$ in fine: «Si cualquiera de estas indemnizaciones debiera hacerse efectiva antes del vencimiento de la obligación asegurada y quien haya de satisfacerlas hubiere sido notificado previamente de la existencia de la hipoteca, se depositará su importe en la forma que convengan los interesados o, en su defecto de convenio, en la establecida por los artículos 1.176 y siguientes del Código Civil».
} 
De la misma manera, en el artículo 111 de la citada Ley se concretan los bienes que no podrán ser hipotecados salvo pacto expreso o disposición legal en contrario. De esta forma, no se incluirán:

- Los objetos muebles que se hallen colocados de manera permanente en la finca hipotecada, bien para su adorno, comodidad o explotación, o bien para el servicio de alguna industria.

- Los frutos, cualquiera que sea la situación en que se encuentren.

- Las rentas vencidas y no satisfechas al tiempo de exigir el cumplimiento de la obligación garantizada.

En este caso, se tendría que hacer una puntualización, pues en el artículo 108 de la misma Ley, también se especifica qué servidumbres, usufructos y derechos no serán objeto de hipoteca. Así, junto a lo contenido en el artículo 111, tampoco se podrán hipotecar:

- Las servidumbres a menos que se hipoteque juntamente con el predio dominante, y exceptuándose, en todo caso, la de aguas, la cual, podrá ser hipotecada.

- Los usufructos legales, excepto el concedido al cónyuge viudo por el Código Civil.

- El uso y la habitación.

En el siguiente precepto, en el artículo 112 se hace referencia a la figura del tercer poseedor y a la extensión de la hipoteca adquirida por éste. En este aspecto, el artículo 113 de la LH hace mención al dueño de las accesiones y mejoras no hipotecadas pero que se encuentren dentro de la finca hipotecada.

Si atendemos al Reglamento Hipotecario, en su artículo 215 párrafo primero, se amplía la extensión de la hipoteca con respecto a lo contenido en el artículo 111 de la LH, señalando que: «La hipoteca se extenderá al exceso de cabida de la finca hipotecada que se haya hecho constar en el Registro con posterioridad a la inscripción de aquélla». 
Y, por último, apuntar que en el artículo 1877 del CC se aborda la extensión de la hipoteca. De tal forma, que ésta se extenderá a las accesiones naturales, a las mejoras, a los frutos pendientes y rentas no percibidas al vencer la obligación, y al importe de las indemnizaciones concedidas o debidas al propietario por los aseguradores de los bienes hipotecados. Y en el supuesto de expropiación por causa de utilidad pública, se extenderá a las declaraciones, ampliaciones y limitaciones establecidas por la ley, tanto en el caso de permanecer la finca en poder del que la hipotecó, como en el de pasar a manos de un tercero.

De esta manera, lo regulado en estos preceptos se podría considerar como la extensión objetiva o natural de la hipoteca, que se podrá ampliar a las accesiones naturales, a las mejoras realizadas en la cosa, a las indemnizaciones que correspondan al hipotecante como consecuencia de un siniestro o de una expropiación forzosa y a las servidumbres de las que el predio hipotecario sea a su vez predio dominante.

Conforme al artículo 1255 del CC y al citado artículo 111 de la LH también se podría dar la posibilidad de establecer una determinada extensión de la hipoteca a través de pacto. De esta manera y atendiendo al artículo 1255 del CC, los contratantes podrían establecer los pactos, cláusulas y condiciones que tengan por conveniente, siempre y cuando no sean contrarios a las leyes, a la moral, ni al orden público. Esta extensión de hipoteca a través de pacto se ha convertido en una cláusula de estilo ${ }^{460}$, a través de la cual se pactaría el alcance de la misma: la extensión de los bienes muebles, los frutos y las rentas del bien hipotecado.

En el caso de la hipoteca inversa, si se diera alguno de los supuestos aquí analizados, es decir, que la vivienda ${ }^{461}$ sufriera una accesión natural,

\footnotetext{
${ }^{460}$ Así lo califica Álvarez Álvarez, H., La hipoteca inversa..., op. cit., p. 161.

461 En el caso de que la hipoteca recaiga sobre un bien inmueble sometido al régimen de propiedad horizontal, se atenderá a lo establecido en la Ley de Propiedad Horizontal (BOE, núm. 176, de 23 de julio de 1960). Al efecto, el artículo 3 (artículo modificado por la DF 1.2 de la Ley $8 / 2013$, de 26 de
} 
unas mejoras sobre la misma, etc., esta extensión en la vivienda la recibirían los herederos, la entidad acreedora o, si se diera el caso, un tercer adquirente, una vez hubiera fallecido el deudor o el último de los beneficiarios.

Por tanto, la vivienda hipotecada inversamente se podrá extender a otros bienes de los hipotecados en el momento de su constitución. De esta manera, no será necesario establecer ningún pacto con ninguna de las partes contratantes ni tampoco será necesario realizar ningún acto de constitución de hipoteca sobre esos nuevos bienes.

En conclusión, la hipoteca inversa se extenderá a aquellos elementos que en el momento de exigir el cumplimiento de la obligación garantizada integren la vivienda o formen parte de ella.

junio (BOE-A-2013-6938)) dispone: «En el régimen de propiedad establecido en el artículo 396 del Código Civil corresponde a cada piso o local:

a) El derecho singular y exclusivo de propiedad sobre un espacio suficientemente delimitado y susceptible de aprovechamiento independiente, con los elementos arquitectónicos e instalaciones de toda clase, aparentes o no, que estén comprendidos dentro de sus límites y sirvan exclusivamente al propietario, así como el de los anejos que expresamente hayan sido señalados en el título, aunque se hallen situados fuera del espacio delimitado.

b) La copropiedad, con los demás dueños de pisos o locales, de los restantes elementos, pertenencias y servicios comunes.

A cada piso o local se le atribuirá una cuota de participación con relación al total del valor del inmueble y referida a centésimas del mismo. Dicha cuota servirá de módulo para determinar la participación en las cargas y beneficios por razón de la comunidad. Las mejoras o menoscabos de cada piso o local no alterarán la cuota atribuida, que sólo podrá variarse de acuerdo con lo establecido en los artículos 10 y 17 de esta Ley.

Cada propietario puede libremente disponer de su derecho, sin poder separar los elementos que lo integran y sin que la transmisión del disfrute afecte a las obligaciones derivadas de este régimen de propiedad». 



\section{CAPÍTULO VI: VENCIMIENTO Y LIQUIDACIÓN DE LA HIPOTECA INVERSA}

\section{FALLECIMIENTO DEL DEUDOR HIPOTECARIO O DEL ÚLTIMO DE LOS BENEFICIARIOS}

Esta causa está contemplada en el Apartado 5 de la DA $1 .^{\text {a }}$ de la Ley $41 / 2007^{462}$. La devolución de lo prestado sólo se podrá solicitar una vez que el deudor o el beneficiario de la vivienda fallezcan, o cuando se incumplan las obligaciones derivadas de la contratación de la hipoteca inversa. Por tanto, el acreedor no podrá solicitar la devolución del dinero prestado hasta que la vivienda se venda o hasta que el propietario o el último de los beneficiarios del crédito fallezcan. En este último caso, si así se establece en el contrato.

Como ya se ha comentado en puntos anteriores, en el caso de que se contrate una hipoteca inversa en su modalidad temporal, cuando se alcance el porcentaje del valor de tasación fijado en el momento de su constitución, el titular de la vivienda dejará de disponer de la renta, pero la deuda seguirá generando intereses.

La deuda estará compuesta por el crédito o préstamo más los intereses generados y se recuperará por la entidad de crédito ${ }^{463}$ cuando fallezca el deudor. Cuando esto suceda, la entidad financiera no cobrará ningún tipo de comisión por cancelación de la hipoteca, ya que, en esta figura, el fallecimiento del deudor y el vencimiento del contrato van unidos.

En cuanto a los beneficiarios, la Ley no especifica un número. No obstante, como ya se ha comentado, las entidades acreedoras no admitirán un número elevado. Dichos beneficiarios también deberán tener 65 años o más 0

\footnotetext{
${ }^{462}$ En el párrafo primero se establece que: «Al fallecimiento del deudor hipotecario, sus herederos $\mathrm{o}$, si así se estipula en el contrato, al fallecimiento del último de los beneficiarios, podrán cancelar el préstamo, en el plazo estipulado, abonando al acreedor hipotecario la totalidad de los débitos vencidos, con sus intereses, sin que el acreedor pueda exigir compensación alguna por la cancelación».

${ }^{463}$ En términos generales, las facultades del acreedor hipotecario son el derecho de realización del valor (derecho a promover la enajenación forzosa, derecho de preferencia sobre el bien hipotecado, derecho de ejecución separada en caso de concursos de acreedores en consonancia con la Ley Concursal), facultades de defensa y conservación del derecho real de hipoteca, facultades de disposición (el crédito hipotecario puede enajenarse o cederse en todo o en parte) y la acción de devastación (si la finca hipotecaria se deteriorase disminuyendo de valor por dolo, culpa o voluntad del deudor hipotecario).
} 
estar afectados de dependencia o ser personas a las que se les haya reconocido un grado de discapacidad igual o superior al 33 por ciento. Cuando se reguló por primera vez la Ley 41/2007, los beneficiarios tenían que ser personas de 65 o más años o estar afectadas de dependencia severa o gran dependencia.

Como ya se ha visto, estos beneficiarios, al no participar en la constitución de la hipoteca inversa, no serán parte de la relación hipotecaria y, por tanto, no deudores. Además, su herencia no quedará afectada por la deuda. Junto a esto, la figura del beneficiario en la hipoteca inversa, tal y como se ha explicado en el punto concerniente a su estudio, genera incertidumbre sobre el plazo en el que debe devolverse el préstamo. Éstos deberán sobrevivir al deudor, por lo que si transcurre mucho tiempo desde que muere el deudor hasta que lo hace el último de ellos, podrán surgir problemas hereditarios, pues antes de proceder a la partición y liquidación de la herencia del deudor se tendrá que esperar a que fallezca el último beneficiario para poder reclamar la deuda ${ }^{464}$.

Aunque la Ley no lo diga expresamente, se ha considerado por algún sector doctrinal que los beneficiarios deberán residir en la vivienda hipotecada, pues al tener la condición de beneficiarios, el deudor, lo que pretende es evitar que, si se diera el caso de ejecución de la garantía por impago de los herederos, estos últimos perdieran la posesión de la vivienda ${ }^{465}$. A juicio de ÁlvAREZ ${ }^{466}$, como la Ley no lo exige, no será necesario que el beneficiario viva en la finca hipotecada ni que tenga siquiera ningún tipo de parentesco con el deudor.

En este sentido, JIMÉNEZ CLAR ${ }^{467}$ se planteó si el fallecimiento del deudor hipotecario era la única causa para el vencimiento de la hipoteca inversa o si, por el contrario, cabía la posibilidad de que el fallecimiento del beneficiario

\footnotetext{
${ }^{464}$ Martínez Escribano, C., La hipoteca inversa, op. cit., p. 46, entiende que tendrá que existir un pacto para que haya beneficiarios y, una vez se hayan nombrado éstos, el préstamo vencerá al fallecimiento del último de los beneficiarios.

${ }^{465}$ RAMOS ChAPARRO, E.J., La garantía..., op. cit., pp. 575 y 576.

${ }^{466}$ Álvarez Álvarez, H., La hipoteca inversa..., op. cit., p. 116.

467 JIMÉNEZ CLAR, A.J., «La hipoteca...», op. cit., p. 129.
} 
se produjera con anterioridad al del deudor y, como consecuencia, diera lugar a dicho vencimiento.

La respuesta que da este autor es que si ésta fuera afirmativa, podría dar lugar a la pérdida del uso de la vivienda por parte del deudor hipotecario. Esta posibilidad sería perfectamente admisible, siempre que se hubiera hecho constar en la escritura de constitución de hipoteca inversa, advirtiendo, de forma expresa, al deudor hipotecario, de las consecuencias que para él comportaría un pacto de esta naturaleza.

No obstante, consideramos que esta situación no tiene cabida en la hipoteca inversa, pues aunque sea el deudor una de las partes en adoptar esta posibilidad, pensamos que éste, al contratar esta hipoteca quiere seguir viviendo en su casa hasta el final de sus días, teniendo los menos problemas posibles.

En definitiva, con la muerte del propietario o del último beneficiario de la vivienda hipotecada debería producirse la extinción de dicha hipoteca, pero para que esto sea así se tendrá que cancelar también la deuda. Simplemente, con la extinción de la hipoteca inversa desaparecerá la realidad jurídica y, además, deberá extinguirse la deuda ${ }^{468}$.

Otro de los problemas que plantea la hipoteca inversa es este plazo ${ }^{469}$ de cancelación de la deuda. Con el fin de evitar que la entidad financiera

\footnotetext{
468 Atendiendo a Roca SASTRE, R.M. y RoCa-SASTRE MUNCUNILL, L., Derecho hipotecario: Hipotecas, tomo VIII, op. cit., pp. 129 y ss. Las causas de extinción del derecho real de hipoteca convencional son las siguientes: extinción o ineficacia de la obligación garantizada, renuncia del derecho de hipoteca, acuerdo extintivo entre acreedor y el propietario gravado, pérdida de la finca hipotecada o extinción del derecho real gravado incluso por expropiación, por consumación o agotamiento (ejercicio de la acción hipotecaria), purga o liberación derivada de la ejecución operada en virtud de una hipoteca anterior o preferente, confusión, expiración del término o cumplimiento de la condición resolutoria, denuncia del hipotecante o dueño de la cosa gravada, prescripción, caducidad de la inscripción, cancelación del asiento y cancelación de la hipoteca voluntaria constituida por acto unilateral del dueño de la finca o titular del derecho hipotecado si transcurridos dos meses no consta aceptación del beneficiario (art. 141 de la LH).

${ }^{469}$ Antes de la Ley $41 / 2007$, las entidades que ofertaban las hipotecas inversas daban a los herederos un tiempo de carencia para tomar una decisión, normalmente este plazo era de 6 meses. Aunque, a modo de ejemplo, el BBVA concedía a los herederos un año para decidir si vendían la vivienda, si saldaban el préstamo con el banco y se quedaban con la diferencia, o incluso se les permitía renegociar la hipoteca y mantener la propiedad del inmueble. En Caixa Terrassa, los herederos de los solicitantes de una hipoteca inversa disponían del plazo de un año para vender la propiedad. En la práctica bancaria, el
} 
establezca en el clausulado de la hipoteca un plazo excesivamente corto, se entiende que deberá fijarse un plazo mínimo ${ }^{470}$ durante el cual los herederos puedan hacerse cargo de la deuda y no pierdan la vivienda.

En este sentido, se perfila como plazo razonable el de dos años, de manera que se dará un margen a los herederos para tomar las decisiones oportunas relativas a la devolución de la deuda.

\section{La prueba y la notificación del fallecimiento del deudor hipotecario o del último de los beneficiarios}

La declaración ${ }^{471}$ del fallecimiento de la persona cuya muerte determine el vencimiento de la deuda, como es evidente, no podrá realizarse por ella misma. Cuando llegue este momento, la certificación de fallecimiento del deudor la podrá instar el cónyuge, los hijos, los hermanos y los parientes consanguíneos hasta el cuarto grado. Ahora bien, dependiendo de la situación personal de este deudor causante, también se podrá promover por el Ministerio Fiscal y cualquier persona que estime tener algún derecho sobre los bienes, en este caso del ausente o del fallecido. Significa lo anterior que el acreedor lo podría pedir aun en contra de la voluntad de la familia.

Para evitar pues, cualquier problema relacionado con esta situación, en la escritura de constitución de esta modalidad hipotecaria se debería contemplar la circunstancia descrita. En el caso de que el deudor tuviera hijos o familiares con los que tuviera relación o incluso conviviera con ellos, no supondría ningún problema a la hora de acreditar el fallecimiento de éste. Sin embargo, en algunos casos no se da esta situación, pues muchas veces se puede tratar de una persona soltera, viuda, etc., que no tenga familia.

plazo habitual es de seis meses, por lo que en las hipotecas inversas debería establecerse también este plazo como mínimo, aunque sería más factible un plazo mayor.

470 En opinión de Álvarez Álvarez, H., La hipoteca inversa..., op. cit., p. 117, desde la fecha del fallecimiento se debería establecer un plazo concreto para la liquidación.

${ }^{471}$ Vid. JIMÉNEZ CLAR, A.J., «La hipoteca...», op. cit., pp. 133 y 134. 
En nuestro Derecho, la libertad de nombrar herederos testamentarios es absoluta, y lo es hasta el momento mismo de la muerte del causante, ya que el testamento es un acto esencialmente revocable. Ahora bien, se prohíbe cualquier pacto $^{472}$ en contra de la libertad revocatoria, por tanto, esta libertad testamentaria otorga al deudor-testador la facultad de poder cambiar a sus herederos (en lo que aquí nos atañe, futuros deudores de la hipoteca inversa) en cualquier momento y sin consentimiento, en este caso, de la entidad acreedora. Sin embargo, si nos vamos al artículo 1205 del CC podemos constatar que la novación, que consista en sustituir un deudor por otro, podrá hacerse sin consentimiento del deudor primitivo, pero no sin el consentimiento de la parte acreedora.

En tal caso, la condición de heredero ${ }^{473}$ se adquirirá en el momento en que se proceda a la sucesión, de manera que, la entidad acreedora no podrá saber hasta el momento de la lectura del testamento quiénes serán los posibles deudores de su crédito. Llegado aquí, estos sucesores ${ }^{474}$, los nuevos deudores de la deuda hipotecaria, podrían ser menores, incapacitados, ausentes y también otros designados libremente por el deudor causante. Estas situaciones podrían causar un grave problema a la entidad acreedora a la hora de poder cobrar su deuda.

En estos supuestos y con el objetivo de evitar sorpresas desagradables, se tendría que proceder a lo siguiente:

Al formalizar la hipoteca inversa y para el caso de que el solicitante no tuviera herederos o familiares cercanos, en la escritura de constitución podrían introducirse los datos personales de aquellas personas que tuvieran una relación de vecindad con el deudor hipotecario: nombre, apellidos y

\footnotetext{
${ }^{472}$ Al respecto, MIQUEL SILVESTRE, J.A., «Hipoteca Inversa...», op. cit., p. 1922, se plantea las siguientes cuestiones: ¿Puede intentar el acreedor limitar la posibilidad del testador prestatario para nombrar a determinados herederos? ¿Sería lícito semejante pacto? La respuesta a las mismas debe ser negativa: nadie puede limitar la libertad del testador para designar sus herederos salvo la Ley imponiéndole determinados legitimarios.

473 Sobre la capacidad para suceder vid., Albaladejo, M., Curso de Derecho Civil, V, Derecho de Sucesiones, Edisofer, Madrid, 2013, pp. 77-93.

${ }_{474}$ MIQUEL SILVESTRE, J.A., «Hipoteca Inversa...», op. cit., pp. 1921 y 1922.
} 
domicilio. Con esta clarificación, cuando se produjera el fallecimiento del deudor, la entidad acreedora gozaría de información de primera mano.

En esta escritura de constitución también se podría establecer el compromiso, tanto por el deudor como por el beneficiario (si lo hubiera), de demostrar cada cierto tiempo que se hallan con vida. Esta justificación se realizaría a través de una certificación notarial de existencia, para remitirla, más tarde, a la entidad acreedora.

A pesar de que la situación de ausencia $^{475}$ no puede equipararse legalmente a la de fallecimiento, la falta de cumplimiento de esta obligación por parte del deudor o beneficiario, podría constituir una causa de vencimiento anticipado. Ahora bien, este vencimiento anticipado sólo se podría dar en el caso de que esta situación de ausencia impidiese la correcta realización de esa hipoteca inversa. No será causa de vencimiento anticipado cuando en estas ausencias, más o menos prolongadas, se conozca el paradero del deudor o beneficiario.

En el Código Civil, la declaración de fallecimiento ${ }^{476}$ viene contemplada en los artículos 193 a 196. Aquí, de manera expresa, se detallan los casos de ausencia de una persona por los que se podría declarar su fallecimiento. Para el caso que aquí nos preocupa, el artículo 182 del CC, en su último párrafo, faculta a la entidad acreedora a promover la declaración de ausencia legal de la parte deudora.

Atendiendo al artículo 193 del CC se procederá a la declaración de fallecimiento cuando hayan transcurrido diez años desde las últimas noticias del ausente 0 , a falta de éstas, desde su desaparición. También se podrá declarar fallecido pasados cinco años desde las últimas noticias o, en defecto de éstas, desde su desaparición, si al expirar dicho plazo el ausente hubiera cumplido setenta y cinco años. Por tanto, para declarar fallecida a una

\footnotetext{
475 Vid., entre otras muchas, la Resolución de la DGRN de 21 de diciembre de 2007 (RJ 2008\2086).

476 Puig Brutau, J., Compendio de Derecho Civil. Volumen I, op. cit., pp. 254-257.
} 
persona entre los 65 y los 75 años, se exigirán diez años de desaparición, y si ésta superara los 75 serían obligatorios 5 años.

Durante este periodo de tiempo, en el caso de que los herederos no quisieran soportar los intereses generados, éstos deberían cancelar la hipoteca, pero con su propio patrimonio o reclamar judicialmente la anulación de los intereses devengados en el periodo que transcurra entre la declaración de fallecimiento y la fecha de desaparición. Si nos fijamos, esta situación, en el caso de que el deudor desaparecido tuviera una edad inferior a los 75 años, supondría un grave problema para la entidad acreedora, que rechazaría la contingencia de quedar privada de un capital durante diez años y no recibir a cambio ninguna suma de dinero.

\section{La identificación de los herederos}

La determinación ${ }^{477}$ de los herederos del deudor hipotecario es otra de las causas que se tendrán que contemplar a la hora de constituir la hipoteca inversa, debiéndose precisar ${ }^{478}$, cuando se formalice esta hipoteca, quiénes serán, con toda probabilidad, los herederos del deudor hipotecario.

En el momento de especificar la relación de herederos sería conveniente hacer constar un domicilio a efecto de notificaciones para que, llegado el momento, la entidad acreedora pudiera dirigirse a éstos. Se podría dar el caso de que los llamados a la herencia no la aceptasen y la notificación que tendría que realizar la entidad acreedora para la ejecución hipotecaria

\footnotetext{
477 JIMÉNEZ CLAR, A.J., «La hipoteca...», op. cit., pp. 134-136.

${ }^{478}$ MIQUel SILVESTRE, J.A., «Hipoteca Inversa...», op. cit., p. 1921, señala que los obligados al pago son los herederos con todas las consecuencias. Pero lo que no queda tan claro es quiénes son estos herederos. La impresión que sugiere la lectura de la Disposición es que el legislador estaba pensando en los descendientes legitimarios, pero éstos no tienen por qué ser necesariamente herederos. En Derecho común, los legitimarios pueden coexistir con herederos testamentarios. $Y$ en los Derechos forales se amplía la libertad testamentaria hasta el punto de que la legítima puede ser una mera mención formal sin contenido económico, como en Navarra, o un simple derecho de crédito frente a los herederos testamentarios, como en Cataluña. Así pues, la determinación de quiénes sean los herederos-deudores obligados al pago de la deuda hipotecaria puede no ser tan sencilla como parece haber creído el legislador.
} 
resultara infructuosa por desconocerse el domicilio de éstos, teniendo que acudir a los edictos ${ }^{479}$.

A simple vista, esto no plantea ningún problema, pero no debemos olvidar que la hipoteca inversa es muy utilizada por residentes de otros países $^{480}$ que han elegido el nuestro para disfrutar de sus últimos años de vida. Si tenemos en cuenta que la sucesión mortis causa de una persona va unida a su nacionalidad, ésta, se regirá por la ley del país del deudor causante.

Por regla general, una vez localizado el Protocolo notarial donde se refleje el testamento de la parte deudora, la entidad acreedora, en calidad de parte legitimada, podrá solicitar y obtener copia autorizada de ese testamento. En el caso de que ese testamento hubiera sido otorgado fuera de España, se tendría que acudir a la legislación pertinente para determinar su validez.

Ahora bien, en el supuesto de que el deudor hubiera fallecido sin haber otorgado testamento, a fin de determinar qué persona o personas poseen la condición de herederos ${ }^{481}$, se iniciaría la correspondiente declaración de herederos abintestato. A estos efectos, la entidad acreedora también estaría legitimada para instar dicha declaración.

Ante la obligación de proceder contra herederos indeterminados del causante, que pueden no residir en nuestro país, o la de tener que probar quiénes son los herederos de un extranjero fallecido en nuestro país sin haber otorgado testamento, se hará necesario que al momento del otorgamiento de

\footnotetext{
${ }^{479}$ Circunstancia ya apuntada por ANGUITA Ríos, R.M., «Regulación relativa...», op. cit., p. 15. La citada profesora propone una fijación en el negocio hipotecario de un plazo razonable para aceptar la herencia, de manera que evitara prolongar la situación de herencia vacante, aunque el problema radicaría en la relatividad de los contratos y la condición de terceros de los herederos respecto del negocio.

${ }^{480}$ El estudio de Costa Font, J.; Gil Trafesí, J. y Mascarilla Miró, O., Capacidad de la vivienda en propiedad como instrumento de financiación de las personas mayores en España, Fundación Edad \& Vida, Mayo 2007, constata que la hipoteca inversa representa un producto con cierta implantación por parte de residentes británicos jubilados que viven en España, en especial en la Costa del Sol.

481 Respecto a la declaración de herederos abintestato vid. MONTERo Aroca, J.; Gómez Colomer, J.L.; Barona Vilar, S. y Calderón CuAdrado, M.P., Derecho jurisdiccional II..., op. cit., pp. 789-792.
} 
escritura de hipoteca inversa se adopten una serie de medidas protectoras a fin de evitar problemas.

En los supuestos de extranjeros residentes en España se podrían adoptar las siguientes medidas:

Cuando el deudor fuera a constituir esta hipoteca, y con anterioridad hubiese otorgado testamento en España, convendría, o bien incorporar en esta escritura de constitución los datos correspondientes a su otorgamiento, es decir, lugar, fecha, notario autorizante y número de Protocolo, o bien introducir una copia del testamento en sobre cerrado.

En el supuesto de que no hubiera testamento o hubiese sido revocado con posterioridad a la constitución de la hipoteca inversa, sería conveniente que el deudor hiciese constar los datos identificativos de las personas que, en este caso, ostentarían la condición de herederos abintestato. De esta manera, se tendrían los datos necesarios para instar la pertinente declaración de herederos abintestato, que se regiría, en cuanto a su contenido, por la ley nacional del deudor $\mathrm{y}$, en cuanto a la forma, por la legislación procesal española.

Finalmente, cuando no conste la existencia de testamento ni de personas llamadas a la sucesión, se tendrá que acudir al procedimiento regulado por la Ley de Enjuiciamiento Civil.

\section{Los herederos en la hipoteca inversa}

Como ya conocemos y tal como se regula en el Apartado 1.c) de la DA 1. ${ }^{\text {, }}$ la causa más común de vencimiento de este crédito hipotecario es el fallecimiento del deudor o del último de los beneficiarios. Al producirse este suceso, el uso de la vivienda por el deudor hipotecario o beneficiario habrá 
desaparecido. Desde ese momento la entidad acreedora ${ }^{482}$ podrá exigir la devolución del capital e intereses a los herederos de éstos, quienes tendrán que hacer frente al pago de las cantidades debidas. Esta situación es la que más problemas genera en la hipoteca inversa.

Cuando se constituye una hipoteca inversa, la obligación ${ }^{483}$ de devolver las cantidades prestadas más los intereses es asumida por el solicitante, pero su cumplimiento no le corresponderá a él sino a sus herederos. Por ello, es aconsejable que los herederos participen ${ }^{484}$ desde el principio en la constitución de la hipoteca inversa, ya que serán ellos los que tomarán la última decisión sobre la ejecución de la misma. El llamamiento a la herencia ${ }^{485}$ será condición suficiente para el ejercicio de esta facultad, ya que en ningún momento, la Ley exige que para ejercitar dicha facultad sea precisa la previa aceptación de la herencia.

El orden de los llamamientos hereditarios, tanto en la sucesión testada como en la intestada, se caracteriza por tener categorías sucesivas de herederos, unas en defecto de las otras, hasta que la herencia haya sido efectivamente aceptada. Ahora bien, en estos casos, la falta de aceptación por los herederos preferentes podría dar lugar a que cualquier persona con posibilidades de ser heredero del deudor pudiera considerarse legitimada para

\footnotetext{
$\overline{482}$ En la STS de 29 de junio de 2006 (RJ 2006\4714) se hace un riguroso análisis del artículo 1851 del CC y de la doctrina jurisprudencial básica dictada en su interpretación, poniendo de relieve el dato fundamental de un previo consentimiento de los fiadores a la concesión de las prórrogas. Los reclamantes no podrán ampararse ni en una supuesta ajenidad de la póliza, ni en su ignorancia. En la misma sentencia también se hace alusión a la ejecución respecto de la viuda del finado avalista y madre de los herederos hijos de éste, donde el cónyuge legitimario no podrá ser demandado por las deudas hereditarias.

${ }^{483}$ Tal y como señala ZURITA MARTín, I., «La nueva normativa...», op. cit., p. 1292, la redacción del precepto resulta algo deshilvanada, el sentido de la norma parece claro: el fallecimiento del deudor -o, en su caso, de los beneficiarios que éste hubiese designado- se contempla como la principal causa de cancelación del préstamo.

${ }^{484}$ RodríGo GARCíA, G., La hipoteca..., op. cit., p. 58, señala que, aún no habiéndose producido ninguna causa de vencimiento de hipoteca inversa, sería recomendable que los herederos participasen desde el principio del proceso, dado que al fallecimiento del prestatario, serán éstos quienes determinen qué hacer con el préstamo y con la hipoteca inversa. Cfr. LASARTE Álvarez, C., Principios de Derecho Civil V. Derechos reales y Derecho hipotecario, $4 .^{a}$ ed., Marcial Pons, Madrid, Barcelona, 2005, p. 74.

${ }^{485}$ PuIg Brutau, J., Compendio de Derecho Civil. Volumen IV. Derecho de familia. Derecho de sucesiones, Bosch, Barcelona, 1990 , p. 330, señala que: «El poder atribuido al llamado para que acepte o repudie la herencia se denomina ius delationis, que la doctrina moderna considera que es un derecho subjetivo, transmisible a los herederos del propio llamado si fallece sin aceptarla ni repudiarla (art. 1006 CC). En cambio, cualquier acto de disposición de este derecho por el llamado, tendría la significación de un acto de aceptación (art. 1000.1 $1^{\circ}$ CC)». Para DíEZ-PICAZO, L. y Gultón, A., Sistema de Derecho Civil IV. Familia, Tecnos, Madrid, 2006, p. 330, se trata de un derecho inembargable, porque sólo el llamado por el testador puede aceptar o repudiar.
} 
el ejercicio de esta facultad. De ahí la importancia de diferenciar la aceptación de la herencia de la adjudicación de los bienes que la integran en pago de los derechos de los herederos.

En el apartado 1 de la DA $1 .^{a}$ de la Ley $41 / 2007$ no se contempla un supuesto de adjudicación para pago de deudas sino el ejercicio de una facultad para la que se requiere ser heredero del deudor hipotecario. Esta condición de heredero es la que permite cancelar la deuda sin pagar comisiones ni intereses de demora. De todas formas, la aceptación de la herencia ${ }^{486}$ en consonancia con el artículo 999 del Código Civil, se entendería mediante el pago de la hipoteca inversa por quien tuviera la condición de heredero del deudor hipotecario.

No obstante, podría darse el caso de que alguno de los herederos no quisiera que este heredero pagador se adjudicara la vivienda hipotecada inversamente. En tal supuesto, este heredero pagador se subrogaría frente a los demás coherederos en la posición del acreedor hipotecario, conforme al artículo 118 de la Ley Hipotecaria. La razón vendría dada por la protección que se da a todos los herederos. Si un heredero tiene más medios económicos que los otros, esto no le da ningún derecho a apropiarse de la vivienda hipotecada por un importe inferior al de su valor real sin el consentimiento de todos los interesados en la herencia. En todo caso, se dará preferencia al heredero a favor del que hubiese dispuesto el deudor hipotecario.

Por otra parte, al tratarse de una deuda creciente, el acreedor hipotecario aún no habrá percibido nada del importe debido, con lo que su interés en el cobro se acentuará, pues será en ese momento cuando perciba los beneficios de su operación. Es decir, a la muerte del deudor, la deuda

\footnotetext{
${ }^{486}$ La STS de 27 de junio de 2000 (RJ 200015909) expresa que: «En materia de adquisición de herencia, y con relación al régimen sucesorio del Código Civil, resulta incuestionable que rige el denominado sistema romano caracterizado porque no basta la delación hereditaria (apertura, vocación y delación) para ser titular del derecho hereditario, sino que además es preciso que el heredero acepte la herencia, lo que puede efectuarse de forma expresa o bien tácita. Producida la delación, el heredero -el llamado a heredar en concreto-, como titular del «ius delationis», puede aceptar o repudiar la herencia, pero en tanto no acepte, como se ha dicho, no responde de las deudas de la herencia, porque todavía no se produjo la sucesión -no es sucesor, sino sólo llamado a suceder-. Si acepta responderá incluso con sus propios bienes, salvo que la aceptación expresa tenga lugar con arreglo a lo prevenido para disfrutar del beneficio de inventario».
} 
habrá vencido pero no su exigibilidad, ya que ésta estará suspendida hasta el momento en que los herederos decidan qué hacer. Por esta causa se tendrá que señalar un plazo razonable para que los herederos puedan hacer uso de su derecho.

Con el propósito de proteger a la entidad acreedora sería aconsejable introducir en la escritura de constitución de hipoteca inversa una cláusula que autorizara a aquélla a la administración y conservación de la vivienda hipotecada mientras los herederos decidan qué hacer con ese bien. Esta facultad se extinguiría al pago de la deuda.

Por último, en el caso de herencia yacente ${ }^{487}$ y la entidad acreedora quisiera ejecutar la hipoteca, ¿contra quién debería dirigirse si los herederos son desconocidos, están ausentes, no aceptan la herencia o hay litigios sobre la condición de heredero?

La Doctrina de la Dirección General de Registros al respecto es clara y exige que para anotar en el Registro embargos sobre los bienes de la herencia yacente, de manera previa, se inste por la vía judicial al nombramiento de un administrador de la herencia que la represente y contra quien pueda dirigirse

\footnotetext{
487 Se analizará más adelante, pero como anticipo se puede hacer mención a la SAP de Asturias de 28 de junio de 2001 (AC 2001\2026) donde se expresa que: «Se presentan cotidianamente demandas «contra la herencia yacente de ...", siendo ello consecuencia de la situación en que se encuentran los bienes, derechos y obligaciones del causante desde la apertura de la sucesión hasta la aceptación por el llamado a ser heredero; no se trata pues, la herencia yacente, de una persona jurídica mas se le ha reconocido capacidad procesal en orden a la posibilidad de dirigir contra la misma «cualquier clase de procedimiento en conjunción con la llamada al proceso de los herederos afectados por tal latente estado». En este sentido, y por citar, entre otras, la sentencia de 21-3-2000 de la Audiencia Provincial de Tarragona, afirma que en cuanto la herencia yacente supone la existencia de un período de tiempo en el que los bienes, derechos y obligaciones que correspondían al causante carecen de titular actual ante la posibilidad de que se extingan los créditos y deudas y los derechos reales limitativos y que los restantes bienes relictos quedasen «nullius», correspondiendo los inmuebles al Estado y los muebles al primer ocupante, frente a ello dice, que todas las relaciones jurídicas transmisibles del causante se mantienen vigentes y válidas como si el causante aún siguiera vivo acudiendo para ello a la teoría de la ficción u otros configurándolo como entidad jurídica especial, así el ordenamiento permite la ausencia de un sujeto actual, durante un tiempo, en atención a que tal sujeto existirá luego y cubrirá con su titularidad, dado el efecto retroactivo de la aceptación, todo el período de yacencia desde el fallecimiento del causante. Cuando no haya una administración regularmente constituida, la doctrina y la jurisprudencia entienden que, ante todo, deben de satisfacerse los legítimos intereses de terceros y que deberán ser admitidas las demandas dirigidas contra la herencia yacente y los llamados a ella, aún cuando en rigor ni el causante viva, ni los herederos la hayan aceptado. Por su parte, la Audiencia Provincial de Almería en sentencia de 15-2-2000 afirma que puesto que fallecido un deudor, desconociéndose el estado real y actual de la herencia (si ha sido o no aceptada, si lo ha sido por todos los llamados a ella, en qué forma...), la acción debe dirigirse contra la herencia yacente, contra los posibles e ignorados herederos, si no se sabe su identidad, o contra los que lo sean, si esa identidad es conocida».
} 
el procedimiento. Si la entidad acreedora intentase la ejecución sin este paso previo, es decir, se limitara a citar a los herederos desconocidos mediante edictos, se podría dar el caso de que algún tribunal admitiera la ejecución, pero este auto de adjudicación no lo inscribiría ningún registrador de la propiedad por vulnerar el derecho a la tutela judicial efectiva regulado en el artículo 117 de la CE.

\section{VENCIMIENTO DEL PRÉSTAMO HIPOTECARIO: EXTINCIÓN DE LA OBLIGACIÓN ASEGURADA Y CANCELACIÓN DE LA HIPOTECA}

El vencimiento del préstamo o crédito hipotecario se regula en los Apartados 5 y 6 de la Disposición Adicional Primera de la Ley $41 / 2007^{488}$. Este vencimiento se podrá originar por causas diferentes, aunque la más común será la producida por el fallecimiento del deudor o del último de los beneficiarios.

En el caso de que haya beneficiarios, el apartado 1.c) de la DA $1 .^{\text {a }}$ dispone: «que la deuda sólo sea exigible por el acreedor y la garantía ejecutable cuando fallezca el prestatario o, si así se estipula en el contrato, cuando fallezca el último de los beneficiarios».

De este punto surgen dudas sobre si en el pacto, además de nombrar al beneficiario o beneficiarios, se debe precisar también si la deuda vencerá al fallecimiento del último beneficiario. En este aspecto, algunos autores entienden que será necesario pactar que la deuda venza con el fallecimiento del último de los beneficiarios, ya que, si no se estipulase en el contrato y hubieran beneficiarios, el préstamo vencería en el momento del fallecimiento del solicitante-deudor. Por tanto, esto tendrá que plasmarse en el contrato

\footnotetext{
${ }^{488}$ El texto originario del Proyecto de Ley dedicaba estos dos apartados de la DA $1{ }^{\mathrm{a}}$ a la extinción del préstamo, si bien ninguno de ellos resultaba del todo afortunado, tanto por su redacción como por su contenido, lo que demuestra el hecho de haber sido ambos objeto de distintas enmiendas por varios grupos parlamentarios. Aunque algunas de estas enmiendas fueron incorporadas al texto definitivo de la Ley, el resultado final merece ser objeto de algunas observaciones.
} 
para permitir que la hipoteca se prolongue más allá de la vida del deudor ${ }^{489}$. En todo caso, habrá que estar a lo dispuesto en el contrato de hipoteca inversa.

Aclarado esto, una vez se haya producido el fallecimiento del deudor o del último de los beneficiarios, los herederos de éstos (parte deudora) deberán elegir entre varias opciones:

1.- Quedarse con la vivienda.

El heredero, con sus propios fondos podría hacerse cargo del pago de la deuda y los intereses. De esta forma, el crédito hipotecario quedaría saldado. En este supuesto y tal como aparece reflejado en la DA $1 .^{a}$, con la devolución del capital y los intereses en el plazo estipulado en la escritura de constitución de esta hipoteca, a la muerte del deudor, la hipoteca quedaría cancelada, no generando derecho alguno a compensación a favor de la entidad acreedora.

2.- Obtener una hipoteca sobre esa finca registral con el fin de no perder la vivienda y cancelar, de esta manera, la deuda pendiente.

En este caso, la novación modificativa de la hipoteca inversa mediante su transformación en una hipoteca a cargo de uno de los herederos, originaría la alteración del rango de la hipoteca, salvo que prestaran su consentimiento los titulares de derechos inscritos de rango posterior, según establece el artículo 4 de la Ley 2/1994, de 30 de marzo, sobre Subrogación de Préstamos Hipotecarios $^{490}$.

3. - Vender la vivienda para pagar la deuda.

En el caso de que la vivienda se hubiere revalorizado tras la tasación inicial, una vez saldadas las cuentas con la entidad, el sobrante pertenecería a los herederos.

\footnotetext{
${ }^{489}$ Vid. Romero CANDAU, P.A., «La hipoteca...», op. cit., p. 315; JimÉnez CLAR, A.J., «La hipoteca...», op. cit., p. 113.

${ }^{490}$ Publicada en el BOE, núm. 80, de 4 de abril de 1994 y desarrollada por Real Decreto núm. 716/2009, de 24 de abril.
} 
4.- Devolver el préstamo una vez fallecido el deudor hipotecario pero antes del plazo estipulado para el vencimiento de la obligación asegurada. En este caso se aplicaría el artículo 7 del Capítulo IV de la Ley 41/2007, relativo al Régimen de la compensación por amortización anticipada:

«El presente Capítulo será de aplicación a los contratos de crédito o préstamo hipotecario formalizados con posterioridad a la entrada en vigor de esta Ley y aunque no conste en los mismos la posibilidad de amortización anticipada, cuando concurra alguna de las siguientes circunstancias:

Que se trate de un préstamo o crédito hipotecario y la hipoteca recaiga sobre una vivienda y el prestatario sea persona física.

Que el prestatario sea persona jurídica y tribute por el régimen fiscal de empresas de reducida dimensión en el Impuesto sobre Sociedades.

En dichos contratos de crédito o préstamo hipotecario no podrá cobrarse comisión por amortización anticipada total o parcial.

En cualquier caso, la entidad estará obligada a expedir la documentación bancaria que acredite el pago del préstamo sin cobrar ninguna comisión por ello».

Los herederos del deudor hipotecario podrían optar a la amortización anticipada por medio de la primera circunstancia de este precepto: «Que se trate de un préstamo o crédito hipotecario y la hipoteca recaiga sobre una vivienda y el prestatario sea persona física». La cantidad a devolver estaría integrada por el principal del préstamo y los intereses devengados hasta el vencimiento de la hipoteca. Aquí, para el supuesto en el que se hubiera dado, también podrían incluirse las cantidades anticipadas por la entidad acreedora necesarias para la conservación del inmueble.

Como se puede apreciar en el último punto de este artículo, la entidad acreedora estará obligada a expedir la documentación bancaria que acredite el pago del préstamo sin cobrar ninguna comisión.

5.- Si los herederos no quisieran recuperar la vivienda, ésta pasaría a ser propiedad de la entidad acreedora sin causarles ningún tipo de gasto.

Al igual que el caso anterior, si la tasación fuera superior a la deuda, el sobrante se entregaría a los herederos. Aunque esta opción choca con la 
prohibición del pacto comisorio ${ }^{491}$, pues lo que se pretende es evitar que la obtención de la financiación se realice condicionada a la aceptación de pactos, por ejemplo, que el acreedor ${ }^{492}$ retuviera un bien de más valor que el de la deuda, perjudicando al deudor y al resto de sus acreedores, en el caso de que los hubiera.

Ahora bien, cierto sector doctrinal sólo prohíbe el pacto comisorio en el que se condiciona la concesión del crédito. Por tanto, los pactos en los que se permitiera la apropiación del bien por el acreedor hipotecario y no estuviesen causalmente conectados a la concesión del crédito, serían válidos. Estos pactos se negociarían una vez el deudor hubiese obtenido la financiación ${ }^{493}$.

En la práctica financiera no es frecuente que el acreedor realice un pacto comisorio, pues no le interesa adquirir la propiedad de inmuebles, sino su valor. Por lo que en caso de impago de la deuda, lo normal sería proceder a la ejecución del inmueble.

6. - A falta de cumplimiento voluntario durante el tiempo pactado se dará lugar al cumplimiento del mismo de manera forzosa.

El acreedor ejecutará la hipoteca (garantía hipotecaria) para poder saldar la deuda. En el caso de que hubiera remanente, éste también pasaría a los herederos.

En estas opciones, podemos apreciar que se concede un plazo ${ }^{494}$ desde el fallecimiento del deudor o del último de los beneficiarios, con el fin de que

\footnotetext{
491 En este aspecto, SerRano de Nicolás, Á., «Régimen jurídico...», op. cit., p. 37, nota al pie 13, ha criticado que no se haya admitido en estos casos expresamente el pacto comisorio, pues considera que el pacto comisorio habría facilitado el cobro de los débitos con sus intereses.

492 En estos casos, nos tendríamos que fijar en el artículo 1859 del CC donde: «El acreedor no puede apropiarse las cosas dadas en prenda o hipoteca, ni disponer de ellas». Y, en el artículo 1869 del CC: «Mientras no llegue el caso de ser expropiado de la cosa dada en prenda, el deudor sigue siendo dueño de ella.

Esto no obstante, el acreedor podrá ejercitar las acciones que competan al dueño de la cosa pignorada para reclamarla o defenderla contra tercero».

493 Cordero Lobato, E., Tratado de..., op. cit., pp. 681 y ss.

${ }^{494}$ Este plazo se contempla en el apartado 5, párrafo primero de la DA 1. ${ }^{a}$, en el que aunque fallecido el deudor hipotecario o el último de los beneficiarios todavía no podrá considerarse incumplido el contrato hasta que transcurra dicho plazo. En este sentido, SERRANO DE Nicolás, Á., «Régimen jurídico...», op. cit., pp. 52 y 53, plantea la duda de si necesariamente se tendría que conceder un plazo de gracia, por breve que fuese, en el que los herederos pudiesen optar «por el pago o no reembolso de la deuda». El mismo
} 
los herederos puedan estudiar diferentes propuestas para satisfacer las cantidades debidas $^{495}$. De esta forma, el plazo ${ }^{496}$ que se dé para realizar estas actuaciones será primordial, pues dependiendo del tiempo que se conceda para cancelar la deuda podrá derivar en una buena o mala operación.

Si nos vamos al Código Civil, las obligaciones a plazo se regulan en los artículos 1125 a $1130^{497}$. Concretamente, el artículo 1125 del CC señala que:

«Las obligaciones para cuyo cumplimiento se haya señalado un día cierto, sólo serán exigibles cuando el día llegue.

Entiéndese por día cierto aquel que necesariamente ha de venir, aunque se ignore cuándo.

Si la incertidumbre consiste en si ha de llegar o no el día, la obligación es condicional, y se regirá por las reglas de la Sección precedente».

De esta manera, en las obligaciones a plazo, se establece un periodo de tiempo para su cumplimiento, por el que se entiende que la obligación ya

autor manifiesta que los diferentes grupos parlamentarios proponían que se contemplasen, en el texto definitivo, plazos de 6 hasta 24 meses para aunque vencido el préstamo o crédito pudiese pagarse, sin incurrir en mora o incumplimiento. Pues, el hecho jurídico que determina la exigibilidad es absolutamente imprevisible, la imposibilidad de saber quién es heredero hasta que no se pueda saber si existía o no testamento, e incluso, de no haberlo, la necesidad de la correspondiente declaración de herederos abintestato, unido a la buena fe contractual, exige conceder un plazo mínimo que permita a los que serán herederos del deudor hipotecario decidir si reembolsan la deuda o consienten que se haga efectiva sobre los bienes de la herencia.

${ }^{495}$ En la práctica -al no fijar un plazo mínimo el legislador sino que lo deja a criterio del acreedor hipotecario-, se advierte que ha devenido en cláusula de estilo el conceder un plazo de seis meses (extinguible con anterioridad si se acepta la herencia) para que pueda pagarse la deuda de capital e intereses. En consecuencia, el legislador lo que ha querido es que dentro de la necesaria concesión de un plazo que sea cada entidad de crédito o aseguradora la que fije el plazo máximo para hacer efectiva la deuda por capital e intereses.

496 Tal y como apunta Álvarez Álvarez, H., La hipoteca inversa..., op. cit., p. 117, cuando no se pacte en el momento de constituir la hipoteca inversa un plazo concreto para realizar el pago, de acuerdo con el artículo 1004 del CC a partir de los 9 días posteriores a la muerte del causante (plazo que se considera de respeto a la memoria del difunto), el acreedor podrá instar judicialmente a los llamados a la herencia para que se pronuncien sobre si aceptan o repudian ésta, y, tras el plazo que conceda el juez para ello, si aceptan la herencia, el acreedor podrá entender que tienen que pagarle el importe de la deuda de la hipoteca inversa, y si éstos se niegan, el acreedor podría ejecutar la hipoteca tras el primer requerimiento de pago. Ahora bien, también podrían surgir dudas en orden a determinar si se ha producido o no la aceptación, si el testamento es válido, etc., lo cual podría dejar en suspenso la efectividad de la pretensión del acreedor. La misma autora señala que: «Esto no hace más que introducir un nuevo elemento de riesgo en las entidades bancarias o aseguradoras que puede provocar reticencias a la hora de ofertar la hipoteca inversa. Y es que la hipoteca no asegura el cumplimiento, sino la satisfacción o el pago después de incumplida la obligación asegurada. Es decir, el acreedor tiene asegurada la recuperación del préstamo, aunque se otorgue a los herederos del deudor un plazo de tiempo para que decidan cómo calcular la deuda».

497 Cfr. Peña LóPeZ, F., «Comentario a los artículos 1125 a 1130», en Bercovitz RodríGuez Cano, R. (coord.), Comentarios al Código Civil, Thomson Aranzadi, Cizur Menor (Navarra), 2006; De LA IGLESIA MonJE, M.I., «Comentario al artículo 1125», en VALPUESTA FernándeZ, R. (coord.), Código Comentado: Libro IV, obligaciones y contratos, Teoría general de la obligación y el contrato, vol. III, Civitas (Thomson reuters), Cizur Menor (Navarra), 2011. 
existe y es eficaz ${ }^{498}$. Así, la obligación sólo será exigible cuando el día señalado llegue (fecha en la que se producirá el vencimiento) ${ }^{499}$.

El tiempo de cumplimiento o tiempo de prestación funciona como límite de las facultades de las partes: para el acreedor determina la exigibilidad y para el deudor opera como momento en el que debe cumplir con lo pactado ${ }^{500}$. Si el vencimiento lleva consigo la exigibilidad de la prestación debida, en caso de que no haga frente a su obligación, podría incurrir en mora.

En el caso de la hipoteca inversa, al formalizarse el contrato se señalará un día cierto para su cumplimiento. Ahora bien, la cuestión que aquí nos planteamos es cuándo va a ser ese momento en que se produzca el vencimiento. Como ya se ha comentado, la DA 1. a de la Ley 41/2007 no concreta este suceso, de manera que se tendrá que determinar si el vencimiento se origina, o bien en la fecha del fallecimiento del solicitante 0 , en su caso, del último de los beneficiarios, o bien una vez haya trascurrido un determinado periodo de tiempo desde el fallecimiento de éstos.

Atendiendo a las características de esta modalidad hipotecaria, hubiera sido recomendable que en el momento de formalizar el contrato de constitución de la misma, se especificase que el vencimiento y la correspondiente exigibilidad no se producirán hasta transcurrido un determinado plazo desde el fallecimiento. Aún así, durante la tramitación parlamentaria se intentó que este plazo ${ }^{501}$ fuera como mínimo de dos años ${ }^{502}$,

\footnotetext{
498 Díez-PICAzo, L., Fundamentos de Derecho Civil Patrimonial..., op. cit., p. 371.

499 Martínez de Aguirre Aldaz, C. (coord.); De Pablo Contreras, P.; Pérez Álvarez, M.Á. y Parra lucán, M.Á., Curso de Derecho Civil (II), op. cit., pp. 151-153.

${ }^{500}$ Díez-PiCazo, L., Fundamentos de Derecho Civil Patrimonial..., op. cit., p. 372.

501 El Partido Popular y Esquerra Republicana entendieron que resultaba preciso conceder y señalar un plazo determinado para que los herederos pudieran cancelar el préstamo. Vid. Enmiendas núms. 103 (Boletín Oficial de las Cortes Generales. Diario de Sesiones del Congreso de los Diputados, VIII Legislatura, Serie A: Proyectos de Ley, núm. 127-7, 9 de mayo de 2007) y 123 en el Congreso y 23 (Boletín Oficial de las Cortes Generales. Diario de Sesiones del Senado, VIII Legislatura, Serie II: Proyectos de Ley, núm. 130 (d), 6 de noviembre de 2007) y 67 en el Senado.

502 En este sentido ZURITA MARTín, I., «La nueva normativa...», op. cit., p. 1294, narra que se propuso fijar un plazo máximo de dos años, contados desde el fallecimiento del deudor, para la cancelación del crédito, en lugar de lo previsto en la norma, pues la referencia al plazo estipulado en el contrato podría dar lugar a que la entidad financiera estableciera en el clausulado de la hipoteca un plazo excesivamente corto para que los herederos reuniesen el dinero con el que pagar la deuda pendiente y
} 
aunque al final no se legisló nada al respecto. En la práctica, este plazo se viene fijando en seis meses ${ }^{503}$ desde el fallecimiento del deudor o del último beneficiario, coincidiendo con el plazo para presentar el impuesto sobre sucesiones y donaciones ${ }^{504}$.

Lo acertado hubiese sido que en la Ley 41/2007, o bien en la Disposición Adicional 1. ${ }^{a}$ encargada de legislar la hipoteca inversa, o bien en otras disposiciones de esta Ley, se hubiese tipificado un plazo razonable para que los herederos pudiesen proceder a la cancelación del préstamo. De manera especial, cuando se diere el caso de que el deudor hubiese sobrevivido al plazo estipulado en la contratación de esta hipoteca, obteniendo un endeudamiento mayor al inicialmente esperado.

Si se hubiera estipulado un plazo de dos años para saldar la deuda por parte de los herederos, éstos hubieran tenido más oportunidades para vender la casa o recoger dinero y comprarla ellos mismo. Y, por parte de la entidad acreedora, ésta, hubiera tenido más posibilidades de cancelar la deuda sin necesidad de tener que acudir al proceso de ejecución. En síntesis, este plazo hubiera sido satisfactorio para ambas partes.

\section{Limitación de la responsabilidad de la deuda hipotecaria a los bienes de la herencia}

Esta opción queda reflejada en el Apartado 6 de la DA 1. ${ }^{a}$ de Ley $41 / 2007$, donde se limita la responsabilidad ${ }^{505}$ de esta deuda hipotecaria a los

no perder la casa. Los enmendantes sostenían que la norma hubiera mejorado sustancialmente si se hubiera concedido un plazo mínimo para que los herederos pudieran, bien vender ellos mismos la casa, bien pedir otra hipoteca, o bien buscar otra solución para la devolución de la deuda. La enmienda, sin embargo, no fue atendida.

${ }^{503}$ MURO VILLALón, J.V., «La hipoteca...», op. cit., p. 166, propone un plazo de seis meses.

504 El artículo 67.1 a) del Real Decreto 1629/1991, de 8 de noviembre, por el que se aprueba el Reglamento del Impuesto sobre Sucesiones y Donaciones, en relación al plazo para presentar el documento o liquidación, señala: «cuando se trate de adquisiciones por causa de muerte, incluidas las de los beneficiarios de contratos de seguro de vida, en el de seis meses, contados desde el día del fallecimiento del causante o desde aquel en que adquiera firmeza la declaración de fallecimiento".

505 SERRANO DE NicolÁs, Á, «Régimen jurídico...», op. cit., p. 54. Este autor con respecto al apartado 6 de la DA $1 .^{a}$, donde se expresa que: «el acreedor sólo podrá obtener recobro hasta donde alcancen los bienes de la herencia», indica que figura como una regla de determinación de la responsabilidad por razón de la deuda. 
bienes de la herencia, y ello, a pesar de que los herederos que acepten una herencia deberán hacer frente a las deudas del causante, aunque con diferente grado de responsabilidad, dependiendo de que la acepten pura y simplemente o a beneficio de inventario (art. $998 \mathrm{del} \mathrm{CC).}$

Este precepto de la DA $1 .^{\mathrm{a}}$, con el fin de favorecer la aceptación de la herencia por parte de los herederos ${ }^{506}$, apunta dos opciones: o bien devolver la deuda, o bien aceptar que se reclame por la parte acreedora, en virtud del principio de responsabilidad universal establecido en el artículo 1911 del CC sobre los bienes de la herencia y justo hasta donde alcancen ${ }^{507}$.

Pese a esto, ÁlvAREZ ${ }^{508}$ señala que puede darse el caso de que se introduzca en el contrato una cláusula de «Inexistencia de Garantía Patrimonial ${ }^{509}{ }$, con la que se limite la responsabilidad al bien hipotecado sin alcanzar a otros bienes del patrimonio del deudor, y como excepción más beneficiosa para este último frente a la aplicación del artículo 1911. No obstante, para poder aplicar correctamente esta cláusula se impondrá al deudor una serie de medidas con el fin de garantizar que el inmueble se venda por su valor de mercado. Junto a esto, también se suele pactar la

\footnotetext{
506 Como caso curioso, destacar la SAP de Barcelona de 23 de julio de 2013 (TOL3.988.466) donde se puede leer lo siguiente: «Fallecida la vendedora, el Sr. Abelardo, en cuanto heredero de la misma, no podía incluir en la escritura de aceptación de herencia ni inscribir registralmente a su nombre la finca litigiosa por cuanto la misma pertenecía en virtud del meritado contrato de 5 de febrero de 2007 al actor Sr. Urbano. Y así consta en la propia escritura de aceptación en la que se constata que por la existencia de ese contrato privado de compraventa lo único que podía incluirse entre los bienes de la herencia era el resto del precio pendiente pero no la finca puesto que ya no pertenecía a la causante y así se lo manifestó el propio demandado al actor en su burofax de 19 de noviembre de 2009 y debía conocer el recurrente dada su condición de administrador de fincas colegiado. Es decir que al existir ya perfeccionado un contrato privado de compraventa, lo que heredaba el demandado era el importe del precio pendiente de abonar por el recurrente, cuestión que fue confirmada por el Notario Sr. Suau en su declaración prestada en el proceso penal al manifestar "que el heredero recibe en este caso un precio y la obligación de elevar a público el documento privado que es lo que recibe en herencia"».

${ }^{507}$ En el mismo sentido se expresa ANGUITA Ríos, R.M., «Regulación relativa...», op. cit., p. 8. En cambio, MORILLO FERNÁNDEZ, F.J., «El crédito...», op. cit., pp. 166 y 167, afirma que «estos herederos (es decir, los del causante solicitante y deudor de la hipoteca inversa), como cualesquiera otros, por virtud de la aceptación quedan personalmente obligados por las deudas transmisibles de su causante; como lo demuestra además, la previsión del inciso final del apartado 6, que establece la ilimitación temporal de la responsabilidad por intereses de la finca hipotecada no sólo en cuanto a los devengados hasta el fallecimiento del deudor, sino hasta el pago de la deuda, lo que implica que ésta forma parte del pasivo inherente a la herencia aceptada».

${ }^{508}$ Vid. más ampliamente ÁlvAREZ ÁlVAREZ, H., La hipoteca inversa..., op. cit., pp. 129-135.

509 Destacar las RRDGRN de 22 de febrero de 2008 (RJ 2008\2790), de 15 de marzo de 2008 (RJ 2008\807), de 19 de marzo de 2008 (RJ 2008\8272), de 25 de marzo de 2008 (RJ 2008\8277), de 27 de marzo de 2008 (RJ 2008\8278), de 14 de mayo de 2008 (RJ 2008\8279) y de 16 de mayo de 2008 (RJ 2008\3154).
} 
posibilidad de retasación del bien para el caso de que se produzca un incremento de valor considerable.

La solución dada para la hipoteca inversa sobre la vivienda habitual se justifica plenamente, pues la garantía dada a los acreedores sobre los bienes del deudor no puede quedar disminuida ${ }^{510}$ por el mero hecho de que el deudor muera $^{511}$-menos cabría añadir justo cuando es el hecho jurídico que determina la exigibilidad- y que los bienes se transfieran al heredero.

En la elaboración del proyecto hubo algunas propuestas por distintos grupos, que proponían que únicamente respondiese el bien hipotecado (art. 140 de la LH), y a la vez, dada la especial configuración de esta hipoteca inversa en la que el valor de la vivienda va disminuyendo al ir disponiendo ${ }^{512}$, hacía pensar ${ }^{513}$ que sólo el bien hipotecado debe responder. Por todo ello y frente a la pretendida responsabilidad ultra vires de los herederos que no aceptan a beneficio de inventario, parece coherente que el legislador aclare que el acreedor hipotecario sólo podrá cobrar con los bienes de la herencia.

Por tanto, en la hipoteca inversa el patrimonio personal ${ }^{514}$ de cada uno de los herederos no se verá afectado. La única garantía de la que dispondrá el acreedor para recuperar el préstamo será el inmueble y la herencia del deudor, pero de acuerdo con este apartado $6^{515}$ nunca podrá dirigirse contra

\footnotetext{
${ }^{510}$ Al efecto García RuBIO, M.P., La distribución de toda la herencia en legados. Un supuesto de herencia sin heredero, Civitas, Madrid, 1989, pp. 201 y 202, afirma, que en lo que aquí nos interesa al relacionarlo con la posible limitación legal de la responsabilidad universal, que ni la ratio ni la lógica jurídica del artículo 1911 CC «permiten que la muerte de un sujeto merme las expectativas que, sobre sus bienes, tenían los acreedores».

511 Para delimitar la responsabilidad del heredero, ROMÁn GARCíA, A., Instituciones de Derecho Civil Español, t. VII, Derecho de Sucesiones, McGrawHill, Madrid, 1999, p. 57, toma como elemento clave las deudas, al afirmar «que, en nuestro sistema, a consecuencia de la sucesión las deudas no cambian de patrimonio, sino que simplemente es el patrimonio el que cambia de titular, considerándose más adecuada, a los efectos, la responsabilidad intra vires hereditarios y la persistencia de la autonomía patrimonial».

${ }^{512}$ Vid. ANGUITA Ríos, R.M., «Regulación relativa...», op. cit., pp. 13-15.

513 Vid. MURO VILLALÓN, J.V., «La hipoteca...», op. cit., p. 16.

${ }^{514}$ En este sentido se manifiesta ANGUITA Ríos, R.M., «Regulación relativa...», op. cit., pp. 15 y 16.

515 La redacción de este apartado fue objeto nuevamente de la proposición de diversas enmiendas al texto inicial del Proyecto, al entenderse que la previsión por él contenida podía perjudicar de forma notable al colectivo de personas mayores. En concreto, se propuso sustituir el tenor literal del inciso referente al alcance de la responsabilidad sobre los bienes de la herencia, en los siguientes términos: «el acreedor sólo podrá obtener recobro hasta donde alcance la garantía real de la deuda» -Grupo Popular- o bien «el acreedor no podrá reclamar a los herederos sobre otros elementos del patrimonio de éstos distintos a dicha vivienda», según propuesta del Grupo de Izquierda Unida-Iniciativa per Catalunya Verds. Una tercera posición -defendida por Esquerra Republicana- consistía en eliminar completamente
} 
cualquier otro bien de los herederos. Incluso en los supuestos de aceptación pura y simple de la herencia, el acreedor no podrá reclamar más allá de los bienes hereditarios, no pudiéndose dirigir contra los bienes propios del heredero.

De esta manera, y con respecto a la aceptación pura y simple de la herencia, SERRANO dE NicolÁs coincide con PEÑA BERNALdo dE QUIRós ${ }^{516}$ al manifestar que aunque se acepte pura y simplemente seguirá habiendo dos patrimonios diferenciados. De la misma opinión es también ALBALADEJO ${ }^{517}$, al manifestar que el heredero que acepte pura y simplemente: «aun en su mano los dos patrimonios, el suyo y el hereditario, y siendo suyos ya los derechos y obligaciones de los dos, permanecen automáticamente como separados o diferenciados tales patrimonios».

También habría que tener en cuenta que la capacidad de decisión de los herederos a la hora de hacer frente al pago de la deuda, podrá verse limitada por algunas disposiciones del Código Civil, como por ejemplo, el legado que contempla el artículo 822 del CC a favor del legitimario persona con discapacidad y también por las atribuciones preferentes que se le otorgan al cónyuge viudo (arts. 1321, 1406.4 y 1407 del CC).

En este último supuesto, y con el fin de proteger los derechos del cónyuge viudo, resultará conveniente que la hipoteca inversa se constituya por los dos cónyuges, subsistiendo así hasta el fallecimiento de ambos. También se podría constituir por uno de los cónyuges pero pactando con la

este apartado sexto de la DA $1 .^{\mathrm{a}}$. La justificación que se esgrimía por el Grupo Popular en apoyo de la enmienda era la siguiente: «Proponemos suprimir que se extienda la responsabilidad para el pago de la deuda contraída al resto de los bienes del deudor hipotecario, de forma que no se pueda abrir la posibilidad de que el acreedor reclame sobre otros bienes del deudor, pues esta regulación debe ser semejante a lo que sucede en las hipotecas reales, en las que la deuda está cubierta con una garantía real y no es extensible al resto de los bienes del deudor, es más, esta garantía real es valorada anticipadamente por el acreedor y forma parte inherente del riesgo del negocio jurídico del crédito. Por tanto, no sería deseable extender la garantía sobre el resto de los bienes del deudor, sobre todo cuando sus herederos no tienen control sobre la «ejecución» de la garantía, en este caso la vivienda». ZURITA MARTín, I., «La nueva normativa...», op. cit., pp. 1302 y 1303, opina que esta enmienda no se encontraba bien argumentada.

${ }^{516}$ Vid. PeÑa BeRnaldo de Quirós, M., La herencia y las deudas del causante, Comares, Granada, 2006, pp. 143-197.

517 Albaladejo, M., Curso de Derecho Civil, v, op. cit., pp. 114 y 115; Puig Brutau, J., Fundamentos de Derecho Civil, t. V, Vol. I, Bosch, Barcelona, 1975, pp. 253-259. Frente a este sector de la civilística española opone serios reparos, a la tesis de la no confusión de los patrimonios, si bien sin manifestarse claramente en contra, De la Cámara Álvarez, M., Compendio de Derecho Sucesorio, La Ley, Madrid, 2. ${ }^{a}$ ed., 1999, pp. 28-32. Una enumeración de las opiniones a favor y en contra puede verse en GARCíA RUBIO, M.P., La distribución de..., op. cit., pp. 188-218. 
parte acreedora que la ejecución de la hipoteca no se produjera hasta el fallecimiento del otro cónyuge. En este caso se entendería que éste último es el beneficiario.

En el caso del legado a favor del legitimario persona con discapacidad, que recoge el artículo 822 del $\mathrm{CC}^{518}$, deberá respetarse cuando se den los presupuestos que se contemplan en dicho precepto.

También se ha de tener en cuenta que el deudor podrá establecer testamentariamente un legado que verse sobre la vivienda hipotecada inversamente. En este caso, la deuda deberá asumirla el heredero, pues es el heredero y no el legatario el que responde de las deudas de la herencia. Otra posibilidad es la de que el legado sea condicional, en el sentido de que el deudor imponga al legatario el pago de la deuda de la hipoteca inversa, en cuyo caso, el obligado al pago a la entidad acreedora sería el legatario y no el heredero, siempre y cuando el legatario acepte la herencia ${ }^{519}$.

No obstante, se podría dar el supuesto de que en garantía de la obligación hipotecaria se hubiese gravado más de una finca registral, es decir, que la vivienda habitual del deudor hipotecario estuviera compuesta por varios inmuebles con posibilidad de utilizarse de forma independiente. En este caso, se admitiría el pago parcial realizado por todos los herederos o por el legatario o heredero que hubiese recibido uno de los inmuebles y no el otro, debiéndose cancelar en ese caso parcialmente la hipoteca ${ }^{520}$.

En cambio, si nos encontráramos con un patrimonio negativo, esta causa de cancelación parcial se complicaría, pues esta cancelación podría ser

\footnotetext{
518 Atendiendo a este artículo: «La donación o legado de un derecho de habitación sobre la vivienda habitual que su titular haga a favor de un legitimario persona con discapacidad, no se computará para el cálculo de las legítimas si en el momento del fallecimiento ambos estuvieren conviviendo en ella.

Este derecho de habitación se atribuirá por ministerio de la ley en las mismas condiciones al legitimario discapacitado que lo necesite y que estuviera conviviendo con el fallecido, a menos que el testador hubiera dispuesto otra cosa o lo hubiera excluido expresamente, pero su titular no podrá impedir que continúen conviviendo los demás legitimarios mientras lo necesiten.

El derecho a que se refieren los dos párrafos anteriores será intransmisible.

Lo dispuesto en los dos primeros párrafos no impedirá la atribución al cónyuge de los derechos regulados en los artículos 1406 y 1407 de este Código, que coexistirán con el de habitación».

519 Ramos Chaparro, E.J., La garantía real..., op. cit., p. 581.

${ }^{520}$ Romero Candau, P.A., «La hipoteca...», op. cit., p. 322.
} 
muy perjudicial con respecto a este patrimonio, y más aún cuando los bienes de la herencia no alcanzaran para costear la deuda. En el caso de la hipoteca inversa esta situación sería muy normal debido al perfil de los solicitantes de este producto financiero, con lo cual, para poder realizar esta cancelación parcial sería necesario el consentimiento expreso de la entidad acreedora ${ }^{521}$.

En conclusión, la preferencia de cobro que ofrece siempre la hipoteca, sea inversa u ordinaria, existirá sólo con el límite del bien hipotecado, con lo que las cantidades que no logren satisfacerse con la ejecución hipotecaria de la vivienda podrían encontrar problemas para ser satisfechas.

Además, en el último inciso del apartado 6 se excluye a la hipoteca inversa de la aplicación del límite frente a terceros del párrafo segundo del artículo 114 de la LH con relación a los intereses. La doctrina reiteradamente aplicada por la DGRN establece este límite de los cinco años. Al efecto, quedó reflejado en las RRDGRN de 21 de diciembre de 2007 y de 14 de enero de $2008^{522}$, que aunque se trataba de hipotecas anteriores a la Ley 41/2007, ya se hacía referencia a la nueva regulación.

Esta excepción únicamente se aplicará a esta modalidad hipotecaria, es decir, será aplicable tanto para la hipoteca inversa sobre la vivienda habitual como para la hipoteca inversa contemplada en el apartado 10 de la DA 1. ${ }^{a}$ sobre cualesquiera otros inmuebles. De esta forma, la deuda dimanante de este préstamo o crédito garantizado con la hipoteca inversa, en el momento

\footnotetext{
521 JIMÉNEZ CLAR, A.J., «La hipoteca...», op. cit., pp. 129 y 130, indica que cualquier tipo de cancelación parcial de la hipoteca inversa requerirá el consentimiento expreso de la entidad acreedora en la medida que pueda alterar la suficiencia de la garantía.

522 Ésta última, en su fundamento de derecho $6^{\circ}$ indica que: «Los intereses sólo pueden reclamarse en cuanto tales y dentro de los límites legales y pactados, pero nunca englobados en el capital. Así resulta claramente del principio registral de especialidad que en el ámbito del derecho real de hipoteca supone la determinación separada de las responsabilidades a que queda efecto el bien por el principal y por intereses (vid. arts. 12 de la LH y 220 del RH), diferenciación que en el momento de la ejecución determina (vid. Art. 692.1 de la LEC) que el acreedor no pueda pretender el cobro del eventual exceso de los intereses devengados sobre los garantizados -dejando a salvo la posibilidad que para el caso de ser propietario del bien hipotecado el propio deudor, prevé el artículo 692.1 párrafo $2^{\circ}$ - con cargo a la cantidad fijada para la cobertura del principal, ni a la inversa. $Y$ así lo impone igualmente el necesario respeto de la limitación legal de la responsabilidad hipotecaria en perjuicio de tercero, establecida en el art. 114 de la LH, si bien esta última, tiene precisamente en el ámbito de la hipoteca inversa (figura, como hemos dicho, de contornos semejantes a la que ahora enjuiciamos), la excepción prevista actualmente -aunque no en el momento de la calificación impugnada- en el apartado 6 de la DA $1 .^{\mathrm{a}}$ de la Ley $41 / 2007$ de 7 de diciembre».
} 
de ser exigible, estará compuesta por los «débitos vencidos»: el principal y los intereses.

En conclusión, la rentabilidad que obtendrían las entidades financieras con la comercialización de este producto financiero aún sigue siendo cuestionable, ya que el margen de beneficio, prácticamente, sería nulo.

Con esta panorámica, si el propietario quisiera dejar la vivienda a sus herederos ${ }^{523}$, la hipoteca inversa no sería la opción más adecuada para obtener ingresos, pues se podría dar el caso de que éstos no recibieran el inmueble hipotecado como consecuencia del pago de la deuda generada, de manera que, sería mejor optar por otras modalidades.

\section{El recobro de la deuda por la entidad acreedora}

Cuando los herederos del deudor hipotecario no resuelvan en el tiempo convenido la devolución del préstamo y la cancelación de la hipoteca inversa, en la Disposición Adicional 1. ${ }^{a}$ de la Ley 41/2007 se contempla la ejecución de la garantía entendida como recobro. En este caso, al recaer la garantía de la hipoteca inversa en el valor de la finca hipotecada, éste (obtenido con la venta de la finca) tendrá que ser suficiente para cubrir la deuda.

El recobro de la deuda en una hipoteca inversa, a diferencia de lo que ocurre en las hipotecas ${ }^{524}$ convencionales, se efectuará, con toda probabilidad, cuando se venda ese inmueble hipotecado inversamente, una vez fallecida la parte deudora. Mientras la parte deudora permanezca con vida no amortizará ni capital ni intereses ${ }^{525}$. Estas cantidades se exigirán a su fallecimiento, momento en que se producirá el vencimiento de la garantía

\footnotetext{
${ }^{523}$ En palabras de LUQUE JIMÉNEZ, M.C., «Una nueva modalidad...», op. cit., p. 256, podríamos estar ante una «desheredación encubierta».

${ }^{524}$ En otros tipos de hipoteca, la amortización se apoya directamente en la capacidad de pago del deudor hipotecario, de forma que la hipoteca en cuanto a garantía desempeña una función subsidiaria respecto de la responsabilidad patrimonial universal del deudor, reforzando la seguridad del cumplimiento de la obligación mediante la afección de un bien inmueble determinado.

${ }^{525}$ Vid. la Resolución de la DGRN de 24 de marzo de 2008 (RJ 2008\8275).
} 
pero, esta parte deudora, como parte subjetiva, habrá dejado de existir. De ahí, que la facultad para la devolución de la deuda la tengan los sucesores de esta parte deudora ya fallecida.

Con respecto a los intereses remuneratorios de este préstamo, el pago se constituirá como una obligación de cumplimiento periódico y se irán generando junto con el pago del capital. En este caso, el incumplimiento de dicha obligación dará lugar al vencimiento anticipado de la deuda y a su exigibilidad, a través de las acciones que se contemplan tanto en la Ley de Enjuiciamiento Civil como en la Ley Hipotecaria.

Por esta causa, se entiende la limitación de la responsabilidad por intereses contenida en el artículo 114 de la LH. Atendiendo a este precepto, las acciones del acreedor por impago de intereses quedarán protegidas con la cobertura temporal pactada por un máximo de 5 años. En el caso de la hipoteca inversa, estos intereses remuneratorios serán exigibles, junto con el principal del préstamo, al momento del fallecimiento del deudor hipotecario.

No obstante, la cobertura de 5 años que establece este artículo 114 de la LH puede ser en muchos casos insuficiente ${ }^{526}$ para asegurar, en perjuicio de terceros, el importe debido por intereses remuneratorios. Por esta razón, en la Disposición Adicional $1 .^{a}$ de la Ley 41/2007 se estableció una excepción a esta regla general, dejando sin efecto, en el caso de la hipoteca inversa, los límites establecidos por el párrafo segundo del artículo 114 de la Ley Hipotecaria.

En este supuesto, los intereses generados por la deuda quedarían cubiertos por la garantía sin limitación alguna respecto de los intereses

\footnotetext{
${ }^{526}$ La denominada cláusula de «Inexistencia de Garantía Patrimonial», la encontramos en la RDGRN de 21 de diciembre de 2007 (FD $7^{\circ}$ ) y la RDGRN de 14 de enero de 2008 (FD $8^{\circ}$ ). Estas hipotecas que la contemplan, parten implícitamente de la concepción de que el bien hipotecado es la única garantía (solución desechada por la Ley 41/2007) de la hipoteca inversa y que, por tanto, debe darse solución al supuesto en que el capital más los intereses pueden ascender a más que el valor del bien hipotecado en el mercado. Para ello se admite, siempre que el deudor no haya tenido sucesos de incumplimiento del contrato, que el deudor hipotecario puede ver limitada su responsabilidad a la cantidad neta obtenida de la venta, si dicha venta de la finca hipotecada es por su valor de mercado, previa verificación por tasador independiente, $y$, además, con notificación de su propósito a la entidad acreedora.
} 
ordinarios, frente a terceros poseedores o frente a acreedores de rango posterior. Este precepto pues, no se refiere a la responsabilidad de los herederos (responsabilidad personal), sino al caso en que éstos decidieran no cancelar el préstamo. Se regula la extensión de la garantía a los intereses del crédito con respecto de terceros, quedando los herederos del deudor excluidos de la consideración de terceros, ya que éstos serán los sucesores del deudor hipotecario.

Cuando la finca hipotecada se adquiera por terceros, el momento en que se realice la venta, tanto si se realiza por el propio deudor o a su fallecimiento, servirá para determinar el importe exacto de la cuantía adeudada por intereses. De esta manera, el tercer adquirente sabrá a cuánto asciende el importe de la deuda por intereses antes de que se formalice la transmisión de ese bien inmueble, eliminando así cualquier duda sobre los intereses.

Asimismo, del carácter excepcional de este precepto se derivan dos consecuencias:

- Esta excepción sólo será de aplicación una sola vez en el caso de la transmisión voluntaria de la finca hipotecada. Si la entidad acreedora no hiciera uso en dicho momento de su derecho a declarar la obligación vencida anticipadamente, la cobertura por intereses quedaría limitada a los cinco años, tal como se establece en el artículo 114 de la $\mathrm{LH}$, pues en el caso de que no se diera esta medida, la información de las cargas que pudiera tener el inmueble no sería fiable.

- En el apartado 6 de la DA $1 .^{a}$ de la Ley 41/2007 se regula la excepción del párrafo segundo del artículo 114 de la LH, la cual sólo podrá entenderse respecto a los intereses remuneratorios y no a los intereses de demora, pues estos últimos ya quedan asegurados mediante la cobertura máxima establecida en el citado artículo. 
Para finalizar, la Disposición Adicional $1 .^{a}$ de la Ley $41 / 2007$, en la forma que establece el artículo 115 de la Ley Hipotecaria, faculta a la parte acreedora para ampliar la responsabilidad por intereses a otros bienes del deudor. En este caso, la DA 1. ${ }^{a}$ no excepciona lo dispuesto en este artículo, tal como lo hace para el artículo 114 del mismo texto legal. Conforme se indica en este precepto:

«Para asegurar los intereses vencidos y no satisfechos que no estuvieren garantizados conforme al artículo anterior el acreedor podrá exigir del deudor ampliación de la hipoteca sobre los mismos bienes hipotecados.

Esta ampliación no perjudicará en ningún caso los derechos reales inscritos con anterioridad a ella.

Si la finca hipotecada no perteneciera al deudor, no podrá el acreedor exigir que se constituya sobre ella la referida ampliación, pero podrá ejercitar igual derecho respecto a cualesquiera otros bienes inmuebles del deudor que puedan ser hipotecados».

De esta manera, para garantizar la ampliación de la hipoteca a otros bienes de la herencia, en el artículo 1082 del Código Civil se faculta a la entidad acreedora para oponerse a la partición de la herencia hasta que se le pague o afiance el importe de su crédito. En el caso de que esta partición ya se hubiera realizado ${ }^{527}$, mediante la aplicación del artículo 1084 del Código Civil, la entidad acreedora podrá dirigirse contra los herederos hasta donde alcance el valor de los bienes adjudicados, para el supuesto de aceptación de la herencia a beneficio de inventario.

\section{La subrogación de la parte acreedora}

La especial naturaleza de la hipoteca inversa regulada por la Ley 41/2007, necesita adaptarse al mecanismo de subrogación regulado por la Ley 2/1994, de 30 de marzo, de Subrogación y Modificación de Préstamos Hipotecarios. No obstante, la aplicación de la Ley 2/1994 resulta viable a la

\footnotetext{
${ }^{527}$ Esta situación se podrá dar cuando fallezca el último de los beneficiarios y nos encontremos con un patrimonio negativo.
} 
modalidad de hipoteca inversa como vía para permitir al deudor hipotecario la posibilidad de obtener las mejores condiciones financieras para su crédito.

En la hipoteca inversa, la aplicación de la Ley 2/1994 para las entidades financieras intervinientes: entidad acreedora y entidad subrogada, deberá ser preferente. De esta manera, las entidades aseguradoras autorizadas para operar en España, quedaron excluidas de esta facultad, debido a que la Ley 41/2007 reformó la citada Ley 2/1994 y no las incluyó de forma expresa. Se trata de una situación un tanto contradictoria, ya que si una entidad aseguradora, tal como se establece en la DA $1 .^{a}$, está autorizada para constituir una hipoteca inversa, también debería estarlo para subrogarse en ella.

El carácter excepcional de esta DA $1 .^{a}$ de la Ley $41 / 2007$, podía haber facilitado una «solución intermedia», permitiendo la subrogación relativa a las hipotecas inversas constituidas a partir de su entrada en vigor. No obstante, por las características que deberá reunir el deudor hipotecario, será de aplicación preferente lo dispuesto por la Ley $41 / 2007^{528}$.

Esta situación habrá de tenerse especialmente en cuenta para los supuestos en los que, junto con la hipoteca inversa, concurran otras hipotecas sobre esta finca ya gravada. La Ley 2/1994, tras la reforma de 2007, obliga en estos casos a que cuando sobre la finca exista más de un crédito hipotecario inscrito a favor de la misma entidad acreedora, la nueva entidad deberá subrogarse respecto de todos ellos. Como consecuencia, cuando la hipoteca que se quiera mejorar no sea una hipoteca inversa, esta última también entrará a formar parte de la subrogación, asumiendo la entidad subrogada todas las obligaciones y derechos contenidos en ella ${ }^{529}$.

En cuanto a la mejora de las condiciones del crédito asegurado con la hipoteca, la mejora del interés, cuando éste sea variable, no debiera plantear ningún problema. Sin embargo, el supuesto de subrogación en la hipoteca

\footnotetext{
${ }_{528}$ Vid. la RDGRN de 9 de diciembre de 2013 (TOL4.072.399).

${ }^{529}$ Al respecto véase la STS de 27 de marzo de 1999 (RJ 1999\2371).
} 
inversa cuyo fin sea alterar el plazo de la misma será difícil que se produzca, ya que por lo general el vencimiento de este plazo se producirá a la fecha de fallecimiento del deudor hipotecario, de manera que no cabrá la alteración del plazo si no más bien su cancelación.

Como se ha venido comentando, en la escritura de constitución de la hipoteca inversa se suele conceder un plazo, por lo general de seis meses, para que los herederos del deudor hipotecario puedan decidir si asumen la obligación o, por el contrario, permiten la ejecución de la garantía. En este asunto, se podría plantear si la alteración de este plazo se podría entender dentro de los supuestos permitidos por la Ley 2/1994 para proceder a la subrogación. Pues bien, como este plazo se producirá como consecuencia del fallecimiento del deudor hipotecario, al tratarse de una fecha incierta, la entidad acreedora no podrá exigir la devolución de la obligación principal más intereses y gastos hasta el vencimiento de dicho plazo. Atendiendo a esto, no tendría mucho sentido incluir las alteraciones de este plazo dentro de los supuestos en los que actúa esta Ley 2/1994.

En el supuesto de que tuviera lugar la ampliación de este plazo, se requeriría la confirmación de todos los titulares de derechos inscritos con rango posterior, para mantener así el rango de la garantía.

\section{Declaración de vencimiento anticipado por la parte acreedora}

Entre las enmiendas formuladas en el apartado 5 de la DA 1. a, se encontraban las que proponían regular el derecho del acreedor hipotecario al vencimiento anticipado de la deuda, enmiendas ${ }^{530}$ que, en este caso, sí fueron atendidas.

Las distintas enmiendas sobre este apartado proponían que el acreedor pudiera declarar el vencimiento anticipado del préstamo en el caso de que el

\footnotetext{
${ }^{530}$ Concretamente las enmiendas $n^{\circ} 55$ y 103.
} 
deudor hipotecario procediera a la transmisión voluntaria del bien hipotecado. De esta manera, atendiendo a la naturaleza de la hipoteca inversa y al público al que iba dirigido, del tenor de las distintas enmiendas formuladas al texto de la Disposición Adicional Primera se deducía que el requisito de la vivienda habitual se debía eliminar.

En cambio, se permitía que la parte acreedora pudiera reclamar anticipadamente la devolución del préstamo en caso de transmisión voluntaria del bien hipotecado por el deudor. Esta opción sería impropia ${ }^{531}$ de la institución hipotecaria, pues coartaría la libertad del deudor para transmitir la titularidad del inmueble con su correspondiente gravamen real. En realidad, desde un punto de vista puramente teórico, sería técnicamente posible mantener la hipoteca y el préstamo tras la enajenación ${ }^{532}$.

En el caso de que se limitara a este deudor hipotecario la transmisión de manera voluntaria de un bien inmueble de su propiedad, (en este caso: la vivienda hipotecada inversamente), el legislador sería el encargado de autorizar esta situación, atendiendo a las especiales circunstancias que lo pudieran haber generado. De no ser así, se trataría de una cláusula abusiva ${ }^{533}$.

\footnotetext{
531 Con idénticos argumentos, dos grupos parlamentarios -Popular y Catalán- proponen la admisión de la declaración de vencimiento anticipado del crédito por el acreedor, si bien la postura que resulta más curiosa es la del Grupo Popular, que aboga por la eliminación del requisito de la vivienda habitual al mismo tiempo que entiende también permisible la declaración del vencimiento anticipado del préstamo por la entidad crediticia, provocando a un tiempo, en opinión de ZURITA MARTín, I., «La nueva normativa...», op. cit., pp. 1296 y 1297, dos efectos claramente contrarios para el deudor: uno beneficioso -al concederle mayor campo de actuación objetivo en cuanto a la constitución de la hipoteca- y otro perjudicial, al impedirle la transmisión de la propiedad de su vivienda. El carácter innecesario de la propuesta se deriva, precisamente, de la existencia de esta garantía, que por lo general, permite al deudor hipotecario vender la finca hipotecada sin necesidad del consentimiento del acreedor, por cuanto la satisfacción del crédito sigue quedando garantizada por medio de la hipoteca que se transmite con la finca.

532 TUSET DEL PINO, P., «La hipoteca...», op. cit., p. 42, durante la tramitación de la ley, se mostró a favor de la posibilidad de transmitir la vivienda hipotecada.

533 Explica Bellod FernándeZ DE PALENCIA, E., «Cláusulas de vencimiento anticipado de un préstamo hipotecario. Resolución de la Dirección General de los Registros y del Notariado de 2 de octubre de 2006", en NUL: Estudios sobre invalidez e ineficacia, $N^{\circ} 1,2007$, que los pactos limitativos de derechos son supuestos que las Resoluciones de la Dirección General de los Registros han considerado no inscribibles por infringir el principio de libertad de contratación que inspira la legislación civil y tratarse de una limitación abusiva del derecho del dueño a disponer de sus bienes. En su opinión, estos pactos serán abusivos siempre que así lo declare la autoridad judicial en base al artículo 10 bis) de la LGDCU -actualmente, arts. 82 y ss. del Texto Refundido de 16 de noviembre de 2007-, por lo que, en principio, y hasta que se dicte la sentencia de nulidad, serán inscribibles en el Registro de la Propiedad. En estos supuestos, la cláusula sería nula, no por ir en contra de la libertad de contratación, ya que esos pactos son válidos cuando las cláusulas son negociadas, sino por ser una cláusula predispuesta la causante de una situación de desequilibrio entre las partes, en perjuicio del prestatario.
} 
No obstante, conforme apunta ÁLVAREZ ${ }^{534}$, si la transmisión del inmueble no es voluntaria por parte del deudor, no se podrá pactar el vencimiento anticipado $^{535}$, y tampoco en los casos en los que se produzca una anotación de embargo sobre la finca gravada o porque sobre ella se constituya algún derecho real.

Tampoco se podrá acordar el vencimiento anticipado si el deudor deja de residir en la finca (tal y como sucedía en muchas hipotecas inversas antes de la entrada en vigor de la Ley 41/2007), ya sea un cambio de domicilio voluntario o forzoso (por ejemplo, por atribución judicial del uso al cónyuge del deudor o a su conviviente tras un proceso matrimonial de separación o divorcio). Asimismo, tampoco tendrá lugar una transmisión voluntaria del inmueble cuando se altere la titularidad dominical entre cónyuges como consecuencia de la liquidación de la sociedad de gananciales ${ }^{536}$.

\section{Venta de la vivienda hipotecada}

Las entidades financieras suelen estipular en las condiciones del contrato de hipoteca que la venta de la vivienda gravada causará el vencimiento anticipado del crédito ${ }^{537}$.

En el caso de la hipoteca inversa se ha admitido esta cláusula con el propósito de proteger los intereses del acreedor hipotecario. Concretamente, en el segundo párrafo del apartado 5 de la DA 1 . $^{a}$ se prevé la resolución del contrato de hipoteca inversa mediante la venta del inmueble ${ }^{538}$. Pero, a diferencia de lo que sucede con la hipoteca convencional, la doctrina

\footnotetext{
${ }^{534}$ Al respecto vid. Álvarez Álvarez, H., La hipoteca inversa..., op. cit., pp. 141-147.

${ }^{535}$ Al respecto vid. las Resoluciones de la DGRN de 3 de octubre de 2014 (RJ/2014l5512 y RJ2014\5514) y de 6 de octubre de 2014 (RJ2014\6721).

536 Cfr. CarRasco Perera, Á.; Cordero lobato, e. y Marín López, M.J., Tratado de..., op. cit., p. 918.

537 Vid. la Resolución de la DGRN de 24 de marzo de 2008 (RJ 2008\8274).

538 Álvarez Álvarez, H., La hipoteca inversa..., op. cit., p. 141, narra que en EEUU la vivienda no puede venderse. Si se vendiera, en ese momento la entidad de crédito podría solicitar que se le pagase la deuda. También ocurre lo mismo en los supuestos de bancarrota, donación de la vivienda, abandono, traslado de la residencia habitual a otro lugar, cometer delitos de fraude o falsa declaración, expropiación de la vivienda, dejar de pagar los impuestos que corresponden a la propiedad, o dejar de tener asegurada la vivienda. En estos casos se resolverá el contrato y la entidad acreedora exigirá que se le pague la deuda.
} 
considera que la hipoteca inversa limita la facultad de disposición, que salvo pacto en contrario, el deudor o prestatario mantendrá la titularidad de la vivienda.

Si se pactara la enajenación de esta vivienda, se debería tener acceso al Registro de la Propiedad, pues este pacto alteraría la concepción de esta hipoteca inversa ${ }^{539}$. Esta medida protegería a la parte acreedora como consecuencia del riesgo que supone la contratación de esta modalidad hipotecaria, pues no tiene ningún sentido que se pueda transmitir voluntariamente a un tercero la vivienda hipotecada y que subsista la garantía sobre la vivienda del que ya no es titular de la vivienda. En este aspecto, si se enajenara esta vivienda, la entidad acreedora podría resolver el crédito o préstamo garantizado. Ahora bien, esto sólo se dará para los casos en los que la vivienda sea la habitual ${ }^{540}$.

De acuerdo con el apartado 10 de la DA 1. ${ }^{a}$, cuando se hipotequen inversamente segundas viviendas $u$ otro tipo de bienes inmuebles no les serán de aplicación los apartados anteriores de esta Disposición y, por tanto, tampoco el párrafo segundo de este apartado 5 . Así pues, en el caso de que se trate de un bien inmueble que no constituya la vivienda habitual del deudor, este bien podrá transmitirse o enajenarse sin que el deudor tenga que sustituir la garantía de manera suficiente, pues en este caso no se producirá la inmovilidad del bien gravado.

\footnotetext{
${ }^{539}$ ANGUITA Ríos, R.M., «La hipoteca...», op. cit., pp. 13 y 14.

540 La RDGRN de 19 de marzo de 2008 (RJ 2008/8272) indica que: «Nuevamente ha de atenderse aquí a la peculiar causa de las financiaciones con hipoteca inversa; a saber, que el cliente pueda permanecer en su vivienda sin efectuar pago alguno de principal e intereses precisamente porque le hace falta, porque no tiene otra vivienda de residencia (ésa es la dimensión social de estas hipotecas, que quizá se pasa por alto con facilidad). Por ello, si el prestatario vende su casa (lo que, lógicamente, presupone que cuenta con otra para vivir) la entidad financiadora pueda exigirle que destine el precio de venta a pagar principal e intereses, sin esperar ya a su muerte, como en el caso precedente; es decir, dicha venta quede configurada en el contrato como supuesto de vencimiento anticipado del préstamo o crédito. Bien es cierto que la Dirección General ha venido rechazando, tradicionalmente, la venta de inmueble hipotecado como supuesto de vencimiento anticipado (por ejemplo, RRDGRN de 27 de enero de 1986 o de 8 de noviembre de 1993); sin embargo, esa negativa siempre ha operado en el marco de préstamos y créditos «promediales», es decir, aquéllos en los que sí hay amortización de principal y pago de intereses de forma regular y continuada antes de que el prestatario fallezca, lo que no es el caso en la hipoteca que nos ocupa».
} 
En este sentido, es importante destacar la discordancia ${ }^{541}$ que existe entre este apartado 5 con el apartado 1 de la misma Disposición Adicional. Mientras que en el apartado 5 se dice que el acreedor podrá declarar el vencimiento anticipado en el caso de que el bien inmueble sea transmitido voluntariamente. En el apartado 1, al definir la hipoteca inversa y sus requisitos, se establece que la deuda sólo será exigible por el acreedor, y la garantía ejecutable cuando fallezca el prestatario o, si así se estipula en el contrato, cuando fallezca el último de los beneficiarios. Luego atendiendo a este apartado 1, no podría enajenarse la vivienda hipotecada inversamente causando, de esta manera, el vencimiento anticipado.

El legislador debería haber sido más preciso y haber incluido unos parámetros o unas directrices para valorar cuándo la garantía se ha sustituido suficientemente. De lo que no hay duda es que debe haber acuerdo entre las partes sobre la procedencia de la garantía sustitutoria y, si no hay acuerdo y el acreedor considera que no es suficiente la garantía ofrecida, tendrá que ser el juez el que decida.

Según ÁlVAREZ ${ }^{542}$, la garantía quedaría cubierta en los casos que, a cambio de vender ese inmueble, se ofreciese otro de similares características, o de igual o mayor valor económico, para que sobre el mismo se constituyese la hipoteca inversa produciéndose así un cambio de objeto. Si se diera este caso, el acreedor debería dar su consentimiento.

Para otros autores ${ }^{543}$ no es necesario que la garantía hipotecaria pueda sustituirse por otra de la misma naturaleza, pues consideran que es posible aportar otro inmueble, en cuyo caso se estaría ante una nueva hipoteca inversa con cambio de objeto, pero también podría establecerse como garantía un bien mueble, como por ejemplo, un paquete de acciones, un

\footnotetext{
541 Para JiMÉnEz CLAR, A.J., «La hipoteca...», op. cit., p. 128. Según este autor la solución adoptada por la Ley 41/2007 es de naturaleza híbrida. De una parte, sanciona el uso como vivienda del inmueble hipotecado como requisito inicial para la válida constitución de la hipoteca inversa, pero por otra no establece la continuidad de dicha circunstancia como requisito de la garantía, de tal forma que su desaparición produzca el vencimiento anticipado de la obligación garantizada.

542 Álvarez Álvarez, H., La hipoteca inversa..., op. cit., p. 143.

${ }^{543}$ De esta opinión es SeRRANO de Nicolás, Á., «Régimen jurídico...», op. cit., p. 50.
} 
depósito bancario o una participación en un fondo de inversión. En estos casos ya no habría hipoteca inversa, pues ya no se trataría de un inmueble ${ }^{544}$.

Ahora bien, esta venta de la vivienda deberá ser voluntaria por parte del deudor, no pudiendo el acreedor utilizar esta posibilidad en los casos de ejecución forzosa. De esta manera, la dación en pago, la donación, la permuta y la venta supondrían la transmisión voluntaria de un bien dando lugar al vencimiento anticipado. En cambio, la constitución de un derecho de usufructo sobre un bien inmueble no produciría esta transmisión. Tampoco habría transmisión voluntaria cuando la traditio no se produjera en vida del deudor hipotecario, ni tampoco en los supuestos de las disposiciones mortis causa $^{545}$.

A pesar de que la Ley 41/2007 no hace mención al tipo de garantías que se podrían dar, se entiende que en caso de que se venda la vivienda sobre la que recae la hipoteca inversa, las garantías se den en el tiempo más breve posible para evitar el vencimiento anticipado del préstamo garantizado. De forma que, si estas garantías no se sustituyeran inmediatamente por otras nuevas e igualmente seguras, el deudor vería perder el plazo y el acreedor podría reclamarle el cumplimiento de la obligación surgida por la contratación de la hipoteca inversa, es decir, la devolución de la deuda.

Asimismo, tal y como han señalado Carrasco Perera y Cordero Lobato ${ }^{546}$, la sustitución de la garantía de manera suficiente, en el caso de la hipoteca inversa resultará insuficiente, pues no tiene sentido que el acreedor tenga que posponer la ejecución hasta que fallezca el deudor cuando se hubiera transmitido el inmueble a un tercero, incluso en aquellos casos en los que la transmisión sea de manera forzosa.

\footnotetext{
544 Romero Candau, P.A., «La hipoteca...», op. cit., p. 324.

545 SerRano de Nicolás, Á., «Régimen jurídico...», op. cit., p. 50.

${ }^{546}$ Al respecto vid. Carrasco Perera, Á. y CoRdero Lobato, E., «La hipoteca inversa y el aseguramiento de intereses o de por qué tiene que ser revocada la doctrina de la DGRN sobre el anatocismo», Actualidad Jurídica Aranzadi (on line), № 741, Civitas, Madrid, 2007, pp. 17-19.
} 
Estos autores tampoco se muestran partidarios de que las partes puedan pactar una prohibición de disponer ${ }^{547}$, pues sólo se satisfaría el interés del deudor poniendo su propiedad a salvo de sus acreedores. Sin embargo, entienden que sí puede permitirse que se pacte como causa de vencimiento anticipado del crédito no sólo la venta, sino también la anotación o el embargo sobre la finca gravada con la hipoteca inversa, siempre que se pacte que el acreedor pueda, en el momento del fallecimiento del deudor, dirigirse sólo contra el inmueble gravado de forma inversa.

Aun así, estas opciones no podrían llevarse a cabo en esta modalidad hipotecaria, pues en el apartado 6 de la DA $1 .^{\text {a }}$ se precisa que el acreedor podrá obtener recobro hasta donde alcancen los bienes de la herencia. Por tanto, la anotación o el embargo de la finca gravada no podrían admitirse como causa de vencimiento anticipado.

Otro inconveniente con el que nos encontramos al realizar una hipoteca inversa es que para que pueda constituirse como tal, el bien inmueble tendrá que ser la vivienda habitual del deudor, por lo que sólo se podría dar esta circunstancia de cambio de objeto en el caso de que el deudor tuviera más de una vivienda habitual. Pero, vivienda habitual sólo hay una, ya que en el caso de que el deudor tuviera más viviendas, éstas serían calificadas como segundas o terceras residencias.

En el supuesto de que el deudor se separe o divorcie y se atribuya el derecho de uso sobre la vivienda hipotecada inversamente a su cónyuge o a su conviviente de hecho, o se produzca la liquidación de la sociedad de

\footnotetext{
547 Martínez Escribano, C., La hipoteca inversa, op. cit., pp. 166 y 167. La citada autora indica que cuando la ley determina la posibilidad del acreedor hipotecario de dar por vencida la deuda si se transmite voluntariamente la vivienda hipotecada, no se está estableciendo una prohibición legal de disponer, sino una obligación de no disponer. En la prohibición de disponer falta la facultad de disposición en el propietario y en consecuencia la transmisión es nula o al menos anulable, sin embargo, esto no ocurre en la obligación de no disponer. La transmisión es válida, pero como consecuencia del incumplimiento de la obligación se deriva una consecuencia que es el vencimiento anticipado del préstamo, cesa la obligación del acreedor hipotecario, que puede pedir la total restitución de las cantidades entregadas con los intereses. Sobre la diferencia entre ambas, cfr. CANo MARTínEZ DE VELASCO, J.I., Las prohibiciones de disponer o la fuerza constitutiva del Registro, Bosch, Barcelona, 2006, pp. 23 y ss.; Cecchini Rosell, X., Eficacia de las prohibiciones de disponer. Causa y derechos de terceros, Thomson Aranzadi, Navarra, 2003, pp. 31 y ss.
} 
gananciales, la Ley 41/2007 tampoco ha previsto nada al respecto ${ }^{548}$. En estos casos, CARRAsco Perera y CORDERo LOBATO ${ }^{549}$ entienden que aunque el deudor se vea privado del uso del inmueble, no cabrá el vencimiento anticipado del crédito.

Pues bien, en lo que aquí nos atañe, si el deudor quisiera transmitir en vida la vivienda hipotecada en garantía de una deuda creciente, cuyo importe en un futuro pudiera llegar a absorber íntegramente el valor de la vivienda (caso de la típica hipoteca inversa), al adquirente le interesaría cancelar la hipoteca, pues esta deuda seguiría creciendo hasta la fecha en que falleciese el deudor. Entonces, si mediante este pago se cancelara la hipoteca inversa, la única solución coherente desde el punto de vista del deudor, sería dar por vencido anticipadamente el préstamo, ya que cualquier disposición que se realizara a partir de ese momento quedaría desprovista de la garantía hipotecaria.

La otra alternativa sería adquirir la vivienda hipotecada sin cancelar el préstamo. Sin embargo, el carácter creciente de la deuda garantizada por la hipoteca inversa dificultaría el cálculo de un precio adecuado del inmueble, ya que se desconoce el importe exacto al que llegará a ascender la deuda. Si se cumplieran los objetivos en la fecha de vencimiento del préstamo, al fallecimiento del deudor, el valor de la deuda y del inmueble tenderían a coincidir pero, en la práctica, la adquisición de inmuebles garantizados con una hipoteca inversa, al menos, en el caso de transmisiones a título oneroso, no será la opción más aconsejable.

\subsection{Breve referencia a la llamada Doctrina del Trienio}

Con la aprobación de la Ley 41/2007, el artículo 12 de la LH quedó redactado de la siguiente manera:

\footnotetext{
548 Álvarez Álvarez, H., La hipoteca inversa..., op. cit., p. 146.

549 Vid. Carrasco Perera, Á. y Cordero Lobato, E., «La hipoteca inversa...», op. cit., pp. 17-19.
} 
«En la inscripción del derecho real de hipoteca se expresará el importe del principal de la deuda y, en su caso, el de los intereses pactados, o, el importe máximo de la responsabilidad hipotecaria, identificando las obligaciones garantizadas, cualquiera que sea la naturaleza de éstas y su duración.

Las cláusulas de vencimiento anticipado y demás cláusulas financieras de las obligaciones garantizadas por hipoteca a favor de las entidades a las que se refiere el artículo 2 de la Ley $2 / 1981$, de 25 de marzo, de Regulación del Mercado Hipotecario, en caso de calificación registral favorable de las cláusulas de trascendencia real, se harán constar en el asiento en los términos que resulten de la escritura de formalización».

La intención del legislador con la nueva redacción era concretar el contenido que debería tener la inscripción del derecho real de hipoteca, evitando calificaciones registrales discordantes que puedan impedir la uniformidad en la configuración registral. Al respecto, convendría señalar que existe un conjunto de resoluciones de la Dirección General, dictadas después de ser aprobada la Ley 41/2007, que hace referencia a hipotecas inversas suscritas con anterioridad a la Ley, y que constituye un fiel ejemplo de la aplicación de la que se ha llamado «doctrina del trienio» ${ }^{550}$.

La RDGRN de 21 de diciembre de 2007, constituye una de las primeras manifestaciones de la doctrina del trienio. En el fundamento jurídico décimo destaca como, tras la aprobación de la Ley 41/2007, el registrador debe limitar su actuación a hacer constar las cláusulas financieras y de vencimiento anticipado, esto es, a transcribir sin más las mismas.

La escritura objeto de inscripción preveía el vencimiento anticipado en la cláusula financiera número 2 . En esta cláusula se indicaba que «el importe del préstamo se reembolsará a) cuando se formalice la venta de la finca o b) cuando la entidad prestamista presente un requerimiento de pago por la deuda pendiente, añadiendo que «mientras el prestatario no haya incumplido la presente escritura» la entidad prestamista sólo podrá requerir el pago en una serie de casos: a) seis meses desde la muerte del último residente nombrado o b) que el último residente nombrado haya dejado de residir en la finca. Incluso se indica que se entiende por dejar de residir: mantenerse ausente seis meses, se tenga o no intención de regresar».

550 Nombre acuñado por CARRASCO PeRERA, Á., en «Comentario a la RDGRN de uno de octubre de 2010", Cuadernos Civitas de jurisprudencia civil, № 86, Civitas, Madrid, 2011, pp. 1159-1206. Cfr. SÁnCHezVentURA MORER, I., La hipoteca inversa..., op. cit., pp. 285-302. 
El registrador consideró que el supuesto de vencimiento por venta de la finca hipotecada «no resulta inscribible, de conformidad, con lo establecido en el art. 27 LH, que niega el acceso al Registro, de las prohibiciones de disponer».

El registrador no había puesto en duda en ningún momento la falta de identificación de la obligación. En el plano obligacional, las partes pueden pactar lo que más les convenga, pero eso no significa que cualquier cláusula contenida en el contrato vaya a acceder al Registro. La argumentación de la Dirección resulta algo más confusa. Como se acaba de observar concede trascendencia real a este tipo de cláusula y dota a su incumplimiento de efectividad hipotecaria.

Sin embargo, esta cláusula no hizo más que aplicar de manera restrictiva el nuevo artículo 12 de la $\mathrm{LH}$, es decir, la cláusula de vencimiento anticipado se inscribirá sin más. Hasta prácticamente mediados de 2008, todas las resoluciones dictadas por la DGRN ${ }^{551}$, a raíz del conflicto planteado por la inscripción de una hipoteca inversa, copian de manera literal lo dispuesto en esta primera resolución de 21 de diciembre de 2007 para el vencimiento anticipado por venta de la finca hipotecada.

Esta situación cambió tras la RDGRN de 1 de octubre de 2010, que declaró la no inscripción de las cláusulas de vencimiento anticipado por transmisión de la finca hipotecada, con la única excepción de las hipotecas inversas constituidas conforme a la Ley 41/2007.

No obstante, esta situación no deja de ser excepcional ya que se vulneran algunos de los principios, tales como la libre contratación o la libre circulación de los bienes, causas suficientes para que la Dirección haya aplicado de manera restrictiva lo previsto en la DA 1. ${ }^{a}$. De esta manera, podrá incluirse en el contrato una cláusula que declare el vencimiento anticipado

\footnotetext{
${ }^{551}$ A modo de recordatorio volvemos a citar las RRDGRN de 14 de enero de 2008 (RJ 200812091), de 14 de marzo de 2008 (RJ 2008\2103), de 19 de marzo de 2008 (RJ 2008\1483), de 22 de marzo de 2008 (RJ 200818273), de 27 de marzo de 2008 (RJ 200818278) y de 20 de mayo de 2008 (RJ 200817715).
} 
por transmisión de la finca gravada con una hipoteca inversa, sólo si se ofrece, a su vez, la posibilidad de recoger la garantía de manera suficiente.

Tal y como señala la RDGRN de 1 de octubre de 2010 en su fundamento jurídico octavo, «si bien se admite dicho pacto, como supuesto de excepción, en el caso precisamente de la hipoteca inversa, se limita al supuesto de transmisión -sin extenderse a la constitución de gravámenes o derechos reales limitados- y condicionado a que se conceda al deudor la facultad de sustituir la garantía de manera suficiente en aplicación de la norma imperativa contenida en el artículo $1129.3^{\circ}$ del CC, lo que ratifica la ilegalidad, y consiguiente rechazo registral, del pacto si no consta la indicada salvedad, como sucede en el presente caso".

En el caso resuelto por esta resolución, la no concesión de la posibilidad de sustituir la garantía de manera suficiente, llevó a la Dirección a rechazar la inscripción de esa cláusula ${ }^{552}$. En la medida en que esa cláusula consta en el asiento registral, el acreedor, en caso de transmisión del inmueble, podrá requerir el pago al deudor. En el supuesto de que no cumpla voluntariamente la obligación de pago, el acreedor podrá ejercitar la acción hipotecaria (art. 130 de la LH). Por esta razón, no da lo mismo que esté o no inscrita la cláusula en el Registro.

\section{Acción de devastación y vencimiento anticipado del préstamo: artículo 1129.3 del Código Civil}

La Ley Hipotecaria, en su artículo 117 contempla la facultad de ejercitar la denominada acción de deterioro o devastación, atribuida a la parte acreedora frente al deudor hipotecario cuando éste no cumpla con la obligación de conservar el inmueble en buen estado. Este artículo atiende a las medidas que el acreedor hipotecario podrá tomar en caso de que vea peligrar la suficiencia de su garantía, concediéndole la facultad de acudir a la autoridad judicial.

\footnotetext{
552 Las RRDGRN de 4 de noviembre de 2010 (RJ 2011\2461) y de 11 de enero de 2011 (RJ 2011 \269) copian, respecto a este tema, literalmente la RDGRN de 1 de octubre de 2010.
} 
La acción de devastación ${ }^{53}$ tiene por finalidad evitar que el deudor hipotecario abandone la finca y su valor pueda resultar insuficiente para hacer frente al pago de la deuda en el momento de la ejecución de la hipoteca. Ahora bien, en el caso de que esta situación se diera en la finca hipotecada inversamente, debido a las peculiaridades de ésta, los efectos causados no tendrían la misma trascendencia que los producidos en la hipoteca convencional.

Así, junto a la acción de devastación, entre las medidas que concede el ordenamiento jurídico al acreedor para la satisfacción de su derecho, el artículo 1129 del Código Civil ${ }^{554}$ le permite dar por vencido anticipadamente el crédito cuando no otorgue el deudor las garantías a que estuviese comprometido. En consecuencia, el acreedor hipotecario, cuando se produzca la disminución de esta garantía, podrá optar entre el vencimiento anticipado de la obligación o las medidas establecidas por la acción de devastación.

En cuanto a la compatibilidad de estas opciones, no parece que exista discrepancia doctrinal ${ }^{555}$. Ello a pesar de que el artículo 117 de la Ley Hipotecaria, el $219.2^{\circ}$ del Reglamento Hipotecario (se permite al juez declarar vencido el crédito) y el 1129 del Código Civil actúan en distintos ámbitos, por lo que difícilmente podrán considerarse aquéllos como normas especiales en relación con este último ${ }^{556}$. No obstante, debe tenerse en cuenta que para que entre en aplicación el artículo $1129.3^{\circ}$ del Código Civil será necesario que la disminución de la garantía ${ }^{557}$ se dé en una cuantía

\footnotetext{
$5^{553}$ Cuestión analizada con anterioridad.

554 Concretamente, en su apartado $3^{\circ}$ : «Cuando por actos propios hubiese disminuido aquellas garantías después de establecidas, y cuando por caso fortuito desaparecieran, a menos que sean inmediatamente sustituidas por otras nuevas e igualmente seguras».

${ }^{555}$ ZURITA MARTín, I., «La nueva normativa...», op. cit., p. 1300.

556 En este sentido encontramos DíEZ-PICAZO, L., «El pago anticipado», en Revista de Derecho Mercantil (RDM), vol. XXVIII, núm. 73, julio-septiembre, 1959, pp. 77 y 78; MonTÉs PENADÉs, V.L., «Comentario del artículo 1129 del CC», en Comentarios al Código Civil y Compilaciones Forales, tomo XV, vol. 2², artículos 1125 a 1155 del CC, VV.AA., dir. por Manuel ALBALADEJO, EDERSA, Madrid, 1983, p. 141; CLEMENTE MEORO, M., «El tercer poseedor de bienes hipotecados como tercero adquirente», en Revista General de Derecho (RGD), diciembre 1992, p. 118.

557 La DGRN en su Resolución de 3 de abril de 2000 (RJ 2000\2741) expresa que: «La doctrina de este centro directivo no sólo ha admitido la modulación por vía de pacto del vencimiento anticipado que establece el artículo $1129.3^{\circ}$ del Código Civil para concretar el grado de quebranto o pérdida de valor de los bienes que se configure como disminución de la garantía, sino también que a su amparo puedan configurarse como causas de vencimiento anticipado pérdidas o disminuciones del valor de los bienes producidas con independencia de la existencia o no de culpabilidad del deudor o propietario,
} 
considerable, en el sentido de que no sería suficiente, en opinión de la doctrina ${ }^{558}$, el mero temor de que la garantía disminuya, dada la gravedad de la sanción impuesta, la excesiva amplitud y ambigüedad del concepto de temor y los mismos términos amplios en que viene concebida la disminución.

En una hipoteca tradicional, la disminución se traduce en una reducción del valor aseguratorio, existiendo un componente de alteración de las circunstancias tenidas en cuenta para otorgar el plazo por el acreedor. Esta disminución podrá producirse tanto por razones materiales como jurídicas, negándose doctrinalmente que pueda suponer una mengua de la garantía otorgada la enajenación de todo el inmueble a un tercero o la constitución de una hipoteca o una servidumbre sobre el inmueble anteriormente hipotecado ${ }^{559}$.

En la hipoteca inversa, por tanto, se tendría que comprobar la disminución exacta de esta garantía ${ }^{560}$. En el caso de que esta pérdida de garantía tuviera su origen por actos o acciones imputables al deudor, éste, necesariamente tendría que sufrir sus consecuencias, como por ejemplo, el vencimiento anticipado por parte de la entidad acreedora.

Ahora bien, cuando esta pérdida de garantía fuera producida por causas fortuitas, no imputables al deudor hipotecario, por ejemplo, la rebaja del precio de la vivienda como resultado de crisis en el sector inmobiliario, esta posibilidad de vencimiento anticipado no estaría tan clara. Pues a pesar de que el artículo $1129.3^{\circ}$ del Código Civil contempla el supuesto de desaparición de las garantías, en lo referente a la disminución de la garantía por la bajada

admitiendo como tales hechos o circunstancias que supongan un riesgo para la subsistencia y rango de la garantía, o para declararlas inadmisibles cuando el supuesto contemplado no implica tal riesgo».

558 Vid. MORENO QUESADA, B., «El vencimiento anticipado del crédito por alteración de sus garantías (artículo 1129.3 del CC)», ADC, 1971, p. 448; ClemENTE MEORO, M., «El tercer poseedor...», op. cit., p.113.

${ }^{559}$ Clemente Meoro, M., «El tercer poseedor...», op. cit., p. 115.

560 Existen argumentos doctrinales que fundamentan ambas teorías, pero por ejemplo, MONTES PENADÉS o MORENO QUESADA se muestran partidarios de la primera tesis, es decir, de considerar que se aplica a las dos hipótesis del artículo 1129.3 del CC, mientras que CLEMENTE MEORO aboga por la segunda tesis, entendiendo que no se puede ampliar o complementar la garantía que ha sido disminuida por los propios actos del deudor si el acreedor da por vencida la obligación. Cfr. MONTÉs PenAdÉs, V.L., «Comentario del...», op. cit., pp. 143 y 144; MORENO QueSAdA, B., «El vencimiento...», op. cit., p. 478; CLEMENTE MEORO, M., «El tercer poseedor...», op. cit., pp. 126 y ss. 
de precios en el sector inmobiliario, se podría introducir una cláusula en el momento de la constitución de esta hipoteca inversa en la que se indicara que, en el caso que se produjera la disminución de esa garantía hipotecada, pudiera causarse el vencimiento anticipado.

Si se produjera esta causa de vencimiento anticipado, con respecto a la situación del deudor, sus efectos serían gravemente perjudiciales, ya que la desaparición de esta garantía produciría el vencimiento anticipado de la misma, e incluso, una posible ejecución. Por este motivo, en la Ley 41/2007 se estableció la obligación de una tasación inicial con el fin de autorizar una cantidad máxima o fija al solicitante de la hipoteca inversa para disponer en proporción al valor del bien inmueble hipotecado. Con esta tasación, las entidades acreedoras y el mismo deudor, se aseguraban el riesgo de que este inmueble, con el transcurso del tiempo, disminuyera de valor.

Aun así, en la hipoteca inversa, los pactos ${ }^{561}$ de vencimiento anticipado como consecuencia de la depreciación del valor del inmueble hipotecado por causas ajenas a la voluntad del deudor, son difíciles que se produzcan. De esta forma, la opción de vencimiento anticipado dependerá de las circunstancias en que se produzca la disminución de ese valor dado en garantía. Estas circunstancias serán las que guiarán al acreedor a decidirse por esta opción de vencimiento anticipado, regulada en el artículo $1129.3^{\circ} \mathrm{del}$ CC o, decantarse por la acción de devastación, prevista en el artículo 117 de la LH.

\subsection{Desaparición o pérdida de la garantía}

\footnotetext{
${ }^{561}$ No obstante, la Dirección General de los Registros y del Notariado ha admitido la posibilidad de que, mediante pacto, pueda establecerse como causas de vencimiento anticipado pérdidas o disminuciones del valor de los bienes producidas con independencia de la existencia o no de culpabilidad del deudor o propietario (Resoluciones de 23 de octubre de 1987, 16 de marzo y 26 de diciembre de 1990), siempre que cumplan unas exigencias mínimas como la concreción de la disminución del valor que la determine (Resolución de 8 de noviembre de 1993) y que ésta no quede al arbitrio de una de las partes (Resolución de 4 de julio de 1984).
} 
En la DA 1. ${ }^{a}$ de la Ley $41 / 2007$ no se especifica el tipo de garantía que se ha de prestar, exigiendo únicamente el requisito de suficiencia en la misma forma en que lo establece el artículo 1129 del Código Civil, para el supuesto de la desaparición o pérdida de la garantía. Aunque se sobreentiende que sería el valor en dinero del inmueble dado en garantía, nos podríamos encontrar con diferentes alternativas:

1.- Que la garantía fuera restituida de la misma forma con el fin de mantener la relación contractual, es decir, al tratarse de una hipoteca, la nueva garantía ${ }^{562}$ debería ser sustituida por otro bien inmueble.

En este caso, se entiende que este nuevo inmueble tendrá que constituir la vivienda habitual del deudor hipotecario, de lo contrario, no se acogería a la hipoteca inversa que se había contratado.

2. - Acudir al mecanismo de subrogación regulado por el artículo 110.2 de la Ley Hipotecaria con respecto a las indemnizaciones debidas por razón de siniestro o expropiación de la finca hipotecada.

Esta opción no sería nada aconsejable para el deudor hipotecario, pues éste quiere disfrutar de la vivienda habitual (en calidad de garantía). Por tanto, el depósito o la consignación de una suma de dinero a percibir por la transmisión de esta vivienda, no se adaptaría a sus necesidades. Además, en esta opción seguiría aumentando la deuda por intereses sin que la vivienda habitual dada en garantía facilitara este uso al deudor.

Con respecto a la primera opción, la de restitución de una nueva garantía, es decir, otro bien inmueble, no debería plantear ningún problema si se tratara de una cantidad de dinero y se optara por el procedimiento regulado en este artículo 110.2 de la Ley Hipotecaria. Ahora bien, en caso de que esta garantía se restituyese por un bien inmueble, podríamos diferenciar dos situaciones:

\footnotetext{
562 El carácter inmediato de la sustitución de la antigua garantía por la nueva, por así decirlo expresamente el precepto, que establece que las garantías deben ser «inmediatamente sustituidas». Ahora bien, dicha expresión hay que interpretarla con flexibilidad de acuerdo con las reglas de la buena fe. Cfr. Montés Penadés, V.L., «Comentario del...», op. cit., pp. 143 y 144; Clemente MeOro, M., «El tercer poseedor...», op. cit., p. 132.
} 
1.- Que el inmueble con el que se pretendiese sustituir la garantía no reuniese las condiciones para constituir una hipoteca inversa, concretamente, a la condición de vivienda habitual. En este caso, se tendría que convenir un nuevo contrato entre la entidad acreedora y el deudor.

2.- Que se quisiera mantener el contrato inicial, es decir, la vivienda hipotecada inversamente se tendría que sustituir por otra con idénticas características. Esta vivienda, al igual que la primera, debería ser tasada y asegurada contra daños. Y, obviamente, destinada a vivienda habitual.

Como causa de desaparición de esta garantía, normalmente la vivienda habitual del deudor hipotecario, también cabría hacer mención a los posibles efectos novatorios producidos por la transmisión voluntaria de esta vivienda con respecto a la hipoteca inversa.

Si atendemos al artículo 1207 del CC: «Cuando la obligación principal se extinga por efecto de la novación, sólo podrán subsistir las obligaciones accesorias en cuanto aprovechen a terceros que no hubiesen prestado su consentimiento».

En este caso, se trataría de un supuesto de subrogación legal objetiva, de forma que la hipoteca inversa seguiría manteniendo su rango. Por tanto, los efectos de novación no se originarían. No obstante, se podría dar la situación que el inmueble con el que se pretendiese restituir al primero gravado con hipoteca inversa no cumpliera las mismas características en lo referente a su garantía. En este caso, al igual que en el primer inmueble hipotecado, este segundo también tendría que ser tasado, y más aún cuando su valor fuera superior al del primer inmueble, ya que se produciría una situación de superposición o reforzamiento de la garantía inicial, esto es, de sobrehipoteca ${ }^{563}$.

${ }^{563}$ Así lo señala JIMÉNEZ CLAR, A.J., «La hipoteca...», op. cit., p. 131. 


\section{Embargo de vivienda sobre la que está constituida una hipoteca inversa}

La vivienda sobre la que se constituya una hipoteca inversa podrá ser objeto de embargo ${ }^{564}$ en aquellos casos en los que su titular figure, por ejemplo, como avalista en un procedimiento ordinario por el que se le reclame una cantidad de dinero. En el supuesto del embargo ${ }^{565}$ sobre una hipoteca, ésta no se vería afectada por las cargas posteriores, pues esta hipoteca constituiría la primera carga que recaería sobre el inmueble, teniendo así prioridad sobre las posibles cargas posteriores.

En este caso, también se ha de señalar que en la hipoteca inversa, como ya se ha comentado en innumerables ocasiones, mientras viva el deudor o el último de los beneficiarios no se podrá realizar ninguna ejecución hipotecaria. Y, dadas las características del público al que va dirigida esta modalidad, a diferencia de lo que sucede con las hipotecas convencionales, tampoco se podrá obligar a que estos sujetos abandonen esta vivienda sobre la que recae un embargo.

Por tanto, para proceder a la ejecución de esta modalidad hipotecaria ${ }^{566}$ se tendrá que esperar al momento del fallecimiento del deudor o del último beneficiario, en el caso de que lo hubiera y, siempre y cuando, los herederos de éstos no quisieran hacer frente a la deuda generada, tal y como lo establecen los apartados 5 y 6 de la DA $1 .^{a}$ de la Ley $41 / 2007$.

\section{Otras posibles causas de vencimiento}

Junto al fallecimiento del deudor o último beneficiario y la venta de vivienda hipotecada inversamente, existen otras causas $^{567}$ que pueden

\footnotetext{
564 Vid. Montero aroca, J.; Gómez Colomer, J.L.; Barona Vilar, S. y Calderón Cuadrado, M.P., Derecho jurisdiccional II, op. cit., pp. 617-622.

565 Vid. la Resolución de la DGRN de 10 diciembre de 1997 (RJ 1997\8821).

${ }^{566}$ Álvarez Álvarez, H., La hipoteca inversa..., op. cit., p. 159.

567 Vid. MARTínez Escribano, C., La hipoteca inversa, op. cit., pp. 168-187. Frente a esta limitación legal por parte de nuestra regulación, en la práctica estadounidense y británica se amplían las circunstancias
} 
justificar el interés del acreedor hipotecario en que se produzca el vencimiento anticipado del préstamo o crédito garantizado.

Antes de la entrada en vigor de la Ley 41/2007 tal y como hemos ido viendo a lo largo de este estudio, en los contratos se venían insertando cláusulas en las que se especificaban posibles causas de vencimiento anticipado del crédito. En ellas se dejaba constancia de que en el caso de que concurrieran todavía viviendo el deudor, se generaba la obligación de devolución del préstamo con los intereses y a falta de un pago voluntario se procedía a la ejecución forzosa de la hipoteca inversa.

En este clausulado podemos encontrar causas, como por ejemplo, la existencia de cargas o arrendamientos no declarados o el incumplimiento de obligaciones por parte del deudor. En este aspecto destacar: la no suscripción del seguro sobre la vivienda, la falta de pago de sus primas o el incumplimiento de otras obligaciones que tengan atribuida preferencia legal sobre la hipoteca inversa. Por tanto, habría una serie de circunstancias ${ }^{568}$ en las se podría dar un interés del acreedor hipotecario en el vencimiento anticipado del préstamo.

Ahora bien, tales circunstancias no se contemplaron en la Disposición Adicional $1 .^{a}$ de Ley $41 / 2007$, pues como se ha ido pormenorizando, estas causas de vencimiento se han limitado al momento del fallecimiento del deudor y a la transmisión voluntaria de la vivienda hipotecada. Según MARTíNEZ ESCRIBANO $^{569}$, en el contrato garantizado con hipoteca inversa se podría plantear la validez de este tipo de cláusulas.

en relación con las causas del vencimiento. Entre las que se incluyen, junto al fallecimiento del deudor, las siguientes:

- Enajenación de la vivienda hipotecada.

- Que la vivienda deje de ser la residencia principal del prestatario.

- La falta de ocupación de la vivienda por el prestatario durante doce meses consecutivos debido a una enfermedad física o mental.

- El incumplimiento de otras obligaciones por parte del prestatario.

568 Sin embargo, durante la tramitación de la Ley no se tuvieron en cuenta ninguna de estas circunstancias, sino que únicamente se mostró cierto interés por resaltar el hecho de que la falta de una residencia efectiva en la vivienda hipotecada, ya fuera por arrendamiento, traslado al domicilio de un familiar o a una residencia de la tercera edad no afectaría a la hipoteca inversa, si bien estas enmiendas no prosperaron (Enmienda núm. 53 en el Congreso y enmienda núm. 97 en el Senado).

${ }^{569}$ MARTínez EsCRIBANO, C., La hipoteca inversa, op. cit., pp.168 y ss. 
A continuación, se analizarán posibles cláusulas contractuales ${ }^{570}$ que darían lugar al vencimiento anticipado de la deuda según la práctica precedente a la entrada en vigor de esta Ley.

\subsection{La falta de ocupación efectiva de la vivienda hipotecada}

La falta de ocupación efectiva de la vivienda habitual hipotecada inversamente podría dar lugar al vencimiento anticipado ${ }^{571}$. En la escasa trayectoria de la hipoteca inversa en España, a diferencia de los sistemas anglosajones, no se ha advertido una preocupación especial por la ocupación efectiva de la vivienda por parte del deudor.

Tal y como se refleja en la DA $1 .^{a}$, en el momento en el que se constituya la hipoteca inversa, se exige que el inmueble hipotecado sea la vivienda habitual del deudor, pero con posterioridad no se especifica la obligación de residir en este inmueble en concepto de vivienda habitual. Con ello, podríamos deducir que el dejar de residir en esa vivienda habitual se trataría de una prohibición expresa. Ahora bien, dada la edad del deudor o del beneficiario y los sujetos afectados de dependencia o que tengan reconocido un grado de discapacidad igual o superior al 33 por ciento, por razones de salud sería normal que éstos abandonaran la vivienda habitual y se marcharan a una residencia con el fin de tener una asistencia especializada.

Por estos motivos se podría permitir compatibilizar la hipoteca inversa con el ingreso en un centro geriátrico o servicio similar. De manera que, esta hipoteca podría servir para afrontar los gastos que con este ingreso se originan, pues en la mayoría de los casos en los que se produce el ingreso en estos centros, como consecuencia de la escasa pensión que tienen los potenciales usuarios para cubrir su coste, los encargados de sufragar esos gastos suelen ser los hijos o los familiares más cercanos. Luego esta renta

\footnotetext{
${ }_{570}^{571}$ Dichas cláusulas no se contemplan en la normativa vigente.

${ }^{571}$ MARTínez EsCRIBANO, C., La hipoteca inversa, op. cit., p. 168.
} 
generada por la contratación de una hipoteca inversa seguiría siendo de gran ayuda, tanto para el ingresado en estos centros como para las personas responsables de su cuidado.

Nuestro ordenamiento jurídico, en el caso de las hipotecas convencionales, no contempla como causa de extinción del crédito el traslado del deudor a otro inmueble distinto a su domicilio habitual ${ }^{572}$, ni tan siquiera que su traslado sea originado como consecuencia de una grave enfermedad que le obligue a ser internado en un centro hospitalario. En este supuesto, el apartado 1 de la DA $1 .^{\text {a }}$ carecería de sentido al producirse el incumplimiento de residir en esa vivienda habitual ${ }^{573}$.

Otra opción ${ }^{574}$ sería otorgar a la entidad acreedora la facultad de exigir a la parte deudora el pago de la deuda por abandono del domicilio habitual, aunque esta posibilidad, dadas las características del colectivo al que va dirigida, no parecería muy oportuna.

\subsection{El arrendamiento de la vivienda hipotecada}

Antes de la entrada en vigor de la Ley 41/2007 se permitía, dentro de ciertos límites, la posibilidad de arrendar la vivienda gravada con hipoteca inversa ${ }^{575}$. Esta situación va más allá de la posibilidad anteriormente planteada, pues además de dejar de ocupar de manera efectiva la vivienda hipotecada, ésta se arrienda a un tercero ${ }^{576}$.

\footnotetext{
${ }^{572}$ Como ya se ha visto en el apartado dedicado a la vivienda habitual, en nuestro sistema hipotecario el uso de un bien inmueble es un dato que en principio no tiene acceso en el Registro de la Propiedad. De esta forma, el uso como vivienda de un inmueble no queda protegido por el principio de legitimación registral contenido en el artículo 38 de la $\mathrm{LH}$, en relación con el artículo 134 del mismo texto legal. Cfr. JIMÉNEZ CLAR, A.J., «La hipoteca...», op. cit., p. 119.

${ }^{573}$ En la RDGRN de 1 de marzo de 2008 (RJ 2008\1482) cuando aún no se había regulado la hipoteca inversa se indicaba que: «Tan sólo se hace alusión en la escritura a tres supuestos de vencimiento anticipado sin incumplimiento de la obligación de pago («mientras el prestatario no haya incumplido la presente escritura, Seniors Money Spain solo podrá requerir el pago de la deuda cuando se produzca cualquiera de las siguientes circunstancias»): a) 6 meses después de la muerte del prestatario - sin más matizaciones; b) dejar de residir en la finca durante 6 meses; y c) Venta de la finca».

${ }^{574}$ ZURITA MARTín, I., «La nueva normativa...», op. cit., pp. 1282 y 1283.

${ }^{575}$ Caja Navarra incluía en su publicidad sobre la hipoteca inversa esta alternativa para el prestatario como forma de obtener mayores ingresos.

${ }^{576}$ En este sentido se expresa MARTínez EsCRIBANo, C., La hipoteca inversa, op. cit., p. 177.
} 
No obstante, este arrendamiento ${ }^{577}$ podría convertirse en una causa de vencimiento anticipado del préstamo cuando se realizara en términos que incrementasen el riesgo para el acreedor hipotecario. Junto a esto, también se deberá tener en cuenta la devaluación que pueda experimentar la vivienda en el momento de su enajenación, bien de forma voluntaria, bien de manera forzosa.

Si la vivienda se encuentra arrendada, se tendrá que respetar el contrato de arrendamiento durante ciertos plazos, conforme al artículo 9 de la Ley de Arrendamientos Urbanos ${ }^{578}$ en relación con el artículo 13 del mismo texto legal.

De esta manera, durante los primeros cinco años del arrendamiento, el derecho del arrendatario a permanecer en la vivienda es prácticamente inatacable y no se verá alterado ni tan siquiera por una eventual ejecución forzosa ${ }^{579}$. En consecuencia, si durante esos cinco años falleciera el prestatario, el acreedor hipotecario obtendría de la venta de la vivienda un importe inferior al que se obtendría si no existiera el arrendamiento. Indudablemente, siempre existirá el riesgo de que el deudor fallezca durante esos primeros cinco años del contrato de arrendamiento, riesgo que se irá incrementando paulatinamente a medida que el citado deudor vaya adquiriendo mayor edad.

En el momento en que se quiera celebrar el contrato de arrendamiento debido a las especiales circunstancias que se puedan plantear, este arrendamiento podría resultar perjudicial para el acreedor hipotecario, o tal vez no. Así, cabe la posibilidad de que la garantía sea suficiente teniendo en cuenta el importe de la deuda y el valor de la vivienda todavía arrendada, o

\footnotetext{
577 Vid. STS de 17 de mayo de 1986 (RJ 1986\2725) sobre el cambio de circunstancias que no justifica la anormalidad del uso. Cláusula «Rebus sic stantibus».

${ }^{578}$ Ley 29/1994, de 24 noviembre de Arrendamientos Urbanos (BOE, núm. 282 de 25 de noviembre 1994).

579 Con relación a la ejecución hipotecaria de la vivienda arrendada vid. Domínguez LUELMO, A., «Comentario a la Resolución de la Dirección General de los Registros y del Notariado de 16 de octubre de 1.999", Cuadernos Civitas de Jurisprudencia Civil, № 53, 2000; MARTínEZ EsCRIBANO, C., «La ejecución hipotecaria de la vivienda arrendada. Estado de la cuestión en la normativa vigente», Revista Crítica de Derecho Inmobiliario, núm. 684, julio-agosto 2004, p. 178.
} 
incluso se podría sopesar la posibilidad de esperar al transcurso de ese plazo para instar la venta forzosa.

En estos casos, al tratarse de una deuda creciente, cuanto antes fallezca el deudor frente a sus expectativas de vida, menor será el importe del préstamo respecto de la previsión inicial y, por tanto, aunque el valor de la vivienda se llegara a devaluar por el arrendamiento, en algunos casos podría ser todavía suficiente para responder a la totalidad de la deuda. Por este motivo, se ha venido pactando que la decisión última en torno al arrendamiento de la vivienda hipotecada quede en manos del acreedor hipotecario, que sopesará en cada caso los posibles riesgos.

En definitiva, tanto la existencia de un arrendamiento en el momento de constitución de la hipoteca como la intención de realizar este contrato con posterioridad a la misma, se trataría de circunstancias que deberían ser conocidas por la parte acreedora ${ }^{580}$ con el fin de que pudiera valorar la suficiencia de la garantía hipotecaria respecto de la totalidad de la deuda. Pues, en el caso de que se ocultara el arrendamiento al constituirse la hipoteca o si se concertara con posterioridad y sin la aprobación del acreedor hipotecario, cuando éste descubriera tal circunstancia podría plantearse recuperar el total de la deuda existente en ese momento para asegurarse, así, su garantía.

\subsection{El incumplimiento de obligaciones con preferencia legal sobre la hipoteca inversa}

\footnotetext{
${ }^{580}$ Con respecto a la prohibición absoluta de arrendar, la STS de 16 de diciembre de 2009 (RJ 20101702) apunta que: «el acreedor hipotecario no puede pretender del hipotecante, y menos todavía imponerle, el compromiso de no arrendar la finca hipotecada, cualquiera que sea la consecuencia que pudiera acarrear la violación de la estipulación, de la misma manera que no caben las prohibiciones de disponer convencionales en los actos a título oneroso (art. $27 \mathrm{LH}$ ). La cláusula que estableciese la absoluta prohibición de arrendar no sólo no es inscribible sino que no es válida. El hipotecante, por lo tanto, puede arrendar libremente la finca hipotecada...». De esta forma, el pacto en virtud del cual se declare el vencimiento anticipado debido a que la vivienda sobre la que se ostente la titularidad, deje de ser la habitual, bien por traslado bien por arrendamiento a un tercero, se considerará abusiva y, en consecuencia, nula. Así, sólo se admitirá la validez de este contrato de arrendamiento, cuando se pacte con posterioridad y no esté sometido a purga y se prevea que la renta estipulada no depreciará, de manera significativa, el valor de la finca hipotecada.
} 
La prioridad en el cobro del préstamo garantizado con hipoteca inversa será un elemento determinante para el adecuado desarrollo de la misma. En nuestro ordenamiento jurídico, por razones registrales, esta causa, a priori, no suscita ningún problema. Aún así, nos podemos encontrar con otras causas, en relación con la prioridad y prelación de créditos, que atenten contra la transparencia de la información registral y, por tanto, contra la seguridad jurídica repercutiendo negativamente en el ámbito hipotecario.

En estos casos, se trataría de las hipotecas legales tácitas reconocidas por ministerio de la ley y sin necesidad de constancia registral, como consecuencia del incumplimiento de determinadas obligaciones, básicamente tributarias, y frente a la comunidad de propietarios, anteponiéndose su cobro a cualquier otro crédito garantizado con una hipoteca inscrita. La parte acreedora estaría legitimada para atender al pago de los gastos de comunidad, del IBI, etc., que podrían ser incluidos en la responsabilidad total de la finca hipotecada.

Como consecuencia del régimen de la hipoteca legal tácita, podría suceder que la vivienda gravada con la hipoteca inversa se convirtiera, de forma sobrevenida, en insuficiente para asegurar la devolución de la totalidad del préstamo con los intereses. De esta forma, el proceso de conversión del patrimonio inmobiliario en dinero líquido se truncaría por la aparición de un crédito que se antepondría en el cobro al préstamo con hipoteca inversa.

En este sentido, se ha de señalar que la hipoteca inversa garantiza una deuda creciente y que el crédito garantizado con hipoteca legal tácita, presumiblemente irá aumentando, al menos, por efecto de los intereses que se vayan devengando y, en consecuencia, el riesgo del acreedor hipotecario se irá incrementando conforme pase el tiempo. Por esta razón, el acreedor hipotecario se puede mostrar interesado en introducir esta causa como vencimiento anticipado del préstamo, evitando así que la situación se agrave todavía más. 
En la práctica, el problema radicaría en el efectivo conocimiento de la existencia de la hipoteca legal tácita por parte del acreedor hipotecario en un momento anterior a la ejecución de la referida hipoteca. Por este motivo, se podría obligar al deudor a acreditar de forma periódica el pago de las obligaciones, ya que si se produjera el incumplimiento de las mismas, se daría lugar a la hipoteca legal tácita, en el caso de que la hubiere. Así pues, se podría tener constancia de la existencia o no de tal gravamen.

En cualquier caso, la existencia de hipotecas legales tácitas en nuestro ordenamiento jurídico causa un grave problema a las entidades financieras que han venido ofertando este producto financiero, ya que se trata de una deuda que va aumentando con el paso del tiempo.

8.4. El incumplimiento de obligaciones en relación con el seguro contratado

Entre las causas contractuales de vencimiento anticipado del préstamo también podemos encontrar la falta de suscripción del seguro o el incumplimiento de la obligación de pago de las primas.

En la hipoteca inversa, el deudor no tiene que responder en vida de la devolución del préstamo y los intereses, a diferencia de otros préstamos, en los que la devolución del principal y los intereses sí que los realiza el deudor respondiendo en primer lugar con sus propios ingresos y, sólo en caso de impago, se procedería a la venta forzosa de la vivienda hipotecada.

En este caso, el cobro de la deuda más los intereses se realizará tras el fallecimiento del deudor, procediéndose al pago de la totalidad de la deuda, generalmente, con la venta de la vivienda hipotecada. La verdadera garantía de cobro para el acreedor, en estos casos será esta vivienda hipotecada. Por tanto, en la modalidad de la hipoteca inversa será importante realizar la suscripción de un seguro que garantice el valor de la vivienda hipotecada en 
caso de posible destrucción o deterioro de la misma. Esto se ha visto reflejado en el apartado 1.d) de la Disposición Adicional Primera: « que la vivienda haya sido tasada y asegurada contra daños...».

En este apartado no se hace referencia al típico seguro de incendios, sino a un seguro de daños, configurándolo de esta manera como un requisito más que debe cumplir la hipoteca inversa. Así, el riesgo de destrucción de la vivienda hipotecada quedará cubierto, no sólo para el propietario, sino también para el acreedor hipotecario, que de producirse el siniestro cobraría de la entidad aseguradora la correspondiente indemnización.

De acuerdo con esto, la falta de suscripción del seguro o la falta de pago de las primas justificaría un interés del acreedor en el vencimiento anticipado del préstamo, habida cuenta del mayor riesgo que asumiría aquél si se diera este caso de siniestro. 


\section{CAPÍTULO VII: PROCEDIMIENTO JUDICIAL DE EJECUCIÓN SOBRE BIENES GRAVADOS CON HIPOTECA INVERSA}

Una vez fallecido el deudor o el último de los beneficiarios y los herederos de éstos -en el caso de que los hubiere- no quisieran hacerse cargo de la deuda, la entidad acreedora podría vender la vivienda hipotecada inversamente. En este supuesto en el que nadie se hace cargo de la deuda, el acreedor podrá acudir al Procedimiento de Ejecución Dineraria de la Ley 1/2000, de 7 de enero, de Enjuiciamiento Civil ${ }^{581}$.

Esta Ley, a diferencia de la de 1881, en lo que concierne a la ejecución forzosa, se presenta como una regulación unitaria, clara y completa donde se confecciona un proceso de ejecución para todo aquello que pueda considerarse un título ejecutivo, bien judicial o contractual, bien de una ejecución forzosa común y otro especial, para los casos en que se ejecuten bienes hipotecados o pignorados. De esta manera, habrá un proceso de ejecución común aplicable tanto si el título es judicial como si no lo es, y otro de ejecución especial en los casos en que se ejecuten bienes hipotecados o pignorados.

Además, esta Ley establece un sistema equilibrado que, por una parte, permite una tutela eficaz del derecho del acreedor ejecutante, mediante una relación limitada y tasada de las causas de oposición y suspensión que no desvirtúa la eficacia del título ejecutivo y, por otro lado, no priva al deudor ejecutado de medios de defensa frente a los supuestos más graves de ilicitud de la ejecución.

Según el artículo 130 de la LH: «El procedimiento de ejecución directa contra los bienes hipotecados sólo podrá ejercitarse como realización de una hipoteca inscrita, sobre la base de aquellos extremos contenidos en el título que se hayan recogido en el asiento respectivo».

${ }^{581}$ Este Procedimiento se encuentra regulado en el LIBRO III. De la ejecución forzosa y de las medidas cautelares, TíTULO IV. De la ejecución dineraria, CAPÍTULO V. De las particularidades de la ejecución sobre bienes hipotecados o pignorados (Arts. 681 a 698). 
Con este artículo podemos comprobar que la ejecución hipotecaria tiene ciertas especialidades, como son el carácter constitutivo de la inscripción, la base registral de la ejecución, la limitación de las causas de oposición y suspensión, así como también las limitaciones impuestas por el principio de especialidad $^{582}$.

Aún así, hay que tener en cuenta que la ejecución hipotecaria sigue conservando las notas de sumariedad y especialidad que la caracterizaban antes de la aprobación de la LEC 1/2000. A consecuencia de esto, la ejecución relativa a los bienes hipotecados o pignorados mantiene, en lo sustancial, el régimen de ejecución hipotecaria anterior a esta Ley, regulado en el artículo 130 de la LH, excepto en lo que a la fase de apremio se refiere ${ }^{583}$.

Si nos adentramos en el caso de la hipoteca inversa, ésta queda instrumentalizada a través de una cuenta corriente contratada con un Banco, Caja de ahorros o entidad aseguradora debidamente autorizada, siendo aplicables los artículos 153 de la LH y 245 del RH. Por tanto, cuando los acreedores acrediten el importe de la obligación asegurada mediante la certificación expedida por la entidad acreedora (Banco, Caja de ahorros, etc.) del saldo que se debe, éstos podrán ejecutar, a través del procedimiento regulado en los artículos 681 y ss. de la LEC, las hipotecas que garanticen saldos de cuenta corriente, de acuerdo con lo previsto en los artículos 572 , $573,574,685.2$ y $695.1 .2 .^{a}$ de la LEC.

\footnotetext{
582 Prueba de ello es la RDGRN de 24 de marzo de 2014 (TOL4.227.933) que matiza lo siguiente: «Para poder inscribir los pactos de ejecución directa sobre bienes hipotecados o el pacto de venta extrajudicial en las escrituras de constitución de hipotecas, o en otras posteriores en que se pretenda incluir dichos pactos, resulta imprescindible que se le acredite al registrador, a través de la certificación pertinente, la tasación de la finca hipotecada «realizada conforme a lo previsto en la Ley 2/1981, de 25 de marzo, de regulación del Mercado Hipotecario", y que el valor (o precio) en que los interesados tasen la finca para que sirva de tipo en la subasta no sea inferior, en ningún caso, al setenta y cinco por ciento del valor señalado en la tasación realizada conforme a la citada Ley. Las normas transcritas que así lo establecen tienen carácter imperativo, inderogable por la voluntad de las partes, por lo que su infracción pararían en la nulidad de la estipulación que incurriesen en tal infracción, lo que la inhabilita para su acceso al Registro de la Propiedad y, por tanto, para permitir el ejercicio de la acción hipotecaria por tales vías procedimentales».

583 Álvarez Álvarez, H., Régimen jurídico del domicilio de las personas físicas, Lex Nova, Valladolid, 2005, p. 573.
} 
La LEC 1/2000 suprimió el procedimiento judicial sumario del artículo 131 de la LH, que surgió con la reforma de 1.909 y que era el que más se utilizaba en la práctica, pues simplificaba y abarataba el procedimiento ejecutivo ordinario. En la actualidad, el artículo 131 de la LH en vigor, es el redactado conforme a la Disposición Final 9. ${ }^{a}$ de la actual LEC, entrando en vigor el 8 de enero de 2001.

$\mathrm{El}$ anterior artículo 131 de la $\mathrm{LH}^{584}$ regulaba las reglas del procedimiento judicial sumario, el cual a partir de la entrada en vigor de la NLEC quedó derogado, siendo de aplicación para la acción directa contra los bienes hipotecados, lo dispuesto en el Título IV del Libro III de la NLEC (arts. 571 y ss.) con las particularidades del Capítulo V del mismo texto legal (arts. 681 y ss.) en los que se regula la ejecución dineraria de las sentencias y, las particularidades de la misma cuando recayese sobre bienes hipotecados 0 pignorados (art. 681 de la LEC en relación con el art. 129 de la LH).

Con motivo de la entrada en vigor de la Ley $1 / 2013$, en el Capítulo II sobre las medidas de mejora del mercado hipotecario, en el artículo 3, apartado Tres, se modifica el artículo 129 de la LH quedando redactado del siguiente modo:

«1. La acción hipotecaria podrá ejercitarse:

a) Directamente contra los bienes hipotecados sujetando su ejercicio a lo dispuesto en el Título IV del Libro III de la Ley $1 / 2000$, de 7 de enero, de Enjuiciamiento Civil, con las especialidades que se establecen en su Capítulo V.

b) 0 mediante la venta extrajudicial del bien hipotecado, conforme al artículo 1.858 del Código Civil, siempre que se hubiera pactado en la escritura de constitución de la hipoteca sólo para el caso de falta de pago del capital o de los intereses de la cantidad garantizada».

Ahora bien, el procedimiento judicial sumario recogido en la LH se seguirá aplicando para aquellos procedimientos iniciados antes del 8 de enero de 2001 (en los términos establecidos en las Disposiciones Transitorias $5 .^{\mathrm{a}} \mathrm{y}$

\footnotetext{
${ }^{584}$ En este aspecto, cabría destacar las SSTC de 9 de mayo de 1995 (RTC 1995169), de 27 de octubre de 1997 (RTC 1997 174), de 15 de diciembre de 1997 (RTC 1997/227) y de 24 de febrero de 1998 (RTC 1998\42).
} 
6. ${ }^{a}$ de la actual LEC) siendo básico, por tanto, el anterior artículo 131 de la $\mathrm{LH}^{585}$.

Como se puede apreciar, este procedimiento judicial sumario sirvió para inspirar a la actual regulación sobre la ejecución de los bienes hipotecados, ya que, a pesar de haber desaparecido la denominación de este proceso como procedimiento judicial sumario, este proceso de ejecución especial sigue en vigor en los casos en los que el título ejecutivo sea la escritura pública de constitución de la hipoteca.

En el caso que aquí nos incumbe, podemos hacer referencia a los siguientes procedimientos ${ }^{586}$ :

\section{PROCEDIMIENTO ESPECIAL DE EJECUCIÓN HIPOTECARIA}

Este procedimiento se regula en los artículos $681^{587}$ y ss. de la LEC, siempre que concurran los requisitos exigidos por el artículo 682 del mismo texto legal.

El citado artículo, como se ha mencionado anteriormente, sustituye el procedimiento judicial sumario del artículo 131 de la $\mathrm{LH}^{588}$, consistente en una vía de apremio sin fase previa de cognición, limitándose drásticamente las causas de oposición del deudor a la ejecución y los supuestos de suspensión de ésta, lo cual no significaba que fuera inconstitucional, ya que el Tribunal Constitucional entendía que la disminución de las posibilidades de oposición no vulneraban el derecho a la defensa del artículo 24.1 de la CE, pudiendo acudir -posteriormente- a un juicio declarativo.

\footnotetext{
585 Según indica Álvarez Álvarez, H., La hipoteca inversa..., op. cit., p. 122, sobre el anterior procedimiento judicial sumario del artículo 131 de la LH, consistente en una vía de apremio sin fase previa de cognición, se limitaba drásticamente las causas de oposición del deudor a la ejecución y los supuestos de suspensión de ésta, lo cual no significaba que fuera inconstitucional, ya que el TC entendía que la disminución de las posibilidades de oposición no vulneraba el derecho a la defensa del artículo 24.1 de la Constitución, ya que se podía acudir a un juicio declarativo ulterior.

${ }^{586}$ Vid. más ampliamente ÁlVAREZ ÁlVAREZ, H., La hipoteca inversa..., op. cit., pp. 121-135.

${ }^{587}$ Cfr. Domínguez Luelmo, A., «Comentario a la...», op. cit., pp. 3376 y 3377.

${ }^{588}$ Al respecto vid. más ampliamente RoCA SASTRE, R.M. y RoCA-SASTRE MUNCUNILL, L., Derecho hipotecario. Ejecución hipotecaria, tomo IX, 8. ${ }^{a}$ ed., Bosch, Barcelona, 1998, pp. 279 y ss.
} 
Con motivo de la entrada en vigor de la Ley 1/2013, el artículo 682 de la LEC ${ }^{589}$ también se modificó. De manera que, en este procedimiento, la acción para exigir el pago de las deudas garantizadas por prenda o hipoteca podrá ejercitarse directamente contra los bienes pignorados o hipotecados. Para ello, se tendrán que cumplir una serie de requisitos:

- En la escritura de constitución de la hipoteca inversa se tendrá que determinar el precio en que los interesados hayan tasado la finca o bien hipotecado para que sirva de tipo en la subasta.

- En la misma escritura tendrá que constar un domicilio fijado por el deudor para la práctica de requerimientos y notificaciones para asegurarse que éste reciba todas las comunicaciones.

Con esta obligación de fijar un precio y un domicilio se pretende agilizar la tramitación del proceso ejecutivo.

Como ya se ha comentado al inicio de este punto, en el caso de que la hipoteca se haya constituido en garantía de una apertura de crédito en una cuenta corriente, se tendrá que aportar también la documentación que acredite el saldo resultante. Tal y como se indica en el artículo 685.2 de la LEC, tendremos que acudir a lo dispuesto en el artículo 573 del mismo texto legal, relativo a los documentos que han de acompañarse a la demanda 590 ejecutiva por saldo de cuenta. De esta manera, se tendrá que aportar:

\footnotetext{
${ }^{589}$ Quedando de la siguiente manera: «1. Las normas del presente Capítulo sólo serán aplicables cuando la ejecución se dirija exclusivamente contra bienes pignorados o hipotecados en garantía de la deuda por la que se proceda.

2. Cuando se persigan bienes hipotecados, las disposiciones del presente Capítulo se aplicarán siempre que, además de lo dispuesto en el apartado anterior, se cumplan los requisitos siguientes:

$1 .^{\circ}$ Que en la escritura de constitución de la hipoteca se determine el precio en que los interesados tasan la finca o bien hipotecado, para que sirva de tipo en la subasta, que no podrá ser inferior, en ningún caso, al 75 por cien del valor señalado en la tasación realizada conforme a las disposiciones de la Ley $2 / 1981$, de 25 de marzo, de Regulación del Mercado Hipotecario.

2. ${ }^{\circ}$ Que, en la misma escritura, conste un domicilio, que fijará el deudor, para la práctica de los requerimientos y de las notificaciones.

En la hipoteca sobre establecimientos mercantiles se tendrá necesariamente por domicilio el local en que estuviere instalado el establecimiento que se hipoteca.

3. El Registrador hará constar en la inscripción de la hipoteca las circunstancias a que se refiere el apartado anterior».

590 Vid. Carrasco Perera, Á.; Cordero lobato, E. y Marín López, M.J., Tratado de..., tomo I, op. cit., pp. 692 y 693.
} 
- El documento o documentos en los que se exprese el saldo resultante de la liquidación efectuada por el acreedor, así como también, el extracto de las partidas de cargo y abono y las correspondientes a la aplicación de intereses que determinen el saldo concreto por el que se pide el despacho de ejecución.

- El documento fehaciente que demuestre que la liquidación se ha practicado conforme a lo pactado por las partes en el título ejecutivo.

- El documento que justifique que se ha notificado al deudor y al fiador, en el caso de que lo hubiere, la cantidad exigible.

Con respecto a la forma de determinar el saldo resultante tendremos que acudir a la Ley Hipotecaria ${ }^{591}$. En este aspecto, el artículo 153 de esta Ley regula dos modalidades para acreditar este saldo ${ }^{592}$ :

1.- Para que pueda determinarse al tiempo de la reclamación, la cantidad líquida a que asciende, los interesados podrán llevar una libreta de ejemplares duplicados: uno en poder del que adquiere la hipoteca y otro en el del que la otorga, en los que, al tiempo de todo cobro o entrega, se hará constar, con aprobación y firma de ambos interesados, cada uno de los asientos de la cuenta corriente.

2. - En el caso de cuentas corrientes abiertas por los Bancos, Cajas de Ahorro y Sociedades de Crédito debidamente autorizadas, podrá convenirse que, a los efectos de proceder ejecutivamente, el saldo podrá acreditarse mediante una certificación de la entidad acreedora.

Una vez presentada la demanda ejecutiva acompañada de estos documentos, el juez despachará auto de ejecución requiriendo de pago al deudor, es decir, tendremos que acudir al requerimiento de pago regulado en el artículo 686 de la LEC. Si leemos el punto 1 de este artículo: «En el auto por el

\footnotetext{
591 Vid. GuzMán FLUJA, V., «Capítulo II De la acumulación de procesos», en BARONA VILAR, S. (coord.), El Proceso Civil. Volumen I. Libro I: artículos 1 a 98 inclusive, Tirant lo Blanch, Valencia, 2001, p. 4988.

${ }^{592}$ Sobre los modos de acreditar el saldo vid. RoCa SASTRE, R.M. y RoCA-SASTRE MUnCUnILL, L., Derecho hipotecario: Hipotecas., op. cit., pp. 335-347.
} 
que se autorice y despache la ejecución se mandará requerir de pago al deudor y, en su caso, al hipotecante no deudor o al tercer poseedor contra quienes se hubiere dirigido la demanda, en el domicilio que resulte vigente en el Registro».

El problema con el que aquí nos encontramos reside en que la hipoteca inversa sólo podrá ejecutarse una vez haya fallecido el deudor, pudiendo surgir problemas como, por ejemplo: que el deudor no tenga herederos, 0 bien que éstos no acepten la herencia ${ }^{593}$ o bien que sean desconocidos, por lo que podría prolongarse la situación de herencia yacente más de lo deseable para la entidad acreedora, pues durante ese período de tiempo nadie se haría cargo de la deuda. En estos casos, la demanda o reclamación se dirigirá contra la herencia yacente ${ }^{594}$.

\section{Citación de la herencia yacente}

Tal y como señala PUIG BRUTAU ${ }^{595}$ en Derecho Romano se llamaba herencia yacente «hereditas jacens» a la situación en que se hallaba el patrimonio hereditario antes de ser adquirido por el heredero. Además, como se puede observar el Código Civil no usa la denominación de herencia yacente, aunque la da por supuesta en el artículo 1934 al disponer que: «La prescripción produce sus efectos jurídicos a favor y en contra de la herencia antes de haber sido aceptada y durante el tiempo concedido para hacer inventario y para deliberar».

No obstante, el análisis realizado por la jurisprudencia demuestra que el concepto de herencia yacente puede referirse, no sólo a la herencia pendiente de aceptación, sino también a la que ha sido repudiada, a la que está pendiente de que se averigüe quienes son los llamados, a la que ha de quedar adscrita a una fundación todavía inexistente, etc. Es decir, en todas

\footnotetext{
${ }^{593}$ Romero Candau, P.A., «La hipoteca...», op. cit., p. 329; Berrocal Lanzarot, A.I., «Hipoteca Inversa...», op. cit., p. 58.

594 Vid. PARDO MUÑOz, J., Eficacia registral de las resoluciones judiciales dictadas en procesos civiles seguidos contra la herencia yacente, comunidad hereditaria o herederos desconocidos, ignorados o inciertos de una persona fallecida, RRDGRN de 19 de agosto de 2010 y 10 de enero de 2011. Referencia a la hipoteca inversa. Cuadernos De Derecho Registral, Madrid, 2011, pp. 124-131. Cfr. Colina GAREA, R., «Comentario a los artículos 988 a 1034», en Bercovitz Rodríguez-Cano, R. (coord.), Comentarios al Código Civil, Thomson Aranzadi, Cizur Menor (Navarra), 2006.

595 Puig Brutau, J., Compendio de Derecho Civil. Volumen IV, op. cit., pp. 256 y 257.
} 
aquellas situaciones que se presentan cuando todavía no es conocido el adquirente. De esta manera, será necesario que la ley adopte una serie de medidas $^{596}$ que regulen tal situación provisional.

Prueba de ello es la definición de herencia yacente que da, entre otras, la STS de 12 de marzo de 1987. En esta sentencia se indica que: «La apertura de la sucesión de una persona se abre justamente en el momento de su muerte en el cual el patrimonio se trasmuta en herencia yacente que no es sino aquel patrimonio relicto mientras se mantiene interinamente sin titular, por lo que carece de personalidad jurídica, aunque, para determinados fines, se le otorga transitoriamente una consideración y tratamientos unitarios, siendo su destino el de ser adquirida por los herederos voluntarios o legales, admitiendo el que, bien por medio de albaceas o administradores testamentarios o judiciales pueda ser demandada y esté habilitada para excepcionar y ahora para recurrir».

De esta manera, la jurisprudencia admite la posibilidad de que los acreedores puedan demandar a la herencia yacente, ya que, a esta herencia yacente se le otorgará capacidad para ser parte en el proceso ${ }^{597}$. En este aspecto, indicar que en la Ley 1/2000 de Enjuiciamiento Civil, la capacidad de la herencia yacente para ser parte en el proceso, aparece regulada en el artículo 6.1.4. ${ }^{\circ 598}$.

Una vez comentado esto, la demanda ejecutiva contra los posibles herederos de esta herencia yacente, deberá ir acompañada de los documentos contemplados en el artículo 685 de la LEC y, junto a estos, se deberán presentar también aquellos documentos que acrediten la sucesión, tal y como se dispone en el artículo 540.2 de la citada Ley. Este artículo indica que para

\footnotetext{
${ }^{596}$ En este sentido se manifiestan Díez-PICAzo, L. y Gullón, A., Sistema de Derecho Civil IV, op. cit., pp. 525 y 526; Puig Brutau, J., Compendio de Derecho Civil. Volumen IV, op. cit., p. 256.

${ }_{597}$ Así, la herencia yacente, a través de albaceas o administradores testamentarios o judiciales puede ser demandada y también facultada para recurrir. Prueba de ello es la STS de 10 de noviembre de 1981 (RJ 1981\4471) donde se señala que: «ante el defecto de regulación en nuestro derecho de la herencia yacente, que no puede ser personificada a los fines de ser llamada al proceso, en la práctica se interpela a quienes «resulten ser herederos o se crean con derecho a la herencia» del causante, esto es, a la masa o comunidad de interesados a la que se otorga transitoriamente y para fines limitados una consideración unitaria».

Y, entre otras, resaltar también la STS de 20 de septiembre de 1982 (RJ 1982\4920) donde: «Según criterio generalmente seguido en la práctica y aceptado por la doctrina y la Jurisprudencia como adecuada solución a los problemas que plantea, la herencia en situación de yacente, puede figurar como término subjetivo de la relación jurídica-procesal y por lo tanto ocupar la posición de demandada».

${ }^{598}$ Artículo $6.1 .4 .^{\circ}$ de la LEC: «1. Podrán ser parte en los procesos ante los tribunales civiles:

$4 .^{\circ}$ Las masas patrimoniales o los patrimonios separados que carezcan transitoriamente de titular o cuyo titular haya sido privado de sus facultades de disposición y administración».
} 
acreditar la sucesión, habrán de presentarse al tribunal los documentos fehacientes en que aquélla conste. Si el tribunal los considera suficientes a tales efectos, procederá, sin más trámites, a despachar la ejecución a favor o frente a quien resulte ser sucesor en razón de los documentos presentados.

En este caso, se trataría del certificado de defunción y con respecto a la documentación para acreditar la condición de heredero ${ }^{599}$, se tendría que aportar el Libro de familia. De esta forma, junto con la demanda se presentará también el certificado de defunción, el certificado de actos de última voluntad, por medio del cual, se sabrá si el causante realizó o no testamento y, por último, el Libro de familia ${ }^{600}$.

Con respecto a la parte acreedora, ésta deberá actuar con la diligencia oportuna para averiguar, dentro de sus posibilidades, la situación de la herencia del deudor, ahora causante. No hay que olvidar que al acreedor le está vedada la posibilidad de solicitar copia del testamento.

No obstante, en el apartado tercero del artículo 5 del Anexo II del Reglamento Notarial se recogen las disposiciones relativas al Registro de Actos de Última Voluntad. Derivado de ellas, se podrá expedir certificación cuando se pida por cualquier persona, si acredita con documento fehaciente el fallecimiento de aquélla de quien desee saber si aparece o no registrado algún acto de última voluntad, siempre que hayan transcurrido quince días desde la fecha de defunción. Será necesario, en todo caso, contar con otra certificación, que se habrá de obtener con carácter previo, como es la de defunción (art. 6 de la Ley del Registro Civil $^{601}$ ). Si se presentan estos documentos, lo normal es que el juez dé por acreditada la sucesión ${ }^{602}$.

\footnotetext{
599 OLIVER LóPEZ, C., «Capítulo V: De las particularidades de la ejecución sobre los bienes hipotecados o pignorados", en Barona VILAR, S. (coord.), El Proceso Civil. Volumen VII. Libro III: artículos 614 a 747 inclusive, Tirant lo Blanch, Valencia, 2001, p. 5648.

${ }^{600}$ A través del Libro de Familia, la parte acreedora podrá conocer si existen o no descendientes que pueden ser herederos y por tanto, dirigir contra ellos la demanda. En la práctica, las entidades acreedoras (Bancos, Cajas de Ahorros, entidades aseguradoras, etc.), en el momento de contratar la hipoteca inversa, requerían copia del Libro de familia al solicitante-deudor.

${ }^{601}$ Ley de 8 de junio de 1957, del Registro Civil (BOE núm. 151 de 10 de junio de 1957).

${ }^{602}$ La RDGRN de 9 de junio de 2009 (RJ 2009\4308), en su fundamento jurídico segundo, recoge como el juez consideró suficiente, a la luz de lo dispuesto en el artículo 540 de la LEC, la presentación del Libro
} 
Sin embargo, la suspensión del procedimiento ejecutivo cuando esté pendiente un procedimiento sucesorio no se podrá dar. En este caso, no se admitirá la posibilidad de que el juez suspenda el procedimiento de ejecución hasta que se haya designado un administrador de la herencia, tal y como se regula en los artículos 790 a 796 de la LEC, relativos al procedimiento de intervención del caudal hereditario.

Ahora bien, si nos fijamos en la LEC, al regular la suspensión y el término de ejecución (arts. 565 a 570), esta causa de suspensión por un procedimiento sucesorio no se encuentra contemplada. En este caso, tendremos que acudir a lo establecido en el artículo 98 del mismo texto legal ${ }^{603}$ donde se regula la acumulación de procesos singulares a procesos universales. De esta manera, se quiere dar celeridad y preferencia sobre los demás acreedores que puedan estar en el mismo procedimiento. Ahora bien, tal y como señala SALINAS MOLINA ${ }^{604}$, con la acumulación, el acreedor hipotecario no se vería privado de su derecho, pero sí se podría dilatar excesivamente la realización del mismo.

En conclusión, la demanda ${ }^{605}$ se presentará contra la herencia yacente, los herederos desconocidos o ignorados y, en último lugar, frente al Estado, conforme se regula en el artículo 956 del CC, aunque como ya se ha comentado, lo normal es que se conozcan los familiares o posibles herederos del deudor de la hipoteca inversa. Una vez se haya despachado el auto de

de Familia y la certificación negativa del Registro de Actos de Última Voluntad. Al respecto vid. también la RDGRN de 22 de enero de 2011 (RJ 2011\2465).

603 Concretamente, en el apartado $2 .^{\circ}$ de este artículo se hace referencia a los procesos sucesorios: «1. La acumulación de procesos también se decretará:

2. ${ }^{\circ}$ Cuando se esté siguiendo un proceso sucesorio al que se halle sujeto el caudal contra el que se haya formulado o se formule una acción relativa a dicho caudal.

Se exceptúan de la acumulación a que se refiere este número los procesos de ejecución en que sólo se persigan bienes hipotecados o pignorados, que en ningún caso se incorporarán al proceso sucesorio, cualquiera que sea la fecha de iniciación de la ejecución».

604 Salinas Molina, F., «Capítulo I De la ejecución dineraria: disposiciones generales», en BARONA VILAR, S. (coord.), El Proceso Civil. Volumen I. Libro I: artículos 1 a 98 inclusive, Tirant lo Blanch, Valencia, 2001, p. 941.

605 La SAP de Asturias de 28 de junio de 2001 (AC 2001\2026) establece: «Cuando no haya una administración regularmente, la doctrina y la jurisprudencia entienden que, ante todo, deben satisfacerse los legítimos intereses de terceros y que deberán ser admitidas las demandas dirigidas contra la herencia yacente y los llamados a ella, aún cuando en rigor ni el causante viva, ni los herederos la hayan aceptado». 
ejecución por el que se emplace a los posibles herederos para proceder al pago de la deuda (art. 686 de la LEC) y se haya emitido la certificación de dominio y cargas conforme al artículo 688 de la LEC, la parte acreedora podrá optar a:

La subasta del bien hipotecado regulada en el artículo 691 de la LEC. En este procedimiento, en el caso de llegar a la subasta ${ }^{606}$ del bien hipotecado, no se tendría que realizar la fase de avalúo del juicio ejecutivo ordinario. Esto sería debido a que la tasación del bien ya se había practicado con anterioridad, constando el valor del bien en la escritura de constitución.

Y, además, siempre y cuando se hubiera pactado, se podrán aplicar los convenios de realización judicialmente aprobados ${ }^{607}$, en concreto:

- El Convenio de realización aprobado por el secretario judicial, tal y como se señala en el artículo 640 de la LEC.

- 0, el Convenio de realización por medio de persona o entidad especializada, de acuerdo con el artículo 641 del mismo cuerpo legal.

No obstante, al poseer la escritura notarial de constitución de hipoteca como título ejecutivo, no habría ningún impedimento en acudir a la ejecución del crédito hipotecario por la vía de la ejecución ordinaria. Pues, tal como señala RIVAS TORRALBA ${ }^{608}$, esta vía de procedimiento de ejecución hipotecaria no es obligatoria, sino potestativa.

\section{VENTA EXTRAJUDICIAL DEL BIEN}

\footnotetext{
${ }^{606}$ Al respecto vid. Álvarez Álvarez, H., Régimen jurídico..., op. cit., pp. 573 y ss; Álvarez Álvarez, H., «El domicilio del deudor en la ejecución hipotecaria», RCDI, N 684, 2004, pp. 1635 y ss.

${ }^{607}$ MURO VILLALÓN, J.V., «La hipoteca...», op. cit., p. 22.

${ }^{608}$ RIVAS ToRRalBa, R., Aspectos registrales del nuevo proceso de ejecución, Centro de Estudios Registrales, Madrid, 2001, pp. 233 y ss.
} 
En esta modalidad, el precio obtenido con la enajenación de la vivienda deberá destinarse en primer lugar a pagar al acreedor la obligación principal, quedando de esta manera libre de cargas o gravámenes el bien enajenado.

La venta extrajudicial aparece regulada en los artículos 234 y siguientes del Reglamento Hipotecario. Sin embargo, tal y como señala ÁlVAREZ ${ }^{609}$, para que este procedimiento pueda realizarse será preciso pacto expreso entre las partes. Junto a estos artículos se ha de hacer mención al artículo 129 de la $\mathrm{LH}^{610}$, que como ya se ha matizado, fue objeto de modificación por la Ley $1 / 2013$ ampliando en gran medida su contenido. $Y$, como novedad, se añade un segundo punto al citado precepto.

De esta manera, la venta extrajudicial del bien hipotecado se realizará por medio de notario con las formalidades establecidas en la citada Ley y, además, se deberá pactar en la escritura de constitución de la hipoteca, conforme al artículo 1858 del CC $^{611}$ y sólo para el caso de falta de pago del capital o de los intereses de la obligación garantizada. Escrito de otro modo, la venta extrajudicial únicamente se podrá dar por impago de capital o intereses y no por otras causas de vencimiento anticipado que se hubieran podido pactar, aunque, en esos casos, la ejecución por otras causas será infrecuente.

Con respecto al valor de tasación, éste no podrá ser inferior al 75\% del valor señalado en la tasación ${ }^{612}$ conforme a lo establecido en la Ley $2 / 1981$, de 25 de marzo, de Regulación del Mercado Hipotecario.

\footnotetext{
609 Álvarez Álvarez, H., La hipoteca inversa..., op. cit., p. 122.

${ }^{610}$ Tal y como se dispone en este artículo: «1. La acción hipotecaria podrá ejercitarse:

a) Directamente contra los bienes hipotecados sujetando su ejercicio a lo dispuesto en el Título IV del Libro III de la Ley $1 / 2000$, de 7 de enero, de Enjuiciamiento Civil, con las especialidades que se establecen en su Capítulo V.

b) 0 mediante la venta extrajudicial del bien hipotecado, conforme al artículo 1.858 del Código Civil, siempre que se hubiera pactado en la escritura de constitución de la hipoteca sólo para el caso de falta de pago del capital o de los intereses de la cantidad garantizada».

${ }^{611}$ Atendiendo al artículo 1858 del CC: «Es también de esencia de estos contratos que, vencida la obligación principal, puedan ser enajenadas las cosas en que consiste la prenda o hipoteca para pagar al acreedor».

612 Que este valor de tasación no sea inferior al 75\% del obtenido en el mercado sirve para poner un tope a la práctica de algunas entidades financieras que simplemente tasan por el principal, sin mayores preocupaciones aunque éste sea muy bajo. Pero ¿Y si no hay una tasación a efectos del mercado hipotecario, por omitirse o no aportar certificación? ¿Pasaría a ser defecto que impediría la constancia
} 
También se hace hincapié en el carácter de la vivienda, sobre si es la habitual o no. Esta condición deberá pactarse para proceder a la venta extrajudicial debiendo constar separadamente del resto de las cláusulas que se puedan llegar a estipular.

Además, se hace referencia a la subasta, que pasará a ser única y se realizará de manera electrónica ${ }^{613}$ con el objetivo de agilizar estos procesos. El notario tendrá que valorar de oficio si hay alguna cláusula abusiva ${ }^{614}$ en la que se fundamente la venta extrajudicial o que hubiese determinado la cantidad exigible y, por último, tendrá que emitir una certificación con el precio del remate, deuda pendiente y reglas de imputación.

En la venta extrajudicial, la Ley Hipotecaria realiza remisiones concretas al Reglamento Hipotecario. De esta manera, en todo lo no remitido, los artículos del $\mathrm{RH}$, que no han sido derogados expresamente, sólo podrán aplicarse en aquello que no se considere reserva de ley ni esté regulado por la Ley 1/2013. Señalar también, que la LEC es supletoria, pero serán directamente aplicables las previsiones sobre remate insuficiente para saldar la deuda, tal y como se dispone en la Disposición Transitoria Cuarta de la Ley 1/2013 correspondiente al Régimen transitorio en los procesos de ejecución.

Finalmente, indicar que en la Disposición Transitoria Quinta ${ }^{615}$ se hace referencia a la venta extrajudicial, es decir, que lo previsto en el artículo 3

\footnotetext{
registral de ese valor de tasación, al no poder compararlo y, en consecuencia, reduciría la posibilidad de venta extrajudicial o del procedimiento de ejecución directa? Pues bien, aunque la respuesta general sería afirmativa, no podría hacerse constar en el Registro de la Propiedad. Al respecto, vid. las Resoluciones de la DGRN de 21 de noviembre de 2013 (RJ 2014\512), donde vale como tasación el precio máximo de venta VPO y la Resolución de 22 de enero de 2014 (RJ 2014\1548) referente a la tasación para todas las hipotecas y por técnico competente.

${ }^{613}$ El legislador entiende que resulta urgente el comienzo efectivo de este tipo de subastas, pues de lo contrario, arrastraría a la paralización de los procedimientos. Prueba de ello, es el colapso que hay en los Juzgados.

${ }^{614}$ Esta cuestión se analizará con mayor detalle al final del Epígrafe.

${ }^{615}$ Atendiendo a esta Disposición Transitoria Quinta de la Ley 1/2013: «En las ventas extrajudiciales iniciadas antes de la entrada en vigor de la presente Ley y en las que no se haya producido la adjudicación del bien hipotecado, el Notario acordará su suspensión cuando, en el plazo preclusivo de un mes desde el día siguiente a la entrada en vigor de esta Ley, cualquiera de las partes acredite haber planteado ante el Juez competente, conforme a lo previsto por el artículo 129 de la Ley Hipotecaria, el carácter abusivo de alguna cláusula del contrato de préstamo hipotecario que constituya el fundamento de la venta extrajudicial o que determine la cantidad exigible».
} 
apartado tres (relativo a la modificación del art. 129 de la LH) se aplicará a las ventas extrajudiciales que se inicien con posterioridad a la entrada en vigor de esta Ley, cualquiera que fuese la fecha en que se hubiera otorgado la escritura de constitución de hipoteca.

Sin embargo, a pesar de que se haya modificado o, mejor dicho, ampliado este artículo 129 de la LH, la venta extrajudicial con respecto a los bienes hipotecados inversamente, no ha distado mucho de la práctica anterior a la entrada en vigor de la Ley $1 / 2013$, pues, para que pudiera llevarse a cabo este procedimiento se requería que en la escritura de constitución de la hipoteca se hubiese estipulado la sujeción de los otorgantes a este procedimiento y, además que constaran los siguientes requisitos:

- El valor ${ }^{616}$ en el que los interesados hubiesen tasado la finca: la vivienda habitual hipotecada inversamente, con el fin de servir de tipo en la subasta. En este sentido, este valor no podría ser distinto del que, en su caso, se hubiese fijado para el procedimiento especial de ejecución.

- El domicilio señalado por el hipotecante para la práctica de los requerimientos y las notificaciones que, conforme a lo previsto en el artículo 155 de la LEC, y para sucesivas comunicaciones, podría ser designado uno distinto.

- La persona que en su día tuviese que otorgar la escritura de venta de la finca en representación del hipotecante, a tal efecto, podría designarse al propio acreedor.

\footnotetext{
${ }^{616}$ En este aspecto, la RDGRN de 18 de febrero de 2014 (TOL4.150.268) declara que: «La falta de rigor y objetividad en la determinación del precio de subasta, en atención al carácter más o menos improbable de la ejecución, puede producir desfases en relación al valor real de la finca hipotecada, que pueden perjudicar al deudor, como por ejemplo en los supuestos en que el precio en que se tasa la finca para subasta se hace coincidir con el importe del capital del préstamo o con la suma de las responsabilidades garantizadas y estos importes se sitúan claramente por debajo del valor real de la finca. Es cierto que lo que se les pide a los interesados no es la averiguación intuitiva del valor real de la finca hipotecada, ya que precisamente se trata de eludir una valoración pericial de la misma, sino de establecer un precio de salida para la subasta. Posteriormente será la dinámica propia de la subasta la que conduzca a la fijación del valor real a través de mecanismo de la oferta en concurrencia. Por ello, si el tipo resultó demasiado bajo la subasta generará las elevaciones correspondientes, y si resultó demasiado alto también serán las pujas presentadas en la subasta las que lo corregirán».
} 
- La estipulación, en virtud de la cual, los otorgantes hubiesen pactado la sujeción al procedimiento de ejecución extrajudicial ${ }^{617}$ de la hipoteca, debiendo constar, en forma separada, de las restantes estipulaciones de la escritura.

Además, de acuerdo con el artículo 235 del RH, la ejecución extrajudicial sólo podía aplicarse a las hipotecas constituidas en garantía de obligaciones cuya cuantía apareciese inicialmente determinada, de sus intereses ordinarios y de demora liquidados de conformidad con lo previsto en el título $y$, de los gastos de ejecución a los que se refiere el artículo $236-\mathrm{k}^{618}$. De esta manera, tal y como se ha indicado más arriba, la venta extrajudicial, en lo no previsto por la Ley Hipotecaria, se ajustará a lo dispuesto en los artículos 236, 236-a., 236-b., 236-c., 236-d., 236-e., 236-f., 236-g., 236-h., 236-i., 236-j., 236-k., 236-l., 236-m., 236-n., 236-ñ., y 236-o.

Traducido a la práctica, que las partes no podrán alterar lo dispuesto en la Legislación Hipotecaria previsto para la venta extrajudicial, por tratarse de normas de carácter imperativo.

\section{PROCEDIMIENTO GENERAL DE EJECUCIÓN}

\footnotetext{
${ }^{617}$ Al respecto la STS de 20 de abril de 1999 (RJ 1999/2589) mandaba: «Anular la sentencia recurrida, declarando, en sustitución de la misma, la inaplicación por derogación al ser norma opuesta a la Constitución del segundo párrafo del artículo 129 de la Ley Hipotecaria y la de los artículos 234 a 236 o), ambos inclusive, del Reglamento Hipotecario, en virtud de la subordinación que impone el principio de jerarquía normativa con la estimación en lo principal de la demanda y, en consecuencia, la nulidad del procedimiento extrajudicial de ejecución hipotecaria seguido...». De igual modo, la STS de 4 de mayo de 1998 (RJ 199813464) había considerado inconstitucional este precepto por ser contrario a la tutela judicial efectiva (art.117 de la CE). Sin embargo, tras la nueva redacción de la LEC, el artículo 129 de la LH, podía considerarse constitucional, pues, conforme a este nuevo artículo en la escritura de constitución de la hipoteca se podía pactar la venta extrajudicial del bien hipotecado ante notario.

${ }^{618}$ Atendiendo a este artículo: «1. El precio del remate se destinará sin dilación al pago del acreedor que haya instado su ejecución en la medida garantizada por la hipoteca.

2. El sobrante, si hubiere acreedores posteriores, se consignará en el oportuno establecimiento público quedando afecto a las resultas de dichos créditos. Esta circunstancia se hará constar en el Registro por nota marginal.

Si no hubiere acreedores posteriores, el sobrante se entregará al dueño de la finca.

3. El Notario practicará la liquidación de gastos considerando exclusivamente los honorarios de su actuación y los derivados de los distintos trámites seguidos».
} 
Se trata de la acción ejecutiva ordinaria ${ }^{619}$ regulada en los artículos 517 a 522 de la LEC. Este procedimiento ${ }^{620}$ sustituye al antiguo juicio ejecutivo, en el que el acreedor ejercitaba la acción personal fundada en el derecho de crédito documentado en la escritura pública de hipoteca. En el artículo 517 de la LEC podemos ver los distintos títulos ejecutivos:

- La sentencia de condena firme.

- Los laudos o resoluciones arbitrales.

- Las resoluciones judiciales que aprueben u homologuen transacciones judiciales y acuerdos logrados en el proceso, acompañadas, si fuere necesario para constancia de su concreto contenido, de los correspondientes testimonios de las actuaciones.

- Las escrituras públicas, con tal que sea primera copia; o si es segunda que esté dada en virtud de mandamiento judicial y con citación de la persona a quien deba perjudicar, o de su causante, o que se expida con la conformidad de todas las partes.

- Las pólizas de contratos mercantiles firmadas por las partes y por corredor de comercio colegiado que las intervenga, con tal que se acompañe certificación en la que dicho corredor acredite la conformidad de la póliza con los asientos de su libro registro y la fecha de éstos.

- Los títulos al portador o nominativos, legítimamente emitidos, que representen obligaciones vencidas y los cupones, también vencidos, de dichos títulos, siempre que los cupones confronten con los títulos y éstos, en todo caso, con los libros talonarios.

- Los certificados no caducados expedidos por las entidades encargadas de los registros contables respecto de los valores representados mediante anotaciones en cuenta a los que se refiere la Ley del Mercado de Valores, siempre que se acompañe copia de la escritura pública de representación de

\footnotetext{
${ }^{619}$ Sobre la ejecución hipotecaria vid. Montero Aroca, J.; Gómez Colomer, J.L.; Barona Vilar, S. y Calderón CUADRADO, M.P., Derecho jurisdiccional II, op. cit., pp. 843-861.

${ }^{620}$ En este sentido Oliver LóPEZ, C., «Capítulo V...», op. cit., p. 5608, señala que en los supuestos en los que se reclame cantidades por conceptos distintos de los incluidos en la cobertura hipotecaria, o en el caso de que la deuda final supere la cifra máxima de responsabilidad, el acreedor podrá acudir a un procedimiento ejecutivo común u ordinario para poder hacer efectivo su derecho. Cfr. ORTELLS RAMOS, M. (coord.); Mascarell Navarro, M.J.; Juan Sánchez, R.; Cucarella Galiana, L.A.; Bonet Navarro, J.; Cámara Ruiz, J.; Bellido Penadés, R.; Martín Pastor, J. y Armengot Vilaplana, A., Derecho Procesal Civil, 10. ${ }^{\text {a }}$ ed., Aranzadi, Cizur Menor (Navarra), 2010, p. 845.
} 
los valores o, en su caso, de la emisión, cuando tal escritura sea necesaria, conforme a la legislación vigente.

- El auto que establezca la cantidad máxima reclamable en concepto de indemnización, dictado en casos de rebeldía del acusado o de sentencia absolutoria o sobreseimiento en procesos penales incoados por hechos cubiertos por el Seguro Obligatorio de Responsabilidad Civil derivada del uso y circulación de vehículos de motor.

- Las demás resoluciones judiciales y documentos que, por disposición de esta u otra ley, lleven aparejada ejecución.

En el caso de que se opte por este procedimiento sólo podrán embargarse los bienes que se encuentren en poder del deudor y sin límite alguno (se trataría, pues, de la responsabilidad personal que veremos más adelante).

De este modo, el deudor responderá con todos sus bienes del cumplimiento de sus obligaciones, ya que la hipoteca no altera la responsabilidad ilimitada del deudor. Esto queda perfectamente reflejado en el artículo 1911 del CC donde comprobamos que: «Del cumplimiento de las obligaciones responde el deudor con todos sus bienes, presentes y futuros». Este artículo también lo podemos relacionar con el artículo 584 de la LEC ${ }^{621}$, el cual hace referencia al alcance objetivo y a la suficiencia del embargo.

Según Domínguez LUELMO ${ }^{622}$, interesará más instar el proceso de ejecución común cuando el acreedor sospeche que el valor que pueda obtener tras la enajenación forzosa no cubra el importe del crédito en la parte garantizada con la hipoteca y también cuando no se den los requisitos que el artículo 682 de la LEC establece como obligatorios para acudir al procedimiento de ejecución especial de los artículos 681 y siguientes de la LEC.

\footnotetext{
${ }^{621}$ Este artículo recoge lo siguiente: «No se embargarán bienes cuyo previsible valor exceda de la cantidad por la que se haya despachado ejecución, salvo que en el patrimonio del ejecutado sólo existieren bienes de valor superior a esos conceptos y la afección de dichos bienes resultare necesaria a los fines de la ejecución».

622 Domínguez LueLmo, A., "Comentario del artículo 681 de la LEC», en Comentarios a la Nueva Ley de Enjuiciamiento Civil, tomo III, 2. ${ }^{a}$ ed., Lex Nova, Valladolid, 2000, pp. 3369 y ss.
} 
Al efecto, el artículo 579 de la LEC $1 / 2000^{623}$, relativo a la Ejecución dineraria en casos de bienes especialmente hipotecados o pignorados, modificado por la Ley $1 / 2013$, determina, al respecto, lo siguiente:

«1. Cuando la ejecución se dirija exclusivamente contra bienes hipotecados o pignorados en garantía de una deuda dineraria se estará a lo dispuesto en el capítulo $V$ de este Título. Si, subastados los bienes hipotecados o pignorados, su producto fuera insuficiente para cubrir el crédito, el ejecutante podrá pedir el despacho de la ejecución por la cantidad que falte, y contra quienes proceda, y la ejecución proseguirá con arreglo a las normas ordinarias aplicables a toda ejecución».

Como se puede observar, este artículo otorga mayor seguridad a la parte acreedora para, caso que se encuentre con un patrimonio negativo, pueda recuperar, igualmente, su crédito, situación muy probable en esta modalidad hipotecaria.

El problema que plantea este procedimiento, a diferencia del procedimiento especial de ejecución, es que, por una parte, las causas de oposición no están tan limitadas y, por otra, se podría dilatar en el tiempo.

Además, en la práctica, lo más normal es que cuando se pretenda ejecutar una hipoteca inversa, el acreedor exija a los herederos la cantidad adeudada, pudiendo afectarse a todo el valor del inmueble. Y, en el caso de que este inmueble no fuera suficiente, se podría continuar persiguiendo el resto de los bienes del deudor fallecido sin la necesidad de iniciar un nuevo procedimiento ${ }^{624}$. Es decir, en el supuesto de que el acreedor considerara que no pudiera cobrar toda la deuda -no cubriéndose ésta aun ejecutando la hipoteca-, en lugar de ejecutar la hipoteca a través del procedimiento ejecutivo de los artículos 681 y ss. de la LEC, se acudiría al procedimiento

\footnotetext{
${ }^{623}$ En opinión de Oliver LóPEZ, C., «Capítulo V...», op. cit., p. 5642, la LEC del año 2000 introdujo una novedad por la que, en virtud del principio de unidad de ejecución «la petición de despacho de ejecución se hace por la cantidad que ampare el título conectado con la garantía, esté o no la misma garantizada en su totalidad». Reflejo de esta modificación ya eran, en aquel entonces, los artículos 692.1 párrafo $2^{\circ}$ y 579 de la LEC.

${ }^{624}$ AngUITA Ríos, R.M., «Regulación relativa...», op. cit., pp. 14 y 15.
} 
ejecutivo ordinario para poder ejecutar el resto de los bienes de la herencia $\mathrm{y}$, de esta manera, cobrar la totalidad de la deuda.

Si se llegara a esta situación, se tendría que concretar el bien o los bienes inmuebles que vayan a responder de la deuda y, además, aunque los posibles herederos fuesen emplazados en el procedimiento y se les hubiese requerido de pago, incluso si se personasen en el procedimiento, mientras no aceptasen la herencia ${ }^{625}$, serían sólo posibles herederos pero no herederos en sentido estricto. Pudiera suceder que estos posibles herederos no hubiesen aceptado la herencia todavía o, incluso, que no llegasen a aceptarla nunca.

Como ya se ha reseñado anteriormente, la aceptación de la herencia tampoco otorgará al acreedor la plena facultad de dirigirse frente al patrimonio del heredero, pues antes se tendrá que comprobar la forma en que se haya aceptado esa herencia: si pura y simple $e^{626}$ o a beneficio de inventario.

En el caso de que el heredero la acepte pura y simple, conforme se indica en el artículo 1003 del CC, quedará responsable de todas las cargas de la herencia, no sólo con los bienes de ésta, sino también con los suyos propios.

En el supuesto de que la acepte a beneficio de inventario, el patrimonio hereditario y el patrimonio del heredero se constituirán en dos patrimonios distintos, separados ${ }^{627}$, de manera que el heredero sólo será responsable de las deudas del causante con los bienes de la herencia ${ }^{628}$. Por tanto, el acreedor sólo podrá perseguir los bienes del heredero cuando éste haya aceptado la herencia de forma pura y simple, pues sólo en esta modalidad se produce la confusión de patrimonios ${ }^{629}$.

\footnotetext{
${ }^{625}$ Al efecto, la STS de 20 de mayo de 1982 (RJ 1982\2585) en su considerando tercero señala que es: «necesaria en nuestro Derecho la aceptación de la herencia para adquirir la condición de heredero». Vid. también SAP de Asturias de 28 de junio de 2001 (RJ 2001\2026).

${ }^{626}$ Vid. Sentencia de 30 de noviembre de 2009 de la Audiencia Provincial de A Coruña (AC 20101885).

627 Se trata de una situación que favorece no sólo al heredero que no hará frente a las deudas de su causante, sino también a los acreedores del causante que no tendrán que concurrir con los posibles acreedores del heredero.

${ }^{628}$ Díez-PICAZo, L. y Gullón, A., Sistemas de Derecho Civil IV. Familia, op. cit., p. 490.

${ }^{629}$ Con la salvedad que se produce en la hipoteca inversa y que seguidamente se verá.
} 
Así, la mera personación en el procedimiento no se entenderá como aceptación de la herencia. En consecuencia, y aunque en el proceso los herederos manifiesten su voluntad de aceptar la herencia, el juez únicamente podrá decretar el embargo de bienes relictos. No obstante, ello no impedirá que el tribunal condene a futuro a los herederos al pago de las deudas hereditarias.

Con respecto a la aceptación pura y simple matizar que, conforme al artículo 999 del CC: «La aceptación pura y simple puede ser expresa y tácita.

Expresa es la que se hace en documento público o privado.

Tácita es la que se hace por actos que suponen necesariamente la voluntad de aceptar, o que no habría derecho a ejecutar sino con la cualidad de heredero».

Además, en su último párrafo, también señala que: «Los actos de mera conservación o administración provisional no implican la aceptación de la herencia, si con ellos no se ha tomado el título o la cualidad de heredero».

De esta manera, aunque el «heredero» realice actos necesarios para mantener la integridad de la herencia, que no supongan ni un aumento ni una disminución patrimonial, no se considerará como tal hasta que no haya aceptado la herencia. Estos $\operatorname{actos}^{630}$, a simple vista, evidencian la mera gestión del patrimonio hereditario. Sin embargo, para que éstos puedan resultar como la firme voluntad de aceptar la herencia, deberán corresponder a un acto positivo e inequívoco «en el sentido de no poder realizarse en otra calidad que la del heredero ${ }^{631}{ }$. En cambio, cuando la aceptación de la herencia sea tácita, conforme se indica en este último apartado del artículo 999 del CC, se considerará la oposición a la ejecución.

\footnotetext{
630 En este sentido la STS de 27 de junio de 2000 (RJ 200015909) matiza lo siguiente: «Para que un heredero pueda ser compelido al cumplimiento de las obligaciones contraídas por su causante, será preciso probar que ha aceptado la herencia, y en tal sentido viene reiterando la jurisprudencia que no constando que el heredero haya adido la herencia no puede ser demandado por responsabilidades que pudiera tener el testador, ni cabe condenarle al pago de cantidad alguna en tal concepto de heredero". Así, no se consideran actos positivos de aceptación de herencia: el hecho de como posibles herederos se les notifique oportunamente (STS de 31 de mayo de 2006 (RJ 2006/3175) ni tampoco la mera personación en juicio (SAP de Coruña de 30 de noviembre de 2009 (AC 20101885).

${ }^{631}$ LACRUZ BerdeJo, J.L., Elementos de Derecho Civil V: Sucesiones, 2. ${ }^{a}$ ed., Dykinson, Madrid, 2004, p. 66.
} 
No obstante, la hipoteca inversa, una vez más, se muestra diferente con respecto a la responsabilidad de los herederos por deudas hereditarias. En esta modalidad la aceptación o no de la herencia resultará indiferente ya que aunque el heredero acepte la herencia y opte por no devolver el préstamo, tal como se indica en el apartado 6 de la DA $1 .^{a}$, hay una limitación de responsabilidad, en este caso, a los bienes del caudal hereditario, de manera que parezca una aceptación a beneficio de inventario. Por tanto, en esta modalidad, lo regulado en el artículo 661 del CC $^{632}$ : «Los herederos suceden al difunto por el hecho sólo de su muerte en todos sus derechos y obligaciones» carecería de sentido.

En este aspecto, BeRROCAL LANZAROT ${ }^{633}$ opina que «resulta innecesario establecer ninguna limitación de responsabilidad de los herederos, ya está la aceptación a beneficio de inventario, que permite garantizar que aunque se acepte la herencia, no serán responsables de la deuda de la hipoteca inversa con su propio patrimonio».

De esta manera, con la aceptación de herencia a beneficio de inventario se limitará la responsabilidad del heredero por la deuda garantizada con hipoteca a los bienes de la herencia, subsistiendo «intacta una responsabilidad patrimonial anterior, o sea, sobre un patrimonio el hereditario, que conserva su identidad ${ }^{634}$ ». No obstante, en el caso de la hipoteca inversa, independientemente de que el heredero acepte o no, su patrimonio personal no quedará afectado por la deuda del causante. Es más, el incumplimiento de esta obligación no generará ningún tipo de sanción sobre el patrimonio personal del heredero.

Con todo esto, nos encontraremos con otro gran inconveniente, pues al optar por el procedimiento general de ejecución nos tendremos que plantear si se puede o no decretar el embargo de los bienes, no sólo de los hipotecados

\footnotetext{
${ }^{632}$ A pesar de lo establecido en este artículo, se requerirá la aceptación para que efectivamente el heredero suceda al causante en todas las relaciones, tal como señala el artículo 1003 del CC por la aceptación pura y simple, o sin beneficio de inventario, el heredero quedará responsable de todas las cargas de la herencia, no sólo con los bienes de ésta, sino también con los suyos propios. De esta forma, el heredero será el continuador de la personalidad del causante. Además, y como ya se ha comentado, la aceptación tendrá efectos retroactivos.

${ }^{633}$ BerRoCAL LANZAROT, A.I., «Hipoteca Inversa...», op. cit., p. 57.

${ }^{634}$ Roca Sastre, R.M. y Roca-SASTRE MuncunilL, L., Derecho hipotecario: Ley del Suelo e Hipotecas, op. cit., p. 624.
} 
sino también del resto de los bienes del deudor y su posterior anotación en el Registro. En este caso, si la ejecución se realizase contra otros bienes del deudor, éstos también serían objeto de embargo ${ }^{635}$.

En este sentido, algunos autores también se plantean dudas en relación con el embargo de los bienes previamente hipotecados. En opinión de RIVAS TORRALBA ${ }^{636}$, cuando no exista un tercer poseedor se tendrá que embargar la finca hipotecada por el exceso cuando la cantidad adeudada sea superior a la responsabilidad hipotecaria, pero en los demás casos duda que se pueda proceder al embargo de los bienes previamente hipotecados ${ }^{637}$, ya que el bien hipotecado puede ser objeto de apremio sin necesidad de practicar el embargo sobre él.

Analizadas estas cuestiones, podemos observar que uno de los problemas que plantea el acudir a este procedimiento general es si se puede decretar o no el embargo de los bienes, no sólo de los hipotecados (en nuestro caso: la vivienda habitual) sino de los otros bienes que tuviera el deudor y su posterior anotación en el Registro, ya que en el supuesto de que esto sucediera, estos otros bienes también serían objeto de embargo.

\section{JUICIO DECLARATIVO ORDINARIO}

Este procedimiento está regulado en los artículos 399 y siguientes de la LEC. El acreedor podrá acudir a los tribunales formulando una pretensión declarativa incoando un proceso ordinario de declaración, que podrá ser ordinario o verbal, dependiendo de la cuantía.

Para el acreedor será más efectivo acudir a un proceso de ejecución, no teniendo que pasar previamente por un proceso de declaración. Esto, como

\footnotetext{
635 Álvarez Álvarez, H., La hipoteca inversa..., op. cit., p. 125.

${ }^{636}$ Rivas TORRALBA, R., Aspectos registrales..., op. cit., pp. 233 y ss.

637 Aún así, algunas resoluciones de la DGRN consideran que es necesario el embargo de los bienes previamente hipotecados. Destacar, entre otras, la de 10 de diciembre de 1997 (RJ 1997 8821 ) y la de 26 de julio de 1999 (RJ 1999\6082).
} 
consecuencia de que el crédito hipotecario ya consta en escritura pública y se ha inscrito en el Registro de la Propiedad. De este modo, el acreedor, al tener el título ejecutivo, podrá instar directamente la ejecución. Debido a lo anterior, no será muy normal que el acreedor utilice está opción (Juicio Ordinario), pues, teniendo en su poder el título ejecutivo se decantará por un procedimiento más rápido y más económico.

En este aspecto, y según la profesora Álvarez ${ }^{638}$, todavía surgen dudas en torno a si el acreedor hipotecario es libre o no de elegir el procedimiento que estime más conveniente a sus intereses. Para un sector doctrinal el acreedor podrá elegir libremente entre utilizar la acción personal y acudir a la totalidad del patrimonio del deudor o bien ejecutar la acción hipotecaria, dirigiéndose tan sólo contra el bien hipotecado ${ }^{639}$.

Sin embargo, para otro sector doctrinal, el acreedor hipotecario deberá dirigirse obligatoriamente contra los bienes hipotecados, pues el deudor tendría derecho a que el crédito hipotecario se hiciese efectivo primero con los bienes hipotecados, y sólo en caso de insuficiencia de éstos cabría dirigirse contra el resto de su patrimonio. De lo citado se infiere que la acción personal sería subsidiaria y sólo podría ejecutarse en el supuesto de que la acción real hipotecaria se hubiese agotado por ser los bienes hipotecados insuficientes para hacer efectivo el crédito ${ }^{640}$.

En resumen, esta última opción será difícil que se produzca, ya que será más rápido y eficaz acudir por vía del título ejecutivo.

Para finalizar, destacar que a raíz de la Sentencia del TJUE de 14 de marzo de 2013 (Caso Aziz [TJCE 2013\89]), la Ley 1/2013 modifica la regulación de los procedimientos de ejecución ordinaria e hipotecaria para introducir la posibilidad de que, de oficio o a instancia de parte, el juez que

\footnotetext{
${ }^{638}$ Álvarez Álvarez, H., La hipoteca inversa..., op. cit., pp. 123 y 124.

639 De hecho, el artículo 681.1 de la LEC determina que: «La acción para exigir el pago de deudas garantizadas por prenda o hipoteca podrá ejercitarse directamente contra los bienes pignorados o hipotecados,...».

${ }^{640}$ Montero Aroca, J., Las ejecuciones..., op. cit., pp. 281 y 282.
} 
conozca de ellos pueda apreciar la existencia de cláusulas abusivas en el título ejecutivo ${ }^{641}$.

En los dos casos (apreciación de oficio o a instancia de parte), se establece que el juez confiera un trámite de audiencia a las partes para que aleguen lo que a su derecho convenga (arts. 552.1.2 y 695.2 de la LEC). Aunque en la ejecución hipotecaria se prevé la celebración de una comparecencia ante el juez, es previsible y razonable que en la práctica no sea necesaria si hay acuerdo de las partes en la tramitación escrita del incidente. Tras oír a las partes, el juez resolverá el incidente de oposición.

Ante el silencio que guarda la Ley al respecto, para valorar el carácter abusivo de una cláusula contractual el juez atenderá a los criterios establecidos en el artículo 82.3 del Real Decreto Legislativo 1/2007, de 16 de noviembre, por el que se aprueba el texto refundido de la Ley General para la Defensa de los Consumidores y Usuarios y otras leyes complementarias, así como a los parámetros contenidos en normas de Derecho interno en relación a la que se plantea en cada caso y, especialmente, a los recogidos en la Ley $1 / 2013$.

Si finalmente el juez declara abusiva una o varias cláusulas del título ejecutivo, deberá determinar las consecuencias que se derivan de tal carácter y decretar:

- En el caso de ejecución ordinaria, bien la improcedencia de la ejecución, o bien su despacho sin aplicación de la cláusula abusiva (art. 561.1.3 $3^{\mathrm{a}}$ de la LEC).

- En el caso de la ejecución hipotecaria, su sobreseimiento (cuando la cláusula considerada abusiva fundamente la ejecución) o en otro caso (debe entenderse que se refiere cuando la cláusula abusiva determine la cantidad

\footnotetext{
641 Véase con mayor detalle el artículo publicado por Actualidad Jurídica Uría Menéndez/35-2013: «Nueva Normativa de Protección de Deudores Hipotecarios», pp. 62-80.
} 
exigible), su continuación con la inaplicación de la cláusula abusiva (art. 695.3, párrafo segundo de la LEC).

Por último, los autos que decidan la oposición no serán recurribles -salvo los que acuerden el sobreseimiento o la inaplicación de una cláusula abusiva, que lo serán en apelación- y sus efectos se limitarán al proceso de ejecución en que se dicten (art. 695.4 de la LEC).

Es indudable que la reforma operada en esta materia supone un refuerzo de la protección de la parte ejecutada. Con todo y aunque habrá que esperar a que se consolide la práctica judicial para poder calibrar mejor su alcance, hay razones para pensar que la novedosa introducción de la posibilidad de apreciar el carácter abusivo de una cláusula contractual puede tener una incidencia práctica limitada.

Ello es así básicamente, porque ni todos lo ejecutados pueden hacer uso de esta causa de oposición, ni a través de ella pueden ser objeto de impugnación todas las cláusulas contractuales contenidas en la escritura de préstamo o crédito hipotecario (ni siquiera las potencialmente abusivas), ni puede apreciarse -ya sea a instancia de parte o de oficio- la existencia de una cláusula abusiva en cualquier fase del procedimiento, sino que el momento procesal oportuno está acotado temporalmente. 



\section{CAPÍTULO VIII: MÉTODO FISCAL Y RETROACTIVIDAD DE LA HIPOTECA INVERSA}

\section{SISTEMA FISCAL DE LA HIPOTECA INVERSA}

Antes de que se aprobara la Ley 41/2007, por la que se regula la hipoteca inversa, este producto financiero ya se comercializaba pero no gozaba, entre otras facultades, de ventajas fiscales.

Los costes para la formalización de esta modalidad hipotecaria, como podían ser los gastos de tasación, la constitución en escritura pública y su posterior inscripción en el Registro de la Propiedad, así como también el pago del Impuesto de Actos Jurídicos Documentados, las comisiones bancarias, seguros, gastos de gestoría, etc., eran muy elevados. Además, a estos importes había que sumar también el precio del seguro de Renta Vitalicia, pues aunque no era obligatorio, sí era aconsejable, siendo el principal gasto de esta hipoteca.

Por tanto, podemos afirmar que este préstamo hipotecario no era un producto financiero atractivo, pues la persona que negociaba este tipo de hipoteca, en muchas ocasiones, no podía hacer frente a estos gastos, o en otras, necesitaba ese dinero para otros fines, como por ejemplo, para el ingreso en un geriátrico. Además, el solicitante de esta hipoteca, a medida que iba realizando las gestiones oportunas para la obtención de la misma, veía como la renta a percibir mermaba con el tiempo, ya que el discurrir de éste iba en su contra.

Estas fueron las razones $^{642}$ por las que en la Ley $41 / 2007$ se introdujeron ${ }^{643}$ una serie de reducciones fiscales para configurar una hipoteca

\footnotetext{
642 ANGUITA Ríos, R.M., «Regulación relativa...», op. cit., p. 13. La autora señala que se pretende evitar uno de los problemas que se venían dando en el derecho comparado: el elevado coste de las hipotecas inversas, que está en contraposición con la finalidad que persigue esta figura.

${ }^{643}$ Tal y como indica ZURITA MARTín, I., «La nueva normativa...», op. cit., 1308 y 1309, esta finalidad fue la única observada por la Proposición de Ley presentada por el Grupo Catalán en el Congreso en noviembre de 2005 -finalmente retirada-, que no recogía otra cosa que no fuera estos beneficios fiscales, sin entrar de lleno en la regulación de los requisitos de esta figura.
} 
más asequible al público al que iba dirigida, en ese momento, personas mayores de 65 años o con dependencia o gran dependencia. En la actualidad, con la entrada en vigor de la Ley $1 / 2013$, nos estaríamos refiriendo a personas de edad igual o superior a los 65 años o afectadas de dependencia, o a personas a las que se les haya reconocido un grado de discapacidad igual o superior al 33 por ciento.

A pesar de esta iniciativa, aun teniendo un tratamiento fiscal favorable y en cierto modo beneficioso para el sujeto que tramitase esta modalidad hipotecaria, en la práctica no ha sido beneficiosa, pues aparte de ofrecer pocos incentivos, éstos nunca han sido lo suficientemente definidos ni por el Gobierno que ha estado en cada momento (PSOE y PP), ni por parte de Bancos y demás entidades de crédito.

Las entidades financieras, casi desde el inicio de la Ley $41 / 2007$, se mostraron desmotivadas a la hora de ofrecer este producto financiero. Apenas si se molestaron en promocionarlo, porque, entre otras cuestiones, se ofrecían pocas ventajas. Además, tampoco se preocuparon por conocer este producto en profundidad, pues en ningún momento se plantearon ni las consecuencias ni la repercusión ciudadana que esta modalidad pudiera llegar a tener con el paso del tiempo.

A esto, hay que añadir que España, desde 2008, ha estado inmersa en una profunda crisis, teniendo que hacer frente a muchas cuestiones de urgencia, dejando de lado, entre otras, la normativa fiscal sobre la hipoteca inversa. Cuando esta crisis empezó a percibirse por la sociedad, esta modalidad hipotecaria llevaba en vigor menos de un año, de forma más concreta, 5 meses (mayo de 2008) ${ }^{644}$. Esta situación derivó en que los Bancos

\footnotetext{
644 Prueba de ello es el artículo publicado por LD (Europa Press) el día 25 de mayo de 2008 (www.libertadigital.com). En el mismo se dice que: «Apenas 5 meses después de su regulación por ley, la hipoteca inversa ha dejado de gozar de buena aceptación por "la bajada del precio de los pisos", según el decano del Colegio de Registradores, Eugenio Rodríguez. Se trata de "una figura basada en la subida de los precios de la vivienda de 2006", por lo que el actual contexto de crisis inmobiliaria la ha convertido en un producto poco atractivo". En el citado artículo también se indica que: "Desde el Colegio de Registradores se explica que "no hay que ser pesimistas" por la baja aceptación de las hipotecas inversas, sino más bien "realistas" y "con el orgullo de haber estimulado la creación de esta figura jurídica, aunque a algunos no les gustara"».
} 
y entidades financieras se olvidarán por completo de esta modalidad, quienes como ya se ha comentado, desde sus inicios o incluso antes de su entrada en vigor, no mostraron ningún tipo de interés hacia la misma.

El pasado 28 de noviembre se publicó en el BOE $^{645}$ la Ley $26 / 2014$, de 27 de noviembre, por la que se modifican la Ley 35/2006, de 28 de noviembre, del Impuesto sobre la Renta de las personas físicas, el texto refundido de la Ley del Impuesto sobre la Renta de no residentes, aprobado por el Real Decreto Legislativo 5/2004, de 5 de marzo, y otras normas tributarias (en adelante Ley 26/2014), pues estos últimos años hemos estado asistiendo a reformas de urgencia, cada vez más restrictivas y negativas para el ciudadano, llegándose, como claro exponente de estas políticas, a subir el IVA $^{646} 5$ puntos en el plazo de dos años.

Por tanto, podemos considerar a la hipoteca inversa como un producto por el que ha habido poca atención por parte de los distintos Gobiernos, tanto por parte del PSOE -momento en el que se constituyó dicha Ley-, como por parte del PP, pues durante el tiempo que lleva de mandato, la única modificación que ha hecho sobre este tipo de hipoteca ha sido la tramitada en la Ley $1 / 2013$, correspondiente a la letra a) del apartado 1 de la DA $1 .^{a}$, por la que se amplían las condiciones de los sujetos solicitantes de esta modalidad.

Por esta razón, aunque la normativa fiscal está actualizándose constantemente, en lo que se refiere a incentivos para la constitución de hipotecas inversas, podemos decir que el tratamiento fiscal que las rige es el mismo que se dio al inicio de su creación, siendo, por tanto, un tipo de hipoteca poco atractiva ${ }^{647}$ en la que las medidas fiscales no están del todo claras. Pues, esta modalidad hipotecaria, debido a la finalidad social para la

\footnotetext{
645 BOE núm. 288.

${ }^{646}$ Respecto a este impuesto, el pasado 28 de noviembre se publicó en el BOE la Ley 28/2014 por la que se modifican, entre otras, la Ley 37/1992, de 28 de diciembre, del Impuesto sobre el Valor Añadido.

647 Según el artículo publicado el día 25 de mayo de 2011 por Óptima Mayores (primera consultora en España, especializada en asesorar a mayores de 65 años en Hipoteca Inversa), aún así, la demanda de hipotecas inversas creció un $17 \%$ en el primer cuatrimestre de 2011. Además, la misma consultora nos revela que la mayoría de estas solicitudes se concentran en las principales capitales españolas, siendo Madrid con un $32 \%$ y Barcelona con un $25 \%$, las ciudades en las que mayor número de solicitudes se realizan, seguidas de Sevilla con un 11\%. (Información disponible en: www.optimamayores.com).
} 
que fue creada (personas mayores de 65 años o dependientes y, normalmente con escasos recursos), debería tener una serie de incentivos fiscales para que, de una vez por todas, fuera posible su aplicación de manera eficiente.

Seguidamente, vamos a hacer un repaso de los incentivos fiscales que se crearon en 2007 para la hipoteca inversa que, como ya se ha mencionado, no se han visto modificados durante estos años.

\section{Impuesto sobre Transmisiones y Actos Jurídicos Documentados}

Como hemos podido observar, para que esta modalidad de hipoteca tuviera aceptación del público al que iba a ir dirigida, era necesario que los costes que iban a gravar su constitución se rebajaran ${ }^{648}$. Estos costes, al figurar en la primera partida del crédito, hacían disminuir, de forma considerada, las cantidades periódicas que el solicitante-deudor iba a recibir. Ante esta problemática se decidió rebajar las comisiones bancarias, los aranceles notariales y registrales y la exención del Impuesto de Actos Jurídicos Documentados, que hasta 2007 gravaba la constitución, subrogación, novación y cancelación de este tipo de hipotecas.

Estos beneficios fiscales se recogen en el Apartado $7^{649}$ de la DA $1 .^{a}$ de la Ley 41/2007, donde se expresa lo siguiente:

«Estarán exentas de la cuota gradual de documentos notariales de la modalidad de actos jurídicos documentados del Impuesto sobre Transmisiones y Actos Jurídicos Documentados las escrituras públicas que documenten las operaciones de constitución, subrogación, novación modificativa y cancelación».

Conforme a este precepto pasarán a quedar exentas del Impuesto de Actos Jurídicos Documentados ${ }^{650}$, las escrituras públicas en las que conste la constitución, subrogación, novación modificativa o cancelación de una

\footnotetext{
${ }^{648}$ Así lo ha considerado Rodrigo GARCíA, G., «La hipoteca...», op. cit., p. 58.

${ }^{649}$ Este apartado fue objeto de enmiendas pero ninguna prosperó. De esta forma, mantuvo su redacción original en la Disposición.

${ }^{650}$ En este sentido vid. la STSJ de Asturias de 19 de septiembre de 2013 (TOL3.955.329).
} 
hipoteca inversa. Aunque la causa más normal de exención será la constitución de una hipoteca inversa donde, en realidad, no se realiza ninguna transmisión patrimonial, de ahí que se produzca esa dispensa. Por tanto, atendiendo a este apartado 7, las personas que constituyan una hipoteca inversa estarán exentas del pago de este impuesto.

Ahora bien, no debemos olvidar que el Gobierno era y es el responsable de subvencionar esta modalidad hipotecaria, que conforme han pasado estos años en los que se ha agravado tanto la situación financiera como económica del país, no ha obtenido un mínimo interés en ser promocionada. Actualmente, estamos viendo que los Impuestos -de todo tipo-, están subiendo de forma continuada y el Gobierno cada vez está ajustando más las partidas presupuestarias, reduciendo al mínimo todo tipo de gastos y, en especial, los destinados a fines sociales. De momento, las rentas obtenidas por personas de 65 años o más, o por personas afectadas de dependencia, o personas que tengan reconocido un grado de discapacidad igual o superior al 33 por ciento, para la constitución de hipotecas inversas sobre su vivienda habitual estarán exentas de tributación.

Esto no ha sido siempre así. Antes de que la Ley 41/2007 entrara en vigor se tenía que pagar el Impuesto de Actos Jurídicos Documentados, el 0,5 por 100 o el 1 por 100, dependiendo de la Comunidad Autónoma donde estuviese situado el inmueble.

En este aspecto, cabría hacer mención a la Disposición Final Décima de la Ley 41/2007 donde se concreta esta entrada en vigor: «La presente Ley entrará en vigor el día siguiente al de su publicación en el «Boletín Oficial del Estado». Es decir, desde el 9 de diciembre de 2007, cualquier escritura pública que verse sobre la constitución, subrogación, novación modificativa y cancelación de una hipoteca inversa estará exenta del Impuesto de Actos Jurídicos Documentados, de forma que se tratará de una exención total. Asimismo, en el caso de que el deudor vendiera su vivienda habitual, las plusvalías obtenidas a raíz de esta venta, también estarían exentas de tributación. 
En cuanto a la novación y subrogación del préstamo o crédito garantizado con hipoteca inversa, sólo cabría la subrogación, es decir, el cambio del acreedor hipotecario, siempre y cuando se tratase de las entidades financieras del artículo 2 de la Ley $2 / 1981$, de 25 de marzo, de Regulación del Mercado Hipotecario (Bancos, Entidades oficiales de crédito, Cajas de Ahorro, Confederación Española de Cajas de Ahorros, Cooperativas de crédito y Establecimientos financieros de crédito).

En este supuesto y conforme a este artículo, la subrogación -al no constar en dicho precepto legal-, tampoco sería posible para las entidades aseguradoras. Además, tal y como se ha podido analizar a lo largo del programa, salvo que las partes pactaran otra cosa, ni la figura del deudor ni la figura del beneficiario podrían ser objeto de suplantación.

\section{Impuesto sobre la Renta de las Personas Físicas}

En la enmienda número 106, el Grupo Parlamentario Popular del Congreso, así como también en la enmienda presentada por el mismo grupo parlamentario pero en el Senado (enmienda número 76 ), se pretendía que se añadiese una nueva disposición adicional por la que se regulase la exención de las rentas vitalicias aseguradas en operaciones de hipoteca inversa o vivienda pensión.

En este sentido, se quería modificar el Artículo 7 de la Ley 35/2006, de 28 de noviembre, del Impuesto sobre la Renta de las Personas Físicas, añadiendo un apartado z) al artículo, quedando de la siguiente manera: «Las prestaciones percibidas en forma de renta vitalicia asegurada por los beneficiarios de contratos de seguro derivadas de las operaciones de hipoteca inversa o de vivienda pensión...» estarán exentas de la tributación de este impuesto.

Con esta modificación, se quería promover la fiscalidad de las rentas vitalicias aseguradas por personas mayores de 65 años o afectadas de 
dependencia severa o gran dependencia ${ }^{651}$ que suscribiesen una hipoteca inversa o una vivienda pensión, obteniendo, de esta manera, unos ingresos adicionales para hacer frente a los gastos cotidianos. Las razones que justificaban esta propuesta de exención del impuesto eran las siguientes:

Por un lado, mediante el cobro en forma de renta vitalicia asegurada se eliminaría el riesgo de longevidad. Este riesgo quedaría asumido por la entidad aseguradora y, así, el beneficiario, en el caso de que lo hubiere, seguiría recibiendo esta renta hasta su fallecimiento.

Por otro, a través de esta renta vitalicia asegurada se eliminaría el riesgo de inversión.

Junto a esto, otros grupos parlamentarios también propusieron más incentivos fiscales durante la tramitación parlamentaria de la Ley 41/2007. Sin embargo, estas enmiendas presentadas, tanto en el Congreso como en el Senado, no prosperaron. Sin más aportaciones, Pedro Solbes, Vicepresidente del Gobierno en aquella fecha, el miércoles 25 de julio de $2007^{652}$ rechazó dar más ayudas fiscales a las hipotecas inversas. El entonces ministro no se avino a modificar la Ley del IRPF, pues consideraba que la Ley remitida al Congreso ya preveía la exención del pago del Impuesto de Actos Jurídicos Documentados.

Es decir, los sujetos que solicitarán este tipo de hipoteca ya contaban con un ahorro de entre el 0,5 por 100 y el 1 por 100 del valor de la vivienda, dependiendo de la Comunidad Autónoma donde se residiese. Asimismo, el ministro consideraba suficiente la bonificación, ya que tras la entrada en vigor de la Ley 41/2007 se había producido una reducción de los costes notariales y registrales en las escrituras públicas que documentaran las operaciones de

\footnotetext{
651 Sujetos a los que entonces iba dirigida. Tras la entrada en vigor de la Ley $1 / 2013$, se amplía a personas afectadas de dependencia o personas a las que se les haya reconocido un grado de discapacidad igual o superior al 33 por ciento.

${ }^{652}$ Álvarez Álvarez, H., La hipoteca inversa..., op. cit., p. 152.
} 
constitución, subrogación, novación y cancelación de este tipo de hipotecas ${ }^{653}$.

Sin embargo, a pesar de que en principio parecía que no iban a aprobarse más beneficios fiscales, el 16 de octubre de 2007 se aprobó un incentivo fiscal más que beneficiaba a las hipotecas inversas, gracias a una enmienda de adición pactada por los grupos parlamentarios PSOE y CIU, aprobada en la Comisión de Economía con competencia legislativa plena, por lo que su tramitación pasó directamente al Senado. Con esta modificación se permitía que los ingresos obtenidos por hipotecas inversas que se canalizasen en la constitución de un Plan de Previsión Asegurado pudieran deducirse de la base imponible del IRPF, con un máximo de 10.000 euros. Por tanto, podríamos hablar de dos incentivos fiscales:

- Por una parte, los que se derivarían de la propia contratación de la hipoteca inversa, en la que el deudor recibiría una renta por hipotecar inversamente su vivienda habitual. Esta renta, según la Ley del IRPF, estaría exenta ${ }^{654}$ de tributación.

Esta exención se daría porque el crédito era anticipado por un Banco o Entidad de Crédito, a cuenta del valor de tasación de la vivienda hipotecada. Estas rentas no se considerarían ingresos de capital inmobiliario, por lo que en la declaración de la renta no se incluirían. A esto, habría que añadir que la contratación de la hipoteca inversa, tal y como se ha venido señalando, estaría libre de impuestos, concretamente, del de Actos Jurídicos Documentados.

Antes de la entrada en vigor de la Ley 41/2007 no se consideraban renta -a los efectos de la tributación en el Impuesto sobre la Renta de las Personas Físicas-, las cantidades percibidas por la contratación de una hipoteca inversa. En este sentido, cabría hacer una mención especial a la

\footnotetext{
${ }^{653}$ Noticia publicada en la Guía Inmobiliaria de El Norte de Castilla, 27 de julio de 2007, p. 3.

${ }^{654}$ En este sentido se pronuncia la Resolución del Departamento de Hacienda y Finanzas de 7 de julio de 2008 (JT\2009\142).
} 
Resolución de la Dirección General de Tributos de 19 de octubre de 2007 (JUR 2007\351721).

Esta Resolución contestó con efectos vinculantes a una consulta realizada por una persona que tenía intención de solicitar una hipoteca inversa, sobre si esta figura hipotecaria generaba alguna renta sujeta al impuesto. La contestación de la Dirección General fue la siguiente:

«La disposición adicional decimoquinta de la Ley 35/2006, de 28 de noviembre, del impuesto sobre la Renta de las Personas Físicas y de modificación parcial de las leyes de los Impuestos sobre Sociedades, sobre la Renta de no Residentes y sobre el Patrimonio (BOE de 29 de noviembre) establece que «no tendrán la consideración de renta las cantidades percibidas como consecuencia de las disposiciones que se hagan de la vivienda habitual por parte de las personas mayores de 65 años, así como de las personas que se encuentren en situación de dependencia severa o de gran dependencia a que se refiere el artículo 24 de la Ley de promoción de la autonomía personal y atención a las personas en situación de dependencia, siempre que se lleven a cabo de conformidad con la regulación financiera relativa a los actos de disposición de bienes que conforman el patrimonio personal para asistir las necesidades económicas de la vejez y de la dependencia».

No obstante, la citada regulación financiera relativa a la hipoteca inversa todavía se encuentra en fase de tramitación parlamentaria en el Congreso de los Diputados, estando constituida por el Proyecto de Ley $121 / 000127$ por la que se modifica la Ley 2/1981, de 25 de marzo, de regulación del mercado hipotecario y otras normas del sistema hipotecario y financiero, de regulación de las hipotecas inversas y el seguro de dependencia y por la que se establece determinada norma tributaria.

En definitiva, y salvo que finalmente el citado Proyecto de Ley sea aprobado en unos términos que establezcan lo contrario, la percepción del importe del préstamo o crédito derivado de la hipoteca inversa no generará rentas sujetas al Impuesto. Lo que comunico a Vd. con efectos vinculantes, conforme a lo dispuesto en el apartado 1 del artículo 89 de la Ley 58/2003, de 17 de diciembre, General Tributaria».

- Por otra parte, los incentivos que se derivarían de la constitución de un Plan de Previsión Asegurado, a través del cual, una parte de la renta que se recibiría por la constitución de una hipoteca inversa se podría invertir en planes de previsión asegurados, obteniendo el mismo beneficio fiscal que los planes de pensiones en lo que a desgravación de las aportaciones se refiere. 
De esta forma, con la renta obtenida se podría contratar un Plan de Previsión Asegurado, total o parcialmente, asimilando a la contingencia de la jubilación el hecho de la supervivencia del tomador, siempre que hubieran transcurrido diez años desde el abono de la primera prima del Plan de Previsión Asegurado.

Esta posibilidad ha sido regulada en la Disposición Adicional $4 .^{a}$ de la Ley 41/2007 sobre Aseguramiento de rentas futuras por la constitución de una hipoteca inversa. En la misma se detalla que:

«Las disposiciones periódicas que pueda obtener el beneficiario como consecuencia de la constitución de una hipoteca inversa podrán destinarse, total o parcialmente, a la contratación de un plan de previsión asegurado, en los términos y condiciones previstos en el apartado 3 del artículo 51 de la Ley 35/2006, de 28 de noviembre, del Impuesto de la Renta de las Personas Físicas y de modificación parcial de las leyes de los Impuestos sobre Sociedades, sobre la Renta de no Residentes y sobre el Patrimonio. A estos efectos, se asimilará a la contingencia de jubilación prevista en la letra b) del apartado 3 del artículo 51 de la citada Ley 35/2006, la situación de supervivencia del tomador una vez transcurridos diez años desde el abono de la primera prima de dicho plan de previsión asegurado.

La provisión matemática del plan de previsión asegurado no podrá ser objeto de movilización a otro instrumento de previsión social, ni podrán movilizarse a aquél los derechos consolidados o las provisiones matemáticas de otros sistemas de previsión social».

De esta manera, en aplicación del artículo 51 de la Ley del IRPF, las cantidades que el deudor reciba periódicamente podrán reducirse en la base imponible del impuesto cuando se destinen a una aportación, total o parcial, para la contratación de un Plan de Previsión Asegurado, como sucede con las contribuciones a planes de pensiones, con las primas satisfechas a planes de previsión asegurados, etc.

Por tanto, esta situación se asimilaría a la contingencia de jubilación de la letra b) del artículo 51.3 de la Ley 35/2006, de 28 de noviembre, del Impuesto sobre la Renta de las Personas Físicas. Ahora bien, atendiendo al apartado 10 de la Disposición Adicional $1 .^{a}$ de la Ley $41 / 2007^{655}$, el Plan de

$\overline{655}$ Esto se ha explicado en puntos anteriores. 
Previsión Social que da derecho a una deducción en el IRPF sólo será aplicable a las hipotecas inversas que se constituyan sobre la vivienda habitual.

En conclusión, las rentas obtenidas a través de la contratación de una hipoteca inversa no tendrán ningún efecto en el IRPF, pues se trataría de disposiciones en una cuenta de crédito y, por tanto, no tributarían. En cambio, los cobros derivados de las rentas vitalicias sí que tributarían como renta vitalicia, los cuales, estarían sometidos a una retención que dependería de la edad del titular y del momento en que se empezó a comprar la renta.

Por otra parte, en el Impuesto de Sucesiones y Donaciones ${ }^{656}$ el valor de la vivienda se verá reducido conforme al crédito consumido.

\section{Derechos arancelarios notariales y registrales}

La hipoteca inversa también cuenta con una bonificación en los derechos arancelarios ${ }^{657}$ notariales y registrales. En esta hipoteca se aplicarán los «Documentos sin cuantía» para los actos notariales y las «Inscripciones» para los registrales. Estas bonificaciones vienen reguladas en los Apartados $8 \mathrm{y}$ 9 de la Ley $41 / 2007$.

En el apartado 8 se hace referencia a los honorarios notariales, especificándose lo siguiente:

«Para el cálculo de los honorarios notariales de las escrituras de constitución, subrogación, novación modificativa y cancelación, se aplicarán los aranceles correspondientes a los «Documentos sin cuantía» previstos en el número 1 del Real Decreto 1426/1989, de 17 de noviembre, por el que se aprueba el arancel de los Notarios».

\footnotetext{
${ }^{656}$ En este aspecto señalar que a través de la Ley $41 / 2007$, en su Disposición final séptima se modificó la Ley 29/1987, de 18 de diciembre, del Impuesto sobre Sucesiones y Donaciones. Concretamente, se modificó el artículo 34 sobre la competencia para la gestión y liquidación del Impuesto.

${ }^{657}$ Al respecto, vid. las Sentencias del Tribunal Superior de Justicia de Madrid de 24 de junio de 2010 (TOL1.940.134), de 4 de junio de 2013 (TOL3.920.002), de 11 de junio de 2013 (TOL3.920.122), de 21 de junio de 2013 (TOL3.856.479), de 10 de julio de 2013 (TOL3.914.982), de 4 de octubre de 2013 (TOL4.018.470) y de 22 de noviembre de 2013 (TOL4.037.941).
} 
Este apartado 8 fue objeto de varias enmiendas, que aunque prosperaron en el Senado, llegando a modificar el texto del Proyecto de Ley, cuando dicho texto se devolvió al Congreso no se tuvo en cuenta lo aprobado por el Senado. Concretamente, en las enmiendas número 57 del Grupo Parlamentario Catalán y número 104 del Grupo Parlamentario Popular, ambas idénticas, presentadas en el Congreso, se pretendía que para el cálculo de los honorarios notariales no se tomase en cuenta los «Documentos sin cuantía», sino los «Documentos de cuantía» del número 2 del mismo Real Decreto, tomando como base la cifra del capital pendiente de amortizar, con una reducción del 90 por 100, y ello para mantener una equivalencia con los aranceles de los registradores.

En la misma línea se encontraban las enmiendas presentadas en el Senado, en este caso, la número 69 presentada por el Grupo Parlamentario Popular y la número 99 presentada por el Grupo Parlamentario Catalán de Convergència i Unió, las cuales se justificaban no sólo para mantener una equivalencia en el trato que se concedía a las inscripciones que realizaban los registradores, sino que además, la verdadera naturaleza jurídica del negocio contenido en la escritura era de novación, subrogación o cancelación de un préstamo o crédito con una cuantía económica concreta y determinada. Estas enmiendas que proponían sustituir para el cálculo de los honorarios notariales los «Documentos sin cuantía» por los «Documentos de cuantía», prosperaron en el Senado. Así, se establecía que se tendrían en cuenta los «Documentos de cuantía»: «tomando como base la cifra del capital pendiente de amortizar, con una reducción del 90 por 100».

De esta forma, este apartado 8 quedó redactado de la siguiente manera: «Para el cálculo de los honorarios notariales de las escrituras de constitución, subrogación, novación modificativa y cancelación, de los créditos o préstamos hipotecarios, se aplicarán los aranceles correspondientes a los "Documentos de cuantía" previstos en el número $2^{658}$ del Real Decreto $1426 / 1989$, de 17 de noviembre, por el que se aprueba el

${ }^{658}$ La redacción de este número 2 del Anexo I del RD viene dada por la Instrucción de 22 de mayo de 2002, de la DGRN, por la que se convierten a euros los Aranceles de los Notarios y Registradores de la Propiedad y Mercantiles. Como instrumentos públicos, cabría destacar: Poderes en general, Poderes para pleitos, Actas, Testamentos, Capitulaciones Matrimoniales y demás documentos (estado civil, emancipación, reconocimiento de filiación, etc.). 
arancel de los notarios, tomando como base la cifra del capital pendiente de amortizar, con una reducción del 90 por 100 ».

Sin embargo, esta modificación que se produjo en el Senado, no se llevó a trámite en el Congreso. De esta manera, para el cálculo de los honorarios notariales, en lugar de los «Documentos de cuantía» se tendrían en cuenta los «Documentos sin cuantía». Pero, a diferencia de lo que sucedería con los aranceles registrales, no se produciría una reducción del 90 por 100 . Significaba esto que, a raíz de esta Ley los notarios obtuvieron un trato más favorable con respecto a los registradores. Además, los aranceles correspondientes a los «Documentos sin cuantía», tampoco deberían utilizarse en las escrituras de subrogación, novación o cancelación de un préstamo hipotecario, ya que en estos casos sí que podríamos hablar de una cuantía concreta y determinada ${ }^{659}$.

Con respecto al cálculo de los honorarios registrales, su regulación viene dada en el apartado ${ }^{660}$ :

«Para el cálculo de los honorarios registrales de las escrituras de constitución, subrogación, novación modificativa y cancelación, se aplicarán los aranceles correspondientes al número 2, «Inscripciones», del anexo I del Real Decreto 1427/1939, de 17 de noviembre, por el que se aprueba el arancel de los Registradores de la propiedad, tomando como base la cifra del capital pendiente de amortizar, con una reducción del 90 por ciento».

Es decir, conforme a este apartado, las Inscripciones Registrales ${ }^{661}$ tendrán una bonificación del 90 por 100. Con esto, una vez más, se puede apreciar que no tiene sentido la no equivalencia de trato entre las inscripciones que realizan los registradores y las escrituras que hacen los notarios al respecto de las hipotecas inversas.

En conclusión, estas ventajas fiscales las podemos calificar de mínimas, pues en sus orígenes, la contratación de esta hipoteca estaba orientada a

\footnotetext{
${ }^{659}$ Vid. la Sentencia del TSJ de Madrid de 11 de junio de 2013 (TOL3.914.741).

${ }^{660}$ Este apartado 9, a diferencia del apartado 8, no sufrió ninguna modificación durante la tramitación parlamentaria.

${ }^{661}$ Sobre el tema de aranceles, vid. también las Sentencias del TSJ de Madrid de 28 enero de 2013 (RJCA 2013\156), de 14 de febrero de 2013 (RJCA 2013\338) y de 30 de abril de 2013 (RJCA 2013\602).
} 
ofrecer a las personas mayores de 65 años o con dependencia o gran dependencia, una nueva modalidad para satisfacer sus necesidades más básicas. Pero, en realidad, este producto financiero ni se promocionó ni tan siquiera se llegó a ofrecer a este colectivo y quienes llegaron a conocer esta posibilidad de hipotecar inversamente su vivienda habitual, tampoco vieron nada favorable, en lo que a ventajas fiscales ${ }^{662}$ se refiere, en la contratación de este producto financiero.

Además, no hay que olvidar que con la entrada en vigor de la Ley 41/2007, en la DA $1 .^{a}$, en su apartado 10 se contempló la constitución de este tipo de hipotecas para bienes inmuebles distintos ${ }^{663}$ a la vivienda habitual. Ahora bien, las personas que tramitasen estas hipotecas no obtendrían ninguna de las ventajas fiscales que se implantaron para esta Ley.

\section{CARÁCTER RETROACTIVO DE LA DISPOSICIÓN ADICIONAL 1. a DE LEY $41 / 2007$}

Cuando se aprobó la Ley 41/2007, de 7 de diciembre, en su Disposición Adicional $1 .^{a}$ por la que se regulaba la hipoteca inversa, no se aclaró ${ }^{664}$ si los efectos de esta nueva Ley tenían carácter retroactivo respecto de aquellas hipotecas inversas que se hubiesen contratado con anterioridad a dicho texto legal. Con esta nueva Ley, se regulaban las hipotecas inversas que se constituyesen una vez ésta estuviese en vigor. En consecuencia, sólo sería aplicable para las hipotecas inversas tramitadas a partir del nueve de diciembre de 2007.

Si atendemos a lo desarrollado en el Artículo 2 del CC, en el punto 2 podemos apreciar que:

\footnotetext{
${ }^{662}$ Al respecto, vid. la Sentencia del TSJ de Madrid de 11 de julio de 2012 (TOL2.651.436).

${ }^{663}$ Cfr. Zurita Martín, I., «La nueva normativa...», op. cit., pp. 1308-1310; Serrano de Nicolás, Á., «Régimen jurídico...», op. cit., p. 48.

${ }^{664}$ Álvarez Álvarez, H., La hipoteca inversa..., op. cit. , p. 163.
} 
«Las leyes sólo se derogan por otras posteriores. La derogación tendrá el alcance que expresamente se disponga y se extenderá siempre a todo aquello que en la ley nueva, sobre la misma materia, sea incompatible con la anterior. Por la simple derogación de una ley no recobran vigencia las que ésta hubiere derogado».

Atendiendo a este precepto, nos tendríamos que dirigir a la anterior Ley sobre hipotecas inversas. No obstante, estas hipotecas tramitadas con anterioridad a la Ley actual estaban regidas por el principio de autonomía de la voluntad de las partes, regulado en el artículo 1255 del CC. Por este motivo, no se podría derogar nada de lo que hasta entonces hubieran convenido las partes.

En este aspecto y conforme al punto 3 del citado artículo 2, se puede observar que: «Las leyes no tendrán efecto retroactivo si no dispusieren lo contrario».

Como hemos ido desglosando a lo largo del estudio de la hipoteca inversa regulada en la Ley 41/2007, analizando todos sus apartados, podemos constatar que en ningún momento se refleja el carácter retroactivo de esta norma. La única referencia que se hace a la figura de la hipoteca inversa la encontramos en la Disposición final novena de la Ley 41/2007 relativa al carácter básico y títulos competenciales, que dicta lo siguiente:

«1. La presente Ley tendrá el carácter de la legislación básica de conformidad con lo dispuesto en el artículo 149.1.11. ${ }^{\mathrm{a}}$ y $13 .^{\mathrm{a}}$ de la Constitución, con excepción del capítulo $\mathrm{V}$, que se dicta, exclusivamente, al amparo del artículo 149.1.8. ${ }^{a}$ de la Constitución.

2. Además del carácter básico establecido en el apartado anterior, los capítulos II, III y VI, la disposición adicional primera y las disposiciones finales primera, segunda y tercera, se dictan asimismo, de conformidad con lo dispuesto en el artículo $149.1 .6{ }^{a}$ y $8 .^{a}$ de la Constitución ${ }^{665}$ 》.

\footnotetext{
665 «Artículo 149 de la CE: «1. El Estado tiene competencia exclusiva sobre las siguientes materias:

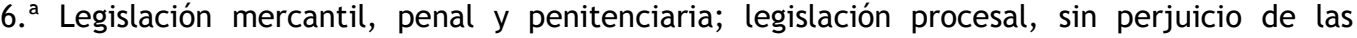
necesarias especialidades que en este orden se deriven de las particularidades del derecho sustantivo de las Comunidades Autónomas.

8. ${ }^{a}$ Legislación civil, sin perjuicio de la conservación, modificación y desarrollo por las Comunidades Autónomas de los derechos civiles, forales o especiales, allí donde existan. En todo caso, las reglas relativas a la aplicación y eficacia de las normas jurídicas, relaciones jurídico-civiles relativas a las formas de matrimonio, ordenación de los registros e instrumentos públicos, bases de las obligaciones contractuales, normas para resolver los conflictos de leyes y determinación de las fuentes del derecho, con respeto, en este último caso, a las normas de derecho foral o especial».
} 
Como podemos observar, además del carácter de legislación básica que se le otorga a la Ley 41/2007 en el punto 1, en el punto 2 se hace referencia a la Disposición Adicional Primera por la que se regula la hipoteca inversa, cuya competencia exclusiva será del Estado sin perjuicio de las particularidades que puedan derivar del derecho sustantivo de las Comunidades Autónomas.

Con esta panorámica, hubiera sido recomendable que, aunque no se hubiera aplicado el carácter retroactivo de la Ley 41/2007 a las hipotecas celebradas con anterioridad a esta Ley, se hubieran concretado unos mínimos requisitos para adaptar esas hipotecas a la legislación vigente.

Con respecto a la Ley $1 / 2013$, de 14 de mayo, de medidas para reforzar la protección a los deudores hipotecarios, reestructuración de deuda y alquiler social, por la que se modifica el punto a) del apartado 1 de la Disposición Adicional Primera de la Ley 41/2007, tampoco se hizo referencia al carácter retroactivo de la misma. Sin embargo, no hay que olvidar que todas las normas que intenten aplicar un régimen uniforme deberán tener carácter retroactivo, aunque sólo sea de aplicación para las situaciones pendientes y no para las consumadas.

Por último, hacer referencia al artículo 12 del $\mathrm{CC}^{666}$, pues esta modalidad hipotecaria, como se ha comentado anteriormente, ha sido muy utilizada por extranjeros residentes en nuestro país. Este artículo será de vital importancia en el caso que surja algún conflicto con respecto a qué norma aplicar.

\footnotetext{
${ }^{666}$ En el citado artículo, se dice que: «1. La calificación para determinar la norma de conflicto aplicable se hará siempre con arreglo a la ley española.

2. La remisión al derecho extranjero se entenderá hecha a su ley material, sin tener en cuenta el reenvío que sus normas de conflicto puedan hacer a otra ley que no sea la española.

3. En ningún caso tendrá aplicación la ley extranjera cuando resulte contraria al orden público.

4. Se considerará como fraude de ley la utilización de una norma de conflicto con el fin de eludir una ley imperativa española.

5. Cuando una norma de conflicto remita a la legislación de un Estado en el que coexistan diferentes sistemas legislativos, la determinación del que sea aplicable entre ellos se hará conforme a la legislación de dicho Estado. español».

6. Los Tribunales y autoridades aplicarán de oficio las normas de conflicto del derecho
} 


\section{CAPÍTULO IX: FIGURAS QUE EN NUESTRO ORDENAMIENTO JURÍDICO} GUARDAN CIERTAS SIMILITUDES CON LA HIPOTECA INVERSA

Para finalizar esta primera parte sobre la hipoteca inversa recalcar que hay una serie de modalidades ${ }^{667}$ que en la práctica ya se realizaban antes de la aprobación de la Ley 41/2007, de regulación de la hipoteca inversa. Antes de profundizar en ellas conviene señalar que la terminología a veces puede resultar confusa. Prueba de ello es que las entidades ofrecen productos combinados entre sí, -incluso con la hipoteca inversa-, o con características similares.

\section{LA RENTA VITALICIA CONSTITUIDA SOBRE UN INMUEBLE}

La renta vitalicia ${ }^{668}$ se regula en el Código Civil, -dentro de los contratos aleatorios o de suerte-, concretamente, en el Libro IV, Título XII, Capítulo IV. Es un contrato ${ }^{669}$ en virtud del cual el transmitente ${ }^{670}$ percibe una pensión durante el resto de su vida a cambio de ceder la propiedad de su vivienda pero conservando el derecho de uso y disfrute de la misma.

La renta vitalicia, según LUQUE JIMÉNEZ ${ }^{671}$ se conoce en España desde antaño. Este censo vitalicio, o renta vitalicia, ya consistía en que una persona cedía a otra un capital en bienes muebles o inmuebles a cambio de que ésta le pagara una renta anual durante la vida de una o más personas.

\footnotetext{
${ }^{667}$ Estas modalidades han sido objeto de estudio por diversos autores, entre otros, ÁlvarEz ÁlvarEZ, H., La hipoteca inversa..., op. cit., pp. 25-34; LUQUE JIMÉNEZ, M.C., «Una nueva modalidad...», op. cit., pp. 238-242; BaLAGUÉ, C., «Cómo convertir...», op. cit., pp. 36 y ss.

668 Se define en el artículo 1802 estableciendo que: «El contrato aleatorio de renta vitalicia obliga al deudor a pagar una pensión o rédito anual durante la vida de una o más personas determinadas por un capital en bienes muebles o inmuebles, cuyo dominio se le transfiere desde luego con la carga de la pensión».

${ }^{669}$ El contrato de renta vitalicia presenta las siguientes características:

Es un contrato consensual, ya que se perfecciona con el consentimiento de las partes (la entrega de las prestaciones se realiza en la fase de ejecución).

Es bilateral o sinalagmático (surgen obligaciones para las dos partes contratantes).

Es oneroso, pues hay una equivalencia entre las prestaciones de las partes (en ocasiones puede ser gratuito, ex art. 1.807 (C).

Es aleatorio, porque la equivalencia de prestaciones no está establecida de antemano.

${ }^{670}$ Vid. la STS de 11 de julio de 1997 (RJ 1997\6152).

${ }^{671}$ LUQUE JIMÉNEZ, M.C., «Una nueva modalidad...», op. cit., pp. 238-240.
} 
Los sujetos contratantes pueden ser cualesquiera personas físicas 0 jurídicas y para su celebración se requiere, al igual que la hipoteca inversa, legitimación para enajenar. Así, en este contrato debemos distinguir dos partes:

1.- El acreedor de la renta.

El perceptor de la renta es la persona que ostenta la titularidad del derecho de crédito a la renta vitalicia. Por regla general, suele coincidir con la persona que constituye la relación de renta, entregando el capital correspondiente. Ahora bien, esta coincidencia se puede incumplir, tanto originaria como sucesivamente:

En primer lugar, puede presentarse en el momento mismo de la constitución del contrato, el cual tendría la estructura y naturaleza de un verdadero contrato ${ }^{672}$.

En segundo lugar, puede darse con posterioridad a dicho nacimiento del contrato, si se utiliza el mecanismo de la sucesión voluntaria ${ }^{673}$ en el crédito que permite el artículo 1203 del Código Civil ${ }^{674}$.

2. - El deudor de la renta.

El deudor de la renta es la persona a la que se obliga a pagar la pensión o rédito por un capital en bienes muebles o inmuebles, cuyo dominio se le transfiere con la carga de la pensión. De esta manera, el objeto del contrato de la renta vitalicia consiste en estas dos prestaciones que atañen a cada una de estas partes contratantes.

\footnotetext{
${ }^{672}$ Así lo dicta el artículo 1257 del CC: «Los contratos sólo producen efecto entre las partes que los otorgan y sus herederos; salvo, en cuanto a éstos, el caso en que los derechos y obligaciones que proceden del contrato no sean transmisibles, o por su naturaleza, o por pacto, o por disposición de la ley.

Si el contrato contuviere alguna estipulación en favor de un tercero, éste podrá exigir su cumplimiento, siempre que hubiese hecho saber su aceptación al obligado antes de que haya sido aquélla revocada».

673 Beltrán De Heredia, J., La renta vitalicia, Editorial Revista de Derecho Privado, Madrid, 1963, p. 93.

674 Según este artículo: «Las obligaciones pueden modificarse:

$1 .^{\circ}$ Variando su objeto o sus condiciones principales.

2. ${ }^{\circ}$ Sustituyendo la persona del deudor.

3. 'Subrogando a un tercero en los derechos del acreedor».
} 
Por una parte, la prestación de capital en bienes muebles o inmuebles con la que se formaliza la renta vitalicia, entregada por el constituyente de la misma, que por lo general, será el propio acreedor.

$\mathrm{Y}$, por otra parte, la renta en sí, bien en forma de pensión o de rédito, que será satisfecha por el deudor de manera anual, conforme se indica en el artículo 1802 del CC.

En todo caso, en la renta vitalicia no se requiere de una edad mínima, pues lo que se contempla es que la renta ha de abonarse en vida de una persona determinada, que puede ser la del que da el capital, la de un tercero o la de varias personas ${ }^{675}$. Sin embargo, las entidades de crédito enfocan este contrato a personas mayores de 70 años, propietarias de viviendas, que desean mejorar su calidad de vida. Con esta modalidad consiguen una rentabilidad de su patrimonio inmobiliario, al igual que con la hipoteca inversa, aunque en este caso pierden su propiedad ${ }^{676}$.

La edad del solicitante de la hipoteca inversa no debería diferenciarse de la edad del rentista, pues en esta hipoteca, únicamente, se exonera el límite de edad para la hipoteca inversa de otros inmuebles en los que no recaiga la vivienda habitual.

También cabe resaltar que en el contrato de renta vitalicia se puede transmitir un inmueble o más de uno, no teniendo porque ser la vivienda habitual, si bien se transmite ésta podría retenerse el usufructo. A diferencia de la hipoteca inversa, no se goza de revalorización del inmueble ni se puede transmitir a los herederos al haberse enajenado ${ }^{677}$. Al ser un contrato por el que se pierde la propiedad sobre el inmueble, éste está enfocado a personas que no tienen herederos o que aun teniéndolos no quieren dejarles la vivienda

\footnotetext{
${ }^{675}$ Así queda reflejado en los artículos 1802 y 1803 del CC.

${ }^{676}$ Sobre la renta vitalicia vid. más ampliamente ZURITA MARTín, I., Contratos vitalicios, Marcial Pons, Madrid, Barcelona, 2001; BADENAS CARPIO, J.M., La renta vitalicia onerosa, Aranzadi, Navarra, 1995; ChIllón Peñalver, S., El contrato de vitalicio: caracteres y contenido, EDERSA, Madrid, 2000; BeLtrán DE HEREDIA, J., «La renta...», op. cit.

677 SeRRANO de Nicolás, Â., «Régimen jurídico...», op. cit., p. 40.
} 
en propiedad bien porque ya tienen los propios herederos suficientes recursos económicos, bien por cualquier otro motivo.

Una de las ventajas que presenta este producto es que el vendedor ya no tiene que afrontar una serie de gastos asociados a la vivienda, como son los gastos de comunidad, el Impuesto sobre Bienes Inmuebles (IBI), derramas de la comunidad, seguro del hogar, etc., pues ya no es el propietario. Sin embargo, los gastos derivados del consumo, como los suministros de agua, luz, gas, etc., son de cuenta del vendedor. Esto es lo que venimos denominando renta vitalicia clásica.

Dentro de la renta vitalicia podemos hacer mención a varias modalidades ${ }^{678}$ que podrían agruparse de la siguiente manera:

a) Renta vitalicia con arrendamiento: se formaliza un contrato de arrendamiento que permite al transmitente residir en la vivienda percibiendo a cambio una renta vitalicia, descontando el importe del arrendamiento de la vivienda. Es decir, la renta se destina a pagar un alquiler para seguir habitando en la vivienda y se obtiene además una pensión complementaria.

b) Renta vitalicia con desembolso inicial: se cede la propiedad de una vivienda a una entidad financiera, pero se conserva el derecho a su uso y disfrute. El beneficiario recibe una importante cantidad inicial y además una renta mensual vitalicia.

c) Renta vitalicia para atención en residencia: se transmite una vivienda a una sociedad que garantiza una plaza en una residencia hasta el fallecimiento del propietario.

d) Renta vitalicia con prima única: se vende la vivienda y con el dinero obtenido se constituye una prima única en una compañía de seguros, la cual paga una renta vitalicia al vendedor de la vivienda.

${ }_{678}$ Álvarez Álvarez, H., La hipoteca inversa..., op. cit., p. 27. 
e) Renta vitalicia con compraventa de nuda propiedad ${ }^{679}$ : se cede la nuda propiedad de la vivienda a cambio de la percepción de una renta vitalicia. Se establece un derecho de usufructo por el cual el transmitente de la vivienda puede continuar residiendo en ella y recibe, además, una renta vitalicia, de la que se descuenta el valor del usufructo, es decir, se paga sólo la nuda propiedad.

Todas estas modalidades que puede revestir la renta vitalicia ${ }^{680}$ tienen en común el elemento aleatorio, debido a la incertidumbre de la duración de la vida que se contempla, es decir, se desconoce si existirá o no una equivalencia entre el capital que se entrega y la renta que se acabará percibiendo.

Este contrato de renta vitalicia confiere la nota de a plazo o a término, de carácter resolutorio o final, pues al igual que en la hipoteca inversa, la finalización ${ }^{681}$ de este contrato dependerá de ese suceso cierto en cuanto a su productividad $^{682}$, es decir, extinción de la vida o vidas contempladas, pero incierto en cuanto al momento en que tendrá lugar (certus an, incertus quando). También, al igual que sucede con la hipoteca inversa, para poder calcular la renta vitalicia que se va a pagar se tiene en cuenta el valor del inmueble y la esperanza de vida del propietario, tomándose en consideración su edad y sexo. Además, la tramitación de la operación debe realizarse ante notario, al igual que la hipoteca inversa.

A pesar de lo anterior, uno de los problemas que pueden surgir con la contratación de una renta vitalicia es que el comprador deje de pagar las rentas. En ese caso, para evitar que queden rentas impagadas, sería

\footnotetext{
${ }^{679}$ BALAGUÉ, C., «Cómo convertir...», op. cit., pp. 34 y ss.

${ }^{680}$ MARTínez EsCribano, C., La hipoteca inversa..., op. cit., pp. 30-33.

681 Beltrán DE HeREDIA, J., «La renta...», op. cit., pp. 99, 103 y 104.

${ }^{682}$ Al respecto, la STS de 8 de mayo de 1992 (RJ 1992\3891) alude a la cesión del negocio familiar a dos de los hijos, con la obligación de satisfacer una pensión vitalicia a una de las hermanas que quedaba fuera del mismo. Posteriormente, se realiza la transmisión a terceros del negocio junto con la obligación del pago de la pensión, pero no cabe la posterior exoneración de dicha obligación alegando su carácter de personalísima.
} 
aconsejable que se estableciera una condición resolutoria ${ }^{683}$ según la cual, si se produjera el impago de las rentas, la persona mayor recuperase la plena propiedad de la vivienda, sin perjuicio de las mensualidades percibidas hasta ese momento. Por este motivo, se suele contratar un seguro de renta vitalicia en una entidad aseguradora ${ }^{684}$ con el fin de asegurar que la persona mayor cobre la renta de por vida. No obstante, al igual que sucede con la hipoteca inversa, si se posee una vivienda de la que falta una pequeña cantidad por satisfacer, del importe que se pague en ese contrato de seguro se extraerá la cantidad necesaria para poder anular la hipoteca pendiente.

Ahora bien, el inconveniente de la renta vitalicia es el tratamiento fiscal que recibe, pues las rentas que percibe están sujetas a tributación ${ }^{685}$. En contrapartida, el transmitente (vendedor) no tiene que abonar ninguna cantidad en concepto de gastos de tramitación de Notaría, Registro de la Propiedad, honorarios profesionales de tasación, impuesto de transmisiones patrimoniales, plusvalía y el impuesto de actos jurídicos documentados, ya que es el adquirente (comprador) el que corre con todos estos gastos.

\section{LA HIPOTECA PENSIÓN ASEGURADA}

En este caso $^{686}$ se suscribe un crédito hipotecario sobre una vivienda -cuya propiedad se conserva-, y con el dinero obtenido se contrata una pensión vitalicia, por lo que en realidad hay dos negocios: el crédito hipotecario y el de seguro de renta vitalicia.

\footnotetext{
$\overline{683}$ Vid. SSTS de 13 de mayo de 1959 (RJ 1959\1999), de 14 de octubre de 1960 (RJ 1960\3086) o de 23 de abril de 1998 (RJ 1998\2599).

${ }^{684}$ Si visitamos la dirección: http:www.jubilaciondefuturo.es, en fecha de 10 de octubre de 2013, se anuncia «Seguros para disponer del ahorro en el momento de la jubilación: Rentas Vitalicias». En dicha propuesta se dice que las rentas vitalicias nos permitirán atenuar de una u otra forma el impacto fiscal de cada uno de los cobros que se van produciendo a lo largo de la vida del seguro, de manera que son una buena alternativa como complemento a los ingresos procedentes de la pensión pública.

${ }^{685}$ Con la entrada en vigor de la Ley 26/2014, se incluye como novedad la exención de las plusvalías para mayores de 65 años si su destino es la constitución de una renta vitalicia que complemente la pensión. La nueva medida permite eximir de tributación la renta obtenida por transmitir cualquier elemento patrimonial, siempre que el importe obtenido, con el límite máximo de 240.000 euros, se reinvierta en la constitución de rentas vitalicias que complementen la pensión en el plazo máximo de seis meses desde que se produzca dicha alteración patrimonial.

${ }^{686}$ Vid. HeRRANZ GonzÁlez, R., «Hipoteca Inversa...», op. cit., pp. 9 y 10.
} 
La hipoteca contratada deberá estar en periodo de carencia hasta que muera el propietario, es decir, la vivienda será propiedad del beneficiario de la pensión hasta su fallecimiento. Si la vivienda se revalorizase en el mercado, el perceptor de la renta podría ampliar la hipoteca para constituir una nueva pensión vitalicia. A su muerte, sus herederos tendrían que hacer frente a la deuda contraída con la entidad acreedora, bien vendiendo el inmueble, bien conservando su propiedad pero pagando la deuda al acreedor. Aquí cabría hacer mención a un tercer negocio jurídico consistente en otro seguro que garantice una indemnización a los herederos - de parte o la total renta pendiente de cobro-, caso de darse un pronto fallecimiento del pensionista ${ }^{687}$.

Por lo que respecta a los intereses de la hipoteca, se hará cargo de ellos el propietario con parte del dinero recibido por la pensión y, como sucede en la hipoteca inversa, no habría transmisión de la propiedad. Ahora bien, el trato fiscal es desfavorable, pues la pensión vitalicia que se obtiene debe tributar como renta por lo que en la práctica, y tras la entrada en vigor de la Ley $41 / 2007$, esta figura apenas se ha venido utilizando.

Por último, en la hipoteca pensión encontramos una gran diferencia con respecto a la hipoteca inversa, y es que en la hipoteca pensión las rentas se recibirán hasta el fallecimiento del dependiente, mientras que en la hipoteca inversa, en el caso de que se optara por la modalidad temporal, podrían acabarse antes de que el solicitante mayor de 65 años o afectado de dependencia o con un grado de discapacidad igual o superior al 33 por ciento reconocido fallecieran.

\section{LA VIVIENDA PENSIÓN}

Se trata de la venta de una vivienda y, a la vez, de la formalización de una pensión vitalicia con una compañía aseguradora. La persona mayor dejará

${ }^{687}$ SerRano de Nicolás, Á., «Régimen jurídico...», op. cit., p. 40. 
de ser propietaria de la vivienda, ya que transmitirá la nuda propiedad, pero seguirá manteniendo el usufructo sobre ella.

Sin embargo, esta opción no ha tenido mucho éxito porque a cambio de conseguir una renta vitalicia, la vivienda pasa a ser propiedad del banco acreedor. Se trata de una operación compleja ${ }^{688}$ que implica el tener que asumir un usufructuario en la vivienda y, además, el pago de los gastos como por ejemplo, el IBI, gastos de comunidad, etc.

Este producto plantea grandes problemas, pues al ser la persona mayor usufructuaria vitalicia, podría ceder su usufructo a otra persona, renegociando su derecho. Otro gran inconveniente es que se pierde el derecho de propiedad $\mathrm{y}$, además, esta modalidad también está sujeta a un duro tratamiento fiscal, ya que se tributa por la pensión íntegra sin descontar la renta derivada del uso. Junto a este inconveniente, señalar también que la pensión no se actualiza con el IPC.

Este contrato tiene las mismas finalidades sociales que la hipoteca inversa, así como los mismos objetivos de ayudar a las personas mayores de 65 años o dependientes a aumentar su nivel de vida, contando con incentivos fiscales similares a los de la hipoteca inversa. No obstante, en la redacción de la Ley 41/2007 esta figura tampoco se reguló ${ }^{689}$. En todo caso, en virtud de la libertad de pacto regulada en el artículo 1255 del CC, nada impide su contratación.

\section{LA CESIÓN PARA ALQUILER}

\footnotetext{
$\overline{688}$ Así lo define SerRano de Nicolás, Á., «Régimen jurídico...», op. cit., p. 41.

${ }^{689}$ El Partido Popular proponía su regulación, como una nueva Disposición Adicional, bajo el concepto de que era «el contrato de seguro en virtud del cual el tomador trasmite la titularidad o la nuda propiedad de su vivienda habitual a una entidad aseguradora a cambio de una renta vitalicia asegurada, pudiéndose pactar o no en el contrato de seguro el derecho del transmitente al uso o usufructo de la misma hasta su fallecimiento, y siempre que el transmitente sea una persona de edad igual o superior a los sesenta y cinco años o afectada de dependencia severa o gran dependencia».
} 
Esta opción se propone a la persona mayor ${ }^{690}$ que desea vivir en una residencia y, por esta causa, abandona su hogar. Es un producto dirigido a las personas que necesitan de unos cuidados específicos o que no quieren vivir en soledad, sino acompañados de personas en situación similar a la suya.

De esta forma, se abandona la vivienda y ésta es alquilada por un tercero para poder asumir los costes de la residencia. El propietario cede su vivienda a una entidad, que se encargará de alquilarla, y que a su vez le garantizará el cobro de ingresos aunque el inmueble no llegue a alquilarse en ese momento. Por tanto, el propietario no pierde su propiedad, pues sólo la cede para que otra entidad la alquile.

Se trata de una modalidad de operación ${ }^{691}$ que no realizan las entidades financieras ni aseguradoras sino los grandes grupos dedicados a gestionar residencias para personas mayores. Ahora bien, esta modalidad va destinada a la persona mayor aunque no se da el requisito de una concreta edad, incluso esta edad puede ser inferior a la que se da para la hipoteca inversa de vivienda habitual (65 años).

La entidad a la que se le ceda la vivienda correrá con los riesgos de que ésta no se alquile, así como con los gastos de mantenimiento y reparación. Sin embargo, las mensualidades que reciba el propietario constituirán una renta inferior a la del precio de alquiler en el mercado, pero a diferencia de la vivienda pensión, tendrá la gran ventaja de que a medida que estas rentas se vayan actualizando conforme al IPC (la fiscalidad se centra, fundamental y prácticamente, en los ingresos por alquiler), puedan ir en aumento. Por tanto, a medida que se actualice el mercado de alquileres se podrá actualizar esta renta, en la que también se puede dar el caso de que los precios sufran una caída.

\footnotetext{
690 En el año 2011, según la encuesta del INE, dentro de la estadística de Censos y Población, en 1.709.186 hogares residía una persona mayor sola, es decir, un 25,8\% más que hacía 10 años. En 3 de cada 4 hogares, la persona mayor que vivía sola era una mujer.

${ }^{691}$ SeRRANO de Nicolás, Á., «Régimen jurídico...», op. cit., p. 41.
} 
Con la proliferación de este producto habría más oferta de viviendas en alquiler pero lo que sucede es que, como los gastos de gestión, mantenimiento y reparación de la vivienda corren de cuenta de la entidad que gestiona la vivienda, aquélla se queda con un porcentaje del alquiler.

Por último, señalar que esta figura carece de elementos estructurales comparativos con la hipoteca inversa.

\section{COMPRAVENTA DE LA VIVIENDA Y LA CONSTITUCIÓN DE UNA LÍNEA DE CRÉDITO O UN DEPÓSITO A PLAZO}

Con este producto se vende la vivienda y a cambio se tiene la posibilidad de utilizar una línea de crédito o un depósito a plazo. De esta línea de crédito se pueden ir efectuando disposiciones $\mathrm{y}$, en el término previsto, se devuelve el importe de esas disposiciones más los intereses. Además, puede pactarse que junto con esta operación se constituya un derecho de usufructo o un contrato de arrendamiento que asegure que el anterior titular de la vivienda pueda seguir viviendo en ella.

Nuevamente, este producto lo demandarían las personas que no tuvieran herederos o bien aquéllos reacios a dejarles en herencia el inmueble, pues en caso contrario, lo más probable es que optaran por constituir una hipoteca inversa, a los efectos de conservar la propiedad del inmueble.

\section{CONTRATO DE RENTA CON OPCIÓN DE COMPRA}

En esta modalidad ${ }^{692}$, se percibe una renta fija o variable a cambio de constituir una opción de compra sobre un bien inmueble por su valor actual. A la finalización del contrato se puede ejercitar la opción de compra, adquiriéndose la vivienda por su valor de tasación.

\footnotetext{
692 Este contrato de renta con opción de compra lo analiza con más detalle Álvarez ÁlvarEZ, H., La
} hipoteca inversa..., op. cit., p. 31. 
Al igual que en la hipoteca inversa, no se produce una transmisión de la vivienda por parte de los propietarios hasta que se ejercita la opción de compra, por lo que es un producto que podrá utilizarse por las personas que tengan reparos a la hora de vender el inmueble.

\section{ENAJENACIÓN DE LA VIVIENDA A CAMBIO DE PROPORCIONAR ALIMENTOS}

Tradicionalmente, el contrato de alimentos ${ }^{693}$ ha sido admitido por la jurisprudencia ${ }^{694}$ como un contrato atípico, autónomo y distinto a la renta vitalicia ${ }^{695}$. En este supuesto, una persona transmite su vivienda a otra y ésta se compromete a proporcionarle vivienda, manutención y asistencia durante su vida.

El contrato de alimentos ${ }^{696}$ se regula en los artículos 1791 a 1797 del CC, introduciéndose esta figura con la Ley $41 / 2003$, de 18 de noviembre ${ }^{697}$,

\footnotetext{
${ }^{693}$ En este sentido se manifiestan GuIlarte Zapatero, V., «Comentarios al artículo 1.802 del Código Civil», en Comentarios al Código Civil y Compilaciones Forales, dir. AlbaladeJo, t. XXII, vol. I, Madrid, 1982, p. 397; Gómez LAPLAZA, C., «Consideraciones sobre la nueva regulación del contrato de alimentos», RDP, 2004, p. 155; BADENAS CARPIO, J.M., La renta vitalicia..., op. cit., p. 307; MESA MARRERO, C., El contrato de alimentos. Régimen jurídico y criterios jurisprudenciales, Thomson Aranzadi, Cizur Menor (Navarra), 2006, p. 45.

694 Según la ponencia «La tipificación del contrato de alimentos» realizada por LLAMAS POMBO, E., «La tipificación del contrato de alimentos» en Protección jurídica de los mayores, La Ley, Madrid, 2004, p. 197, son numerosas y variadas las denominaciones que se han venido empleando para designar este contrato. La expresión más difundida en la doctrina es, sin duda, la de «vitalicio» o «contrato vitalicio», con la que se conoce normalmente por nuestra jurisprudencia. Vid. SSTS de 6 de mayo de 1980 (RJ 1980 1785 ), de 1 de julio de 1982 (RJ 1982\4213), de 30 de noviembre de 1987 (RJ 1987\8708), de 3 de noviembre de 1988 (RJ 1988\8407), de 2 de julio de 1992 (RJ 1992\6502), de 21 de octubre de 1992 (RJ 1992\8592), de 1 de julio de 2003 (RJ 2003\4321), entre otras. Y, por parte de la Dirección General de los Registros y el Notariado, señalar las Resoluciones de 16 de octubre de 1989 (RJ 1989\7048) y de 26 de abril de 1991 (RJ 1991\3169).

695 Como en la renta vitalicia nos encontramos ante un contrato consensual, bilateral, oneroso y aleatorio. La principal diferencia se encuentra en el contenido de las prestaciones, mientras que en la renta vitalicia la obligación consiste en pagar una cantidad periódica, en el contrato de alimentos el contenido de esta obligación es más complejo, ya que el alimentante se compromete a atender las necesidades materiales del alimentista, a facilitarle residencia, cuidados y asistencia.

696 Sobre el contrato de alimentos vid. con más detalle LAMBEA RUEDA, A., Caracteres del contrato de alimentos y estructura del contrato de alimentos a favor de tercero, Aranzadi civil-mercantil, $\mathrm{N}^{\circ} 19$, BIB 2006\1991; BELTRÁN DE HEREDIA DE ONIS, P., La obligación legal de alimentos entre parientes, Universidad de Salamanca, t. III, núm. 3, 1958; COBACHo GómEZ, J.A., La deuda alimenticia, Montecorvo, Madrid, 1990; Doral GarCía, J.A., «Pactos en materia de alimentos», ADC, 1971, pp. 313 y ss.; FuENMAYOR CHAMPIN, A., «La deuda alimenticia del donatario», RDP, 1942, pp. 154 y ss.; MARTíneZ ROdRÍGUEZ, N., La obligación legal de alimentos entre parientes, La Ley, Madrid, 2002; MESA MARRERO, C., El contrato..., op. cit.; NúNEEZ ZoRRILLA, M.C., El contrato de alimentos vitalicio: configuración y régimen jurídico,
} 
que ha dotado de contenido a estos artículos del CC, pues esta modalidad contractual $^{698}$ se venía realizando en nuestro país a pesar de no estar regulada.

En el artículo 1791 del CC se define el contrato de alimentos, también denominado vitalicio, como aquel en el que: «una de las partes se obliga a proporcionar vivienda, manutención y asistencia de todo tipo a una persona durante su vida, a cambio de la transmisión de un capital en cualquier clase de bienes y derechos».

En síntesis, cabe señalar que el contrato de alimentos es aquél que permite que una persona transmita un capital en cualquier clase de bienes y derechos a cambio de que se le proporcionen alimentos.

El contenido del contrato consiste en la prestación de alimentos y dentro de esta prestación debemos incluir la manutención, la vivienda y la asistencia médica, todo esto a cambio de entregar unos bienes durante la vida del acreedor de los alimentos.

Las partes que configuran este contrato, son las siguientes:

1.- El alimentante.

El alimentante es la persona que se compromete a realizar la prestación alimenticia convenida. Éste se obliga a transmitir al alimentista un capital en cualquier clase de bienes, sea o no beneficiario de esta prestación. En contrapartida, recibe un capital en bienes o derechos.

El contenido de esta prestación dependerá de la voluntad de ambas partes, que en principio podrán pactar el contenido que estimen conveniente

Marcial Pons, Madrid, Barcelona, 2003; PIÑAR LóPEZ, B., «La prestación alimenticia en nuestro derecho civil», RGLJ, 1955, pp. 7 y ss.

697 Ley $41 / 2003$, de 18 de noviembre, de protección patrimonial de las personas con discapacidad y de modificación del Código Civil, de la Ley de Enjuiciamiento Civil y de la Normativa Tributaria con esta finalidad. Publicada en el BOE, núm. 277, el día 19 de noviembre.

698 Llamas Pombo, E., «La tipificación del contrato de alimentos» en Protección jurídica de los mayores, La Ley, Madrid, 2004, p. 197, en la ponencia sobre «La tipificación del contrato de alimentos», indica que desde la entrada en vigor de la Ley 41/2003 y tras su incorporación en el Código Civil, se trata de un contrato típico, frente a la tipicidad forzosa que hasta esa fecha se predicaba (con la excepción de Galicia, donde ya existía una regulación). 
aunque, por regla general, se fijará en función de las necesidades del alimentista $^{699}$. De ahí que esta prestación de alimentos, en cada caso, pueda tener un contenido en el que se incluyan prestaciones dispares conforme a los intereses de las partes y a sus circunstancias concretas.

2.- El alimentista.

El alimentista es la persona que goza de la asignación de alimentos. 0 lo que es lo mismo, la acreedora de la prestación de alimentos. Ésta puede ser la parte en el contrato que transmita el capital, o bien puede ser un tercero beneficiario de la prestación alimenticia.

En este caso nos encontramos ante un contrato a favor de tercero ${ }^{700}$ (art. 1257 CC, in fine) celebrado entre el alimentista o cedente de los bienes y el alimentante o promitente. De esta manera, la parte que hace la cesión de capital en cualquier clase de bienes o derechos -alimentista-, a favor del sujeto obligado -alimentante-, suele ser la persona que ha de recibir durante su vida la prestación de alimentos (art. 1791 del CC). La prestación del alimentista $^{701}$, además de la entrega de una suma de dinero, también puede consistir en la cesión de un determinado derecho o en una combinación de todo lo anterior.

En el análisis de las resoluciones judiciales dictadas en esta materia destaca en una mayoría de casos, que el alimentista se obliga a la transmisión de un bien, normalmente inmueble. Aun así, es bastante frecuente que para garantizar el cumplimiento de la prestación por parte del alimentante, el alimentista transmita la nuda propiedad de un bien y se reserve el usufructo vitalicio para seguir disfrutando mientras viva del bien cedido, así como también de los frutos o rendimientos que pueda generar.

\footnotetext{
699 Por ejemplo, si el alimentista quiere tener sus necesidades materiales cubiertas, la prestación alimenticia a cargo del alimentante consistirá en atender sólo la manutención (ropa y alimentos, gastos médicos, etc.). En cambio, si el alimentista quiere evitar una situación de soledad o desamparo, en esta prestación podrá incluir un pacto de convivencia con el alimentante.

700 Díez-PICAzo, L., Fundamentos del Derecho Civil Patrimonial, t. I, Madrid, 1996, pp. 440-441; MESA MARRERO, C., El contrato..., op. cit., pp. 57, 70 y 72.

701 lbíd., pp. 79 y 80 .
} 
Se trata de una prestación mixta, de dar y hacer, por la que se realiza un intercambio de prestaciones entre las dos partes contratantes. No obstante, el alcance de la prestación depende del acuerdo de las partes, siempre y cuando respeten los límites del artículo 1255 del CC.

En este contrato $^{702}$ se considera válida la cláusula que establece la posibilidad de rescatar los bienes entregados, y también cualquier otro pacto o estipulación que no contraríe el interés de terceros ni el orden público. De esta manera, se tendrá que tener muy en cuenta el caso en el que la persona mayor o dependiente que lleva a cabo este contrato esté muy necesitada de protección, pues puede encontrarse en una situación desesperada ${ }^{703}$ y podrían producirse abusos por la otra parte que celebra el contrato.

A diferencia de otros contratos como, por ejemplo, el de renta vitalicia que puede constituirse sobre la vida de otra persona, en el contrato de alimentos regulado por el CC, el alimentista sólo puede ser la persona sobre cuya vida se estructura la duración del contrato. Además, el alimentista siempre será una persona física. Aunque como ya se ha dicho, también podrá ser un tercero ajeno beneficiado por éste.

El contrato de alimentos se extingue, de acuerdo con el artículo 1794 del CC, con la muerte del alimentista. Asimismo, según el artículo 1795 del CC, el incumplimiento de la obligación convencional de alimentos permite al alimentista optar entre exigir el cumplimiento o resolver el contrato ${ }^{704}$, con la restitución inmediata de los bienes y capital recibidos.

\footnotetext{
702 No hay que confundir el contrato de alimentos con la obligación legal de prestar alimentos entre parientes de los artículos 142 y ss. del CC, pues el contrato de alimentos surge de pacto y no de la ley, a diferencia de la obligación de prestar alimentos entre parientes.

${ }^{703}$ Esta situación la podemos definir como aquellas personas que se encuentran en situación de riesgo de exclusión, prevista en la Ley $1 / 2013$, de 14 de mayo para reforzar la protección a los deudores hipotecarios, reestructuración de deuda y alquiler social.

${ }^{704}$ Así lo señala LLAMAS POMBO, E., «La tipificación...», op. cit., p. 213, la facultad de desistimiento ya era posible y legítima pactar, con arreglo a la opinión doctrinal mayoritaria (BELTRán DE HEREDIA, J., La renta..., op. cit., p. 153; GUILARTE ZAPATERO, V., «Comentarios al...», op. cit., p. 399, entre otros) basada en el especial régimen en que se prestan los alimentos y las dificultades que puede originar, y en la reciprocidad por la admisión del pacto a favor del alimentista, sobre la que no existía ninguna duda con arreglo a la jurisprudencia. En este aspecto, la STS de 2 de julio de 1992 (RJ 1992\6502) admitía abiertamente el pacto de revocación unilateral a favor del alimentista.
} 
Y de acuerdo con el artículo 1792 del CC, si se produce la muerte del obligado a prestar alimentos, o si concurre cualquier circunstancia grave que impida la pacífica convivencia de las partes, "cualquiera de ellas podrá pedir que la prestación de alimentos convenida se pague mediante la pensión actualizable a satisfacer por plazos anticipados que para esos eventos hubiere sido prevista en el contrato o, de no haber sido prevista, mediante la que se fije judicialmente».

Esta podría ser una mejor opción para la persona antes que solicitar una hipoteca inversa, ya que no tendría que pagar intereses, costes de operación, comisiones, etc., y la finalidad que logra es la misma, pues el contrato de alimentos tiene como objetivo la transmisión de un capital en bienes o derechos a cambio de la prestación de vivienda, manutención y asistencia. Además, la duración de este contrato es vitalicia, pues se pagarían alimentos a una persona durante su vida.

Este contrato también cuenta con graves inconvenientes, pues su regulación no ha otorgado una protección especial a la parte débil, que no es otra que la persona mayor o dependiente que transmite la propiedad de la vivienda habitual. Puede suceder también que el deudor del crédito no lleve a cabo su prestación.

En definitiva, en estos contratos ${ }^{705}$ hay un elevado riesgo, de ahí que en la práctica no se suelan celebrar, salvo en situaciones límites con el fin de cubrir las necesidades más básicas de asistencia. Así pues, en los casos en que se celebren no se acudirá de forma libre y voluntaria con la intención de rentabilizar al máximo su patrimonio, más bien vendrán justificados por una gran necesidad y sin otra alternativa a la que recurrir.

Para concluir, indicar que en algunos Derechos Forales ${ }^{706}$, como es el caso de Aragón, Cataluña, Galicia y Navarra, existen figuras ${ }^{707}$ afines a las analizadas.

\footnotetext{
705 Vid. la ponencia de TORAL LARA, E., «El contrato de alimentos y los mayores. Especial referencia a la pluralidad de partes» en Protección jurídica de los mayores, La Ley, Madrid, 2004, pp. 401-423, donde se efectúa un amplio estudio del contrato de alimentos y las partes que en el mismo intervienen.

${ }^{706}$ Vid. LUQUE JIMÉNEZ, M.C., «Una nueva modalidad...», op. cit., p. 244.
} 
${ }^{707}$ Como curiosidad y, según datos publicados en el INE en fecha de 1 de enero de 2013, las provincias del noroeste peninsular son las más envejecidas, las Comunidades Autónomas con mayor proporción de personas mayores se encuentran en el noroeste peninsular: Castilla y León $(22,9 \%)$, el Principado de Asturias $(22,5 \%)$ y Galicia $(22,4 \%)$. 
PARTE II

ESTUDIO COMPARATIVO DE LA HIPOTECA INVERSA EN REINO UNIDO Y ESTADOS UNIDOS 



\section{CAPÍTULO X: LA HIPOTECA INVERSA EN REINO UNIDO: LOS PLANES EQUITY RELEASE}

Tras el estudio realizado sobre la hipoteca inversa en España podemos observar que esta modalidad hipotecaria, tanto en Reino Unido como en Estados Unidos, se creó con la intención de incrementar los ingresos de las personas mayores utilizando su vivienda sin dejar, por ello, de habitarla. En estos dos países, entre las causas que motivaron el desarrollo de esta figura, también encontramos la reducción de ingresos de los mayores tras la jubilación y la falta de recursos para satisfacer los cuidados de larga duración.

Atendiendo al orden cronológico iniciaremos esta comparativa ${ }^{708}$ con los planes equity release de Reino Unido. Luego trataremos la modalidad adoptada por Estados Unidos.

Como ya se ha comentado al inicio del programa, en el apartado dedicado a los orígenes de la hipoteca inversa, ésta se introdujo ${ }^{709}$ en Reino Unido en 1965. Ahora bien, es a partir de la década de los $80^{710}$ cuando el interés por los productos equity release obtiene su mejor resultado. En este aspecto, la aceptación que tuvieron estos productos con respecto a la establecida en Estados Unidos no fue la misma.

Mientras que en Estados Unidos, por medio del plan HECM, la negociación y protección de estos contratos era asumida por el Gobierno dotando a este producto de una mayor seguridad para el público al que iba dirigido, en Reino Unido, la situación económica a finales de los años 80 evidenciaba una caída en los precios de la vivienda y una subida de los tipos de interés. Esta coyuntura provocó que se infiltraran productos de alto riesgo,

\footnotetext{
708 Sin embargo, en la bibliografía dedicada a este producto financiero no se encuentran demasiadas referencias de un país a otro, es decir, no se analizan desde un punto de vista comparativo. Aún así, se ha de hacer referencia a Del Pozo García, E.; Díaz MARTíneZ, Z. y Fernández SEVILLA, L., «La hipoteca inversa en España: un estudio comparativo con otros países de la Unión Europea y EEUU», Revista Universitaria Europea, No 15, Julio-Diciembre 2011, pp. 85-106.

${ }^{709}$ ZOE, H., A Detailed History of Equity Release, Retirement Plus, 8 de diciembre de 2008, disponible en: http://www.retirement-plus.co.uk/downloads/570-2-7-2008-HistoryER-050608.pdf, p.1.

710 MullingS, B.; HamnetT, C., «Equity Release Schemes and Equity Extraction by Elderly Household», Ageing and Society (on line), $\mathrm{N}^{\circ} 12$, Cambridge University Press, 1992, p. 413.
} 
llevando a muchas personas de edad avanzada a perder el inmueble por el que se había efectuado el contrato.

Esta tesitura, además de la falta, o más bien, pésima información, devino también por las incongruencias de las entidades con respecto al asesoramiento $^{711}$ ofrecido a los clientes. Tras esta situación, diferentes organizaciones, cuyo máximo exponente es la organización Safe Home Income Plans (SHIP), ahora absorbida por el Equity Release Council, han puesto todos los medios para intentar devolver la confianza en estos planes. La Financial Services Authority ${ }^{712}$ (FSA) junto con SHIP, han establecido los criterios que deben guiar la contratación de estos planes.

Ese país, tal y como sucede en el nuestro es uno de la Unión Europea con mayor riesgo de pobreza entre las personas de más de 65 años. De ahí que el legislador británico se preocupe, en lo que a las pensiones se refiere, en adoptar nuevas soluciones para reducir esta situación. No obstante, observamos que en ese país se ha apostado más por los instrumentos de cobertura privada, pasando a un segundo plano la intervención estatal a la hora de establecer unas pautas o garantías en materia de pensiones.

La población inglesa, al igual que la española, sigue optando por la percepción de las pensiones públicas aun siendo éstas insuficientes para mantener un nivel de vida adecuado a sus circunstancias. Es decir, este colectivo se muestra reacio a la hora de contratar este tipo de productos financieros.

En cuanto a los cuidados de larga duración, son atendidos por los servicios sociales, lo que aquí sucede es que estos servicios se caracterizan por depender de las entidades locales, de manera que son distintos en las diferentes poblaciones que conforman el país y además no se rigen por los

\footnotetext{
711 Por este motivo, uno de los principales puntos sobre los que más hincapié hace la regulación inglesa es sobre la protección del consumidor.

712 La Autoridad de Servicios Financieros (FSA) hasta 2013 era la responsable de regular los préstamos hipotecarios y la transparencia de la información proporcionada al prestatario. Actualmente, sus funciones han sido asumidas por estos dos órganos: The Prudential Regulation Authority y the Financial Conduct Authority.
} 
mismos criterios de calidad. Por tanto, nos encontramos con un sistema sanitario bastante complejo, pues por una parte interviene el Estado, a través del Servicio Nacional de Salud y, por otra intervienen los diferentes organismos locales con competencia para legislar sobre las prestaciones sociales. En resumen, como si se tratara de la negociación de dos partes, una, en calidad de servicio público y otra como servicio privado.

\section{¿En qué escenario se plantean los planes equity release?}

La insuficiencia de recursos y servicios por parte del sector público lleva, en ocasiones, a la necesidad de buscar otras fuentes de financiación, en este caso privadas, para hacer frente a la etapa de jubilación ${ }^{713}$. Los planes equity release $e^{714}$, a través de sus principales vertientes, home reversion plans y lifetime mortgages, se idean como una posible solución para personas con bajos recursos.

No obstante, en Reino Unido la finalidad por la que se contrata este tipo de préstamos no sólo tiene que ser para complementar la pensión de

\footnotetext{
713 Según la publicación realizada por MEDIASEGCV en fecha de 31 de octubre de 2013, en el marco del IV Congreso de Dependencia y Calidad de Vida, que tuvo lugar en Barcelona, organizado por la Fundación Edad\&Vida: Dave Hodges, Director de Relaciones con el Cliente y Servicios de Zurich Corporate Saving, habló de los «Cambios en el Mercado de Pensiones. La perspectiva del Reino Unido" describiendo el sistema británico de pensiones, del cual dijo que "es sostenible porque tiene un coste bajo, el 5,4\% del PIB, en relación a sistemas más generosos como el de Francia, Italia o España, aunque también necesita cambios". El Reino Unido comparte con España el envejecimiento progresivo de su población lo que provocará que el sistema de pensiones "sea financiado cada vez por menos trabajadores". En estos momentos el ratio de Gran Bretaña es de tres trabajadores para pagar a un jubilado y la previsión es que en 25 años sean sólo dos trabajadores, tal y como sucede en estos momentos en Japón. Ante esta perspectiva, el ponente indicó que "necesitamos un sector privado potente". Las soluciones para hacer frente a las necesidades de un país donde la esperanza de vida "aumentará en los próximos 25 años" pasa por diferentes medidas, "alguna no muy popular", como pueden ser aumentar los impuestos a los trabajadores, reducir pensiones de los jubilados o aumentar la edad de jubilación.

El experto en pensiones británico habló de la implantación en su país de un sistema de afiliación automática, introducido en octubre del 2012, según el cual, todas las personas que ganen 9.440 libras al año, quedan afiliadas automáticamente al sistema al que aportan el $8 \%$ de lo que cobran. "Este sistema es popular en Gran Bretaña porque afecta a los trabajadores. Ha tenido una buena aceptación pasando la afiliación del $61 \%$ al $83 \%$ en muy poco tiempo y borrándose solo un $9 \%$ de los trabajadores", comentó Hodges, quien calcula que en 2018 "este experimento" tendrá 16 millones de afiliados.

La previsión del Gobierno británico en el caso de que en ese período de cinco años hasta 2018 se borrara un $30 \%$ de los afiliados a este sistema de pensiones prepagadas, "sería obligar a un ahorro obligatorio a sus trabajadores para tener pensiones en el sector privado". Al finalizar, el ponente se refirió a las prestaciones por discapacidad señalando que "hay que buscar un sistema lógico de filiación automática para la afiliación de estas personas a largo plazo".

${ }^{714}$ La normativa en materia de home reversion plans y lifetime mortgage, con el fin de proteger al consumidor frente a los riesgos que conllevan estos planes, abarca hasta el más mínimo detalle del contrato.
} 
jubilación, ya que las solicitudes son muy diversas, no teniendo porqué destinarse a cuidados de larga duración. De esta manera, los planes equity release ofertados por las distintas entidades financieras servirán para incrementar los ingresos, independientemente de cual sea su finalidad, no tratándose de una lista cerrada.

En esta modalidad, a diferencia de lo que sucede en España, el valor del inmueble que los mayores ofrecen no se considera suficiente para cubrir los costes de larga duración, se considera más bien un ingreso extra por el que se reduce la presión de determinados gastos que pueden aparecer en esta etapa de la vida ${ }^{715}$ en la que los ingresos suelen ser inferiores.

El concepto equity release schemes, lo podemos observar desde dos esferas distintas:

Por una parte, desde una esfera general, en la que el patrimonio inmobiliario puede utilizarse para obtener unos ingresos complementarios.

Por otra, desde una esfera limitativa, los planes equity release permiten a la persona mayor acceder al valor acumulado de la vivienda siempre que continúe habitando en el inmueble.

Matizado esto, en Reino Unido podemos encontrar dos modalidades ${ }^{716}$ para lograr un complemento a los ingresos ordinarios en el hogar o dicho de otra manera, dos instrumentos por los que se permite, a través del patrimonio inmobiliario, obtener liquidez:

1. - Venta total o parcial de la vivienda o Home Reversion Plans.

El objetivo de esta modalidad consiste en la venta de la totalidad o parte de la vivienda, sin tener por ello que dejar de habitar en ella. El vencimiento del contrato se producirá al fallecimiento del solicitante o

\footnotetext{
715 HANCOCK, R., «Housing Wealth, Income and Financial Wealth of older People in Britain», Ageing and Society (on line), № 18, Cambridge University Press, 1998, pp. 29 y 30.

${ }^{716}$ Este marco de productos equity release, aunque a simple vista resulte sencillo, es fruto de un proceso complejo y distinto al experimentado, con similares productos, en Estados Unidos.
} 
cuando éste se traslade de forma permanente a otro inmueble. Normalmente, el precio de venta del inmueble es algo inferior al precio de mercado y la diferencia se corresponde con lo que se abonaría en concepto de renta ${ }^{717}$.

2. - Hipoteca vitalicia o hipoteca inversa o Lifetime Mortgage.

En este caso se trata de un préstamo garantizado con la vivienda habitual de la persona mayor cuya devolución se producirá en el momento de la muerte del solicitante. Se exige la permanencia del mayor en el inmueble, de tal forma que, en caso de abandono de la vivienda o traslado a otra distinta, el acreedor declarará vencido de forma anticipada el préstamo. Existen distintos tipos que vienen determinados en función de cómo se abona el interés y en qué consiste el interés.

Se ha de hacer referencia a una posible tercera opción, aunque si nos fijamos en la revista Equity Release Schemes ${ }^{718}$, en su edición de 2014, no hace mención a la misma. Esta figura es:

\section{3.- Sale and Rent Back Agreement (SARB).}

SARB es una figura que desde 2008 se lleva ofertando en el mercado de los equity release schemes. Su traducción literal es «esquema de venta y alquiler de vuelta».

Esta modalidad mantiene una estructura similar a la de los home reversion plans. Consiste en la venta de la totalidad de la vivienda por un valor que de forma aproximada se corresponde con el valor de mercado sin tener que dejar de habitar en el inmueble. Sin embargo, a diferencia de lo que ocurre con los home reversion plans, en este caso sí se pacta el alquiler por una cantidad determinada ${ }^{719}$. Se trata de «una venta y alquiler de

\footnotetext{
717 Fox-O Mahony, L., Home Equity and Ageing Owners: between Risk and Regulation, Hart Publishing, Oxford, 2012, p. 284.

718 Equity Release Schemes. Raising money from your home, 2014, disponible en: www.moneyadviceservice.org.uk.

719 Vid. AdAMS, J.; James, S., Retirement Income and Assets: How can Housing support Retirement, Pensions Policy Institute, octubre de 2009, disponible en: www.pensionspolicyinstitute.org.uk. También se puede consultar en Equity release schemes. cit., disponible en: www.moneyadviceservice.org.uk, pp. 14-17.
} 
vuelta», de esta forma, el vendedor de la vivienda pasa a ser el inquilino de la misma.

Al tratarse de una modalidad gestionada por el sector privado se ha de tener sumo cuidado en la negociación de la misma. Sin embargo, cuenta con el respaldo de la FCA, Autoridad de Conducta Financiera, responsable de que estas ventas privadas para un posterior alquiler sean seguras y se ajusten a las reglas establecidas ${ }^{720}$.

No obstante, y tal como se ha apuntado más arriba, aunque en el Reino Unido la posibilidad de convertir en líquido el patrimonio inmobiliario existe desde mediados de los años 60 , no se debe olvidar que la implantación de estos productos en el mercado británico se ha diferenciado por utilizar una metodología poco fiable, en la que se introducían productos innovadores pero que eran retirados al poco por no ajustarse al objetivo por el que se habían creado.

A consecuencia de esto y aun teniendo el respaldo por parte del Gobierno y de distintas asociaciones que respaldan al colectivo de personas mayores que llegan a la jubilación con una pensión básica estatal media ${ }^{721}$, los planes equity release, desde una perspectiva financiera, no acaban de asentarse 0 , dicho de otro modo, no encuentran su espacio.

Esto, en parte, se debe a los hechos sucedidos a finales de la década de los ochenta, donde muchos consumidores de estos productos resultaron gravemente afectados por la falta de protección recibida. Por ello, muchos de los que ahora pueden optar a estos planes se resisten a suscribirlos, pues puede darse el caso de que sean hijos, incluso nietos o amigos, de los

\footnotetext{
720 Para una mayor información, vid. la página: http:www.adviceguide.org.uk.

721 Según datos publicados en Revista Seguridad Social Activa-Internacional, disponible en: www1.segsocial.es/Activalnternet/BuenasPracticas, en Reino Unido, desde abril de 2010, se requieren 30 años de cotización para acceder a la pensión básica estatal. La edad ordinaria de jubilación de los hombres está fijada en 65 años. La de las mujeres, en 60, edad que va aumentando gradualmente hasta los 65 entre 2010 y 2018 . Entre 2018 y 2020, la edad ordinaria de jubilación aumentará para ambos sexos hasta los 66 años. No existe la jubilación anticipada.
} 
afectados en su día y por eso se muestren reacios a contratar este producto o ni tan siquiera a solicitar información.

Por este motivo ha costado mucho restablecer los planes equity release en el mercado británico. Gran parte del éxito de esta nueva reincorporación se debe a la campaña que se ha desarrollado en Reino Unido por parte de la Autoridad de los servicios financieros, Financial Services Authority ${ }^{722}$ (FSA) y la organización Safe Home Income Plans ${ }^{723}$ (SHIP), absorbida por la organización Equity Release Council ${ }^{724}$.

En cuanto a los organismos responsables de facilitar la comercialización de estos planes ${ }^{725}$, al igual que sucede en nuestro país, indicar que también son las entidades de crédito, bancos, compañías aseguradoras y sociedades financieras, de ahí la importancia de una regulación protectora del consumidor.

A continuación se va a ampliar la información acerca de los planes equity release en sus diferentes modalidades.

\footnotetext{
722 La FSA era un organismo independiente no gubernamental al que la Ley de los Servicios y Mercados Financieros del año 2000 le dotó de poder para dictar normas con rango legal o inferior a la ley, así como cualquier otro tipo de orientación, con la finalidad de regular los servicios financieros en Reino Unido. Con la nueva reforma de la Ley de los servicios Financieros de Reino Unido en 2013, se ha suprimido la FSA y se ha sustituido por dos órganos que asumirán las funciones que hasta ese momento eran asumidas por la FSA. Estos dos órganos son: The prudential Regulation Authority (PRA) y the Financial Conduct Authority (FCA). The prudential Regulation Authority o Autoridad de Regulación Prudencial trata de favorecer la estabilidad del sistema financiero inglés a través de la autorización y supervisión de las actividades de determinadas entidades de las que depende, en buena parte, la estabilidad del mercado financiero: bancos de depósito, de inversión o aseguradoras (vid.: www.bankofengland.co.uk). The Financial Conduct Authority o Autoridad de Conducta Financiera tiene como objetivo principal lograr una mayor confianza en el sistema financiero asegurando, entre otras medidas, un buen nivel de protección a los consumidores (vid: www.fca.org.uk).

${ }^{723}$ SHIP, organización que acogía al $90 \%$ de las entidades que ofrecían este tipo de productos, ha tratado de establecer, durante estos años, un clima de seguridad y protección de los clientes, a través de la imposición de un código de buena conducta a sus miembros.

${ }^{724}$ El 28 de mayo de 2012, se presentó en Londres una nueva organización que va a representar al mercado de los productos equity release. Esta organización recibe el nombre de Equity release council y nace como una ampliación de las competencias de SHIP (anteriormente seguros Planos de casas de ingresos) del Consejo de Lanzamiento de Equidad. Representa los proveedores, asesores financieros cualificados, abogados, intermediarios y topógrafos que trabajan en el sector de la equidad de liberación. El principal objetivo de la organización consiste en garantizar que las distintas modalidades de movilización de patrimonio sean seguras y estén accesibles a los consumidores. Información disponible en: http://www.equityreleasecouncil.com/equity-release-council/.

${ }^{725}$ Entre las compañías que fueron pioneras en el lanzamiento de estos productos, entre otras muchas, destacar que la primera entidad con la que se contrató un plan equity release en 1965 fue Hodge Lifetime (más tarde pasaría a llamarse Home Reversion Ltd y Carlyle Life Assurance Company que se especializaría en los Home Reversion Plans. Vid. DAVEY, J.A., Equity Release: an Option for Older Home Owners, University of York, Centre for Housing Policy York, 1996, p. 11; Fox-O'MAHONY, L., Home Equity and Ageing Owners: between Risk and Regulation..., op. cit., p. 269.
} 


\section{LOS HOME REVERSION PLANS}

Los home reversion plans, al igual que las hipotecas inversas o vitalicias, nacieron para dar solución a una necesidad concreta de los mayores como era la de proporcionar financiación a través de la vivienda, manteniendo el derecho a vivir en ella.

Un Home Reversion Plan consiste en la venta total o de parte del inmueble manteniendo el derecho a vivir en él sin necesidad de tener que abonar un alquiler ${ }^{726}$. Ello no quita que la parte vendedora, es decir la persona mayor, se siga haciendo cargo del mantenimiento de la vivienda y de los impuestos asociados a la misma.

Ahora bien, entre los inconvenientes que presentan los home reversion plans, se ha de señalar que esta persona mayor junto con su cónyuge, en el caso de que lo tuviere, tan sólo ostenta los derechos en calidad de arrendatario, mientras que la entidad o parte compradora actúa en calidad de arrendador o propietario. Junto a esto, indicar también que los home reversion plans, podrán llevar aparejada la obligación de permanecer en la vivienda, de manera que, si la persona mayor deja de residir en la vivienda puede producirse la extinción del contrato.

La cantidad a percibir se puede recibir en un sólo pago o de forma periódica. Para el cálculo del importe de esta renta se tendrá en cuenta tanto el valor del inmueble como la edad del solicitante. Esta segunda circunstancia viene justificada por la valoración de su esperanza de vida. Independientemente de la modalidad que se haya escogido (única o periódica), sólo estará sujeta a impuestos una determinada cantidad del capital $^{727}$.

\footnotetext{
${ }_{726}$ AdAMS, J.; James, S., Retirement Income and Assets: How can Housing support Retirement..., op. cit., p. 14.

727 LUSH, D.; BIELANSKA, C., et alii, Elderly clients: a precedent manual, $3^{\text {Th }}$ ed., Jordans, Bristol, 2010, p. 590.
} 
La entidad adquiere el bien a un precio inferior al valor del mercado, pues se tiene en cuenta la permanencia del vendedor en el inmueble ${ }^{728}$. Y, en el caso de que se venda la totalidad del inmueble, el precio de la transacción suele oscilar entre el $20 \%$ y el $60 \%$ del valor de mercado $^{729}$, dependiendo de la edad del propietario. Además, en el supuesto de que se pacte una renta, ésta es mínima. Si nos fijamos en algunos trabajos se hace referencia a una renta de doce libras al año ${ }^{730}$.

Para optar a este plan se exige una edad más elevada ${ }^{731}$ que para la modalidad de lifetime mortgage. Esto se justifica porque las entidades oferentes no quieren que la contratación de este instrumento perdure demasiado en el tiempo ${ }^{732}$.

Si bien es cierto que la contratación de cualquier producto financiero siempre conlleva sus riesgos, en el caso de los home reversion plans, con la intención de aminorar e incluso evitar ciertos riesgos, se han creado una serie de coberturas o garantías para las diferentes contingencias o situaciones que nos podamos encontrar durante la vigencia de este plan. De esta manera, en el caso de que se produzca el fallecimiento de la persona mayor antes de lo esperado, y con el fin de evitar la pérdida de todo derecho por parte de los herederos, éstos, a través de la cláusula Inheritance Protection Guarantee podrán, atendiendo al periodo de duración del contrato, optar al cobro de una determinada suma de dinero.

Otra situación que podemos encontrar en este plan es que mientras la parte compradora, es decir, tanto en el caso de que se efectúe la transmisión de una parte como de toda la vivienda, puede negociar en el incremento del

\footnotetext{
728 Equity release schemes: Finance Intelligence, p. 3, disponible en: www.equityreleasecouncil.com. 729 Ibíd., p. 10

${ }^{730}$ LUSH, D.; BIELANSKA, C., et alii, Elderly clients: a precedent manual..., op. cit., p. 591.

731 Según Del Pozo García, E.; Díaz Martínez, Z. y Fernández SeViLla, L., «La hipoteca inversa en España...», op. cit., p. 95, este tipo de producto está destinado, principalmente, a la población de mayor edad (generalmente personas que superen los 80 años).

732 LUSH, D.; BIELANSKA, C., et alii, Elderly clients: a precedent manual..., op. cit., p. 555.
} 
valor del inmueble, mientras que la parte vendedora no interviene en el posible aumento de valor del inmueble.

Junto a esto, esta parte vendedora, en el caso de que reciba la cantidad generada por la venta del inmueble de forma periódica, esta cantidad no se actualiza, es decir, es la que se señala al inicio de la contratación. Esta situación ha llevado a las partes a introducir, como pauta general, la cláusula denominada Price Inflation Guarantee. Con la incorporación de esta cláusula se pretende disminuir las consecuencias negativas que puede conllevar la falta de actualización de estas disposiciones. Así, en el supuesto de que el aumento del precio del inmueble supere un determinado porcentaje, la cantidad a percibir $^{733}$ por la persona mayor se verá incrementada.

Como sucede con la hipoteca inversa española, la persona que haya contratado un home reversion plan, con el dinero obtenido por el mismo podrá realizar cualquier otra operación de inversión, como por ejemplo, la contratación de una renta personal vitalicia, la cual sí se actualiza con el tiempo.

Para concluir, y con respecto a nuestro ordenamiento jurídico, podemos encontrar una figura similar a los home reversion plans. En el caso español, se trataría del contrato de renta vitalicia regulado en los artículos 1802 y siguientes del Código Civil, donde una de las partes entrega un capital en bienes muebles o inmuebles a cambio de la constitución de una renta vitalicia $^{734}$. Esta figura se regula con mayor detalle en el Derecho español.

Por último, matizar que en el Derecho anglosajón la posibilidad de realizar este contrato entre particulares es inexistente ${ }^{735}$.

\footnotetext{
733 Ibíd., pp. 555 y 556.

${ }^{734}$ Esta figura se ha analizado en la primera parte del Programa.

735 En nuestro país, como ya se ha podido observar, se ha mantenido el contrato de alimentos o el contrato de renta vitalicia permitiendo que se utilice el patrimonio para la obtención de dinero o cuidados entre particulares.
} 


\section{LIFETIME MORTGAGE O HIPOTECA INVERSA}

Esta modalidad de equity release scheme permite al cliente la posibilidad de obtener un préstamo que será garantizado con el inmueble que constituya la vivienda habitual del solicitante.

El capital puede entregarse de una sola vez o bien de forma periódica o con una combinación de ambos. Esta tercera posibilidad, en nuestra hipoteca inversa no se da, pues una vez se haya pactado una u otra modalidad, es decir, vitalicia o temporal, ya no se podrá modificar.

Desde el punto de vista del PRA o Prudential Regulation Authority, lifetime mortgage es un contrato de hipoteca regulado (regulated mortgage contract) restringido a personas de una determinada edad.

Para proceder a la devolución del préstamo se tendrán que dar alguna de estas circunstancias:

- Que fallezca la parte vendedora o persona mayor.

- Que se abandone el inmueble objeto del contrato de forma indefinida, aunque se produzca por causas de fuerza mayor, como sería el caso de ingresar en una residencia para recibir determinados cuidados o tratamientos.

- Por la adquisición de una segunda vivienda que pase a ostentar la condición de vivienda habitual.

- Y, por último, la venta del inmueble.

En todo caso, y al igual que sucede con la hipoteca inversa española, siempre que el inmueble por el que se ha optado a este producto equity release, constituya la residencia habitual del solicitante, no se podrá exigir la devolución total del préstamo hasta que no se produzca alguna de las causas arriba citadas. 
En la actualidad existen, según la información publicada por Equity Release Council ${ }^{736}$, tres tipos de lifetime mortgages en función de cómo se disponga del capital concedido y del pago del interés:

- Interest-only mortgage.

- Rolled-up mortgage.

- Fixed-repayment mortgage.

Estas modalidades las vamos a desarrollar a continuación.

\section{Formas en la que se puede pactar una Hipoteca Vitalicia}

\subsection{Interest-only mortgage o hipoteca de sólo interés}

El préstamo que se pide a la entidad financiera se puede recibir en forma de renta mensual o como un pago único, pero el contratante paga sólo los intereses del préstamo cada mes. De esta manera, la persona mayor corre más riesgo, porque ella misma debe asegurarse que podrá pagar mes a mes todos los intereses del préstamo. En este caso, algunas entidades no sólo tienen en cuenta el valor del inmueble, sino también los ingresos de la persona mayor para conocer con exactitud si podrá o no hacer frente al devengo de los intereses.

El interés en este tipo de préstamos puede ser de tipo fijo o variable. No obstante, en el caso de que el interés sea variable y, según indica el Council of Mortgage Lenders ${ }^{737}$, puede suceder que la pensión que obtenga el mayor no sea suficiente para hacer frente al pago de los intereses vencidos. La modalidad de abono de estos intereses podrá efectuarse bien con cargo al

\footnotetext{
${ }_{736}$ Equity Release Council disponible en: www.equityreleasecouncil.com; Vid. también DeL Pozo GARCíA, E.; Díaz MARTínez, Z. y Fernández SeVILLA, L., «La hipoteca inversa en España: un estudio comparativo con otros países de la Unión Europea y EEUU», op. cit., pp. 95-97.

737 Para una mayor información véase la página web: www.cml.org.uk.
} 
capital objeto del préstamo por el que el solicitante los percibe de forma periódica, o bien que el deudor los satisfaga conforme vayan venciendo.

En el supuesto de que el deudor no cumpla con la obligación de pago, la parte acreedora se reserva el derecho a declarar vencido de forma anticipada el préstamo. Esto ha supuesto que en algunas ocasiones, para poder satisfacer el crédito pendiente, se tenga que proceder a la venta del inmueble.

Por el citado motivo, esta modalidad no cumple con los estándares de SHIP, acogidos por el nuevo Equity Release Council, ya que se exige como requisito previo de incorporación a las entidades oferentes de productos equity release, que se garantice en todos ellos la tenencia del inmueble hasta el fallecimiento del deudor.

\subsection{Rolled-up mortgage o hipoteca de reinversión de intereses}

El prestamista entrega una única cuantía, una renta periódica o una combinación de ambas al cliente, tomando como referencia el valor patrimonial de la vivienda y la edad del propietario o propietarios, si se diera el caso. Con esta modalidad no se amortiza nada, bien hasta el fallecimiento del titular o titulares de la vivienda, o bien cuando se tramite la venta de la vivienda, acumulándose así a la cuantía prestada ${ }^{738}$.

Por tanto, al tratarse de un préstamo de interés capitalizado, al que no habrá que hacer frente hasta que no se produzca algún acontecimiento de los contemplados en el contrato, la cantidad a deber aumenta de manera desproporcionada, lo que lleva a algunas entidades a prestar una cantidad menor de la que concederían en otros $\operatorname{casos}^{739}$.

\footnotetext{
738 Sánchez Álvarez, I.; López Ares, S. y Quiroga García, R.: «Diseño de hipotecas inversas en el mercado español», op. cit., p. 40.

${ }^{739}$ Fox-O' MAHONY, L., Home Equity and Ageing Owners: between Risk and Regulation..., op. cit., p. 273.
} 
Por esta causa, la cantidad que la persona mayor pide prestada suele ser, generalmente, pequeña. Si el solicitante decide recibir una suma global al inicio de la operación, la cantidad adeudada puede crecer rápidamente, hasta el punto que la cantidad puede ser superior al valor de la vivienda.

\subsection{Fixed-repayment mortgage o hipoteca de capital prefijado}

El cliente solicita un préstamo y recibe un capital único que se asegura contra el valor del hogar. En esta modalidad, en lugar de pagar intereses, el solicitante se obliga a pagar a la entidad crediticia, en el momento en que venda su vivienda una suma mayor de la que pidió prestada. Esta suma quedará fijada al inicio de la operación. Junto a esto, los gastos de mantenimiento de la vivienda correrán a cargo del propietario.

La ventaja que aquí encontramos es que el tratamiento fiscal al contratar esta modalidad resulta muy interesante, pues el dinero que se recibe de la hipoteca inversa está exento de tributación.

Como añadidura a las descritas, conviene hacer una breve mención a la modalidad Drawdown mortgage ${ }^{740}$. Esta figura se asemeja a la hipoteca en garantía de una línea de crédito regulada en nuestro país. El cliente puede disponer, cuando y como quiera, de un capital que la entidad le concede en concepto de préstamo para el que normalmente se ha abierto una cuenta de crédito. El interés devenga en el momento en el que se realiza alguna disposición. En los últimos años se ha generalizado bastante su uso por la facilidad de poder decidir cuándo retirar el dinero. La única desventaja es el hecho de que los intereses suelen ser algo más elevados.

\section{Características del contrato de Hipoteca Vitalicia}

\footnotetext{
${ }^{740}$ Vid., la dirección: http://www.equity-release-centre.co.uk.
} 
Tal y como se ha analizado en la hipoteca inversa española, en el Derecho anglosajón sucede lo mismo, es decir, tanto la hipoteca ordinaria como la inversa permiten que el deudor, por medio del valor del inmueble, lo ofrezca como garantía de un préstamo ${ }^{741}$. No obstante, también se pueden apreciar algunas diferencias entre ambas hipotecas.

En el caso del préstamo garantizado con una hipoteca ordinaria, el deudor normalmente cumple con los plazos y pagos establecidos en el contrato. De modo que la garantía sólo es ejecutada como último recurso. En contrapartida, la garantía ofrecida en la hipoteca inversa no es utilizada como último recurso sino que, desde el principio, se presenta como medio de pago de la obligación. De esta manera, y al igual que sucede en España, el legislador inglés otorga al acreedor hipotecario la facultad de proceder a la venta del inmueble en el supuesto de que se produzca el incumplimiento de la obligación. Esta es la práctica habitual para saldar la inversión ${ }^{742}$.

En esta modalidad de préstamo o crédito hipotecario, a diferencia de lo que sucede en el Derecho español, no se va a tener tan en cuenta la capacidad personal del deudor para hacer frente al cumplimiento de su obligación. Más bien se va a tener en cuenta el valor del bien inmueble que la persona mayor ofrece como medio de garantía para el cumplimiento de la obligación. Escrito de otro modo, lo que aquí realmente importa es el valor del inmueble y, que en un futuro, ese valor se mantenga o incluso aumente, para que así el acreedor pueda cobrar la deuda generada.

En la hipoteca inversa británica, como en la española, la garantía queda limitada al bien inmueble objeto de contratación. De esta manera, puede acontecer la existencia de un patrimonio negativo, resultando insuficiente el valor de la vivienda para proceder a la cancelación de la deuda. Por ello, y con el fin de aminorar este riesgo, la normativa sobre

\footnotetext{
${ }^{741}$ Equity release schemes: Finance Intelligence, cit., pp. 2 y 3.

742 FoX-O'MAHONY, L., Home Equity and Ageing Owners: between Risk and Regulation..., op. cit., p. 270. Esta opción se considera, por determinados sectores, como un supuesto de mala práctica bancaria.
} 
protección de consumidores ${ }^{743}$ de estos productos financieros está mucha más detallada que la regulada para la contratación de hipotecas ordinarias ${ }^{744}$.

\section{Requisitos subjetivos}

\section{- El acreedor hipotecario.}

Conforme se ha comentado más arriba, los entes encargados de la distribución de estos planes serán las entidades de crédito, bancos, compañías aseguradoras y sociedades financieras.

\section{- El deudor.}

Desde sus orígenes, los planes equity release se habían creado con la intención de producir ingresos para aquellos «house-rich, cash-poor», es decir, ricos en propiedad y pobres en liquidez ${ }^{745}$. De esta manera, para poder optar a la contratación de estos planes, la persona interesada deberá tener en propiedad un bien inmueble con valor suficiente para poder obtener cierta liquide $^{746}$.

Al igual que en España, cuanto mayor sea el precio de este inmueble, más posibilidades se tendrá para que las entidades oferentes muestren un mayor interés a la hora de facilitar algún plan equity release en un futuro ${ }^{747}$.

\footnotetext{
743 Los planes equity release en Reino Unido gozan de una excelente regulación en materia de protección de consumidores.

${ }^{744}$ FoX-O' MAHONY, L., Home Equity and Ageing Owners: between Risk and Regulation..., op. cit., pp. 310 y 311.

${ }_{745}$ Entre otros autores, reflejan esta situación HAMMOND, C.M., «Reverse mortgages: a financial planning device for the elderly», Elder Law Journal, Spring 1993, p. 77; MARTIN, A., "The life and death of a reverse mortgage», Arkansas Lawyer, Spring 2006, p. 16; NAUTS, C.W., «Reverse mortgages. Backing into the '90s», Probate \& Property, January-February 1994, p.56; SAWYER, C.H., «Reverse Mortgages: an Innovative Tool for Elder Law Attorneys», Stetson Law Review, Winter 1996, p. 619; ZoE, A., A Detailed History of Equity Release, op. cit., p. 1.

${ }^{746}$ MuLLINGS, B.; HAMNETT, C., «Equity Release Schemes and Equity Extraction by Elderly Household», op. cit., p. 435.

${ }_{747}$ Clery, E.; MCKAY, S., et alii, Attitudes to Pensions: The 2006 Survey, Department for Work and Pensions, 2007, disponible en :

http://research.dwp.gov.uk/asd/asd5/report_abstracts/rr_abstracts/rra_434.asp, p. 39.
} 


\section{- Edad del solicitante.}

Con respecto al requisito de la edad de la persona interesada en contratar estos planes, matizar que la legislación inglesa no específica una edad determinada, aunque en la práctica la edad mínima para poder contratar estos productos se fija en 55 años $^{748}$. Como se puede observar, esto no sucede ni en la legislación española ni en la establecida por Estados Unidos con los planes HECM.

Ahora bien, como ya se ha podido contemplar a lo largo de todo el programa, la esperanza de vida ${ }^{749}$ del solicitante de estas hipotecas inversas juega un papel muy importante tanto para determinar la cuantía del crédito como para vaticinar una fecha aproximada en la que se produzca la resolución del contrato.

El ente oferente se encargará de realizar los oportunos cálculos para que la inversión en cuestión resulte lo menos costosa posible, de ahí se deduce que esta figura, al igual que en España, se dirija a personas de edad muy avanzada, cuya operación sea contratada para un periodo breve de tiempo ${ }^{750}$.

Como dato curioso, señalar que el perfil a la hora de contratar esta modalidad hipotecaria suele ser el de una mujer, en la mayoría de los casos viuda, y que reside en la que en un pasado fue la vivienda conyuga ${ }^{751}$.

- Beneficiario.

\footnotetext{
748 Del Pozo García, E.; Díaz Martínez, Z. y Fernández SeVilla, L., «La hipoteca inversa en España...», op. cit., p. 41. Cfr. LUSH, D.; BIELANSKA, C., et alii, Elderly clients: a precedent manual..., op. cit., p. 566. 749 Ibíd., p. 567. A modo de ejemplo, en el caso de que el solicitante tenga 60 años en el momento de contratar este plan se le entregará una cantidad inicial de un $20 \%$ del valor del inmueble. Este porcentaje se incrementa en un uno por ciento año a año conforme avanza la edad del cliente, hasta un máximo de un $50 \%$ cuando el solicitante cumple 90 años.

${ }^{750}$ Fox-O'MAHONY, L., Home Equity and Ageing Owners: between Risk and Regulation..., op. cit., p. 270.

751 HANCOCK, R., «Housing Wealth, Income and Financial Wealth of older People in Britain», op. cit., p.
} 29. 
Respecto a esta figura, en Reino Unido no se regula de forma expresa. No obstante, en el punto dedicado al inmueble objeto de garantía se analizan los posibles beneficiarios de este producto, así como los posibles casos que pueden dar lugar.

\section{Requisitos objetivos}

- El crédito o préstamo garantizado con hipoteca vitalicia.

La hipoteca por la que se ha constituido esta modalidad de equity release (en su vertiente de lifetime mortgage), será siempre una hipoteca de primer rango. Esto también se contempla en el ordenamiento jurídico español. De esta manera, en caso de incumplimiento de la obligación de devolución por parte del solicitante o de los herederos, el acreedor podrá enajenar la vivienda para saldar la deuda.

El importe que se concede en esta hipoteca inversa no suele alcanzar la suma total del bien inmueble, más bien se hace entrega de una parte de ese valor. Con esto, la parte acreedora se asegura que cuando se produzca la venta del bien se obtenga una cantidad suficiente para saldar el capital debido por principal e intereses.

\section{- El bien inmueble.}

El bien inmueble por el que se contrata esta modalidad hipotecaria debe constituir la vivienda habitual $^{752}$.

Situación muy normal es que en este inmueble conviva una pareja, pero puede darse el caso de que sólo uno de sus miembros sea el propietario. En este supuesto, y a diferencia de lo que ocurre en el caso español, la entidad encargada de suministrar esta figura solicitará que la vivienda figure a nombre

752 LUSH, D.; BIELANSKA, C., et alii, Elderly clients: a precedent manual..., op. cit., p. 584. 
de los dos. De esta forma, esta obligación generará más gastos al solicitante, ya que para acceder a los beneficios de esta modalidad, antes deberá transmitir parte del inmueble a la otra parte.

Además, y con anterioridad a la firma del contrato de hipoteca, el cliente tiene la obligación de informar a la entidad de la existencia de cualquier otro ocupante en el inmueble mayor de diecisiete años ${ }^{753}$.

Como nota característica de los planes equity release, que no de hipoteca inversa española, la entidad acreedora requerirá a ese habitante no propietario de la vivienda hipotecada, a sellar un pacto a través del cual el segundo transfiere a favor del primero cualquier derecho que le faculte para residir en el inmueble.

Junto a lo anterior, pueden originarse ciertos cambios, como por ejemplo que el deudor, soltero o viudo en el momento de la firma del contrato, contraiga matrimonio. Otra situación podría ser que en esa vivienda hipotecada inversamente vaya a vivir un familiar o amigo del solicitante. Estas nuevas situaciones también se deben comunicar a la parte acreedora para que ésta pueda decidir si, ante el cambio de las condiciones que originaron el contrato, declara o no vencido de forma anticipada el préstamo. Con esta salvedad, el Derecho anglosajón quiere proteger el derecho de la entidad acreedora sobre cualquier otro derecho ${ }^{754}$.

En cuanto a la existencia de estos habitantes en esta vivienda, la entidad les requerirá el otorgamiento de un documento, normalmente deed, en el que se haga constar el conocimiento de la constitución de esta garantía $^{755}$.

\footnotetext{
753 SÁNCHEZ-VentURA MORER, I., La hipoteca inversa..., op. cit., p. 173.

${ }^{754}$ LUSH, D.; BIELANSKA, C., et alii, Elderly clients: a precedent manual..., op. cit., p. 606.

755 Silverman, F.; HeWITSON, R., Conveyancing checklist, $2^{\text {Th }}$ ed., The Law Society, London, 2010, p. 97.
} 
Por último, este bien inmueble deberá ser tasado ${ }^{756}$ y además estar libre de cargas y encontrarse en condiciones óptimas para afrontar la vida diaria.

\section{Requisitos formales}

- Asesoramiento independiente.

En Reino Unido, a diferencia de lo que ocurre en España, las entidades proveedoras de estos planes son en su mayoría aseguradoras y allí sí promocionan el producto, ya que cuentan con un bagaje de muchos años y por tanto tienen los riesgos mucho más limitados. Además, las compañías derivan las operaciones hacia los asesores independientes para que los clientes puedan recibir una información transparente y profesional, y puedan tomar la mejor decisión.

La figura del asesor está mucho más desarrollada en todo el sistema financiero británico, en el que los clientes acuden siempre a un asesor antes de pedir consejo en su banco, un comportamiento muy poco habitual en España, aunque también es cierto que tras la crisis financiera y determinados comportamientos por parte de ciertos Bancos o Cajas de Crédito, se ha vuelto a generar cierta desconfianza (por ejemplo, las preferentes de Bankia o Caja Madrid y el caso de las Tarjetas Opacas, como los más significativos).

En virtud de lo descrito, la persona interesada en la contratación de esta figura hipotecaria tiene la posibilidad de solicitar información previa a una entidad especializada y habilitada por la FCA o Autoridad de Conducta Financiera para ofrecer asesoramiento independiente, o bien puede acudir directamente a la entidad que oferta el plan. El posible cliente de estos productos equity release, tal y como se prevé en nuestro país, podrá obtener información de los mismos a través de diferentes canales, como por ejemplo:

\footnotetext{
${ }^{756}$ LUSH, D.; BIELANSKA, C., et alii, Elderly clients: a precedent manual..., op. cit., pp. 569 y 570.
} 
anuncios publicados en prensa escrita, radio, Internet o incluso en televisión, además de que también la pueda recibir a través de su banco o entidad de la que es ya cliente.

Con este asesoramiento independiente, proporcionado por abogado, entidad u otro tipo de intermediario, la persona de edad avanzada obtiene información del plan que le parece interesante para financiar la jubilación, así como también la de otras opciones, bien de ámbito público, bien de ámbito privado. De ese modo, las personas encargadas de suministrar este asesoramiento obtendrán información del posible cliente, de manera que les permita aconsejarle un producto $u$ otro atendiendo a sus circunstancias personales, y así dar solución a esa necesidad de ingresos ${ }^{757}$.

Para que este asesoramiento resulte adecuado al cliente, tendrán que constar más ventajas que inconvenientes para formalizar su contratación, contándose entre algunas de las primeras las siguientes circunstancias:

- La modalidad propuesta se adapta a las necesidades y a los objetivos del consumidor (MCOB 8.5.4).

- El importe obtenido por la contratación de esta modalidad no impide el acceso a otros beneficios sociales.

- Cualquier otra modalidad equity release u otras medidas ofrecidas por el Gobierno local resultan menos beneficiosas.

- Y, por supuesto, que el deudor pueda hacer frente al pago del interés, en el caso de que se haya pactado su devolución de forma periódica.

Los motivos que llevan a la población de más edad a contratar esta hipoteca vitalicia son de lo más variado, pues, en ocasiones, estas personas muestran interés en la contratación de esta modalidad por motivos distintos a la mera obtención de un complemento a sus ingresos. Como ejemplos podemos citar la compra de un coche, la reforma de la vivienda o el pago de unas vacaciones. Sin embargo, la causa predominante es la de hacer frente a

\footnotetext{
${ }^{757}$ LUSH, D.; BIELANSKA, C., et alii, Elderly clients: a precedent manual..., op. cit., p. 575.
} 
los costes del día a día ${ }^{758}$. Ahora bien, no existe una limitación para su contratación ni tampoco, en un principio, queda excluida ninguna causa.

No obstante, y con respecto a la financiación de los cuidados de larga duración, señalar que estos planes no son los más idóneos. Las razones son las siguientes:

Por una parte, la entidad concede una cuantía que representa un porcentaje del valor total del inmueble, pudiendo resultar insuficiente para hacer frente a los costes que suponen estos cuidados.

Por otra, únicamente es apropiada para el caso de que los cuidados se presten en la vivienda habitual de la persona mayor, cuya permanencia en la misma es obligatoria.

Las personas encargadas de proporcionar este asesoramiento también deben advertir sobre la falta de capacidad o comprensión para llevar a cabo este tipo de negocio, así como también de la existencia de una situación de conflicto de intereses.

Los asesores financieros especializados en el asesoramiento de los planes equity release, cuentan con las herramientas necesarias para informar sobre estos productos. En este aspecto, la FSA cuando se creó en el año 2000, insistió en la preparación y competencia del personal que asesoraba a estos clientes. Prueba de ello es la excelente preparación a través de una serie de exámenes que realiza el llamado Financial Services Skills Council (FSSC) ${ }^{759}$.

Junto a estos asesores independientes, encontramos a los abogados ${ }^{760}$, solicitors en Reino Unido. Éstos, con respecto a estos productos, no suelen

\footnotetext{
758 ZOE, H., A Detailed History of Equity Release, op. cit., p. 1.

759 Fox-O' MAHOny, L., Home Equity and Ageing Owners: between Risk and Regulation..., op. cit., p. 315. Vid. también la página web: www.gov.uk.

${ }^{760}$ El abogado está obligado a informar al cliente de que no está habilitado por la FSA. Por tanto, no puede recomendar ningún tipo de producto ni asesorar desde una perspectiva financiera. No obstante, el abogado se preocupará de que el cliente obtenga un adecuado asesoramiento antes de negociar con la entidad.
} 
tener una formación especializada, simplemente, actúan como intermediarios entre cliente y entidad, informando sobre los aspectos concretos de la transacción para, posteriormente, formalizar la operación ${ }^{761}$. Por este motivo encontramos organizaciones como Solicitors for the elderly o Equity Release Solicitors Alliance, las cuales, se encargan de facilitar a los posibles clientes la información necesaria para conocer quién está autorizado para prestar este asesoramiento $^{762}$.

Una vez se tenga toda la información, y habiendo recibido un adecuado asesoramiento, la entidad realizará una propuesta de contratación. Esta propuesta podrá o no constituir el documento de oferta, pero siempre y cuando el contrato siga adelante, se incorporará a un documento al que el Handbook $^{763}$ de la FSA denomina Illustration ${ }^{764}$. De esta manera, se hace constar toda la información ${ }^{765}$ correspondiente al producto ofrecido: costes, obligaciones, devolución del préstamo, intereses, etc. (MCOB 6.4.1).

La FSA ofrece un modelo orientativo, de manera que la entidad se podrá acoger o no al modelo. No obstante, en dicho documento deberá constar obligatoriamente:

- El producto específico equity release en el que el consumidor está interesado.

- La cuantía que solicita el consumidor, así como el modo de disposición.

- El valor del inmueble para determinar si el producto equity release resulta adecuado a la petición del cliente.

- La información acerca del cliente.

- El plazo estimado.

\footnotetext{
${ }^{761}$ LUSH, D.; BIELANSKA, C., et alii, Elderly clients: a precedent manual..., op. cit., p. 595.

762 lbíd., p. 576.

${ }^{763}$ En la actualidad, y desde 2013, esta función corresponde a la Financial Services Authority (FSA). Vid. con más detalle Reader's Guide: an introduction to the Handbook (on line), disponible en: http://fsahandbook.info/FSA/index.jps.

764 La Illustration está regulada en el capítulo 9 del MCOB, relativo a la divulgación de productos financieros, y consta de 16 secciones.

${ }^{765}$ Esta información se hace conforme a las reglas establecidas en the MCOB (Mortgages and Home Finance: Conduct of Business), concretamente en el MCOB 6 se hace referencia a la divulgación de esta información en la fase de oferta.
} 
Este documento se remite al abogado para que éste, a su vez, lo entregue al interesado.

El principal inconveniente con que cuenta este asesoramiento independiente es el coste ${ }^{766}$ que supone durante todo el proceso de recopilación de datos y suministro de información. Además, también se ha de tener en cuenta quién va a ser el encargado de sufragar el coste de este asesoramiento $^{767}$.

Junto a esto, la FCA contempla aquellos supuestos en los que la entidad no cumple con la obligación de suministrar correctamente este asesoramiento independiente. En este aspecto, el cliente tiene la posibilidad de acudir al Servicio del Defensor Financiero, Financial Ombudsman Service ${ }^{768}$. Se trata de un organismo independiente creado por el Gobierno para tratar las reclamaciones $^{769}$ de los clientes en relación a cualquier servicio financiero. Este servicio es gratuito.

En el supuesto de que se resuelva a favor del cliente, la entidad tendrá que indemnizar por los daños y perjuicios causados. En caso de que la entidad no disponga de los recursos necesarios para costear la indemnización, el Fondo de Compensación de los Servicios Financieros asumirá el pago de la correspondiente indemnización ${ }^{770}$.

La FSA tiene también competencia para ejercer acciones ${ }^{771}$ en contra de determinadas entidades e imponer multas si no cumplen con la regulación

\footnotetext{
766 LUSH, D.; BIELANSKA, C., et alii, Elderly clients: a precedent manual..., op. cit., p. 591. Uno de los aspectos más negativos, y que más se ha criticado de la regulación inglesa, es el coste de contratación que lleva consigo un plan de este tipo, pudiendo llegar a alcanzar las 3.200 libras.

${ }^{767}$ Vid. Fox-O'MAHOnY, L., Home Equity and Ageing Owners: between Risk and Regulation..., op. cit., p. 315.

${ }^{768}$ Información disponible en: http: //www.financial-ombudsman.org.uk/.

769 En los informes que anualmente emite la organización apenas se recogen quejas planteadas por los clientes con respecto a los home reversion plans.

${ }^{770}$ Fox-O' MAHONY, L., Home Equity and Ageing Owners: between Risk and Regulation..., op. cit., pp. 298 y 299.

771 Ibíd., pp. 299 y 300. La primera vez que se llevó a cabo una acción de este tipo fue en el año 2007 contra el grupo Mintel, que fue multado con 10.500 libras por el riesgo al que había expuesto a algunos de sus clientes respecto de productos Lifetime Mortgages que no resultaban adecuados para su situación.
} 
contenida en el MCOB (Mortgages and Home Finance: Conduct of Business sourcebook).

Además de este sistema de protección al consumidor implantado en Reino Unido, se ha de señalar que en su día el SHIP estableció unas garantías, así como también determinadas formas de actuar, a todos sus miembros mediante el cumplimiento de un código de conducta ${ }^{772}$ que ha sido asumido por el Equity Release Council. En ese Código $^{773}$ se recogen, entre otras cuestiones, las obligaciones que tienen estas entidades:

- Harán constar las ventajas e inconvenientes del producto, los costes, así como las obligaciones que tendrá que asumir el consumidor. Cada uno de esos aspectos deberá constar en el contrato de forma clara.

- Deberán informar de los efectos y consecuencias que se puedan derivar del traslado de la vivienda, así como también de las subidas o bajadas que pueda experimentar el precio de la vivienda por la que se ha originado el préstamo.

- Deberán asegurar al consumidor la permanencia en el inmueble mientras esta constituya su vivienda habitual.

- El derecho del consumidor a escoger a un abogado independiente que le ayude en todo el proceso.

- La entidad deberá explicar al abogado los beneficios que va a reportar a su cliente la contratación del plan. El abogado, tras explicar a su cliente los riesgos que conlleva la aceptación, y éste haberlos comprendido, firma un certificado en el que confirma que su cliente entiende los riesgos y beneficios del $\operatorname{plan}^{774}$.

Para finalizar, en Reino Unido todos los planes están asegurados contra el riesgo de patrimonio negativo, de manera que el consumidor nunca va a deber más del valor que representa su inmueble. Esta opción no ha sido

\footnotetext{
772 LUSH, D.; BIELANSKA, C., et alii, Elderly clients: a precedent manual..., op. cit., p. 588.

773 Este Código de conducta se puede consultar en la página web oficial de la organización: http:// www.equityreleasecouncil.com/equity-release-council/code-of-conduct/.

${ }^{774}$ ZoE, H., A Detailed History of Equity Release, op. cit., p. 6.
} 
contemplada por la regulación española, donde sí puede darse el caso de que se produzca la existencia de un patrimonio negativo.

\section{Constitución de la Hipoteca Vitalicia en Reino Unido}

La constitución de esta modalidad hipotecaria se realiza de la misma forma que la estipulada para cualquier hipoteca ordinaria o convencional. No obstante, en esta modalidad, además de las obligaciones que asuman las partes en materia contractual, se tendrá que hacer constar, como nota más característica de esta hipoteca vitalicia, que el vencimiento del préstamo se producirá en la fecha en la que fallezca el cliente o consumidor y que el inmueble objeto de esta garantía debe constituir en todo momento la vivienda habitual del solicitante.

- Trámite registral de la hipoteca vitalicia o inversa.

En Reino Unido, para proceder a la transmisión de cualquier derecho sobre un bien inmueble, se requiere de un instrumento denominado deed, cuyos requisitos $^{775}$ han sido estipulados por la Ley de Propiedad de 1989. De ahí que la mayoría de las entidades financieras o aseguradoras utilicen documentos formalizados conforme a la Ley de 1989 y aceptados por el Registro de la Propiedad ${ }^{776}$.

No obstante, aunque la transmisión se haya realizado, para que tenga plena validez, debe inscribirse en el Registro de la Propiedad. De esta forma, en Reino Unido, al igual que sucede en el nuestro, la inscripción tiene carácter constitutivo $^{777}$. Sin embargo, hay que hacer una matización relativa a las funciones que en nuestro país ejerce el notario, y que en el Derecho

\footnotetext{
775 La Ley de Propiedad de 1989 estableció como requisitos de este documento:

- La necesidad de que las partes manifestaran de forma clara su intención de utilizar este instrumento para la transmisión de un derecho en relación con un inmueble.

- Se requiere la firma por ambas partes en presencia de un testigo, que a su vez con su firma certifica la autenticidad de las partes.

776 Goss, A.; RICHARDSON, L., et alii, Conveyancing forms and procedures, $4^{\text {Th }}$ ed., The Law Society London, 2009, p. 291.

777 SMITH, R.J., Property Law, $7^{\text {Th }}$ ed., Longman, London, 2011, p. 100.
} 
anglosajón son ejercidas por abogados u otros profesionales. Con carácter general, es el abogado o solicitor el que actúa como testigo en este tipo de operaciones $^{778}$. Esta intervención supone un aumento en el coste de la contratación.

Para la inscripción del derecho se hace llegar el documento original al registrador. Una vez se efectúa la inscripción, el original es devuelto al deudor, aunque en la práctica es la entidad la que suele quedarse con el original, mientras que al deudor se le hace entrega de una copia certificada del original ${ }^{779}$.

Puede que el inmueble no esté inmatriculado, por lo que no puede procederse a inscribir la hipoteca. En este caso se aplican las reglas tradicionales de transmisión de derechos reales que existían con anterioridad al Registro, basadas principalmente en la entrega del deed a la parte interesada. Esta situación, es decir, que una finca pueda no estar inmatriculada, se debe a que la Ley del Registro de 1925 impuso la inscripción de ciertos negocios jurídicos de forma gradual, por zonas, sin llegar a imponer la inmatriculación ${ }^{780}$ con carácter obligatorio. De esta manera, la inscripción era obligatoria para determinados contratos como la compraventa de un bien inmueble o la constitución de una hipoteca, y sólo cuando se realizaban estos negocios jurídicos se procedía a la inmatriculación ${ }^{781}$.

En el caso que aquí nos atañe, es decir, la constitución de una hipoteca vitalicia, ésta se hace constar en el apartado destinado a recoger las cargas y gravámenes, en inglés Charges Register, que recaen sobre una finca ${ }^{782}$.

\footnotetext{
778 Goss, A.; RICHARDSON, L., et alii, Conveyancing forms and procedures..., op. cit., p. 291.

779 Ibíd., p. 293.

780 Cfr. SánChez-Ventura MORER, I., La hipoteca inversa..., op. cit., p. 163.

${ }^{781}$ Vid. con más detalle a MARTínEZ ESCRIBANO, C., «El registro de derechos en Inglaterra y Gales: avances y obstáculos en su implantación», RCDI, Año n 87, marzo-abril, № 724, Madrid, 2011, pp. 975 y 976.

782 Goss, A., Richardson, L., et alii, Conveyancing forms and procedures..., op. cit., pp. 26 y 27. La información en relación a la finca se divide en tres apartados:

- Property Register: donde se hace constar toda la información relativa a la situación geográfica de la finca mediante una breve descripción (normalmente incluye la dirección) así como la referencia del plano que suele adjuntarse con la documentación proporcionada al encargado del registro.

- Propietorship Register: se indica la clase de título, normalmente un título absoluto, con el nombre y la dirección del propietario así como si existe alguna limitación en el inmueble.
} 


\section{- Costes de contratación.}

En la publicación realizada por the Money Advice Service ${ }^{783}$ en el apartado dedicado a los honorarios y costes, entre otros, nos encontramos con los siguientes:

- Los honorarios profesionales, cuya cifra está en torno a las 750 libras.

- Los costes de tasación. Para una vivienda tasada en 240.000 libras el importe de esa tasación ascendería a 200 libras.

- Costes legales, entre 300 y 700 libras.

- Y, la contratación de un seguro de hogar que estaría entre las 200 y 300 libras al año.

De esta manera, los gastos ${ }^{784}$ que genera la contratación de un plan equity release son bastante elevados, sobre todo teniendo en cuenta al público al que van dirigidos.

\section{Vencimiento del préstamo}

El vencimiento de préstamo en la modalidad de lifetime mortgage se origina con la defunción del deudor. Esta es la causa común por la que se produce el vencimiento de este préstamo y por la que se declara la exigibilidad del mismo.

Por lo general, desde la fecha de fallecimiento del deudor, y atendiendo a las estipulaciones que figuran en el contrato de hipoteca, la parte acreedora cuenta con un plazo de entre seis a dieciocho meses para

- Charges Register: recoge las posibles cargas (incluyendo la hipoteca) que pueden gravar un inmueble y da noticia de la existencia de otros posibles derechos a los que queda sujeta la propiedad como por ejemplo, un acuerdo lease u otro tipo de limitaciones que restringen el uso del inmueble.

783 Vid. Equity release schemes. Raising money from your home, p. 13 . Disponible en: www.moneyadviceservice.org.uk.

${ }^{784}$ Véase más ampliamente TOGORES, A., «El valor económico de la seguridad jurídica», Escritura Pública, (on line), $\mathrm{N}^{\circ}$ Extra 5, 2007 (Ejemplar dedicado a: $25^{\circ}$ Congreso Internacional), p. 14. 
valorar cómo recuperar ese importe concedido. Entre estas opciones, se contempla el derecho de venta del inmueble, en inglés power of sale, bien a los herederos o bien a un tercero.

La parte acreedora, para poder llevar cabo la venta de este inmueble con el objetivo de cobrar el dinero obtenido en la transacción y así saldar la deuda $^{785}$, deberá ejercitar este derecho de venta, siempre y cuando concurra alguna de estas circunstancias:

- Que pasados los tres meses desde que solicitó a la parte deudora el pago del débito, ésta no haya correspondido.

- Que se hayan impagado dos o más mensualidades de intereses.

- Que se haya incumplido cualquiera de las obligaciones previstas en el contrato.

Por tanto, mientras la parte deudora acate lo convenido en el contrato, la parte acreedora no ejercitará este derecho de venta. Para la realización de este derecho, la parte acreedora no requiere de ningún pronunciamiento judicial previo. Sin embargo, se puede dar el caso de que el deudor no quiera abandonar su domicilio, de manera que la parte acreedora tendrá que conseguir la orden de desalojo ${ }^{786}$ por el tribunal correspondiente.

Cuando el inmueble hipotecado se haya vendido por un importe superior al establecido en el momento de la firma del contrato, el remanente $^{787}$ que se haya originado pasará a formar parte del patrimonio personal del que fuera deudor en el caso de que se produzca el vencimiento de forma anticipada, o si se produjera por la causa común, es decir, el fallecimiento del deudor, pasará al patrimonio hereditario.

\footnotetext{
${ }^{785}$ Goss, A.; RICHARDSON, L., et alii, Conveyancing forms and procedures..., op. cit., pp. 23 y 24.

786 En el caso de préstamos garantizados con hipoteca ordinaria, el acreedor suele necesitar de un pronunciamiento judicial previo para ejercitar su derecho de venta, pronunciamiento que tiene carácter obligatorio en el caso de que el inmueble constituya la vivienda habitual del solicitante. Cfr., CLARKE, A.; KoHLER, P., Property Law: Commentary and Materials, Cambridge University Press, Cambridge, 2005, p. 684.

${ }^{787}$ Equity Release guide-unlocking the value of your home, Council of Mortgage Lenders, disponible en: http://www.cml.org.uk/cml/filegrab/Equityreleaseleaflet, p. 6.
} 
Por otra parte, y al igual que sucede en el caso español, pueden concurrir otras causas por la que se concluya esta relación contractual de forma anticipada. Estas pueden ser por:

1.- La venta del bien inmueble.

2. - Cuando la persona mayor deje de habitar en la vivienda hipotecada durante un periodo de tiempo superior a los seis meses y no tenga intención de volver a residir en esa vivienda ${ }^{788}$.

Esta situación se puede producir porque esta persona haya decidido irse a vivir a otro lugar, como puede ser la vivienda de un familiar, o trasladarse a una residencia para recibir los cuidados correspondientes a su edad o historial médico.

En el supuesto de que esta persona se mude a otra vivienda, se permite la portabilidad ${ }^{789}$ del plan equity release al nuevo inmueble. Ahora bien, este inmueble deberá ajustarse a las condiciones por las que la entidad había concedido ese préstamo, sobre todo en lo referente a la valoración económica.

Respecto a estas causas, en la hipoteca inversa española no se contemplan, ya que una vez la persona mayor de 65 años o afectada de dependencia o con un grado de discapacidad igual o superior al 33 por ciento, haya obtenido esta hipoteca a través de su vivienda habitual, podrá habitar donde quiera, pues no se la obliga a residir en ese inmueble $y$, mucho menos que se fije un plazo por el que se produzca el vencimiento anticipado, como en el caso inglés, que es de seis meses.

Cuando se den estas causas, es decir, la transmisión del inmueble o el dejar de residir en esa vivienda habitual, este préstamo se amortizará de manera anticipada, pues lo normal es que el vencimiento se prevea al fallecimiento de la parte deudora. De esta manera, y siempre que se

\footnotetext{
${ }^{788}$ LUSH, D.; BIELANSKA, C., et alii, Elderly clients: a precedent manual..., op. cit., p. 585.

789 Ibíd., p. 585.
} 
concreten determinados motivos, la parte acreedora podrá solicitar el cobro de una compensación por amortización anticipada ${ }^{790}$.

En el mercado inglés se contempla la posibilidad de realizar la venta del inmueble ${ }^{791}$ tanto en el sector privado como en el público, aunque la modalidad más utilizada por las entidades financieras es la de venta privada.

La parte acreedora debe actuar de buena fe y solicitar un precio razonable por la transacción de la vivienda. Además, en virtud del ejercicio del poder que el derecho le ha conferido, no puede adjudicarse la vivienda. En Reino Unido, el plazo de que dispone la parte acreedora para vender el inmueble es de doce años desde el momento en que se le ha autorizado para ello, pero en la práctica este plazo es mucho más breve, pues hasta que se produzca la venta del inmueble, el préstamo sigue generando intereses, con lo cual, la cantidad cada vez será más elevada. De ahí, que la FSA obligue a las entidades a tramitar la venta del inmueble lo antes posible y obtener el mejor precio conforme a las circunstancias del mercado.

Por último, señalar que en Reino Unido, al igual que en España, la hipoteca inversa está exenta de tributación ${ }^{792}$.

Analizado todo esto, sorprende que en Reino Unido los clientes de esta hipoteca vitalicia o inversa la soliciten para realizar reformas en la vivienda o para irse de vacaciones. Mientras que en nuestro caso, la razón o el motivo de tramitar esta modalidad consiste en obtener un complemento a los ingresos 0 pensiones y poder así pagar, de forma más desahogada, los gastos del día a día o también los servicios de una residencia especializada o sanatorio.

En Reino Unido, a diferencia del nuestro, la mentalidad que se tiene sobre la vivienda en propiedad es que ésta es considerada como un plan de pensiones del que se puede obtener más ingresos $\mathrm{y}$, por tanto, una mejor

\footnotetext{
${ }^{790}$ Vid. MCOB 9.4.83 (Handbook de la FSA).

791 Vid. la sección 103 de la Ley de Propiedad de 1925.

792 Del Pozo García, E.; Díaz Martínez, Z. y Fernández Sevilla, L., «La hipoteca inversa en España: un estudio comparativo con otros países de la Unión Europea y EEUU», op. cit., p. 96.
} 
calidad de vida. Los ciudadanos británicos no ambicionan tener un patrimonio inmobiliario como nosotros los españoles, ni tampoco consideran necesario el dejar a sus herederos una vivienda libre de cargas. En España seguimos aferrados a la idea de dejar en herencia un inmueble libre de cargas aun a costa de malvivir durante la jubilación. Si bien es cierto que esta tendencia está cambiando a medida que pasa el tiempo y son otras generaciones las que llegan a los 65 años o más.

En Reino Unido, para poder optar a esta modalidad hipotecaria, el inmueble objeto de garantía deberá constituir la vivienda habitual mientras dure el contrato. En el caso de que se incumpla este requisito, la parte acreedora puede declarar el vencimiento del préstamo de forma anticipada. Por este motivo, las personas interesadas en concertar este producto optan por otras figuras que igualmente les generen una fuente de ingresos.

A pesar de que Reino Unido se ha esforzado en implantar este tipo de planes a través de una pormenorizada regulación (sólo hay que fijarse en el tema relativo al asesoramiento de este producto), lo cierto es que el resultado obtenido no ha sido demasiado alentador, pues apenas representa un pequeño porcentaje dentro del mercado financiero ${ }^{793}$.

El gobierno español, a la hora de implantar esta modalidad en nuestro país, tenía que haber valorado la respuesta de los ciudadanos británicos.

\footnotetext{
793 Aún así, hay que decir que en el año 2007 (año en que esta modalidad se introdujo en nuestro ordenamiento) el número global de hipotecas vitalicias en Reino Unido superó la cifra de 124.000 operaciones. A finales del primer trimestre de ese año, el valor estimado de las hipotecas inversas superaba los 6.500 millones de libras esterlinas. Vid. más ampliamente SÁnCHEZ ÁlvareZ, I.; López ARES, S. y Quiroga GaRcía, R., «Diseño de hipotecas inversas en el mercado español», op. cit., p. 41.
} 


\section{CAPÍTULO XI: LA HIPOTECA INVERSA EN ESTADOS UNIDOS: EL PLAN HOME EQUITY CONVERSION MORTGAGE}

En este punto, al igual que se ha visto en el apartado anterior, se va a realizar un análisis comparativo de la Disposición Adicional Primera de la Ley 41/2007 con respecto a su homóloga en Estados Unidos ${ }^{794}$. En este país, la hipoteca inversa se define como un préstamo contra la vivienda donde no se necesita ningún reembolso mientras el titular del inmueble viva en dicho inmueble.

Anticipar que, aún tratándose de un sistema jurídico muy diferente al utilizado en España, nuestra regulación ha adoptado ciertos criterios de este contrato HECM. De ahí que nuestra hipoteca inversa se asemeje a la mantenida por Estados Unidos.

\section{PLANTEAMIENTO GENERAL SOBRE LAS HIPOTECAS EN ESTADOS UNIDOS: THE REVERSE MORTGAGE}

En Estados Unidos no se puede reconocer un derecho real de hipoteca como se concibe en España. Una diferencia fundamental puede encontrarse en la naturaleza misma de la hipoteca. En este aspecto, en Estados Unidos la hipoteca se entiende de tres maneras distintas ${ }^{795}$ :

- Dos tercios de los estados conciben la hipoteca como un mero gravamen en la propiedad.

\footnotetext{
${ }^{794}$ Para obtener una mayor información véase las siguientes páginas web:

Departamento de Vivienda y Desarrollo Urbano de los Estados Unidos: www.hud.gov/offices/hsg/sfh/hecm/hecmlist.cfm.

Fundación AARP, Proyecto Informativo sobre Hipotecas Inversas: www.aarp.org/revmort.

Asociación Nacional de Prestamistas de Hipotecas Inversas: www.reversemortgage.org.

Consejo Nacional sobre el Envejecimiento (información sobre programas asistenciales del gobierno y otras alternativas a las hipotecas inversas): www. benefitscheckup.org.

${ }^{795}$ SpRANKLING, J.G., Understanding Property Law, Lexis Nexis, New York, 2000, p. 343.
} 
- Otros estados, por herencia del sistema del common law inglés, entienden la hipoteca como el resultado de la transmisión de toda o parte de la propiedad ${ }^{796}$.

La parte acreedora, en este caso, tiene el derecho a tomar posesión de la propiedad asegurada y obtener las rentas necesarias para saldar el crédito en cualquier momento, sin necesidad de acudir a un procedimiento de ejecución. No obstante, para llegar a este procedimiento se tendrá que haber producido el incumplimiento de la obligación.

- Otro grupo de estados son partidarios de una teoría de carácter más intermedio. La parte acreedora sólo tomara la posesión del inmueble cuando se produzca el incumplimiento de la obligación.

En el mercado estadounidense nos podemos encontrar con supuestos de pacto comisorio o de venta directa del bien $^{797}$, en los que el deudor hipotecario, ante la imposibilidad de cumplir con la obligación de devolver el capital junto con los intereses, hace entrega del inmueble por el que se tramitó la hipoteca a la entidad de crédito. En cambio, en nuestro ordenamiento, la hipoteca convencional no implica adquisición de parte del dominio, sino que recae siempre sobre un derecho cuya titularidad pertenece a otro y se define por su contenido ${ }^{798}$. Junto a esto, señalar que la práctica de pacto comisorio en nuestro país está prohibida ${ }^{799}$.

Atendiendo a estas notas, observamos que la hipoteca como garantía real inmobiliaria en EEUU establece más mecanismos para que la entidad acreedora pueda cobrar su crédito. Esto lleva consigo que el legislador incorpore también un sistema que regule la protección del consumidor ante

\footnotetext{
796 BAZ IZQUIERDO, F., Derecho Inmobiliario Hipotecario inglés y su comparación con el sistema inmobiliario español, EDERSA, Madrid, 1980, p. 577.

797 Ibíd., pp. 577 y 578. Cfr., De LA PUENTE DE AlFARO, F., «La eficacia de los derechos reales, con especial atención al de hipoteca, en los Estados Unidos de América. Un caso concreto: el condado de Dane, Wisconsin», RCDI, Año n 78, № 674, Madrid, 2002, p. 2198.

${ }^{798}$ De Pablo Contreras, P. (coord.); Martínez de Aguirre Aldaz, C. y Pérez Álvarez, M.Á., Curso de Derecho Civil (III), op. cit., pp. 38 y 39.

${ }_{799}$ Así lo establece el artículo 1859 del CC: «El acreedor no puede apropiarse las cosas dadas en prenda o hipoteca, ni disponer de ellas».
} 
estos instrumentos financieros con el objetivo de garantizar que la operación se ha tramitado correctamente.

En este país, la formalización del contrato de préstamo garantizado con un inmueble se suele dividir en tres etapas:

1.- Constitución de un negocio de tipo causal bilateral.

2.- Celebración de un negocio de tipo unilateral por parte del deudor hipotecario.

3.- $Y$, por último, en el supuesto de que se realice la transmisión de algún derecho sobre inmuebles, la inscripción en el Registro del documento por el que se constituye o se trasmite ese derecho real.

El préstamo $0^{800}$ se inicia con la solicitud, application en inglés, por parte del posible cliente. En este documento se adhieren las condiciones del préstamo, es decir, la cantidad objeto de préstamo, tipo de interés, plazo de devolución, etc. En el caso de que esta solicitud se acepte por la entidad crediticia, ésta se registra en un instrumento denominado Commitment. Tras haber sido aceptado, las partes contratantes procederán a la firma del note o promissory note ${ }^{801}$.

A través de este documento se identifica a las partes y se hace constar que el prestatario o deudor promete (de ahí el nombre de promissory note 0 documento promesa) devolver el préstamo en los términos y condiciones fijados en el contrato. En este documento debe constar también:

- La cantidad por la que se asegura el inmueble objeto de hipoteca (el límite máximo en la concesión de un préstamo asegurado con hipoteca está en el 90\% del valor de tasación del inmueble, mientras que en España este límite oscila entre el $70-80 \%)$.

\footnotetext{
${ }^{800}$ Moro Serrano, A., Los sistemas registrales inmobiliarios en los Estados Unidos, Centro de Estudios Hipotecarios y Servicio de publicaciones de la Universidad Complutense de Madrid, Madrid, 1986, p. 40. 801 SPRANKLING, J.G., Understanding Property Law, op. cit., pp. 347-349.
} 
- El tipo de interés, que como sucede en nuestra hipoteca inversa, podrá ser fijo o variable. Aunque en nuestro caso, la preferencia ha sido la de optar por la de tipo fijo.

- La duración del préstamo.

- El calendario de amortización.

Respecto a la forma que debe adoptar este documento o note, en un principio no se sigue ninguna pauta, aunque en la práctica existen modelos estándar realizados por las entidades ${ }^{802}$ que negocian estos préstamos en el mercado secundario.

En cuanto a la constitución de la hipoteca, así como de cualquier otro derecho real, al igual que en el caso inglés, es necesario el otorgamiento del deed. Como ya se ha comentado en el apartado dedicado a Reino Unido, el deed es el documento que se utiliza para transmitir un derecho o cualquier otro interés sobre la propiedad. El contrato se perfecciona en el momento en el que el deed es entregado al adquirente del derecho y hasta que no se produzca ese momento no surtirán efectos para las partes. Por tanto, hasta que no se tenga este documento no se podrá constituir este derecho de hipoteca $^{803}$.

A diferencia de lo que sucede en nuestro sistema registral, donde la formalización de este contrato se obtendrá una vez se haya tramitado la inscripción en el Registro de la Propiedad ${ }^{804}$, en el caso de EEUU la constitución de la hipoteca depende de la entrega de este documento o deed. Por lo general, este acto de entrega, para certificar que este acto se ha producido $^{805}$, se realiza ante un notario de tipo sajón ${ }^{806}$.

\footnotetext{
802 Entre estas entidades encontramos the Federal Home Loan National Mortgage Association (FNMA) y the Federal Home Loan Mortgage Corporation (FHLMC). Vid., SPRANKLING, J.G., Understanding Property Law, op. cit., p. 345.

${ }^{803}$ De la Puente de Alfaro, F., «La eficacia de...», op. cit., p. 2199 y Moro Serrano, A., Los sistemas registrales inmobiliarios en los Estados Unidos, op. cit., p. 43.

${ }^{804}$ Artículo 1875 del CC y artículos 145 y 159 de la LH.

805 SPRANKLING, J.G., Understanding Property Law, op. cit., p. 374.

${ }^{806}$ A diferencia del notario de tipo latino, el notario de tipo sajón se caracteriza por lo siguiente:

- No se requiere de ninguna profesión.

- No hay impedimento para desarrollar otras profesiones.

- La veracidad no se refiere al contenido del documento sino a las firmas, aunque el contrato
} sea privado. 
Este documento, cuando se trate de una hipoteca, también se le llama mortgage. Es la forma técnica por la que se distingue al instrumento otorgado por las partes contratantes garantizando la deuda expresada en el note $e^{807}$.

En cuanto al sistema registral utilizado en EEUU, señalar que hay dos modos de Registro: Recording y Torrens.

No obstante, la mayor parte de los Estados se rigen por el sistema de Registro de documentos o Recording. Este método no es muy fiable. Esto se debe a que los Estados que optan por este sistema se caracterizan por tener sus propias leyes. Así un Estado, con respecto a este Registro de documentos, puede exigir unos requisitos, mientras otro Estado opte por otros, es decir, este Registro de documentos no se establece de manera homogénea para los Estados que se acogen a este sistema. Dicho de otra manera, se está negando el verdadero valor de la garantía inmobiliaria ${ }^{808}$. Como consecuencia, el adquirente, para salvaguardar su derecho, opta por otros métodos como por ejemplo la contratación de una póliza de seguro de título. La contratación de estos seguros supone un mayor coste para la operación.

Por el contrario, algunos Estados han optado por un sistema de Registro de derechos denominado Torrens. Este sistema se asemeja más al utilizado en nuestro país. Más adelante se ampliará esta información referente a la práctica registral.

Ahora nos vamos a centrar en la figura de la hipoteca inversa en el mercado estadounidense.

- No hay presunción de certeza del documento, solo de las firmas.

- No existe colegiación.

- El valor formal se obtiene con la actuación judicial.

807 Johnson, A.M., Understanding Modern Real Estate Transactions, Lexis Nexis, New York, 2001, p. 91.

808 LASARTE ÁLVAREZ, C., «Crisis financiera estadounidense, tercero hipotecario y seguridad inmobiliaria: la STS 6/2008 y la reciente doctrina del Tribunal Supremo», Diario La Ley, Año XXIX, N 6899, 7 de marzo de 2008, p.4. 


\section{LAS HIPOTECAS INVERSAS EN ESTADOS UNIDOS}

En Estados Unidos esta modalidad hipotecaria se conoce como reverse mortgage. Tal y como se comentó al inicio de este trabajo, el nombre que se da en nuestro país como «hipoteca inversa» no es más que la traducción al español del término anglosajón reverse mortgage. Se le llama así como contraposición a la forward mortgage, hipoteca ordinaria o de amortización.

En este país, y de manera técnica, esta modalidad hipotecaria se denomina rising debt, falling equity loans ${ }^{809}$. De esta forma, se describe el modo de operar de este instrumento caracterizado por un aumento constante de la deuda (rising debt) y una caída del valor (falling equity).

Atendiendo a la entidad encargada de suministrar esta modalidad hipotecaria, la hipoteca inversa en Estados Unidos puede ser pública o privada $^{810}$.

A continuación, y de forma más detallada, pasamos a citar estas modalidades.

\section{Home Equity Conversion Mortgage}

La mayor parte de las hipotecas inversas en el mercado estadounidense corresponde a las Hipotecas de Conversión del Valor Acumulado de la Vivienda o Home Equity Conversion Mortgage (en adelante HECM). Los requisitos para su celebración, al tratarse de un préstamo en el que va a intervenir una entidad de crédito autorizada por el gobierno federal, son de mayor exigencia que la simple autonomía de voluntad que rige en aquellas hipotecas inversas concertadas sin intervención de la administración. Este producto es el único

\footnotetext{
809 ZURITA MARTín, I., «La nueva normativa...», op. cit., p. 1279.

${ }^{810}$ Vid. la Comisión Federal de Comercio. Información para Consumidores en: www.consumer.ftc.gov.
} 
tipo de hipoteca inversa asegurada por el gobierno federal, representando más del 90 por ciento del mercado ${ }^{811}$.

Dentro de esta modalidad, diferenciamos los planes Home Equity Conversion Mortgage (HECM) de otro tipo de hipotecas inversas públicas, aunque con una menor relevancia. Son de carácter específico y su objetivo suele ser la financiación de obras de mejora o reparación, o incluso, para el pago de los impuestos que recaen sobre el inmueble. Así encontramos:

\section{Deferred Payment Loan (DPL)}

Algunos estados y agencias locales ofrecen Préstamos de Pago Diferido (Deferred Payment Loans, DPL) para realizar reparaciones o mejoras en general de la vivienda. Este tipo de préstamos otorgado por el sector público se concede mediante una entrega única que no debe ser amortizada mientras el beneficiario viva en la casa.

Los requisitos de este tipo de hipotecas varían mucho, pero la mayor parte están dirigidos a propietarios con rentas limitadas. Muchos establecen un límite en el valor estimado de la vivienda y suelen estar supeditados a ciertas áreas geográficas. Este tipo de hipotecas tienen limitado el uso para cierto tipo de reparaciones o mejoras: accesibilidad, uso eficiente de la energía, instalaciones sanitarias, etc.

Estos préstamos son compatibles con las hipotecas HECM, si bien el prestamista de pago diferido debe aceptar que su hipoteca esté subordinada al pago en primer lugar de la HECM. La principal ventaja de los préstamos de pago diferido es su bajo coste: en general, no tienen comisiones de apertura ni primas de seguro, los costes iniciales son mínimos y los tipos de interés muy bajos, o incluso inexistentes.

811 Sánchez Álvarez, I.; López Ares, S. y Quiroga García, R., «Diseño de hipotecas inversas en el mercado español», op. cit., p. 26. 
Los intereses suelen ser fijos y se suele aplicar interés simple en vez de compuesto, lo cual implica que no se acumulan al saldo del préstamo. En algunos casos, incluso se condona todo o parte del préstamo si el beneficiario ocupa la vivienda durante un cierto periodo de tiempo.

\section{Property Tax Deferral (PTD)}

Este tipo de hipoteca inversa también es de carácter público. Algunos gobiernos locales y estatales ofrecen préstamos con el objetivo de prorrogar el pago del impuesto sobre los inmuebles (Property Tax Deferral, PTD). Esta modalidad sólo puede ser utilizada para pagar el citado impuesto.

La devolución del importe solicitado en esta hipoteca no se reclamará mientras el beneficiario ocupe la vivienda.

Los requisitos para su concesión también varían mucho de unos programas a otros, pero se suele exigir una edad mínima de 65 años y unos niveles de renta limitados. Su cuantía está normalmente limitada al importe del impuesto al que se dedica, si bien en algunos casos sólo se cubre una parte del mismo, o consiste en la entrega de una cuantía fija. En la mayor parte se limita además el importe total que se ha obtenido en el préstamo durante los sucesivos años en que se ha percibido.

En general, este tipo de préstamos no admite la subordinación a otros. Los costes asociados suelen ser muy reducidos: no tienen comisiones de apertura ni primas de seguro y los costes iniciales son mínimos. El interés suele ser fijo y en muchos casos simple.

\section{Proprietary Reverse Mortgages}


En Estados Unidos también encontramos una modalidad de hipoteca inversa privada se trata de la Proprietary Reverse Mortgages o Hipotecas Inversas Dominicales. Estas hipotecas son ofrecidas por compañías privadas.

La cantidad que se puede obtener con su contratación puede ser incluso mayor que la proporcionada por un plan HECM, ahora bien, los costes de la operación pueden ser también más elevados. Estas hipotecas no cuentan con el respaldo de ninguna agencia gubernamental y se financian a través de los bancos y compañías prestamistas privadas que las ofrecen. De esta forma, la contratación de esta hipoteca no está sujeta a la misma regulación que el plan HECM, sino con una mejor práctica, ya que la mayoría de las compañías que las ofrecen emulan las mismas protecciones que reciben los consumidores de un HECM, incluido el asesoramiento.

A estas hipotecas dominicales también se las conoce como Jumbo hipotecas inversas, ya que se realizan en las viviendas de mayor valor, por lo general de 750.000 dólares o más. En este momento existen muy pocas hipotecas inversas dominicales. No obstante, y debido a las condiciones del mercado, éstas pueden cambiar en un futuro, cuando los valores de la propiedad se estabilicen.

En definitiva, en Estados Unidos encontramos tres tipos de hipoteca inversa pública: las Hipotecas de Conversion del Valor Acumulado de la Vivienda o Home Equity Conversion Mortgage, el Deferred Payment Loan o Préstamo de Pago Diferido y Property Tax Deferral o Aplazamiento de Impuesto de la Propiedad. Y, como hipoteca inversa privada, encontramos la Proprietary Reverse Mortgages o Hipotecas Inversas Dominicales.

No obstante, y a pesar de la oferta de todos estos productos, la modalidad más utilizada en el mercado estadounidense es la HECM asegurada por la FHA. Esta hipoteca es la que se ha tomado como modelo para introducirla en nuestro país. 
A continuación, y siguiendo en todo lo posible el esquema utilizado en el estudio de la hipoteca inversa en nuestro país, se van a desglosar los requisitos y caracteres para poder optar a un plan $H E C M$.

\section{EL PLAN HOME EQUITY CONVERSION MORTGAGE}

Los planes HECM se regulan principalmente en el título 24 del Code of Federal Regulations (en lo sucesivo, CFR) ${ }^{812}$. En este título se indican las funciones que tiene asignadas el Departamento de vivienda y desarrollo urbano.

En el parágrafo 206.3 del citado título se contempla el concepto de hipoteca a efectos de un HECM, como una garantía que se establece sobre una vivienda para asegurar un determinado interés. La Ley establece los caracteres de una HECM como un todo en el que el punto de apoyo o la realidad de mayor fuerza es la garantía inmobiliaria. Parte de una concepción unitaria del crédito hipotecario, sin distinguir el préstamo de la garantía.

\section{Requisitos subjetivos}

- El acreedor hipotecario.

Esta parte, en calidad de prestamista, para operar debe contar con la autorización del Departamento de vivienda y desarrollo urbano (Department of Housing an Urban Development, HUD).

\footnotetext{
812 En este Código, desde 1996, se contemplan las normas generales y permanentes de los departamentos y agencias del Gobierno Federal. Cada título hace referencia al organismo emisor que en su día dictó tales normas. El origen de la regulación de la hipoteca inversa se encuentra en la Ley de 1989, esta Ley ha sido reformada en varias ocasiones, caracterizándose por ser una regulación muy minuciosa. No obstante, encontramos otras normas relativas a los planes HECM en la National Housing Act (NHA) y en The Truth in Lending Act. Esta última Ley recoge una serie de normas generales sobre protección de consumidores y se aplica tanto a las hipotecas inversas de carácter privado como a aquellas que cuentan con garantía federal, de manera que la regulación no es de aplicación exclusiva a las HECM. Vid. Truth in Lending Act: Comptroller's Handbook: Comptroller of the Currency Administrator of National Banks, disponible en: http://www.occ.treas.gov/handbook/til.pdf.
} 
En la práctica es muy habitual que la entidad oferente, aun teniendo el control del préstamo, delegue en otras compañías los aspectos relativos a su tramitación. De manera, que estas gestiones pueden suponer un incremento de los gastos de la operación ${ }^{813}$.

- El deudor.

Respecto a esta figura (la ley estadounidense utiliza el término mortgagor en sentido global incluyendo tanto al prestatario como a la persona que ofrece el bien en garantía), no se hace ningún tipo de distinción. En realidad, en este supuesto no es necesario, pues el solicitante, para poder contratar esta hipoteca deberá ser el titular del bien inmueble (§ 206.35 CFR).

De esta manera, entre los requisitos que tendrá que tener el solicitante para acceder a una hipoteca HECM, se han de destacar tres de ellos:

- El propietario o propietarios del bien inmueble deberán tener al menos 62 años.

- El inmueble objeto de garantía deberá ser la vivienda habitual.

- El solicitante está obligado a recibir asesoramiento de una agencia reconocida por el HUD.

Observamos pues, que con respecto al requisito de la edad, a diferencia de lo que sucede en el caso español donde se exige tener 65 años o en Reino Unido donde se puede contratar a partir de los 55 años, en Estados Unidos el solicitante de este producto financiero deberá tener cumplidos los 62 años (§ 206.33 CFR).

Nos podemos encontrar con la típica situación de un matrimonio que se muestre interesado en conseguir una HECM, pero que sólo uno de los cónyuges 
cumpla con el requisito de la edad. En este caso, sólo éste podrá contratar la HECM con la entidad de crédito.

Además, en el caso de que la titularidad del inmueble sea de los dos cónyuges, el que tenga los 62 años cumplidos deberá absorber la parte de su cónyuge. Esta situación puede ser muy conflictiva, ya que el cónyuge que no cumple los requisitos puede no estar de acuerdo en vender o donar su parte al cónyuge que sí los cumple. Es muy importante tener en cuenta que si éste le otorgara la titularidad del inmueble y contratara una HECM, a su fallecimiento se podría dar la ejecución del bien inmueble, de manera que el cónyuge supérstite podría perder el derecho a residir en esa vivienda ${ }^{814}$.

De esta manera, la mejor opción para poder optar a esta modalidad, sea que el solicitante o solicitantes tengan los 62 años cumplidos y que ambos, ostenten la titularidad del inmueble en iguales proporciones. Así, los titulares deben autorizar la constitución de la garantía y a su vez convertirse todos ellos en deudores. No obstante, el perfil típico del solicitante de una HECM suele ser el de una mujer viuda, de una media de 76 años $^{815}$.

En cuanto a la capacidad de obrar de estas personas, no hay duda de que deben ser plenamente capaces para otorgar el préstamo y, en caso de no tener la capacidad exigida, será un tercero el que lo haga en su nombre siempre que tenga poder suficiente.

La legislación estadounidense apenas hace referencia al supuesto de falta de capacidad para contratar esta hipoteca. En la normativa española, con respecto a este producto, tampoco se hace ninguna referencia. Ahora bien, mientras que en nuestro ordenamiento jurídico tenemos la figura del notario para advertir esa falta de capacidad para otorgar un préstamo con garantía hipotecaria, Estados Unidos no cuenta con esa figura u otra similar para examinar la capacidad de las partes.

\footnotetext{
${ }^{814}$ No obstante, este supuesto no suele darse. Vid. Boroson, W., The Reverse Mortgage Advantage: The Tax-Free, House-Rich. Way to Retire Wealthy!, McGraw-Hill Companies, New York, 2006, p. 17.

${ }^{815}$ SAWYER, C.H., «Reverse mortgage: an Innovative Tool for Elder Law Attorneys», op. cit., p. 627.
} 
Este tema no se debería pasar por alto. El motivo no es otro que a partir de cierta edad -requisito imprescindible para la contratación de esta hipoteca-, la presencia de enfermedades de carácter degenerativo es cada vez mayor y el umbral de discernimiento en muchos supuestos es bastante difuso.

Por último, y al igual que sucede con nuestra hipoteca, el deudor o prestatario de una HECM se compromete a pagar los impuestos del inmueble, a mantener la vivienda en buen estado, a contratar un seguro de hogar y, por supuesto, a no abandonarla, venderla o donarla ${ }^{816}$. Pues, de no ser así, la hipoteca se tornaría exigible.

- El Beneficiario.

La regulación estadounidense, con respecto a esta figura, no hace ninguna referencia. Como tampoco la hace la regulada en Reino Unido. Cosa bien distinta a la posición adoptada por nuestra regulación, donde sí se admiten posibles beneficiarios no poniendo, ni tan siquiera, un límite a su número.

Esta Ley sólo desarrolla las condiciones, obligaciones y derechos de los que ocupan la posición de deudor hipotecario. No caben beneficiarios $^{817}$, de tal forma que todo aquel que pretenda participar en todo o parte del capital pactado, deberá ser solicitante del préstamo y reunir los requisitos comentados más arriba.

\section{Requisitos objetivos}

- El préstamo garantizado.

\footnotetext{
${ }^{816}$ Sánchez Álvarez, I.; López Ares, S. y Quiroga García, R., «Diseño de hipotecas inversas en el mercado español», op. cit., p. 28.

817 § 206.3 CFR.
} 
La cuantía prestada depende de:

- La edad del prestatario, en caso de que haya más de un deudor se tiene en cuenta la edad del más joven.

- De los tipos de interés en el momento de la contratación del préstamo.

- Y del valor de la vivienda.

Para la obtención de una HECM no se tienen en cuenta otro tipo de rentas $\mathrm{o}$ ingresos familiares ${ }^{818}$. Así, el elemento clave en esta modalidad consiste en la existencia de una vivienda, es decir, si no hay vivienda, no se va a plantear este préstamo.

La hipoteca inversa se sitúa entre los contratos de conversión de activos inmobiliarios donde el valor de la vivienda es convertible en dinero del que la entidad de crédito hace entrega al deudor. La obligación garantizada en esta hipoteca, siempre y cuando no se haya dispuesto de una sola vez, engloba una deuda que asciende conforme avanza el tiempo en función de las entregas que la entidad de crédito va realizando.

A modo de ejemplo, si la línea de crédito es de 100.000 dólares y se ha dispuesto de 20.000 dólares, quedará un saldo de 80.000 dólares. Transcurrido un año, el saldo se habrá incrementado de acuerdo con la tasa de interés del préstamo: si la tasa fuera del $6 \%$ anual, el límite de crédito un año después sería de 84.800 dólares $(80.000 \times 6 \%)$.

Respecto al modo en el que la entidad de crédito hace entrega de las rentas pactadas, encontramos las siguientes modalidades:

- La entrega de una única suma al comienzo de la vida del préstamo.

${ }^{818}$ TAFFIN, C., «La hipoteca inversa o vitalicia», op. cit., p. 10. 
- La disposición de la cantidad a través de una línea de crédito, con un límite establecido del que se puede disponer en el momento en que se desee.

- A través de entregas periódicas ${ }^{819}$.

Estas cuotas periódicas, mensuales o no, se pueden conceder bien para un plazo determinado, o bien se puede pactar que tengan carácter vitalicio ( $\S$ 206.19 (FR). Al igual que ocurre con nuestra hipoteca inversa, en uno y otro caso, la devolución del préstamo no es exigible hasta el fallecimiento del prestatario.

Junto a esto, señalar que tanto una como otra presentan ventajas e inconvenientes. En el caso del préstamo concedido durante un periodo de tiempo determinado, el mayor dispone de cantidades mayores, sin embargo, si transcurre el periodo convenido, no se realizará ninguna entrega más, pero el préstamo seguirá generando intereses hasta el fallecimiento. Por otro lado, hay que resaltar el riesgo de inflación que supone la disminución de las rentas conforme avanza el tiempo. Esta situación ha llevado a las distintas asociaciones de protección de consumidores a recomendar la combinación de los sistemas de línea de crédito y entregas de carácter periódico ${ }^{820}$.

- Mediante combinaciones de las opciones anteriores.

La forma más común de disponer del montante es a través de una línea de crédito ${ }^{821}$ y la que goza de menor aplicación es la entrega de una única suma dineraria a la firma del contrato.

Mientras que en España, la modalidad por la que ha optado el deudor, temporal o vitalicia, no se puede cambiar durante la vida del contrato, en Estados Unidos, por un coste aproximado de 20 dólares $^{822}$, se puede cambiar de modalidad en cualquier momento.

\footnotetext{
819 ZURITA MARTín, I., «La nueva normativa...», op. cit., p. 1281.

${ }^{820}$ Vid. Borrowing Against your Home, cit., p. 12.

821 Información disponible en la página web de la National Reverse Mortgages Lenders Association http: //www.nrmlaonline.org.

822 Véase la página web de la Comisión Federal de Comercio. Información para Consumidores: www.consumer.ftc.gov.
} 
- Intereses.

El interés aplicable en las HECM, al igual que la hipoteca inversa española, puede ser fijo o variable ${ }^{823}$.

El interés es algo superior al normal ya que la hipoteca inversa lo que garantiza es un préstamo en el que no se precisa con exactitud o fecha exacta el momento de devolución del mismo, e incierto también en relación a cuál será la cantidad total a devolver ${ }^{824}$. Estos datos se sabrán cuando la parte prestataria fallezca.

En el caso de que se opte por el tipo de interés variable ${ }^{825}$, la normativa del programa HECM exige que la parte prestamista ofrezca una tasa igual al tipo de interés de los valores del Tesoro a un año, más un margen o diferencial. El tipo aplicado se revisa anualmente. Además, se establecen unos límites de variación, con un máximo de 2 puntos porcentuales anuales, y un total de 5 puntos durante la vigencia del préstamo si varía anualmente, o 10 puntos si varía mensualmente.

De esta manera, el solicitante al contratar este producto con un tipo de interés variable, sabe donde están los límites. Esto no sucede en nuestro país, es decir, no se ha fijado ni un límite máximo ni mínimo para hacer frente a las subidas o bajadas de interés, pudiendo resultar gravemente perjudicada la parte deudora.

- El bien inmueble hipotecado.

Como ya se ha explicado, en lo que concierne al bien inmueble objeto de garantía, hay muchas similitudes entre nuestra hipoteca inversa y la HECM.

\footnotetext{
823 § 206.21 CFR.

${ }^{824}$ TAFFIN, C., «La hipoteca inversa o vitalicia», op. cit., p. 4.

${ }^{825}$ El 3 de enero de 2006, la tasa de interés de las hipotecas HECM con revisión mensual era del 5,87\% y en el caso de las revisiones anuales era del 7,47\%. Mientras que, la referencia de Bankrate.com para los préstamos hipotecarios convencionales a interés variable era del 5,56\%. En la actualidad, marzo de 2015, la tasa interanual es del $4,50 \%$.
} 
Este inmueble debe cumplir una serie de condiciones entre las que cabe destacar:

En primer lugar, debe constituir la vivienda habitual del solicitante (§ 206.9 (FR) ${ }^{826}$. Esta condición debe mantenerse durante toda la vigencia del contrato. Así pues, este requisito constituye un rasgo esencial de la hipoteca inversa norteamericana, de ahí que una de las cláusulas de vencimiento del préstamo, sea la pérdida del carácter habitual de la vivienda.

En segundo lugar, la vivienda tiene que tener, al menos, un año de antigüedad.

En tercer lugar, la vivienda debe estar libre de cargas, de tal forma que la hipoteca inversa sea una hipoteca asegurada de primer rango ( $\$ 206.8$ y 206.27 del CFR, parágrafo 255 b) NHA).

En cuarto lugar, la parte deudora debe tener la vivienda asegurada contra daños (\$ 206.27 CFR).

Por último, esta vivienda debe ajustarse al modelo de calidad fijado por el Departamento de vivienda y desarrollo humano, HUD. La vivienda tiene que estar en perfectas condiciones para el desarrollo de la vida diaria (por ejemplo, instalación eléctrica o de agua correctas, etc.). Esta obligación de mantener en buen estado el inmueble se sostendrá durante toda la vigencia del préstamo (§ 206.27 CFR).

Para el caso de que la vivienda del solicitante no cumpla con esos mínimos de calidad, el legislador ha sido precavido y permite que el acondicionamiento de esta vivienda se pueda financiar a través del importe concedido en la contratación de la hipoteca inversa, siempre y cuando las

${ }^{826}$ Estos artículos de la CFR (Code of Federal Regulation), relativos a the Mortgage provisions, se pueden consultar en la página de la Cornell University Law School: Legal Information Institute: http://www.gpo.gov. 
reformas no superen el $15 \%$ del importe total. Estas obras podrán ser inspeccionadas por el acreedor (§ 206.47 CFR).

\section{Requisitos formales}

- Sistema de protección al consumidor.

A estas alturas del programa no cabe duda que el público al que va dirigido la hipoteca inversa, independientemente del país que la oferte, se caracteriza por ser muy vulnerable.

En sus inicios, la HECM tenía mala reputación ${ }^{827}$, pues además del elevado coste que suponía su contratación, las entidades que la ofertaban, prestamistas, brokers u otro tipo de vendedores, realizaban prácticas de carácter dudoso, que posteriormente fueron denunciadas por distintas organizaciones. Para que esta hipoteca gozara de la mayor seguridad posible se necesitaba de un sistema de protección a los consumidores para asegurar en todo momento, la prestación de una buena información al mayor y evitase los abusos de las entidades prestamistas. Así, con la aprobación de la legislación reguladora de las HECM, se desarrolló un programa de información a los consumidores sobre este tipo de productos, dirigido a todo tipo de sectores: consumidores, asociaciones de mayores, otras entidades ${ }^{828}$, etc.

Junto a esto, el órgano administrativo sobre envejecimiento, dependiente del Departamento Federal de Salud, llegó a un acuerdo de cooperación con el Departamento de vivienda y desarrollo humano para financiar la preparación de este grupo de asesores ${ }^{829}$. Desde 1999 se debe realizar un examen ${ }^{830}$ para adquirir la acreditación de asesor independiente de una HECM.

\footnotetext{
${ }^{827}$ TAFFIN, C., «La hipoteca inversa o vitalicia», op. cit., pp. 3 y 4.

${ }^{828}$ Vid. Agbamu, A., The HECM at 20 series...A principal architect of HECM (Reverse Mortgage. Pioneers and Leaders: A visionary non-commercial entrepeneur). Disponible en: http: / / nationalmortgageprofessional.com.

${ }_{829}$ A capsule history of reverse mortgage, disponible en: http: / /www.reverse.org.

${ }^{830} \mathrm{La}$ validez de este examen caduca a los tres años (\$ 206.32 CFR).
} 
Este asesor puede actuar de manera individual o por medio de una agencia sin ánimo de lucro autorizada por el Departamento de vivienda ${ }^{831}$. Su cometido consiste en orientar al solicitante sobre una serie de cuestiones ${ }^{832}$. Entre estas cuestiones, el asesor preguntará al solicitante sobre los motivos que le han llevado a plantearse este suplemento económico y a qué va a destinarse esa cantidad, en el caso de que se la concedieran. Esto se hace para comprobar cuáles son realmente las necesidades de este posible cliente, pues no es lo mismo que se solicite para hacer frente a las necesidades más básicas o para cubrir los cuidados de larga duración que, por ejemplo, para realizar unas obras en la vivienda.

Otra de las cuestiones que se plantea es si el solicitante de esta hipoteca, está capacitado para emplear correctamente el capital que representa su inmueble, pues no debemos olvidar que la hipoteca inversa se recomienda siempre como último recurso ${ }^{833}$. De esta manera, otro de los puntos que se tratará será el de ofrecer otras alternativas que se adapten mejor al perfil del solicitante. Por ejemplo, puede darse el caso de que este solicitante necesite una pequeña cantidad de dinero para cubrir un gasto imprevisto, pues en lugar de contratar esta hipoteca, lo más normal es que contrate un préstamo convencional.

Una vez realizado este asesoramiento, bien de forma individual bien de forma colectiva, se emite un certificado en el que se hace constar que el consumidor ha recibido la información exigida legalmente ( $\$ 206.41$ CFR). Este asesoramiento, dependiendo de la agencia en que se solicite, puede ser o no gratuito. La mayor parte de las agencias que proporcionan este asesoramiento, desde 2008, cobran -como máximo- 125 dólares por sus servicios. Este importe se puede pagar con el dinero obtenido por la hipoteca. Así, cuando se vaya a solicitar información, la persona interesada tendrá que

\footnotetext{
831 SAWYER, C.H., «Reverse mortgage: an Innovative Tool for Elder Law Attorneys», op. cit., pp. 631 y 632.

${ }^{832}$ Vid. Borrowing Against your Home, cit., p. 1.

833 SÁnCHEZ-VENTURA MORER, I., La hipoteca inversa..., op. cit., p. 26.
} 
cerciorarse de si va a tener que pagar o no por este servicio, ahora bien, a nadie se le podrá privar de él.

Este sistema de protección del consumidor ${ }^{834}$ se completa con una serie de deberes que debe cumplir la parte prestamista. Dentro de estos deberes, la parte acreedora debe de informar sobre las condiciones del préstamo. Esto se lleva a cabo mediante la entrega de unas tablas en las que queda claramente definido:

- El principal y el interés a pagar con carácter anual.

- El importe total del préstamo, es decir, la suma del principal, el interés, y los gastos por prestación de servicios (§ 255 e) NHA).

La introducción de esta figura en nuestra regulación ha sido toda una novedad.

\section{- Costes de Contratación.}

Entre los inconvenientes a la hora de decantarse por la contratación de una hipoteca inversa nos encontramos con el elevado coste que supone esta operación. Entre estos costes ${ }^{835}$, podemos distinguir:

- La comisión de apertura en concepto de preparación de la documentación del préstamo y su seguimiento hasta la formalización de la operación. Esta tasa se limita a un porcentaje calculado sobre el valor del bien inmueble: un $2 \%$ sobre los primeros 200.000 dólares y $1 \%$ sobre la cantidad que supere esos 200.000 dólares.

- Costes abonados a terceros para poder llevar a cabo la constitución de la garantía inmobiliaria. Dentro de estos gastos incluiremos la tasación de la vivienda, las posibles inspecciones en la misma, gastos de registro, impuestos,

\footnotetext{
834 Para obtener una mayor información, se puede consultar la página web: http: / / www.consumidor.ftc.gov.

${ }^{835}$ Borrowing Against your Home, cit., pp. 12-14.
} 
etc. El importe de estos conceptos depende del valor del bien inmueble y suele oscilar entre los 2.000 y 3.000 dólares.

- La prima del contrato de seguro de riesgo contra el patrimonio negativo, negative equity.

- Los gastos por los servicios prestados por parte de la entidad prestamista. Se corresponden con la administración del préstamo: transferencias, información del estado de cuenta, etc. La Administración Federal de la Vivienda, FHA, fija un precio por estos servicios, así el cliente, cuando haya contratado la revisión del tipo de interés de forma anual, pagará 30 dólares y cuando la haya contratado de forma mensual abonará 35 dólares ${ }^{836}$.

Después de analizado lo anterior, se deduce que el coste de la contratación de una HECM es bastante elevado, pues además de los gastos aquí citados habría que incluir también los intereses.

- Breve referencia a los costes relativos de la contratación de un seguro.

Como ya se ha comentado más arriba, dentro de los costes abonados a terceros, encontramos los correspondientes al registro de la garantía. Al inicio de este epígrafe ya se ha hecho referencia al sistema utilizado en este país, caracterizado por ofrecer una mínima protección a los adquirentes de derechos sobre los bienes inmuebles, donde se protege al adquirente respecto de las anotaciones posteriores pero nunca de las anteriores. Esto deriva en que el adquirente del derecho y para una mayor protección, contrate un seguro.

De esta forma, el interesado en adquirir la propiedad u otro derecho real, contrata una póliza por la que se asegura, no el derecho como tal, sino 836 Sánchez Álvarez, I.; López ARes, S. y Quiroga García, R., «Diseño de hipotecas inversas en el mercado español», op. cit., p. 31 . 
una determinada indemnización por si se diera el caso de sufrir algún daño que fuera descubierto tras la firma del contrato con el riesgo incluso de perder el inmueble ${ }^{837}$.

La contratación de este seguro genera un coste adicional con respecto a la contratación de un préstamo ordinario ${ }^{838}$. La compañía aseguradora para tramitar este seguro deberá realizar una investigación previa. En el caso de que acepte la contratación del seguro, el cliente o tomador del seguro tiene que abonar una prima única que asciende al $4 \%$ del valor garantizado ${ }^{839}$.

El contrato de este seguro se ofrece tanto desde el sector privado, a través de compañías aseguradoras privadas, como desde el sector público. En Estados Unidos, el organismo encargado de realizar este servicio es la Federal Housing Administration, $\mathrm{FHA}^{840}$. Estos seguros contratados en el sector público se caracterizan por ser seguros de primas más bajas, concedidos para favorecer determinadas iniciativas o a determinados grupos, como por ejemplo la adquisición de vivienda para familias de renta baja ${ }^{841}$.

Junto a esto, destacar que las pólizas más utilizadas son:

\section{1.- El seguro de título.}

Se contrata para asegurar una indemnización en el supuesto de que se produzca la pérdida del derecho como consecuencia de defectos descubiertos con posterioridad a su adquisición. El pago de esta póliza corre a cargo del adquirente del derecho.

2.- El seguro de acreedor hipotecario.

En esta póliza se asegura que la vivienda sobre la que recae la garantía es propiedad de la entidad que concede el préstamo. El pago de la prima de este seguro es asumido por la parte acreedora, pero en la práctica las

\footnotetext{
${ }^{837}$ MORO SerRano, A., Los sistemas registrales inmobiliarios en los Estados Unidos, op. cit., p. 83.

${ }^{838}$ TAFFIN, C., «La hipoteca inversa o vitalicia», op. cit., p. 10.

839 De LA PUENTE DE AlFARO, F., «La eficacia de...», op. cit., pp. 2207 y 2208.

840 Moro Serrano, A., Los sistemas registrales inmobiliarios en los Estados Unidos, op. cit., p. 86.

841 Información disponible en la página web del Departamento de vivienda y desarrollo urbano: http://www.hud.gov.
} 
entidades suelen repercutir este coste a la parte deudora ${ }^{842}$. Así en el caso de la adquisición de una vivienda a través de un préstamo hipotecario, la parte deudora asumirá el pago de una doble póliza.

\section{Vencimiento y exigibilidad del préstamo}

El vencimiento y exigibilidad de esta HECM se producirá al fallecimiento del deudor, o en caso de que haya un segundo deudor residente en esa vivienda, al fallecimiento de éste. Esta es la causa típica por la que se produce el vencimiento, pero en esta modalidad hipotecaria también se consideran otras causas por las que se otorga a la parte acreedora la facultad para declarar vencido de manera anticipada este préstamo.

Al respecto, la regulación norteamericana no específica las causas por las que se origina este vencimiento. Este vencimiento anticipado se puede producir por el incumplimiento de cualquiera de las obligaciones que se hayan estipulado en el contrato ${ }^{843}$. Así pues, aunque no se diga expresamente, el acreedor puede solicitar el vencimiento anticipado del préstamo porque se haya producido la venta del inmueble o porque el deudor haya abandonado la vivienda.

La parte acreedora, cuando devenga el incumplimiento ${ }^{844}$ de alguna de las obligaciones aseguradas con la hipoteca, podrá elegir entre:

1.- Un procedimiento judicial de ejecución.

Este proceso se inicia con la demanda del acreedor hipotecario frente al deudor y demás titulares de derechos que recaigan sobre el bien inmueble, así como cualquier otra persona que ostente algún interés sobre el inmueble.

\footnotetext{
842 MORO SeRrano, A., Los sistemas registrales inmobiliarios en los Estados Unidos, op. cit., pp. 86-88. 843 Vid. § 206.27 c) iiii CFR.

844 SPRANKLING, J.G., Understanding Property Law, op. cit., pp. 350 y 351.
} 
Para el supuesto de que el juez resuelva a favor de la parte acreedora, en la sentencia se concretará a cuánto asciende la deuda, así como las cláusulas en las que se procederá a la venta pública del inmueble. Los medios de comunicación locales serán los encargados de publicar la venta de esa vivienda.

Este procedimiento, además de ser lento y complejo, se caracteriza por tener un elevado coste.

2. - La venta extrajudicial del bien.

Conocido también como power of sale foreclosure. En este procedimiento, al no existir ningún tipo de control externo, la parte deudora se encuentra más desprotegida.

La parte acreedora, antes de proceder a la venta del inmueble en un lugar público, como sucede con la subasta judicial, debe requerir el pago al deudor, poniendo de manifiesto su intención de ejercer la facultad que le reconoce el contrato en caso de incumplimiento. En caso de que el deudor no haga efectivo el importe de la deuda, la entidad acreedora pasará a notificarle el día, lugar y hora en el que se va a realizar la venta del inmueble.

Esta posibilidad de pactar en el contrato la venta extrajudicial del bien no ha sido admitida en todos los estados.

La parte deudora, tanto si se ha optado por el procedimiento judicial de ejecución como por la venta extrajudicial, a lo largo del proceso siempre podrá abonar el importe de la deuda.

Con respecto a este importe, es decir, la suma total que se debe desembolsar, en esta modalidad hipotecaria la obligación de pago por principal e intereses se limita al valor del bien inmueble. La parte deudora 
únicamente responde con la cantidad obtenida por la venta del bien inmueble. De esta manera, puede suceder que la deuda sea superior al valor del inmueble $y$, por tanto que la parte acreedora se encuentre con un patrimonio negativo. Con el fin de evitar este riesgo, la Administración Federal de la Vivienda ofrece una cobertura federal ${ }^{845}$ a este tipo de préstamos.

La entidad acreedora, para la obtención de esta cobertura (§ 206.15 (FR), debe presentar ante el órgano competente, el certificado en el que conste que el deudor hipotecario ha recibido el asesoramiento contemplado por el Departamento de Vivienda y Desarrollo Humano y una copia del seguro de título concertado. Una vez se haya aportado esta documentación se suscribe un contrato de seguro financiado con cargo a las primas o premiums que abona el deudor o prestatario (§ 206.27 CFR).

A pesar de que el abono de estas primas a la Administración Federal de la Vivienda es asumido por la parte acreedora que debe efectuar cada mes, junto a estas primas mensuales, esta parte tiene que hacer frente al pago de una prima inicial que asciende al $2 \%$ de la cantidad exigible. Pero, en realidad, la entidad acreedora carga esta cantidad al préstamo, de manera que el que paga estas primas es el deudor hipotecario junto con el principal e intereses.

\section{Sistema de Registro adoptado en Estados Unidos}

Dentro del sistema registral aplicado por los Estados Unidos encontramos dos métodos:

1.- Recording.

2.- Torrens.

\footnotetext{
${ }^{845}$ Esta es una de las grandes diferencias que presenta la hipoteca inversa regulada por el sector público
} de la regulada por el sector privado. 
La mayoría de los Estados se sirve del sistema de Registro de documentos o Recording, mientras que una minoría de Estados ha optado por el sistema Torrens o sistema de Registro de derechos más similar al utilizado en nuestro país.

Respecto al sistema Recording o Registro de documentos podemos apreciar que:

Se trata de un Registro de mera transcripción de documentos en el que no se comprueba su contenido. Lo único que se consigue con la inscripción es publicar que un determinado acto se ha celebrado ${ }^{846}$. Mientras que en nuestro país, el registrador ${ }^{847}$ se encarga, bajo su responsabilidad, de la legalidad de las formas extrínsecas de los documentos de toda clase por los que se solicita la inscripción, así como de comprobar la capacidad de los otorgantes y de la validez de los actos constituidos en las escrituras públicas, en este sistema Recording, el registrador solamente asume tareas de archivo de estos documentos, no contemplando si ese acto es o no válido.

El único control que existe, y se da para todos los Estados, con independencia del modo de registro que empleen, es un control externo previo a la celebración del contrato o derecho. Este control se realiza por el notario, figura que verifica la legitimación de las firmas de las partes que otorgan el contrato.

En el caso de que esté todo correcto, el título ${ }^{848}$ se presenta en la oficina registral correspondiente junto con la solicitud de registro del mismo. Este documento se fotocopia y el original sellado se devuelve al titular. De esta manera, se permite el acceso de este documento en su totalidad al Registro sin revisar su contenido y, por tanto, las cláusulas estipuladas por las partes. En el caso de incumplimiento de cualquiera de estas cláusulas ${ }^{849}$ por

\footnotetext{
${ }^{846}$ MORO SeRrano, A., Los sistemas registrales inmobiliarios en los Estados Unidos, op. cit., p. 64. 847 Vid. Artículo 18 de la LH.

${ }^{848}$ De la Puente de Alfaro, F., «La eficacia de...», op. cit., pp. 2222-2226.

849 SprankLING, J.G., Understanding Property Law, op. cit., p. 348. La corte suprema de Estados Unidos, desde 1982, permite las cláusulas por las que en caso de transmisión del inmueble, el acreedor puede
} 
parte del deudor, la parte acreedora podrá solicitar la ejecución de la hipoteca ${ }^{850}$.

Junto a esto, es muy importante señalar que con la utilización de este sistema de Registro, la inscripción del derecho se realiza sin contemplar el principio de tracto sucesivo registral ${ }^{851}$. Con la inscripción de ese documento lo único que se protege es la nueva titularidad, dejando desprotegidas las titularidades hasta ese momento inscritas.

Así, tal y como señala MORO SERRANo ${ }^{852}$, el adquirente, en virtud de un contrato posterior inscrito, goza de preferencia sobre el anterior no inscrito. Por esta razón, el adquirente del derecho debe asegurarse de que la titularidad de ese derecho por parte del transmitente es válida. Esta comprobación, con la finalidad de descartar cualquier error o defecto, la podrá realizar investigando ${ }^{853}$ sobre los documentos que hacen referencia a ese inmueble desde el tiempo más remoto posible. Así, en el caso de que alguna de las anteriores titularidades se impugne porque se efectuó sin la correspondiente facultad para transmitir, o padecía de algún vicio, las inscripciones realizadas con posterioridad sobre la misma finca no serán válidas. Esto significa que el actual propietario podría perder su derecho, en el caso de una HECM, la vivienda habitual. Lo único que podrá plantear o solicitar es una indemnización por daños y perjuicios.

declarar el vencimiento anticipado del préstamo. Estas cláusulas se conocen con el nombre de «due-onsale-clause».

850 De la Puente de Alfaro, F., «La eficacia de...», op. cit., p. 2267.

${ }^{851}$ Artículo 20.1 de la LH: «Para inscribir o anotar títulos por los que se declaren, transmitan, graven, modifiquen o extingan el dominio o demás derechos reales sobre inmuebles, deberá constar previamente inscrito o anotado el derecho de la persona que otorgue o en cuyo nombre sean otorgados los actos referidos».

${ }^{852}$ Moro Serrano, A., Los sistemas registrales inmobiliarios en los Estados Unidos, op. cit., p. 62.

${ }^{853}$ En este punto se ha de hacer una breve matización: el Registro no es un Registro de folio real, sino que es personal, donde sólo se anotan las transmisiones inter vivos y no las mortis causa. Con la intención de agilizar la obtención de esta información, en su día, se creó un índice de personas en el que se detallaba la titularidad de los bienes que poseían. Sin embargo, los Estados Unidos, atendiendo al derecho de libertad civil, no emplean un documento para identificar a las personas, como es nuestro Documento Nacional de Identidad. De ahí, que muchas personas se llamen de la misma manera y sea imposible identificar correctamente el titular de ese derecho. 
Con todo esto, y conforme señala LASARTE ÁLVAREZ ${ }^{854}$, Estados Unidos cuenta con un sistema de publicidad mucho más costoso que el imperante en los mercados europeos.

Según el estudio realizado por la Consultora Oliver Wyam junto con la Federación Hipotecaria Europea ${ }^{855}$, muestra cómo el coste de contratación de un crédito hipotecario es mucho más elevado en los países con un Registro de documentos ${ }^{856}$ que en los países con un Registro de derechos como el nuestro, cuya base se asienta sobre un sistema de publicidad y protección de los derechos $^{857}$. En el mismo estudio también se advierte que en los países donde se utiliza un Registro de documentos, el volumen de préstamos es inferior, el sistema de inscripción y de ejecución es más lento y existen tipos de interés altos y plazos de amortización más breves que en aquellos donde se práctica un Registro de derechos ${ }^{858}$.

En conclusión, aunque la modalidad de hipoteca inversa o HECM ha sido el modelo de referencia en el que se ha basado el legislador español para regular la DA $1 .^{\text {a }}$ de la Ley 41/2007, la regulación de los Estados Unidos es muy extensa y abarca todo tipo de detalles o situaciones, a diferencia de la nuestra, donde se plantean dudas acerca de su interpretación. Además, también ofrece la posibilidad de contratar hipotecas inversas realizadas por el sector privado, así como otras modalidades.

La hipoteca inversa, como instrumento de financiación, en su modalidad de HECM nace con la idea de ser un complemento a la pensión de las personas mayores, y así lograr un mayor bienestar. Para ello, se vale de la existencia de normas de carácter imperativo, de un cuidado sistema de

\footnotetext{
${ }^{854}$ LASARTE ÁlVAREZ, C., «Crisis financiera estadounidense...», op. cit., p. 3.

855 Oliver Wyman, M., Study on the Financial Integration of European Mortgage Markets, European Mortgage Federation, disponible en: http: //www.hypo.org, p. 44.

${ }^{856} \mathrm{~A}$ modo de ejemplo: Francia o Italia.

857 Este estudio se presentó ante la Comisión Europea como uno de los trabajos adjuntos que le permitiría a la Comisión elaborar, con posterioridad, el Libro Blanco sobre la integración de los mercados de crédito hipotecario de la Unión Europea. Libro Blanco de la Comisión, de 18 de diciembre de 2007: Sobre la integración del mercado europeo de crédito hipotecario, (COM (2007) 807 final - no publicado en el Diario oficial).

${ }^{858}$ Vid. con más detalle RAJOY, E., La calificación registral en el marco de la Unión Europea, Colegio de Registradores de la Propiedad, Mercantiles y Bienes Muebles de España, Madrid, 2005, p. 27.
} 
protección de los consumidores y, por supuesto, de la intervención del Gobierno Federal por medio del Departamento de Vivienda y Desarrollo Humano.

A pesar de tener buenos propósitos, el coste de contratación de esta HECM suele ser elevado, de manera que el solicitante de este producto, antes de formalizar la operación deberá estudiar otras posibles opciones que se ajusten a su perfil y supongan el menor riesgo posible. Esta nota es de vital importancia para el solicitante, por ejemplo cuando éste no lleve idea de residir en su vivienda habitual durante mucho tiempo o necesite un préstamo para cubrir un gasto imprevisto de poca cantidad, lo lógico es que opte por otros instrumentos o productos financieros.

Tanto las hipotecas HECM como las hipotecas inversas privadas se caracterizan por ser más costosas que los préstamos convencionales. No obstante, conforme se ha visto en el último punto del epígrafe, encontramos otras modalidades de préstamos HECM, las cuales no requieren un importe mínimo de ingresos y además se pueden usar para cualquier fin.

Junto a este coste, para la contratación de este producto es indispensable que el inmueble objeto de garantía constituya la vivienda habitual. Pues bien, como ya se ha dicho en innumerables ocasiones, dadas las características del público al que esta modalidad va dirigida, el tener que obedecer a este requisito de residir en esa vivienda resultará, en algunas situaciones, difícil de cumplir, pues siguiendo la ley de la naturaleza, estas personas, a medida que vayan cumpliendo años serán candidatas a sufrir enfermedades graves o degenerativas, de manera que tengan que trasladarse a una residencia u hospital para permanecer en una situación estable. En estos casos, y según el tiempo que permanezca fuera de su hogar, puede suceder que al deudor se le notifique la obligación de entregar el inmueble hipotecado o devolver el préstamo que ha sido declarado vencido anticipadamente por parte del acreedor. 
Por último, el sistema registral adoptado por Estados Unidos no ofrece las garantías suficientes para verificar, en un momento dado, que una persona es titular de un derecho.

\section{SEMEJANZAS Y DIFERENCIAS EN LA CONSTITUCIÓN DE UNA HIPOTECA INVERSA, UNA HIPOTECA VITALICIA INGLESA Y UN PLAN HECM}

A modo de realizar una valoración conjunta de estos países, el nacimiento de la hipoteca inversa como un posible instrumento de movilización del patrimonio inmobiliario viene generado por la falta de recursos económicos que se activan con la jubilación.

Esta falta de recursos, en parte se debe a la falta de capacidad del pertinente Estado para garantizar una pensión suficiente y adecuada a las circunstancias de este grupo de población. En nuestro país esta falta de capacidad viene motivada por la insuficiencia de recursos públicos para garantizar un sistema de pensiones adecuado a las circunstancias actuales, en las que cada vez hay más personas en situación de jubilación y la población activa es menor, de manera que este sistema de pensiones no goza de todas las garantías para poder cubrir la totalidad de las pensiones.

En cambio, en Reino Unido y en EEUU esta incapacidad se ha producido porque, desde un principio, siempre se han apoyado en la vía privada como medio para complementar las prestaciones sociales. De ahí que, en estos países, y desde los años sesenta en el caso de Reino Unido, se planteara la hipoteca inversa como un préstamo con cargo al inmueble en la medida en que no implica la transmisión de ese bien. Se presenta como una posible solución para que la persona mayor, dando ese inmueble en garantía, obtenga unos ingresos sin abandonar su hogar. Con esa intención es como surgió esta figura Lifetime Mortgage en Reino Unido y Reverse Mortgage en Estados Unidos. 
Esta hipoteca inversa en ambos países citados, además de presentarse como un complemento a las pensiones de las personas mayores, también se puede utilizar para otros fines, como por ejemplo, para realizar reformas en el inmueble o para financiar otro tipo de actividades, bien comerciales bien de recreo o tiempo libre. No obstante, tanto en Reino Unido, como en EEUU, como en España, atendiendo a la finalidad económico-social para la que ha sido creada esta modalidad hipotecaria, encontramos una serie de características comunes para poder proceder a su contratación. Entre éstas, cabe destacar:

1.- El requisito de la edad. En los tres países y para poder contratar esta hipoteca, la persona interesada deberá contar con una edad elevada, aunque con diferencias en el corte establecido, pues mientras en Reino Unido se exige 55 años o más, en el caso de los Estados Unidos se exige como mínimo 62 y en nuestro país esta edad es más elevada, pues se ha de contar con 65 años cumplidos.

2.- El solicitante, además, deberá ser el titular del inmueble.

3.- La duración del contrato es de carácter vitalicio, es decir, el préstamo vencerá en el momento en que el solicitante o último solicitante fallezca. A partir de ese suceso, la parte acreedora podrá solicitar la devolución del préstamo. Como excepción, en los tres países se contemplan determinados supuestos de vencimiento anticipado.

4.- Para la implantación de esta figura se ha contado con el apoyo del Estado. En los tres países, y más en particular en Reino Unido, la intervención del Estado ha quedado reflejada con la introducción de un régimen de protección de los consumidores basado en la prestación de asesoramiento independiente.

Tanto en Reino Unido como en Estados Unidos esta independencia está garantizada plenamente. Mientras que en España este asesoramiento 
independiente, aunque se contempla en los apartados 3 y 4 de la DA $10^{a}$ de la Ley 41/2007, se reforzó más tarde con la aprobación de la Ley 1/2013 donde se asegura la independencia de las tasadoras para evitar que existan conflictos de intereses por la relación o pertenencia al grupo financiero encargado de la tasación.

En el caso español, este asesoramiento es facilitado por el mismo personal de la entidad de crédito o entidad aseguradora mientras que en Reino Unido y EEUU los encargados de suministrar este asesoramiento son agentes especializados sin ningún vínculo profesional con la entidad que finalmente pueda conceder esta hipoteca.

5.- Los costes de contratación en esta hipoteca son más elevados con respecto a los que se requieren para la formalización de un préstamo convencional. Esta situación se da en los tres países.

Como ya se ha analizado, este coste viene justificado porque se desconoce el momento exacto en que se va a producir el vencimiento del préstamo. De manera que, esta situación genera unos mayores costes a la hora de constituir esta hipoteca, junto a un tipo de interés mayor al fijado para una hipoteca ordinaria.

Dentro de estos costes incluiríamos los de asesoramiento, tal y como se ha comentado en el caso de Reino Unido y en el caso de EEUU, aunque de una manera generalizada se pague por ellos, algunas entidades lo ofrecen de manera gratuita. En nuestro país, nada se dice al respecto. Lo habitual es que el asesoramiento sea gratuito, aunque no quita que en la tramitación de la hipoteca, el banco o entidad crediticia o aseguradora, cobre una determinada comisión por este concepto u otros en los que se incluya este asesoramiento.

Junto a esto, y como se ha visto al final de este epígrafe, en Estados Unidos la constitución de cualquier hipoteca ya no sólo la inversa, es mucho más costosa, y ello, porque el sistema de Registro adoptado por la mayoría de 
los estados es un Registro de documentos o sistema Recording. De forma que, la parte deudora se vea obligada a contratar una póliza con el objetivo de asegurarse la titularidad del bien inmueble o de cualquier otro derecho real.

Estos serían los puntos comunes entre estos tres países. No obstante, también encontramos una serie de diferencias entre España y sus homólogos inglés y estadounidense:

1.- La diferencia más significativa es nuestra Ley $41 / 2007$. En su DA 1 . $^{\text {a }}$ en el apartado 1.a) se ha contemplado la posibilidad de que las personas que pueden optar a esta modalidad hipotecaria, además de las personas mayores de 65 años y los beneficiarios que éste pueda designar, sin tan siquiera fijar un número, también puede ser contratada por todas aquellas personas afectadas de dependencia o personas a las que se les haya reconocido un grado de discapacidad igual o superior al 33 por ciento.

Esta posibilidad de incorporar un beneficiario o beneficiarios no está contemplada ni en Reino Unido ni en EEUU. En estos países, en el caso de que haya más de un solicitante, éste actuará como titular de ese préstamo. Y con respecto a las personas afectadas de dependencia o personas con un grado de discapacidad igual o superior al 33 por ciento, en ambas regulaciones, la inglesa y la estadounidense, la alusión a este colectivo se prevé como una finalidad indirecta, conocida en estos países como situaciones que requieren de cuidados de larga duración.

2. - Otra diferencia sería la relativa al carácter habitual de la vivienda. Mientras que en España, con el propósito de fomentar la contratación de esta hipoteca, se ha dotado de ciertos beneficios fiscales y arancelarios (apartados 7, 8 y 9 de la DA $1 .^{a}$ de la Ley $41 / 2007$ ), para poder optar a esta rebaja fiscal se exige que ese bien inmueble sea la vivienda habitual, de manera que nuestra regulación también nos da la posibilidad de poder contratar una hipoteca inversa sin necesidad de dar en garantía la vivienda habitual, en este caso, sin percibir esas ventajas fiscales. En cambio, tanto en Reino Unido 
como en Estados Unidos el requisito de que esa vivienda dada en garantía sea la habitual, será una condición previa y constante durante toda la vigencia del contrato.

3. - En el estudio realizado de la hipoteca inversa en nuestro país, se ha podido observar que entre las causas de vencimiento anticipadas se contempla la posibilidad de la venta anticipada de ese bien inmueble. En Reino Unido y Estados Unidos estas causas de vencimiento pueden darse por el incumplimiento de cualquiera de las estipulaciones que se hayan contemplado en el contrato por parte del deudor.

Como ya se ha visto, esto viene dado por las diferencias entre nuestro régimen jurídico sustantivo-material con respecto al régimen adoptado por estos dos países.

4. - Y por último, destacar que la información sobre este producto en nuestro país nada tiene que ver con la ofrecida en estos dos países. Esto no hay más que verlo a la hora de acceder a las distintas páginas oficiales en Internet. En nuestro país la información no es clara, incluso induce a error.

Como curiosidad, en muchas de las páginas aseguran que esta hipoteca se puede realizar con la vivienda habitual para posteriormente alquilarla a un tercero, cuando eso, en realidad, a pesar de las lagunas que pueda crear, no tiene ningún sentido. Junto a esto, en 2015 sigue sin actualizarse la única modificación que ha sufrido la Ley 41/2007 a través de la Ley 1/2013 referente a los sujetos que pueden acceder a esta hipoteca inversa.

En cambio, durante el estudio sobre la Lifetime Mortgage en Reino Unido y la Reverse Mortgage en Estados Unidos se ha podido comprobar que la información se actualiza y además en la misma página podemos encontrar una gran carta de productos y servicios para que tanto los clientes, solicitantes o simples curiosos tengamos acceso a todo tipo de información desde los 
productos que se pueden contratar, un apartado para quejas y, por supuesto, toda la legislación vigente.

En el siguiente capítulo se presenta una relación sobre otros productos bancarios o aseguradores para preparar la jubilación y/o para afrontar la situación de dependencia o de discapacidad. 



\section{PARTE III}

\section{EXAMEN DE LA HIPOTECA INVERSA EN ESPAÑA}





\title{
CAPÍTULO XII: OTROS INSTRUMENTOS DE PREVISIÓN PARA MEJORAR
}

\section{LA JUBILACIÓN Y LAS SITUACIONES DE DEPENDENCIA Y/O DISCAPACIDAD}

\begin{abstract}
Analizados estos datos, lo normal sería que durante nuestra etapa en activo nos dedicáramos, con cierta intensidad o regularidad, a planificar nuestra jubilación. Tras repasar los distintos escenarios: nacional, europeo e incluso a nivel mundial ${ }^{859}$, se pude inferir que ahorrar ${ }^{860}$ y disponer de un ahorro privado ${ }^{861}$ para complementar nuestra pensión pública será el mejor modo de garantizarnos una jubilación tranquila y en línea con nuestras necesidades.
\end{abstract}

No hay que olvidar que tras la jubilación se abre otra etapa que debemos planificar para administrar correctamente nuestros recursos. Como principales cambios y en lo que concierne a los ingresos ${ }^{862}$, éstos se verán reducidos en comparación con el último salario de nuestra etapa en activo en un porcentaje que se conoce como tasa de sustitución. Esta tasa dependerá del último salario en activo y de los parámetros que determinen la pensión pública, pero por término medio ronda en España el 75\%. Esto significa que nuestra pensión supondrá un $75 \%$ de nuestro último salario en activo, es decir, nuestros ingresos se verán reducidos en un $25 \%$.

\footnotetext{
${ }^{859}$ Vid. Artículo publicado por el Instituto BBVA de Pensiones: «Los españoles, entre los más confiados a la hora de cumplir sus metas de ahorro para la jubilación» en fecha de 1 de mayo de 2014 (www.jubilaciondefuturo.es). Según este artículo, los expertos en la materia dicen que «cuando se habla de lograr los objetivos para la jubilación, preocupan los datos» y añaden que «los inversores mundiales tienen una cosa en común: la necesidad de ahorrar para la jubilación. Los países tienen distintos programas sociales para ayudar a sus jubilados pero al final los inversores de todo el mundo pueden, y deberían, hacer más cosas para prepararse para ese momento». Así como también el Artículo publicado el día 2 de mayo de 2014: «La UE aboga por impulsar los planes de pensiones privados en su última Directiva» publicado por el Instituto BBVA de Pensiones.

${ }^{860}$ Artículo editado en fecha de 23 de abril de 2014 "Cómo administrar tu ahorro una vez jubilado» publicado por el Instituto BBVA de Pensiones. El citado artículo nos indica unas pautas de cómo administrar nuestros ahorros. Y, además, se hace mención a la hipoteca inversa, que la ofrece de la siguiente manera: «Si nos preocupa descapitalizarnos e ir viendo como bajan nuestros ahorros, y a la vez somos propietarios de una vivienda que ya hemos pagado totalmente, podemos recurrir a la hipoteca inversa». Visto esto, se ha de resaltar que aunque a lo largo de este trabajo, en varias ocasiones, se ha dicho que la hipoteca inversa es un producto en desuso y que a lo largo de su trayectoria ha sido poco comercializado, este artículo está fechado en abril de 2014.

${ }^{861}$ Según el artículo publicado en fecha de 29 de abril de 2014 por el Instituto BBVA de Pensiones denominado «Barómetro del Ahorro en España», las familias españolas ahorraron en 2013 una mayor cantidad de su capital en activos financieros, como es el caso de los fondos de inversión y los fondos de pensiones. Además, según los datos del Banco de España, redujeron su deuda hasta niveles de 2006.

${ }^{862}$ Vid. SAP de Barcelona de 28 de noviembre de 2013 (TOL4.049.895).
} 
Con respecto a los gastos, lo normal es que tras la jubilación, la estructura de los mismos se vea alterada, aunque no tienen por qué reducirse respecto a la etapa en activo. Lo que suele ocurrir en muchos casos es que se sustituyan unos gastos por otros. Por ejemplo, lo normal es que se reduzcan los gastos de desplazamiento, los derivados de las comidas fuera de casa y también los ocasionados por el vestuario de trabajo. Sin embargo puede que surjan otros, como los asociados a una nueva afición para ocupar el tiempo libre.

En definitiva, lo realmente importante a tener en cuenta es que, dada la situación demográfica del país y la difícil situación de la Seguridad Social, basada en un sistema de reparto, en la que los que cotizan ahora pagan las pensiones actuales de los jubilados, se hace imprescindible ir pensando en un complemento para la jubilación.

Cada vez resultará más dificultoso poder cobrar la pensión máxima y además, las previsiones de los estudios que ligan las pensiones a la esperanza de vida, arrojan como conclusión el que las pensiones públicas puedan disminuir en cuantía un $6 \%$ cada década ${ }^{863}$. Por tanto, se ha de tener en cuenta el ahorro para la jubilación y elegir el producto idóneo para cada uno, ya que es una estrategia ganadora dentro de una buena planificación financiera. Ahora bien, en nuestro país, esta planificación resultará un poco difícil de implantar debido, por una parte, a la falta de cultura de ahorro que caracteriza a los ciudadanos españoles y, por otra, la falta de una información clara y concreta por parte de las entidades oferentes.

Señalar también, que además de esta falta de cultura de ahorro por parte de los españoles, nuestra población se está caracterizando por el sobreendeudamiento en los hogares o familias, pues hasta bien entrada la crisis era muy fácil obtener un préstamo para financiar cualquier necesidad o

863 Según datos publicados en la página dedicada a la información financiera por Internet: http: //www.expertofinanciero.es. 
dicho de otra manera, cualquier capricho (por ejemplo, desde un viaje de placer a un televisor de última tecnología). De esta forma, junto a la falta de cultura de ahorro se une la falta de previsión, de ahí que sea necesario plantearse la práctica de un consumo sostenible a lo largo de toda nuestra vida laboral para lograr unos ahorros a la llegada de la jubilación ${ }^{864}$.

Desde el punto de vista de las entidades oferentes ${ }^{865}$, nuestro país carece de un fuerte mercado de productos de financiación de la jubilación. Para cambiar esto, debería haber una mayor transparencia en la comercialización de estos productos a través de un asesoramiento financiero individualizado, y sin que ello suponga un gasto adicional para el cliente. Además, el Estado mediante guías ${ }^{866}$ y campañas de concienciación tendría que procurar una mayor información y acceso a estos productos. Para ello, sería necesario establecer un marco legal más claro que el existente y una normativa fiscal que beneficie la contratación de los distintos instrumentos financieros para la jubilación ${ }^{867}$.

A continuación se van a desarrollar los diferentes instrumentos de previsión que hay en el mercado, aunque los más conocidos, tal vez porque han gozado de una mayor campaña publicitaria y de promoción, tanto por las compañías aseguradoras como por los bancos y entidades de crédito, son: los planes y fondos de pensiones y los seguros de vida. Pese a su menor popularidad, también se ha de hacer mención al Plan de Previsión Asegurado (PPA), al seguro de dependencia, al seguro de jubilación y, por su reciente

\footnotetext{
${ }^{864}$ Tan sólo un $18 \%$ de la población ha calculado los recursos necesarios para mantener un nivel de vida adecuado una vez llegada la edad de jubilación. Confían en que, llegado el momento si surgen problemas, sea la Administración o sus familiares quienes los resuelvan. Aunque ya se ha visto como el Estado, en muchas ocasiones, no cuenta con los recursos para hacer frente a esas situaciones. Así lo han resaltado Alfaro FAUS, M. y VALLÉs LóPEZ, I., La previsión y el ahorro ante el envejecimiento de la población, Fundación Edad \& Vida, IV Premio Edad \&Vida, 2009, p. 31, disponible en: http://www.edadvida.org/publicaciones_ficha.php?id=47६ide $=$.

${ }^{865}$ Prueba de ello, es la noticia publicada en fecha de 18 de noviembre de 2013 en ABC, Economía, correspondiente al XX Encuentro del Sector Asegurador, organizado por $A B C$ y Deloitte en colaboración con Mapfre. Se dice que España no ahorra. Teniendo en cuenta seguros y fondos de pensiones contratados, en toda Europa hay un déficit de provisiones que se tenían que haber constituido, pero no lo han hecho, de unos 425.000 millones de euros. En el caso concreto de las familias españolas, ese déficit es de al menos 70.000 millones. De ahí, que el sector asegurador reclame incentivos fiscales al ahorro y una reforma de las pensiones más profunda que garantice la viabilidad del sistema.

${ }^{866}$ Como ejemplo destacar la Guía útil para Planes de Pensiones elaborada por CASER. Ediciones Empresa Global, 2012.

${ }^{867}$ Alfaro Faus, M. y Vallés López, I., La previsión..., op. cit., p. 56.
} 
incorporación, a los Planes Individuales de Ahorro Sistemático (PIAS) y al Plan de Ahorro a Largo Plazo (PALP).

\section{PLANES Y FONDOS DE PENSIONES}

En España, actualmente, los planes y fondos de pensiones, por su comodidad y sus ventajas fiscales, son los productos más utilizados para financiar la jubilación. Los Planes y Fondos de Pensiones se regulan en el Real Decreto Legislativo 1/2002, de 29 de noviembre, por el que se aprueba el texto refundido de la Ley de Regulación de los Planes y Fondos de Pensiones ${ }^{868}$.

En cuanto a la naturaleza de los planes de pensiones, ésta viene tipificada en el artículo 1 del citado Real Decreto Legislativo y expresa lo siguiente:

«1. Los planes de pensiones definen el derecho de las personas a cuyo favor se constituyen a percibir rentas o capitales por jubilación, supervivencia, viudedad, orfandad o invalidez, las obligaciones de contribución a los mismos y, en la medida permitida por la presente Ley, las reglas de constitución y funcionamiento del patrimonio que al cumplimiento de los derechos que reconoce ha de afectarse.

2. Constituidos voluntariamente, sus prestaciones no serán, en ningún caso, sustitutivas de las preceptivas en el régimen correspondiente de la Seguridad Social, teniendo, en consecuencia, carácter privado y complementario o no de aquéllas.

Queda reservada la denominación de «planes de pensiones», así como sus siglas, a los planes regulados por esta Ley».

De esta manera, los planes de pensiones individuales ${ }^{869}$ son contratos en virtud de los cuales se efectúan aportaciones que se van acumulando y quedan permanentemente invertidas en activos financieros, con la finalidad

\footnotetext{
868 BOE núm. 298, de 13 de diciembre de 2002.

869 Para Jiménez SÁnCHEZ, G.J., Derecho Mercantil: IV. Títulos-Valores, V. Obligaciones y contratos mercantiles, VI. Derecho Concursal mercantil y VII. Derecho de la navegación, Ariel Derecho, Barcelona, 2000, p. 680: Los Planes de Pensiones pueden definirse como: «contratos colectivos de previsión... de los que surge una relación jurídica entre las partes de la que deriva la obligación de hacer aportaciones en los términos pactados y el derecho a recibir pensiones, bien a favor de los propios partícipes o bien de terceros beneficiarios».
} 
de ir constituyendo un ahorro ${ }^{870}$ (derechos consolidados) para el cobro de prestaciones cuando se produzca alguna de las contingencias previstas ${ }^{871}$ :

- Jubilación: acceso efectivo a la jubilación en el Régimen de la Seguridad Social correspondiente, ya sea a la edad ordinaria, anticipada o posteriormente.

- Incapacidad laboral del partícipe: incapacidad permanente total para la profesión habitual, absoluta y permanente para todo trabajo o gran invalidez, según los criterios de la Seguridad Social.

- Fallecimiento del partícipe o beneficiario: puede dar derecho a prestaciones de viudedad, orfandad o a favor de otras personas designadas.

- Dependencia severa o gran dependencia: cuando, por pérdida de autonomía mental o física, se necesita la asistencia continua de otra persona para realizar actividades básicas de la vida diaria.

Cuando se produzca cualquiera de estas contingencias, el beneficiario, que puede ser el partícipe, es decir, la persona a cuyo nombre se crea el Plan y la encargada de realizar las aportaciones (o también puede ser otra persona designada) tendrá derecho a recibir una prestación que será compatible con las prestaciones y pensiones públicas a las que también pudiera tener derecho.

Con respecto a las aportaciones, éstas son cantidades de dinero que se van realizando al Plan. En este caso, el partícipe suele tener mucha flexibilidad para fijar la cuantía y la periodicidad de las aportaciones, por lo que se puede decir que es un producto accesible a cualquier economía. Además, se suele permitir que el partícipe realice aportaciones periódicas de

\footnotetext{
870 Así lo señalan MANCHÓN, R. y ALBERT, M., Conocer los productos seguros: Planes y fondos de pensiones, estrategia de planificación de la jubilación, Profit. Colección Manuales de Asesoramiento Financiero, Barcelona, 2008, p. 61, los planes de pensiones «son el producto por excelencia para captar el ahorro privado para la jubilación».

${ }^{871}$ En cuanto a la liquidez, los Planes de Pensiones sólo se pueden rescatar cuando se produce la contingencia de: fallecimiento, invalidez o jubilación; en casos de paro de larga duración -una vez agotada la prestación por desempleo-, por enfermedad grave y desde hace un tiempo (mayo de 2013) también se puede rescatar para evitar desahucios. Según el artículo publicado en $A B C$ en fecha de 24 de junio de 2013, el actual Gobierno ya se plantea abrir ventanas de liquidez a partir de los diez años de vida del plan. En este sentido, en el año 11 se podría rescatar lo aportado en el primero, en el doce, lo del segundo, y así sucesivamente. Además, en el mismo artículo también se recoge que el Gobierno plantea que se estudien medidas fiscales para incentivar la contratación de estos planes de pensiones.
} 
cuantía determinada, fijando previamente la frecuencia (mensual, trimestral, bianual...) de las mismas al margen de las extraordinarias que desee.

Las prestaciones de los Planes de Pensiones son dinerarias y pueden ser:

- En forma de capital, a través de la percepción de un pago único.

- Como renta: percepción de dos o más pagos sucesivos con periodicidad regular.

- Prestaciones mixtas que combinen rentas y capital.

- Y, por último, prestaciones distintas de las anteriores en forma de pagos sin periodicidad regular.

La opción de renta a su vez puede ser:

- Vitalicia: pagos durante el resto de la vida del beneficiario.

- Temporal: pagos periódicos durante un tiempo determinado.

La cuantía de la prestación vendrá dada por los derechos consolidados que son el importe acumulado de las aportaciones realizadas por el partícipe más los rendimientos generados, es decir, la rentabilidad obtenida.

Entre los mayores atractivos de los Planes de Pensiones destacan sus ventajas fiscales $^{872}$, ya que todas las aportaciones podrán reducirse en la base imponible del Impuesto sobre la Renta de Personas Físicas (IRPF). Este ahorro fiscal se produce en el mismo año en el que se hayan realizado las aportaciones. Ahora bien, existen unos límites máximos de reducción.

Respecto a las prestaciones, siempre tributarán como rendimientos del trabajo, sujetos a retención a cuenta. Esto es así independientemente de cuál haya sido la forma de su percepción (capital, renta, combinación de ambas o cobros flexibles), el sujeto que las reciba (el propio partícipe u otro $\overline{872}$ Vid. más ampliamente la Guía útil para Planes de Pensiones..., op. cit., pp. 69-79. 
beneficiario) y la contingencia de la que deriven (jubilación, fallecimiento, incapacidad permanente o dependencia). También se tratarán fiscalmente como rendimientos del trabajo las cantidades percibidas en los supuestos excepcionales de enfermedad grave y desempleo de larga duración.

Además de lo citado, también conviene subrayar que:

1.- No es un producto que ofrece liquidez. Sólo se puede disponer del dinero de un Plan de Pensiones si se produce alguna de las contingencias cubiertas por el Plan. En consecuencia, no es un producto adecuado para otros fines. No obstante, si el Plan de Pensiones así lo establece, se podrá rescatar su ahorro, en tres supuestos:

- Enfermedad grave.

- Desempleo de larga duración.

- Y, desde la entrada en vigor de la Ley $1 / 2013$ se añade una Disposición Adicional Séptima sobre la Disponibilidad de los planes de pensiones en caso de procedimiento de ejecución sobre la vivienda habitual.

2.- No es un producto exento de riesgo: las aportaciones de los partícipes y cualesquiera otros recursos adscritos al Plan de Pensiones, se integrarán obligatoriamente en un fondo de pensiones administrado por una entidad gestora con el concurso de una entidad depositaria. El gestor es el responsable de invertir el dinero en distintos instrumentos financieros con diferentes niveles de riesgo, como por ejemplo, depósitos bancarios, títulos de renta fija (deuda pública y privada), renta variable (en Bolsa), futuros y opciones, otros fondos, etc.

En el mercado hay infinidad de planes con diferentes políticas de inversión, más o menos agresivas. Cuanto mayor es la hipotética rentabilidad, mayor el riesgo. Por tanto, será importante elegir un producto que se ajuste a las expectativas de rentabilidad y riesgo del contratante o beneficiario. 
Existe no sólo la posibilidad sino la facilidad para cambiar de un plan a otro sin penalización. Y, además, cualquier persona puede disponer de varios planes con niveles de riesgo distintos y así diversificar su inversión.

3.- Nadie puede garantizar el futuro: los planes de pensiones han sufrido desde su aprobación cambios legislativos y fiscales. Por ello, nunca estará de más que se cuente con otro producto adicional de ahorro-inversión para la jubilación.

Prueba de ello, es que con la aprobación de la Ley $26 / 2014$, los planes de pensiones y otros sistemas de previsión social han sufrido varios cambios con la reforma fiscal, tanto en las aportaciones como en el rescate. Así, se reducen los máximos para las aportaciones a planes de pensiones a 8.000 euros anuales, sin que pueda superar el 30\% de la suma de los rendimientos netos del trabajo y de actividades económicas.

Además, se regula un nuevo supuesto de liquidez por aportaciones a Planes de Pensiones, Planes de Previsión Asegurados, Planes de Previsión Social Empresarial y Contratos de Seguro concertados con mutualidades de previsión social, permitiendo el rescate anticipado a partir del décimo año de antigüedad de sus aportaciones.

Respecto a los Fondos de Pensiones, en el artículo 2 del Real Decreto Legislativo, se legisla la naturaleza de los mismos. Citamos textualmente: «Los fondos de pensiones son patrimonios creados al exclusivo objeto de dar cumplimiento a planes de pensiones, cuya gestión, custodia y control se realizarán de acuerdo con la presente Ley».

Y, en palabras de ROMERo BURILLO ${ }^{873}$ : «El Fondo de Pensiones, tal y como nos dice la Ley y el Reglamento, es un patrimonio conformado a partir del acuerdo de constituir un Plan de Pensiones, lo cual lleva al establecimiento de la obligación de realizar unas aportaciones económicas ya sea por parte del promotor, por parte del partícipe o de forma

873 Romero Burillo, A.M., Los Planes de Pensiones del Sistema de Empleo, Aranzadi, Cizur Menor (Navarra), 2002, pp. 147 y 148. 
conjunta por ambas partes. Por tanto, inicialmente el Fondo se constituye por medio de aportaciones de las partes que constituyen un Plan de Pensiones».

Además, tal y como señala la misma autora ${ }^{874}$ un Fondo de Pensiones, no es únicamente un medio de acumulación y mantenimiento de un patrimonio que va generando e incrementando a medida que se realizan las contribuciones de los sujetos obligados de acuerdo con lo establecido en el Plan sino que, además, el Fondo se encarga de la gestión de los recursos que lo conforman, abordando la inversión de los mismos.

\section{PLANES DE PREVISIÓN ASEGURADOS}

Los Planes de Previsión Asegurados (PPA) son seguros de vida destinados a constituir un capital que se percibe en el momento de producirse la contingencia establecida en el contrato. La cobertura mayoritaria es la de jubilación.

Esta modalidad se incorporó en el Real Decreto 27/2003, de 10 de enero y en la actualidad se regula en la Ley 35/2006, de 28 de noviembre, del Impuesto sobre la Renta de las Personas Físicas y de modificación parcial de las leyes de los Impuestos sobre Sociedades, sobre la Renta de no Residentes y sobre el Patrimonio ${ }^{875}$ (LIRPF). Así, los Planes de Previsión Asegurados se pueden contemplar en el artículo 51.3 de la citada Ley.

Los Planes de Previsión Asegurados también fueron regulados en la Disposición adicional cuarta de la Ley 41/2007 correspondiente al Aseguramiento de Rentas Futuras por la constitución de una hipoteca inversa. En esta Disposición se señala que:

«Las disposiciones periódicas que pueda obtener el beneficiario como consecuencia de la constitución de una hipoteca inversa podrán destinarse, total o parcialmente, a la

\footnotetext{
874 Ibíd., pp. 148 y 149.

875 BOE núm. 285, de 29 de noviembre.
} 
contratación de un plan de previsión asegurado, en los términos y condiciones previstos en el apartado 3 del artículo 51 de la Ley 35/2006, de 28 de noviembre, del Impuesto sobre la Renta de las Personas Físicas y de modificación parcial de las leyes de los Impuestos sobre Sociedades, sobre la Renta de no Residentes y sobre el Patrimonio. A estos efectos, se asimilará a la contingencia de jubilación prevista en la letra b) del apartado 3 del artículo 51 de la citada Ley 35/2006, la situación de supervivencia del tomador una vez transcurridos diez años desde el abono de la primera prima de dicho plan de previsión asegurado.

La provisión matemática del plan de previsión asegurado no podrá ser objeto de movilización a otro instrumento de previsión social, ni podrán movilizarse a aquél los derechos consolidados o las provisiones matemáticas de otros sistemas de previsión social».

De esta manera, el contribuyente debe ser el tomador, asegurado y beneficiario y como ya se ha comentado, la principal contingencia a cubrir es la de jubilación. Además, este tipo de seguro estará obligado a ofrecer una garantía de interés. Junto a esto, en el condicionado de la cláusula deberá constar, de forma expresa y destacada, que se trata de un plan de previsión asegurado.

Su régimen jurídico y fiscal se asimila al de los Planes de Pensiones individuales. En otras palabras, esta modalidad está a medio camino entre los seguros de vida y los planes de pensiones.

Su funcionamiento y características: contingencias cubiertas, forma de cobrar la prestación, iliquidez y supuestos excepcionales de liquidez, también son iguales a los de los Planes de Pensiones.

Tal y como señala COSTA FonT ${ }^{876}$, esta figura, además de la posible desgravación fiscal, ofrece una rentabilidad y un capital fijos. Por tanto, la diferencia entre los dos productos es que el Plan de Previsión Asegurado ofrece un tipo de interés garantizado, de manera que no existe la posibilidad de perder el capital invertido.

La Ley permite movilizar los derechos económicos de un Plan de Pensiones y de un Plan de Previsión Social empresarial a un Plan de Previsión 876 Costa Font, J.; Gil Trafesí, J. y Mascarilla Miró, O., Capacidad de..., op. cit., p. 48. 
Asegurado y al revés sin penalización. No obstante, hay que tener en cuenta que, en aquellos contratos que cuenten con inversiones asignadas, el importe a movilizar será el valor de mercado de esas inversiones en ese momento, por tanto, su valor puede variar en función de las fluctuaciones de los mercados financieros.

Los Planes de Previsión Asegurados (PPA) son productos pensados para personas más conservadoras, o cercanas a la edad de la jubilación, que no quieren correr riesgos. Pese a su planteamiento conservador no han tenido todo el éxito que se pretendía con su regulación, ya que, el número de partícipes hasta la fecha es apenas significante ${ }^{877}$.

\section{LOS PLANES INDIVIDUALES DE AHORRO SISTEMÁTICO}

Los Planes Individuales de Ahorro Sistemático (PIAS) ${ }^{878}$ también son seguros de vida que buscan canalizar el ahorro a largo plazo para acumular un capital que sirva de complemento a la jubilación. Se trata de seguros individuales de ahorro a largo plazo cuya finalidad es ir pagando primas para constituir una renta vitalicia asegurada que podrá percibirse a partir de una edad señalada en el contrato.

Desde el punto de vista fiscal, a diferencia de los Planes de Pensiones y los Planes de Previsión Asegurados, las primas pagadas no reducen la base imponible del IRPF y por ello no tienen beneficios fiscales durante la etapa del ahorro. En cambio, cuando se cobra la prestación como renta vitalicia, los rendimientos generados, es decir, la diferencia entre el valor de la renta en el momento de percibirla y la suma de las primas satisfechas, están totalmente exentos de impuestos, siempre que se cumplan los siguientes requisitos:

\footnotetext{
877 Según el Informe Estadístico de Instrumentos de Previsión Social Complementaria 2010, Ministerio de Economía y Hacienda, Dirección General de Seguros y fondos de pensiones, disponible en: www.dgsfp.meh.es, a finales del año 2010, el número de Planes de Previsión Asegurados era de 158 y el número de asegurados ascendía a 638 de los que un 65\% aportaba únicamente menos de 900 euros, es decir, cifras apenas significativas.

${ }^{878}$ En la página web de Finanzas para todos del Banco de España: www.finanzasparatodos.es/ y la de la Comisión Nacional del Mercado de Valores (CNMV): www.cnmv.es se puede encontrar más información.
} 
- Que el cobro de la renta empiece como mínimo diez años más tarde que el pago de la primera prima.

- Que el tomador del seguro, asegurado y beneficiario sean la misma persona.

- Que las primas pagadas no sean ni inferiores a 8.000 ni superiores a 240.000 euros anuales.

Otra característica diferenciadora de los Planes Individuales de Ahorro Sistemático $(\mathrm{PIAS})^{879}$ es que su disfrute no está ligado a los supuestos de jubilación, incapacidad laboral, fallecimiento y gran dependencia, como ocurre en los Planes de Pensiones y en los Planes de Previsión Asegurados (PPA). Esto significa que se puede empezar a cobrar la renta sin esperar a la edad de la jubilación, aunque sí tiene que haber pasado el plazo mínimo de 10 años desde la primera aportación para su disfrute.

\section{PLAN DE AHORRO A LARGO PLAZO}

Con la incorporación de la Ley 26/2014 se aprueba de manera definitiva la reforma fiscal en materia del impuesto sobre la Renta de las Personas Físicas. De esta forma, se ha creado un nuevo instrumento denominado Plan de Ahorro a Largo Plazo o PALP, por el que se establece una exención para los rendimientos positivos generados por seguros de vida, depósitos y contratos financieros a través de los cuales se instrumentan los PALP, siempre que no se efectúen disposiciones del capital resultante antes de finalizar un plazo de cinco años desde su apertura.

\footnotetext{
${ }^{879}$ Un ejemplo de un Plan de Inversión de Ahorro Sistemático sería el siguiente: Si ahorramos desde los 40 a los 65 años 200 euros al mes, y suponemos una rentabilidad media anual del $8 \%$ (sólo alcanzable si la inversión se realiza en renta variable e invirtiendo a largo plazo), conseguiremos al final un capital de unos 220.000 euros. Cuando nos jubilemos obtendremos durante 20 años unos 15.000 euros, es decir, un sueldo mensual de 1.311 euros. Si la inversión la hacemos durante 30 años, obtendríamos unos 375.000 euros.
} 


\section{SEGURO DE JUBILACIÓN}

Los seguros de jubilación son seguros de vida mixtos, en los que se combinan, por una parte, una prestación en caso de muerte $y$, por otra, una prestación en caso de supervivencia y cuya finalidad es la de constituir un capital asegurado a largo plazo mediante el pago de cuotas periódicas denominadas primas de seguro. La prestación se podrá recibir en forma de capital, renta temporal o renta vitalicia.

Este producto ofrece mayor flexibilidad que un Plan de Pensiones y un Plan de Previsión Asegurado. No existen límites respecto al importe de las primas y goza de total liquidez, aunque las entidades aseguradoras cobran gastos por la desinversión anticipada. Además, no hay que esperar a los 65 años, ni a que transcurra ningún plazo determinado para poder recibir la prestación. De tal manera, que en el momento en que se quiera retirar el capital y las plusvalías generadas, se podrá hacer en forma de capital, renta temporal o renta vitalicia. En estos casos, se pagará el impuesto sólo por las plusvalías generadas como rendimiento de capital mobiliario que en la actualidad oscila entre el 21 y el $27 \%$.

En cuanto a su tratamiento fiscal, las aportaciones no dan derecho a ninguna deducción del IRPF.

\section{SEGURO DE DEPENDENCIA}

El seguro de dependencia ${ }^{880}$ se reguló por primera vez en la Disposición Adicional Segunda de la Ley 41/2007 de 7 de diciembre, es decir, en la misma Ley que legisla la hipoteca inversa.

\footnotetext{
${ }^{880}$ El seguro de dependencia es consecuencia de la Disposición Adicional Séptima de la Ley 39/2006 de Dependencia en la que se específica que:

«1. El Gobierno, en el plazo de seis meses, promoverá las modificaciones legislativas que procedan, para regular la cobertura privada de las situaciones de dependencia.

2. Con el fin de facilitar la cofinanciación por los beneficiarios de los servicios que se establecen en la presente Ley, se promoverá la regulación del tratamiento fiscal de los instrumentos
} 
En esa Disposición Adicional Segunda relativa al seguro de dependencia se indica que la cobertura de la dependencia podrá instrumentarse bien a través de un contrato de seguro suscrito con entidades aseguradoras, incluidas las mutualidades de previsión social, o bien a través de un plan de pensiones.

En el apartado 2 de la citada Disposición Adicional se refleja que: «La cobertura de la dependencia realizada a través de un contrato de seguro obliga al asegurador, para el caso de que se produzca la situación de dependencia, conforme a lo dispuesto en la normativa reguladora de la promoción de la autonomía personal y atención a las personas en situación de dependencia, y dentro de los términos establecidos en la ley y en el contrato, al cumplimiento de la prestación convenida con la finalidad de atender, total o parcialmente, directa o indirectamente, las consecuencias perjudiciales para el asegurado que se deriven de esta situación.

El contrato de seguro de dependencia podrá articularse tanto a través de pólizas individuales como colectivas.

En defecto de norma expresa que se refiere al seguro de dependencia, resultará de aplicación al mismo la normativa reguladora del contrato de seguro y la de ordenación y supervisión de los seguros privados.

Conforme a lo establecido en el artículo 6 del Texto Refundido de la Ley de Ordenación y Supervisión de los Seguros Privados, aprobado por Real Decreto Legislativo $6 / 2004$, de 29 de octubre, las entidades aseguradoras deberán contar con la preceptiva autorización administrativa y demás requisitos necesarios para el desarrollo de la actividad aseguradora en España en los ramos de vida o enfermedad.

Para la cobertura de la contingencia de la dependencia por las mutualidades de previsión social resultará de aplicación lo dispuesto por los artículos 64, 65 y 66 del Texto Refundido de la Ley de Ordenación y Supervisión de los Seguros Privados, aprobado por Real Decreto Legislativo 6/2004, de 29 de octubre, y su normativa reglamentaria de desarrollo».

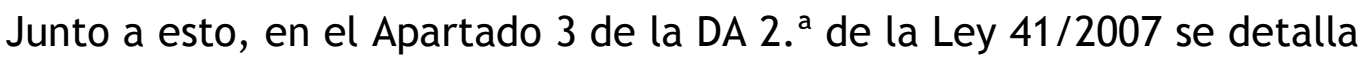
que: «Los planes de pensiones que prevean la cobertura de la contingencia de dependencia deberán recogerlo de manera expresa en sus especificaciones. En todo aquello no expresamente previsto resultará de aplicación el Texto Refundido de la Ley de Regulación de los Planes y Fondos de Pensiones, aprobado por Real Decreto Legislativo 1/2002, de 29 de noviembre, y su normativa de desarrollo».

privados de cobertura de la dependencia». Es decir, se trata de una orden por parte del legislador al Gobierno. 
De esta manera, el seguro de dependencia ${ }^{881}$ se puede definir como un seguro privado en el que el asegurador se compromete, para el caso de que se produzca la situación de dependencia, conforme a lo dispuesto en la normativa reguladora de la promoción de la autonomía personal y atención a las personas en situación de dependencia y dentro de los términos establecidos en la Ley y en el contrato, al cumplimiento de la prestación convenida con la finalidad de atender, total o parcialmente, directa o indirectamente, los perjuicios para el asegurado que se deriven de dicha situación, recibiendo a cambio y en contraprestación, el cobro de prima única o periódica.

La compañía aseguradora cumplirá con su obligación, utilizando alguna de estas fórmulas: prestaciones económicas, en forma de capital o renta fijadas a tanto alzado, o mediante prestaciones asistenciales.

Estos servicios podrán ser prestados de forma directa o también a través de la contratación de un tercero. En cualquier caso y dadas las características de la dependencia, y en particular la necesidad de unos cuidados que suelen perdurar en el tiempo, la mayoría de las compañías aseguradoras no se han esmerado en ofrecer este producto.

\section{SEGURO DE VIDA}

El seguro de vida viene legislado en la Ley $50 / 1980$, de 8 de octubre, de Contrato de Seguro (LCS) ${ }^{882}$. En concreto, se regula en el artículo 83 de la LCS que dispone lo siguiente:

«Por el seguro de vida el asegurador se obliga, mediante el cobro de la prima estipulada y dentro de los límites establecidos en la Ley y en el contrato, a satisfacer al beneficiario un capital, una renta u otras prestaciones convenidas, en el caso de muerte o bien de supervivencia del asegurado, o de ambos eventos conjuntamente.

\footnotetext{
${ }^{881}$ Heras Manzano, M.M., «El seguro privado de dependencia como mecanismo de previsión voluntaria de la dependencia», RCDI, Año n 85, noviembre-diciembre, № 716, Madrid, 2009, pp. 2879 y 2880.

882 Publicada en el BOE de 17 de octubre de 1980.
} 
El seguro de vida puede estipularse sobre la vida propia o la de un tercero, tanto para caso de muerte como para caso de supervivencia o ambos conjuntamente, así como sobre una o varias cabezas.

Son seguros sobre la vida aquellos en que, cumpliendo lo establecido en los párrafos anteriores, la prestación convenida en la póliza ha sido determinada por el asegurador mediante la utilización de criterios y bases de técnica actuarial».

Como se puede observar, el seguro de vida ${ }^{883}$ interesa más para el caso de muerte o supervivencia que como instrumento de previsión o ahorro.

Con respecto al derecho a la prestación en el caso de supervivencia, ésta se producirá en el momento en el que se cumpla una determinada edad, que en la práctica suele coincidir con la edad de jubilación. De esta manera, la prestación generada por la contratación de este seguro de vida ${ }^{884}$ se configurará como un complemento privado a la pensión recibida de la Seguridad Social.

También parece oportuno señalar que en la Disposición final segunda de la Ley $1 / 2013$ se modificó el Texto Refundido de la Ley de Ordenación y Supervisión de los Seguros Privados, aprobado por el Real Decreto Legislativo $6 / 2004$, de 29 de octubre.

En este sentido, el apartado 3 del artículo 60 del Texto Refundido de la Ley de Ordenación y Supervisión de los Seguros Privados, aprobado por el Real Decreto Legislativo 6/2004, de 29 de octubre, sufrió una pequeña variación en los siguientes términos:

«En los seguros de vida en que el tomador asume el riesgo de la inversión se informará de forma clara y precisa acerca de que el importe que se va a percibir depende de fluctuaciones en los mercados financieros, ajenos al control del asegurador y cuyos resultados históricos no son indicadores de resultados futuros.

\footnotetext{
${ }^{883}$ La hipoteca inversa tiene ciertas similitudes con el seguro de vida, prueba de ello es la enmienda número 52 presentada en el Congreso por el grupo parlamentario catalán Convergència i Unió, donde se proponía limitar la concesión de la llamada hipoteca inversa a las entidades aseguradoras que operasen en el ramo de vida.

${ }^{884}$ Para una mayor información vid. JURADo GIL, J., «El Seguro de Vida en España: Factores que influyen en su proceso», Fundación Mapfre, 2009.
} 
En aquéllas modalidades de seguro de vida en las que el tomador no asuma el riesgo de la inversión se informará de la rentabilidad esperada de la operación, considerando todos los costes. Las modalidades a las que resulte aplicable así como la metodología de cálculo de la rentabilidad esperada se determinarán reglamentariamente».

En resumen, la hipoteca inversa podría ser una alternativa a los Planes de Pensiones y a los Planes de Inversión de Ahorro Sistemático para que los jubilados o los futuros jubilados puedan afrontar su retiro laboral sin perder poder adquisitivo.

Por último, destacar la escasa utilización en nuestro país de estos instrumentos privados complementarios. Ahora bien, tras el breve repaso realizado en este punto, y tal y como se presenta el escenario relativo a las pensiones públicas $\mathrm{y}$, más concretamente, las correspondientes a la jubilación, nos deberíamos plantear la contratación de estos instrumentos para percibir unas rentas complementarias en la etapa de nuestra jubilación. De manera que, tanto por el Gobierno como por el sector bancario y por el sector de las aseguradoras se debería hacer una mayor publicidad para que el público objetivo conozca estas figuras y pueda así formalizar su contratación estableciendo como primera pauta la necesidad de ahorrar para el futuro ${ }^{885} \mathrm{o}$ etapa de la tercera edad.

En el último capítulo del programa se realiza un examen planteando las posibilidades que podría tener nuestra hipoteca inversa para poder comercializarse como cualquier otra hipoteca, es decir, con qué o cuántos recursos tendremos que partir para que esta hipoteca pueda tener éxito en nuestro país.

\footnotetext{
${ }^{885}$ En este sentido, LóPEZ CUMBRE, L., «La revisión del sistema de pensiones: recorte/reforma de las pensiones en 2010», El Cronista del Estado Social y Democrático del Derecho, núm. 14, lustel, Madrid, 2010, p. 28, señala que: «El mantenimiento del incentivo a la protección privada complementaria y el incremento de su ámbito de cobertura son dos fórmulas que sirven para aliviar los déficit de cobertura que surgirán, en un futuro no muy lejano, para garantizar la viabilidad del sistema público».
} 



\section{CAPÍTULO XIII: PERSPECTIVA DE DESARROLLO DE LA HIPOTECA INVERSA EN ESPAÑA}

\section{ANÁLISIS ESTRATÉGICO DE LA HIPOTECA INVERSA EN ESPAÑA: DAFO/CAME}

Una vez analizada la hipoteca inversa en nuestro país, así como la comparativa con Reino Unido y Estados Unidos, donde esta figura sí que está asentada, y tras proponer otros productos para afrontar la etapa de jubilación o situación de dependencia o de discapacidad, se va a realizar un estudio estratégico que se completará con el análisis DAFO/CAME de nuestra Hipoteca Inversa como un posible producto hipotecario en nuestro mercado crediticio.

\section{Perspectiva Interna}

\begin{tabular}{|l|l|}
\hline \multicolumn{1}{|c|}{ Debilidades } & \multicolumn{1}{|c|}{ Fortalezas } \\
\hline $\begin{array}{l}\text { Dependencia de los Bancos, entidades de } \\
\text { crédito y entidades aseguradoras. }\end{array}$ & $\begin{array}{l}\text { Orientación exclusiva a las personas para } \\
\text { alcanzar los mayores índices de fidelidad de } \\
\text { este producto, tanto por parte de las } \\
\text { entidades colaboradoras como de los } \\
\text { clientes. }\end{array}$ \\
\hline $\begin{array}{l}\text { Producto creado en 2007, pero su } \\
\text { incorporación en el mercado y captación de } \\
\text { clientes ha resultado fallida. }\end{array}$ & $\begin{array}{l}\text { Instrumento idóneo para propietarios de } \\
\text { inmuebles muy bien valorados y que perciban } \\
\text { unas rentas pequeñas. }\end{array}$ \\
\hline
\end{tabular}




\begin{tabular}{|l|l|}
\hline \multicolumn{1}{|c|}{ Debilidades } & \multicolumn{1}{|c|}{ Fortalezas } \\
\hline $\begin{array}{l}\text { Personal no cualificado para asesorar sobre } \\
\text { este instrumento financiero. }\end{array}$ & $\begin{array}{l}\text { Modalidad dirigida a las personas de edad } \\
\text { igual o superior a los 65 años o afectadas de } \\
\text { dependencia o personas que se les haya } \\
\text { reconocido un grado de discapacidad igual o } \\
\text { superior al 33 por ciento. }\end{array}$ \\
\hline $\begin{array}{l}\text { Alta necesidad de colaboración por parte del } \\
\text { Gobierno para regular correctamente esta } \\
\text { Ley, de manera que se ajuste al fin para el } \\
\text { que fue creada. Necesidad de una Ley más } \\
\text { minuciosa. }\end{array}$ & $\begin{array}{l}\text { Las escrituras públicas que documentan las } \\
\text { operaciones de constitución, subrogación, } \\
\text { novación modificativa y cancelación de las } \\
\text { cuota gradual de documentos notariales del } \\
\text { Impuesto sobre Transmisiones y Actos } \\
\text { Jurídicos Documentados (ITP y AJD). }\end{array}$ \\
\hline Sensación de desprotección. & $\begin{array}{l}\text { dependiente y/o discapacitada sufragar sus } \\
\text { gastos con su propia vivienda. }\end{array}$ \\
\hline $\begin{array}{l}\text { inmovilizado permite a la persona mayor o } \\
\text { convertir en líquido el patrimonio }\end{array}$ \\
\hline
\end{tabular}

\section{Perspectiva Externa}

\begin{tabular}{|l|l|}
\hline \multicolumn{1}{|c|}{ Amenazas } & \multicolumn{1}{|c|}{ Oportunidades } \\
\hline $\begin{array}{l}\text { Dificultades de acceso a la promoción de } \\
\text { esta figura hipotecaria. }\end{array}$ & $\begin{array}{l}\text { Posible aumento de la demanda de esta } \\
\text { modalidad hipotecaria. }\end{array}$ \\
\hline $\begin{array}{l}\text { Demanda creciente de otros productos para } \\
\text { preparar la jubilación o soportar la situación } \\
\text { de dependencia: Planes y Fondos de } \\
\text { Pensiones, Planes de Previsión Asegurado, } \\
\text { etc. }\end{array}$ & $\begin{array}{l}\text { Captar la atención de Bancos y entidades de } \\
\text { crédito de capital extranjero que quieran } \\
\text { invertir en nuestro país. }\end{array}$ \\
\hline
\end{tabular}




\begin{tabular}{|c|c|}
\hline Amenazas & Oportunidades \\
\hline $\begin{array}{l}\text { La DA } 1 .^{\text {a }} \text { de la Ley } 41 / 2007 \text { por la que se } \\
\text { regula la hipoteca inversa, no acaba de dar } \\
\text { el apoyo deseado ni a los posibles } \\
\text { solicitantes ni a las posibles entidades } \\
\text { encargadas de suministrar este producto. }\end{array}$ & $\begin{array}{l}\text { Profesionalidad, eficiencia y flexibilidad en } \\
\text { la gestión de este instrumento hipotecario } \\
\text { por parte de las entidades crediticias. }\end{array}$ \\
\hline $\begin{array}{l}\text { Establecimiento en un mercado muy poco o } \\
\text { nada especializado en la hipoteca inversa. }\end{array}$ & $\begin{array}{l}\text { Orientación y excelencia en el asesoramiento } \\
\text { y durante todo el proceso hasta la } \\
\text { formalización de la operación. }\end{array}$ \\
\hline Política fiscal poco estable. & $\begin{array}{l}\text { Importante crecimiento de la demanda de } \\
\text { otros servicios o productos financieros, } \\
\text { siendo la hipoteca inversa uno de ellos. }\end{array}$ \\
\hline $\begin{array}{l}\text { Los elevados gastos de formalización ya que } \\
\text { pueden oscilar entre los } 3.000 \text { y más de } \\
6.000 \text { euros, entre otros, los gastos de } \\
\text { notaría, de registro y de gestoría, los gastos } \\
\text { de tasación, impuestos diversos y la } \\
\text { suscripción del seguro de rentas. }\end{array}$ & $\begin{array}{l}\text { Tratamiento fiscal favorable. Éste es menos } \\
\text { gravoso que el de otras operaciones afines, } \\
\text { pues la renta que percibe este cliente de } \\
\text { hipoteca inversa no tributa. }\end{array}$ \\
\hline
\end{tabular}

Este estudio estratégico ha de ir acompañado del análisis CAME, con la finalidad de desarrollar las estrategias ofensivas, defensivas, de supervivencia y de reorientación que Corrijan las debilidades, Afronten las amenazas, Mantengan las fortalezas y Exploten las oportunidades. 


\section{1.- Estrategias ofensivas: Fortalezas + Oportunidades.}

- Orientación y excelencia en el asesoramiento y durante todo el proceso hasta la formalización de la operación.

- Instrumento idóneo para propietarios de inmuebles muy bien valorados y que perciban unas rentas pequeñas.

- Profesionalidad, eficiencia y flexibilidad en la gestión de este instrumento hipotecario por parte de las entidades crediticias.

- Captación de la atención de Bancos y entidades de crédito de capital extranjero que quieran invertir en nuestro país.

\section{2.- Estrategias defensivas: Fortalezas + Amenazas.}

- Orientación exclusiva a las personas para alcanzar los mayores índices de fidelidad de este proyecto, tanto por parte de las entidades colaboradoras como de los clientes.

- Modalidad dirigida a las personas de edad igual o superior a los 65 años o afectadas de dependencia o personas que se les haya reconocido un grado de discapacidad igual o superior al 33 por ciento.

- Demanda creciente de otros productos para preparar la jubilación o soportar la situación de dependencia: Planes y Fondos de Pensiones, Planes de Previsión Asegurado, etc.

- La DA 1. ${ }^{a}$ de la Ley 41/2007 por la que se regula la hipoteca inversa, no acaba de dar el apoyo deseado ni a los posibles solicitantes ni a las posibles entidades encargadas de suministrar este producto.

- Establecimiento en un mercado muy poco o nada especializado en la hipoteca inversa.

- Las escrituras públicas que documentan las operaciones de constitución, subrogación, novación modificativa y cancelación de las hipotecas inversas estarán exentas de la cuota gradual de documentos notariales del Impuesto sobre Transmisiones y Actos Jurídicos Documentados (ITP y AJD). 
- Al convertir en líquido el patrimonio inmovilizado permite a la persona mayor o dependiente y/o discapacitada sufragar sus gastos con su propia vivienda.

\section{3.- Estrategias de supervivencia: Debilidades + Amenazas.}

- Dependencia de los Bancos, entidades de crédito y entidades aseguradoras.

- Política fiscal poco estable.

- Sensación de desprotección.

- Dificultades de acceso a la promoción de esta figura hipotecaria.

- Los elevados gastos de formalización ya que pueden oscilar entre los 3.000 y más de 6.000 euros, entre otros, los gastos de notaría, de registro y de gestoría, los gastos de tasación, impuestos diversos y la suscripción del seguro de rentas.

\section{4.- Estrategias de reorientación: Debilidades + Oportunidades.}

- Alta necesidad de colaboración por parte del Gobierno para regular correctamente esta Ley, de manera que se ajuste al fin para el que fue creada. Necesidad de una Ley más minuciosa.

- Posible aumento de la demanda de esta modalidad hipotecaria.

- Importante crecimiento de la demanda de otros servicios o productos financieros, siendo la hipoteca inversa uno de ellos.

- Tratamiento fiscal favorable. Éste es menos gravoso que el de otras operaciones afines, pues la renta que percibe este cliente de hipoteca inversa no tributa.

\section{LA HIPOTECA INVERSA EN ESPAÑA ¿UNA FIGURA PRESCRITA?}

Tras este análisis estratégico se puede observar que esta modalidad hipotecaria, tras siete años en vigor y con muy poca aceptación, o escrito de otro modo, una figura apenas comercializada en el mercado bancario o 
asegurador, resulta muy improbable que tenga éxito en un futuro a corto plazo y en las actuales condiciones de regulación. Se han de modificar muchos términos, ya que cuenta con muchos puntos oscuros.

En primer lugar, y con respecto a su regulación, es muy poco probable que el Gobierno, durante este año, se proponga hacer algo por esta figura, pues este 2015 va a ser un año político muy intenso al encontrarnos inmersos tanto en elecciones generales como autonómicas y locales. Tanto el gobierno como los distintos partidos que conforman la oposición se juegan mucho en estos próximos cuatro años. De ahí que esta figura no constituya, ni de largo, un asunto prioritario a reformar.

En segundo lugar, la economía española necesita de la recuperación del mercado de la vivienda y a su vez éste necesita que la economía avance. Son dos variables que se retroalimentan y, en particular, en el caso de nuestro país, cuya actividad estuvo sustentada durante muchos años sobre la construcción. Por eso, los expertos consideran que la situación actual es especialmente delicada para el mercado de la vivienda: se atisba la recuperación, pues pese a la crisis, en nuestra sociedad siguen habiendo nacimientos, bodas, divorcios, defunciones, y eso propicia cambios en la necesidad de vivienda, pero habida cuenta del stock existente, se prevé que no sea ni completa ni, menos, inmediata.

Según los datos estadísticos oficiales (INE y Ministerio de Fomento) de los precios de viviendas correspondientes al año 2014, se puede afirmar que los inmuebles se han depreciado más del 30\% desde 2008. Es decir, las viviendas valen hoy lo mismo que en 2004 y en muchos lugares, como la costa mediterránea, las transacciones que se cierran ahora lo hacen a la mitad del precio por el que fueron escrituradas esas mismas viviendas en la compra anterior.

En cuanto a la demanda, en lo que concierne a las operaciones de compraventa, el año 2014 sí que fue notablemente mejor que el anterior. Se 
mida como se mida, es decir, con datos de los notarios o de los registradores (INE), en 2014 en España se vendieron más viviendas que un año antes, y ello fue así gracias a la mejora de la coyuntura económica global y la suave recuperación del crédito. Para quienes han logrado mantener su empleo y su nivel de ingresos durante la crisis, adquirir una vivienda ahora sólo conlleva ventajas. Su precio medio es un 30\% más barato y, si requieren hipoteca, los bancos vuelven a estar en disposición de concederlas aunque con otras condiciones.

No obstante, en cuanto a la figura inversa nada se dice por parte de las entidades oferentes, es decir, de los bancos, entidades de crédito 0 aseguradoras. Tras estos años rotos el mercado inmobiliario ha sufrido un gran cambio. Las entidades capacitadas para ofrecer esta modalidad ni se lo plantean, pues como se ha señalado a lo largo del estudio de esta figura, ni se molestaron en sus inicios, es decir, desde diciembre de 2007 y durante todo el primer semestre de 2008.

Habida cuenta pues de la evolución del mercado inmobiliario y de la economía durante estos últimos años, tampoco parece previsible que lo vayan a hacer ahora, volcados sus intereses inmobiliarios en sacar al mercado las viviendas que les quedaron por vender durante estos años de crisis tanto financiera como económica $y$, dentro de ésta y especialmente intensa, la sufrida en el sector inmobiliario. Además, la hipoteca inversa, por lo apresurado de su alumbramiento, siempre ha planteado cuestiones que todavía hoy no se han resuelto.

En cuanto a las personas que pueden optar a este producto: mayores de 65 años o afectadas de dependencia o personas a las que se les haya reconocido un grado de discapacidad igual o superior al 33 por ciento, es prácticamente imposible que se decanten por la contratación de este producto por varias razones: 
- En el caso de que estas personas reúnan el requisito de que su vivienda habitual sea de su propiedad, si no disponen de los suficientes medios económicos para su sustentación será más fácil que opten por la venta de la vivienda y se trasladen a una residencia en la que tendrán que pagar sólo los gastos mensuales en concepto de ingreso.

En cambio, si hipotecan su vivienda inversamente, además de los gastos ordinarios tendrán que seguir pagando los de mantenimiento de la misma como por ejemplo: IBI, agua, luz, y, obligatoriamente, y debido a la contratación de esta modalidad, un seguro del hogar contra daños. Por tanto será más cómodo pagar un único recibo al mes en concepto de residencia.

- En el caso de los dependientes, dadas sus características, con mayor motivo preferirán trasladarse a una residencia o centro especializado que optar por la formalización de una hipoteca de estas características. Además, este colectivo ya tiene suficiente con la Ley de Dependencia que todavía no se ha desarrollado correctamente ${ }^{886}$.

Además también, si consultamos el Portal de la Dependencia, en el catálogo de servicios regulado en el artículo 15 de la Ley 39/2006, de 14 de diciembre, de Promoción de la Autonomía Personal y Atención a las Personas en Situación de Dependencia, encontramos, entre otros, el servicio de Centro de Día y de Noche o el Servicio de Atención Residencial. De manera que, aunque en algunas ocasiones sea difícil el poder optar a estos servicios, la persona afectada de dependencia o que se le haya reconocido un grado de discapacidad igual o superior al 33 por ciento, preferirá esperar a poder hacer uso de estos servicios que el tener que contratar una hipoteca inversa como complemento a su pensión.

- En el hipotético caso de que se quisiera contratar una hipoteca inversa, sorprenderíamos al banco o entidad en la que nos gustaría contratar

\footnotetext{
${ }^{886}$ Vid. el primer Informe del Observatorio de la Dependencia en España, un instrumento creado para analizar por parte de los agentes sociales de forma rigurosa y sistemática el desarrollo e implantación de la Ley de Dependencia en nuestro país, con el objetivo de dar respuestas a los problemas de viabilidad con los que se encuentra en la actualidad.
} 
esta figura, pues al no ser un producto que ofrezcan, podrían encontrarse con serias dificultades técnicas, legales y administrativas para formalizar su tramitación, aunque estén obligados a ello. Parecida sorpresa que la que le causaría al notario a la hora de formalizar esta hipoteca, ya que la falta de hábito de este colectivo al haberse formalizado un muy reducido número de esta modalidad, podría ocasionarle contratiempos similares a los de la entidad bancaria.

En tercer lugar, en España, después de estos años tan delicados que han afectado al bienestar de la práctica totalidad de las clases sociales, y dadas las experiencias acontecidas con respecto a la contratación de hipotecas, es muy normal que ahora las personas estudien mejor este producto antes de formalizarlo ante un notario.

Así pues, será preferible que, antes de hipotecar inversamente una vivienda, el propietario se plantee venderla aunque el precio de la misma haya bajado al nivel de 2004, dato que también contemplaría la tasadora en el caso de formalizar una hipoteca inversa. De lo anterior se deriva que los ingresos, bien de manera temporal bien de manera vitalicia, sean menores que los que se ofrecían en 2007 o 2008 cuando aún no se había asentado la crisis financiera y económica. Otra opción sería alquilar el inmueble y trasladarse a una residencia especializada en mayores o dependientes.

Por tanto, y después del análisis estratégico de esta figura a lo largo del texto, para que la hipoteca inversa pudiera tener una primera y tímida aceptación por parte de potenciales suscriptores, se debería constituir una mesa de trabajo con la participación de Gobierno, Bancos, cajas y entidades aseguradoras, con el objeto de perfilar y subsanar todas las deficiencias que presenta esta DA $1 .^{a}$ de la Ley $41 / 2007$ relativa a la hipoteca inversa. No se entrevé sin embargo, la posibilidad de que esta alternativa pueda darse siquiera a medio plazo, ya que tanto por parte del actual Gobierno como por parte de las entidades apuntadas, seguirá resultando más sencillo ofrecer esos otros productos para la jubilación, o para afrontar la situación de 
dependencia, a través de la contratación de un seguro de dependencia o de vida, como se ha visto más arriba.

Otra situación sería que los bancos británicos, donde esta modalidad sí se comercializa con una cierta fluidez, se asentaran en España y ofrecieran este producto tanto para los ciudadanos españoles o de cualquier otra nacionalidad, como a los ciudadanos ingleses que residen de manera permanente o temporal en nuestro país.

En definitiva, para que la hipoteca inversa se haga visible y se pueda comercializar como cualquier otra hipoteca convencional, en nuestro país se necesita de una reorientación de la figura, que pasa por la revisión a conciencia de la actual Ley o por la elaboración de una nueva, escenarios que se presentan, a día de hoy y a la vista de la futura y prevista evolución de la economía y de los mercados, incluido el inmobiliario, prácticamente imposibles. 


\section{CONCLUSIONES}





\section{CONCLUSIONES}

I

Esta tesis doctoral tiene por finalidad dar a conocer la normativa española reguladora de la hipoteca inversa, que en nuestro ordenamiento jurídico se reguló por primera vez a través de la Ley 41/2007, de 7 de diciembre, por la que se modifica la Ley $2 / 1981$, de 25 de marzo, de Regulación del Mercado Hipotecario y otras normas del sistema hipotecario y financiero, de regulación de las hipotecas inversas y el seguro de dependencia y por la que se establece determinada norma tributaria, concretamente, en la Disposición Adicional Primera de esta Ley.

Se corresponde con un estudio pormenorizado sobre los once apartados que conforman esta Disposición Adicional Primera. A través del mismo, se ha definido el concepto y las características de esta hipoteca en nuestro ordenamiento jurídico. Junto a esta Ley, en lo que afecta a esta modalidad hipotecaria, también se analiza la Ley $1 / 2013$, de 14 de mayo, de medidas para reforzar la protección a los deudores hipotecarios, reestructuración de deuda y alquiler social.

\section{II}

El desarrollo de esta figura, entre otras causas, fue a consecuencia del aumento de la esperanza de vida, la disminución del poder adquisitivo de los pensionistas, el cambio en la estructura de la familia y la insuficiencia de ayudas al colectivo de personas dependientes. Además, en España la implantación de esta figura se presentaba como idónea debido a la cultura tan arraigada en nuestro país por tener una vivienda en propiedad. En nuestra sociedad hay un número muy elevado de personas mayores de 65 años que son propietarias de más de una vivienda.

III

El origen de la hipoteca inversa se produjo en los años sesenta, en el Reino Unido. No obstante, a finales de los ochenta dejó de utilizarse debido al 
aumento de los tipos de interés y la caída de los valores inmobiliarios. Esta situación ocasionó la existencia de patrimonios negativos que incitaron a la venta del inmueble ante la falta de una garantía contra ese patrimonio negativo y a prácticas de dudosa reputación, causando, así una mala imagen a este producto financiero.

El éxito de su posterior comercialización y de su crecimiento vino dado por la imposición, por parte de los principales prestamistas, de un Código de Buenas Prácticas y a la asunción de responsabilidad por parte de la Autoridad de Servicios Financieros respecto de la regulación de las hipotecas inversas.

En el caso de Estados Unidos, el desarrollo de esta modalidad hipotecaria ha sido muy similar al del Reino Unido. En ese país, la implantación de la hipoteca inversa se vio favorecida por la intervención del Departamento de Vivienda y Desarrollo Urbano y la implantación de los préstamos federales proporcionados por cualquier entidad de crédito autorizada por la Federal Housing Administration.

A ello, había que sumar la supervisión por parte del Estado Federal y la sujeción a la evaluación de la operación por parte de un experto externo antes de que se produjera la firma del contrato. De esta manera, se solventaron las posibles dudas que producía la comercialización de este producto financiero dirigido a un público muy vulnerable.

\section{IV}

La hipoteca inversa con la entrada en vigor de la Ley 1/2013 está dirigida a personas de edad igual o superior a los 65 años o afectadas de dependencia, o personas a las que se les haya reconocido un grado de discapacidad igual o superior al 33 por ciento.

Anteriormente, cuando se reguló por primera vez a través de la Ley 41/2007, para optar a esta modalidad se exigía tener una edad igual o 
superior a los 65 años o ser personas afectadas de dependencia severa o gran dependencia.

Lo comentado en el punto anterior se puede contemplar en el apartado VIII del Preámbulo de la Ley 41/2007, de 7 de diciembre, en el que se establecía que con la hipoteca inversa se pretendía paliar uno de los grandes problemas socio-económicos que por aquel entonces ya tenía nuestro país y la mayoría de los países desarrollados, que no era otro que introducir la posibilidad de incrementar las rentas de los colectivos a los que iba dirigida, para mejorar sus umbrales de necesidad durante los últimos años de vida.

De esta manera, a través de la contratación de una hipoteca inversa, estos colectivos más desfavorecidos -a través de su patrimonio inmobiliario, en este caso, la vivienda habitual-, podían aumentar su renta, obteniendo así unos ingresos adicionales a su pensión y una mayor calidad de vida.

\section{VI}

Con respecto a la formalidad de la hipoteca inversa, señalar que se reguló a través de la Disposición Adicional $10^{\mathrm{a}}$ y la Disposición Adicional $4 .^{\mathrm{a}}$ de la Ley 41/2007 y no se contempló ni en la Ley Hipotecaria ni en el Código Civil.

Desde sus inicios, o lo que es lo mismo, desde su tramitación parlamentaria, esta Ley ya se calificaba de «cajón desastre» por asimilarse a la Ley de Acompañamiento de Presupuestos que se solía utilizar en los últimos años. Así, esta nueva modalidad hipotecaria se reguló en una Disposición Adicional dentro de una Ley de Reforma, de manera que, desde que entró en vigor, ya no cumplía con una ubicación adecuada dentro de nuestro sistema normativo. Junto a esto, se deben añadir ciertas deficiencias, o incluso lagunas, con respecto al contenido de la norma. 
La hipoteca inversa se caracteriza, principalmente, por ser una hipoteca de desamortización. De esta manera, se permite que las personas mayores de 65 años o afectadas de dependencia, o personas a las que se les haya reconocido un grado de discapacidad igual o superior al 33 por ciento, a través de una vivienda ya pagada y amortizada, puedan obtener una renta para complementar sus pensiones o sus ingresos. Es decir, el procedimiento es el inverso al de la hipoteca convencional destinada a la adquisición de una vivienda.

\section{VIII}

Tal y como se ha comentado a lo largo de este estudio, la realidad social española ya venía advirtiendo de un aumento del número de personas mayores cuya situación requeriría de ciertas atenciones y, además, muchas de estas personas no dispondrían de los medios económicos suficientes para hacer frente a los nuevos gastos, necesarios e indispensables para el correcto desarrollo de su vida diaria.

Junto a esta situación, durante los años anteriores a la entrada en vigor de la Ley 41/2007, en nuestro país el valor de los bienes inmuebles se incrementó de forma desmesurada. Por esta misma razón, a pesar del esfuerzo que se requería para la adquisición de una vivienda, en contrapartida, también se había producido una fuerte revalorización de estos activos inmobiliarios.

Como reflejo del estilo de vida de nuestro país, el ahorro de una gran mayoría de personas mayores descansa sobre la propiedad de bienes inmuebles. Este patrimonio o activo inmobiliario ha sido consecuencia de la inversión de los ingresos generados a través de su trabajo o por medio de la aceptación de una herencia familiar. Es por todos conocido que aunque la propiedad de un bien inmueble no produzca rentas para aliviar las necesidades económicas de este colectivo, a través de los mecanismos jurídicos adecuados, estos bienes inmuebles podrían convertirse en una fuente de ingresos con el objetivo de aliviar ciertas carencias económicas 
relativas a la jubilación o el estado de dependencia o grado de discapacidad reconocido.

\section{IX}

Entre estos mecanismos jurídicos, a pesar de la novedad que suponía la legislación de la hipoteca inversa, en nuestro Derecho ya existían otros instrumentos con similar finalidad de atención a necesidades asistenciales. Entre otros, cabría destacar la renta vitalicia y el contrato de alimentos, conocido tradicionalmente como vitalicio.

\section{$\mathbf{X}$}

La obligación garantizada con esta hipoteca será un préstamo o crédito del que el deudor (persona de edad igual o superior a los 65 años o afectada de dependencia, o persona con un grado de discapacidad reconocido igual o superior al 33 por ciento) podrá recibir una cantidad única o periódica que normalmente servirá de complemento a su pensión durante un determinado tiempo o para el resto de su vida.

La hipoteca inversa, excepto en lo pertinente a su configuración como derecho de garantía accesorio y de realización de valor, no se asemeja en nada a la hipoteca clásica. Esta modalidad hipotecaria goza de ciertas particularidades con respecto a la hipoteca convencional. Entre otras, la más llamativa quizá sea la posposición de la devolución de la deuda al fallecimiento del solicitante-deudor de la misma.

En este caso, el artículo 1876 del CC señala que: «La hipoteca sujeta directa e inmediatamente los bienes sobre que se impone, cualquiera que sea su poseedor, al cumplimiento de la obligación para cuya seguridad fue constituida».

De esta manera, la hipoteca se configura como un derecho real que sujeta bienes al cumplimiento de una obligación. En el caso de la hipoteca ordinaria su finalidad sería comprar un inmueble cuya amortización de capital, con el transcurso del tiempo, irá reduciendo el importe de la deuda y aumentando el valor de la finca dada en garantía. Bajo esta fórmula, al 
vencimiento del préstamo, el prestatario no deberá nada, pues durante ese tiempo habrá saldado la deuda.

En cambio, en el caso de la hipoteca inversa, su objetivo será la generación de unos ingresos a través de la vivienda hipotecada. Bajo esta modalidad, a medida que pase el tiempo, el valor de este inmueble irá disminuyendo pero la deuda y los intereses irán aumentando. En esta modalidad hipotecaria, el solicitante-deudor, a diferencia de la hipoteca clásica, no tendrá la obligación de realizar pagos periódicos ni tampoco tendrá que liquidar la deuda en vida. Mientras tanto, el deudor o beneficiario seguirá conservando la propiedad de su vivienda. La deuda será exigible al fallecimiento del mismo o del último de los beneficiarios, en el caso de que se hubiesen designado.

Es decir, hasta que no se produzca el deceso de éstos, la entidad acreedora no podrá exigir la devolución de los débitos vencidos, el equivalente al importe de todas las cantidades que éstos hubieran percibido durante el tiempo que duró el contrato. De igual modo tampoco podrá ejecutar la garantía. Por tanto, la cuantía a que ascienda esta deuda generada con hipoteca inversa corresponderá a los herederos del solicitantedeudor. Por este motivo, con respecto a la hipoteca convencional se puede afirmar que se trata de un producto financiero de mayor coste.

\section{XI}

Desde el punto de vista subjetivo, la hipoteca inversa tiene ciertas limitaciones para su contratación, pues a pesar de que la Ley 1/2013 ha ampliado las circunstancias de los solicitantes que pueden optar a esta modalidad, sigue estando dirigida al colectivo de personas de edad igual o superior a los sesenta y cinco años y al de dependientes, concretamente a las personas a las que se les haya reconocido un grado de discapacidad igual o superior al 33 por ciento. Anteriormente, con la Ley 41/2007, esta modalidad la podían contratar tan sólo aquellas personas de 65 años o más o quienes estuvieran afectadas de dependencia severa o gran dependencia. 


\section{XII}

No obstante, en cuanto a la designación de la figura del beneficiario, la Ley 41/2007 no fija ningún límite. Se podrá pues, designar a cualquier persona, independientemente del grado de parentesco o afinidad que le una al solicitante-deudor. Además, la Ley tampoco específica el número de beneficiarios que pueden figurar en el contrato de esta hipoteca.

En estos casos, el beneficiario tendrá que reunir las mismas condiciones que la figura del solicitante, debiendo ser una persona de edad igual o superior a sesenta y cinco años o estar afectada de dependencia, o persona a la que se le haya reconocido un grado de discapacidad igual o superior al 33 por ciento.

El legislador tenía que haber regulado con mayor detalle esta figura, ya que tanto la falta de una limitación numérica como la no especificación en el grado de parentesco en la designación del mismo, podrían conducir a graves enfrentamientos con los futuros herederos.

\section{XIII}

Con respecto a los requisitos objetivos, indicar que el legislador tampoco estuvo del todo acertado al restringir la garantía de esta hipoteca a la vivienda habitual del solicitante-deudor.

Podríamos considerar esta limitación como una de las notas negativas de esta Ley, pues la aplicación de los beneficios fiscales y arancelarios previstos en la misma, sólo se podrían aplicar a las hipotecas inversas en las que se grave la vivienda habitual del prestatario. Esta restricción no se entiende debido a que muchas de estas personas reúnen los requisitos subjetivos y, aun no teniendo liquidez, podrían poseer más bienes inmuebles para poder hipotecar. En estos casos, aunque se hipotecaran esos otros bienes -que no quiere decir que sean de un valor inferior o bajo, incluso todo lo 
contrario-, estos solicitantes no optarían al disfrute de los beneficios inherentes al espíritu de la hipoteca inversa.

También al respecto de la condición de vivienda habitual del solicitante y futuro deudor de la hipoteca inversa habría que hacer una matización:

En algunos casos podría suceder que el valor o precio de la vivienda habitual dada en garantía por un solicitante de hipoteca inversa fuera de mucho más valor que el de otro aspirante, aun dando en garantía este último dos viviendas, una en calidad de vivienda habitual y otra como segunda residencia, cuya suma de ambas no llegará a alcanzar la cuantía de la vivienda presentada por el primer solicitante. Sin embargo, atendiendo al apartado 1 de la Ley, se beneficiaría de las ventajas fiscales y arancelarias, la persona que hubiera hipotecado su vivienda habitual, independientemente del valor que pudiera tener esa vivienda. En el supuesto de una persona que tuviera una segunda residencia -aun con un patrimonio inferior a otro que sólo tuviera la vivienda habitual-, para poder optar a estos beneficios tendría que hipotecar su vivienda habitual.

Junto a esta matización, otra de las razones por la que esta condición de vivienda habitual tenía que haberse suprimido, vendría dada por la cultura de la herencia que tenemos en nuestro país. Para muchas personas, el hecho de tener que hipotecar la vivienda habitual, es decir, «la vivienda de toda la vida», «la vivienda de nuestros abuelos», etc., supondría un drama familiar, ya que podría darse el caso de que esta vivienda desapareciera de la masa hereditaria debido a que los herederos no pudieran o no quisieran responder al pago de la deuda. En cambio, esta situación sería diferente si en lugar de hipotecar esa vivienda familiar se hipotecara otro bien inmueble, ya que posiblemente, no tendría la misma repercusión para la familia.

\section{XIV}

Con esta limitación a la vivienda habitual, el legislador se olvidó por completo del principal motivo que había originado esta Ley, concebida, tal y 
como se concretaba en el punto VIII de su Preámbulo, para permitir a los mayores utilizar parte de su patrimonio inmobiliario para transformarlo en dinero y, de esta manera, aumentar la calidad de vida de la tercera edad y las personas en situación de dependencia.

En virtud de ello, la transformación de este patrimonio en dinero no tendría por qué provenir de la vivienda habitual hipotecada inversamente, sino que podría proceder de cualquier otro bien inmueble. En este aspecto, señalar que la hipoteca inversa sobre otro bien inmueble distinto a la vivienda habitual no tiene porque ser de menor rango o condición, al igual que sucede con la hipoteca convencional. Sin embargo, el legislador quiso mantener esta diferencia.

\section{XV}

Aunque el legislador hizo referencia a la condición de vivienda habitual para optar a las ventajas fiscales y arancelarias, en ningún momento, la citada Ley estableció qué se entendía por vivienda habitual.

Esto planteó ciertas dudas teniendo que acudir a la normativa fiscal, tributaria y civil para determinar -en aquellos casos en que el solicitante fuera titular de varios inmuebles en los que reside con regularidad-, cuál debía entenderse como vivienda habitual.

\section{$\mathrm{XVI}$}

Con respecto a la posibilidad de realizar una hipoteca inversa «sobre cualesquiera otros bienes inmuebles», ésta aparece reflejada en el apartado 10 de la Disposición Adicional $1 .^{a}$. No obstante, en el citado apartado, al final, se dice que: «a estas hipotecas no les serán de aplicación los apartados anteriores de esta disposición».

De esta manera y atendiendo al tenor literal del mismo, desde su entrada en vigor ya surgieron dudas sobre su aplicación. En este caso, hubiera resultado clarificador haber especificado qué apartados no debían aplicarse. Sin embargo, el legislador, una vez más, lo dejó a criterio interpretativo. 


\section{XVII}

Al tratarse de la vivienda habitual del solicitante y no de cualquier otro bien inmueble, para optar a las ventajas fiscales y arancelarias que la misma Ley ofrece, ya no se dio la posibilidad de que esta vivienda objeto de hipoteca inversa pudiera ser arrendada a un tercero. De esta forma, el solicitantedeudor hubiera podido obtener más ingresos.

Esta opción se podía haber contemplado, pues podría darse el caso de que el deudor con las rentas obtenidas por la hipoteca inversa no tuviera los suficientes recursos para poder ingresar en una residencia. El legislador también hubiera podido prever esta posibilidad, pues por la naturaleza del público al que iba dirigido, sería muy normal que estas personas abandonaran su vivienda para ingresar en centros adaptados a sus circunstancias.

\section{XVIII}

En el apartado 5, párrafo segundo de la DA $1 .^{\text {a }}$ de la Ley $41 / 2007$ se contempla la posibilidad de que el bien hipotecado se transmita voluntariamente por parte del deudor. En este caso, la entidad acreedora declararía el vencimiento anticipado del préstamo o crédito hipotecario, salvo que se procediese a la sustitución de la garantía de manera suficiente.

Como regla general, no se podrá vender la vivienda sobre la que recaiga una hipoteca inversa, ya que si se diera este caso, la entidad acreedora podría resolver el contrato. Ahora bien, conforme a este segundo párrafo de este apartado 5, la parte acreedora no podrá resolver este contrato cuando el deudor, con la venta del inmueble, proceda de manera suficiente a la sustitución de la garantía.

El problema que radica en esta Ley es que no se hace referencia ni a la persona o entidad encargada de determinar que la garantía sea suficiente ni a qué se entiende por garantía suficiente. En este caso, interpretaríamos que el legislador, al regular este precepto, entendía que habría un acuerdo entre las 
partes: acreedor y deudor. Sin embargo, podría darse el supuesto de que éstos no llegasen a un acuerdo y que con la garantía presentada por el deudor no resultara suficiente para que el acreedor no pudiera resolver el préstamo, teniendo que acudir entonces a la autoridad judicial.

Hubiera sido pues recomendable que el legislador, para estas situaciones, hubiera especificado la cuantía de esta garantía suficiente, así como también la entidad o sujeto responsable de concretarla, como por ejemplo, jueces o tribunales, así como también fedatario público.

\section{XIX}

La hipoteca inversa podría constituirse por personas que fueran menores de 65 años y que no estuvieren afectadas de dependencia o no tuvieren reconocido un grado de discapacidad igual o superior al 33 por ciento. Además, esta hipoteca podría gravarse sobre un inmueble distinto a la vivienda habitual. Sin embargo, en estos casos, no se beneficiarían de las reducciones arancelarias y de los incentivos fiscales regulados en la Ley. En estos supuestos, estaríamos hablando de las llamadas hipotecas inversas atípicas, las cuales, al carecer de una normativa específica, se regirían por la voluntad de las partes, conforme al artículo 1255 del CC.

Junto a esto, señalar que en estas hipotecas atípicas, la facultad del acreedor para reclamar el cobro de la deuda generada no se limitaría a los bienes del deudor y podría ir contra otros bienes. $\mathrm{Y}$, con respecto a la cobertura de los intereses, a esta modalidad no se le eximiría del límite de cinco años.

\section{$\mathrm{XX}$}

Cuando la hipoteca inversa se reguló por primera vez a través de la Disposición Adicional Primera de la Ley 41/2007, en su apartado 4 se hacía referencia al régimen de transparencia y protección de la clientela. De manera que las entidades que ofrecieran este producto financiero deberían 
facilitar a los solicitantes del mismo, determinados servicios de asesoramiento independiente.

Estos servicios se realizarían teniendo en cuenta la situación financiera del solicitante y los riesgos económicos derivados de la suscripción de este producto. Este servicio independiente estaría dirigido por los mecanismos fijados por el aquel entonces Ministro de Economía y Hacienda, sin entrar en más detalle.

Así pues, este apartado no entraba en detalle sobre qué información se tenía que ofrecer, es decir, no se especificaba lo que la entidad de crédito tenía que facilitar al solicitante de este producto antes de su celebración, como por ejemplo, informar correctamente y por escrito de las condiciones del préstamo, de la modalidad del mismo, del tipo de interés, de las diferentes tasas e impuestos, del valor del bien hipotecado, en definitiva, del coste total de la hipoteca.

No obstante, con el objetivo de proteger al consumidor de este producto financiero, el artículo 5 del Real Decreto-Ley 6/2012, modificado por la Ley 1/2013, en el punto 8 alude a que los solicitantes de estas hipotecas podrán, con carácter potestativo, gozar de las previsiones contenidas en el Código de Buenas Prácticas.

\section{XXI}

Junto al asesoramiento citado en el anterior punto, siempre se ha planteado la posibilidad de que el solicitante contratara un seguro de vida asociado a la hipoteca inversa. De esta forma, este solicitante-deudor tendría garantizado el cobro de una renta de por vida, independientemente de que se hubiera superado el plazo establecido en el contrato de hipoteca. No obstante, esta opción conllevaría a aumentar el coste de la operación.

Como se puede observar, en la hipoteca inversa, en el supuesto de que se hubiera pactado la modalidad temporal y no la vitalicia, podría darse el 
caso de que el deudor dejara de percibir las rentas y además perdiera el derecho a residir en su vivienda habitual por pasar ésta a ser propiedad de la entidad acreedora. Planteándose con lo citado, un inconveniente más a la hora de contratar este producto. Aun así, para que no se llegara a esa situación tan desagradable, sería aconsejable que el solicitante contratara este seguro con la finalidad de percibir unas rentas a lo largo de su vida.

El solicitante con la contratación de este seguro tendría garantizado el seguir percibiendo rentas y, por tanto obtener una mayor tranquilidad. Pero, en este caso, la renta a percibir sería menor y los gastos de constitución se verían incrementados por la contratación de este seguro.

La implantación de este seguro podría haberse realizado a un bajo coste en colaboración con las entidades acreedoras, para que estas personas mayores o afectadas de dependencia o discapacidad igual o superior al 33 por ciento tuvieran garantizadas estas rentas y evitar así que pudieran llegar a perder su vivienda.

\section{XXII}

Tal y como se señala en el punto d) del apartado 1 de la DA $1 .^{a}$, la vivienda objeto de hipoteca inversa deberá ser tasada y asegurada contra daños, conforme a los artículos 7 y 8 de la Ley 2/1981, de 25 de marzo, de Regulación del Mercado Inmobiliario.

En este sentido, la tasación de la vivienda que se dé en garantía será conforme con el valor de mercado. Además, en el artículo 3 bis I) de la Ley 2/1981, modificado por la Ley 1/2013, se indica que las entidades de crédito, aunque tengan servicios propios de tasación, estarán obligadas a aceptar cualquier tasación de un bien aportado por el cliente, a la vez solicitante y futuro deudor, siempre que sea certificada por un tasador homologado de conformidad a la presente Ley y no esté caducada. Ello no impedirá que la entidad de crédito pueda realizar las comprobaciones voluntarias pertinentes, de las que en ningún caso podrá repercutir su coste al cliente. 
Por tanto, la tasación será necesaria para poder celebrar esta hipoteca. No obstante, se hubiera podido plantear, o incluso fijar, que esta tasación fuera supervisada cada cierto tiempo, pues este bien inmueble dado en garantía podría verse revalorizado, o tal vez no. De manera que, el deudor, en función del valor que se le otorgase a su vivienda, podría percibir unas mayores rentas.

\section{XXIII}

Debido a las peculiares características de la hipoteca inversa, donde no existirá reembolso del capital ni pago de intereses por parte del deudor hipotecario y la deuda sólo será exigible al fallecimiento del mismo o del último beneficiario, en el caso de que lo hubiere, conforme se indica en el apartado 6 , in fine, de la DA $1 .^{a}$, no se considerará aplicable la limitación legal de cinco años de cobertura hipotecaria para los intereses regulados en el artículo 114 de la Ley Hipotecaria.

Esta excepción supuso una gran novedad respecto a la configuración general establecida para la hipoteca en nuestro ordenamiento. Así, podría suceder que la obligación principal continuase generando intereses debido a que el deudor o el último beneficiario falleciese una vez se hubiesen terminado las disposiciones del crédito. Es decir, que ese intervalo de tiempo transcurrido entre el término del crédito o préstamo hasta el fallecimiento del deudor o último beneficiario podría ser superior a cinco años.

De esta manera, la Ley $41 / 2007$, en su DA 1. a estableció que la garantía hipotecaria en la hipoteca inversa también debía abarcar la totalidad de esos intereses, sin que para ello se aplicara el límite de cinco años fijado en el artículo 114 de la LH, permitiendo pues pactar, en esta modalidad, que el plazo de estos intereses fuera superior a cinco años.

En este aspecto, la Ley tenía que haber expresado que estos intereses fueran fijos, y en el caso de que fueran variables, se tenía que haber señalado 
un límite a través de una banda de fluctuación para el supuesto de que los tipos de interés sufrieran un aumento considerable.

Con respecto al capital entregado en función del valor de la vivienda, para el caso de que ese bien se revalorizase con el tiempo, se podría haber contemplado la posibilidad de actualizar esa cantidad disponible. Esto se hubiera podido plasmar a través de un contrato de novación.

Lo cierto es que en esta nueva modalidad, al igual que la hipoteca convencional, la entidad acreedora aplica unos intereses sobre el dinero que produce la vivienda dada en garantía. Es decir, se trata de un negocio en el que las partes contratantes pueden tener una serie de ventajas, pero en ningún caso se celebra de manera desinteresada.

Por tanto, antes de contratar esta hipoteca, la persona interesada o solicitante debería examinar a fondo las condiciones que la entidad de crédito hubiera fijado en el contrato, pues en muchos casos sería mejor optar por la venta de la vivienda y destinar esa cantidad al ingreso en una residencia y, así poder vivir dignamente sin necesidad de soportar ninguna carga.

\section{XXIV}

En la DA 1. ${ }^{\text {a }}$ por la que se regula esta modalidad hipotecaria, tampoco se determina la responsabilidad máxima a la que queda afectada la finca gravada con esta hipoteca, todo lo contrario, no se puso un límite. De esta forma, el apartado 6 de la DA 1. a permite que la parte acreedora, además de dirigirse contra el bien hipotecado, pueda ir contra todos los bienes del causante (antiguo deudor).

Durante su tramitación en el Senado se modificó esta circunstancia, de manera que el acreedor sólo tendría derecho al cobro de la deuda con el bien inmueble hipotecado inversamente. Sin embargo, en el Congreso se decidió que el acreedor, para recibir el crédito pendiente, pudiera dirigirse contra todos los bienes del deudor. 
Si esto se hubiese regulado, se habrían despejado las dudas sobre la intangibilidad del principio hipotecario de especialidad, principio esencial para determinar su naturaleza jurídica, extensión, cargas y limitaciones, denominación y su valor cuya publicidad se realiza a través del Registro de la Propiedad.

\section{XXV}

Con respecto a la extensión de la responsabilidad por la deuda contraída, ésta podrá alcanzar todo el patrimonio hereditario, es decir, no se limitará a la vivienda hipotecada inversamente.

De esta forma, la garantía por la que se ha otorgado esta hipoteca podría afectar tanto directa como indirectamente a los herederos del deudor en el caso de que los hubiese. Serían éstos los responsables de saldar esa deuda, ya que la misma será exigible al fallecimiento del deudor o del último beneficiario. Es más, la exigencia de liquidar esta deuda podría afectar a la legítima de estos herederos, ya que al realizar el deudor esta hipoteca el futuro patrimonio hereditario sufriría una aminoración.

Por tanto, esta situación, en el caso de que el deudor tuviera hijos y, posteriormente, futuros herederos, supondría un inconveniente más para la celebración de esta modalidad. Pues, no debemos olvidar que, en nuestro país, el deseo o la satisfacción por transmitir el patrimonio a los hijos están muy consolidados.

No obstante, la contratación de esta figura podría llevarse a cabo si el solicitante se encontrara en una situación económica muy grave y no le preocupara el no legar esa vivienda a sus herederos, rompiendo así con esta costumbre tan arraigada en nuestro país. 
En cuanto a la situación de los herederos, éstos, una vez haya fallecido el deudor o el último beneficiario, dispondrán de un plazo para decidir la manera de saldar la deuda y, así, proceder a la cancelación del préstamo.

Este período de tiempo se señala en el apartado 5 de la DA $1 .^{a}$ de la Ley 41/2007, que detalla que se podrá cancelar el préstamo «en el plazo estipulado", no estableciendo intervalo de tiempo alguno para que los herederos decidan.

Por consiguiente, el legislador debería haber establecido un límite de tiempo para que los herederos pudieran decidir sobre las distintas posibilidades y no cometer, así, ningún error. Además, al establecerse este periodo tampoco sufrirían ningún tipo de acoso por parte de la entidad acreedora.

Como ya se ha analizado, sobre este asunto, durante la tramitación parlamentaria hubo varias enmiendas que pretendían que este plazo no fuera inferior a dos años. Aun así, no se reguló, de manera que se volvía a dejar desprotegida a la parte deudora, representada por los herederos.

\section{XXVII}

Cuando en el año 2007 se reguló por primera vez esta modalidad, nuestro país se encontraba en una situación favorable con respecto al mercado inmobiliario, donde el precio de la vivienda seguía subiendo en la misma proporción en la que lo hacía la demanda de todo tipo de inmuebles (viviendas, terrenos, naves industriales, etc.). De esta manera, se pensó que la vivienda gravada con esta modalidad siempre mantendría el valor estipulado en el contrato o incluso aumentaría con el transcurso de los años.

Sin embargo, tras la crisis económica y financiera surgida, el precio de estos inmuebles ha descendido de manera insospechada. Esta posibilidad no llegó a plantearse por el legislador. Es más, nos atreveríamos a decir que ni tan siquiera la imaginó y si lo hizo no plasmó ese casi imposible escenario. 
Pero bajo la actual coyuntura, la parte más perjudicada sería la entidad acreedora, pues a ésta lo que le interesa es vender ese inmueble para liquidar la deuda y, además, obtener beneficios, pero si este bien se infravalorara, ni tan siquiera reuniría el dinero necesario para saldar la deuda pendiente.

La única opción que ofreció el legislador la podemos encontrar en el apartado 6 de la DA 1. a de la Ley 41/2007, donde estableció que el acreedor, para cobrar los débitos vencidos, con sus intereses, sólo podría dirigirse contra los bienes de la herencia del deudor, pero no contra el patrimonio de sus herederos.

Como consecuencia, muchos de los Bancos, entidades de crédito y entidades aseguradoras que eran aptas para comercializar este producto financiero, se quedaron al margen, debido a que no les generaba buenas expectativas de negocio.

\section{XXVIII}

Otra cuestión que nos podríamos plantear es si en esta modalidad hipotecaria se podría producir la cesión del crédito, así como la subrogación y modificación del préstamo hipotecario. Pues bien, en la hipoteca inversa, a diferencia de la hipoteca convencional u ordinaria, dado al público al que va dirigida y la finalidad por la que fue creada, estas opciones no sólo no serían posibles, sino que ni siquiera serían recomendables.

\section{XXIX}

La hipoteca inversa, aun a pesar de estos siete años que lleva en vigor, si el legislador se plantease realizar ciertas modificaciones o aclaraciones, todavía podría ser un instrumento idóneo para movilizar patrimonios inmobiliarios de personas que, por su edad, situación de dependencia o discapacidad, carezcan de los ingresos necesarios para sobrevivir y no puedan optar a otros productos financieros para la obtención de estos recursos. 
Cada vez la esperanza de vida es mayor, y si a la escasa pensión de jubilación se sumase un complemento por contratar una hipoteca inversa, a muchas personas, incluidos los futuros herederos, no les importaría concertar este producto. Conviene fijarse en que las personas de la tercera edad o pensionistas, en la actualidad, han de pagar sus medicamentos o en cómo cada vez y con mayor frecuencia aumentan los impuestos, por ejemplo, el IBI, y, cómo no, la factura de electricidad o del gas.

Por estas razones, con una regulación más clara y detallada y una buena campaña de comercialización, esta modalidad se podría plantear como una buena opción para que este público obtuviera financiación a través del valor de su vivienda o cualquier otro inmueble del que fuese titular, sin necesidad de venderlo. Y, así, con el importe que se recibiera se podría vivir más holgadamente para hacer frente a gastos médicos, de mantenimiento de la vivienda, etc., en definitiva, lograr una mejor calidad de vida.

\section{$\mathrm{XXX}$}

Conviene reseñar que una de las mayores críticas que ha tenido este DA $1 .^{a}$ de la Ley 41/2007 es que se ha regulado en tan sólo once apartados, y en consecuencia, se han generado innumerables lagunas. Pobreza reguladora que ha fraguado una norma deficiente, que deja pendiente de regulación muchos aspectos.

Prueba de ello es el último apartado, el once, donde se establece una cláusula de cierre un tanto imprecisa, ya que señala que: «En lo no previsto en esta disposición y su normativa de desarrollo, la hipoteca inversa se regirá por lo dispuesto en la legislación que en cada caso resulte aplicable».

Tal y como se ha podido apreciar a lo largo de este estudio «lo no previsto» es demasiado, de manera que esta regulación necesita de una profunda revisión y no la «pequeña» modificación que sufrió con motivo de la entrada en vigor de la Ley $1 / 2013$ en la que se amplió el punto a) del apartado 1 , relativo a los sujetos que podían optar a esta modalidad. 
Por tanto, el Gobierno debería plantearse el regular correctamente esta Ley, ya que el colectivo al que va dirigida cada vez es mayor y los recursos obtenidos por éstos, a la vista del escenario de pensiones y ayudas, van aminorando cada vez más. Sin duda estamos ante una situación delicada digna de abordar, pues este público cada vez es más endeble.

\section{XXXI}

De todas formas, la regulación sobre esta modalidad hipotecaria ha supuesto todo un progreso para nuestro ordenamiento jurídico. Al introducir esta figura, se ha dado entrada a nuevos instrumentos o productos financieros pensados para un público muy numeroso.

El legislador se ha preocupado por estas personas: ancianos, dependientes o con una discapacidad reconocida, que con el transcurso del tiempo cada vez son más. De esta manera, nuestra sociedad se tendrá que ir adaptando a estos cambios sociológicos y que mejor manera que la de crear nuevas figuras para solventar o facilitar estas nuevas situaciones.

A través de la Disposición Adicional Primera de la Ley $41 / 2007$, el legislador español, escrito en abstracto, ha introducido los medios necesarios para proyectar la utilización de esta modalidad hipotecaria, aunque la citada norma, toda una novedad en nuestra legislación, está llamada a ser regulada de nuevo y, esta vez de una manera más exhaustiva, pues su primera regulación se podría calificar de deficiente.

Entre otras cosas a regular, se debería profundizar sobre la oferta de este producto con una información clara, transparente y específica y difundir las ventajas fiscales y arancelarias resultantes de la contratación del mismo.

Con independencia de las entidades y personas que la pudieran llegar a ofertar y a contratar respectivamente, la regulación de esta hipoteca deberá ser sometida a un nuevo estudio, a través de los cauces jurídicos oportunos, 
para eliminar todo tipo de dudas, tanto para la parte acreedora como para la parte deudora.

Si bien es cierto que cuando surjan dudas sobre la aplicación e interpretación de esta Ley y para dar solución a las mismas, siempre nos podremos dirigir a la jurisprudencia y la doctrina, aunque con respecto a la hipoteca inversa, nuestro ordenamiento no disponga de una amplia y análoga jurisprudencia sobre las distintas cuestiones que la misma suscita. 

LISTADO DE SENTENCIAS Y RESOLUCIONES 



\section{LISTADO DE SENTENCIAS Y RESOLUCIONES}

SENTENCIA DEL TRIBUNAL DE JUSTICIA DE LA UNIÓN EUROPEA

Sentencia del TJUE de 14 de marzo de 2013 (Caso Aziz [TJCE 2013।89])

SENTENCIAS DEL TRIBUNAL CONSTITUCIONAL

STC de 9 de mayo de 1995 (RTC 1995\69)

STC de 27 de octubre de 1997 (RTC 1997\174)

STC de 15 de diciembre de 1997 (RTC 1997\227)

STC de 24 de febrero de 1998 (RTC 1998\42)

\section{SENTENCIAS DEL TRIBUNAL SUPREMO}

STS de 13 de mayo de 1959 (RJ 1959\1999)

STS de 14 de octubre de 1960 (RJ 1960\3086)

STS de 6 de mayo de 1980 (RJ 1980\1785)

STS de 10 de noviembre de 1981 (RJ 1981\4471)

STS de 20 de mayo de 1982 (RJ 1982 2585)

STS de 1 de julio de 1982 (RJ 1982\4213)

STS de 20 de septiembre de 1982 (RJ 1982\4920)

STS de 12 de marzo de 1985 (RJ 1985\1153)

STS de 17 de mayo de 1986 (RJ 1986\2725)

STS de 12 de marzo de 1987 (RJ 1987\1435)

STS de 30 de noviembre de 1987 (RJ 1987\8708)

STS de 3 de noviembre de 1988 (RJ 1988\8407)

STS de 4 de julio de 1989 (RJ 1989\5289)

STS de 12 de marzo de 1991 (RJ 1991\2219)

STS de 8 de mayo de 1992 (RJ 1992\3891)

STS de 2 de julio de 1992 (RJ 1992\6502)

STS de 21 de octubre de 1992 (RJ 1992\8592)

STS de 30 de enero de 1993 (RJ 1993\350) 
STS de 19 de febrero de 1997 (RJ 1997\791)

STS de 11 de julio de 1997 (RJ 1997 6152)

STS de 23 de abril de 1998 (RJ 1998\2599)

STS de 29 de abril de 1998 (RJ 1998\3650)

STS de 4 de mayo de 1998 (RJ 1998\3464)

STS de 14 de noviembre de 1998 (RJ 199819903)

STS de 27 de marzo de 1999 (RJ 1999\2371)

STS de 20 de abril de 1999 (RJ 199912589)

STS de 11 de junio de 1999 (RJ 1999\4607)

STS de 27 de junio de 2000 (RJ 2000\5909)

STS de 1 de julio de 2003 (RJ 2003\4321)

STS de 9 de marzo de 2005 (RJ 2005\2219)

STS de 7 de febrero de 2006 (RJ 2006\2831)

STS de 31 de mayo de 2006 (RJ 2006\3175)

STS de 29 de junio de 2006 (RJ 2006\4714)

STS de 17 de julio de 2007 (RJ 2007 4961)

STS de 21 de enero de 2008 (TOL1.245.335)

STS de 14 de mayo de 2008 (RJ 2008\418)

STS de 12 de noviembre de 2009 (RJ 2010\1737)

STS de 16 de diciembre de 2009 (RJ 2010 702 )

STS de 13 de septiembre de 2011 (RJ 2013\7856)

STS de 9 de mayo de 2013 (RJ 2013\3088)

STS de 2 de abril de 2014 (RJ 2014\2164)

\section{SENTENCIAS DE LOS TRIBUNALES SUPERIORES DE JUSTICIA}

STSJ de Madrid de 24 de junio de 2010 (TOL1.940.134)

STSJ de País Vasco de 28 de febrero de 2011 (TOL4.372.976)

STSJ de Madrid de 11 de julio de 2012 (TOL2.651.436)

STSJ de Madrid de 28 de enero de 2013 (RJCA 2013\156)

STSJ de Madrid de 14 de febrero de 2013 (RJCA 2013\338)

STSJ de Madrid de 30 de abril de 2013 (RJCA 2013\602)

STSJ de Madrid de 4 de junio de 2013 (TOL3.920.002) 
STSJ de Madrid de 11 de junio de 2013 (TOL3.914.741)

STSJ de Madrid de 11 de junio de 2013 (TOL3.920.122)

STSJ de Madrid de 21 de junio de 2013 (TOL3.856.479)

STSJ de Madrid de 10 de julio de 2013 (TOL3.914.982)

STSJ de Asturias de 19 de septiembre de 2013 (TOL3.955.329)

STSJ de Madrid de 4 de octubre de 2013 (TOL4.018.470)

STSJ de Madrid de 22 de noviembre de 2013 (TOL4.037.941)

\section{SENTENCIAS DE AUDIENCIAS PROVINCIALES}

AP de Soria Auto de 18 de febrero de 1998 (AC\1998\3622)

SAP de Cuenca de 6 de octubre de 1998 (AC 1998\7917)

SAP de Tarragona de 29 de julio de 1999 (AC 1999\6672)

SAP de Asturias de 28 de junio de 2001 (AC\2001\2026)

SAP de Madrid de 6 de julio de 2002 (JUR\2003\48705)

SAP de Barcelona de 23 de marzo de 2007 (TOL1.123.467)

SAP de A Coruña de 30 de noviembre de 2009 (AC 20101885)

SAP de Málaga de 23 de abril de 2012 (AC 2012 12301)

SAP de Madrid de 25 de julio de 2012 (TOL2.664.101)

SAP de Salamanca de 11 de octubre de 2012 (TOL2.686.612)

SAP de Girona de 17 de octubre de 2012 (AC 2013\789)

SAP de Madrid de 19 de octubre de 2012 (TOL2.694.455)

SAP de Almería de 7 de noviembre de 2012 (JUR 2014\126110)

SAP de Málaga de 24 de enero de 2013 (JUR 2013\182553)

AP de Madrid Auto de 13 de marzo de 2013 (AC 2013\1063)

SAP de Málaga de 17 de abril de 2013 (AC 2013\1316)

SAP de Málaga de 21 de mayo de 2013 (JUR 2014\16522)

SAP de Murcia de 4 de junio de 2013 (TOL3.793.508)

SAP de Málaga de 13 de junio de 2013 (AC 2013\1634)

SAP de Barcelona de 23 de julio de 2013 (TOL3.988.466)

SAP de Barcelona de 28 de noviembre de 2013 (TOL4.049.895)

SAP de Les Illes Balears de 13 de febrero de 2014 (TOL4.120.443)

SAP de Cáceres de 7 de julio de 2014 (TOL4.463.250) 
SAP de Barcelona de 15 de octubre de 2014 (JUR\2015\42617)

SAP de Barcelona de 3 de diciembre de 2014 (JUR\2015\55056)

SAP de Tarragona de 4 de diciembre de 2014 (JUR\2015\57141)

\section{SENTENCIA DE JUZGADO DE PRIMERA INSTANCIA}

SJPI de Madrid de 8 de abril de 2013 (AC 2013\963)

SJPI de Benidorm (Provincia de Alicante) de 31 de marzo de 2015 (JUR\2015\103742)

\section{RESOLUCIONES DE LA DIRECCIÓN GENERAL DE LOS REGISTROS Y DEL NOTARIADO}

RDGRN de 4 de julio de 1984 (RJ 1984\3851)

RDGRN de 27 de enero de 1986 (RJ 1986\1002)

RDGRN de 23 de octubre de 1987 (RJ 1987\7660)

RDGRN de 16 de octubre de 1989 (RJ 1989\7048)

RDGRN de 16 de marzo de 1990 (RJ 1990\2301)

RDGRN de 26 de diciembre de 1990 (RJ 1990\10497)

RDGRN de 26 de abril de 1991 (RJ 1991\3169)

RDGRN de 8 de noviembre de 1993 (RJ 1993\9114)

RDGRN de 19 de enero de 1996 (RJ 1996\586)

RDGRN de 22 de julio de 1996 (RJ 1996\5617)

RDGRN de 23 de octubre de 1996 (RJ 1996\7359)

RDGRN de 14 de enero de 1997 (RJ 1997\280)

RDGRN de 12 de febrero de 1997 (RJ 1997\856)

RDGRN de 19 de marzo de 1997 (RJ 1997 2044)

RDGRN de 24 de marzo de 1997 (RJ 1997 2047)

RDGRN de 10 de diciembre de 1997 (RJ 1997\8821)

RDGRN de 28 de enero de 1998 (RJ 1998\279)

RDGRN de 3 de diciembre de 1998 (RJ 1998\10482)

RDGRN de 16 de junio de 1999 (RJ 1999\4379)

RDGRN de 26 de julio de 1999 (RJ 1999\6082) 
RDGRN de 3 de abril de 2000 (RJ 2000\2741)

RDGRN de 22 de marzo de 2001 (RJ 2002\2188)

RDGRN de 13 de marzo de 2002 (RJ 2002\6182)

RDGRN de 11 de octubre de 2004 (RJ 2005\2549)

RDGRN de 3 de septiembre de 2005 (RJ 2005\6928)

RDGRN de 21 de diciembre de 2007 (RJ 2008\2086)

RDGRN de 14 de enero de 2008 (RJ 2008\2091)

RDGRN de 1 de febrero de 2008 (RJ 2008\633)

RDGRN de 8 de febrero de 2008 (RJ 2008\639)

RDGRN de 8 de febrero de 2008 (RJ 2008\2094)

RDGRN de 22 de febrero de 2008 (RJ 2008\2790)

RDGRN de 28 de febrero de 2008 (RJ 2008\2792)

RDGRN de 29 de febrero de 2008 (RJ 2008\2793)

RDGRN de 1 de marzo de 2008 (RJ 2008\1482)

RDGRN de 6 de marzo de 2008 (RJ 2008\805)

RDGRN de 14 de marzo de 2008 (RJ 2008\2103)

RDGRN de 15 de marzo de 2008 (RJ 2008\807)

RDGRN de 19 de marzo de 2008 (RJ 2008\1483)

RDGRN de 19 de marzo de 2008 (RJ 2008\8272)

RDGRN de 22 de marzo de 2008 (RJ 2008\8273)

RDGRN de 24 de marzo de 2008 (RJ 2008\8274)

RDGRN de 24 de marzo de 2008 (RJ 2008\8275)

RDGRN de 25 de marzo de 2008 (RJ 2008\8277)

RDGRN de 27 de marzo de 2008 (RJ 2008\8278)

RDGRN de 6 de mayo de 2008 (RJ 2008\2796)

RDGRN de 14 de mayo de 2008 (RJ 2008\8279)

RDGRN de 16 de mayo de 2008 (RJ 2008\3154)

RDGRN de 19 de mayo de 2008 (RJ 2008\7714)

RDGRN de 20 de mayo de 2008 (RJ 2008\7715)

RDGRN de 9 de junio de 2009 (RJ 2009\4308)

RDGRN de 22 de julio de 2009 (RJ 2010\1659)

RDGRN de 1 de octubre de 2010 (RJ 2010\5273)

RDGRN de 4 de noviembre de 2010 (RJ 2011\2461) 
RDGRN de 21 de diciembre de 2010 (RJ 2011\263)

RDGRN de 5 de enero de 2011 (RJ\2011\3432)

RDGRN de 11 de enero de 2011 (RJ 2011\269)

RDGRN de 22 de enero de 2011 (RJ 2011\2465)

RDGRN de 12 de mayo de 2011 (RJ\2011\5826)

RDGRN de 2 de marzo de 2013 (RJ\2013\2912)

RDGRN de 21 de noviembre de 2013 (RJ 2014\512)

RDGRN de 9 de diciembre de 2013 (TOL4.072.399)

RDGRN de 22 de enero de 2014 (RJ 2014\1548)

RDGRN de 5 de febrero de 2014 (RJ 2014\1178)

RDGRN de 18 de febrero de 2014 (TOL4.150.268)

RDGRN de 24 de marzo de 2014 (TOL4.227.933)

RDGRN de 31 de marzo de 2014 (TOL4.234.476)

RDGRN de 30 de septiembre de 2014 (RJ\2014\5504)

RDGRN de 3 de octubre de 2014 (RJ\2014\5512)

RDGRN de 3 de octubre de 2014 (RJ\2014\5514)

RDGRN de 6 de octubre de 2014 (RJ\2014\6721)

\section{RESOLUCIONES DE LA DIRECCIÓN GENERAL DE TRIBUTOS}

Consulta vinculante de la Dirección General de Tributos de 7 de marzo de 2005

Consulta vinculante de la Dirección General de Tributos de 2 de junio de 2005

Consulta vinculante de la Dirección General de Tributos de 9 de agosto de 2006

Consulta vinculante de la Dirección General de Tributos de 23 de noviembre de 2006

Consulta vinculante de la Dirección General de Tributos de 26 de mayo de 2009 (JT\2009\1171)

Resolución de 19 de octubre de 2007 (JUR 2007\351721)

Resolución de 22 de abril de 2009 (JUR 2009\895)

Resolución de 20 de mayo de 2009 (JUR 2009\367878) 
Resolución de 16 de junio de 2009 (JUR 2009\373019)

\section{RESOLUCIONES DEL TRIBUNAL ECONÓMICO-ADMINISTRATIVO CENTRAL}

Resolución del Tribunal Económico-Administrativo Central de 19 de enero de 2001 (JT 2001\190)

\section{RESOLUCIÓN DEL DEPARTAMENTO DE HACIENDA Y FINANZAS}

Resolución del Departamento de Hacienda y Finanzas de 7 de julio de 2008 (JT\2009\142). 



\section{BIBLIOGRAFÍA}





\section{BIBLIOGRAFÍA GENERAL}

abellán García, A. y Pujol Rodríguez, R.: «Un perfil de las personas mayores en España, 2013. Indicadores estadísticos básicos», Informes Envejecimiento en red no 1, Madrid, 2013.

Adams, J.; James, S.: Retirement Income and Assets: How can Housing support Retirement, Pensions Policy Institute, octubre de 2009, disponible en: www. pensionspolicyinstitute.org.uk.

Agbamu, A.: The HECM at 20 series...A principal architect of HECM (Reverse Mortgage. Pioneers and Leaders: A visionary non-commercial entrepeneur). Disponible en: http://nationalmortgageprofessional.com.

Albaladejo, M.: Curso de Derecho Civil, V, Derecho de Sucesiones, Edisofer, Madrid, 2013.

Alfaro Faus, M. y Vallés LóPez, I.: La previsión y el ahorro ante el envejecimiento de la población, Fundación Edad \& Vida, IV Premio Edad \&Vida, noviembre 2009. Disponible en:

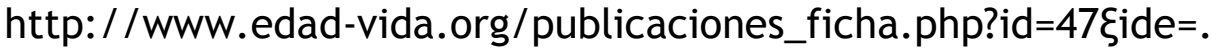

Alonso PÉREZ, M.: «Diversas formas de valorar la ancianidad y sus consecuencias», Protección jurídica de los mayores, La Ley, Madrid, 2004.

Álvarez ÁlvAREZ, H.: La hipoteca inversa. Una alternativa económica en tiempos de crisis, Lex Nova, Valladolid, 2009.

- El legado de rentas o prestaciones periódicas: su protección registral, La Ley, Madrid, 2007.

- Régimen jurídico del domicilio de las personas físicas, Lex Nova, Valladolid, 2005.

- «El domicilio del deudor en la ejecución hipotecaria», RCDI, N 684 , 2004, pp. 1635 y ss. 
ANGUITA Ríos, R.M.: «Regulación relativa a la hipoteca inversa según la Ley 41/2007, de 7 de diciembre», El Consultor Inmobiliario, núm. 87, febrero de 2008, pp. 3 y ss.

- «La hipoteca inversa y la transformación de los activos inmobiliarios en rentas», El Consultor Inmobiliario, núm. 83, octubre de 2007, pp. 3 y ss.

- Aspectos críticos en la estructura de la hipoteca inmobiliaria, Dykinson, Madrid, 2006.

- «Algunas reflexiones sobre la acción de devastación», en Libro Homenaje al profesor Manuel Albaladejo García, I, VV.AA., coord., por J.M. González Porras y F.P. MÉndez GonzÁlez, Colegio de Registradores de la Propiedad y Mercantiles de España, Servicio de Publicaciones de la Universidad de Murcia, Murcia, 2004, pp. 299 y ss.

BAdENAS CARPIO, J.M.: La renta vitalicia onerosa, Aranzadi, Navarra, 1995.

BALAGUÉ, C.: «Cómo convertir la vivienda en dinero. Reflexiones en torno a la hipoteca inversa, dos caras de una misma moneda. (Incluye modelo)», Revista del Sector Inmobiliario, núm. 64, 2006, pp. 34-51.

Balluguera Gómez, C.: «Hipoteca Inversa (notas prácticas)», Seminario de Derecho Registral, Boletín del Colegio de Registradores de la Propiedad, año XLII, núm. 131 (2ª́poca), Bilbao, enero de 2007.

BAZ IZQUIERDO, F.: Derecho Inmobiliario Hipotecario inglés y su comparación con el sistema inmobiliario español, EDERSA, Madrid, 1980.

Bellod Fernández de Palencia, E.: «Cláusulas de vencimiento anticipado de un préstamo hipotecario. Resolución de la Dirección General de los Registros y del Notariado de 2 de octubre de 2006», en NUL: Estudios sobre invalidez e ineficacia, № 1, 2007.

- Hipoteca en garantía de crédito abierto en cuenta corriente bancaria, Centro de Estudios Registrales, Madrid, 2001. 
BeLtRÁN DE HEREDIA DE ONIS, P.: La obligación legal de alimentos entre parientes, Universidad de Salamanca, tomo III, núm. 3, 1958.

Beltrán de Heredia, J.: La renta vitalicia, Editorial Revista de Derecho Privado, Madrid, 1963.

BerRoCAL LANZAROT, A.I.: «Hipoteca Inversa y otros instrumentos afines», Academia sevillana del notariado: Conferencias del Curso Académico 2007/08 (on line), tomo XIX, Comares, Granada, 28 de enero de 2008.

- «Novedades en la Ley 41/2007, de 7 de diciembre de regulación del mercado hipotecario y otras normas del sistema hipotecario y financiero: el seguro privado de dependencia y la hipoteca inversa», en ALVENTOSA DEL Río, J. (coord.), Estudios jurídicos en homenaje al profesor Enrique Lalaguna Domínguez, Universidad de Valencia, 2008, pp. 115-152.

Boroson, W.: The Reverse Mortgage Advantage: The Tax-Free, HouseRich. Way to Retire Wealthy!, McGraw-Hill Companies, New York, 2006.

CALEGARI DE GRosso, L.E.: «La hipoteca revertida y las desventajas de su instrumentación». En XXI Jornadas Nacionales de Derecho Civil, tomo I, Facultad de Derecho, Universidad Nacional de Lomas de Zamora, septiembre de 2007, pp. 319 y ss.

Canals Brage, F.: «El incierto porvenir de la hipoteca en España (a propósito de algunos proyectos más o menos normativos)», La Ley, núm. 6691, 12 de abril de 2007.

CANo MaRtínez de Velasco, J.I.: Las prohibiciones de disponer o la fuerza constitutiva del Registro, Bosch, Barcelona, 2006. 
Carrasco Perera, Á.: «Comentario a la RDGRN de 1 de octubre de 2010», Cuadernos Civitas de jurisprudencia civil, № 86, Civitas, Madrid, 2011, pp. 1159-1206.

Carrasco Perera, Á. y Cordero lobato, E.: «La hipoteca inversa y el aseguramiento de intereses o de por qué tiene que ser revocada la doctrina de la DGRN sobre el anatocismo», Actualidad Jurídica Aranzadi (on line), $\mathrm{N}^{\circ}$ 741, Civitas, Madrid, 2007, pp. 17-19.

Carrasco Perera, Á.; Cordero lobato, E. y Marín López, M.J.: Tratado de los derechos de garantía, tomo I, 2. ${ }^{a}$ ed., Thomson Aranzadi, Navarra, 2008.

Castañ Tobeñas, J.: Derecho civil español, común y foral, T. 4: Derecho de obligaciones. De las particulares relaciones obligatorias, Reus S.A., Madrid, 1993.

Catena Oliva, A.: «L'anomenada hipoteca inversa. Una perspectiva des del dret comparat a través de l'anàlisi d'una escriptura pública signada a Catalunya-Espanya», 2006, pp. 1-11.

Disponible en: http://civil.udg.es/tossa/2006/textos/com/4/aco.htm.

CeCCHINI Rosell, X.: Eficacia de las prohibiciones de disponer. Causa y derechos de terceros, Thomson Aranzadi, Navarra, 2003.

ChICO Y ORTIZ, J.M.: Estudios sobre Derecho hipotecario, tomo II, 4. ${ }^{\mathrm{a}}$ ed., Marcial Pons, Madrid, Barcelona, 2000.

ChIllón Peñalver, S.: El contrato de vitalicio: caracteres y contenido, EDERSA, Madrid, 2000.

Clarke, A.; Kohler, P.: Property Law: Commentary and Materials, Cambridge University Press, Cambridge, 2005. 
Clemente Meoro, M.: «El tercer poseedor de bienes hipotecados como tercero adquirente», en Revista General de Derecho, diciembre 1992.

- Los supuestos legales de vencimiento anticipado de las obligaciones, Tirant lo Blanch, Valencia, 1991.

Clery, E.; MCKay, S., et alii: Attitudes to Pensions: The 2006 Survey, Department for Work and Pensions, 2007, disponible en: http://research.dwp.gov.uk/asd/asd5/report_abstracts/rr_abstracts/rra_434. asp.

CoBAcho Gómez, J.A.: La deuda alimenticia, Montecorvo, Madrid, 1990.

Colina Garea, R.: «Comentario a los artículos 988 a 1034», en Bercovitz Rodríguez-Cano, R. (coord.), Comentarios al Código Civil, Thomson Aranzadi, Cizur Menor (Navarra), 2006.

Cordero Lobato, E.: Tratado de los Derechos de Garantía, VV.AA., Aranzadi, Navarra, 2002.

- «Proyectadas novedades en materia hipotecaria», Actualidad Jurídica Aranzadi, núm. 732, 2007, BIB 2007\1006.

Costa Font, J.; Gil Trafesí, J. y Mascarilla Miró, O.: Capacidad de la vivienda en propiedad como instrumento de financiación de las personas mayores en España, Fundación Edad \& Vida, Mayo 2007, disponible en: http://www.amma.es/pdf/estudio_vivienda_edadyvida.pdf.

- «Preferencias de la población ante la financiación de la dependencia: La hipoteca inversa en España», 2006, disponible en: http://www.fedea.es/pub/eee230.pdf.

CRESPO AlLuÉ, E.: «Comentario del artículo 695 de la LEC», en Comentarios a la Nueva Ley de Enjuiciamiento Civil, tomo III, Lex Nova, Valladolid, 2000. 
DAVEY, J.A.: Equity Release: an Option for Older Home Owners, University of York, Centre for Housing Policy York, 1996.

De la Cámara Álvarez, M.: Compendio de Derecho Sucesorio, 2. ${ }^{a}$ ed., La Ley, Madrid, 1999.

De LA IgLesia MONJe, M.I.: «Comentario al artículo 1125», en ValPueSTA Fernández, R. (coord.), Código Civil comentado: Libro IV, obligaciones y contratos, Teoría general de la obligación y el contrato, vol. III, Civitas (Thomson reuters), Cizur Menor (Navarra), 2011.

De la Puente de Alfaro, F.: «La eficacia de los derechos reales, con especial atención al de hipoteca, en los Estados Unidos de América. Un caso concreto: el condado de Dane, Wisconsin», RCDI, Año $\mathrm{n}^{\circ} 78, \mathrm{~N}^{\circ} 674$, Madrid, 2002, pp. 2191-2274.

De Pablo Contreras, P. (coord.); Martínez de Aguirre Aldaz, C.; Pérez Álvarez, M.Á. y Parra lucán, M.Á.: Curso de Derecho Civil (I) Derecho Privado. Derecho de la Persona, 4. ${ }^{\mathrm{a}}$ ed., COLEX, Madrid, 2011.

De Pablo Contreras, P. (coord.); Martínez de Aguirre Aldaz, C. y Pérez Álvarez, M.Á.: Curso de Derecho Civil (III): Derechos Reales, 3. ${ }^{a}$ ed., COLEX, Madrid, 2011.

Del Pozo García, E.; Díaz Martínez, Z. y Fernández SeVILla, L.: «La hipoteca inversa en España: un estudio comparativo con otros países de la Unión Europea y EEUU», Revista Universitaria Europea, № 15, Julio-Diciembre 2011, pp. 85-106.

Devesa Carpio, J.E.; Devesa Carpio, M.; Domínguez-Fabián, I.; EncinasGoenechea, B., Meneu-Gaya, R. y Nagore-García, A.: «Análisis financiero-fiscal de la hipoteca inversa en España». Innovar. Revista de Ciencias 
Administrativas y Sociales, Universidad Nacional de Colombia, vol. 22, núm. 45, julio-septiembre 2012.

Díaz Alabart, S.: Comentarios al Código Civil y Compilaciones Forales, tomo VII, vol. 6, Artículos 104 a 130, Revista de Derecho Privado, Madrid, 2000.

DíaZ FraILE, J.M.: «La nueva regulación de las novaciones y subrogaciones de los préstamos hipotecarios. Retos y riesgos de la reforma hipotecaria», Diario La Ley, № 6727, 4 de junio de 2007.

Díez-Picazo, L.: Fundamentos de Derecho Civil Patrimonial. Las relaciones obligatorias, vol. II, $6^{\text {a }}$ ed., Thomson-Civitas, Cizur Menor (Navarra), 2008.

- Fundamentos del Derecho Civil Patrimonial, t. I, Madrid, 1996.

- «El pago anticipado», en Revista de Derecho Mercantil, vol. XXVIII, núm. 73, julio-septiembre, 1959.

Díez-Picazo, L. y Gullón, A.: Sistemas de Derecho Civil. Introducción. Derecho de la persona, vol. I, 11. a ed., Tecnos, Madrid, 2004.

- Sistemas de Derecho Civil II: El contrato en general. La relación obligatoria. Las particulares relaciones obligatorias. La responsabilidad civil, 9. ${ }^{a}$ ed., Tecnos, Madrid, 2001.

- Sistema de Derecho Civil IV. Familia, 10. ${ }^{a}$ ed., Tecnos, Madrid, 2006.

Domínguez LUeLmo, A.: La hipoteca de propiedad intelectual, Reus, Madrid, 2005.

- «Comentario del artículo 681 de la LEC», en Comentarios a la Nueva Ley de Enjuiciamiento Civil, tomo III, 2. ${ }^{a}$ ed., Lex Nova, Valladolid, 2000, pp. 3369 y ss.

- «Comentario a la Resolución de la Dirección General de los Registros y del Notariado de 16 de octubre de 1.999», Cuadernos Civitas de Jurisprudencia Civil, № 53, 2000. 
Doral García, J.A.: «Pactos en materia de alimentos», $A D C, 1971$, pp. 313 y ss.

FÁBREGA RUIZ, C.F.: La guarda de hecho y la protección de las personas con discapacidad, Editorial Universitaria Ramón Areces, Madrid, 2006.

Fox-O'MAHONY, L.: Home Equity and Ageing Owners: between Risk and Regulation, Hart Publishing, Oxford, 2012.

FUENMAYOR CHAMPIN, A.: «La deuda alimenticia del donatario», RDP, 1942, pp. 154 y ss.

GARCíA RuBIO, M.P.: La distribución de toda la herencia en legados. Un supuesto de herencia sin heredero, Civitas, Madrid, 1989.

Gomá SALCEDO, J.E.: «Principales problemas de la constitución de una renta vitalicia», Revista de Derecho Notarial, Madrid, 1960, pp. 309-337.

Gómez-Ferrer SAPIÑA, R.: «La Hipoteca», en Delgado DE Miguel, J.F., Instituciones de Derecho Privado, tomo II: Reales, vol. $3^{\circ}$, Consejo General del Notariado y Thomson-Civitas, Madrid, 2003, pp. 223-1227.

Gómez GÁlligo, J.: «Principios generales de la Ley 41/2007, de 7 de diciembre, de modificación de la ley de regulación del mercado hipotecario y otras normas del sistema hipotecario y financiero», Boletín del Colegio de Registradores de España, núm. 150, octubre de 2008, pp. 2171 y ss.

Gómez LaPLAZA, C.: «Comentario al artículo 40», en Bercovitz RodríGuezCano, R. (coord.), Comentarios al Código Civil, Thomson Aranzadi, Cizur Menor (Navarra), 2006.

- «Consideraciones sobre la nueva regulación del contrato de alimentos», RDP, 2004. 
GonzÁlez PaCanowska, I.: «Comentario al art. 1257 CC», en Albaladejo García, M. (dir.) y díAz Alabart, S., Comentarios al Código Civil y Compilaciones Forales, tomo XVII, vol. $1^{\circ}$ A, EDERSA, Madrid, 1993.

Goss, A.; RICHARDSON, L., et alii: Conveyancing forms and procedures, $4^{\text {Th }}$ ed., The Law Society, London, 2009.

GRIMALDI, M.: «L'hypothèque rechargeable et le prêt viager hypothécaire», Revue Lamy Droit des affaires, supplement au $n^{\circ}$. 7, juillet 2006.

Gullarte ZaPatero, V.: «Comentarios al artículo 1.802 del Código Civil», en Comentarios al Código Civil y Compilaciones Forales, dir. AlBALADEJo, t. XXII, vol. I, Madrid, 1982.

GuZMÁN FLUJA, V.: «Capítulo II De la acumulación de procesos», en Barona Vilar, S. (coord.), El Proceso Civil. Volumen I. Libro I: artículos 1 a 98 inclusive, Tirant lo Blanch, Valencia, 2001.

HAMMOND, C.M.: «Reverse mortgages: a financial planning device for the elderly», Elder Law Journal, Spring 1993.

HANCOCK, R.: «Housing Wealth, Income and Financial Wealth of older People in Britain», Ageing and Society (on line), $\mathrm{N}^{\circ} 18$, Cambridge University Press, 1998, pp. 5-33.

Heras Manzano, M.M.: «El seguro privado de dependencia como mecanismo de previsión voluntaria de la dependencia», RCDI, Año $\mathrm{n}^{\circ} 85$, noviembre-diciembre, $N^{\circ} 716$, Madrid, 2009, pp. 2863-2909.

Herranz GonzÁLEZ, R.: «Hipoteca Inversa y figuras afines», Portal Mayores, Informes Portal Mayores, núm. 49, Madrid, 2006, pp. 1-18. 
Í̃̃IGO ARROYO, L.: «La hipoteca inversa (Disposiciones Adicionales 1.a y 4.a Ley 41/2007)» en MUÑIZ ESPADA, E., (coord.), La reforma del mercado hipotecario y otras medidas financieras en el contexto de la crisis económica, Edisofer, Madrid, 2009, pp. 323-356.

JACHIET, N., et alii: Rapport sur le prêt viager hypothécaire et la mobilisation de l'actif residential des personnes âgées, Agence Nationale pour l'information sur le logement, Paris, 2004.

JIMÉNEZ CLAR, A.J.: «La hipoteca inversa como instrumento de protección social», Revista de Derecho Bancario y Bursátil, Año $\mathrm{n}^{\circ} \mathrm{XXVIII,}$ núm. 113, Enero-Marzo 2009, pp. 97-142.

JIMÉnez SÁnCHEZ, G.J. (coord.): Derecho Mercantil: IV. Títulos-Valores, V. Obligaciones y contratos mercantiles, VI. Derecho Concursal mercantil y VII. Derecho de la navegación, Ariel Derecho, Barcelona, 2000.

JoHnson, A.M.: Understanding Modern Real Estate Transactions, Lexis Nexis, New York, 2001.

Lacruz Berdejo, J.L.: Elementos de Derecho Civil V: Sucesiones, 2. ${ }^{a}$ ed., Dykinson, Madrid, 2004 (revisada y puesta al día por Joaquín Rams Albesa).

Lambea Rueda, A.: Caracteres del contrato de alimentos y estructura del contrato de alimentos a favor de tercero, Aranzadi civil-mercantil (on line), $\mathrm{N}^{\circ} 19$, BIB 2006\1991.

Lasarte Álvarez, C.: Principios de Derecho Civil V. Derechos reales y Derecho hipotecario, 4. ${ }^{\text {a }}$ ed., Marcial Pons, Madrid, Barcelona, 2005.

$-\ll$ Crisis financiera estadounidense, tercero hipotecario y seguridad inmobiliaria: la STS 6/2008 y la reciente doctrina del Tribunal Supremo», Diario La Ley, Año XXIX, № 6899, 7 de marzo de 2008. 
Llamas Pombo, E.: «La tipificación del contrato de alimentos» en Protección jurídica de los mayores, La Ley, Madrid, 2004.

LÓPEZ CUMBRE, L.: «La revisión del sistema de pensiones: recorte/reforma de las pensiones en 2010», El Cronista del Estado Social y Democrático del Derecho, núm. 14, lustel, Madrid, 2010, pp. 22-41.

LÓPEZ JIMÉNEZ, J.M. y MUÑOZ DE BENAVIDES, C.: «Principales novedades de la Ley $41 / 2007$, con relación al ámbito del mercado hipotecario y el sistema financiero», Diario La Ley, núm. 6864, 18 de enero de 2008.

LóPez PelÁEZ, P.: «El contrato de vitalicio: la cesión de un inmueble a cambio de alimentos», en El Consultor Inmobiliario, núm. 52, diciembre de 2004.

LUQUE JIMÉNEZ, M.C.: «Una nueva modalidad de hipoteca: la hipoteca inversa», RCDI, Año nº 85, Enero-Febrero, № 711, Madrid, 2009, pp. 215-260.

LUSH, D.; BIELANSKA, C., et alii: Elderly clients: a precedent manual, $3^{\text {Th }}$ ed., Jordans, Bristol, 2010.

MANChÓN, R. y ALBERT, M.: Conocer los productos seguros: Planes y fondos de pensiones, estrategia de planificación de la jubilación, Profit. Colección Manuales de Asesoramiento Financiero, Barcelona, 2008.

MARTIN, A.: «The life and death of a reverse mortgage», Arkansas Lawyer, Spring 2006.

Martínez de Aguirre Aldaz, C. (coord.); De Pablo Contreras, P.; Pérez Álvarez, M.Á. y Parra LucÁn, M.Á.: Curso de Derecho Civil (II) Derecho de Obligaciones, 3. ${ }^{a}$ ed., COLEX, Madrid, 2011. 
MARTíNEZ ESCRIBANO, C.: «El registro de derechos en Inglaterra y Gales: avances y obstáculos en su implantación», RCDI, Año $\mathrm{n}^{\circ} 87$, marzo-abril, $\mathrm{N}^{\circ}$ 724, Madrid, 2011, pp. 969-999.

- La hipoteca inversa, Cuadernos De Derecho Registral, Fundación Registral, Colegio de Registradores de la Propiedad y Mercantiles de España, Madrid, 2009.

- «La ejecución hipotecaria de la vivienda arrendada. Estado de la cuestión en la normativa vigente», RCDI, № 684, julio-agosto 2004.

MARTínez Martínez, M.: Temas sobre validez y eficacia en la «Ley de hipoteca inversa», Nulidad, 2008 (Estudios), NUL. Estudios sobre invalidez $e$ ineficacia. Nulidad de los actos jurídicos. Disponible en: http://www.codigocivil.info/nulidad/lodel/document.php?id=595.

MARTínez RodrígueZ, N.: La obligación legal de alimentos entre parientes, La Ley, Madrid, 2002.

MARTínez VÁzQUEz de CASTRO, L.: Responsabilidad patrimonial de la sociedad de gananciales. Cuadernos Civitas, Madrid, 1995.

Meléndez Morillo-Velarde, L.: «Delimitación conceptual de la dependencia», en Sempere NAVArRo, A.V. (dir.), Comentario sistemático de la Ley de la dependencia, Thomson-Aranzadi, Cizur Menor (Navarra), 2008, pp. 157-179.

MESA MARRERO, C.: El contrato de alimentos. Régimen jurídico y criterios jurisprudenciales, Thomson Aranzadi, Cizur Menor (Navarra), 2006.

MIQUEL SILVeStRE, J.A.: «Hipoteca Inversa. Algunas hipótesis de conflicto», Diario La Ley, núm, 6924, Sección Tribuna, 14 de abril de 2008.

Montero Aroca, J.: Las ejecuciones hipotecarias en la nueva Ley de Enjuiciamiento Civil, Tirant lo Blanch, Valencia, 2001. 
Montero Aroca, J.; Gómez Colomer, J.L.; Barona Vilar, S. y Calderón Cuadrado, M.P.: Derecho jurisdiccional II. Proceso Civil, 21. ${ }^{a}$ ed., Tirant lo Blanch, Valencia, 2013.

Montés Penadés, V.L.: «Comentario del artículo 1129 del CC», en Comentarios al Código Civil y Compilaciones Forales, tomo XV, vol. $2^{\circ}$, artículos 1125 a 1155 del CC, VV.AA., dir. por Manuel ALBALADEJo, EDERSA, Madrid, 1983.

MORENO QUeSADA, B.: «El vencimiento anticipado del crédito por alteración de sus garantías (artículo 1129.3 del CC)», ADC, 1971, pp. 429 y ss.

- «Comentario del artículo 117 de la LH», en Comentarios al Código Civil y Compilaciones Forales, tomo VII, vol. 6ªrtículos 104 a 130 de la Ley Hipotecaria, VV.AA., dir. por Manuel Albaladejo y Silvia DíAZ Alabart, EDERSA, Madrid, 2000, pp. 321 y ss.

MORILLO FERNÁNDEZ, F.J.: «El crédito hipotecario inverso», El notario del siglo XXI, núm. 17, enero-febrero 2008.

Moro Serrano, A.: Los sistemas registrales inmobiliarios en los Estados Unidos, Centro de Estudios Hipotecarios y Servicio de publicaciones de la Universidad Complutense de Madrid, Madrid, 1986.

MULlingS, B.; HamNeTt, C.: «Equity Release Schemes and Equity Extraction by Elderly Household», Ageing and Society (on line), $\mathrm{N}^{\circ} 12$, Cambridge University Press, 1992, pp. 413-442.

MULLOR, L.: «La Ley de reforma del mercado hipotecario», Circular núm. 1 de la Federación Hipotecaria Europea, enero de 2008, pp. 4 y ss. 
MURo VilLALón, J.V.: «La hipoteca inversa» III Congreso de Registradores de España celebrado en Granada del 30 de octubre al 1 de noviembre, 2007, pp. 1-26. Disponible en:

http: //www.congresoderegistradores.org/ficheros/ponencias/ponencia2.pdf.

NASARRE AZNAR, S.: «Malas prácticas bancarias en la actividad hipotecaria», $R C D I, N^{\circ} 727$, septiembre 2011, pp. 2665-2737.

NAUTS, C.W.: «Reverse mortgages. Backing into the '90s», Probate \& Property, January-February 1994.

Nigel P.; Gravells, M.A.: Land Law: Text and Materials, $3^{\text {TH }}$ ed., Thomson: Sweet \& Maxwell, London, 2004.

NúÑEZ ZORRILLA, M.C.: El contrato de alimentos vitalicio: configuración y régimen jurídico, Marcial Pons, Madrid, Barcelona, 2003.

OliVer LóPeZ, C.: «Capítulo V: De las particularidades de la ejecución sobre los bienes hipotecados o pignorados», en BARONA VILAR, S. (coord.), El Proceso Civil. Volumen VII. Libro III: artículos 614 a 747 inclusive, Tirant lo Blanch, Valencia, 2001.

OLIVER WyMAN, M.: Study on the Financial Integration of European Mortgage Markets, European Mortgage Federation, October 2003, disponible en: http: //www.hypo.org.

Ortells Ramos, M. (coord.); Mascarell Navarro, M.J.; Juan Sánchez, R.; Cucarella Galiana, L.A.; Bonet Navarro, J.; Cámara Ruiz, J.; Bellido Penadés, R.; Martín Pastor, J. y Armengot Vilaplana, A.: Derecho Procesal Civil, 10. a ed., Aranzadi, Cizur Menor (Navarra), 2010.

PARDO MUÑOZ, J.: Eficacia registral de las resoluciones judiciales dictadas en procesos civiles seguidos contra la herencia yacente, comunidad 
hereditaria o herederos desconocidos, ignorados o inciertos de una persona fallecida, RRDGRN de 19 de agosto de 2010 y 10 de enero de 2011. Referencia a la hipoteca inversa. Cuadernos De Derecho Registral, Madrid, 2011.

ParRa LuCÁn, M.Á.: «Los principios generales de la Ley 41/2007, de 7 de diciembre, de modificación de la Ley del mercado hipotecario y otras normas del sistema hipotecario», Revista Crítica de Derecho Inmobiliario, № 711, 2008, pp. 261 y ss. (Versión escrita de la ponencia defendida en el curso «Nuevas contrataciones. Las ofertas de recompra con revalorización y la reforma hipotecaria», celebrado en el Consejo General del Poder Judicial, Escuela Judicial, el 1 de octubre de 2008).

PeÑa Bernaldo de Quirós, M.: La herencia y las deudas del causante (reproduce, con un epílogo, la 1. ${ }^{a}$ edición de 1967), Comares, Granada, 2006.

- Derechos reales. Derecho hipotecario. Tomo I. Propiedad. Derechos reales (excepto los de garantía), 4. ${ }^{a}$ ed., Centro de Estudios Registrales, Madrid, 2001.

PeÑa LóPEZ, F.: «Comentario a los artículos 1125 a 1130», en BerCovitz Rodríguez Cano, R. (coord.), Comentarios al Código Civil, Thomson Aranzadi, Cizur Menor (Navarra), 2006.

Pereña Vicente, M.: «La protección de la vivienda habitual en los supuestos de sobreendeudamiento y dependencia», $A C, \mathrm{~N}^{\circ} 16$, septiembre de 2008, pp. 1725 y ss.

Pérez Conesa, C.: El contrato a favor de tercero, Comares, Granada, 1999.

PIÑAR LóPEZ, B.: «La prestación alimenticia en nuestro derecho civil», $R G L J, 1955$, pp. 7 y ss. 
Puig Brutau, J.: Compendio de Derecho Civil. Volumen IV. Derecho de familia. Derecho de sucesiones, Bosch, Barcelona, 1990.

- Compendio de Derecho Civil, Volumen III, Derechos reales, Derecho hipotecario, Bosch, Barcelona, 1989.

- Compendio de Derecho Civil, Volumen I, Bosch, Barcelona, 1987.

- Fundamentos de Derecho Civil, t. V, Vol. I, Bosch, Barcelona, 1975.

QUESADA SÁNCHEZ, A.J.: «Apuntes jurídico-civiles sobre la llamada "hipoteca inversa": inquietudes iniciales sobre la cuestión», El Consultor Inmobiliario, $\mathrm{N}^{\circ} 88$, marzo de 2008.

- «La Hipoteca Inversa: ¿una opción realmente atractiva?» Revista del Ministerio de Trabajo e Inmigración, (on line), № 81, Madrid, marzo de 2008, pp. 135-148.

RAJOY, E.: La calificación registral en el marco de la Unión Europea, Colegio de Registradores de la Propiedad, Mercantiles y Bienes Muebles de España, Madrid, 2005.

RAmos ChaparRo, E.J.: La garantía real inmobiliaria. Manual sistemático de la hipoteca, Thomson Aranzadi, Navarra, 2008.

REILLY, J.: «Reverse mortgages: backing into the future» Elder Law Review, Spring 1997.

Rivas ToRRALBA, R.: Aspectos registrales del nuevo proceso de ejecución, Centro de Estudios Registrales, Madrid, 2001.

Roca SASTRe, R.M. y Roca-SASTRe Muncunill, L.: Derecho hipotecario: Hipotecas, tomo VIII, 8. ${ }^{a}$ ed., Bosch, Barcelona, 1998.

- Derecho hipotecario. Ejecución hipotecaria, tomo IX, 8. ${ }^{\mathrm{a}}$ ed., Bosch, Barcelona, 1998.

- Derecho hipotecario: Ley del Suelo e Hipotecas, tomo VII, 8. a ed., Bosch, Barcelona, 1998. 
Roca Sastre, R.M.; Roca-Sastre Muncunill, R. y Bernà I Xirgó, J.: Derecho hipotecario, tomo VIII, 9. ${ }^{\mathrm{a}}$ ed., Bosch, Barcelona, 2009.

Rodrígo GarcíA, G.: «La hipoteca condicionada y la hipoteca inversa. Soluciones y novedades en torno a la hipoteca», Observatorio inmobiliario, núm. 14, enero de 2007, pp. 54-58.

Román García, A.: Instituciones de Derecho Civil Español, t. VII, Derecho de Sucesiones, McGrawHill, Madrid, 1999.

Romero Burillo, A.M.: Los Planes de Pensiones del Sistema de Empleo, Aranzadi, Cizur Menor (Navarra), 2002.

Romero Candau, P.A.: «La hipoteca inversa», en Hacia un nuevo derecho hipotecario. Estudios sobre la Ley 41/2007, de reforma del mercado hipotecario, VV.AA., coord. por Valerio PÉREZ DE MADRID CARRERAS, Academia Sevillana del Notariado, Consejo General del Notariado, Madrid, 2008, pp. 307 y ss.

Rubio ToRrano, E.: «De la Ley que define la hipoteca inversa y regula otras muchas cosas», Aranzadi Civil, núm. 17, 2007.

SAÉNZ de Jubera HigueRo, B.: Relación entre el crédito y la hipoteca: alcance del principio de accesoriedad, Colegio de Registradores de la Propiedad y Mercantiles de España, Madrid, 2008.

Salinas Molina, F.: «Capítulo I De la ejecución dineraria: disposiciones generales», en Barona VILAR, S. (coord.), El Proceso Civil. Volumen I. Libro I: artículos 1 a 98 inclusive, Tirant lo Blanch, Valencia, 2001. 
Sánchez Álvarez, I.; López Ares, S. y Quiroga García, R.: «Diseño de hipotecas inversas en el mercado español», Instituto de Mayores y Servicios Sociales, marzo 2007.

SÁnCHEZ-Ventura MORER, I.: La hipoteca inversa en el Derecho Español, Aranzadi, Cizur Menor (Navarra), 2013.

SAWYER, C.H.: «Reverse mortgage: an Innovative Tool for Elder Law Attorneys», Stetson Law Review (on line), vol. XXVI, Winter 1996, pp. 617646.

Sempere Navarro, A.V.: «El escondite jurídico. (Un apunte sobre topografía normativa)», Actualidad Jurídica Aranzadi, núm. 746, 2008.

SERRANO dE NicolÁs, Á.: «Régimen jurídico de la hipoteca inversa», Revista de Derecho Privado, enero-febrero de 2008, pp. 33 y ss.

Silverman, F.; Hewitson, R.: Conveyancing checklist, $2^{\text {Th }}$ ed., The Law Society, London, 2010.

SMITH, R. J.: Property Law, $7^{\text {Th }}$ ed., Longman, London, 2011.

SprankLING, J.G.: Understanding Property Law, Lexis Nexis, New York, 2000.

TAFFIN, C.: «La hipoteca inversa o vitalicia», 2004, traducido de la versión original por la AHE, 2005, pp.1-12, disponible en: http://www.ahe.es.

TOGORES, A.: «El valor económico de la seguridad jurídica», Escritura Pública, (on line), № Extra 5, 2007 (Ejemplar dedicado a: 25 Congreso Internacional), pp. 14-17. 
TORAL LARA, E., «Hipoteca Inversa o Contrato de renta vitalicia», Actualidad Civil, № 16, $2^{\mathrm{a}}$ quincena de septiembre de 2009.

- «El contrato de alimentos y los mayores. Especial referencia a la pluralidad de partes» en Protección jurídica de los mayores, La Ley, Madrid, 2004.

TRUJILlo DíEZ, I.J.: «Comentario al artículo 1790» en BERCOVITZ RodRíGUEZCano, R. (coord.), Comentarios al Código Civil, Thomson Aranzadi, Cizur Menor (Navarra), 2006.

TUSET DEL PINO, P.: «La hipoteca inversa: un valor en alza» Inmueble: Revista del Sector Inmobiliario, núm. 71, 2007, pp. 38-42.

URÍA FERnÁNDEZ, F.: «Conclusiones provisionales a propósito de la Ley 41/2007» Revista de Derecho Bancario y Bursátil, núm. 112, octubrediciembre 2008, pp. 7 y ss.

URÍA GonzÁLEZ, R.: Derecho Mercantil, 27. ${ }^{a}$ ed., Marcial Pons, Barcelona, 2000

VAÑó VAÑó, M.J.: «Aproximación al régimen de la hipoteca inversa», en GonzÁlez Castilla, F. (coord.), Estudios de Derecho del Mercado financiero: homenaje al profesor Vicente Cuñat Edo, Universidad de Valencia, Valencia, 2010, pp. 579-592.

VICent Chulí́, F.: Compendio Crítico de Derecho Mercantil, tomo II: Contratos, Títulos valores y Derecho Concursal, 3. ${ }^{a}$ ed., José $M^{a}$ Bosch, Barcelona, 1990.

ZoE, H.: A Detailed History of Equity Release, Retirement Plus, 8 de diciembre de 2008, disponible en: http://www.retirementplus.co.uk/downloads/570-2-7-2008-HistoryER-050608.pdf. 
ZURITA MARTín, I.: «La nueva normativa reguladora de la hipoteca inversa», $R C D I$, N 707, mayo-junio de 2008, pp. 1275 y ss.

- Contratos vitalicios, Marcial Pons, Madrid, Barcelona, 2001.

\section{MATERIALES COMPLEMENTARIOS}

ACTUALIDAD JURÍDICA URÍA MENÉNDEZ/35-2013: «Nueva Normativa de Protección de Deudores Hipotecarios», pp. 62-80.

ASOCIACIÓN HIPOTECARIA ESPAÑOLA (AHE): «Anteproyecto de Ley de Modernización del Mercado Hipotecario, de Regulación del Régimen de las Hipotecas Inversas y del Seguro de Dependencia», 3 de noviembre de 2006, pp. 1-11, disponible en: http://www.ahe.es.

- «Resumen de las propuestas de modificación formuladas al anteproyecto de Ley de Modernización del Mercado Hipotecario, de regulación del régimen de las Hipotecas Inversas y del Seguro de Dependencia», Madrid, 5 de diciembre de 2006, disponible en: http: //www.ahe.es.

Australian SeCurities ANd InVESTMENTS COMmision (ASIC), Equity Release Products, 2005.

Canadian Center for Elder Law Studies (CCELS), Report on Reverse Mortgage, Report № 2, February 2006.

Guía útil para Planes de Pensiones elaborada por CASER. Ediciones Empresa Global, 2012.

Instituto de Mayores y Servicios Sociales (IMSERSO): Autonomía Personal y Dependencia. Página web: www.imserso.es.

Instituto Nacional de Estadística (INE): www.ine.es. 
Informe Estadístico de Instrumentos de Previsión Social Complementaria 2010, Ministerio de Economía y Hacienda, Dirección General de Seguros y fondos de pensiones.

JURADO GIL, J.: «El Seguro de Vida en España: Factores que influyen en su proceso», Fundación Mapfre, 2009.

Libro Blanco sobre la atención a las personas en situación de dependencia en España, Ministerio de Trabajo y Asuntos sociales, disponible en: http://www.tt.mtas.es.

Merino Escartín, J.F.: «Resumen de la Ley 1/2013 de Protección de Deudores Hipotecarios, Reestructuración de Deuda y Alquiler Social», mayo de 2013, disponible en la página: www.notariosyregistradores.com.

Ministerio de Empleo y Seguridad Social para el año 2014. Apartado Seguridad Social: Prestaciones/Pensiones de Trabajadores: http://www.empleo.gob.es.

Ministerio de Sanidad, Servicios Sociales e Igualdad: http://www.msssi.gob.es.

Novedades Laborales 2014 y Reforma Laboral: http: //www.supercontable.com.

Servicio Público de Empleo (Sepe): https://www.sepe.es.

Observatorio Económico. Inclusión Financiera - México. Realizado por el BBVA, México, D.F., Análisis Económico, octubre 2013, pp. 1-13. Disponible en: https://www.bbvaresearch.com.

PASCUAL, R.: Hacia menos herencias y más rentas vitalicias, cincodias.com, 13 de julio de 2007. 
TROWBRIDGE DeloItTE, The Equity Release Opportunity for Financial Planners, Julio, 3-6, 2005.

\section{1.- ESTADOS UNIDOS:}

Borrowing Against your Home, AARP Foundation, disponible en: http://assets.aarp.org/www.aarp.org_/articles/money/financial_pdfs/hmmm _hires_nocrops.pdf.

- «Dinero hecho en casa. Hipotecas revertidas: guía para el consumidor», de la American Association of Retired Persons (AARP), disponible en: http://www.aarp.org/espanol/ dinero/articles/a2004-11-11hipotecas.html.

\section{2.- REINO UNIDO:}

Equity release schemes: Finance Intelligence, Mintel International Group, London, 2007

\section{DIRECCIONES WEB CON INTERÉS SOBRE HIPOTECAS INVERSAS}

\section{AUSTRALIA:}

Www. bluestoneequityrelease.com.au

Página de la empresa dominante en el mercado de hipotecas inversas en Australia.

www.sequal.com.au

Asociación de prestamistas de hipotecas inversas en Australia. Tiene un listado de miembros con enlaces web, e información sobre el código de buenas prácticas comerciales al que se suscriben sus miembros. 


\section{CANADÁ:}

www.chip.ca/

Página de la empresa dominante en el mercado de hipotecas inversas en Canadá.

\section{ESPAÑA:}

www.optimamayores.com

Óptima Mayores, primera consultora en España, especializada en asesorar a mayores de 65 años en Hipoteca Inversa.

www.imsersomayores.csic.es

Portal especializado en gerontología y geriatría. Tiene una importante y actualizada base de datos sobre noticias, estadísticas y documentación en temas relacionados con personas mayores, y concretamente en relación a las hipotecas inversas.

www.edad-vida.org

El Instituto Edad\&Vida es una asociación de empresas procedentes de diferentes sectores de la economía relacionados, directa o indirectamente, con las personas mayores. Su razón de ser es promover las respuestas a los retos económicos y sociales del envejecimiento de la población. Tiene buen número de publicaciones disponibles en la web sobre aspectos relacionados con la vejez, y en concreto con las hipotecas inversas.

WwW.gruporetiro.com

Pioneros y líderes en España en Hipotecas Inversas Rentas Vitalicias.

\section{ESTADOS UNIDOS:}

www.aarp.org/money/revmort 
Sección de la American Association of Retired Persons (AARP) sobre las hipotecas inversas. Esta asociación es una organización sin ánimo de lucro dedicada a atender las necesidades e intereses de sus miembros, las personas de 50 años de edad o mayores. Dispone de una guía del consumidor titulada Dinero Hecho en Casa (Home Made Money) que se puede descargar gratuitamente tanto en inglés como en español, donde se describen las hipotecas inversas, sus modalidades y decisiones clave para su selección.

www.hud.gov

Departamento de Vivienda y Desarrollo Urbano del gobierno de los Estados Unidos.

www.hudclips.gov

En esta página se proporciona acceso gratuito a informaciones y recursos del Departamento, en concreto la regulación federal sobre el programa de Home Equity Conversion Mortgage Insurance.

www.fanniemae.com

Compañía privada, nacida inicialmente del gobierno federal, que canaliza un porcentaje muy elevado de las hipotecas de Estados Unidos.

wWw.financialfreedom.com

La mayor compañía de hipotecas inversas privadas de Estados Unidos.

www.nrmlaonline.org

Página de la asociación de prestamistas de hipotecas inversas (National Reverse Mortgage Lenders Association).

www.reversemortgage.org

Página orientada a consumidores de la asociación de prestamistas de hipotecas inversas (National Reverse Mortgage Lenders Association). 
Proporcionada por el National Center for Home Equity Conversion Mortgage, organización sin ánimo de lucro sin vinculaciones con las empresas del sector. Se plantea como un complemento a la información básica proporcionada por la AARP. Contiene información relevante en relación con las diferentes opciones comerciales, la comparación entre las mismas, software y bibliografía. Algunos enlaces no están actualizados.

\section{REINO UNIDO:}

www.cml.org.uk

Asociación que agrupa al $98 \%$ de las entidades de préstamo hipotecario en el Reino Unido.

www.aviva.co.uk

Compañía líder en el mercado británico. 

ANEXO 

APÉNDICE 1: DA $1 .^{\mathrm{a}}$ de la Ley $41 / 2007$, de 7 de diciembre, por la que se modifica la Ley 2/1981, de 25 de marzo, de Regulación del Mercado Hipotecario y otras normas del sistema hipotecario y financiero, de regulación de las hipotecas inversas y el seguro de dependencia y por la que se establece determinada norma tributaria ${ }^{887}$.

\section{Disposición adicional primera.}

\section{Regulación relativa a la hipoteca inversa.}

1. A los efectos de esta Ley, se entenderá por hipoteca inversa el préstamo o crédito garantizado mediante hipoteca sobre un bien inmueble que constituya la vivienda habitual del solicitante y siempre que cumplan los siguientes requisitos:

$(a)^{888}$ que el solicitante y los beneficiarios que este pueda designar sean personas de edad igual o superior a los 65 años o afectadas de dependencia severa o gran dependencia).

a) ${ }^{889}$ que el solicitante y los beneficiarios que éste pueda designar sean personas de edad igual o superior a los 65 años o afectadas de dependencia o personas a las que se les haya reconocido un grado de discapacidad igual o superior al 33 por ciento,

b) que el deudor disponga del importe del préstamo o crédito mediante disposiciones periódicas o únicas,

c) que la deuda sólo sea exigible por el acreedor y la garantía ejecutable cuando fallezca el prestatario o, si así se estipula en el contrato, cuando fallezca el último de los beneficiarios,

d) que la vivienda hipotecada haya sido tasada y asegurada contra daños de acuerdo con los términos y los requisitos que se establecen en los artículos 7 y 8 de la Ley $2 / 1981$, de 25 de marzo, de Regulación del Mercado Hipotecario.

2. Las hipotecas a que se refiere esta disposición sólo podrán ser concedidas por las entidades de crédito y por las entidades aseguradoras autorizadas para operar en España, sin perjuicio de los límites, requisitos o condiciones que, a las entidades aseguradoras, imponga su normativa sectorial.

\footnotetext{
887 Publicada en el BOE núm. 294, en fecha de 8 de diciembre de 2007. Copia de la parte de la Ley $41 / 2007$ que hace referencia expresa a la hipoteca inversa.

${ }^{888}$ En su origen, este era el contenido de la letra a).

${ }^{889}$ Es el contenido actual de esta letra a) del apartado 1 de la Disposición Adicional Primera, tras la publicación del artículo 5 de la Ley $1 / 2013$, de 14 de mayo, de medidas para reforzar la protección a los deudores hipotecarios, reestructuración de deuda y alquiler social. De esta manera, se altera la Ley $41 / 2007$, de 7 de diciembre, por la que se modifica la Ley $2 / 1981$, de 25 de marzo, de regulación del Mercado Hipotecario y otras normas del sistema hipotecario y financiero, de regulación de las hipotecas inversas y el seguro de dependencia y por la que se establece determinada norma tributaria.
} 
3. El régimen de transparencia y comercialización de la hipoteca inversa será el establecido por el Ministro de Economía y Hacienda.

4. En el marco del régimen de transparencia y protección de la clientela, las entidades establecidas en el apartado 2 que concedan hipotecas inversas deberán suministrar servicios de asesoramiento independiente a los solicitantes de este producto, teniendo en cuenta la situación financiera del solicitante y los riesgos económicos derivados de la suscripción de este producto. Dicho asesoramiento independiente deberá llevarse a cabo a través de los mecanismos que determine el Ministro de Economía y Hacienda. El Ministro de Economía y Hacienda establecerá las condiciones, forma y requisitos para la realización de estas funciones de asesoramiento.

5. Al fallecimiento del deudor hipotecario sus herederos o, si así se estipula en el contrato, al fallecimiento del último de los beneficiarios, podrán cancelar el préstamo, en el plazo estipulado, abonando al acreedor hipotecario la totalidad de los débitos vencidos, con sus intereses, sin que el acreedor pueda exigir compensación alguna por la cancelación.

En caso de que el bien hipotecado haya sido transmitido voluntariamente por el deudor hipotecario, el acreedor podrá declarar el vencimiento anticipado del préstamo o crédito garantizado, salvo que se proceda a la sustitución de la garantía de manera suficiente.

6. Cuando se extinga el préstamo o crédito regulado por esta disposición y los herederos del deudor hipotecario decidan no reembolsar los débitos vencidos, con sus intereses, el acreedor sólo podrá obtener recobro hasta donde alcancen los bienes de la herencia. A estos efectos no será de aplicación lo dispuesto en el párrafo segundo del artículo 114 de la Ley Hipotecaria.

7. Estarán exentas de la cuota gradual de documentos notariales de la modalidad de actos jurídicos documentados del Impuesto sobre Transmisiones y Actos Jurídicos Documentados las escrituras públicas que documenten las operaciones de constitución, subrogación, novación modificativa y cancelación.

8. Para el cálculo de los honorarios notariales de las escrituras de constitución, subrogación, novación modificativa y cancelación, se aplicarán los aranceles correspondientes a los «Documentos sin cuantía» previstos en el número 1 del Real Decreto 1426/1989, de 17 de noviembre, por el que se aprueba el arancel de los Notarios.

9. Para el cálculo de los honorarios registrales de las escrituras de constitución, subrogación, novación modificativa y cancelación, se aplicarán los aranceles correspondientes al número 2, «Inscripciones», del anexo I del Real Decreto 1427/1989, de 17 de noviembre, 
por el que se aprueba el arancel de los Registradores de la Propiedad, tomando como base la cifra del capital pendiente de amortizar, con una reducción del 90 por ciento.

10. Podrán, asimismo, instrumentarse hipotecas inversas sobre cualesquiera otros inmuebles distintos de la vivienda habitual del solicitante. A estas hipotecas inversas no les serán de aplicación los apartados anteriores de esta disposición.

11. En lo no previsto en esta disposición y su normativa de desarrollo, la hipoteca inversa se regirá por lo dispuesto en la legislación que en cada caso resulte aplicable. 

